\title{
Trends in Annual, Seasonal, and Monthly Streamflow Characteristics at 227 Streamgages in the Missouri River Watershed, Water Years 1960-2011
}
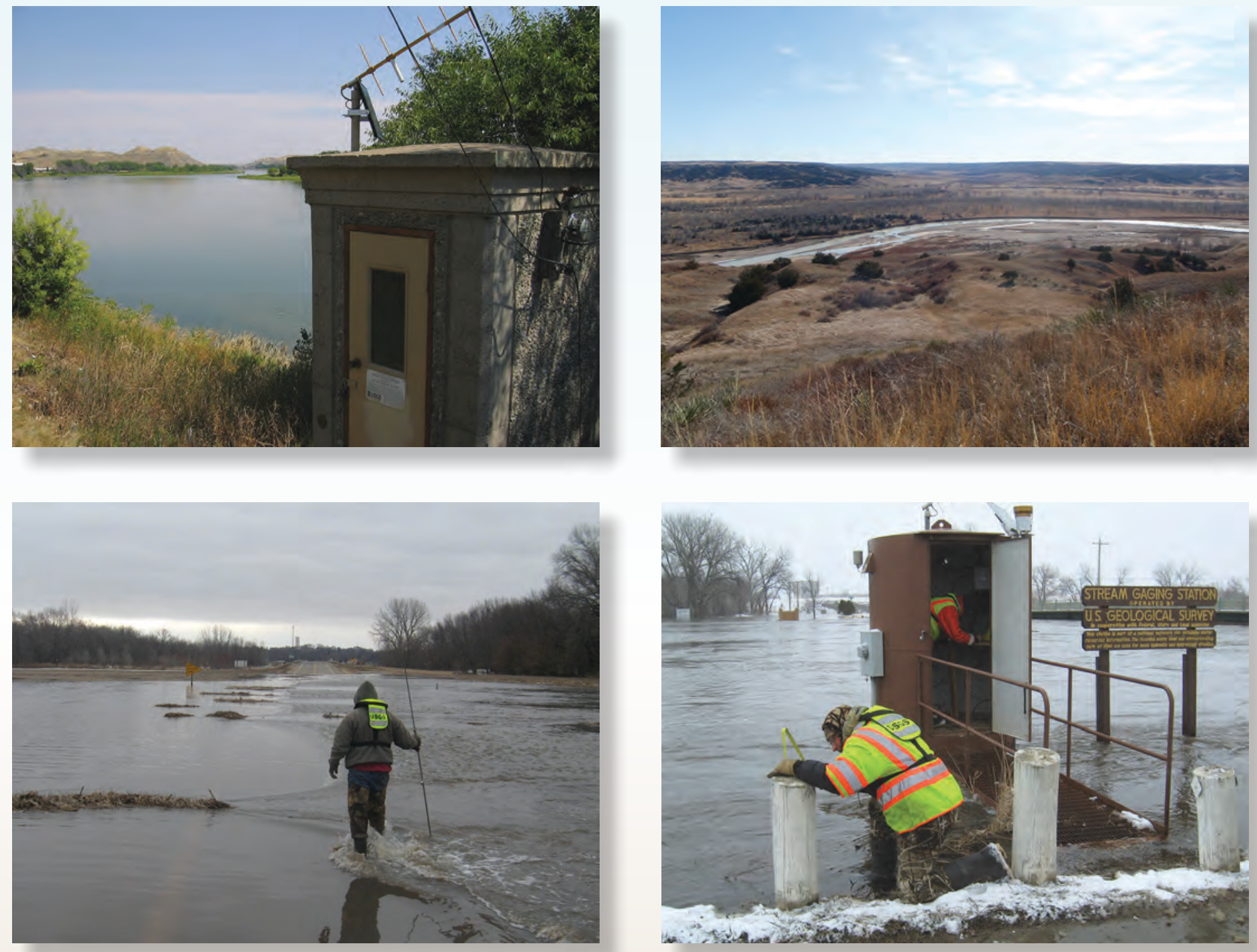

Scientific Investigations Report 2014-5053

U.S. Department of the Interior

U.S. Geological Survey 
Cover. Upper left: View of U.S. Geological Survey (USGS) streamgage on the Missouri River at Fort Benton, Montana. Photograph taken August 22, 2006, by Stewart Tomlinson, USGS.

Upper right: Cheyenne River upstream from USGS streamgage near Plainview, South Dakota. Photograph by John Stamm, USGS.

Lower left: USGS hydrologic technician documenting the river stage on the Big Sioux River at Akron, lowa (USGS streamgage 06485500 ). A streamflow measurement of 29,600 cubic feet per second at a stage of 22.3 feet was made during the site visit. Photograph taken March 17, 2010, by Nathan Stevens, USGS.

Lower right: USGS hydrologic technicians documenting the river stage and ensuring that the streamgage at the James River at Huron, South Dakota, is working properly. A streamflow measurement of 17,500 cubic feet per second was made during the site visit. Photograph taken March 2011 by USGS.

Back cover. Missouri River between Havre and Fort Benton, Montana. Photograph courtesy Montana Department of Natural Resources \& Conservation. 


\section{Trends in Annual, Seasonal, and Monthly Streamflow Characteristics at 227 Streamgages in the Missouri River Watershed, Water Years 1960-2011}

By Parker A. Norton, Mark T. Anderson, and John F. Stamm

Scientific Investigations Report 2014-5053 


\title{
U.S. Department of the Interior SALLY JEWELL, Secretary
}

\section{U.S. Geological Survey Suzette M. Kimball, Acting Director}

\author{
U.S. Geological Survey, Reston, Virginia: 2014
}

For more information on the USGS - the Federal source for science about the Earth, its natural and living resources, natural hazards, and the environment, visit http://www.usgs.gov or call 1-888-ASK-USGS.

For an overview of USGS information products, including maps, imagery, and publications, visit http://www.usgs.gov/pubprod

To order this and other USGS information products, visit http://store.usgs.gov

Any use of trade, firm, or product names is for descriptive purposes only and does not imply endorsement by the U.S. Government.

Although this information product, for the most part, is in the public domain, it also may contain copyrighted materials as noted in the text. Permission to reproduce copyrighted items must be secured from the copyright owner.

Suggested citation:

Norton, P.A., Anderson, M.T., and Stamm, J.F., 2014, Trends in annual, seasonal, and monthly streamflow characteristics at 227 streamgages in the Missouri River watershed, water years 1960-2011: U.S. Geological Survey Scientific Investigations Report 2014-5053, 128 p., http://dx.doi.org/10.3133/sir20145053.

ISSN 2328-0328 (online) 


\section{Contents}

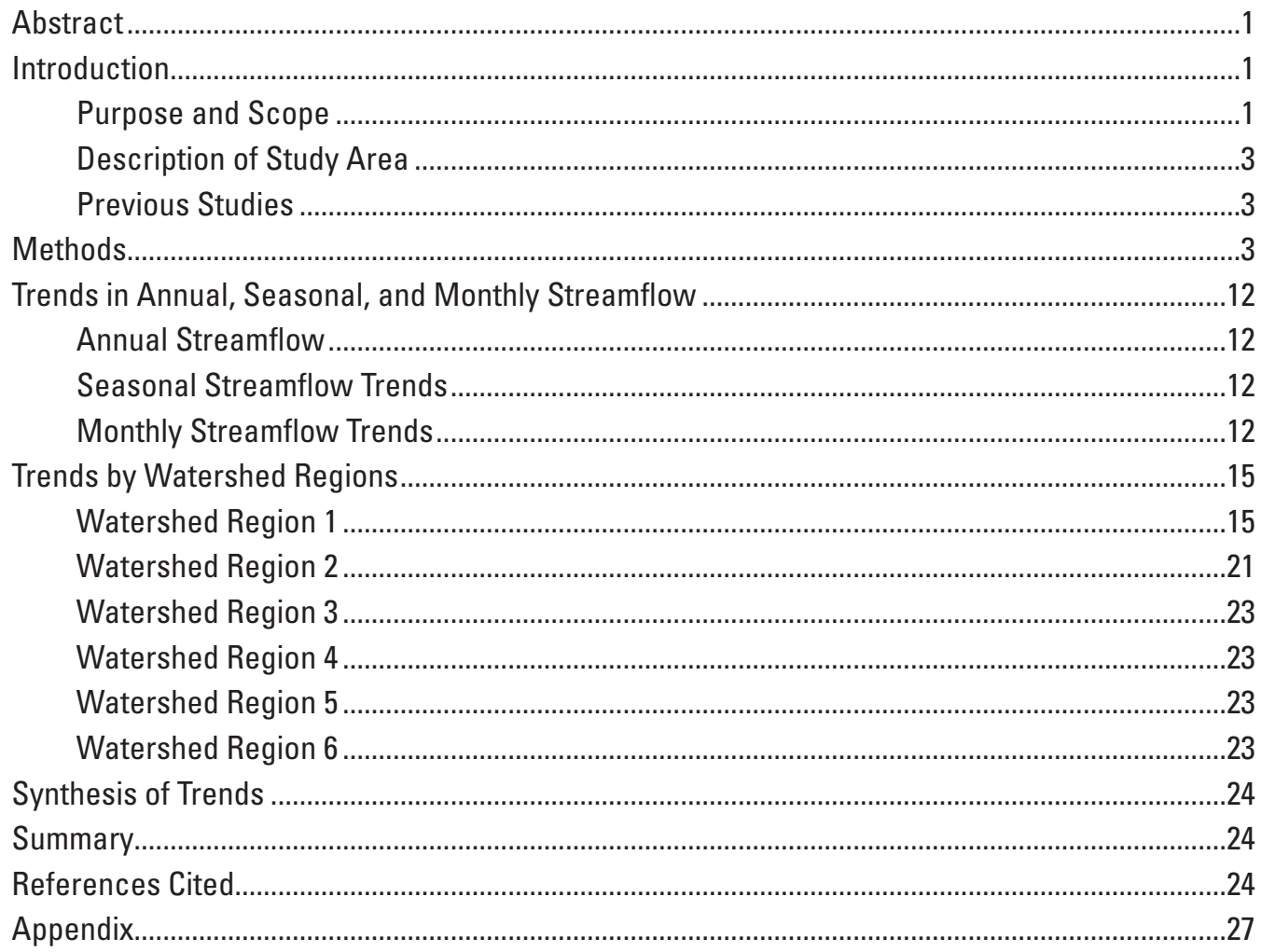

\section{Figures}

1. Map showing the watershed of the Missouri River and its tributaries ...............................2

2. Map showing physiographic provinces in the Missouri River watershed .........................4

3. Graphs showing the Parameter-elevation Regressions on Independent Slopes Model output of total precipitation and minimum and maximum air temperatures in the Missouri River watershed within the United States for water years 1960-2011........6

4. Map showing the Parameter-elevation Regressions on Independent Slopes Model output of mean annual total precipitation in the Missouri River watershed within the United States for water years 1960-2011 ...........................................................

5. Map showing the Parameter-elevation Regressions on Independent Slopes Model output of mean annual of monthly mean daily minimum air temperature in the Missouri River watershed within the United States for water years 1960-2011

6. Map showing the Parameter-elevation Regressions on Independent Slopes Model output of mean annual of monthly mean daily maximum air temperature in the Missouri River watershed within the United States for water years 1960-2011 .............9

7. Map showing ecological regions in the Missouri River watershed .................................10

8. Map showing U.S. Geological Survey streamgages within the Missouri River watershed with continuous streamflow records for water years 1960-2011 .................11

9. Map showing watershed regions within the Missouri River watershed .........................13 
10. Map showing streamgages used to calculate contributions from watershed regions to the total streamflow volume of the Missouri River watershed for water years 1960-2011.....

11. Map showing streamgages in the Missouri River watershed with statistically significant trends in annual streamflow for water years 1960-2011.

12. Map showing streamgages in the Missouri River watershed with statistically significant trends in October-December (autumn) seasonal streamflow and annual streamflow for water years 1960-2011

13. Map showing streamgages in the Missouri River watershed with statistically significant trends in January-March (winter) seasonal streamflow and annual streamflow for water years 1960-2011

14. Map showing streamgages in the Missouri River watershed with statistically significant trends in April-June (spring) seasonal streamflow and annual streamflow for water years 1960-2011

15. Map showing streamgages in the Missouri River watershed with statistically significant trends in July-September (summer) seasonal streamflow and annual streamflow for water years 1960-2011

16. Schematic diagram showing long-term mean annual contributions of streamflow from each watershed region to the total mean annual streamflow of the Missouri River watershed for water years 1960-2011

1-1 to 1-101. Graphs showing annual streamflow trends, October through December streamflow trends, January through March streamflow trends, April through June streamflow trends, and July through September streamflow trends, for streamgages in the Missouri River watershed for water years 1960-2011

\section{Tables}

1. Summary of total precipitation, minimum air temperature, and maximum air temperature from Parameter-elevation Regressions on Independent Slopes Model output for water years 1960-2011

2. Streamflow trends at annual, seasonal, and monthly intervals for each streamgage with a significant annual streamflow trend for water years 1960-2011 ( http://pubs.usgs.gov/sir/2014/5053/downloads/TableDownloadsDirectory/Table2.xlsx)

3. Summary of statistically significant annual streamflow trends for streamgages in the Missouri River watershed for water years 1960-2011.

4. Summary of statistically significant seasonal streamflow trends for streamgages with statistically significant trends in annual streamflow in the Missouri River watershed for water years 1960-2011

5. Summary of statistically significant monthly streamflow trends for streamgages with statistically significant trends in annual streamflow in the Missouri River watershed for water years 1960-2011 (http://pubs.usgs.gov/sir/2014/5053/downloads/ TableDownloadsDirectory/Table5.xIsx)

6. Summary of total precipitation, daily minimum temperature, and daily maximum temperature by watershed region from Parameter-elevation Regressions on Independent Slopes Model output for water years 1960-2011 (http://pubs.usgs.gov/ sir/2014/5053/downloads/TableDownloadsDirectory/Table6.xlsx) 
1-1. Descriptions for streamgages included in statistical analysis, water years 1960-2011 (http://pubs.usgs.gov/sir/2014/5053/downloads/TableDownloadsDirectory/

AppendixTable1-1.x/sx)

1-2. Streamgages used in statistical analyses of trends in annual, seasonal, and monthly streamflow in the Missouri River watershed and results of trend analyses, water years 1960-2011 (http://pubs.usgs.gov/sir/2014/5053/downloads/ TableDownloadsDirectory/AppendixTable1-2.x/sx).....

\section{Conversion Factors}

Inch/Pound to SI

\begin{tabular}{lcl}
\hline & Multiply & \multicolumn{1}{c}{ To obtain } \\
\hline inch (in.) & Length & \\
inch (in.) & 2.54 & centimeter $(\mathrm{cm})$ \\
& 25.4 & millimeter $(\mathrm{mm})$ \\
\hline square mile $\left(\mathrm{mi}^{2}\right)$ & Area & \\
\hline & 2.590 & square kilometer $\left(\mathrm{km}^{2}\right)$ \\
\hline cubic foot per second $\left(\mathrm{ft}^{3} / \mathrm{s}\right)$ & Flow rate & \\
\hline
\end{tabular}

Temperature in degrees Fahrenheit $\left({ }^{\circ} \mathrm{F}\right)$ may be converted to degrees Celsius $\left({ }^{\circ} \mathrm{C}\right)$ as follows:

${ }^{\circ} \mathrm{C}=\left({ }^{\circ} \mathrm{F}-32\right) / 1.8$

Vertical coordinate information is referenced to the North American Vertical Datum of 1988 (NAVD 88).

Water year (WY) is the 12-month period, October 1 through September 30, and is designated by calendar year in which it ends.

\section{Abbreviations}

$\begin{array}{ll}\leq & \text { less than or equal to } \\ \tau & \text { Kendall's tau value } \\ \text { HCDN } & \text { Hydro-Climatic Data Network } \\ \text { LOESS } & \text { locally weighted regression } \\ \text { NWIS } & \text { National Water Information System } \\ \text { PRISM } & \text { Parameter-elevation Regressions on Independent Slopes Model } \\ p \text {-value } & \text { probability value } \\ T_{\max } & \text { monthly means of daily maximum air temperature } \\ T_{\min } & \text { monthly means of daily minimum air temperature } \\ \text { USGS } & \text { U.S. Geological Survey } \\ \text { WR } & \text { watershed region } \\ \text { WY } & \text { water year }\end{array}$





\title{
Trends in Annual, Seasonal, and Monthly Streamflow Characteristics at 227 Streamgages in the Missouri River Watershed, Water Years 1960-2011
}

\author{
By Parker A. Norton, Mark T. Anderson, and John F. Stamm
}

\section{Abstract}

The Missouri River and its tributaries are an important resource that serve multiple uses including agriculture, energy, recreation, and municipal water supply. Understanding historical streamflow characteristics provides relevant guidance to adaptive management of these water resources. Streamflow records in the Missouri River watershed were examined for trends in time series of annual, seasonal, and monthly streamflow. A total of 227 streamgages having continuous observational records for water years 1960-2011 were examined. Kendall's tau nonparametric test was used to determine statistical significance of trends in annual, seasonal, and monthly streamflow. A trend was considered statistically significant for a probability value less than or equal to 0.10 that the Kendall's tau value equals zero. Significant trends in annual streamflow were indicated for 101 out of a total of 227 streamgages. The Missouri River watershed was divided into six watershed regions and trends within regions were examined. The western and the southern parts of the Missouri River watershed had downward trends in annual streamflow (56 streamgages), whereas the eastern part of the watershed had upward trends in streamflow (45 streamgages). Seasonal and monthly streamflow trends reflected prevailing annual streamflow trends within each watershed region.

\section{Introduction}

The Missouri River is the longest river in the United States (Kammerer, 1987) and drains an area of approximately 521,238 square miles $\left(\mathrm{mi}^{2}\right)$, of which $509,655 \mathrm{mi}^{2}$ is within the United States (fig. 1). The watershed includes all or parts of 10 States and small parts of Alberta and Saskatchewan in Canada (fig. 1). Flow on the Missouri River main stem is regulated by six dams located in Montana, North and South Dakota, and Nebraska managed by the U.S. Army Corps of Engineers, and reservoirs created by these dams are an important water, recreation, and energy resource for the region. The two largest reservoirs by surface area in the United States, Lake Sakakawea and Lake Oahe (Bue, 1963), are located along the upper Missouri River in North Dakota and South Dakota, respectively (fig. 1). The authorized purposes of the Missouri River reservoir system are flood control, navigation, hydropower, water supply, water quality, irrigation, recreation, and fish and wildlife (U.S. Army Corps of Engineers, 2006). Major tributaries to the Missouri River include the Yellowstone, Cheyenne, Platte, and Kansas Rivers. Flows in tributaries also are important water resources and serve multiple uses and purposes, such as municipal water supply, agricultural, and recreational uses, as well as providing wildlife habitat. Understanding the changes and trends in historical streamflow along the Missouri River and its tributaries would provide important input to adaptive management of these resources.

\section{Purpose and Scope}

The purpose of this report is to document statistically significant trends in streamflow at 227 U.S. Geological Survey (USGS) streamgages within the Missouri River watershed for water years 1960-2011, and identify regional patterns of streamflow trends; a water year (WY) is the 12-month period, October 1 through September 30, and is designated by the calendar year in which it ends. Annual, seasonal, and monthly streamflow were analyzed for significant trends based on the Kendall's tau nonparametric test (Kendall, 1938). Seasons are defined as October-December (autumn), January-March (winter), April-June (spring), and July-September (summer). Trends in monthly and seasonal streamflow were computed for streamgages with significant trends in annual streamflow based on the Kendall's tau nonparametric test. This criterion identified those monthly and seasonal trends with sufficient magnitude of change in streamflow to affect annual flows at streamgages.

This study did not examine forcing factors that may explain the observed streamflow trends, such as climate change, climate variability, land- and water-use changes, or groundwater pumping; however, possible causes are described in the context of the need for further research. 


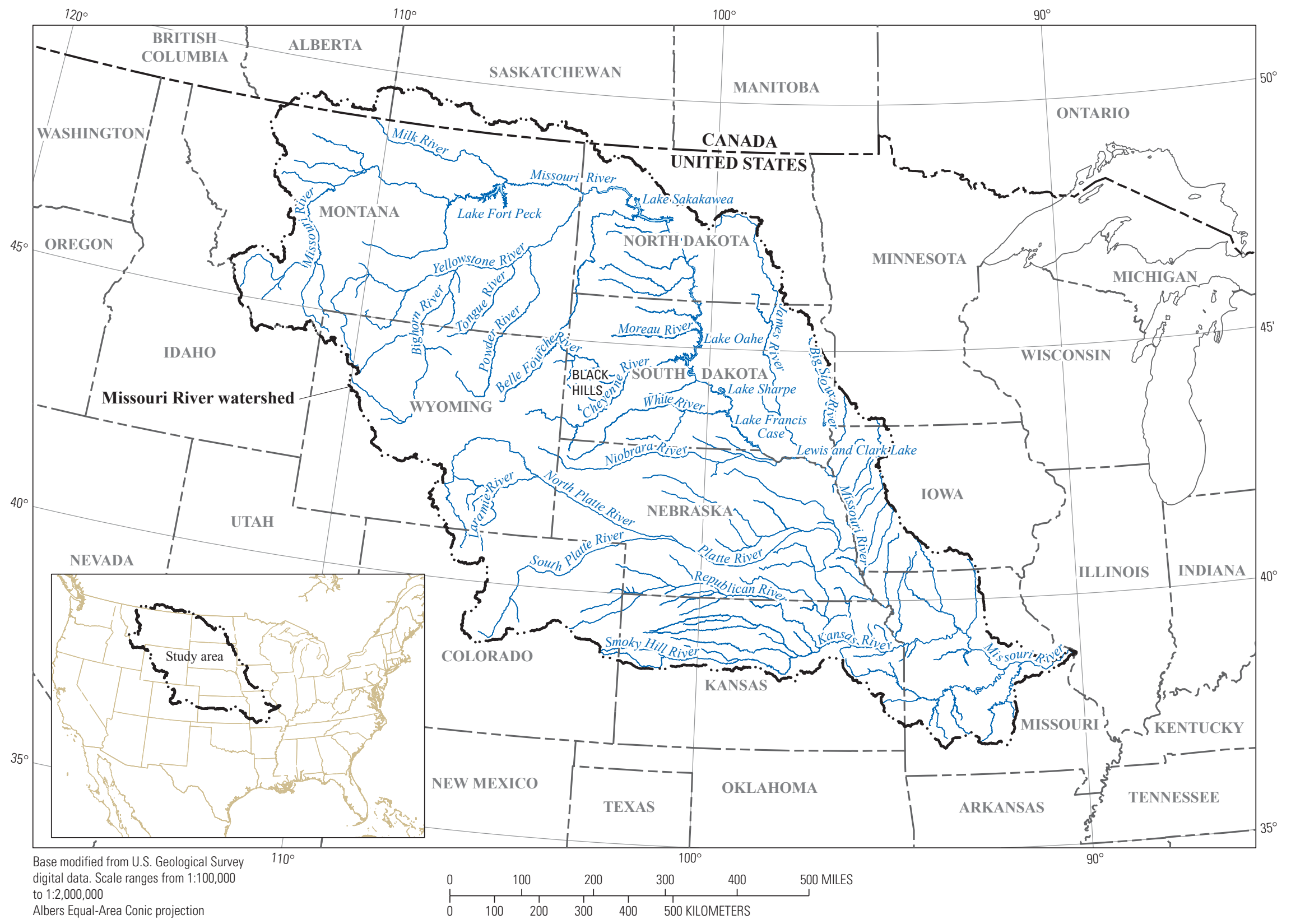

Figure 1. The watershed of the Missouri River and its tributaries. Major reservoirs along the main stem of the Missouri River are labeled. 


\section{Description of Study Area}

The Missouri River watershed hosts a variety of physiographic provinces, ecoregions, and climates. Physiographic provinces are classifications of landscape features, and within the Missouri River watershed include the Northern, Middle, and Southern Rocky Mountains to the west, the Missouri Plateau to the north, and the High Plains to the east and south (fig. 2; Fenneman and Johnson, 1946). The Missouri Plateau and High Plains sections are within the Great Plains physiographic province; the Missouri Plateau is the northern part and the High Plains is the southern part (Fenneman, 1931). The northern part of the Missouri Plateau was glaciated during the Quaternary Period and commonly is referred to as the Prairie Pothole Region, which includes areas outside of the Missouri River watershed.

Climate within the watershed can be estimated using output from the Parameter-elevation Regressions on Independent Slopes Model (PRISM; Daly and others, 1994, 2002), which interpolates monthly means of daily minimum air temperature $\left(T_{\min }\right)$, monthly means of daily maximum air temperature $\left(T_{\max }\right)$, and monthly total precipitation from weather stations to a 2.5-arc-minute grid for the conterminous United States. The PRISM output for the Missouri River watershed (within the United States), averaged for each WY during 1960-2011, and for a 10-year moving average, is shown in figure 3. During WY 1960-2011, mean annual $T_{\min }$ and $T_{\max }$ were 33.1 degrees Fahrenheit $\left({ }^{\circ} \mathrm{F}\right)$ and $58.6{ }^{\circ} \mathrm{F}$, respectively, and the mean annual total precipitation was 20.7 inches (in.) (table 1). Annual total precipitation ranged from 16.0 in. (WY 1988) to $28.1 \mathrm{in}$. (WY 1993), annual means of $T_{\min }$ ranged from $29.7^{\circ} \mathrm{F}$ (WY 1979) to $35.5^{\circ} \mathrm{F}$ (WY 2006), and annual means of $T_{\max }$ ranged from $54.6{ }^{\circ} \mathrm{F}$ (WY 1993) to $62.5^{\circ} \mathrm{F}$ (WY 2000). Precipitation in the Missouri River watershed followed a west-toeast gradient with the least amount of precipitation in the west and the greatest amount of precipitation in the east (fig. 4). The minimum temperatures follow a north-to-south gradient with the warmest temperatures in the southern part of the watershed (fig. 5). Maximum temperatures generally were warmest in the south and coolest in the west (fig. 6).

Ecological regions within the Missouri River watershed reflect regional climate patterns and include Cold Deserts and Western Cordillera in the mountainous west, Semiarid Prairies of the Great Plains in the central part of the Missouri River watershed, and Temperate Prairies to the east (fig. 7; U.S. Environmental Protection Agency, 2006).

\section{Previous Studies}

Previous studies have documented streamflow trends for various time periods and at national and regional scales. Lins and Slack (1999) evaluated streamflow trends for 1914-93 in the conterminous United States and observed upward trends in streamflow across broad sections of the United States with downward trends in the Pacific Northwest and the southeast
United States. Upward trends were most prevalent in annual minimum and median streamflows. Trends were less apparent for annual maximum flows, indicating that the Nation is getting wetter, but less extreme. McCabe and Wolock (2002) observed an abrupt increase in streamflow in the eastern United States in about 1970, coincident with increases in precipitation. In contrast to extreme precipitation events, McCabe and Wolock (2002) observed that flood events had become less extreme. Minimum and median daily streamflows increased east of the 100th meridian during 1941-99. Anderson and Woosley (2005) examined streamflow trends in large western rivers and identified statistically significant (based on the Kendall's tau nonparametric test) upward trends during 1950-2000 for the Columbia and Rio Grande Rivers (not shown). They also noted an apparent, but not statistically significant, upward trend in streamflow for the Missouri River during 1990-2000. Hirsch (2011) noted an anomalous and pronounced upward trend in annual minimum daily streamflow in the Big Sioux River (at Akron, Iowa, 1929-2009), a tributary to the Missouri River. Hirsch and Ryberg (2011) reported significant trends of decreasing peak flows for streamgages with at least 85 years of continuous record through WY 2008 in the northwest United States, which included parts of the Missouri River watershed. Streamflow trends for the Missouri River watershed were analyzed by Anderson and others (2008), who studied trends in streamflow at 202 streamgages in the Missouri River watershed with a continuous record for WY 1957-2007. For streamgages with identified trends (81 streamgages), a spatial pattern emerged of upward trends in the eastern part of the Missouri River watershed and downward trends in the western and southern parts of the watershed.

\section{Methods}

Streamflow records from 227 streamgages (table 1-1) within the Missouri River watershed were examined for trends for WY 1960-2011. This study adds 25 streamgages to the number of streamgages previously analyzed by Anderson and others (2008) and extends the record length to 52 years.

Annual and monthly streamflow records for the USGS streamgages were obtained from the USGS National Water Information System (NWIS) database (U.S. Geological Survey, 2012). Streamgages were required to have a continuous record of monthly and annual streamflow for WY 1960-2011 to be included in this study, resulting in records for 227 streamgages available for analyses (fig. 8). Monthly streamflow records were used to compute seasonal means. Of the 227 streamgages used in the analyses, 54 streamgages are part of the USGS's Hydro-Climatic Data Network (HCDN; Slack and Landwehr, 1992). These HCDN streamgages are considered to have minimal human activities, such as artificial diversions, reservoir storage, or other anthropogenic works in the gaged watershed, and therefore are considered to more clearly express climate variability and change. Comparison of 


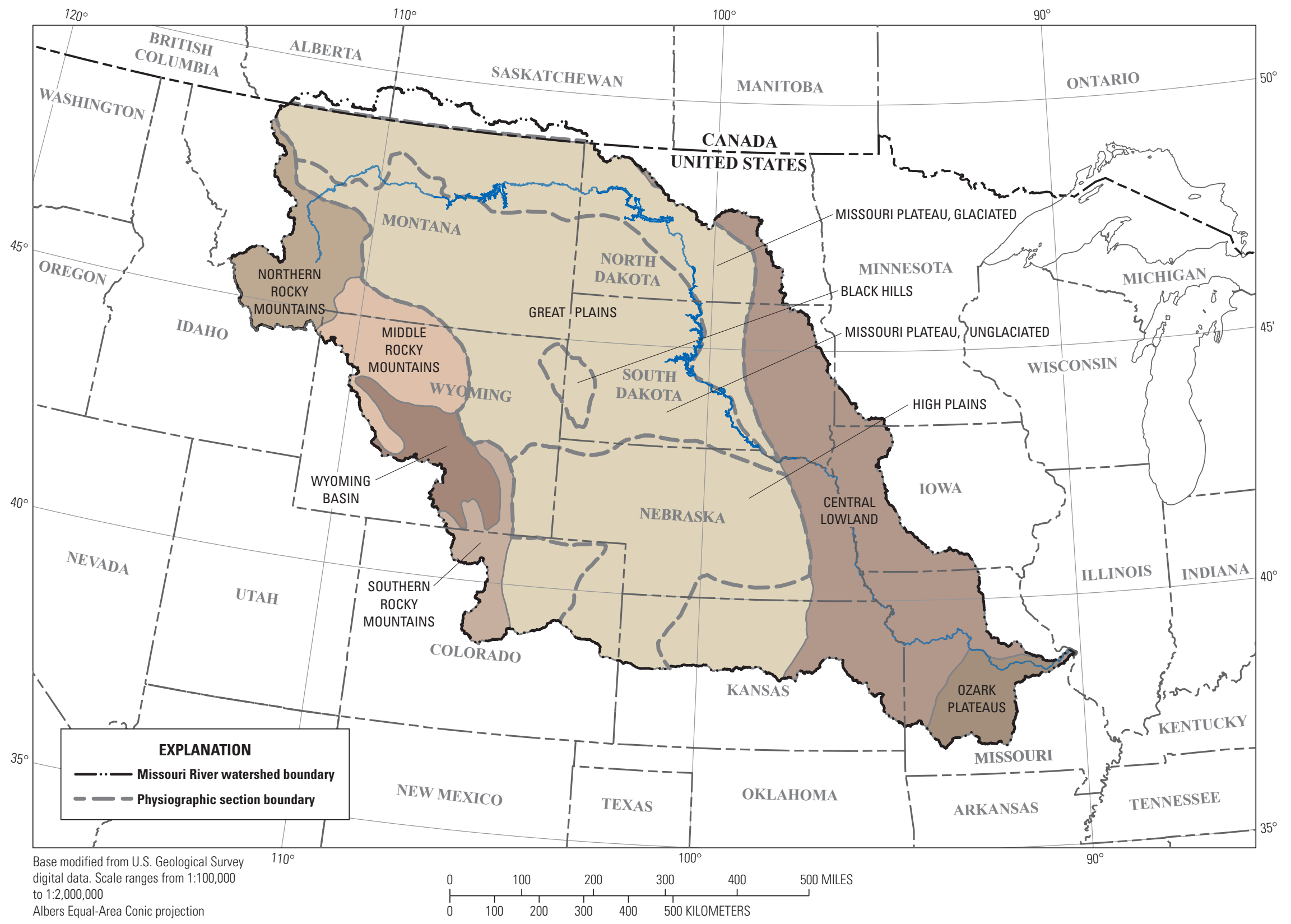

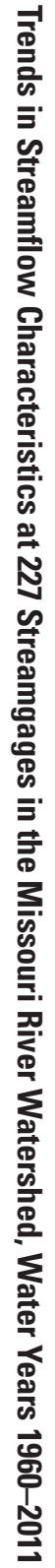

Figure 2. Physiographic provinces in the Missouri River watershed (modified from Fenneman and Johnson, 1946). 
Table 1. Summary of total precipitation, minimum air temperature, and maximum air temperature from Parameter-elevation Regressions on Independent Slopes Model output for water years 1960-2011.

$\left[T_{\text {min }}\right.$, monthly mean of daily minimum temperature; $T_{\max }$, monthly mean of daily maximum temperature; ${ }^{\circ} \mathrm{F}$, degrees Fahrenheit; --, not applicable $]$

\begin{tabular}{|c|c|c|c|c|c|c|}
\hline \multirow{2}{*}{ Statistic } & \multicolumn{2}{|c|}{ Total precipitation } & \multicolumn{2}{|c|}{$T_{\min }$} & \multicolumn{2}{|c|}{$T_{\max }$} \\
\hline & Inches & Water year & ${ }^{\circ} \mathrm{F}$ & Water year & ${ }^{\circ} \mathrm{F}$ & Water year \\
\hline Minimum of annual means for water years 1960-2011 & 16.0 & 1988 & 29.7 & 1979 & 54.6 & 1993 \\
\hline Maximum of annual means for water years 1960-2011 & 28.1 & 1993 & 35.5 & 2006 & 62.5 & 2000 \\
\hline Mean annual for water years $1960-2011$ & 20.7 & -- & 33.1 & -- & 58.6 & -- \\
\hline
\end{tabular}

HCDN streamgages with non-HCDN streamgages allows for inferences regarding climate-forcing factors.

For analysis, the Missouri River watershed was divided into six watershed regions (WRs) based on their geomorphic or hydrologic setting, and numbered sequentially from WR1 to WR6 from upstream to downstream (fig. 9). Watershed region one (WR1) includes the headwaters of the Missouri River, which is an important region with respect to snowpack runoff into main-stem reservoirs. Watershed region two (WR2) is dominated by semiarid prairies with the exception of the Black Hills (fig. 1), which is in the Western Cordillera ecoregion (fig. 7). Watershed region three (WR3) includes a mix of semiarid prairies in the west and temperate prairies in the east contributing streamflow to Lewis and Clark Lake. Watershed region four (WR4) includes the Platte River with the headwaters of the Platte River watershed originating in the high altitudes of the central Rocky Mountains. The westernmost part of this region is a mix of Western Cordillera and Cold Deserts ecoregions that transition to semiarid prairies to the east. Watershed region five (WR5) contains the Republican River, Smoky Hill River, and Kansas River, which constitute the Kansas River drainage area. This region is dominated by the South-Central Semiarid Prairies ecoregion transitioning to Temperate Prairies ecoregion in the easternmost part of the region. Watershed region six (WR6) includes the lower Missouri River as it flows from the Temperate Prairies ecoregion to the north into the Southeastern USA Plains and Ozark/ Ouachita-Appalachian Forests ecoregions. Each watershed region is composed of several 4-digit hydrologic unit code subregions (fig. 9) and generally successively drain into lower reaches of the Missouri River, with the exception of WR5 and WR6.

Within each watershed region, the results are summarized for annual, seasonal, and monthly streamflow by (1) HCDN streamgages and (2) all other streamgages. Additionally, the contribution of each watershed region to the total streamflow volume of the Missouri River watershed was calculated using the long-term mean streamflow from selected streamgages within each watershed region. The long-term mean for each watershed region was calculated for WY 1960-2011. Streamgages used to calculate contributing flows are shown in figure 10. Note that a streamgage near the outlet of WR2 was not available, so streamflow was estimated by integrating streamflow of tributary streams to the Missouri River. The climate within each watershed region is estimated using annual averages of precipitation, minimum daily air temperature, and maximum daily air temperature from the PRISM model output. Results of the analyses were analyzed and graphed using the R statistical package (Venables and others, 2013). Graphs of annual and seasonal streamflow trends are provided for streamgages with significant annual trends.

Kendall's tau nonparametric test (Kendall, 1938) was used to determine statistical significance of trends in annual, seasonal, and monthly streamflow. A trend was considered statistically significant for a probability value ( $p$-value) less than or equal to $(\leq) 0.10$ that the Kendall's tau value equals zero. Although a more restrictive $p$-value would reduce the Type I error, the spatial distribution of the observed trends is underscored with the relaxed $p$-value and is a reasonable compromise for a natural system. A Type I error occurs when the null hypothesis that Kendall's tau equals zero is rejected when true, or, otherwise stated, accepting a trend when, in fact, no trend exists. Relaxation of the Type I error probability also reduces the probability of a Type II error. A Type II error occurs when the null hypothesis that Kendall's tau equals zero is accepted when not true, or, otherwise stated, rejecting a trend when, in fact, a trend exists.

Kendall's tau measures the degree of correspondence between two variables (for example, $x$ and $y$ ). For this analysis, the $y$ variable is streamflow and the $x$ variable is time. A concordant pair occurs when both $x$ and $y$ variables increase or decrease; a discordant pair occurs when $x$ increases and $y$ decreases or $x$ decreases and $y$ increases. The number of concordant pairs and the number of discordant pairs were tallied for each streamgage and the Kendall's tau value $(\tau)$ was computed according to the following equation:

$$
\tau=\frac{C-D}{n(n-1) / 2}
$$

where

$C$ is the number of concordant pairs,

$D \quad$ is the number of discordant pairs, and

$n \quad$ is the sample size. 

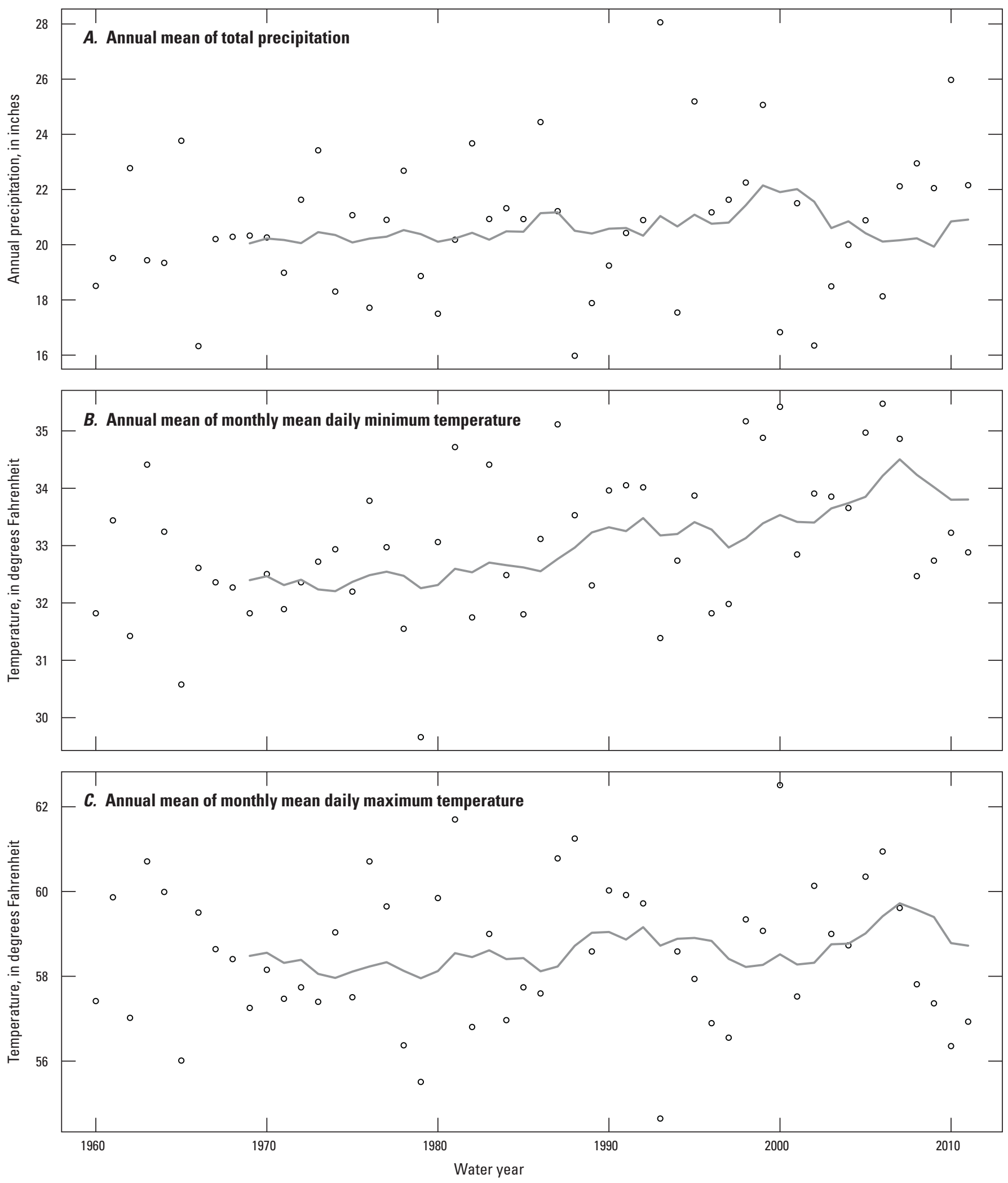

Figure 3. The Parameter-elevation Regressions on Independent Slopes Model output of total precipitation and minimum and maximum air temperatures in the Missouri River watershed within the United States for water years 1960-2011. A, annual mean of total precipitation; $B$, annual mean of monthly mean daily minimum air temperature; and $C$, annual mean of monthly mean daily maximum air temperature. 


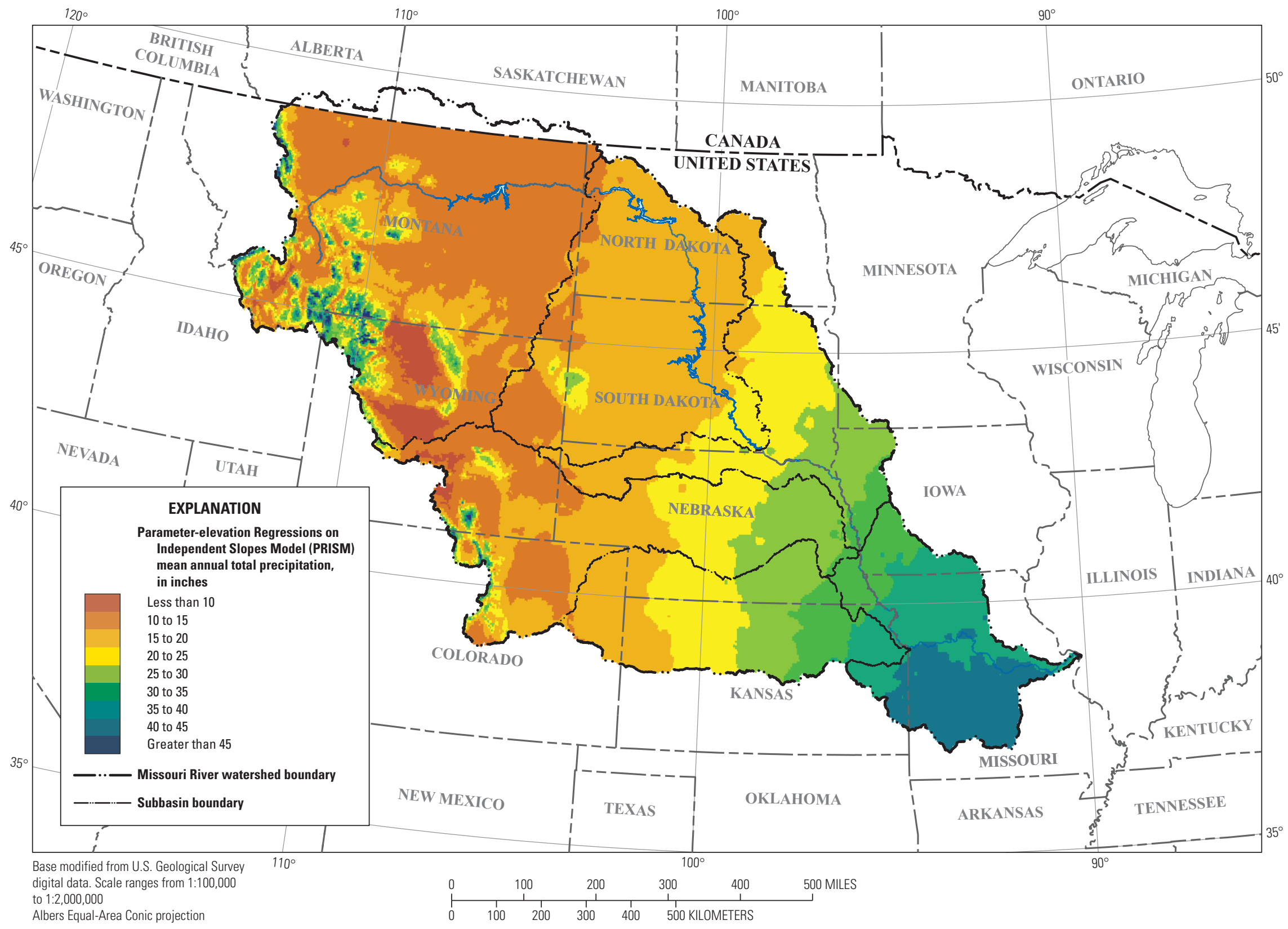

Figure 4. The Parameter-elevation Regressions on Independent Slopes Model output of mean annual total precipitation in the Missouri River watershed within the United States for water years 1960-2011. 


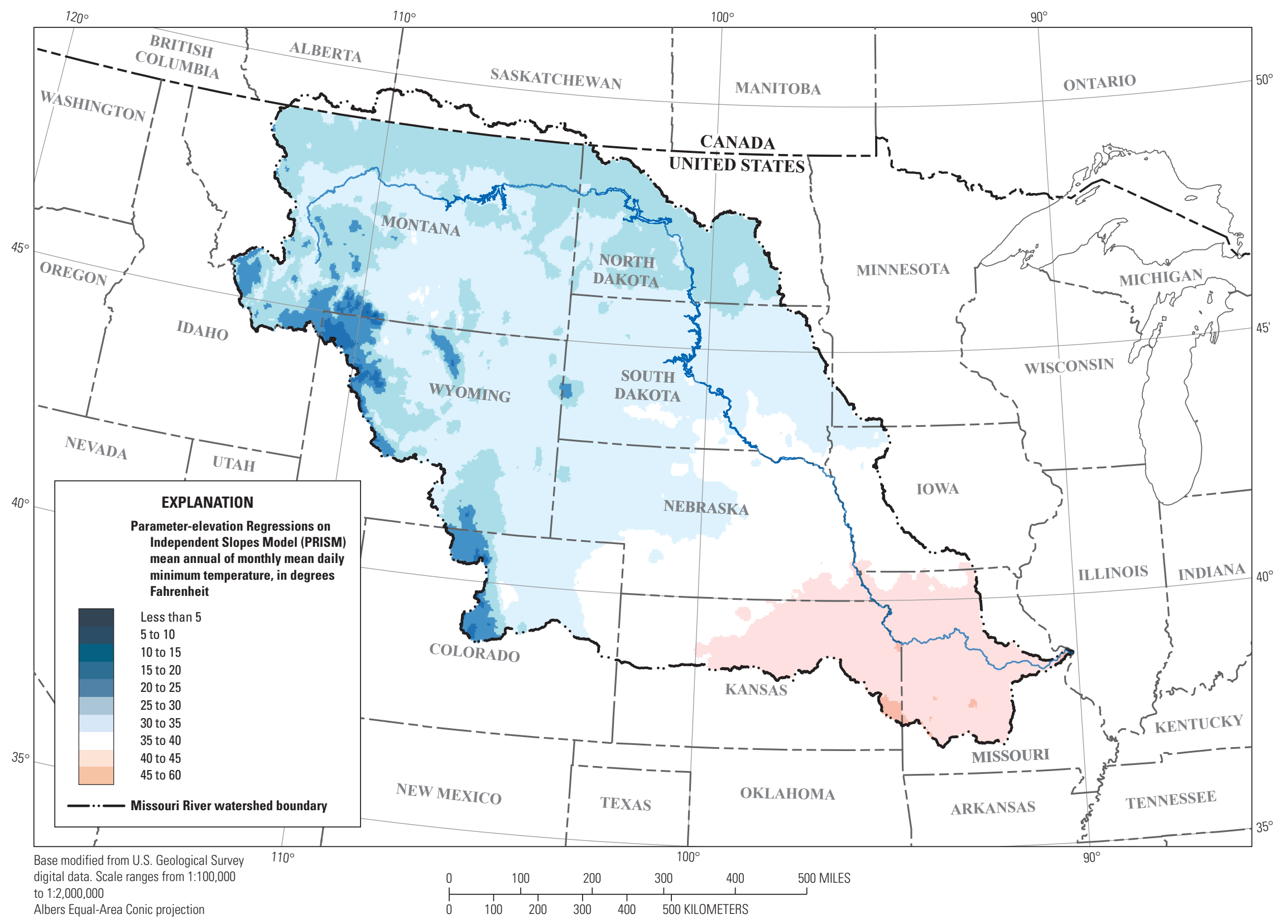

Figure 5. The Parameter-elevation Regressions on Independent Slopes Model output of mean annual of monthly mean daily minimum air temperature in the Missouri River watershed within the United States for water years 1960-2011. 


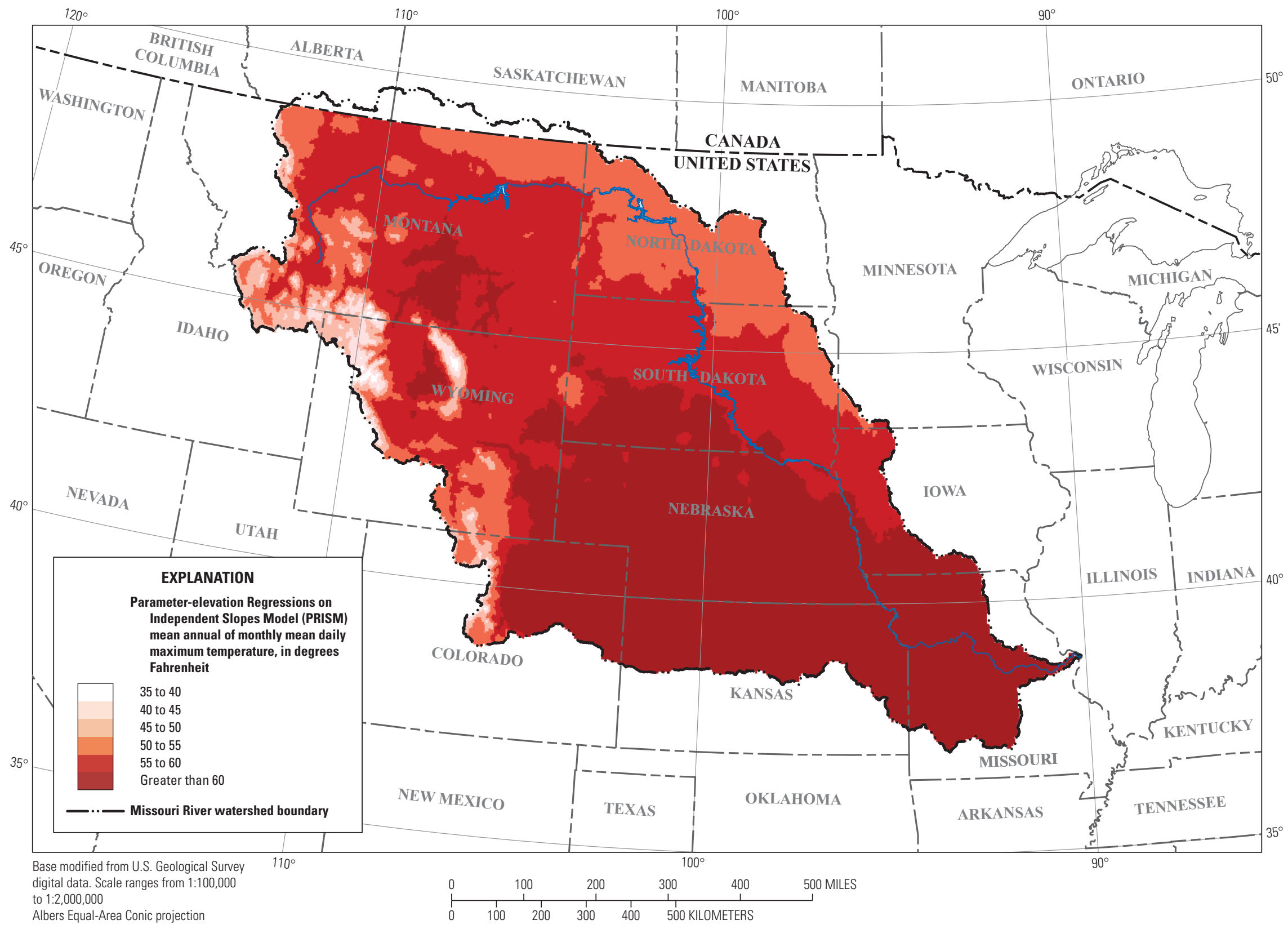

Figure 6. The Parameter-elevation Regressions on Independent Slopes Model output of mean annual of monthly mean daily maximum air temperature in the Missouri River 


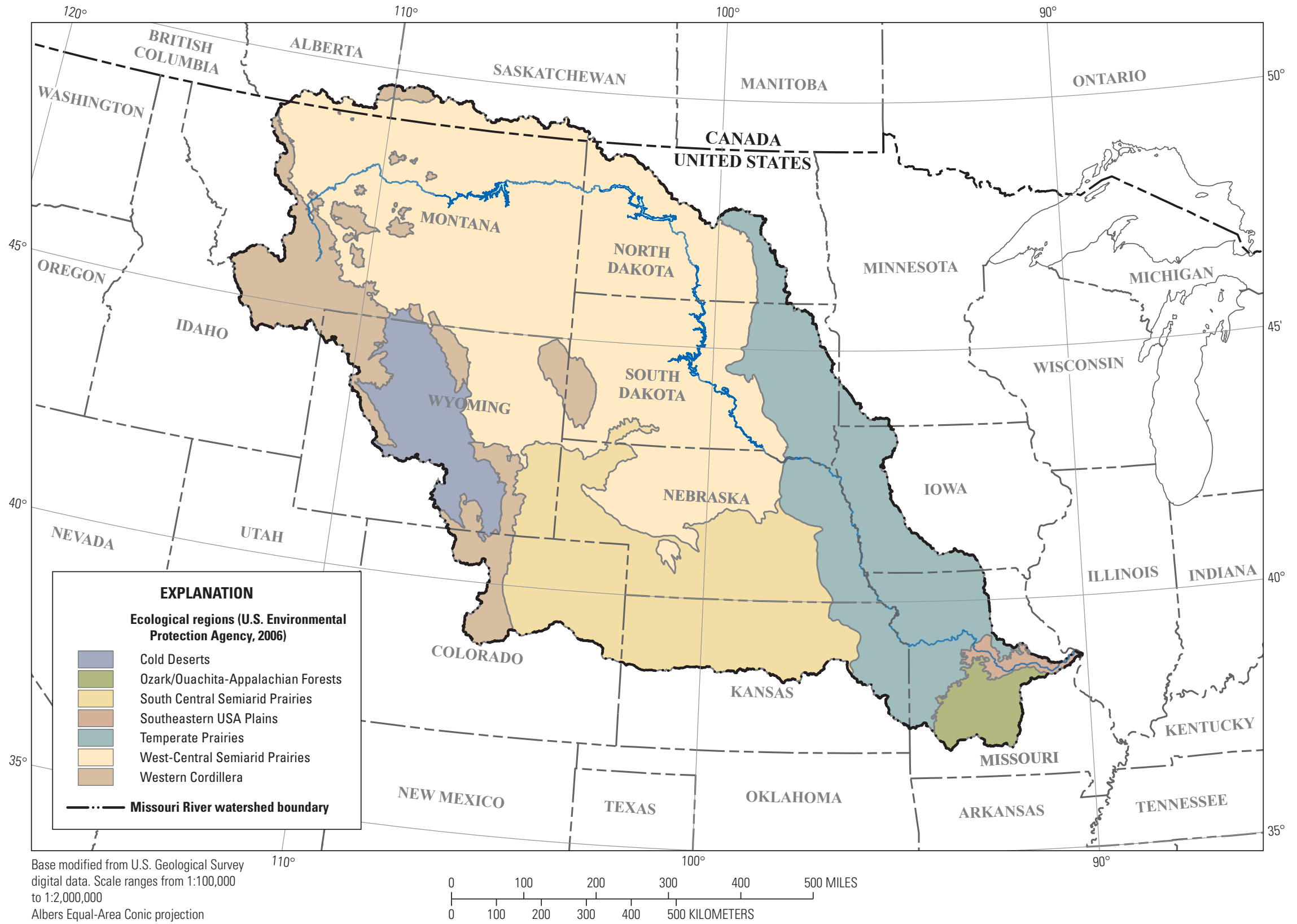

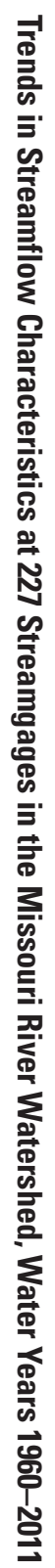

Figure 7. Ecological regions in the Missouri River watershed. 


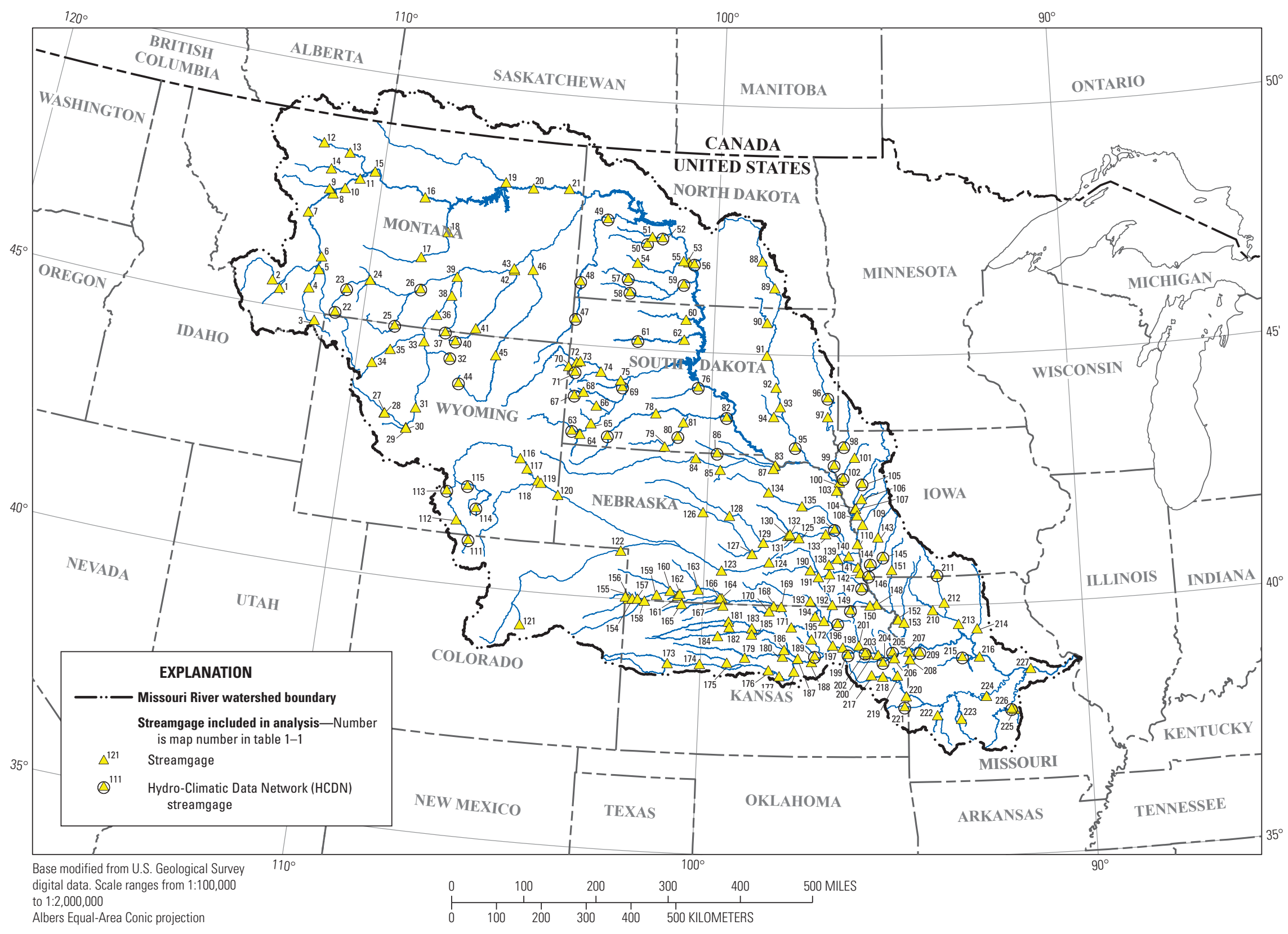

Figure 8. U.S. Geological Survey streamgages within the Missouri River watershed with continuous streamflow records for water years 1960-2011. 
If the data exhibit perfect positive correlation, then $\tau=1$; if there is perfect negative correlation, then $\tau=-1$; and if there is no correlation between the pairs, then $\tau=0$. Therefore, a positive $\tau$ is associated with an upward trend and a negative $\tau$ is associated with a downward trend.

Times-series streamflow data were plotted, and a locally weighted regression (LOESS) curve was plotted as an aid in visualizing significant trends. The LOESS curve is a multivariate smoothing procedure that is applied to a time series (Cleveland and Devlin, 1988). Note that plots of precipitation and temperature (fig. 3) indicate a 10 -year moving average curve rather than a LOESS curve.

\section{Trends in Annual, Seasonal, and Monthly Streamflow}

Trends in annual, seasonal, and monthly streamflow for all 227 streamgages analyzed for this study are included in table 1-2 in the "Appendix" section. Trends in annual, seasonal, and monthly streamflow are described in the following subsections for those streamgages within the Missouri River watershed that had significant annual trends based on the Kendall's tau nonparametric test.

\section{Annual Streamflow}

Streamgages in the Missouri River watershed were examined for statistically significant trends in annual streamflow for water years 1960-2011. Significant trends $(p$-value $\leq 0.10)$ in annual streamflow were indicated for 101 out of 227 streamgages (tables 2, 3, and 1-2). Dominant trends are prevalent in several watershed regions (fig. 11). The western and the southern parts of the Missouri River watershed had downward trends in annual streamflow (56 streamgages, mostly in WR1 and WR5), whereas the eastern part of the watershed had upward trends in streamflow (45 streamgages; WR3 and eastern part of WR4).

Graphs of the annual and seasonal streamflow trends for each of the 101 streamgages in the Missouri River watershed that had significant annual streamflow trends are presented in figures 1-1 through 1-101 in the "Appendix" section of this report. Five graphs are presented for each streamgage: annual mean streamflow and seasonal (quarterly) mean streamflows for October-December (autumn), January-March (winter), April-June (spring), and July-September (summer) for WY 1960-2011.

\section{Seasonal Streamflow Trends}

Streamgages with significant trends in annual streamflow were analyzed for any significant changes in seasonal streamflow, with the exception of streamgages 06099500 and 06827500 (map numbers 12 and 158) because of gaps in the monthly data. Seasonal trends for all 227 streamgages are presented in table 1-2; however, seasonal trends for the 101 streamgages with significant annual trends are described in this and subsequent sections of the report. Significant trends in seasonal streamflow were determined at streamgages for autumn (80), winter (73), spring (67), and summer (71) (table 4; figs. 12-15, respectively). Trends in seasonal streamflow by watershed region reflect the dominant upward or downward trends indicated by the annual streamflow, and trends tended to persist across one or more consecutive seasons. A summary of seasonal streamflow trends for each watershed region is listed in table 4 . Summer had the greatest number of upward trends (41), whereas winter had the fewest number of upward trends (31). Winter had the greatest number of downward trends (42) attributed mostly to 24 streamgages in WR1 (most upstream watershed region) and to 16 streamgages in WR5 (Republican River, a tributary to the Kansas River). The fewest significant downward seasonal streamflow trends were in spring (30) and summer (30).

\section{Monthly Streamflow Trends}

Monthly streamflow trends for streamgages with a significant trend in annual streamflow are summarized in table 5. Observed monthly streamflow trends tended to persist across one or more consecutive months. January had the greatest number of upward streamflow trends (45), whereas March had the fewest number of upward streamflow trends (18). The greatest number of significant downward monthly streamflow trends was in February (44), and the fewest number of downward trends was in May (18). 


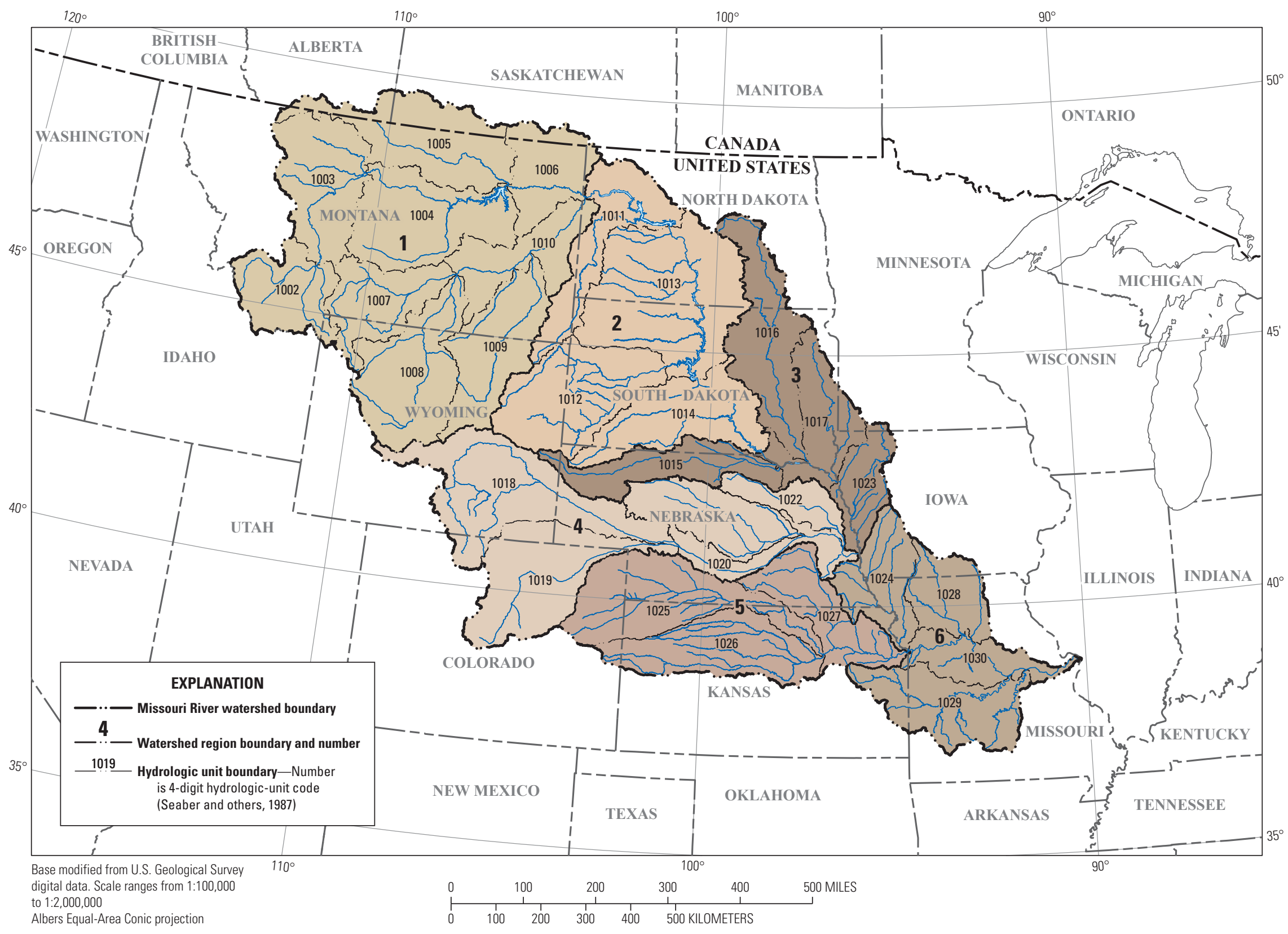

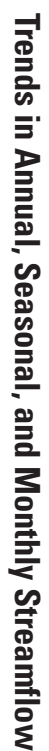

Figure 9. Watershed regions within the Missouri River watershed. 


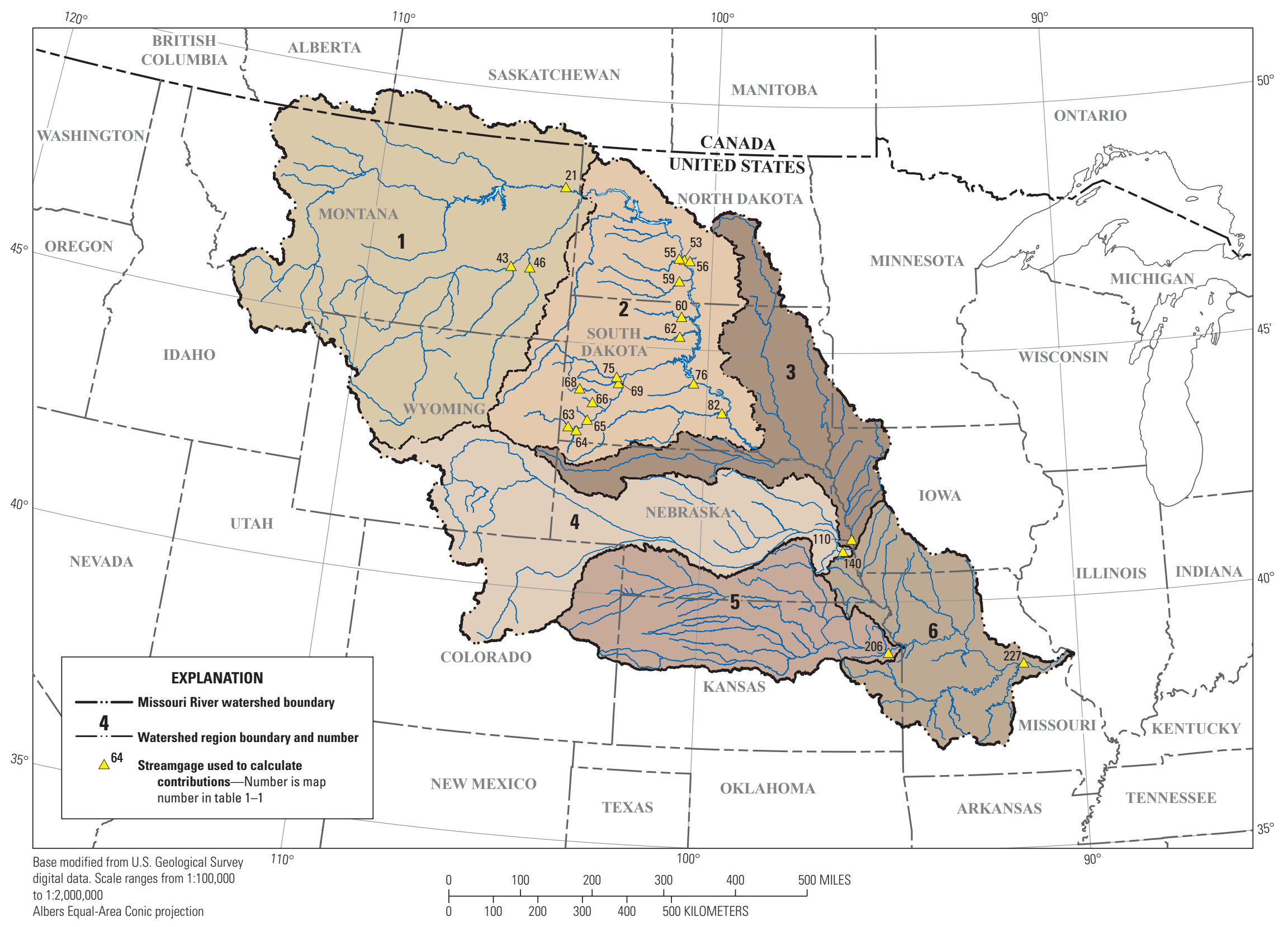

Figure 10. Streamgages used to calculate contributions from watershed regions to the total streamflow volume of the Missouri River watershed for water years 1960-2011. 
Table 3. Summary of statistically significant annual streamflow trends for streamgages in the Missouri River watershed for water years 1960-2011.

[Significant trends are based on probability values ( $p$-values) less than or equal to 0.10 for Kendall's tau nonparametric test (Kendall, 1938). HCDN, HydroClimatic Data Network; WR, watershed region]

\begin{tabular}{|c|c|c|c|c|c|c|}
\hline \multirow{2}{*}{$\begin{array}{l}\text { Watershed } \\
\text { region } \\
\text { (fig. 9) }\end{array}$} & \multicolumn{3}{|c|}{ HCDN streamgages } & \multicolumn{3}{|c|}{ All other streamgages } \\
\hline & $\begin{array}{c}\text { Available } \\
\text { streamgages }\end{array}$ & Upward & Downward & $\begin{array}{c}\text { Available } \\
\text { streamgages }\end{array}$ & Upward & Downward \\
\hline WR1 & 8 & 0 & 2 & 38 & 0 & 28 \\
\hline WR2 & 18 & 3 & 0 & 18 & 4 & 1 \\
\hline WR3 & 7 & 7 & 0 & 21 & 16 & 0 \\
\hline WR4 & 5 & 1 & 0 & 25 & 7 & 1 \\
\hline WR5 & 6 & 0 & 0 & 47 & 0 & 24 \\
\hline WR6 & 10 & 4 & 0 & 24 & 3 & 0 \\
\hline Total & 54 & 15 & 2 & 173 & 30 & 54 \\
\hline
\end{tabular}

\section{Trends by Watershed Regions}

The contribution of streamflow volume for WY 1960-2011 from each watershed region within the Missouri River watershed to the total volume is summarized in figure 16. The mean annual streamflow contribution from the Missouri River watershed to the Mississippi River watershed was 89,400 cubic feet per second $\left(\mathrm{ft}^{3} / \mathrm{s}\right)$ at streamgage 06934500 (map number 227). This streamgage had no significant trends in annual streamflow. Each of the watershed regions are dominated by either upward or downward trends (table 2). This consistency within watershed regions contrasts with the variability among watershed regions, as described further in the following subsections.

\section{Watershed Region 1}

The headwaters of the Missouri River are represented by WR1, which supplies a mean of 25 percent of the total streamflow of the Missouri River watershed (fig. 16). This watershed region had a mean annual total precipitation of 15.9 in., a mean annual $T_{\min }$ of $29.3^{\circ} \mathrm{F}$, and a mean annual $T_{\max }$ of $55.4^{\circ} \mathrm{F}$ for WY 1960-2011 (table 6). A total of 30 streamgages, of which 2 were HCDN streamgages, in this watershed region had significant trends in annual streamflow, all of which were downward (table 3).
Trends in seasonal streamflow reflected the trends in annual streamflow for streamgages in WR1 (table 1-2). The winter season (January-March) had the greatest number of streamgages with significant downward streamflow trends (24), whereas the summer season (July-September) had the fewest number of streamgages with downward streamflow trends ( 7 ; table 4). Two streamgages were exceptions to the dominant downward trends in seasonal streamflow. Streamgage 06101500 (map number 13) had a significant upward trend in the winter season and significant downward trends in the spring and summer seasons. Streamgage 06278300 (map number 32) had a significant upward trend in the winter season and a significant downward trend in the spring.

Significant trends in monthly streamflow are consistent with annual streamflow trends (table 1-2). February had the greatest number of streamgages with downward trends (26), whereas May, June, and July had the fewest number of streamgages with downward streamflow trends (5; table 5). Two streamgages had exceptions to the dominant downward monthly streamflow trends. Streamgage 06101500 (map number 13) had upward monthly streamflow trends for December, January, and February and downward monthly streamflow trends for October, May, June, July, and September. Streamage 06278300 (map number 32) had upward trends for January, February, March, and April, and a significant downward trend in June. 


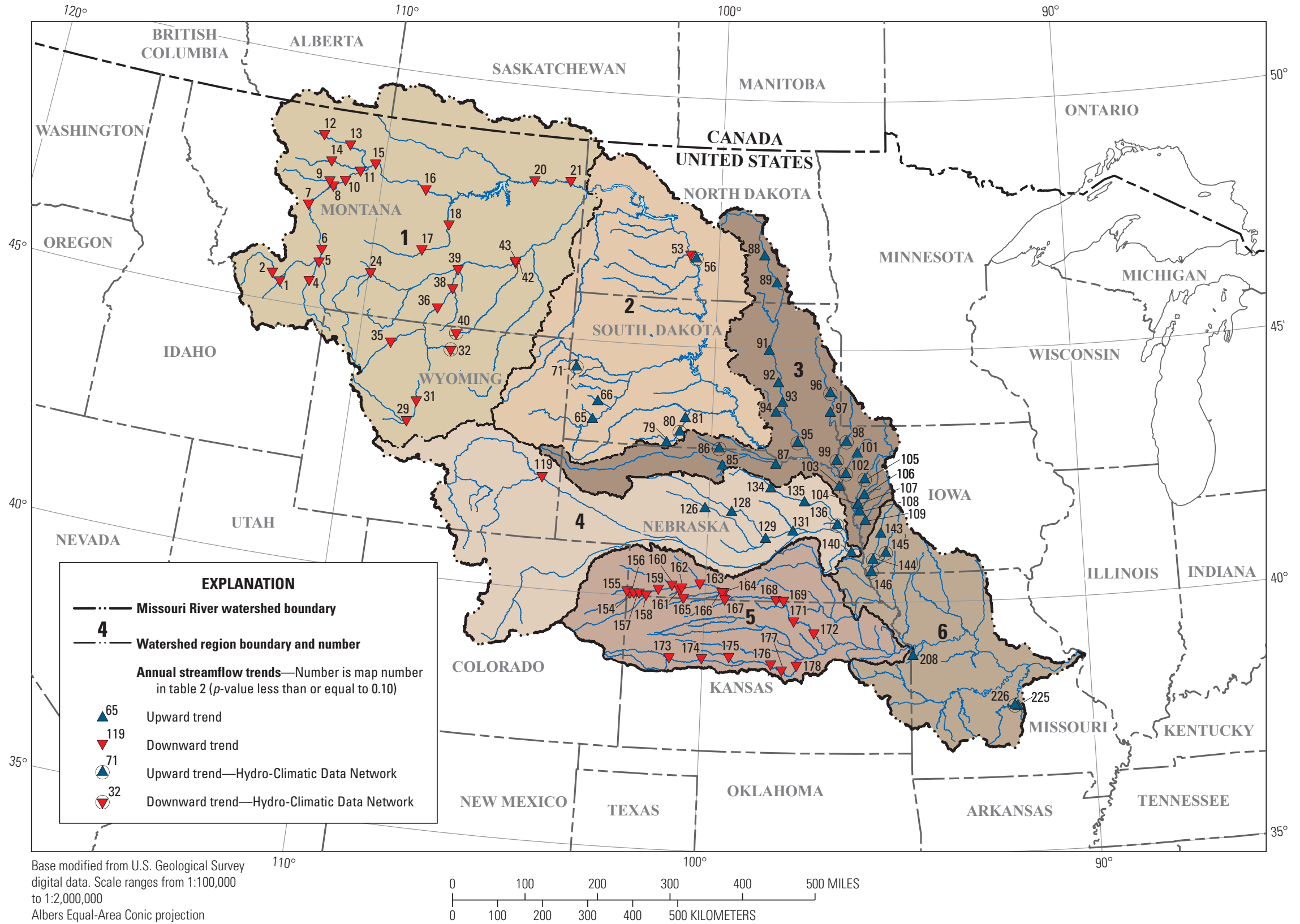

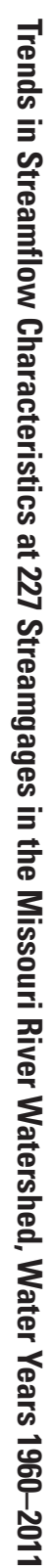

Figure 11. Streamgages in the Missouri River watershed with statistically significant trends in annual streamflow for water years 1960-2011. 


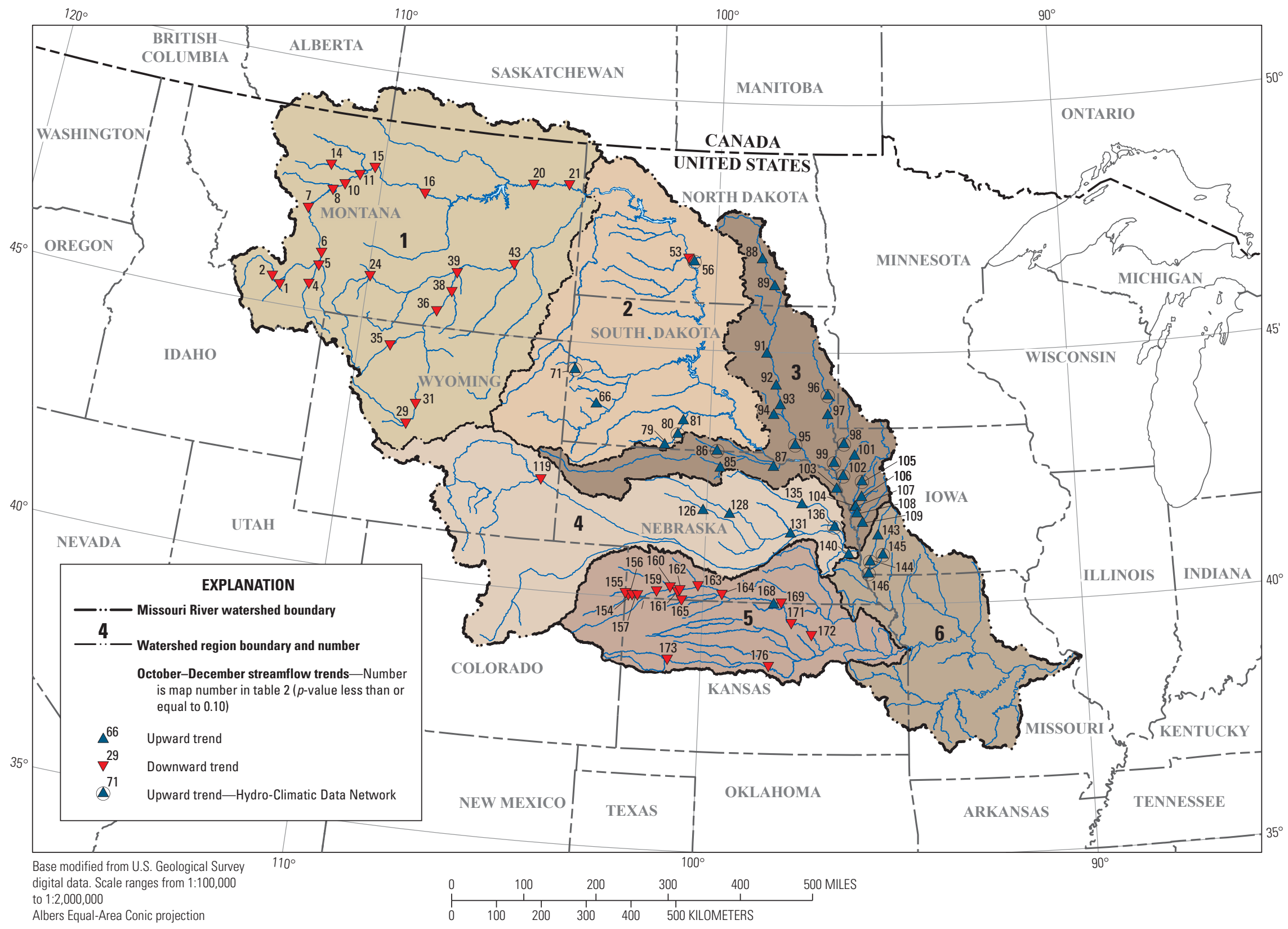

Figure 12. Streamgages in the Missouri River watershed with statistically significant trends in October-December (autumn) seasonal streamflow and annual streamflow for water years 1960-2011. 


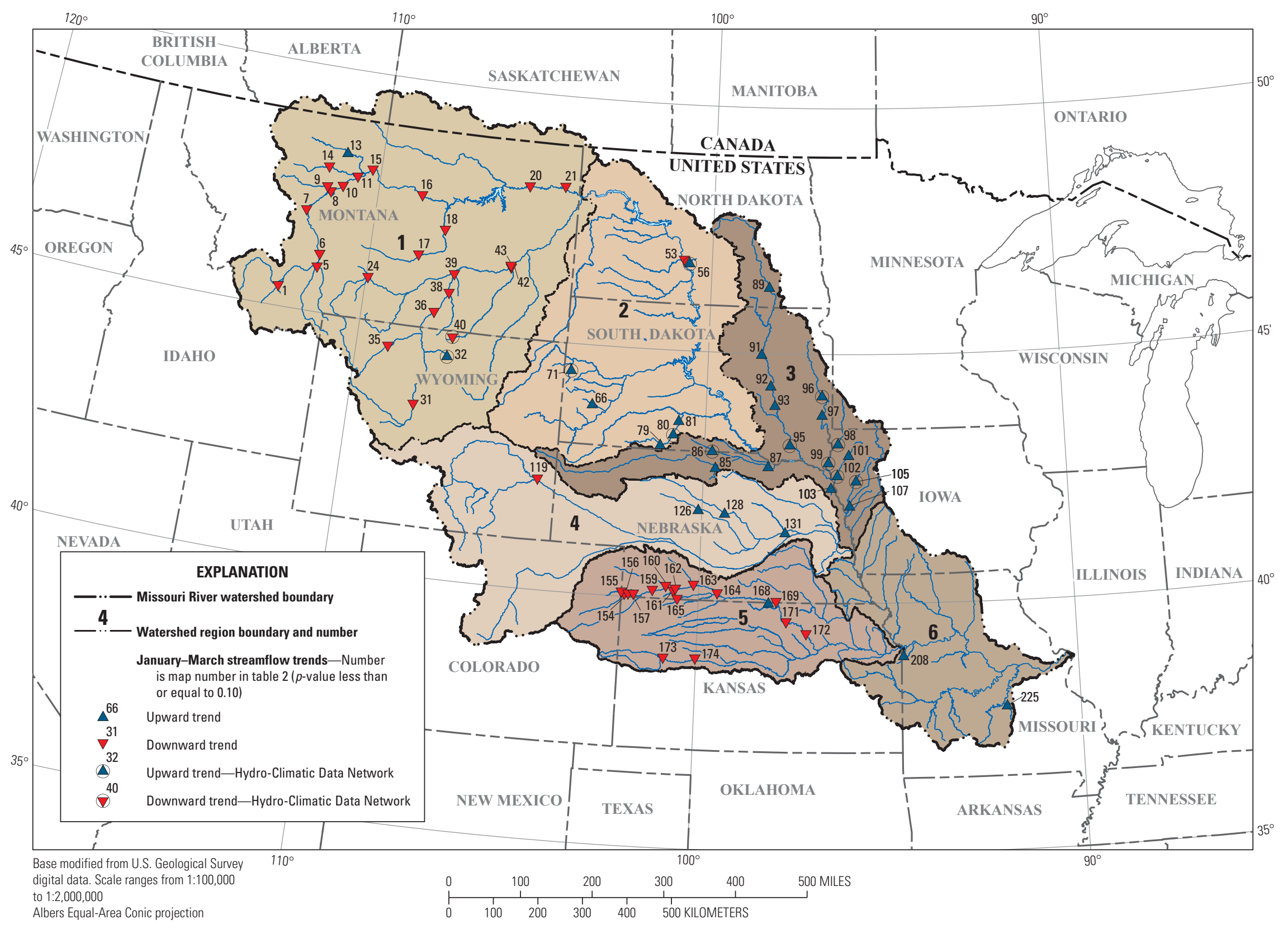

Figure 13. Streamgages in the Missouri River watershed with statistically significant trends in January-March (winter) seasonal streamflow and annual streamflow for water years 1960-2011. 


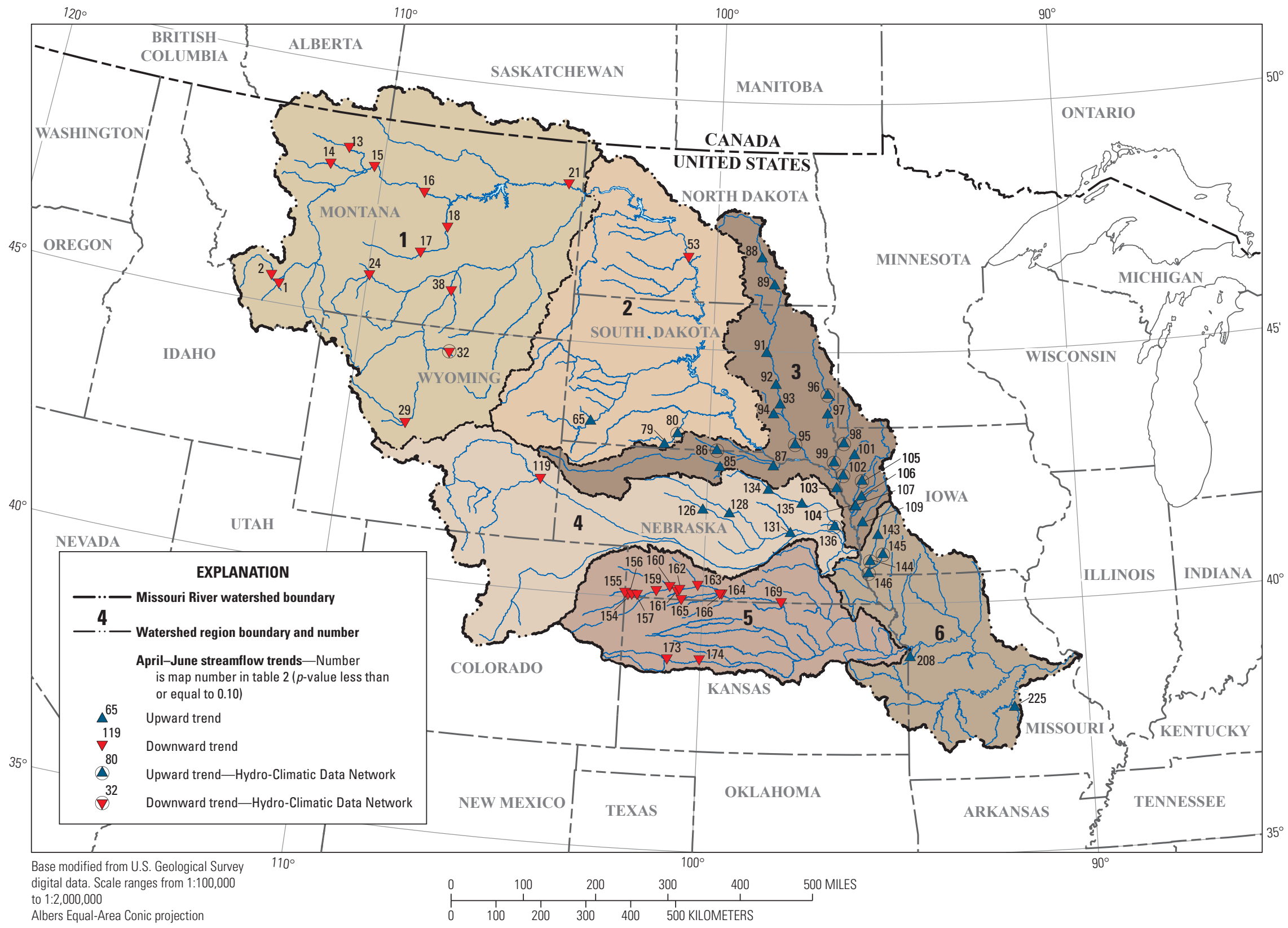

Figure 14. Streamgages in the Missouri River watershed with statistically significant trends in April-June (spring) seasonal streamflow and annual streamflow for water years 1960-2011. 


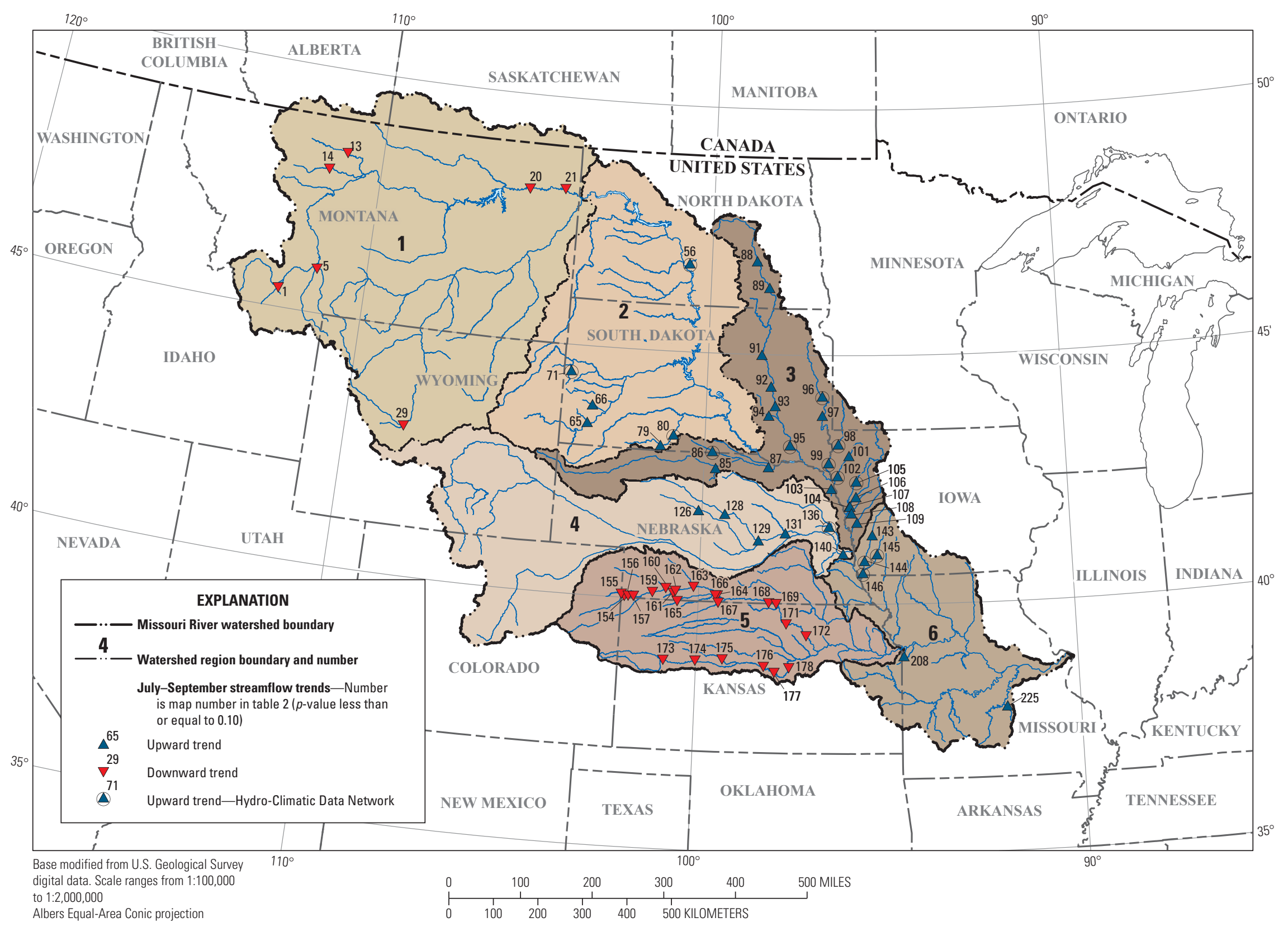

Figure 15. Streamgages in the Missouri River watershed with statistically significant trends in July-September (summer) seasonal streamflow and annual streamflow for water years 1960-2011. 
Table 4. Summary of statistically significant seasonal streamflow trends for streamgages with statistically significant trends in annual streamflow in the Missouri River watershed for water years 1960-2011.

[Significant trends are based on probability values ( $p$-values) less than or equal to 0.10 for Kendall's tau nonparametric test (Kendall, 1938). WR, watershed region]

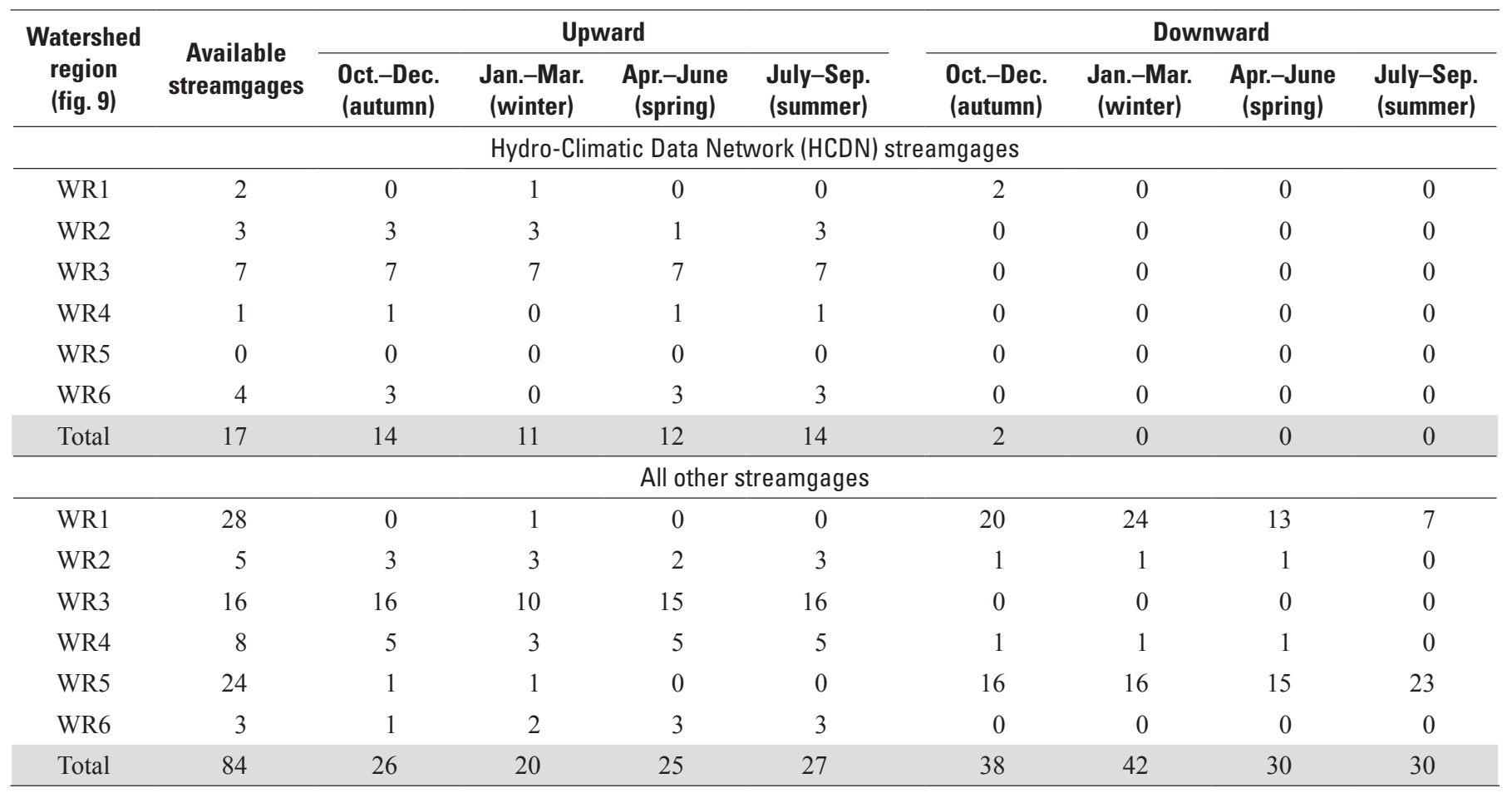

\section{Watershed Region 2}

Unglaciated parts of the Missouri Plateau are represented by WR2, which contributes 4 percent of the total average streamflow of the Missouri River watershed (fig. 16). This watershed region had a mean annual precipitation of $17 \mathrm{in}$., a mean annual $T_{\min }$ of $31.4^{\circ} \mathrm{F}$, and a mean annual $T_{\max }$ of $57.0^{\circ} \mathrm{F}$ (table 6). A total of 8 streamgages including $3 \mathrm{HCDN}$ streamgages in WR2 had significant trends in annual streamflow. Trends in annual streamflow were significantly upward for 7 streamgages, of which 3 streamgages are part of the HCDN subset (table 3). Of particular interest is streamgage 06342500 (map number 53) on the main stem of the Missouri River below Lake Sakakawea, which had a significant downward trend in annual streamflow. This streamgage is the downstream-most USGS streamgage below a main-stem reservoir on the Missouri River that had a significant annual trend for WY 1960-2011.

Trends in seasonal streamflow were dominated by significant upward trends (table 4). Autumn (October-December), winter (January-March), and summer (July-September) had the greatest number of upward trends (6), whereas spring
(April-June) had the fewest number of upward trends (3). Streamgage 06342500 (map number 53) was the only exception to the dominant upward seasonal trends in this watershed region with significant downward trends in autumn, winter, and spring. This may reflect a continuation of downward trends from WR1 on this part of the Missouri River.

The months with the greatest number of streamgages with upward trends were October, August, and September (7), whereas the months with the fewest number of streamgages with upward trends were June and July (3). January had the greatest number of streamgages with downward trends (2) and October, November, December, February, March, and April had the fewest number of streamgages with downward trends ( 1 each; table 5). Two streamgages had exceptions to the dominant upward monthly trends. Streamgage 06342500 (map number 53) had significant downward trends in monthly streamflow for October through April and no significant streamflow trends for the other months. Streamgage 06402500 (map number 65) had a significant downward trend in monthly streamflow for January and significant upward trends for October, April, May, June, August, and September. 


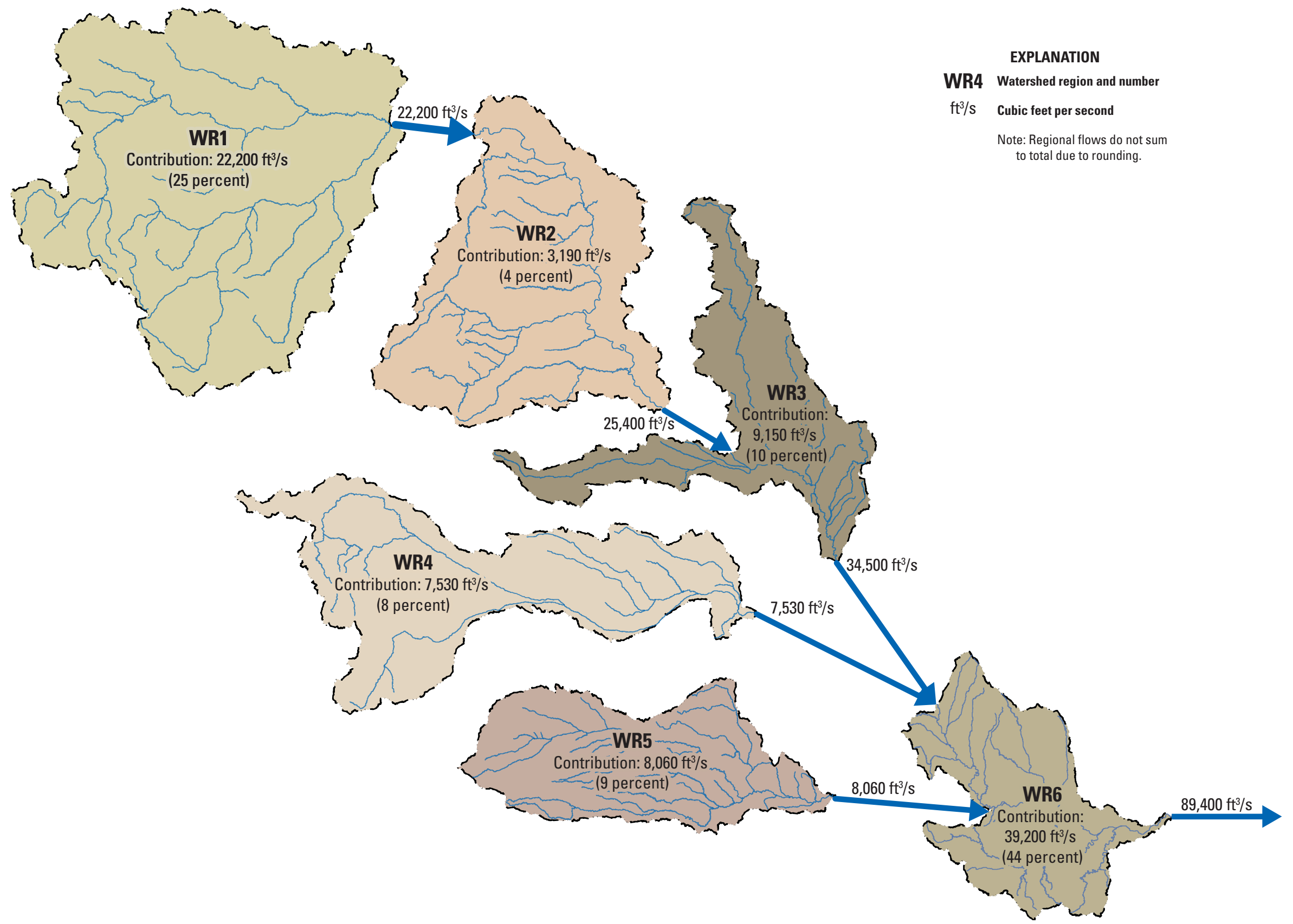

Figure 16. Long-term mean annual contributions of streamflow from each watershed region (WR) to the total mean annual streamflow of the Missouri River watershed for water years 1960-2011. 


\section{Watershed Region 3}

The Niobrara River watershed and glaciated parts of the Missouri Plateau are represented by WR3, which contributes 10 percent of the total average streamflow of the Missouri River watershed and drains into WR6 (fig. 16). This region had a mean annual precipitation of 23.0 in., a mean annual $T_{\min }$ of $33.6^{\circ} \mathrm{F}$, and a mean annual $T_{\max }$ of $57.3^{\circ} \mathrm{F}$ (table 6). A total of 23 streamgages, of which 7 are HCDN streamgages, in this region had significant trends in annual streamflow, all of which were upward (table 3). No trends in annual, seasonal, or monthly streamflow in WR3 were significantly downward.

Trends in seasonal streamflow were consistent with trends in annual streamflow (table 4). Autumn (OctoberDecember) and summer (July-September) had the greatest number of streamgages with upward trends (23), whereas winter (January-March) had the fewest number of streamgages with upward streamflow trends (17). Trends in monthly streamflow (table 5) were consistent with the upward annual streamflow trends. October through February, and May, July, and August had the greatest number of streamgages with significant upward streamflow trends (23), whereas March had the fewest number of streamgages with significant upward streamflow trends (8).

\section{Watershed Region 4}

Watershed region 4 represents the Platte River watershed, which supplies 8 percent of the total streamflow for the Missouri River watershed (fig. 16). This watershed region had a mean annual precipitation of 19.2 in., a mean annual $T_{\min }$ of $32.7^{\circ} \mathrm{F}$, and a mean annual $T_{\max }$ of $59.6^{\circ} \mathrm{F}$ (table 6 ). A total of nine streamgages, of which one is part of the HCDN subset, had significant trends and were included in the seasonal and monthly trend analyses. Significant upward trends in annual, seasonal, and monthly streamflow dominate this region with a single exception: streamgage 06670500 (map number 119) in the western part of WR4 had significant downward trends in annual, seasonal, and monthly streamflow. The eight streamgages in the eastern part of WR4 had significant upward trends in annual streamflow (table 3).

Autumn (October-December), spring (April-June), and summer (July-September) had the greatest number of streamgages with upward seasonal streamflow trends (6 in each season; table 4), and winter had the fewest number of streamgages with upward seasonal streamflow trends (3). The greatest number of streamgages with upward trends in monthly streamflow was in December and January (7), whereas March (1) had the fewest number of streamgages with upward trends in monthly streamflow (table 5).

\section{Watershed Region 5}

The watershed of the Kansas River is represented by WR5, which supplies 9 percent of the total streamflow for the
Missouri River watershed (fig. 16). This watershed region had a mean annual precipitation of $24.5 \mathrm{in}$, a mean annual $T_{\min }$ of $38.9^{\circ} \mathrm{F}$, and a mean annual $T_{\max }$ of $65.1^{\circ} \mathrm{F}$ (table 6). A total of 24 streamgages, of which no streamgages were part of the HCDN subset, had significant trends in annual streamflow, all of which were downward (table 3).

Seasonal streamflow was dominated by downward trends; however, a single streamgage, 06852500 (map number 168), which had a downward annual streamflow trend, had upward seasonal streamflow trends for autumn (October-December) and winter (January-March) and a downward seasonal streamflow trend for summer (July-September). The primary purpose of this canal is to divert water from the Republican River to Lovewell Reservoir near Wayne, Kansas (not shown). Summer (July-September) had the greatest number of streamgages (23) with significant downward streamflow trends, and spring (April-June) had the fewest number of streamgages with downward streamflow trends (15; table 4). Monthly streamflow was dominated by downward trends (table 5). The greatest number of streamgages with significant downward streamflow trends was for September (20), and the fewest number of streamgages with significant trends in monthly streamflow was for December and January (12 for each month). Trends in monthly streamflow were significantly upward for streamgage 06852500 (map number 168) for October through April and significantly downward for July and August.

\section{Watershed Region 6}

The downstream-most part of the Missouri River watershed is represented by WR6 (fig. 16), which supplies 44 percent of the total streamflow for the Missouri River watershed and drains at its outlet into the Mississippi River watershed. This represents the largest percentage of the total streamflow of all watershed regions, which reflects the higher precipitation for this region. The mean annual precipitation for this watershed region was 38.6 in., the mean annual $T_{\min }$ was $42.1^{\circ} \mathrm{F}$, and the mean annual $T_{\max }$ was $64.3^{\circ} \mathrm{F}$ (table 6 ). A total of seven streamgages, of which four were HCDN streamgages, had significant trends in annual streamflow, all of which were upward (table 3). No downward trends in annual, seasonal, or monthly streamflow were statistically significant for streamgages in WR6.

Streamgages with seasonal trends were mainly clustered in the northern part of WR6 (figs. 12-15). Spring (April-June) and summer (July-September) had the greatest number of streamgages with upward seasonal streamflow trends (6), whereas winter (January-March) had the fewest number of streamgages with upward seasonal streamflow trends (2; table 4). Monthly streamflow trends (table 5) were consistent with annual trends (table 3 ). The greatest number of streamgages with upward streamflow trends were in November, January, and June through August (six each month). The fewest number of streamgages with upward streamflow trends were in March and April (one each month). 


\section{Synthesis of Trends}

Either upward or downward significant trends in annual, monthly, and seasonal streamflow were pervasive within three watershed regions: downward trends in WR1 (upper Missouri River), upward trends in WR3 (Great Plains and Central Lowland physiographic provinces and Niobrara River), and downward trends in WR5 (Kansas River watershed). A comprehensive analysis of cause of trends is outside the scope of this report. An increase in diversions or consumptive use of water during the study period, however, could not result in upward trends in annual streamflows over broad regions, such as WR3. All seven HCDN streamgages in WR3 have upward trends, which supports a climatological forcing for the upward trends. Although not examined in this study, an increase in consumptive use because of groundwater pumping has been identified as a contributing factor to the downward trends in WR5 (Wen and Xunhong, 2006).

Downward trends in WR1, the upper Missouri River, were significant throughout this region and even on main-stem streamgages below reservoirs, such as streamgages 06177000 and 06185500 (map numbers 20 and 21, respectively) in WR1 and streamgage 06342500 (map number 53) in WR2. Two out of eight HCDN streamgages had downward trends, streamgage 06278300 (map number 32) and streamgage 06298000 (map number 40), whereas the remaining HCDN streamgages had no significant streamflow trends. Future studies could examine the forcing factors of these observed trends in streamflow, the watershed effects and potential long term consequences.

\section{Summary}

Streamflow records at U.S. Geological Survey streamgages in the Missouri River watershed were examined for annual, seasonal, and monthly trends. A total of 227 streamgages having continuous observational records for water years 1960-2011 were included in the trend analyses. Monthly streamflow records were used to compute seasonal averages. Of the 227 streamgages used in the analyses, 54 streamgages are part of the U.S. Geological Survey's Hydro-Climatic Data Network. Kendall's tau nonparametric test was used to determine statistical significance of trends in annual, seasonal, and monthly streamflow. A trend was considered statistically significant for a probability value less than or equal to 0.10 that the Kendall's tau value equals zero.

The Missouri River watershed was divided into six watershed regions for analyses. Significant trends in annual streamflow were indicated for 101 out of 227 streamgages. Dominant trends are prevalent in several watershed regions. The western and the southern parts of the Missouri River watershed had downward trends in annual streamflow (56 streamgages), whereas the eastern part of the watershed had upward trends in streamflow (45 streamgages). Streamflow data from the
101 streamgages with significant trends in annual streamflow were analyzed for any significant trends in seasonal and monthly streamflow. Annual streamflow trends tended to perseverate at seasonal and monthly timescales for all watershed regions within the Missouri River watershed. Seasonal and monthly streamflow trends reflected prevailing annual streamflow trends within each watershed region.

\section{References Cited}

Anderson, M.T., and Woosley, L.H., Jr., 2005, Water availability in the western United States-Key scientific challenges: U.S. Geological Survey Circular 1261, 85 p. [Also available at $h t t p: / / p u b s . u s g s . g o v / c i r c / 2005 /$ circ1261/.]

Anderson, M.T., Stamm, J.F., and Norton, P.A., 2008, Changes in monthly streamflow conditions in the Missouri River Basin from 1957 to 2007: Eos Transactions, American Geophysical Union, v. 89, no. 53, Fall Meeting Supplement, Abstract H11I-02, December 15-19, 2008, San Fransisco, Calif., accessed March 14, 2013, at http://abstractsearch. agu.org/meetings/2008/FM/sections/H/sessions/H11I/ abstracts/H11I-02.html.

Bue, C.D., 1963, Principal lakes of the United States: U.S. Geological Survey Circular 476, 22 p. [Also available at http://pubs.usgs.gov/circ/1963/0476/report.pdf.]

Cleveland, W.S., and Devlin, S.J., 1988, Locally-weighted regression-An approach to regression analysis by local fitting: Journal of the American Statistical Association, v. 83, no. 403, p. 596-610. [Also available at $h t t p: / / d x$.doi.org/10. 1080/01621459.1988.10478639.]

Daly, Christopher, Neilson, R.P., and Phillips, D.L., 1994, A statistical-topographic model for mapping climatological precipitation over mountainous terrain: Journal of Applied Meteorology, v. 33, no. 2, p. 140-158. [Also available at http://dx.doi.org/10.1175/1520-0450(1994)033<0140:AST $M F M>2.0 . C O ; 2$.

Daly, Christopher, Gibson, W.P., Taylor, G.H., Johnson, G.L., and Pasteris, Phillip, 2002, A knowledge-based approach to the statistical mapping of climate: Climate Research, v. 22, no. 2, p. 99-113. [Also available at $h t t p: / / d x . d o i$. org/10.3354/cr022099.]

Fenneman, N.M., 1931, Physiography of the Western United States (1st ed.): New York, McGraw Hill, 534 p. plus map.

Fenneman, N.M., and Johnson, D.W., 1946, Physiographical divisions of the conterminous United States: U.S. Geological Survey special map, scale 1:7,000,000, accessed February 4, 2014, at http://water.usgs.gov/GIS/metadata/usgswrd/ XML/physio.xml. 
Hirsch, R.M., 2011, A perspective on nonstationarity and water management: Journal of the American Water Resources Association, v. 47, no. 3, p. 436-446. [Also available at http://dx.doi.org/10.1111/j.1752-1688.2011.00539.x.]

Hirsch, R.M., and Ryberg, K.R., 2011, Has the magnitude of floods across the USA changed with global CO2 levels?: Hydrological Science Journal, v. 57, no. 1, p. 1-9. [Also available at $h t t p: / / d x$. doi.org/10.1080/02626667.2011.6218 95.]

Kammerer, J.C., 1987, Largest rivers in the United States: U.S. Geological Survey Open-File Report 87-242. [Also available at http://pubs.usgs.gov/of/1987/ofr87-242/.]

Kendall, M.G., 1938, A new measure of rank correlation: Biometrika, v. 30, no. 1-2, p. 81-93. [Also available at http://dx.doi.org/10.1093/biomet/30.1-2.81.]

Lins, H.F., and Slack, J.R., 1999, Streamflow trends in the United States: Geophysical Research Letters, v. 26, no. 2, p. 227-230. [Also available at http://dx.doi. org/10.1029/1998GL900291.]

McCabe, G.J., and Wolock, D.M., 2002, A step increase in streamflow in the conterminous United States: Geophysical Research Letters, v. 29, no. 24, p. 38-1-38-4. [Also available at http://dx.doi.org/10.1029/2002GL015999.]

Seaber, P.R., Kapinos, F.P., and Knapp G.L.,1987, Hydrologic unit maps: U.S. Geological Survey Water-Supply Paper 2294. [Also available at http://pubs.usgs.gov/wsp/wsp2294.]

Slack, J.R., and Landwehr, J.M., 1992, Hydro-Climatic Data Network-A U.S. Geological Survey streamflow data set for the United States for the study of climate variations, 1874-1988: U.S. Geological Survey Open-File Report 92-129, accessed March 4, 2011, at http://pubs.usgs.gov/ of/1992/ofr92-129/.

U.S. Army Corps of Engineers, 2006, Missouri River mainstem reservoir system-Master water control manual-Missouri River Basin: Omaha, Nebraska, U.S. Army Corps of Engineers, Northwestern Division, accessed March 14, 2013, at http://www.nwd-mr.usace.army.mil/rcc/reports/ mmanual/MasterManual.pdf.

U.S. Environmental Protection Agency, 2006, Ecological regions of North America, Level I-II: scale 1:10,000,000, accessed February 3, 2014, at ftp://ftp.epa.gov/wed/ ecoregions/cec_na/NA_LEVEL_II.pdf.

U.S. Geological Survey, 2012, National Water Information System (NWISWeb) - USGS surface-water data for the Nation: U.S. Geological Survey database, accessed July 2, 2012, at http://waterdata.usgs.gov/usa/nwis/sw.
Venables, W.N., Smith, D.M., and the R Development Core Team, 2013, An introduction to $\mathrm{R}$-Notes on $\mathrm{R}-\mathrm{A}$ programming environment for data analysis and graphics, version 2.15.3 (2013-03-01): The Comprehensive R Archive Network, 102 p., accessed March 14, 2013, at http://cran.rproject.org/doc/manuals/R-intro.pdf.

Wen, Fujiang, and Chen, Xunhong, 2006, Evaluation of the impact of groundwater irrigation on streamflow in Nebraska: Journal of Hydrology, v. 327, no. 3-4, p. 603-617. [Also available at http://dx.doi.org/10.1016/j. jhydrol.2005.12.016.] 



\section{Appendix}

Streamflow records from 227 U.S. Geological Survey streamgages (fig. 8) in the Missouri River watershed were analyzed for trends in annual, seasonal, and monthly streamflow. Streamgage description, including map number, streamgage number and name, latitude and longitude, and drainage area, is included in table 1-1 (Microsoft ${ }^{\circledR}$ Excel format). Trends in annual, seasonal, and monthly streamflow for all 227 streamgages regardless of statistical significance are included in table 1-2 (Microsoft ${ }^{\circledR}$ Excel format).

Table 1-1. Descriptions for streamgages included in statistical analysis, water years 1960-2011. (http://pubs.usgs.gov/sir/2014/5053/downloads/TableDownloadsDirectory/AppendixTable1-1.xlsx)

Table 1-2. Streamgages used in statistical analyses of trends in annual, seasonal, and monthly streamflow in the Missouri River watershed and results of trend analyses, water years 1960-2011. (http://pubs.usgs.gov/sir/2014/5053/downloads/TableDownloadsDirectory/AppendixTable1-2.xlsx)

Graphs of the annual and seasonal streamflow trends for each of the 101 streamgages in the Missouri River watershed that had significant annual streamflow trends are presented in figures 1-1 through 1-101. Five graphs are presented for each streamgage. Graph $A$ shows the annual mean streamflow for WY 1960-2011 and annual streamflow trends. Graphs $B-E$ show the seasonal mean streamflows for October-December (autumn), January-March (winter), April-June (spring), and July-September (summer), respectively. On the graphs, a solid green line indicates the locally weighted regression (LOESS) smooth line for a significant trend [probability value ( $p$-value) less than or equal to 0.10]. A solid gray line indicates the LOESS smooth line for a nonsignificant trend ( $p$-value greater than 0.10 ). A dash-dot gray line indicates the long-term (1960-2011) mean streamflow. Seasonal streamflow trends for the Marias River

near Shelby, Montana (06099500; fig. 1-11) and South Fork Republican River near Benkelman, Nebraska (06827500; fig. 1-79) are not plotted because of gaps in the monthly data.

Figures 1-1 to 1-101. Graphs showing $A$, annual streamflow trends; $B$, 0 ctober through December streamflow trends; $C$, January through March streamflow trends; $D$, April through June streamflow trends; and $E$, July through September streamflow trends, for streamgages in the Missouri River watershed for water years 1960-2011. 

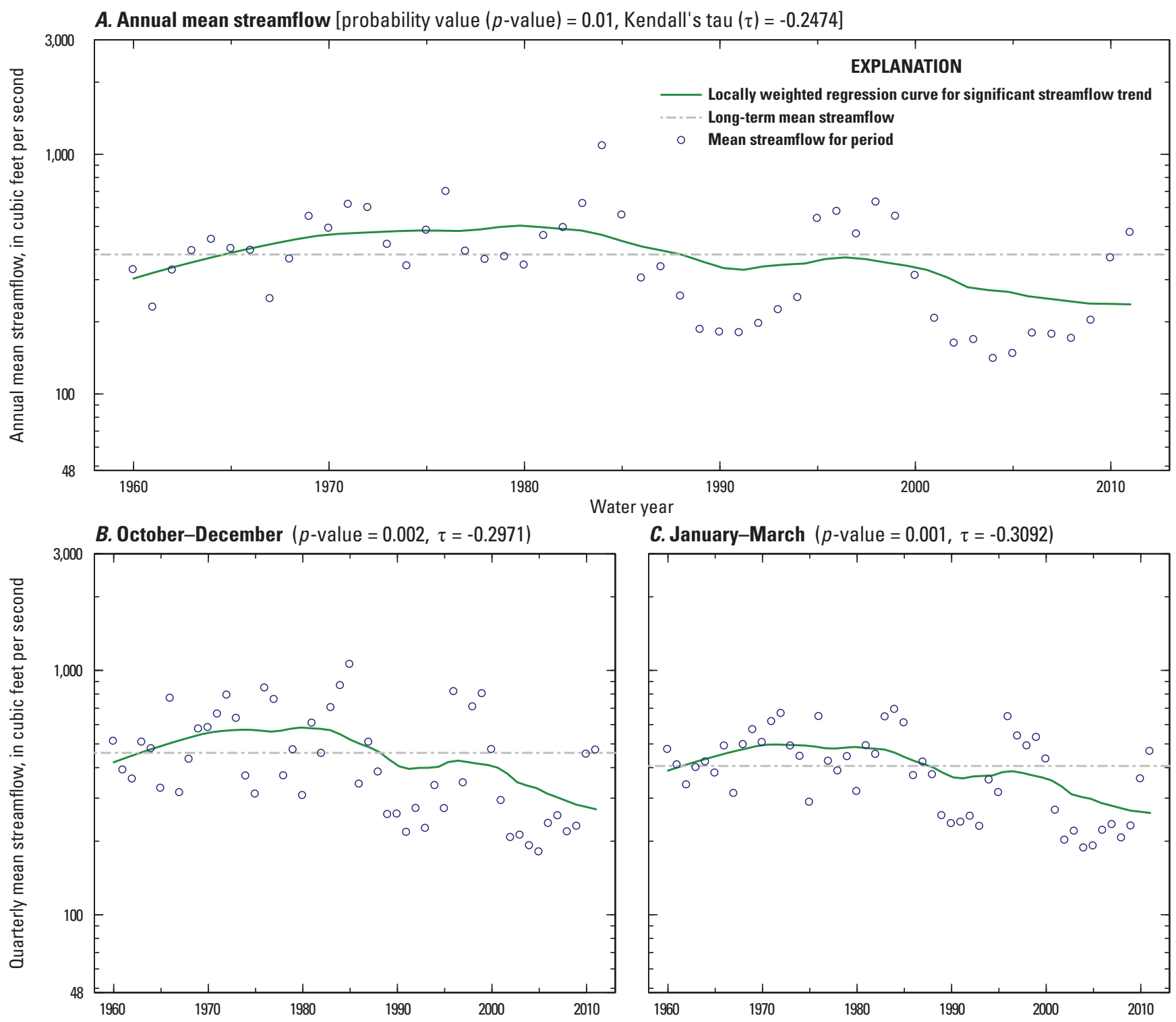

C. January-March ( $p$-value $=0.001, \tau=-0.3092)$
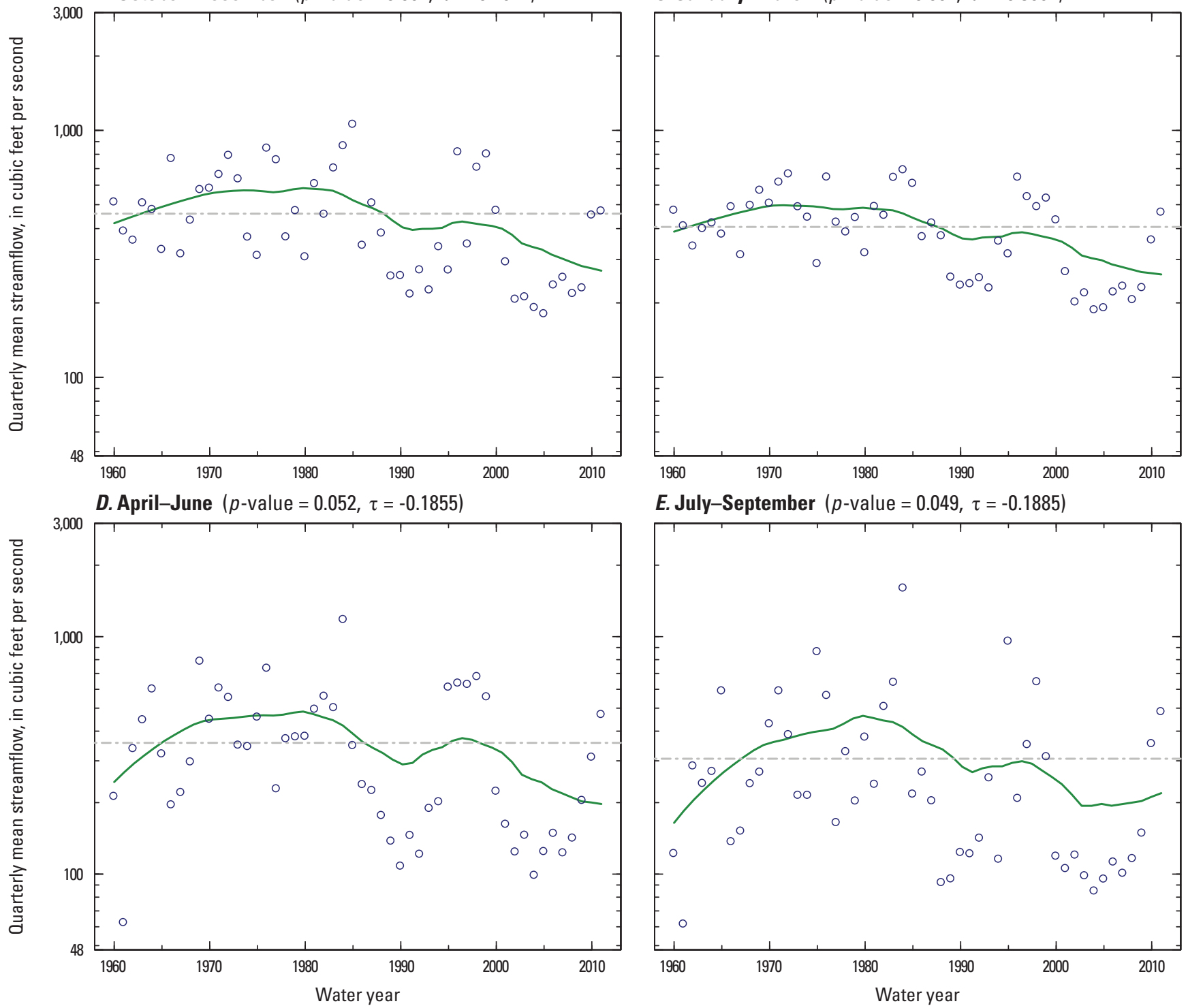

E. July-September $(p$-value $=0.049, \tau=-0.1885)$

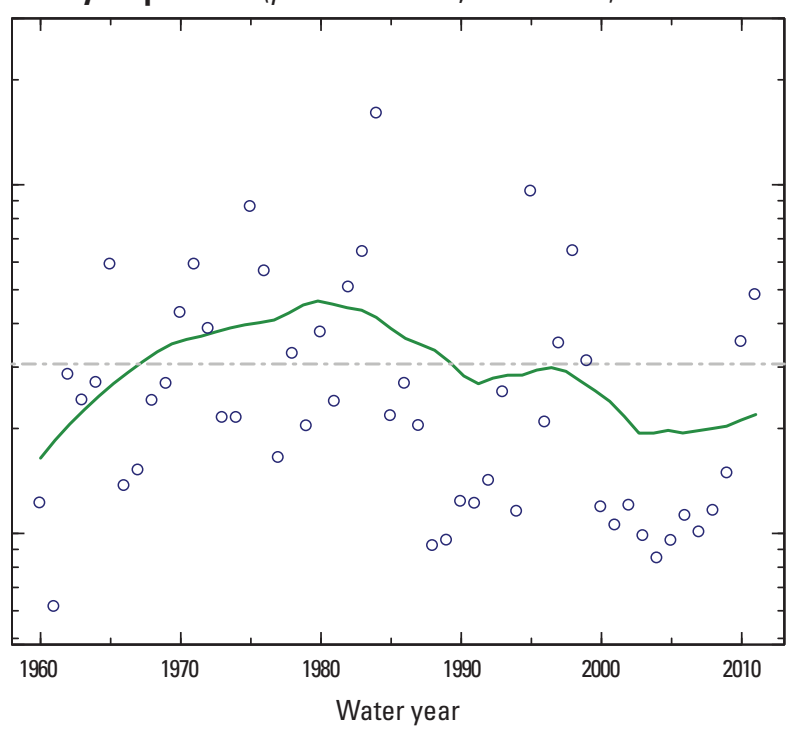

Figure 1-1. Beaverhead River near Twin Bridges, Montana (streamgage 06018500), water years 1960-2011. 
A. Annual mean streamflow [probability value $(p$-value $)=0.077$, Kendall's tau $(\tau)=-0.1689$ ]

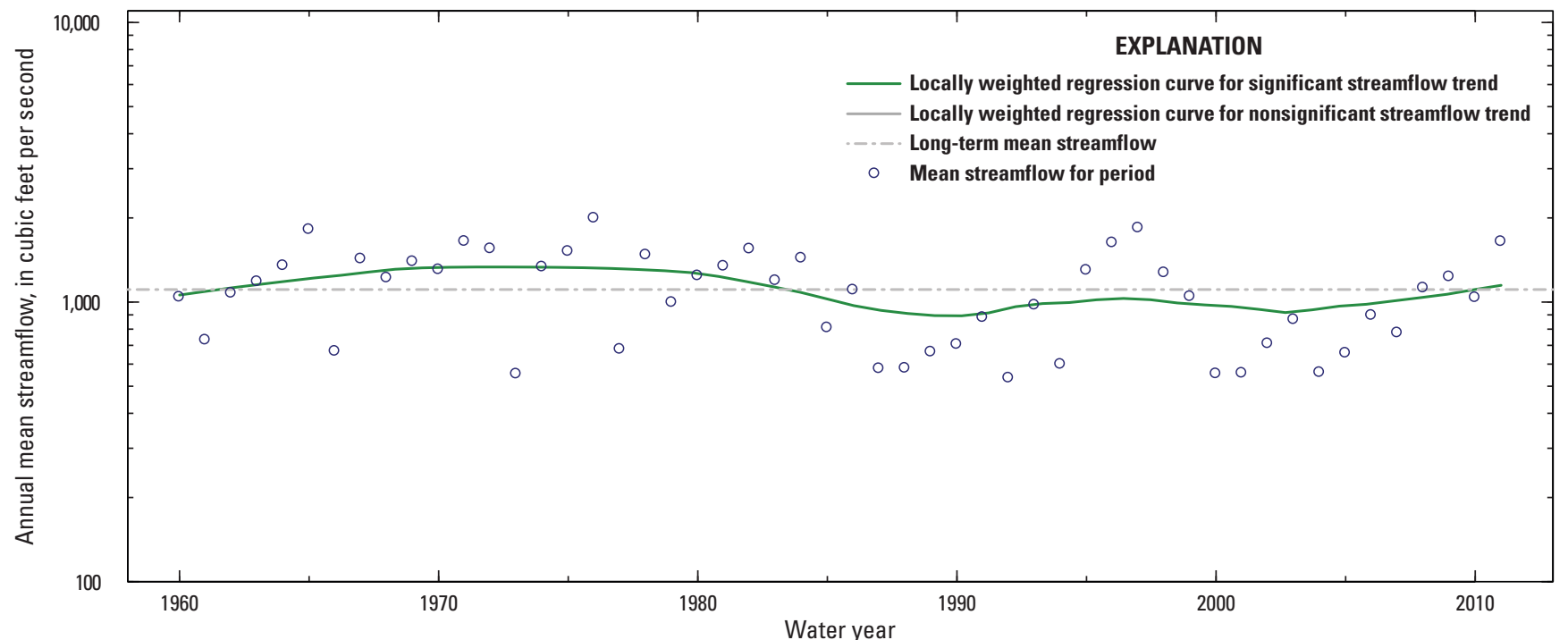

B. October-December ( $p$-value $=0.018, \tau=-0.2256)$

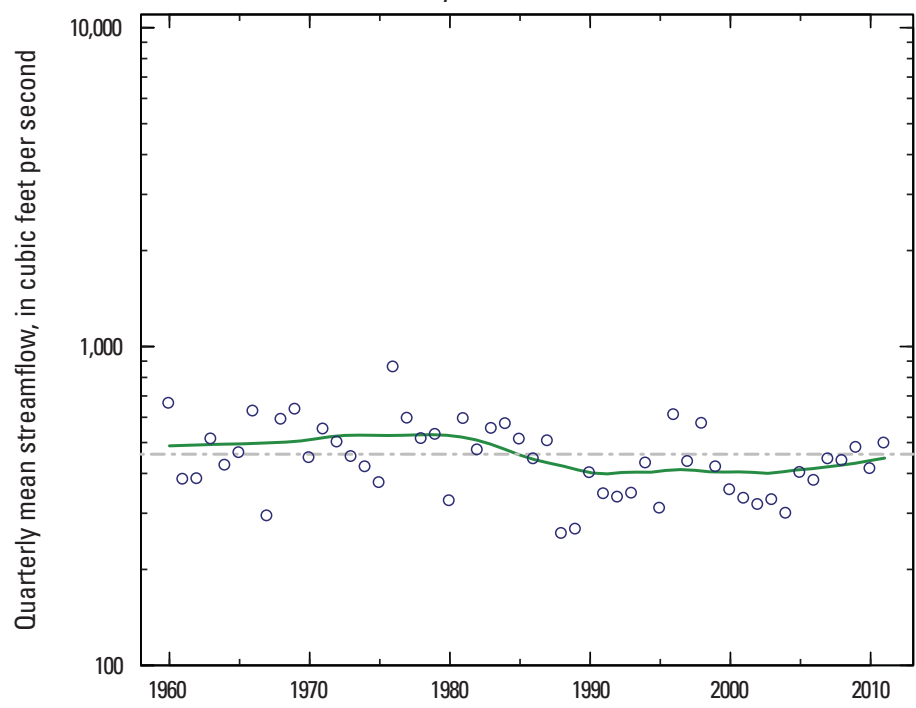

C. January-March ( $p$-value $=0.256, \tau=-0.1086)$

D. April-June ( $p$-value $=0.065, \tau=-0.1765)$
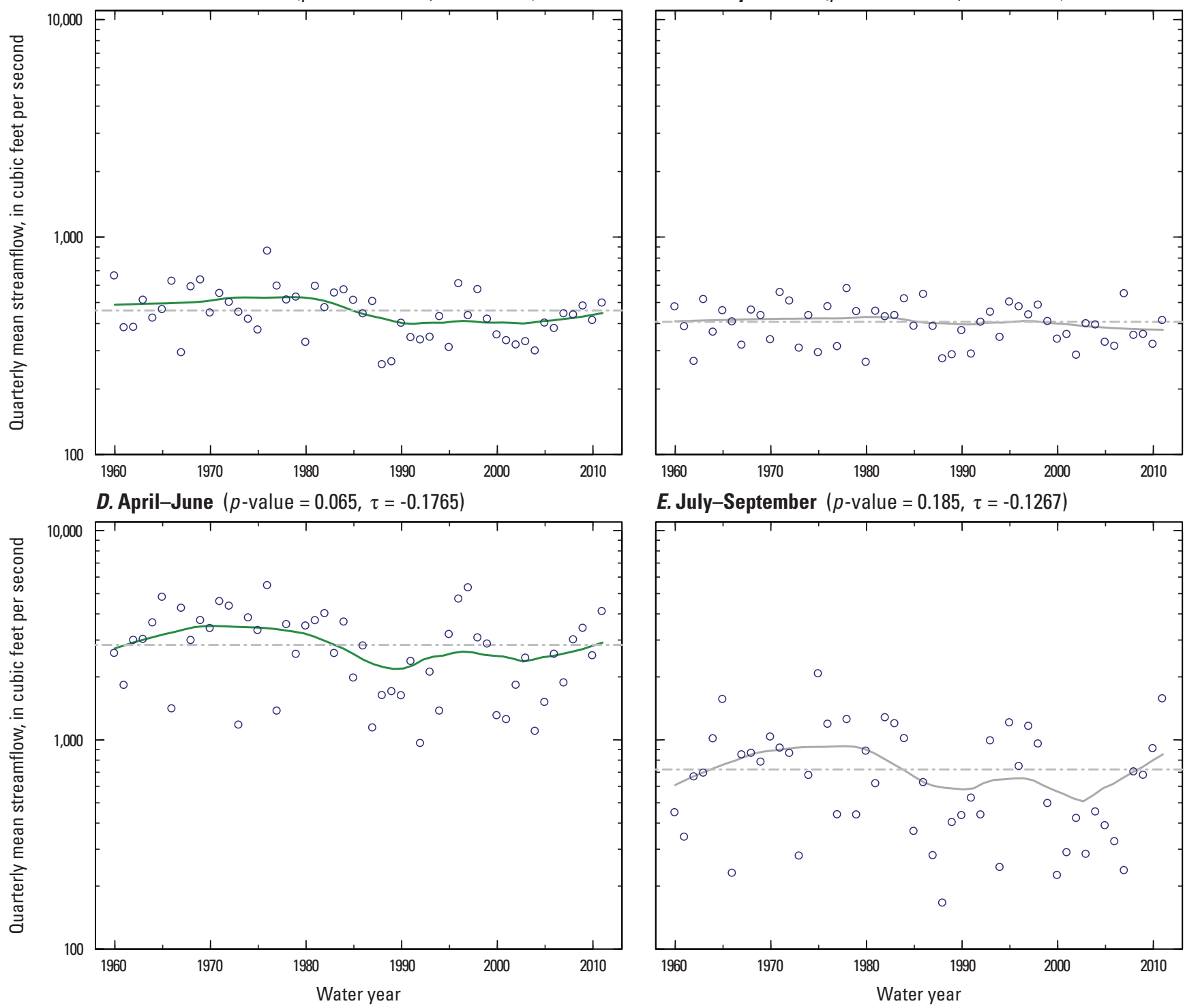

E. July-September $(p$-value $=0.185, \tau=-0.1267)$

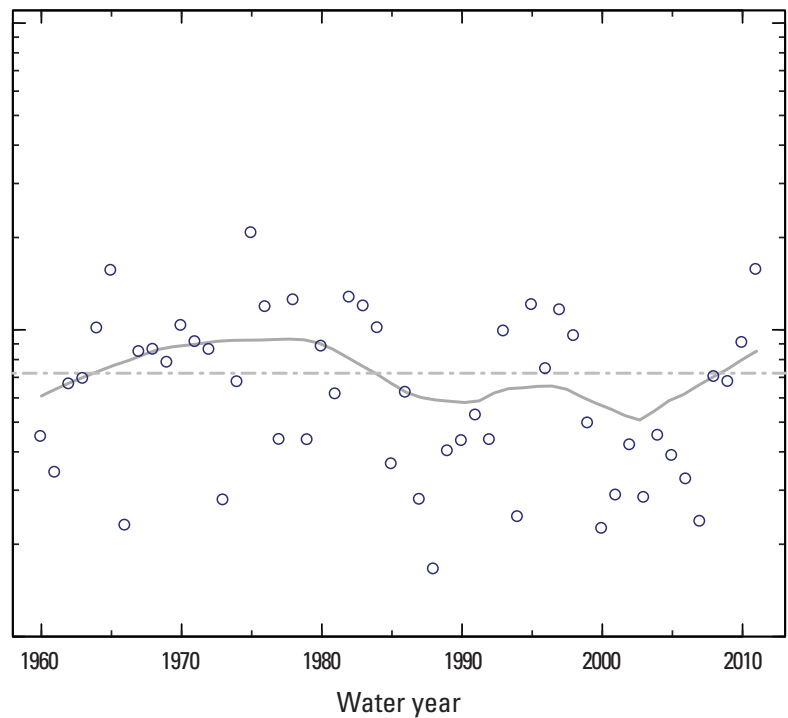

Figure 1-2. Big Hole River near Melrose, Montana (streamgage 06025500), water years 1960-2011. 

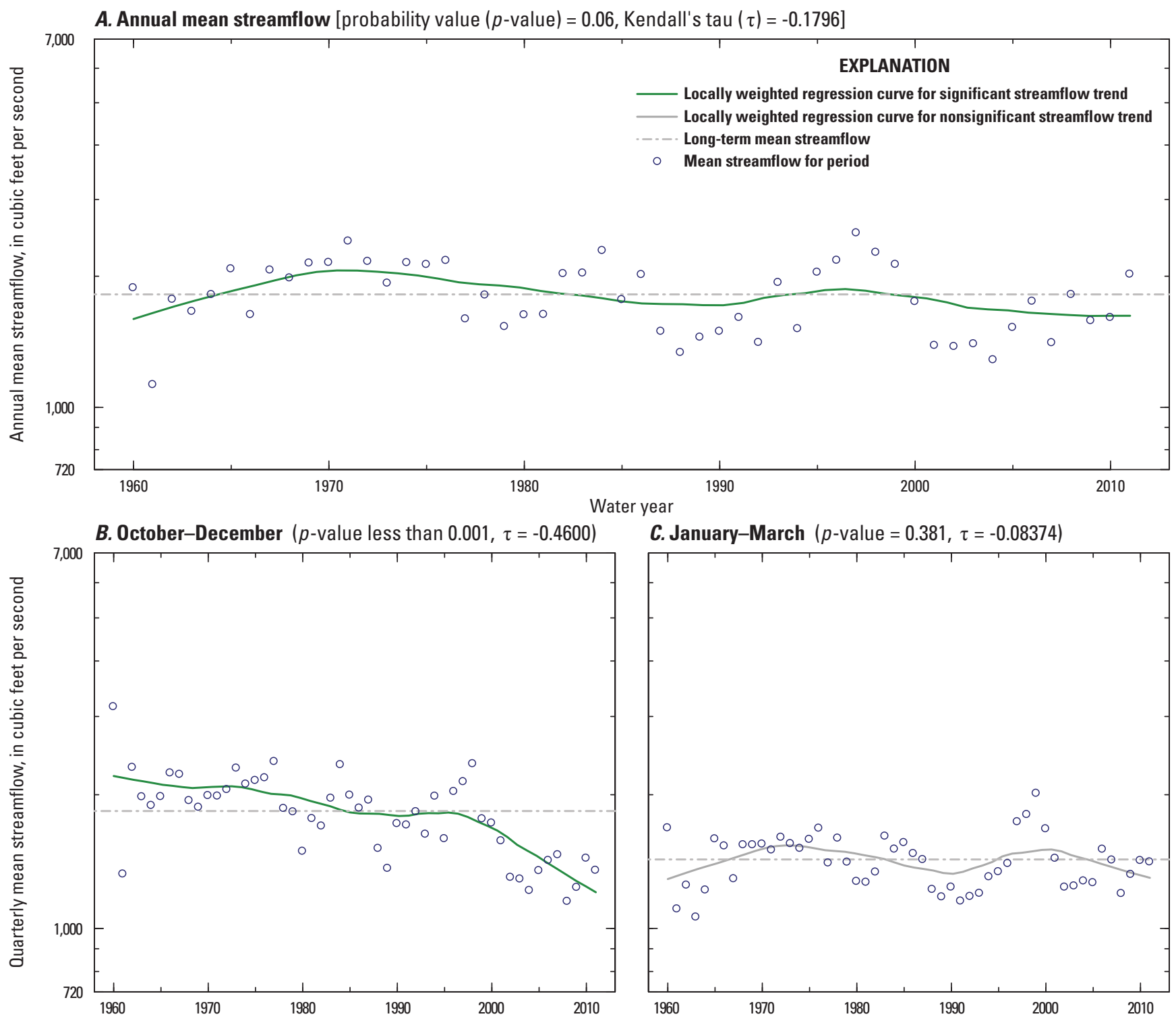

C. January-March ( $p$-value $=0.381, \tau=-0.08374)$
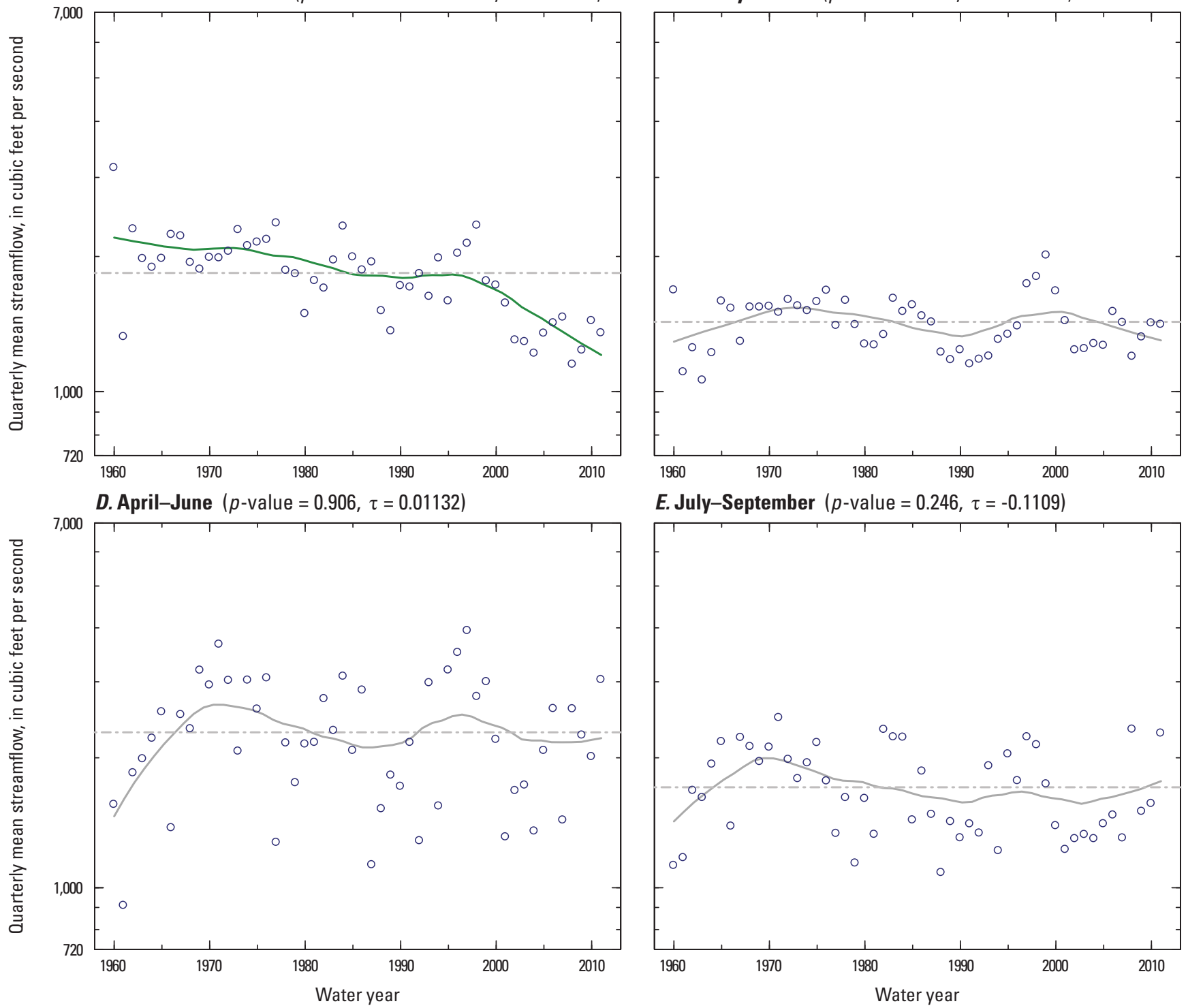

E. July-September $(p$-value $=0.246, \tau=-0.1109)$

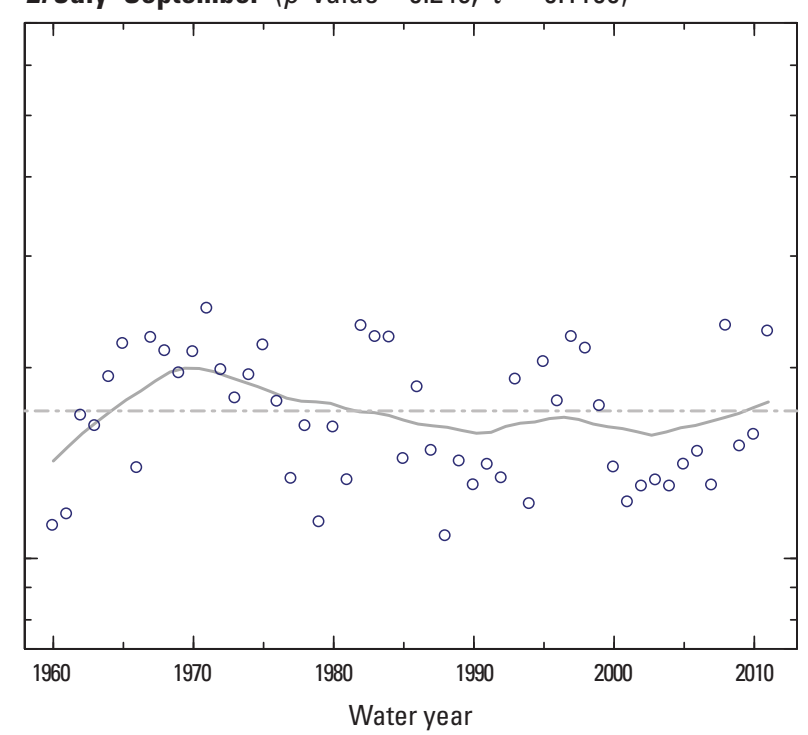

Figure 1-3. Madison River below Ennis Lake near McAllister, Montana (streamgage 06041000), water years $1960-2011$. 
A. Annual mean streamflow [probability value ( $p$-value $)=0.038$, Kendall's tau $(\tau)=-0.1986$ ]

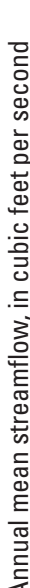

7,000

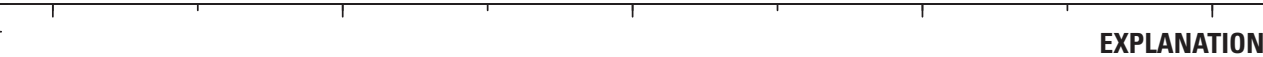

1,000

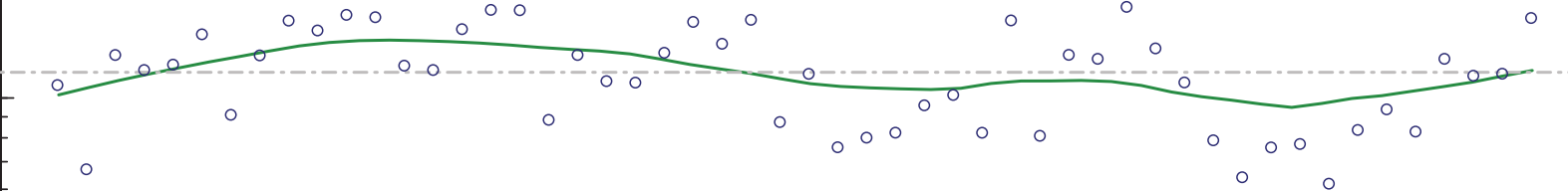

200

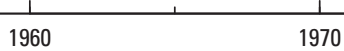

1980

1990

2000

Water year

B. October-December ( $p$-value less than $0.001, \tau=-0.4208$ )

C. January-March ( $p$-value less than $0.001, \tau=-0.4525$ )

0
0
0
0
0
0
0
0
0
0
0

7,000

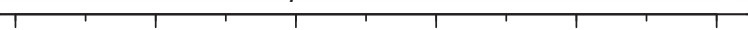

1,000

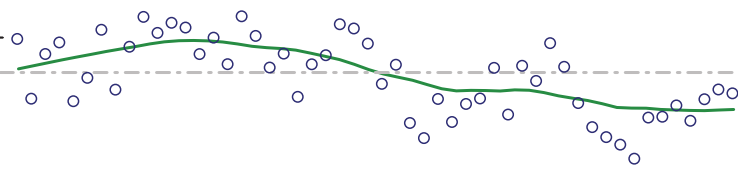

200

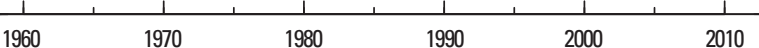

D. April-June ( $p$-value $=0.328, \tau=-0.09351)$

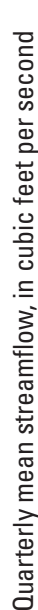

7,000
1,000
200
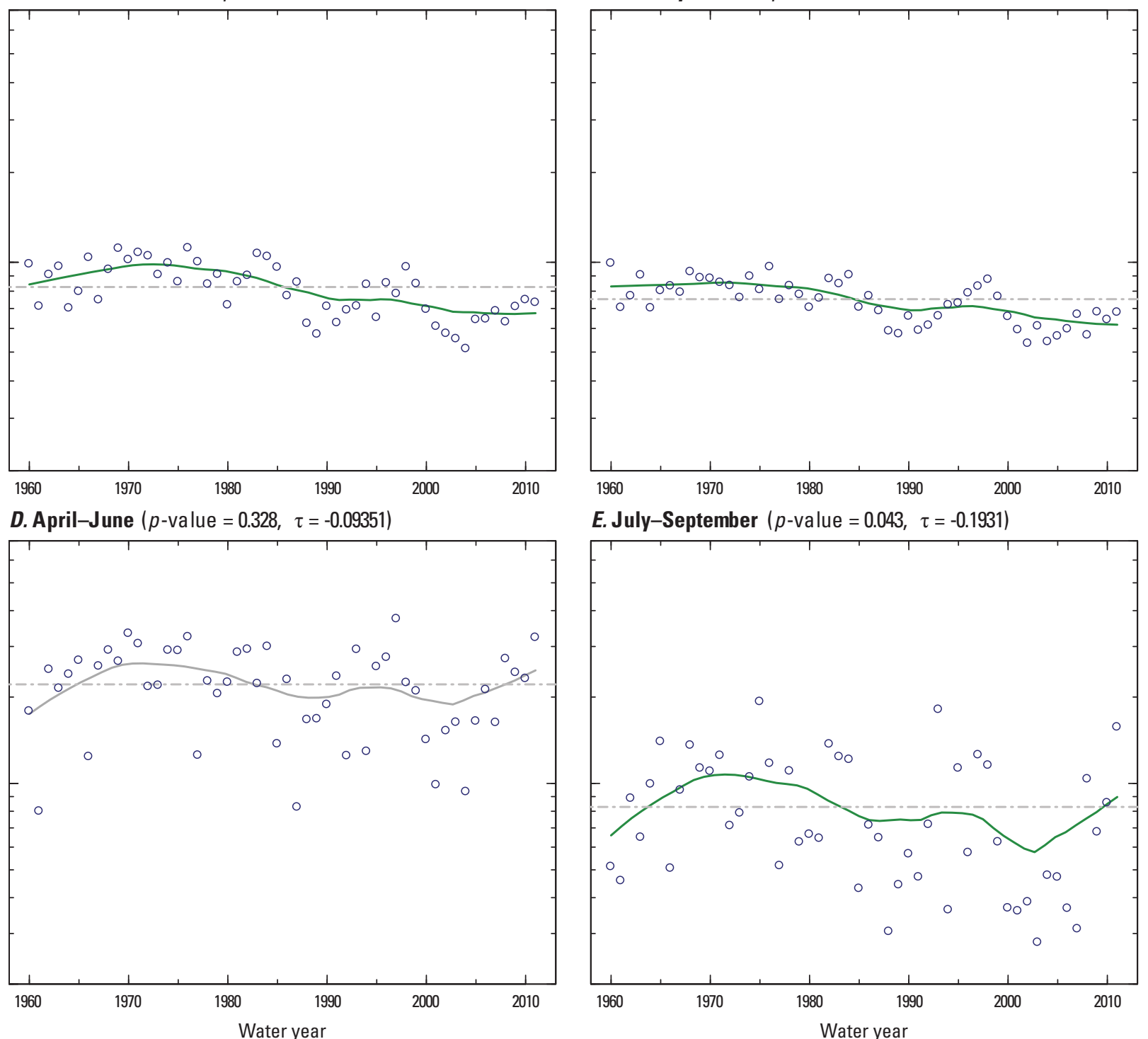

E. July-September $(p$-value $=0.043, \tau=-0.1931)$

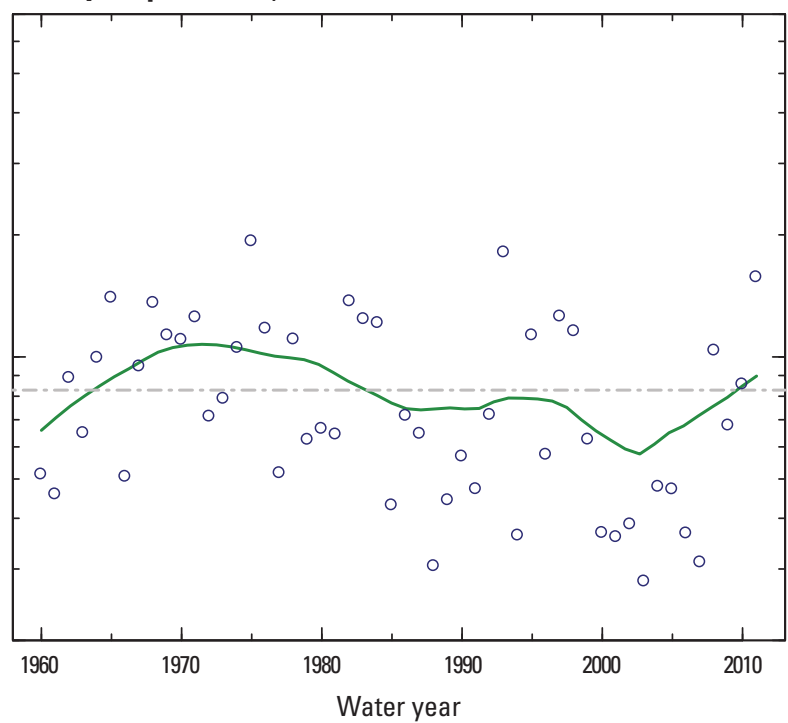

Figure 1-4. Gallatin River at Logan, Montana (streamgage 06052500), water years 1960-2011. 

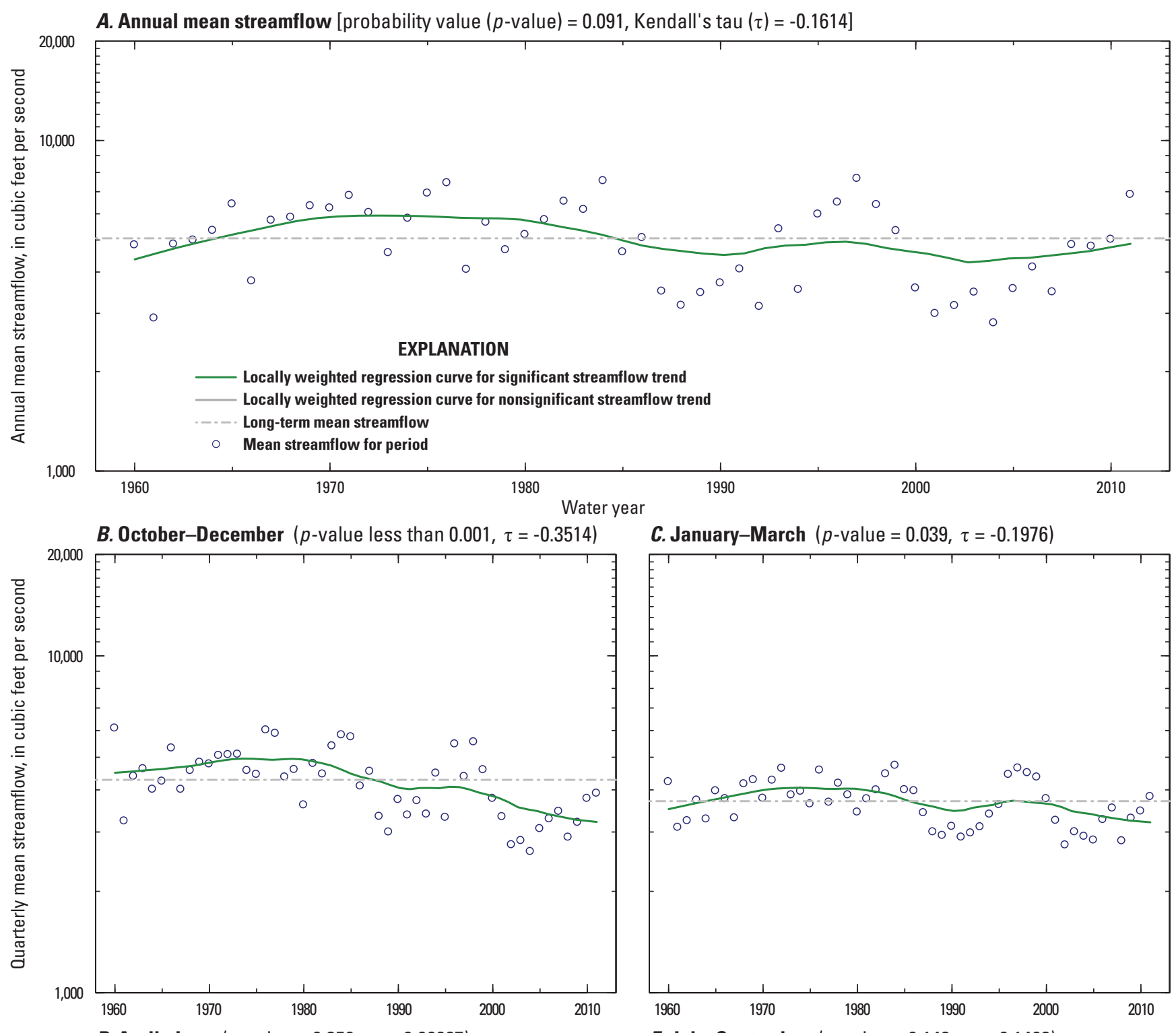

C. January-March $(p$-value $=0.039, \tau=-0.1976)$
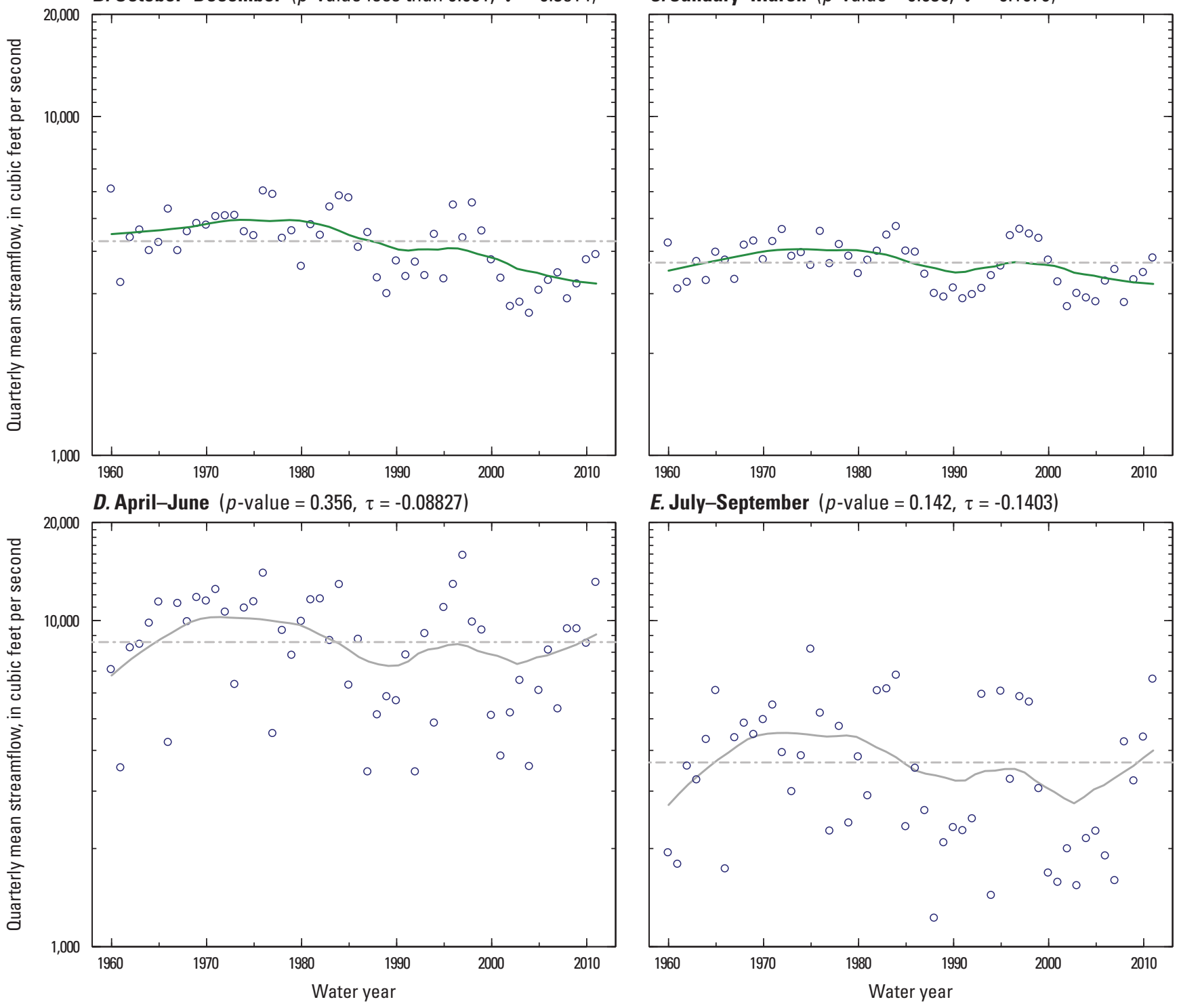

E. July-September $(p$-value $=0.142, \tau=-0.1403)$

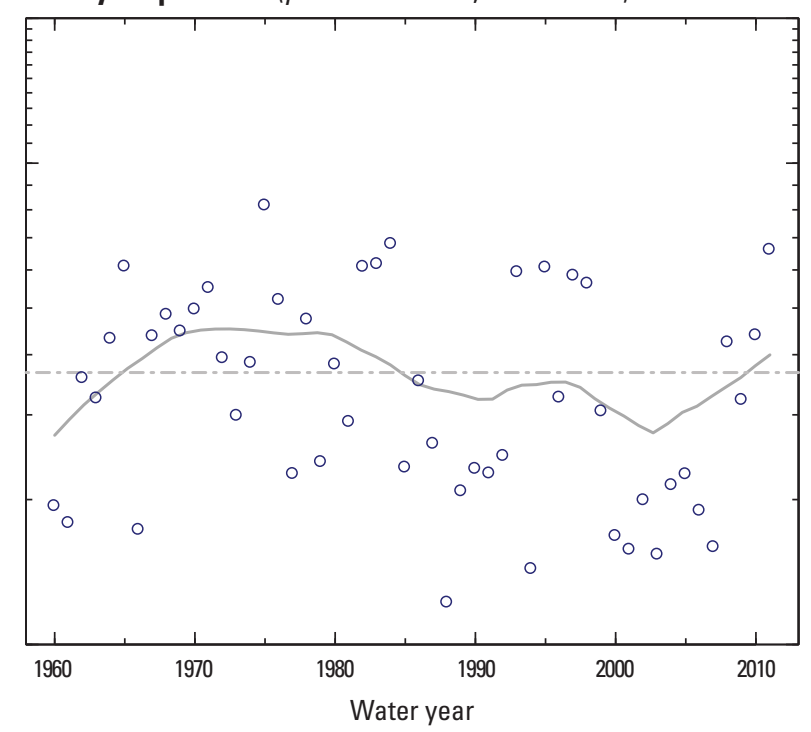

Figure 1-5. Missouri River at Toston, Montana (streamgage 06054500), water years 1960-2011. 
A. Annual mean streamflow [probability value $(p$-value $)=0.063$, Kendall's tau $(\tau)=-0.1780$ ]

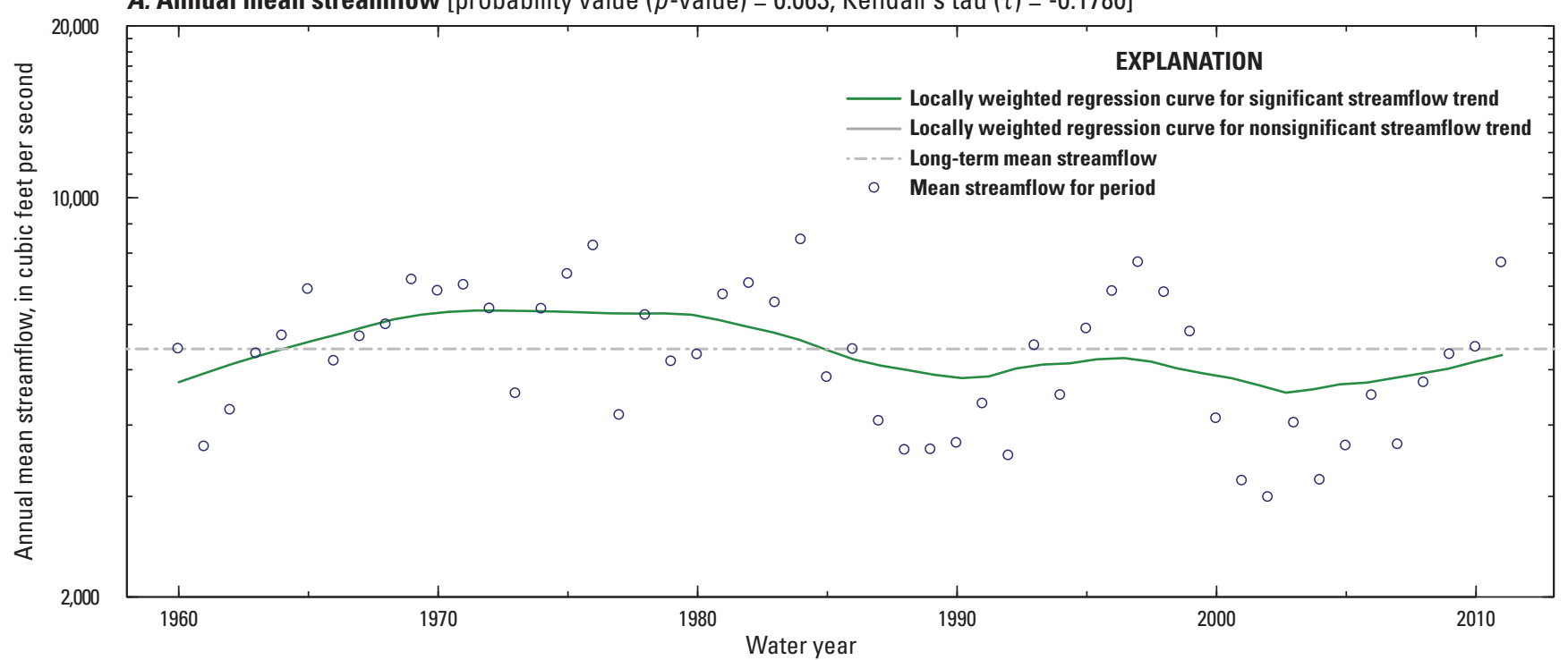

B. October-December $(p$-value $=0.005, \tau=-0.2655)$

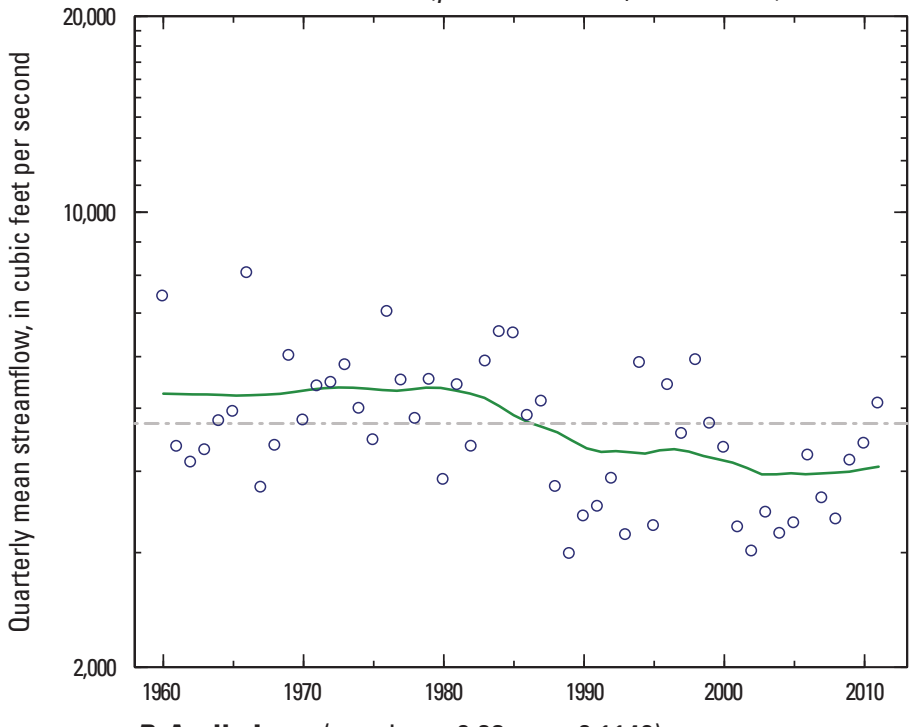

C. January-March ( $p$-value $=0.012, \tau=-0.2413)$
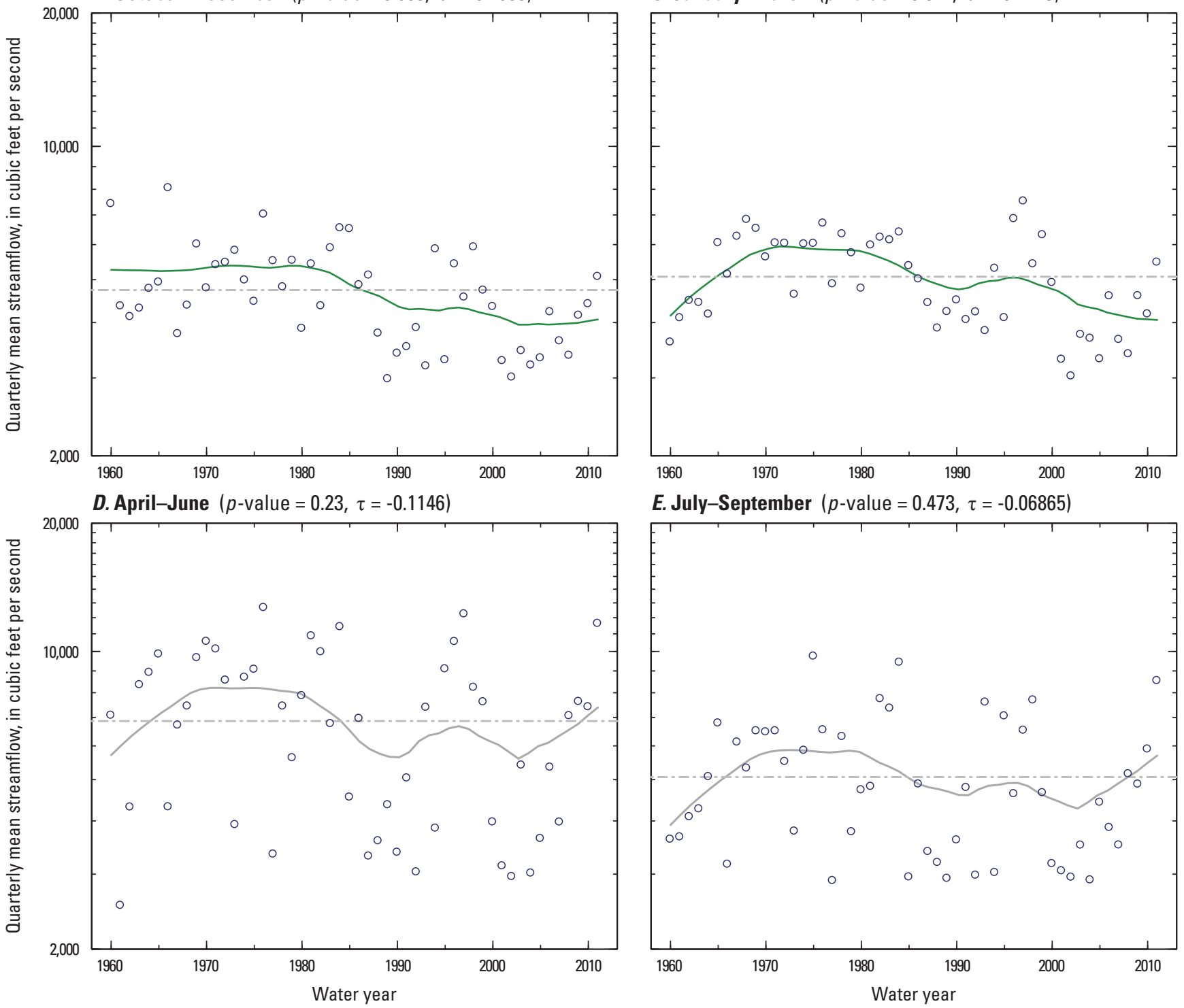

E. July-September $(p$-value $=0.473, \tau=-0.06865)$

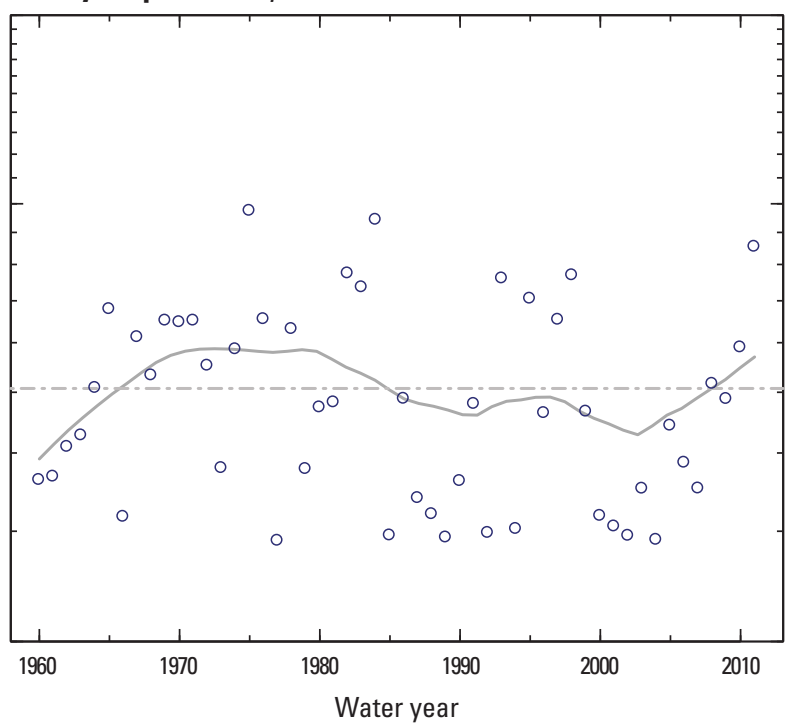

Figure 1-6. Missouri River below Holter Dam near Wolf Creek, Montana (streamgage 06066500), water years 1960-2011. 

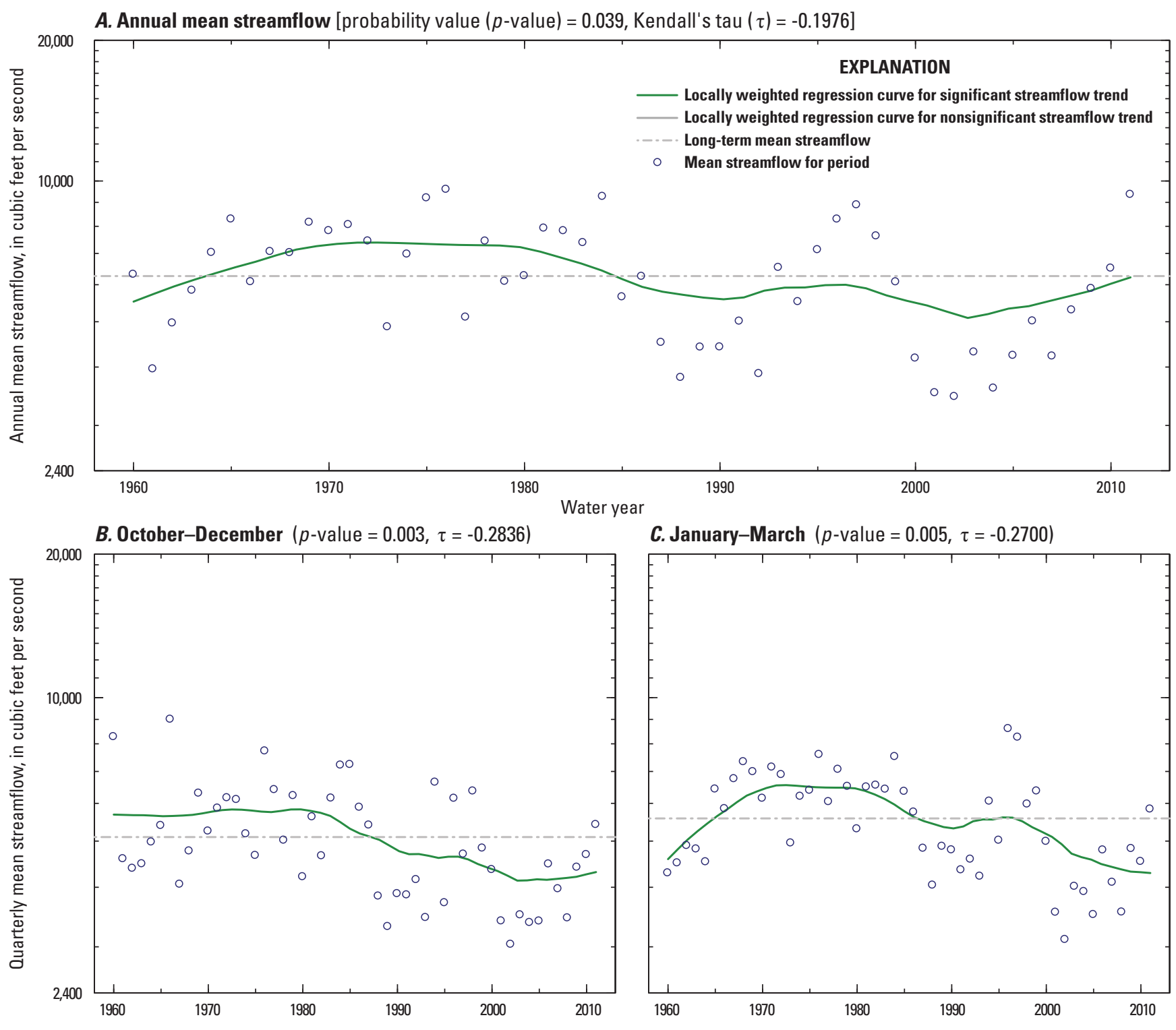

C. January-March $(p$-value $=0.005, \tau=-0.2700)$
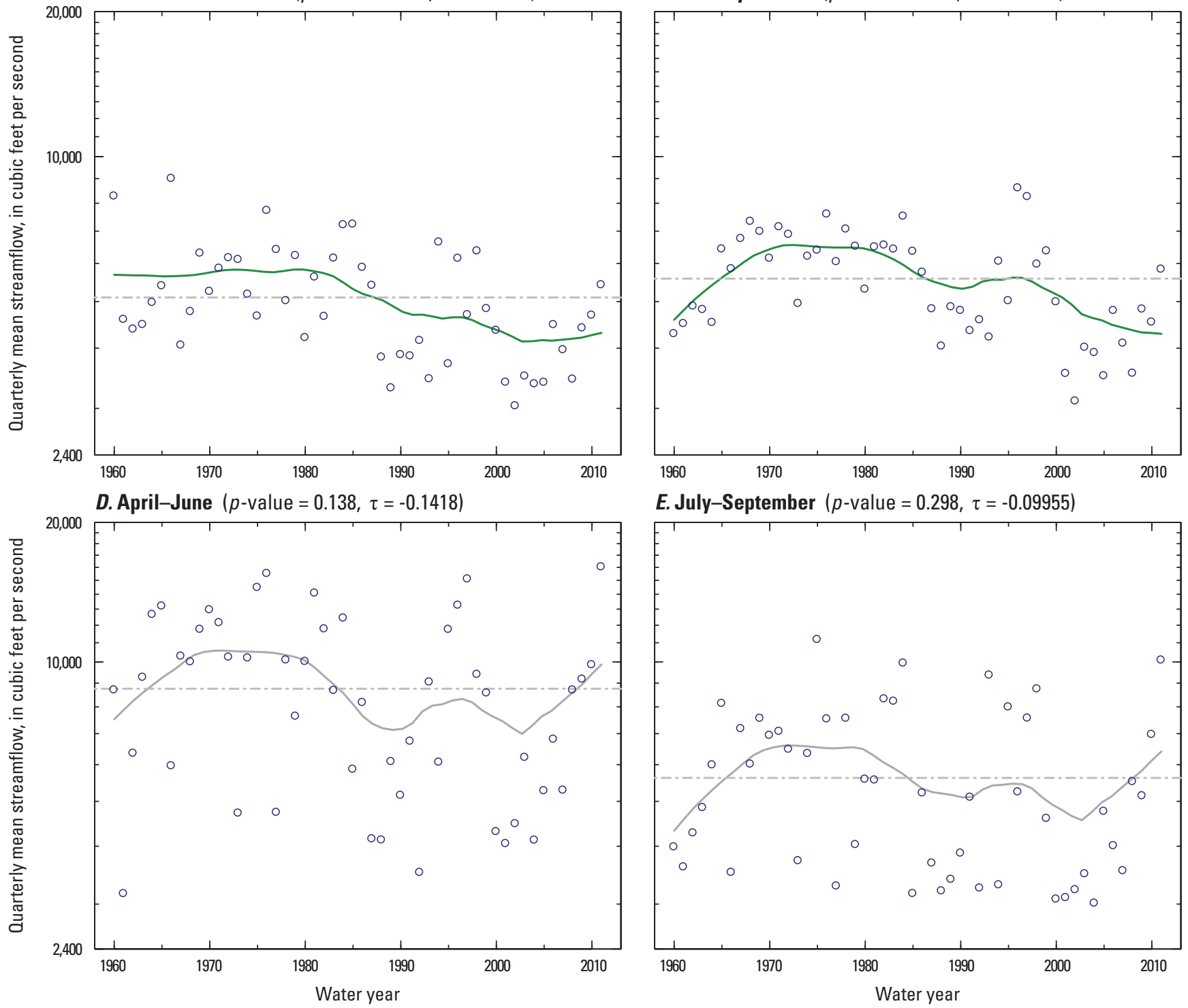

E. July-September $(p$-value $=0.298, \tau=-0.09955)$

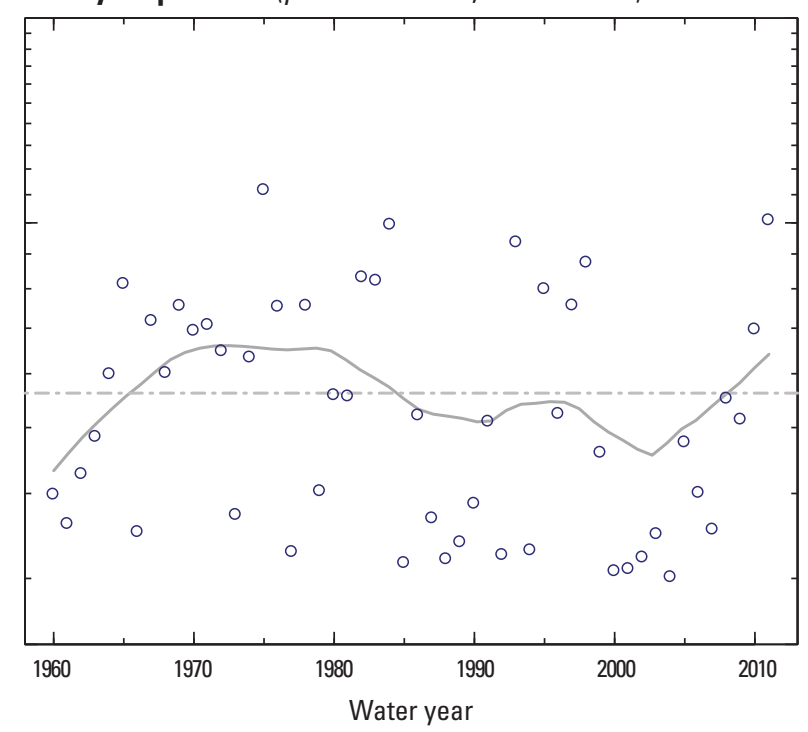

Figure 1-7. Missouri River near Ulm, Montana (streamgage 06078200), water years 1960-2011. 
A. Annual mean streamflow [probability value $(p$-value $)=0.043$, Kendall's tau $(\tau)=-0.1939$ ]
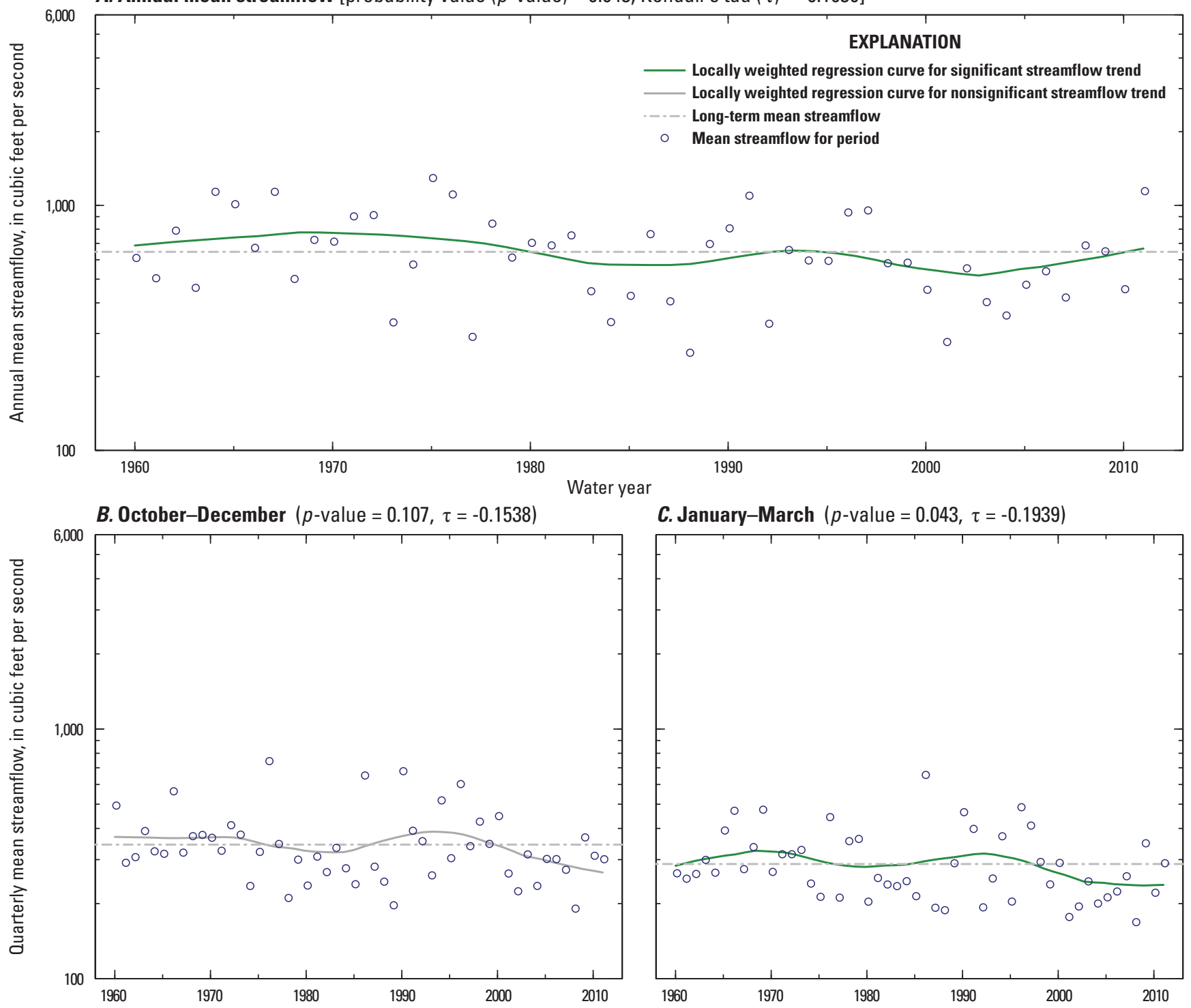

C. January-March ( $p$-value $=0.043, \tau=-0.1939)$
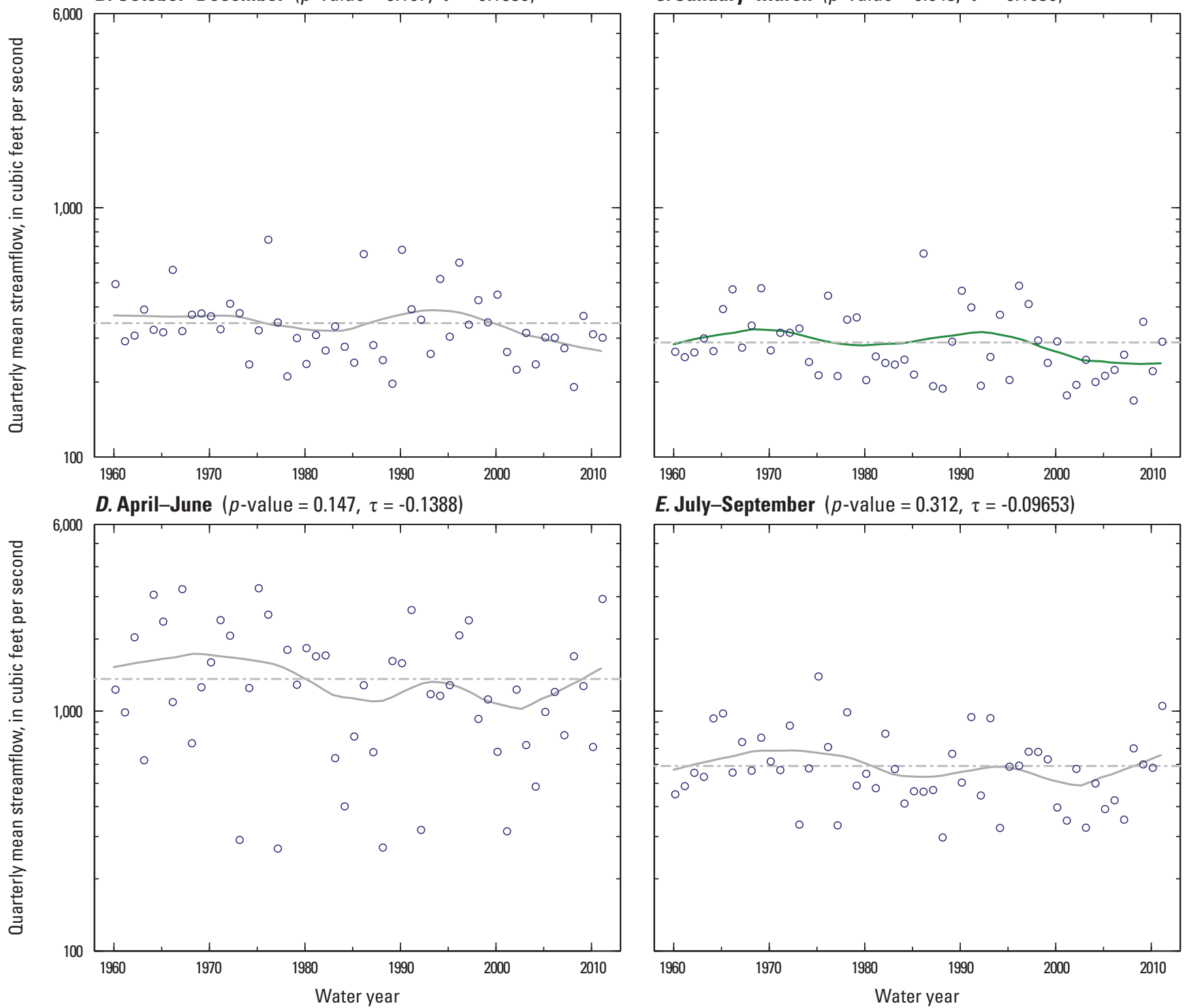

E. July-September $(p$-value $=0.312, \tau=-0.09653)$

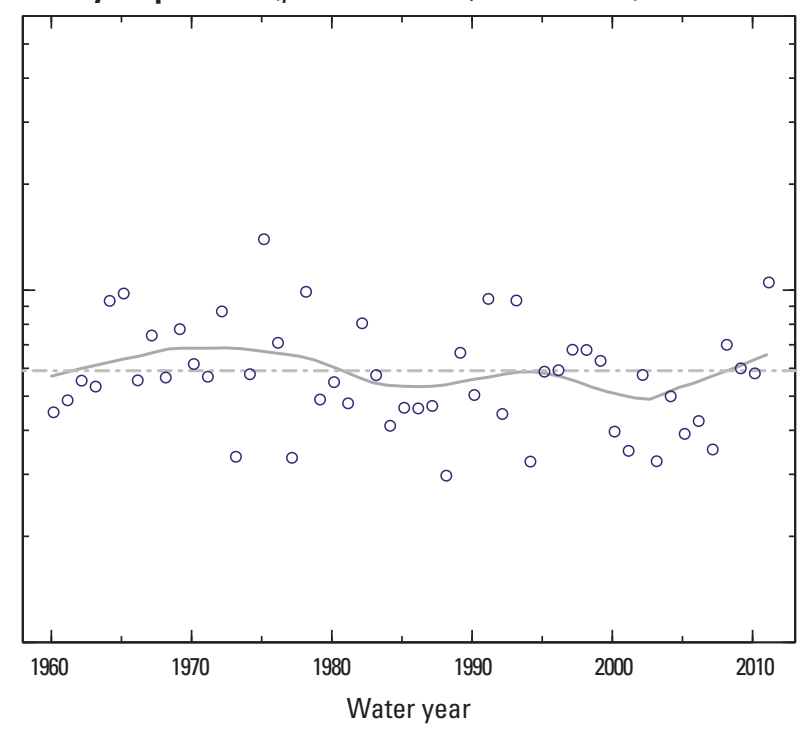

Figure 1-8. Sun River near Vaughn, Montana (streamgage 06089000), water years 1960-2011. 
A. Annual mean streamflow [probability value $(p$-value $)=0.052$, Kendall's tau $(\tau)=-0.1855$ ]

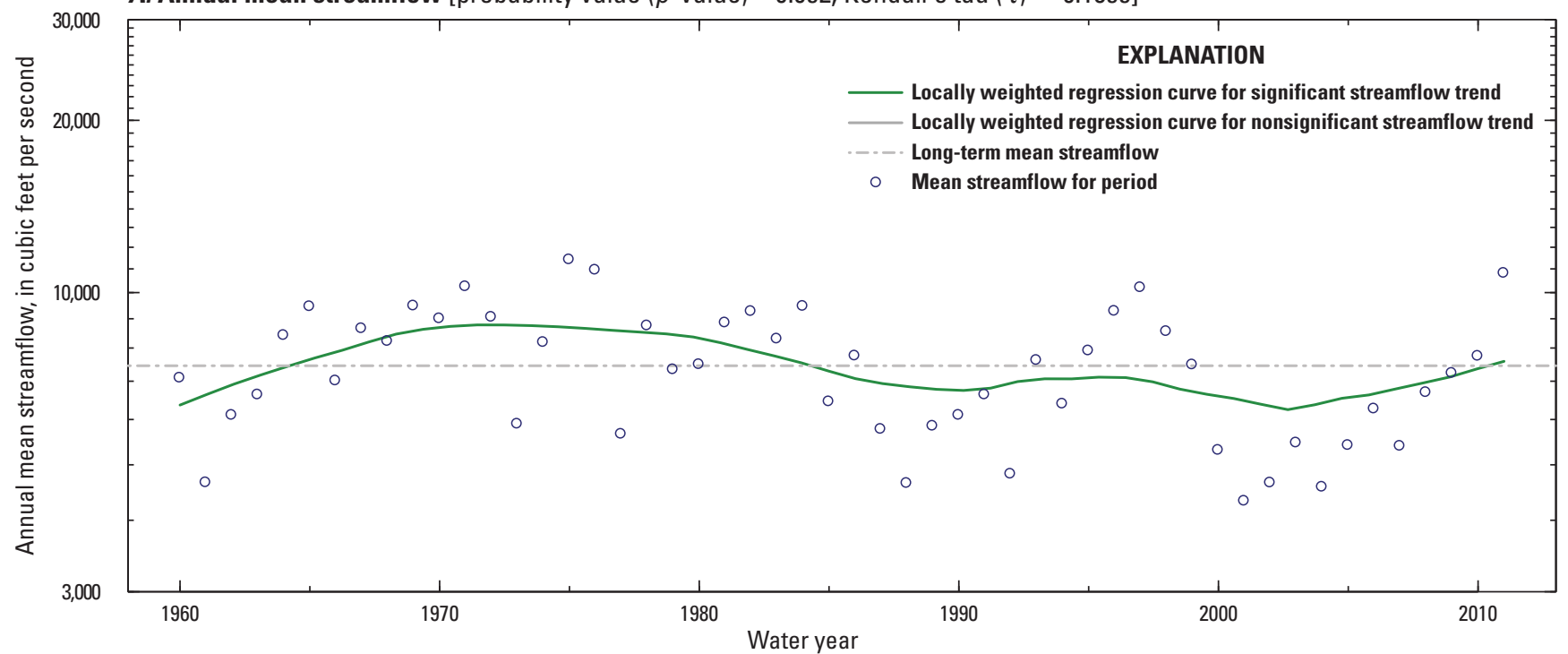

B. October-December $(p$-value $=0.019, \tau=-0.2247)$

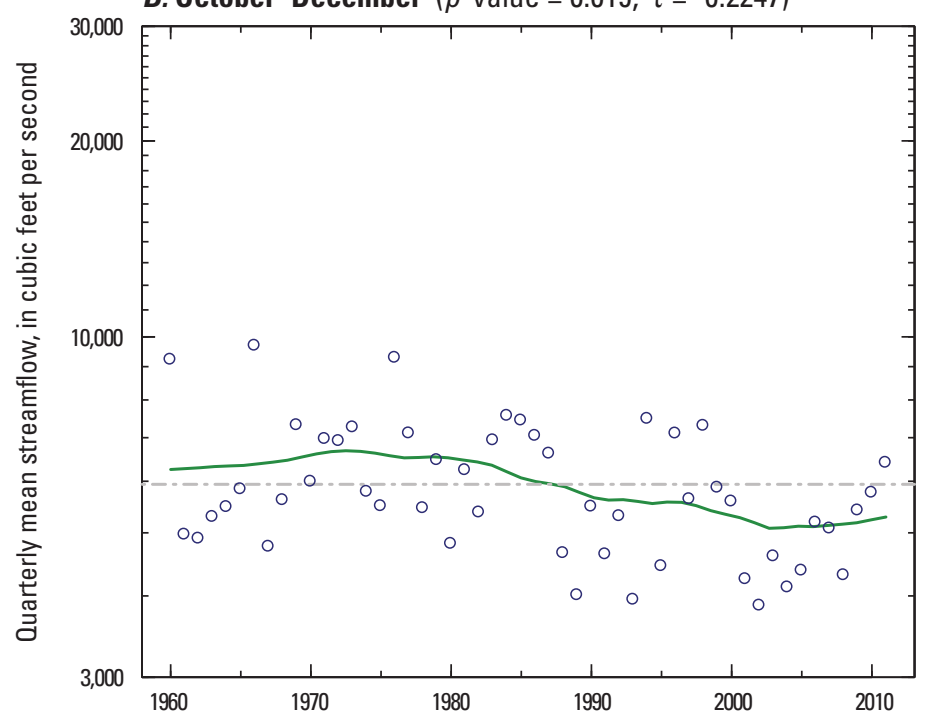

C. January-March $(p$-value $=0.024, \tau=-0.2157)$
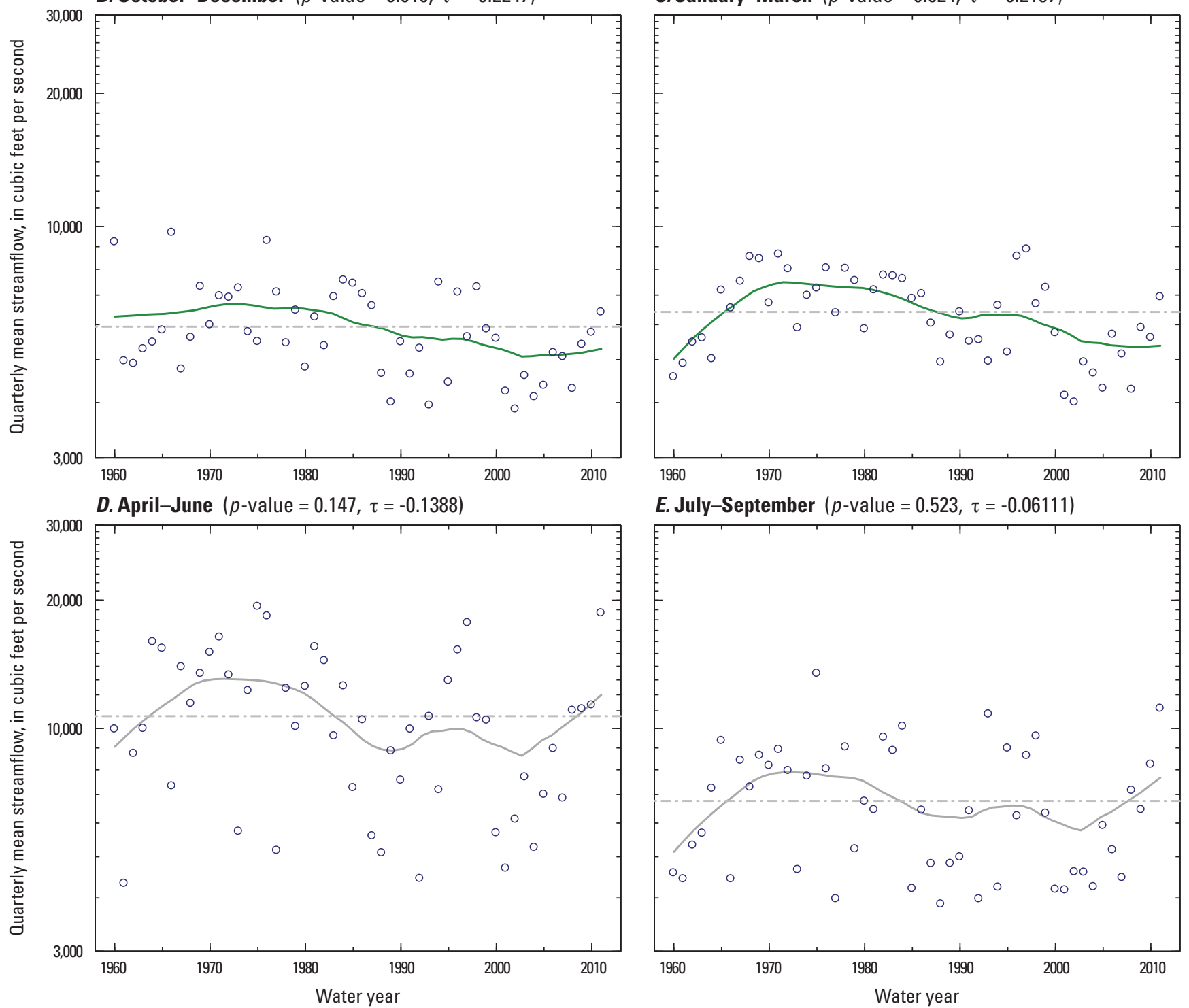

E. July-September $(p$-value $=0.523, \tau=-0.06111)$

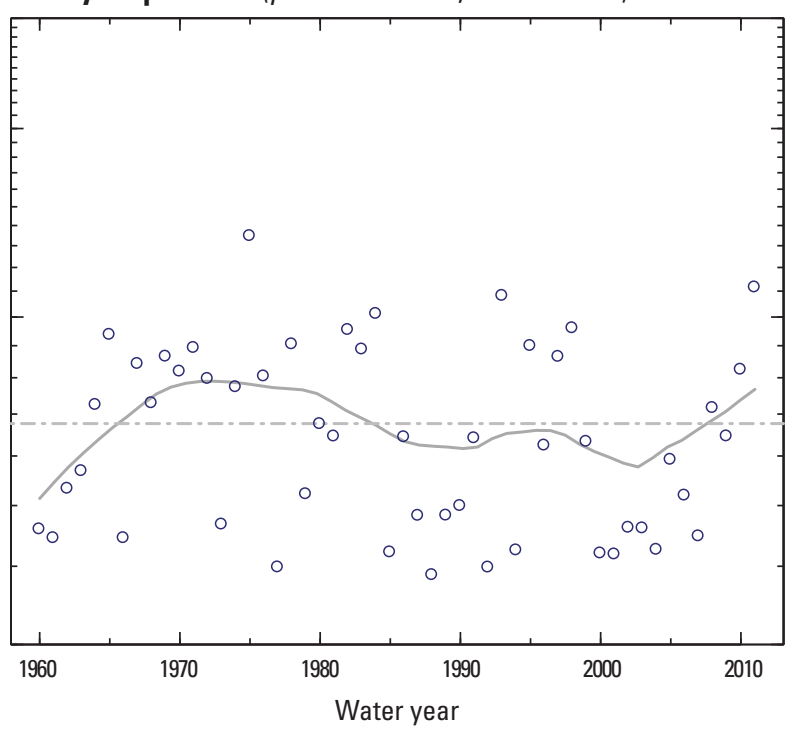

Figure 1-9. Missouri River near Great Falls, Montana (streamgage 06090300), water years 1960-2011. 
A. Annual mean streamflow [probability value $(p$-value $)=0.039$, Kendall's tau $(\tau)=-0.1976$ ]
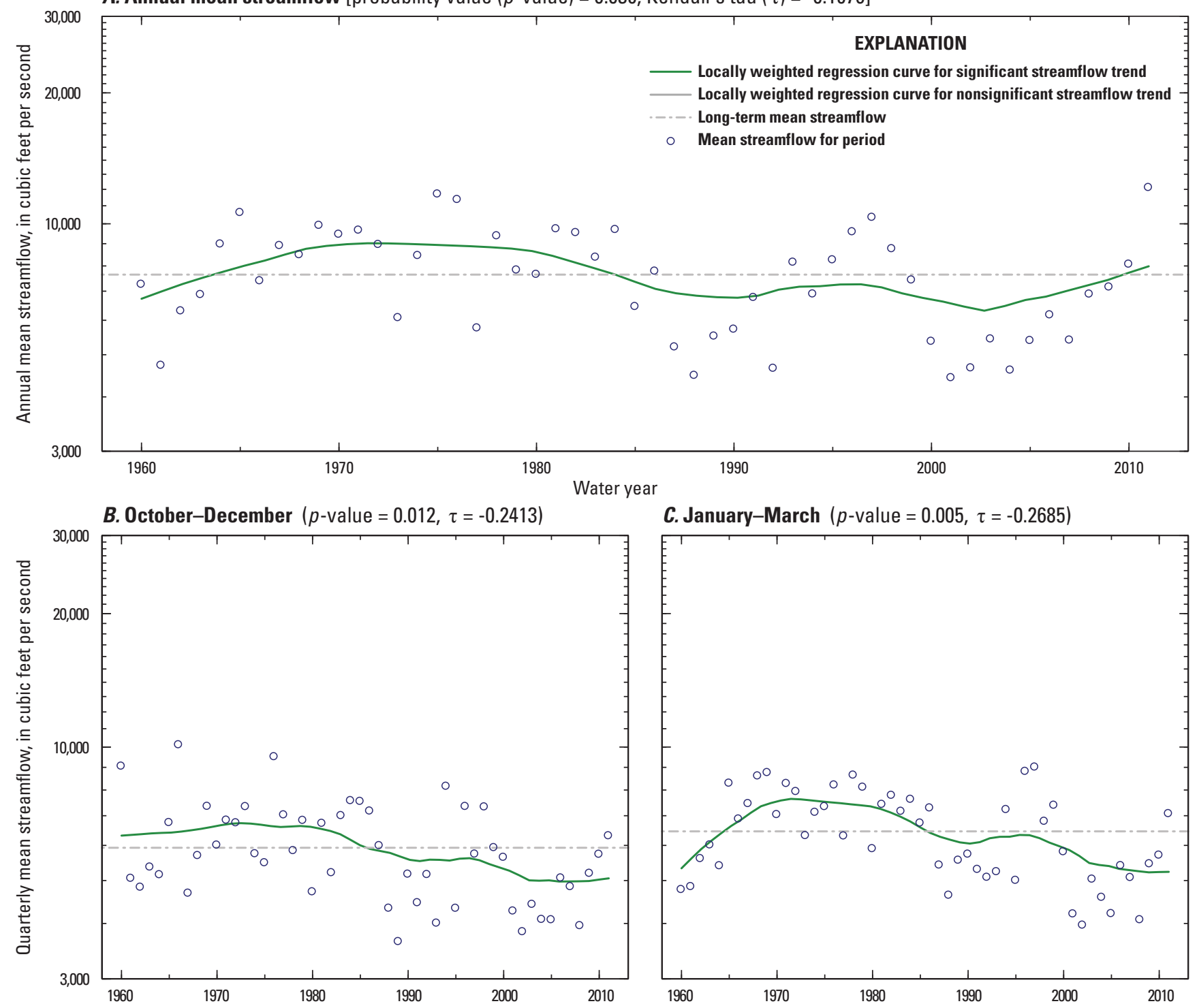

C. January-March ( $p$-value $=0.005, \tau=-0.2685)$
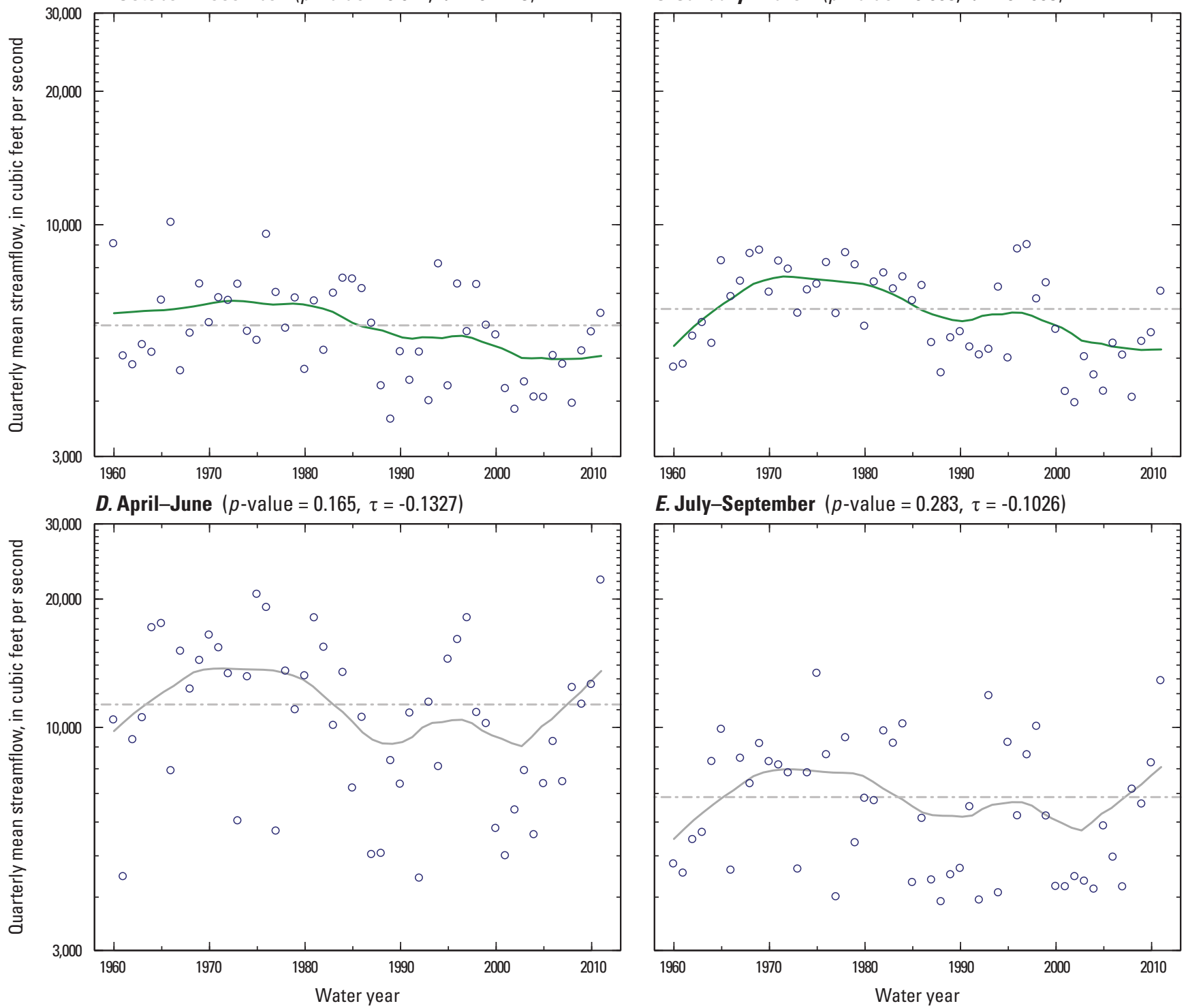

E. July-September $(p$-value $=0.283, \tau=-0.1026)$

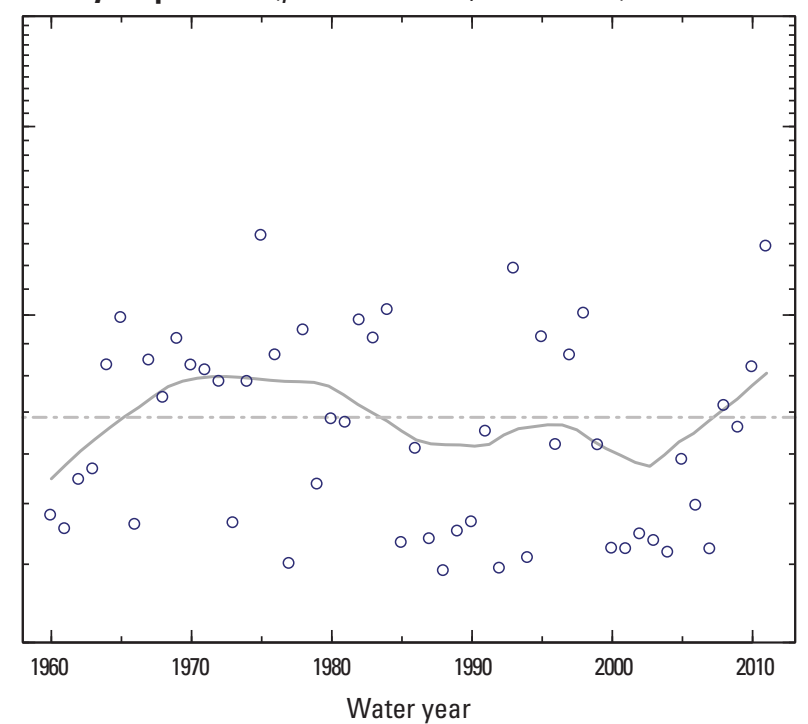

Figure 1-10. Missouri River at Fort Benton, Montana (streamgage 06090800), water years 1960-2011. 


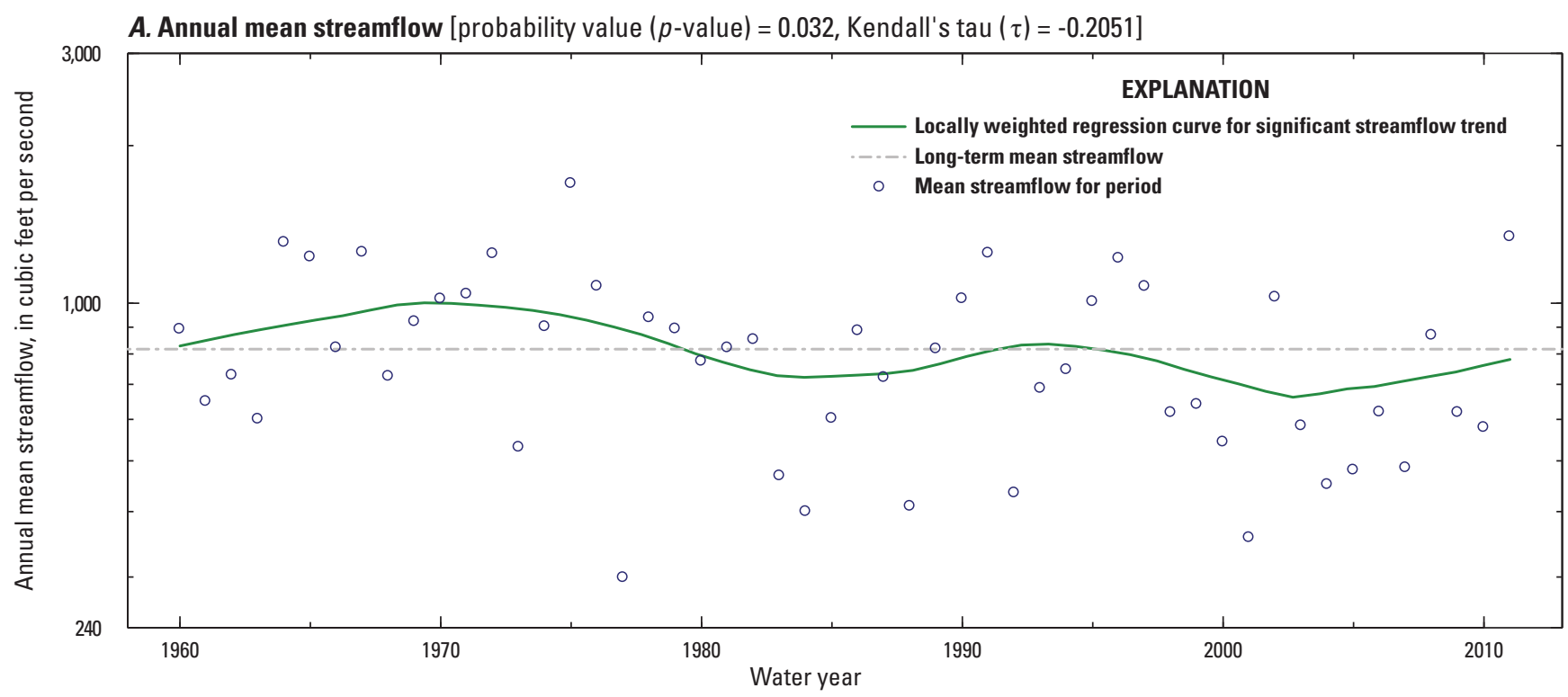

Note: Seasonal plots of streamflow are not presented for this streamgage because of gaps in the monthly streamflow data.

Figure 1-11. Marias River near Shelby, Montana (streamgage 06099500), water years 1960-2011. 
A. Annual mean streamflow [probability value $(p$-value $)=0.014$, Kendall's tau $(\tau)=-0.2346$ ]
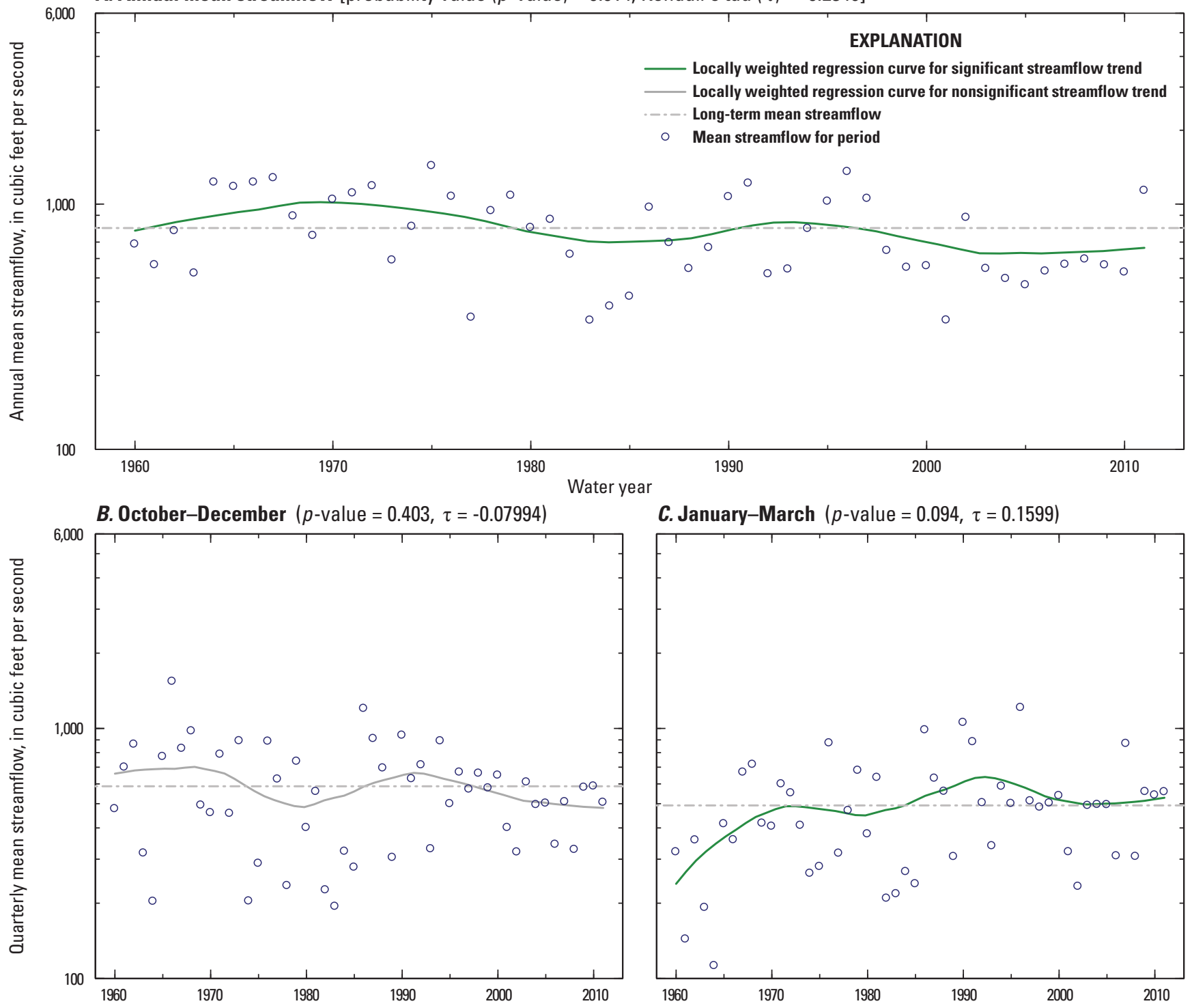

C. January-March ( $p$-value $=0.094, \tau=0.1599)$
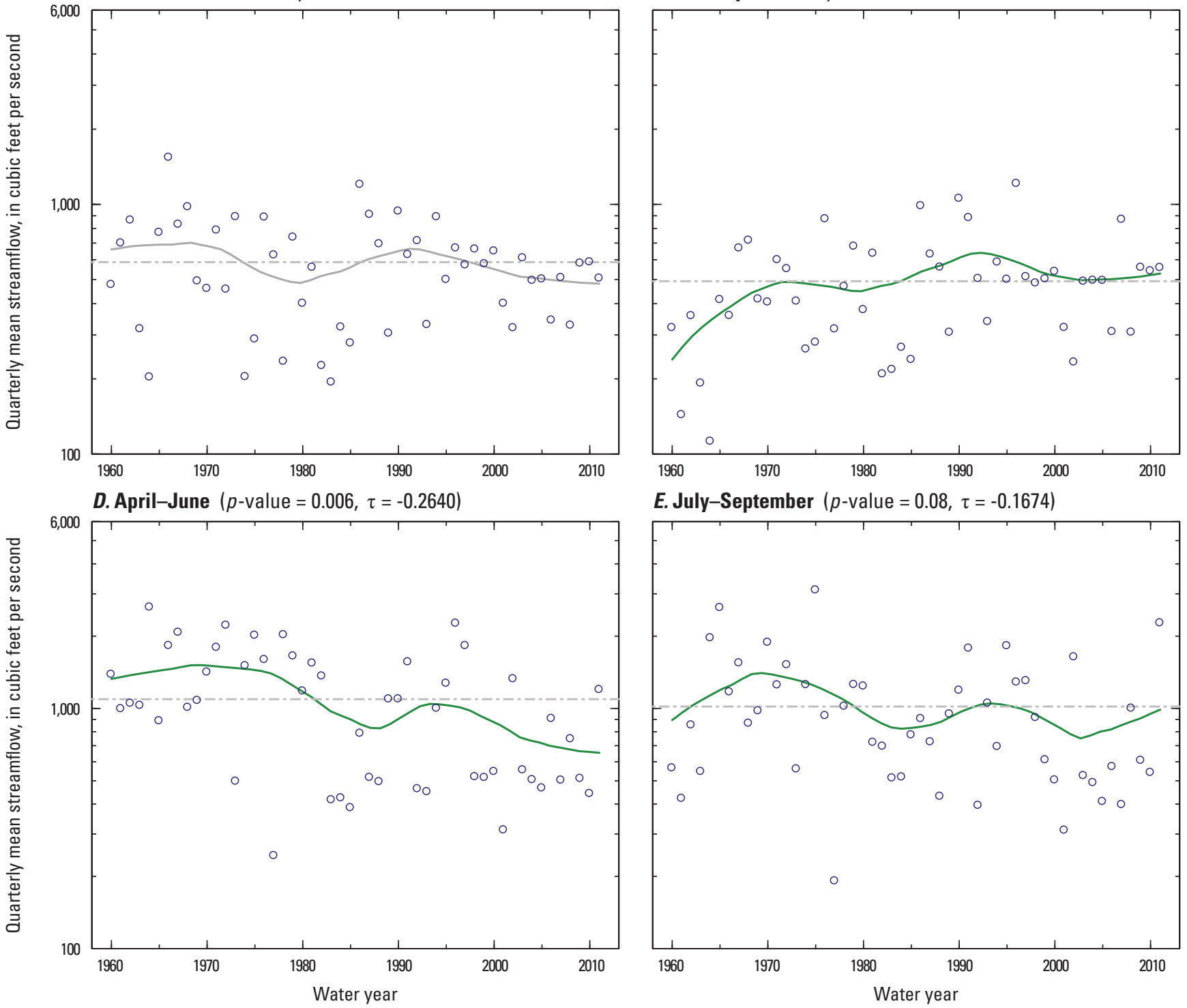

E. July-September $(p$-value $=0.08, \tau=-0.1674)$

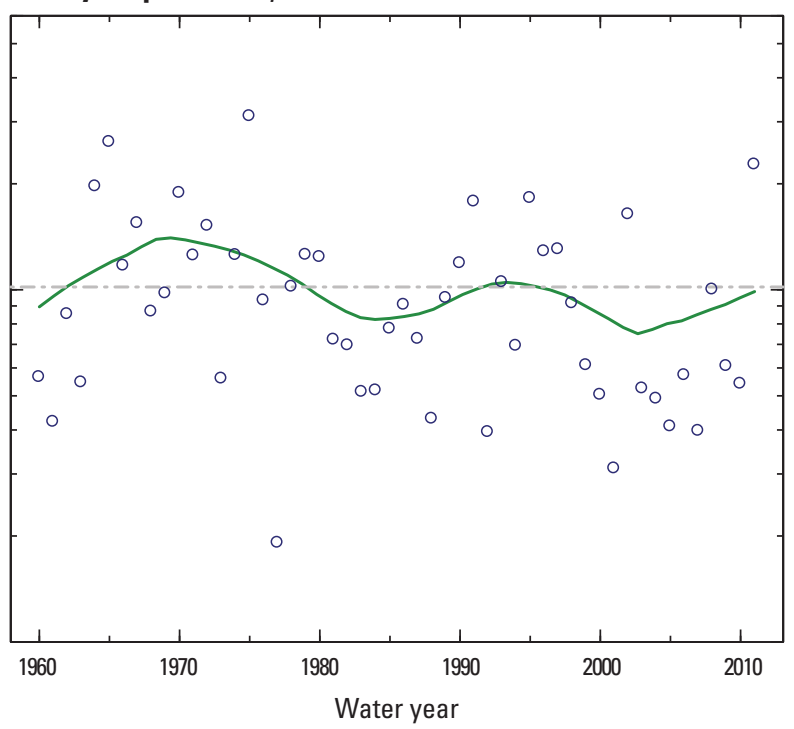

Figure 1-12. Marias River near Chester, Montana (streamgage 06101500), water years 1960-2011. 

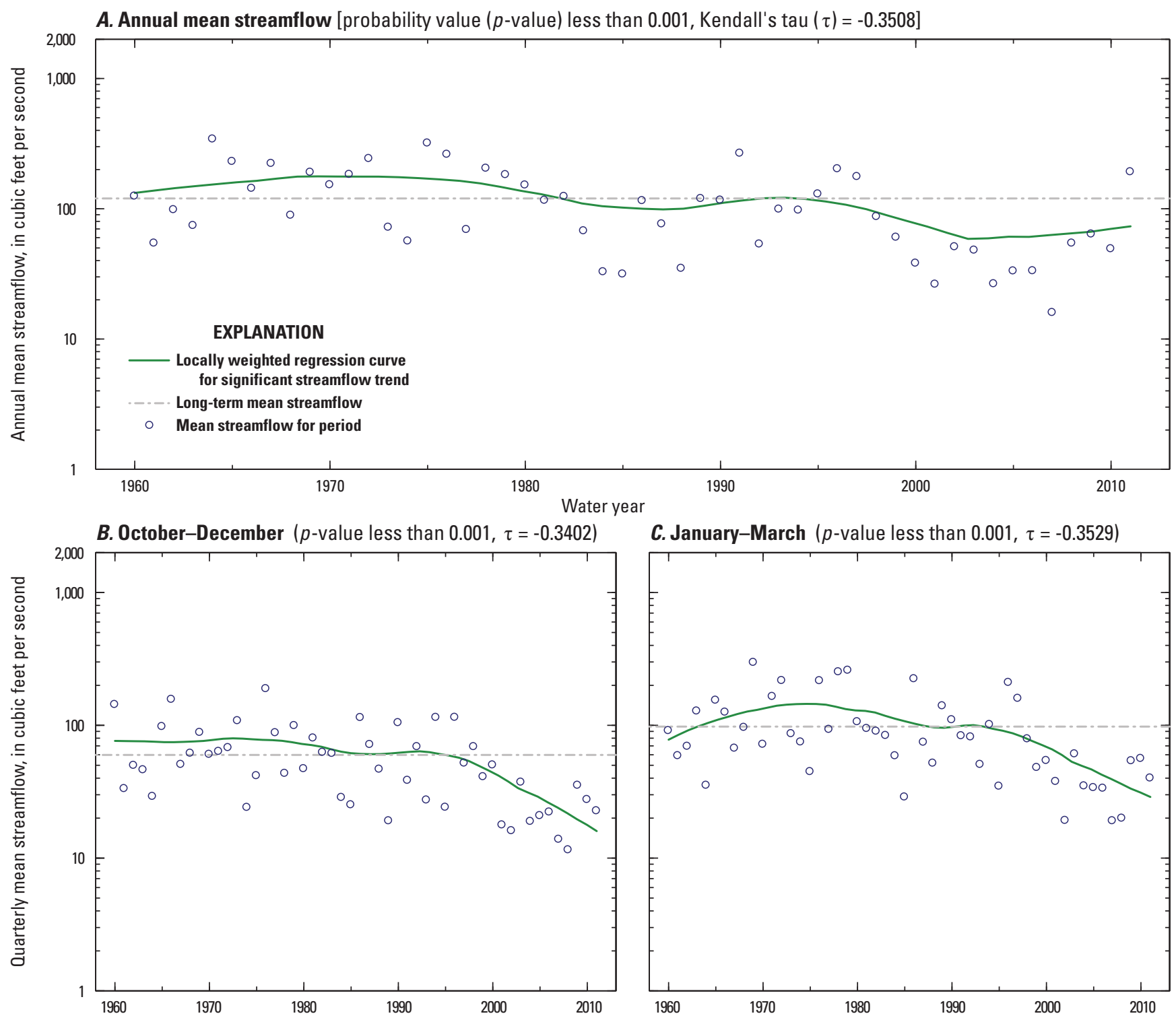

C. January-March ( $p$-value less than $0.001, \tau=-0.3529)$
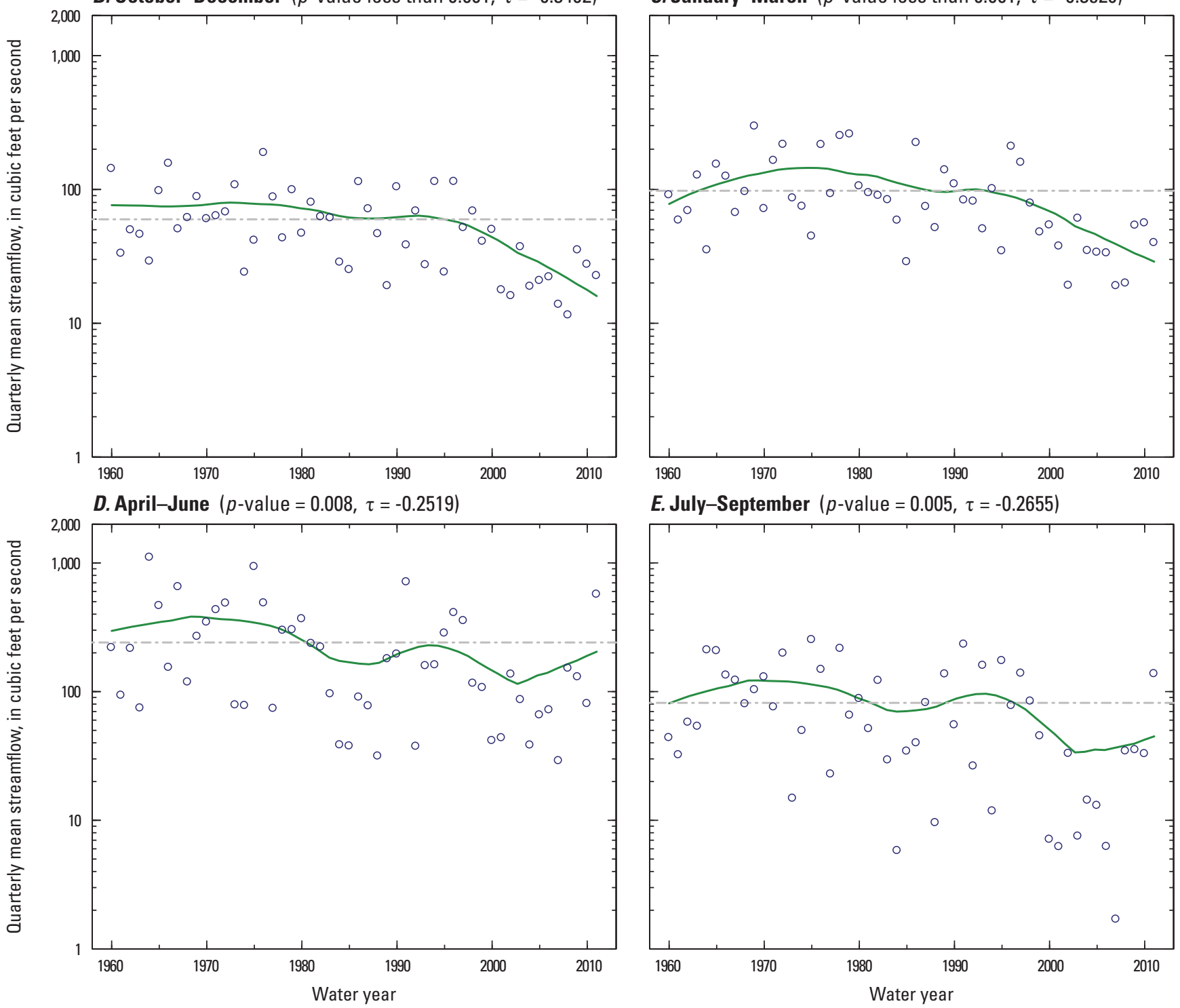

E. July-September $(p$-value $=0.005, \tau=-0.2655)$

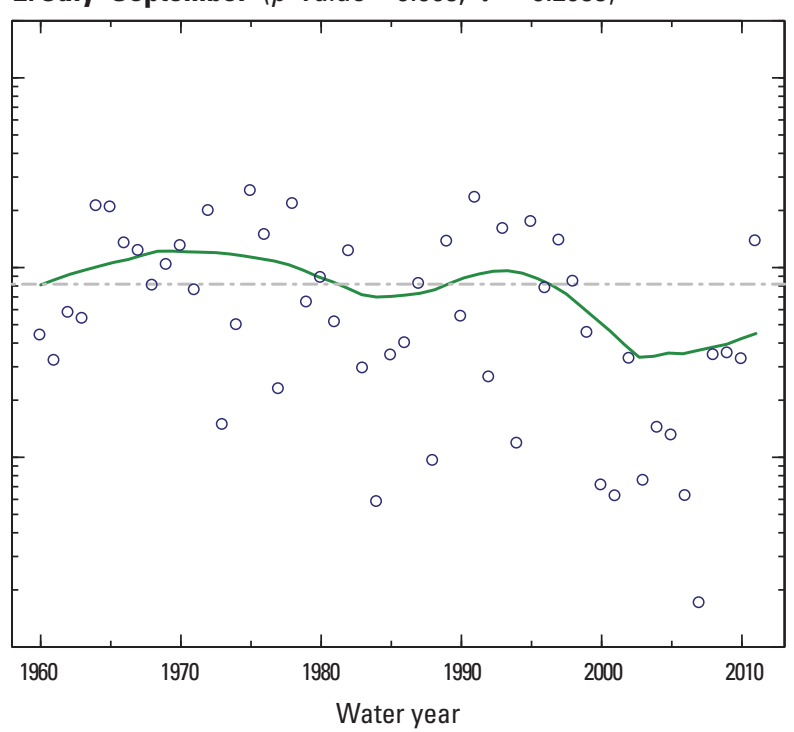

Figure 1-13. Teton River near Dutton, Montana (streamgage 06108000), water years 1960-2011. 
A. Annual mean streamflow [probability value $(p$-value $)=0.02$, Kendall's tau $(\tau)=-0.2217$ ]
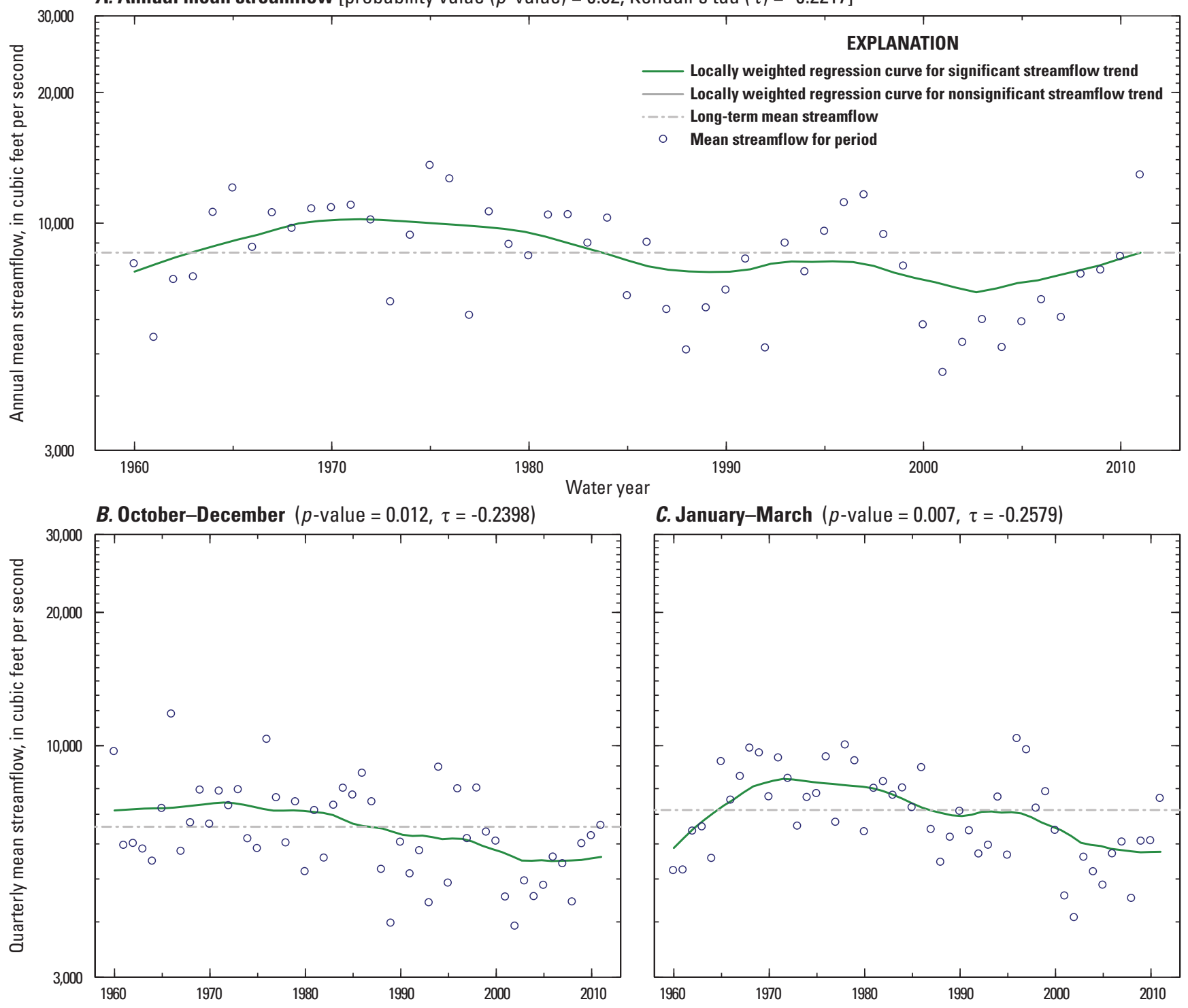

C. January-March ( $p$-value $=0.007, \tau=-0.2579)$
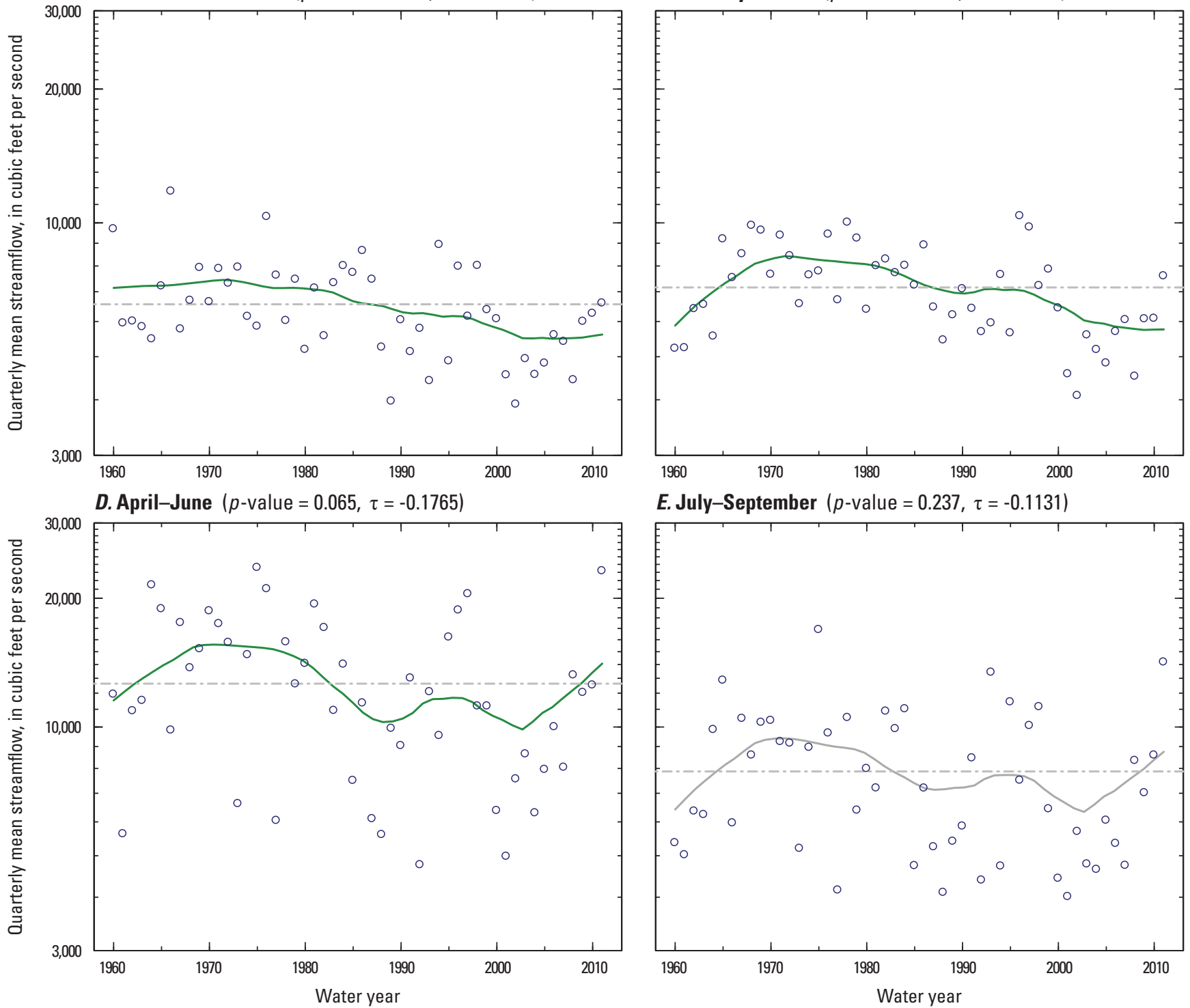

E. July-September $(p$-value $=0.237, \tau=-0.1131)$

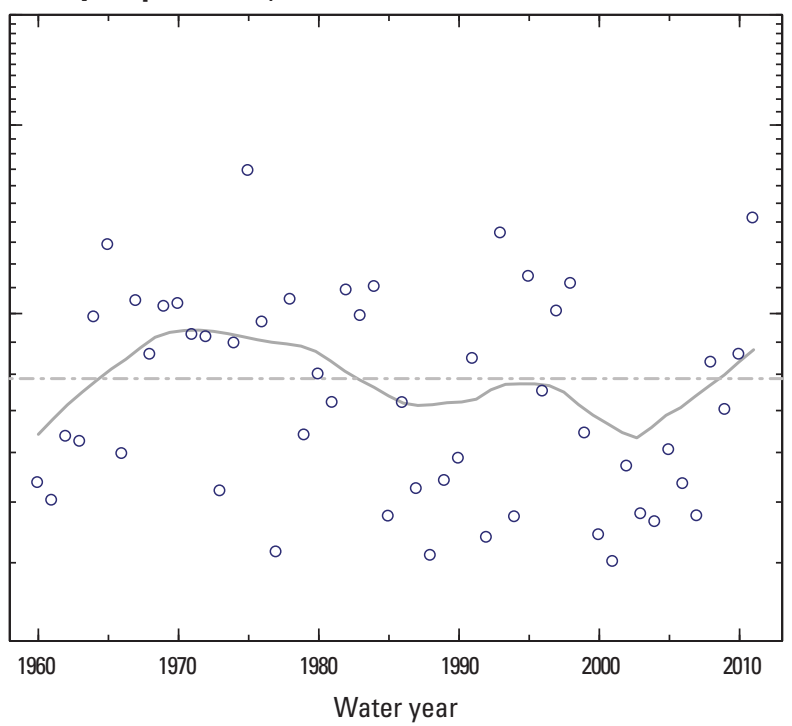

Figure 1-14. Missouri River at Virgelle, Montana (streamgage 06109500), water years 1960-2011. 

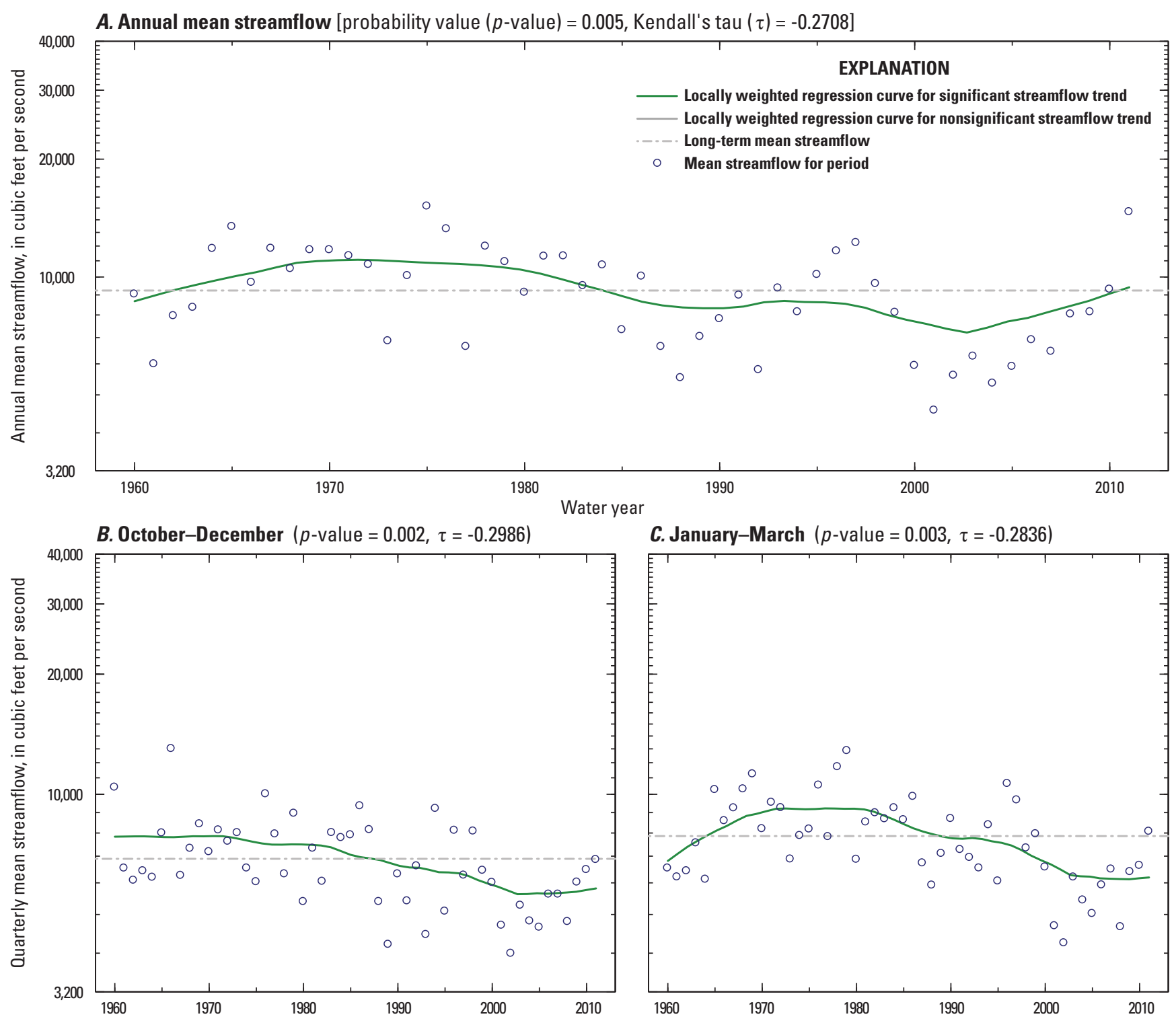

C. January-March $(p$-value $=0.003, \tau=-0.2836)$
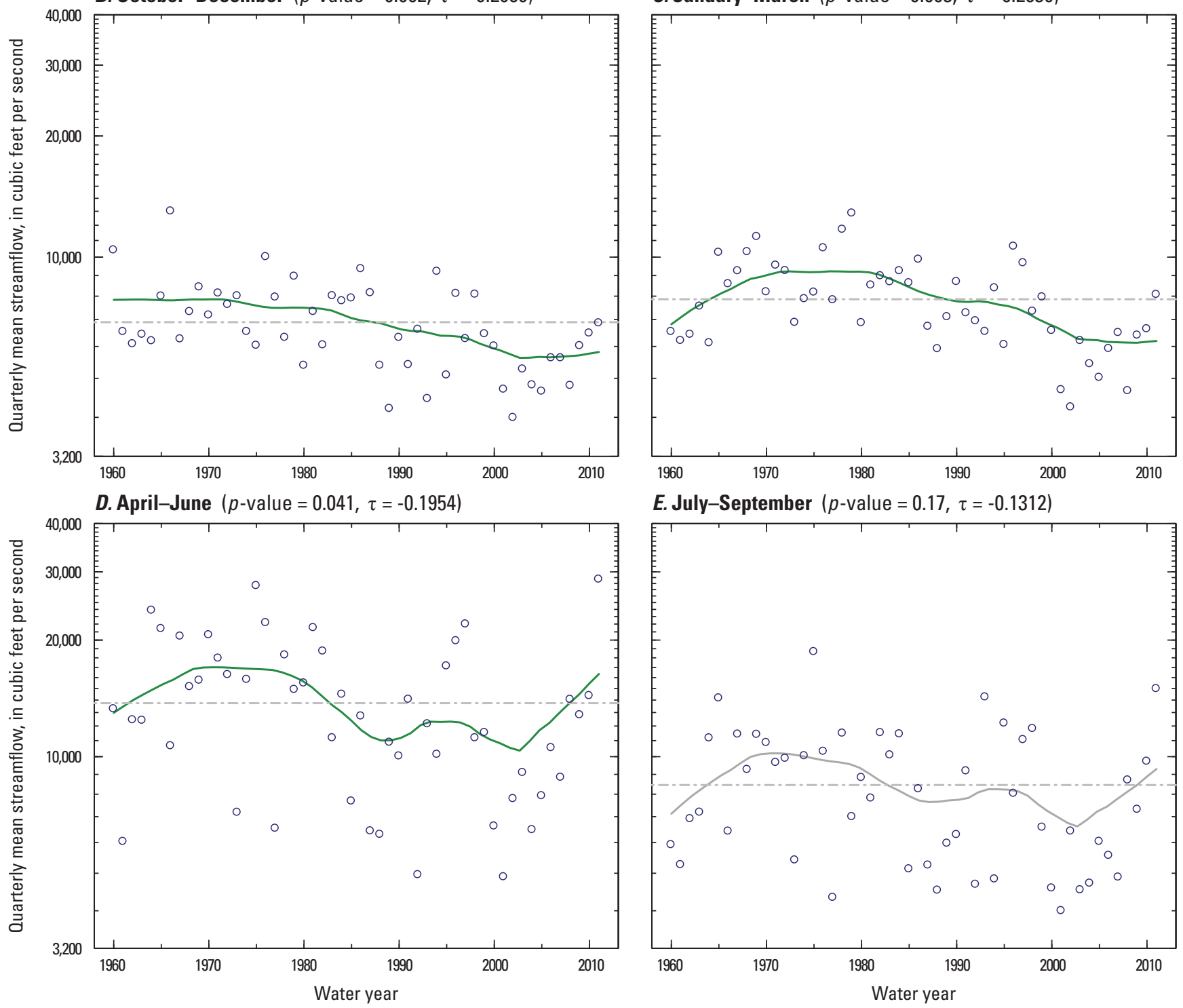

E. July-September $(p$-value $=0.17, \tau=-0.1312)$

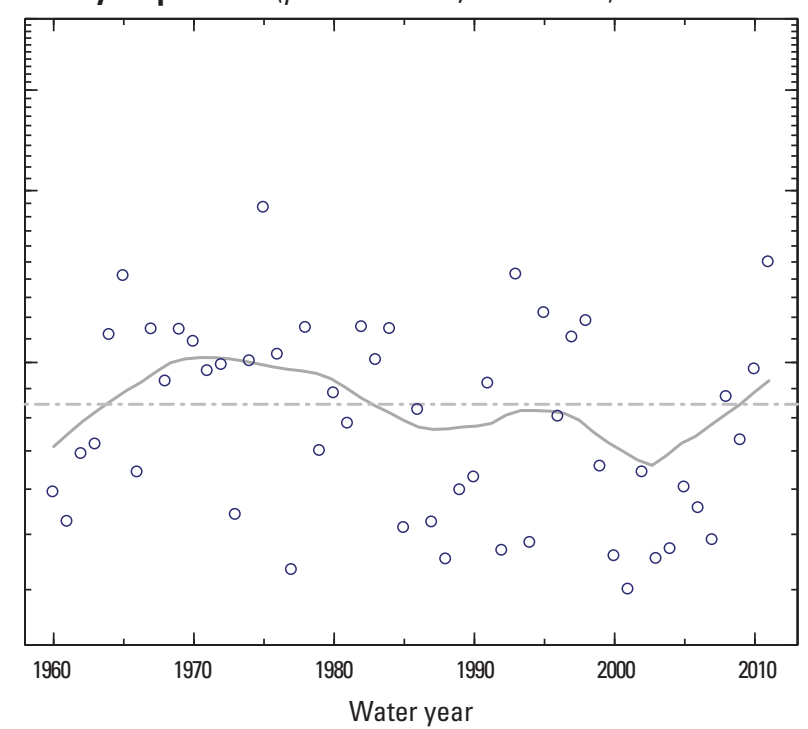

Figure 1-15. Missouri River near Landusky, Montana (streamgage 06115200), water years 1960-2011. 
A. Annual mean streamflow [probability value $(p$-value $)=0.039$, Kendall's tau $(\tau)=-0.1976$ ]
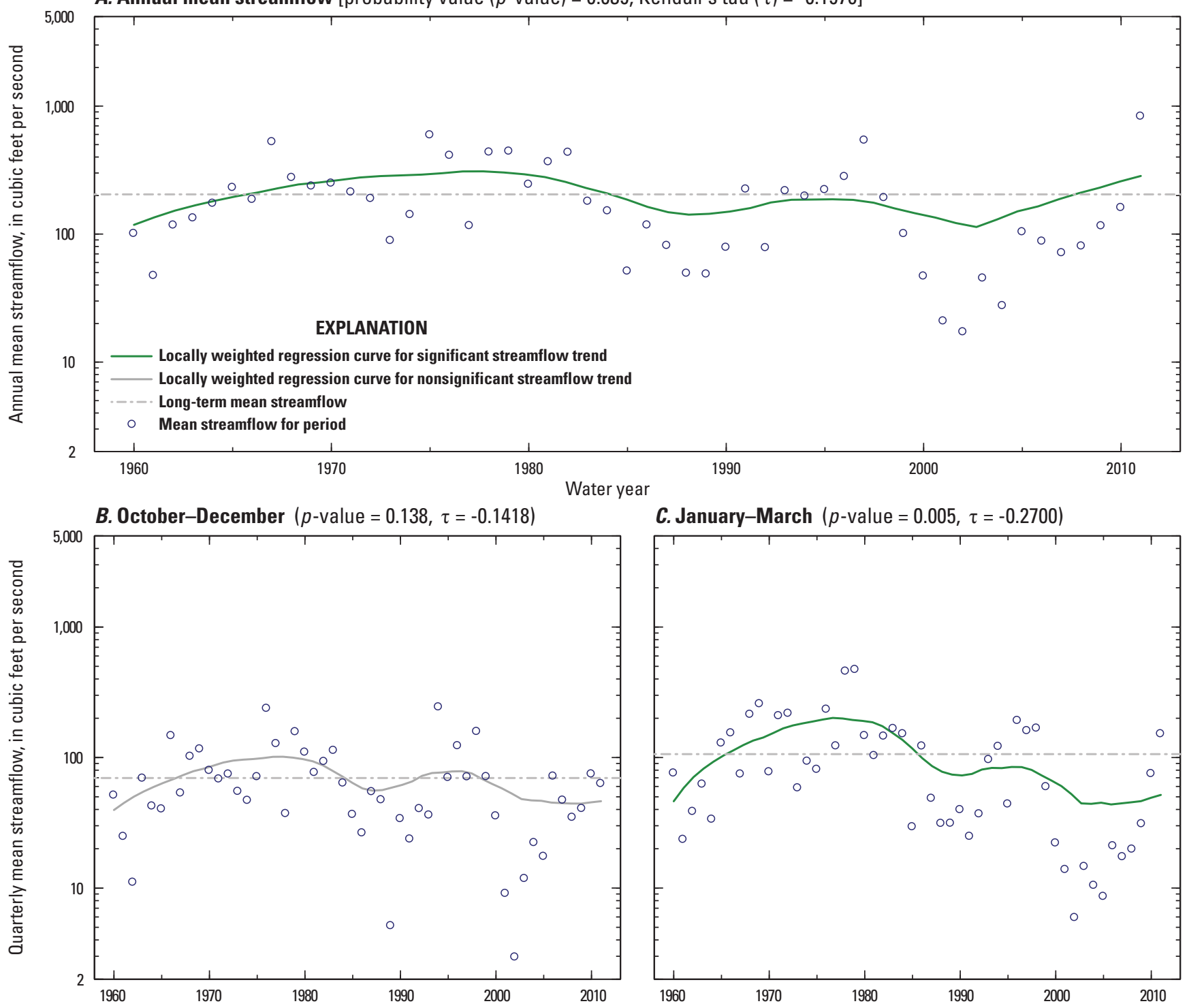

C. January-March $(p$-value $=0.005, \tau=-0.2700)$
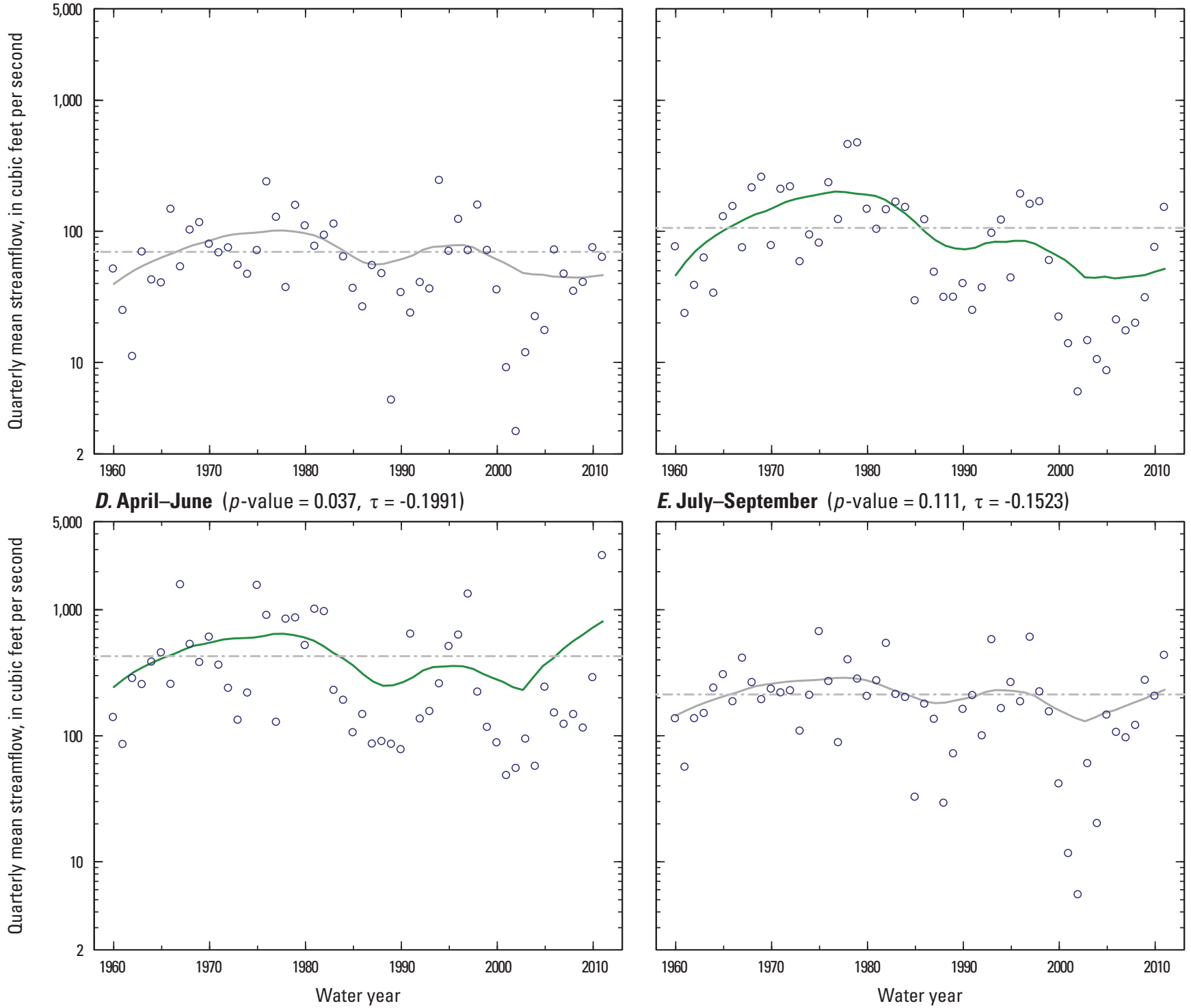

E. July-September $(p$-value $=0.111, \tau=-0.1523)$

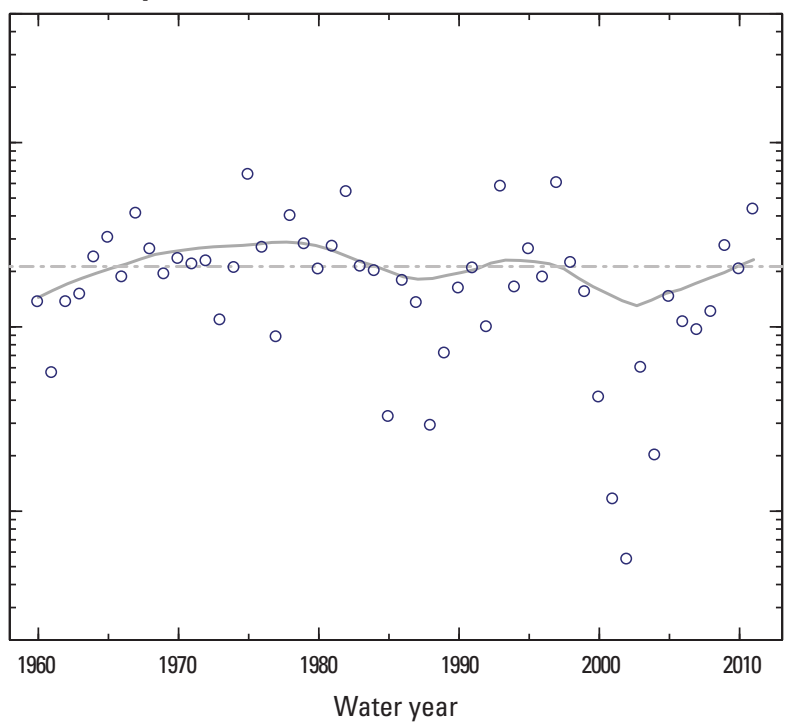

Figure 1-16. Musselshell River near Roundup, Montana (streamgage 06126500), water years 1960-2011. 
A. Annual mean streamflow [probability value $(p$-value $)=0.043$, Kendall's tau $(\tau)=-0.1931$ ]

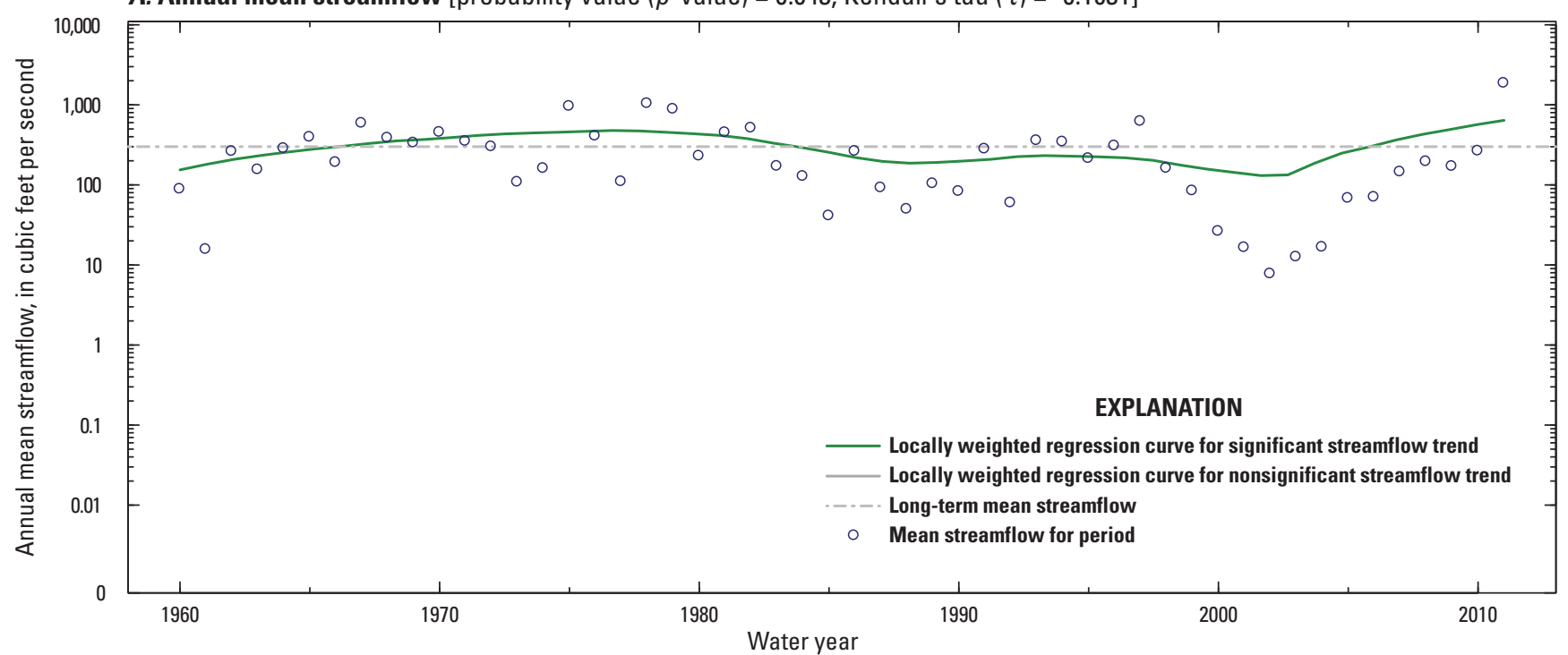

B. October-December $(p$-value $=0.201, \tau=-0.1222)$

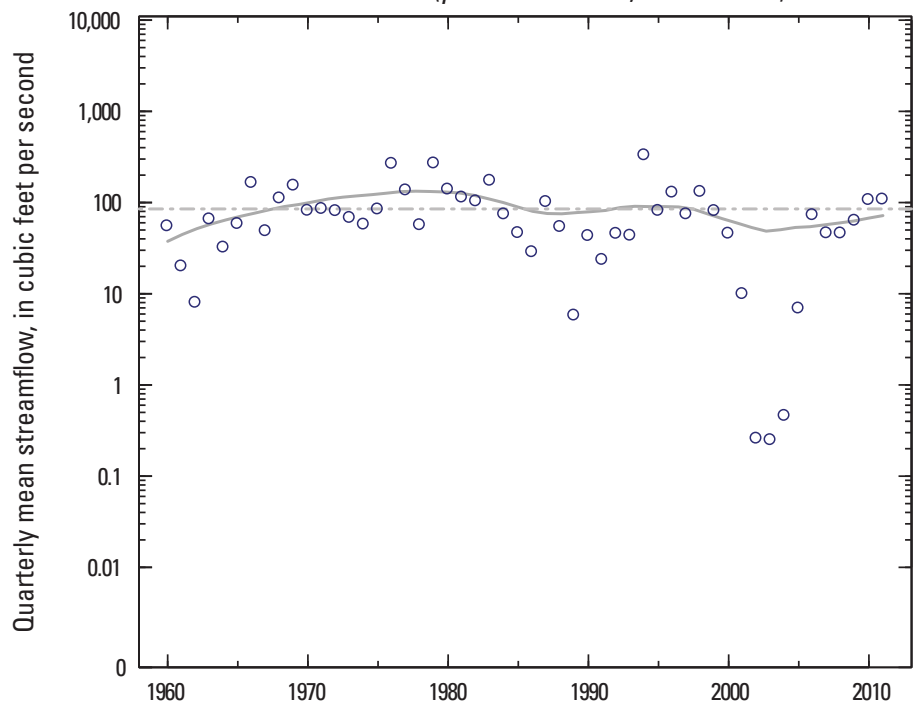

C. January-March $(p$-value $=0.045, \tau=-0.1916)$
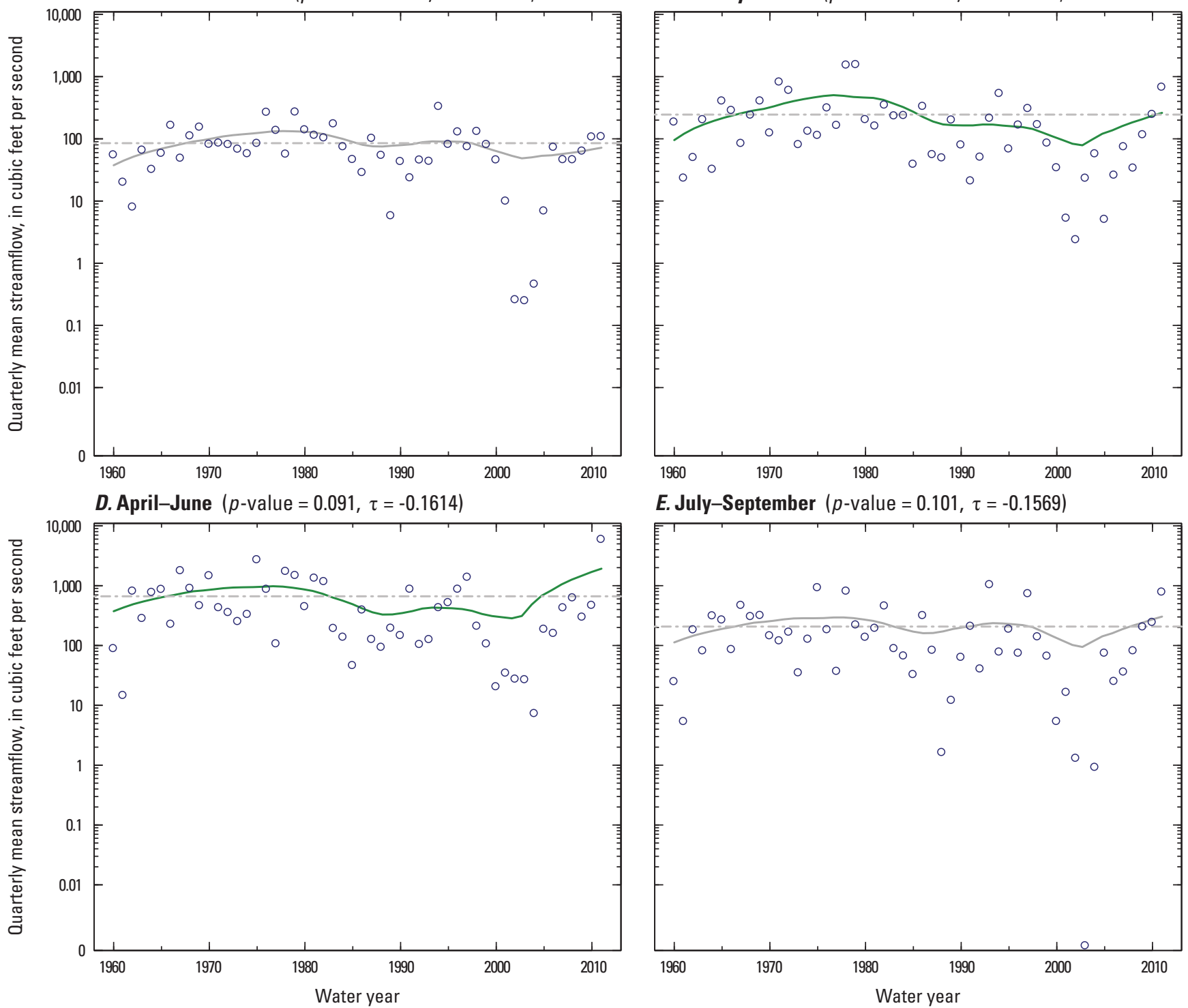

E. July-September $(p$-value $=0.101, \tau=-0.1569)$

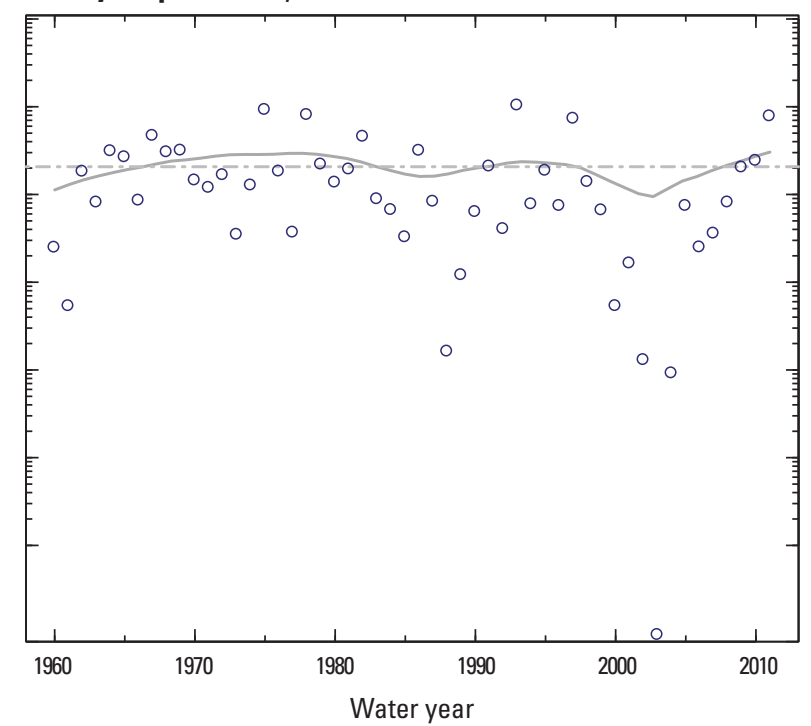

Figure 1-17. Musselshell River at Mosby, Montana (streamgage 06130500), water years 1960-2011. 
A. Annual mean streamflow [probability value $(p$-value $)=0.001$, Kendall's tau $(\tau)=-0.3040$ ]

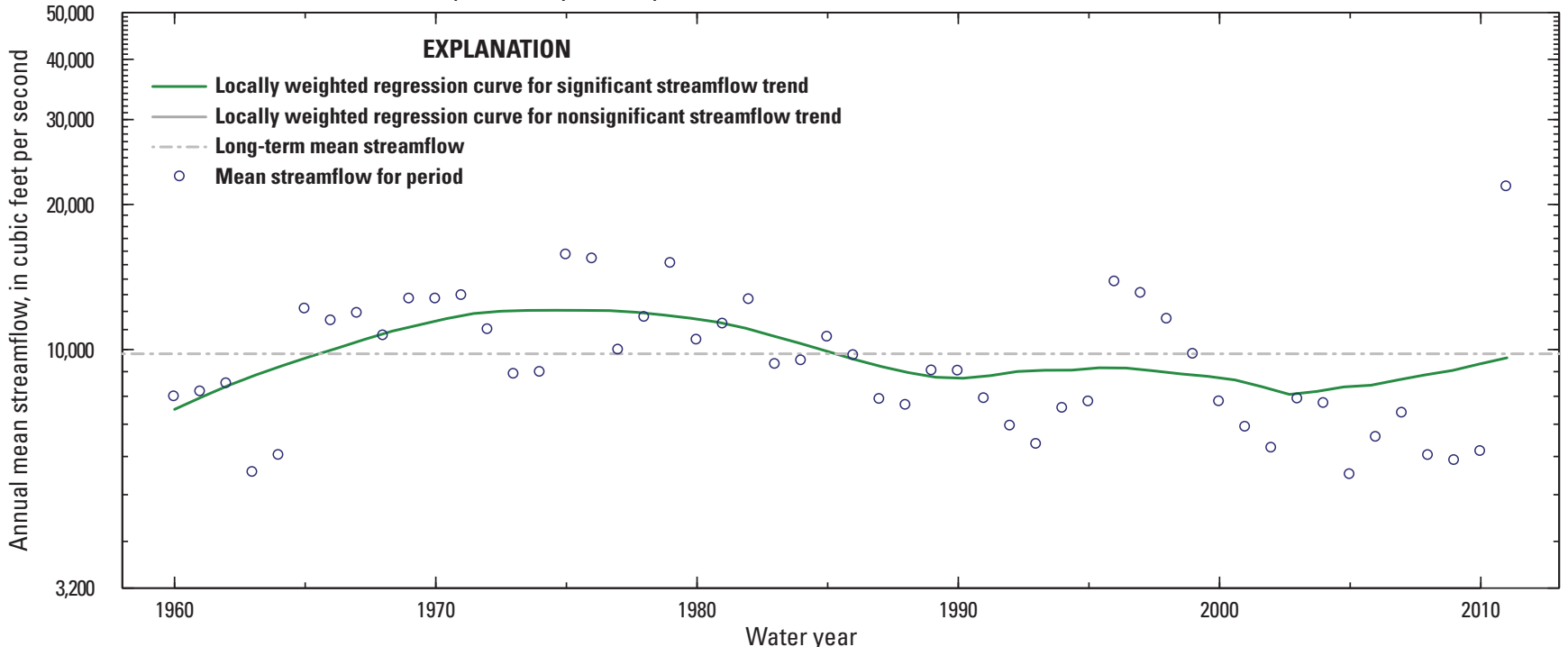

B. October-December $(p$-value $=0.001, \tau=-0.3122)$

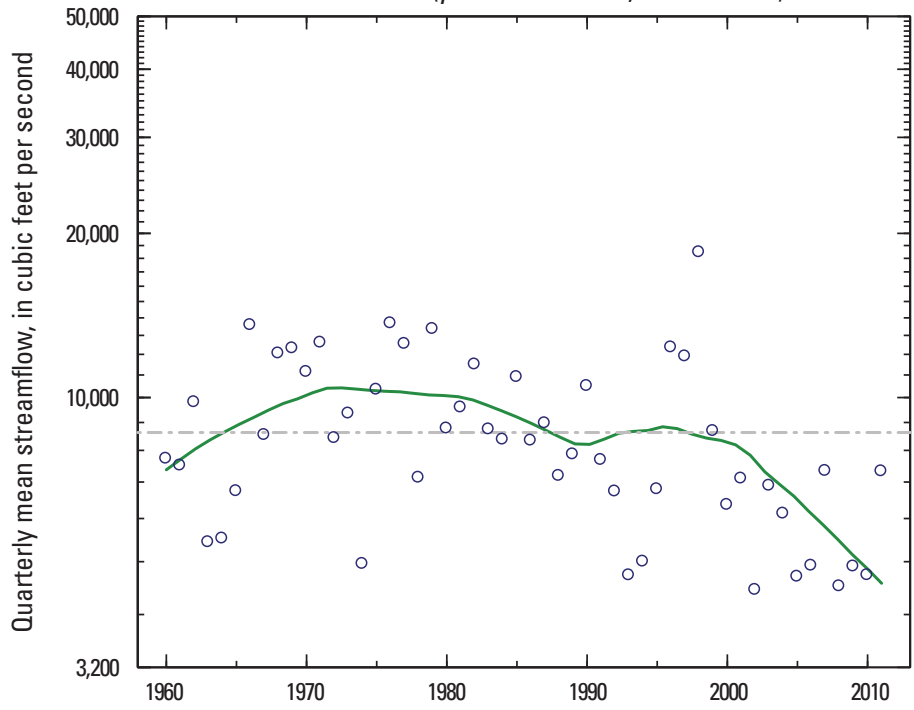

C. January-March ( $p$-value less than $0.001, \tau=-0.3484)$

D. April-June $(p$-value $=0.111, \tau=-0.1523)$
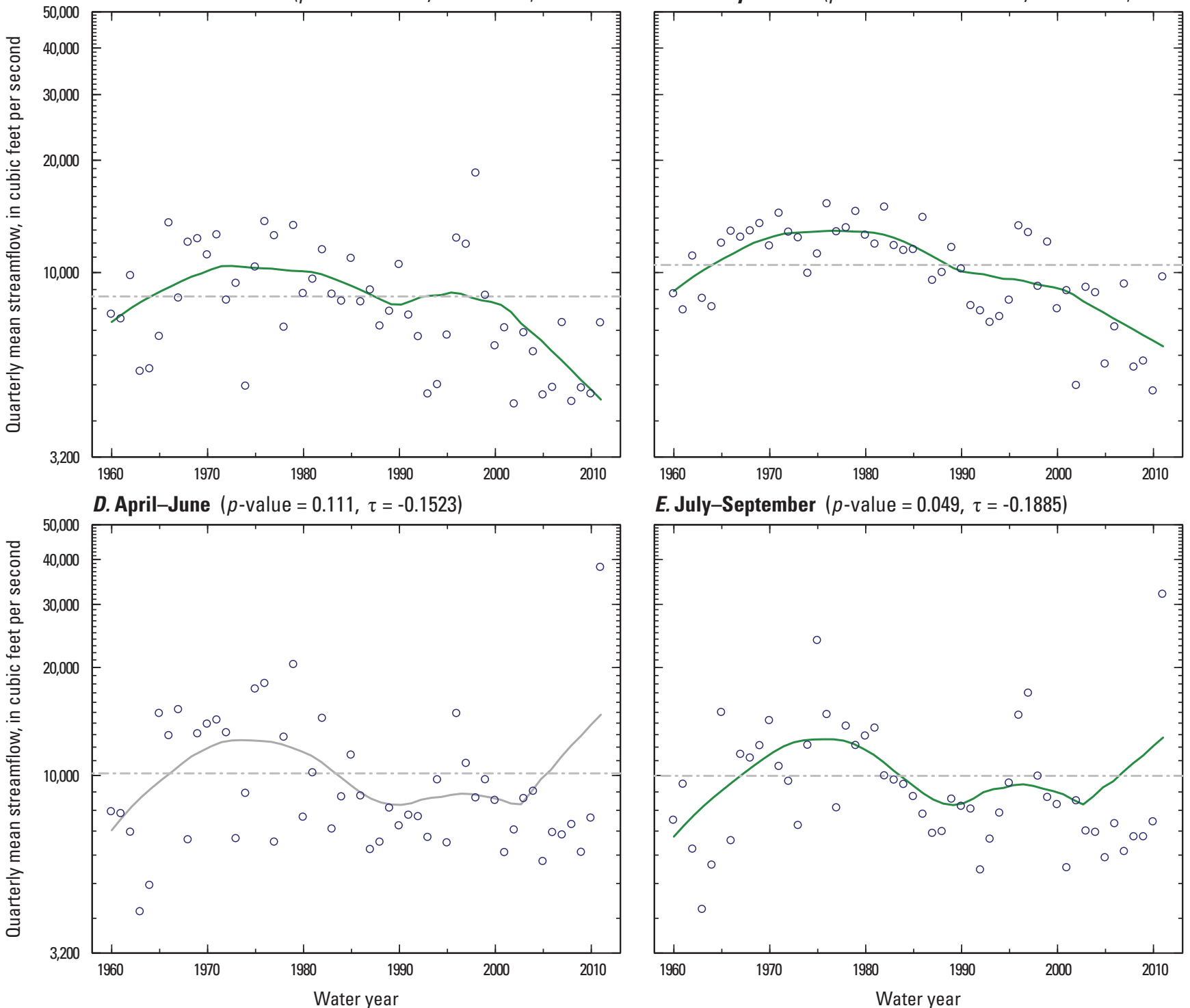

E. July-September $(p$-value $=0.049, \tau=-0.1885)$

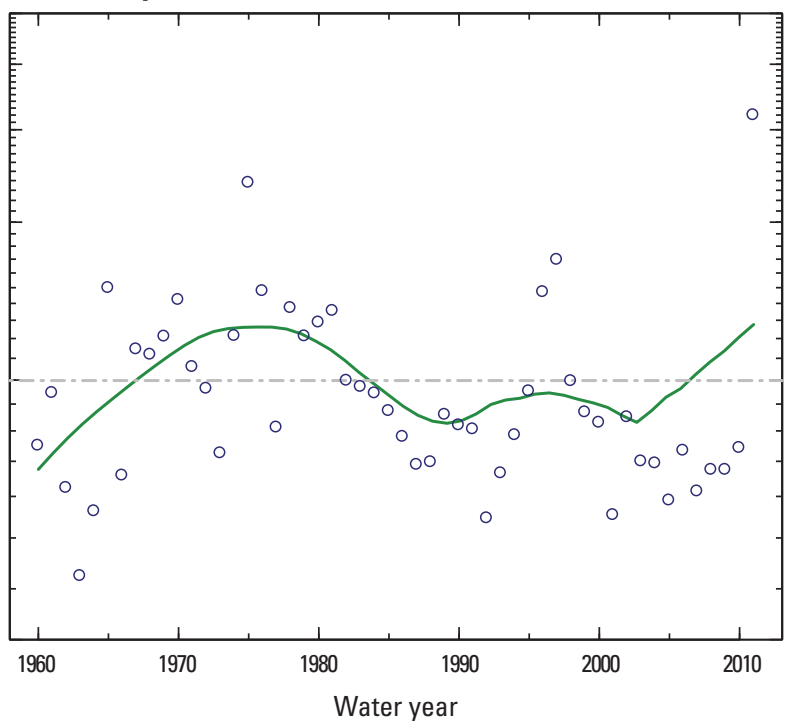

Figure 1-18. Missouri River near Wolf Point, Montana (streamgage 06177000), water years 1960-2011. 
A. Annual mean streamflow [probability value ( $p$-value) less than 0.001 , Kendall's tau $(\tau)=-0.3183$ ]

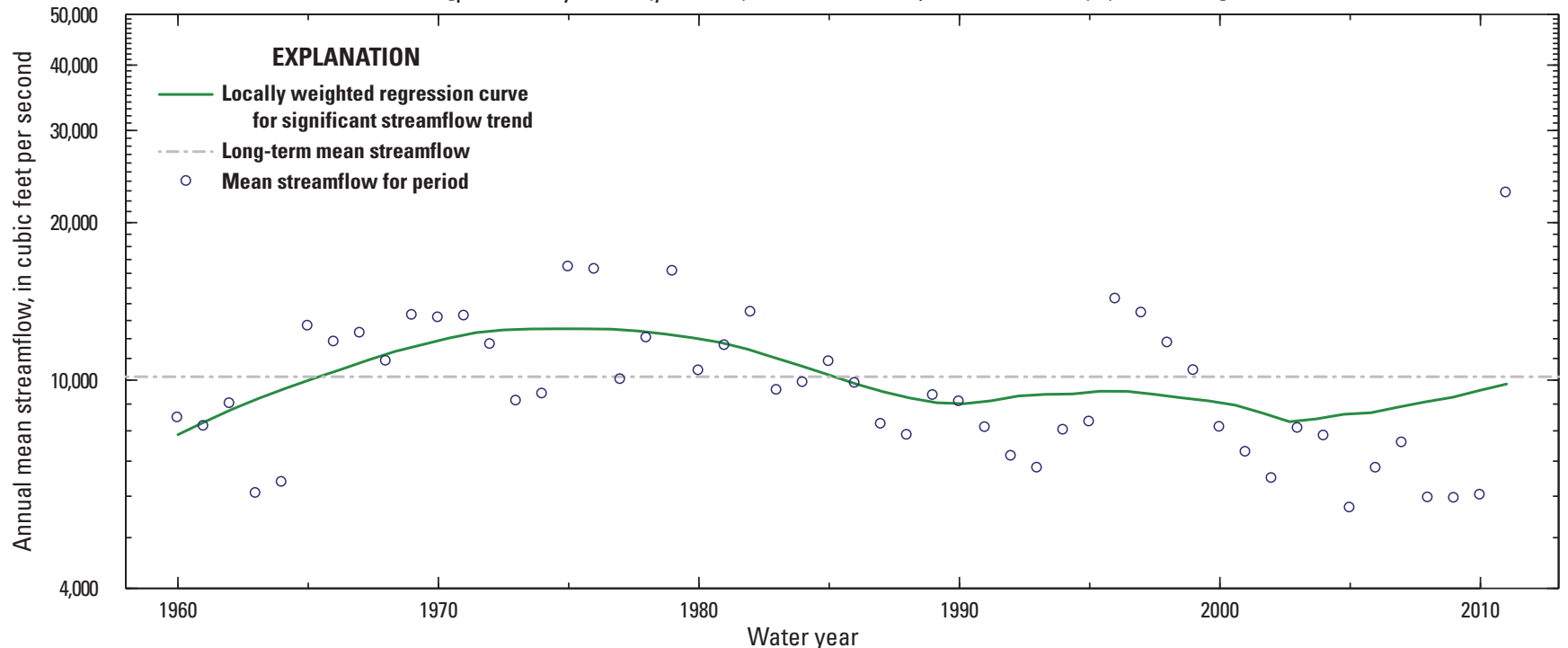

B. October-December $(p$-value $=0.002, \tau=-0.2971)$

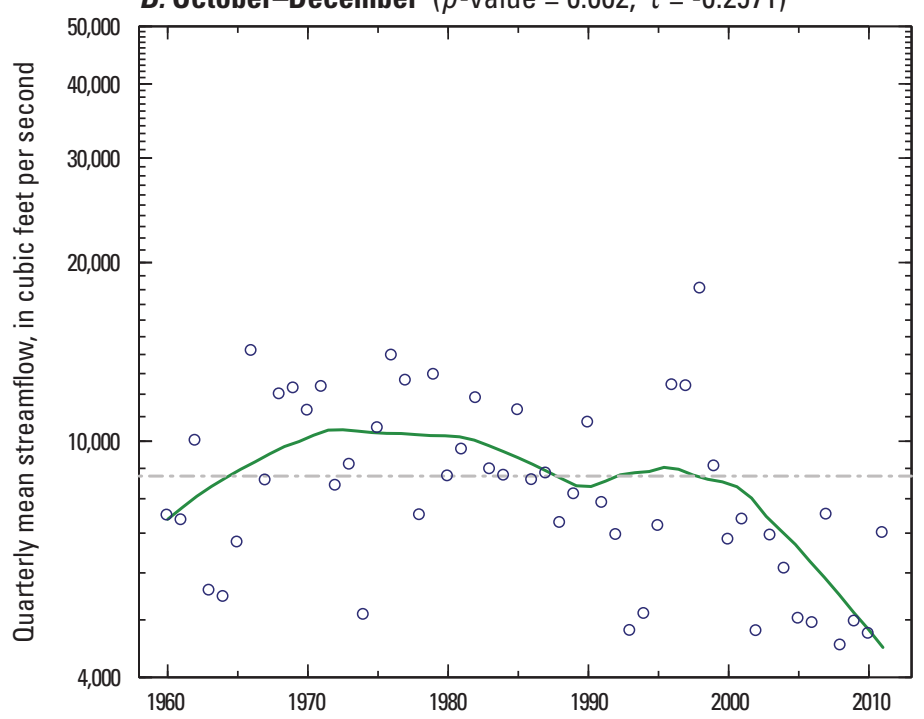

C. January-March ( $p$-value less than $0.001, \tau=-0.3590)$
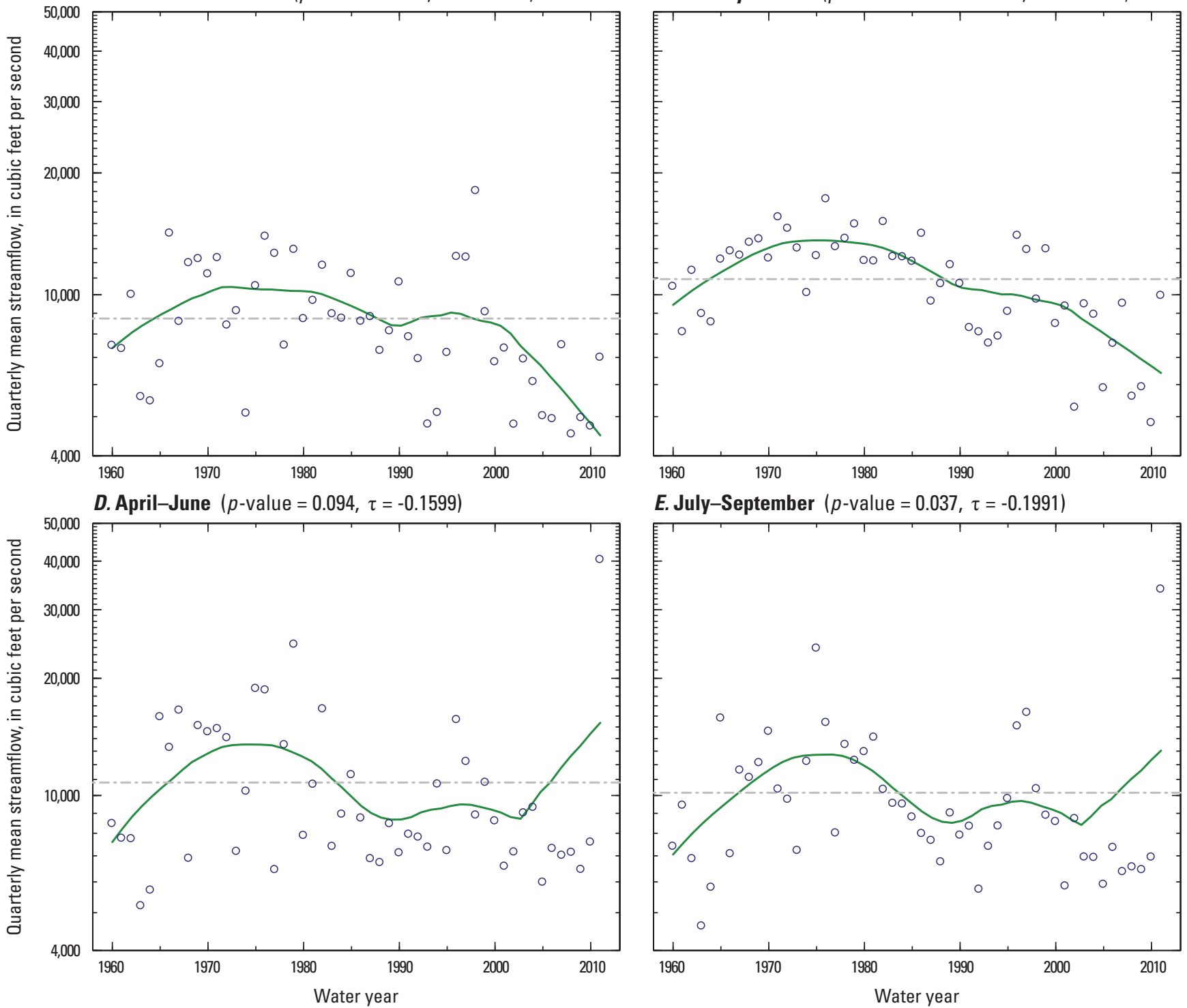

E. July-September $(p$-value $=0.037, \tau=-0.1991)$

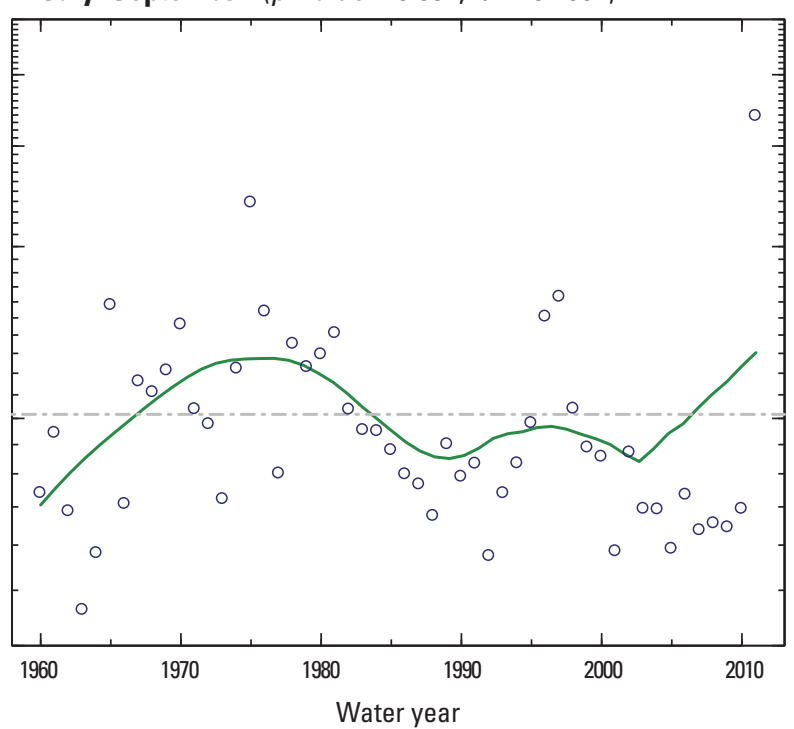

Figure 1-19. Missouri River near Culbertson, Montana (streamgage 06185500), water years 1960-2011. 
A. Annual mean streamflow [probability value $(p$-value $)=0.051$, Kendall's tau $(\tau)=-0.1863$ ]

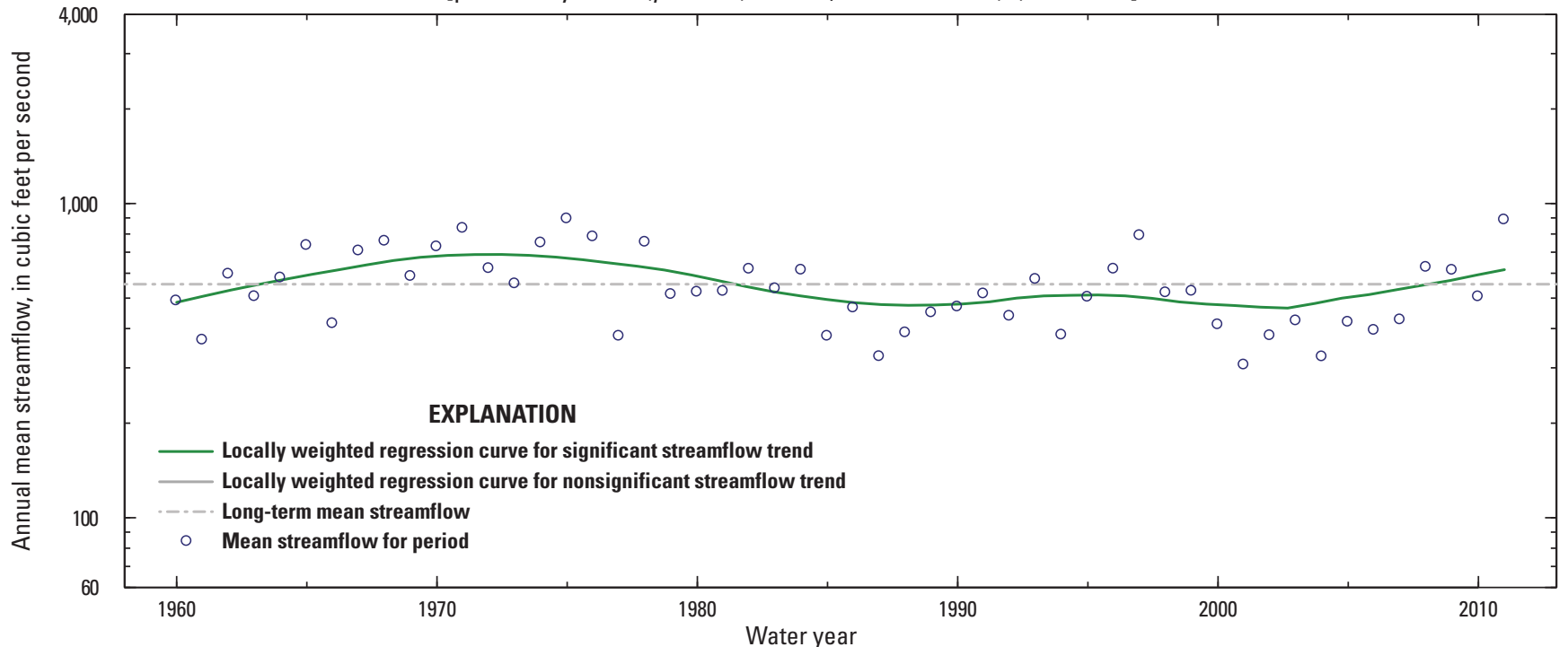

B. October-December $(p$-value $=0.004, \tau=-0.2775)$

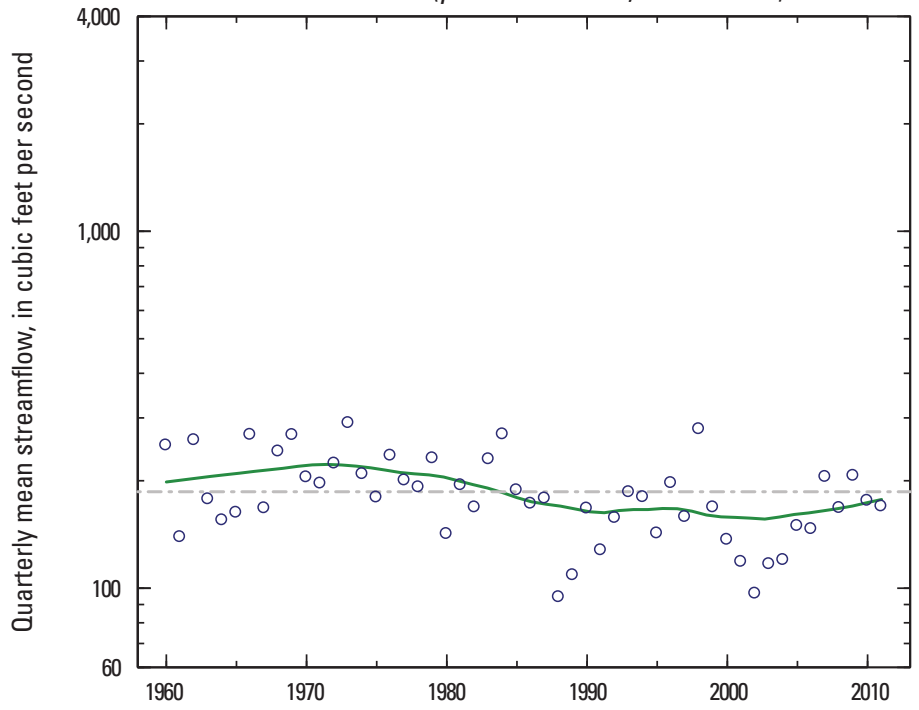

C. January-March ( $p$-value less than $0.001, \tau=-0.3243$ )
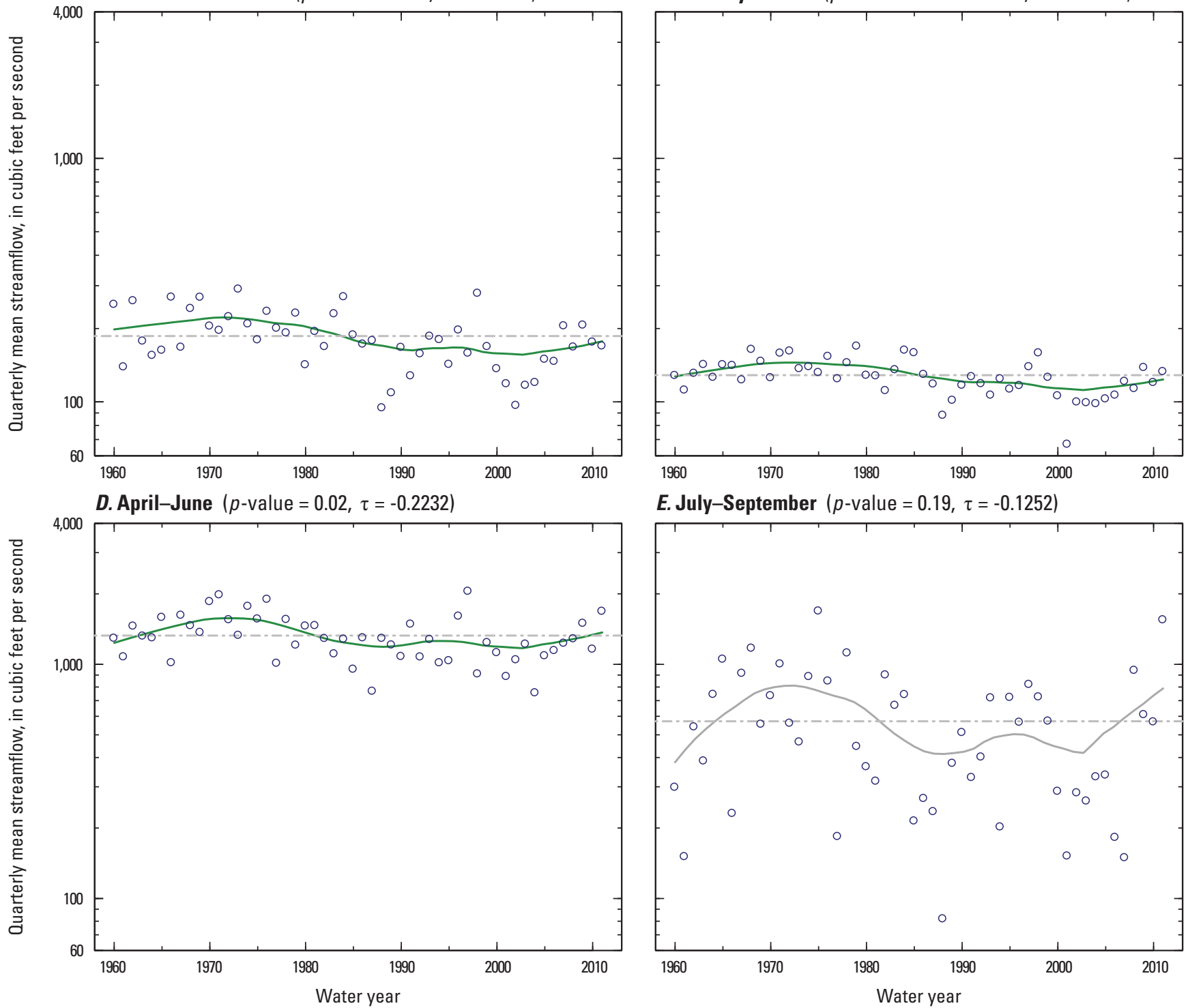

E. July-September $(p$-value $=0.19, \tau=-0.1252)$

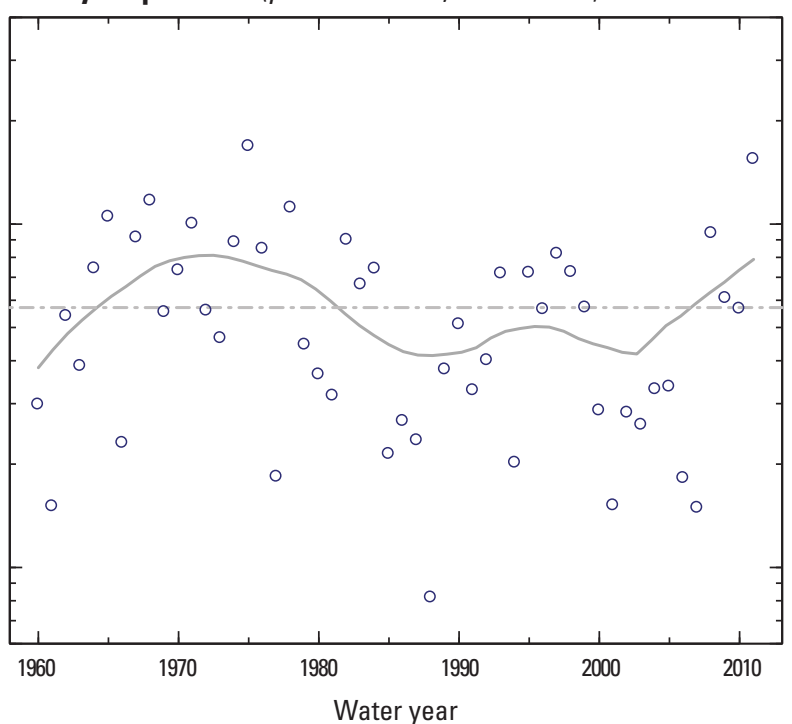

Figure 1-20. Boulder River at Big Timber, Montana (streamgage 06200000), water years 1960-2011. 
A. Annual mean streamflow [probability value $(p$-value $)=0.04$, Kendall's tau $(\tau)=-0.1961$ ]

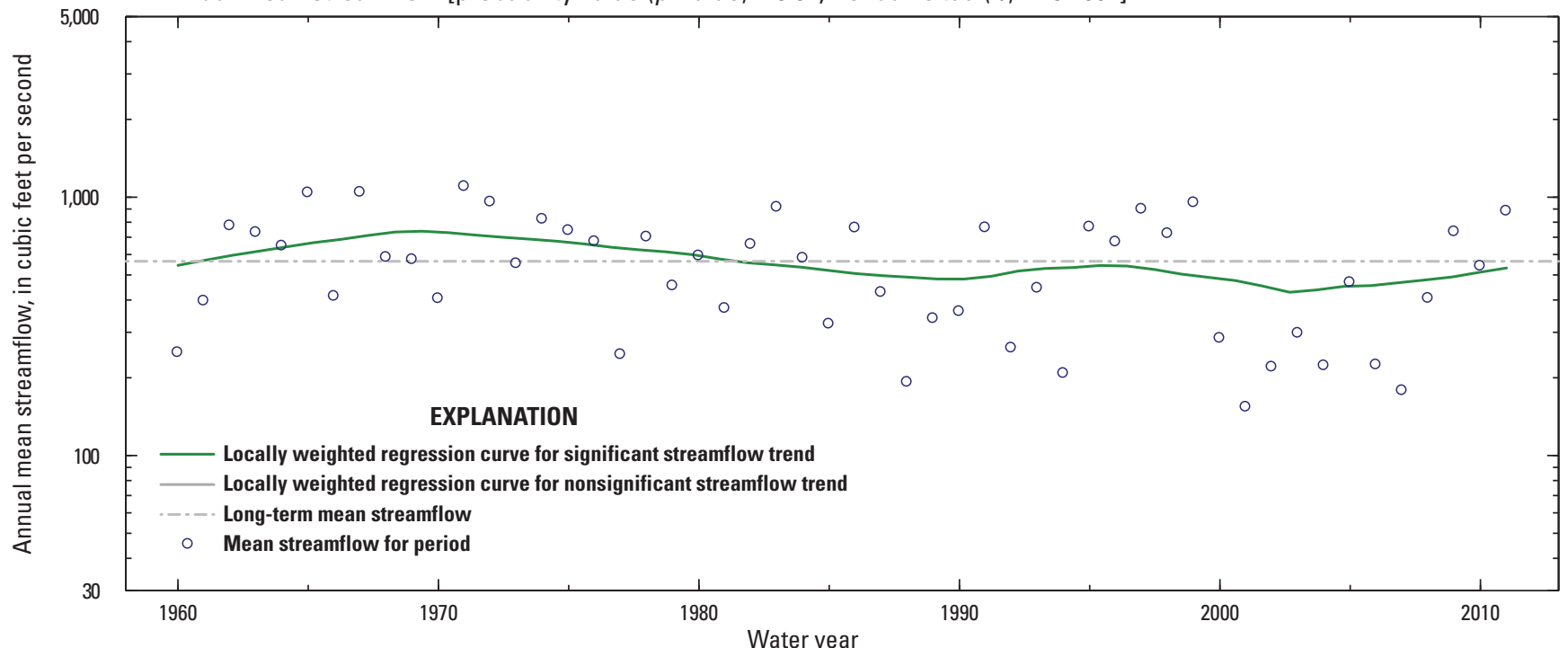

B. October-December $(p$-value $=0.006, \tau=-0.2611)$

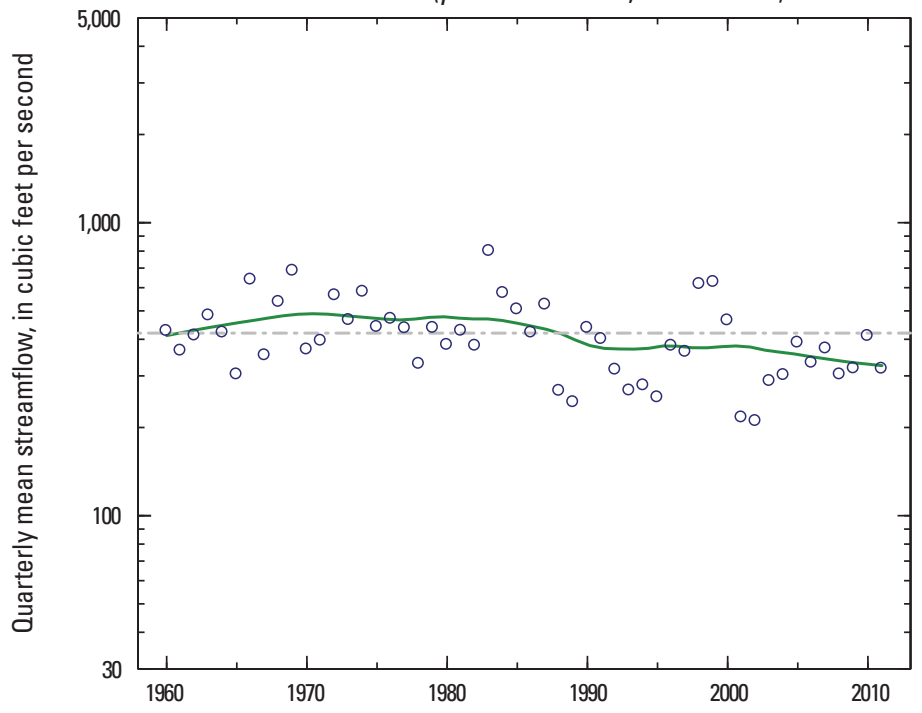

C. January-March $(p$-value $=0.167, \tau=-0.1320)$
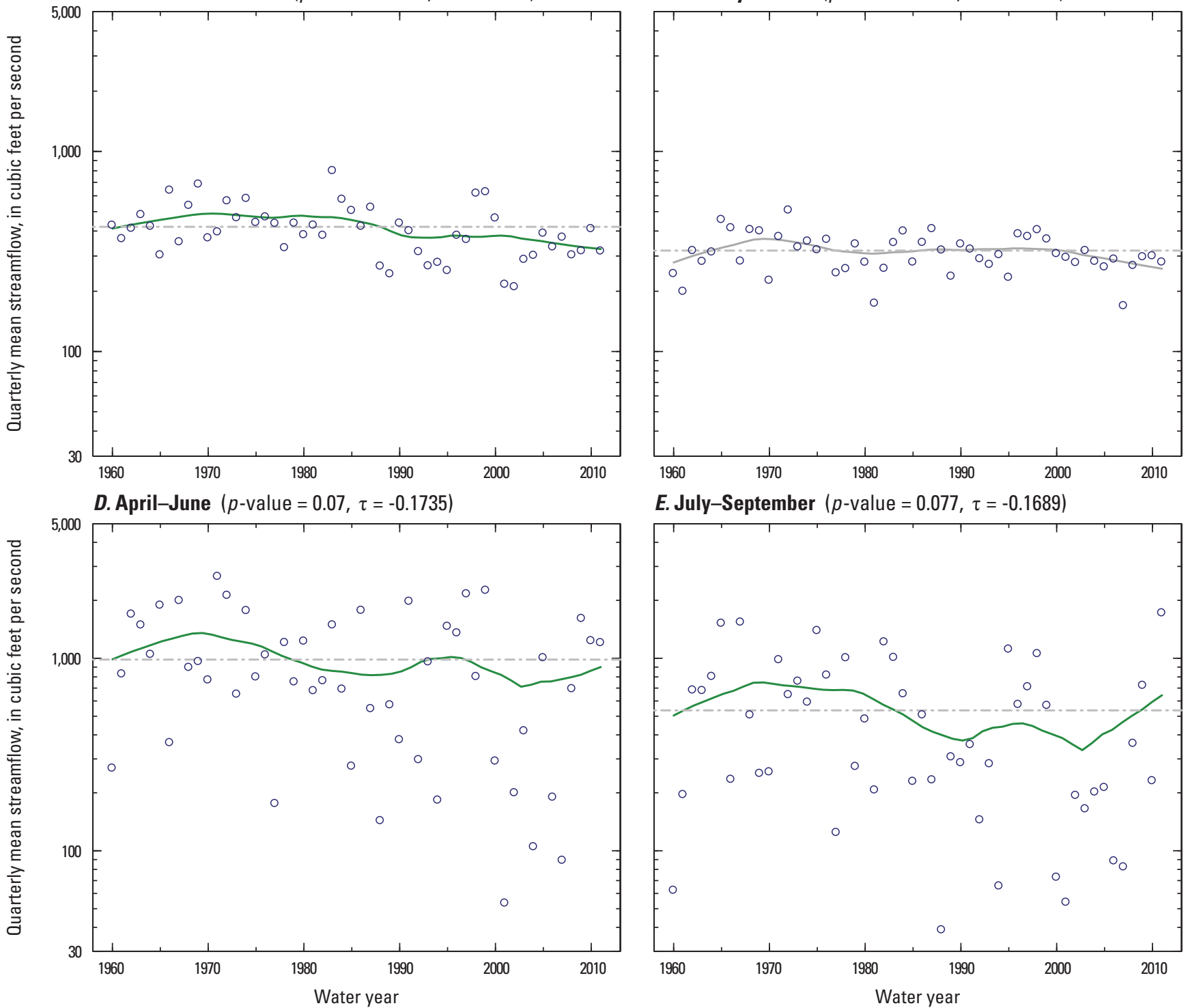

E. July-September $(p$-value $=0.077, \tau=-0.1689)$

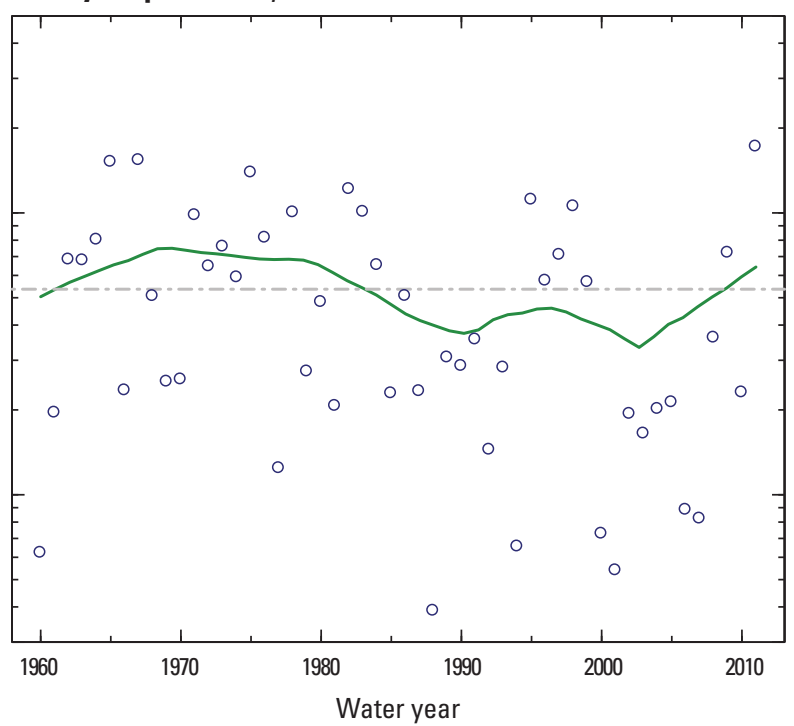

Figure 1-21. Wind River at Riverton, Wyoming (streamgage 06228000), water years 1960-2011. 
A. Annual mean streamflow [probability value $(p$-value $)=0.09$, Kendall's tau $(\tau)=-0.1622$ ]

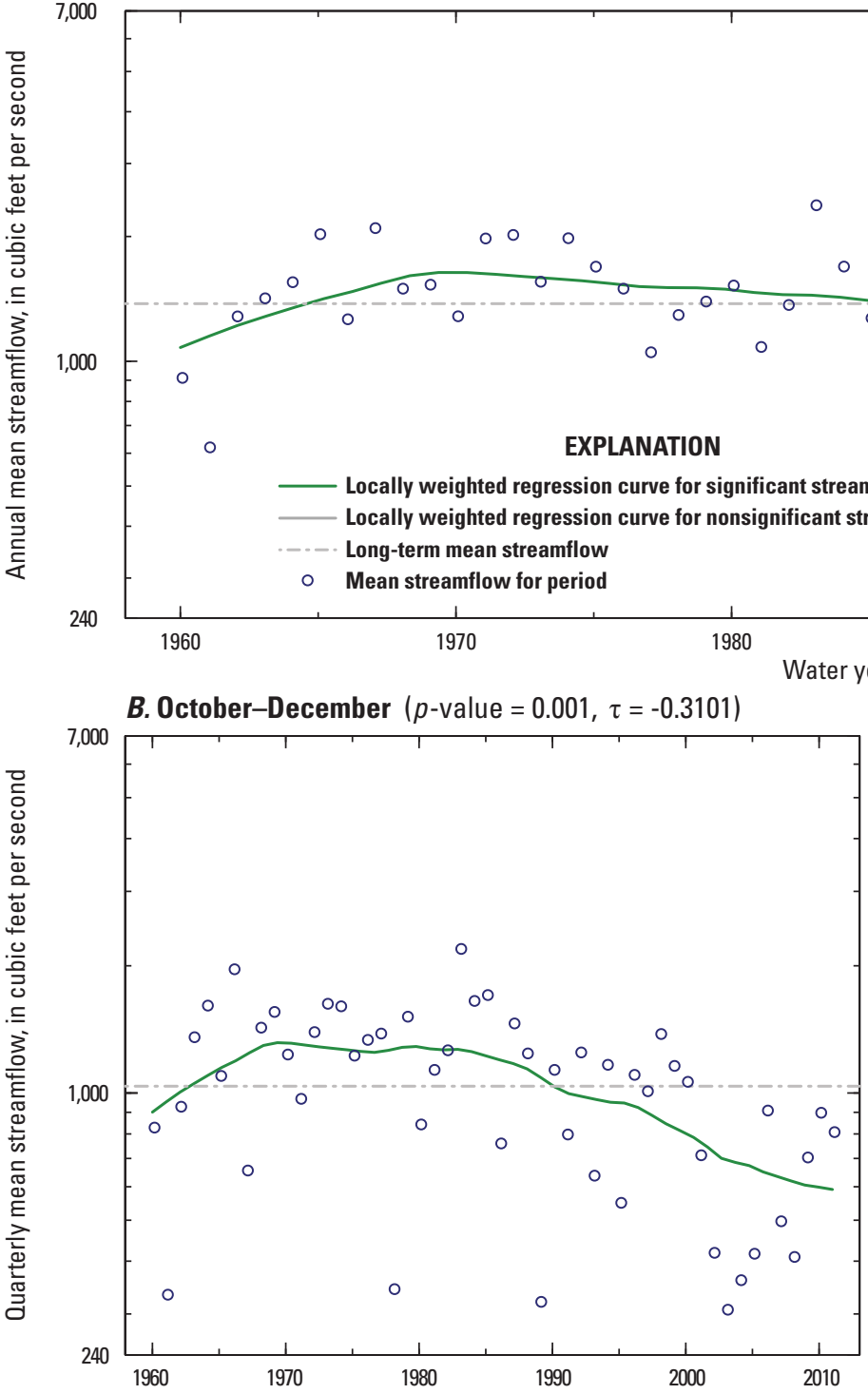

D. April-June $(p$-value $=0.813, \tau=0.02262)$

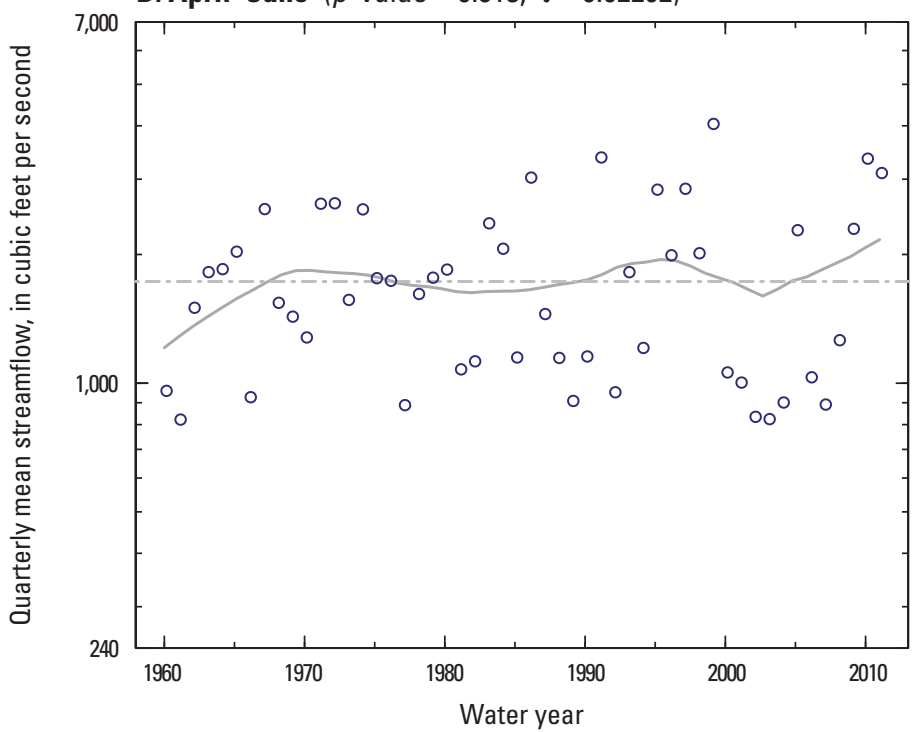

C. January-March ( $p$-value less than $0.001, \tau=-0.3183$ )

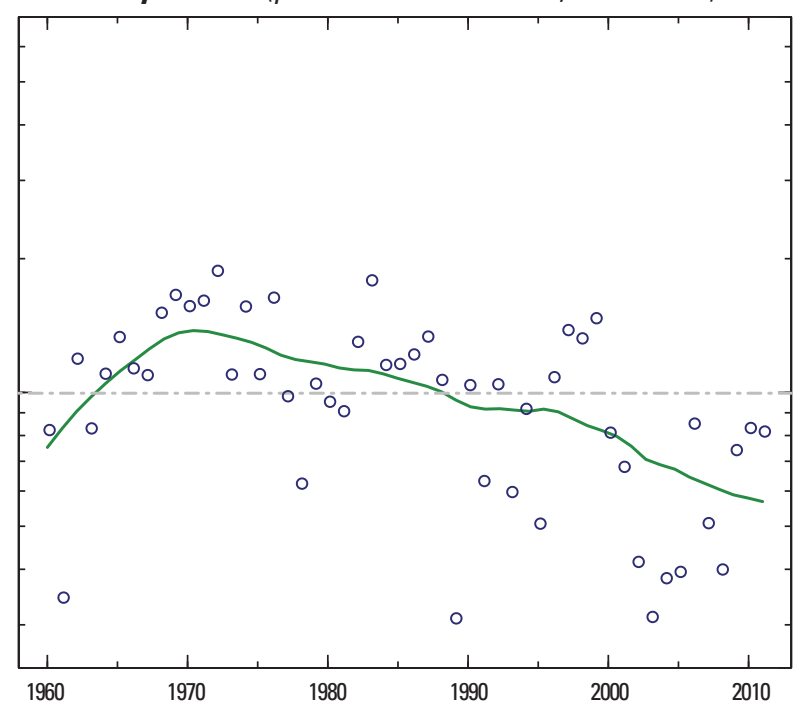

E. July-September $(p$-value $=0.328, \tau=-0.09351)$

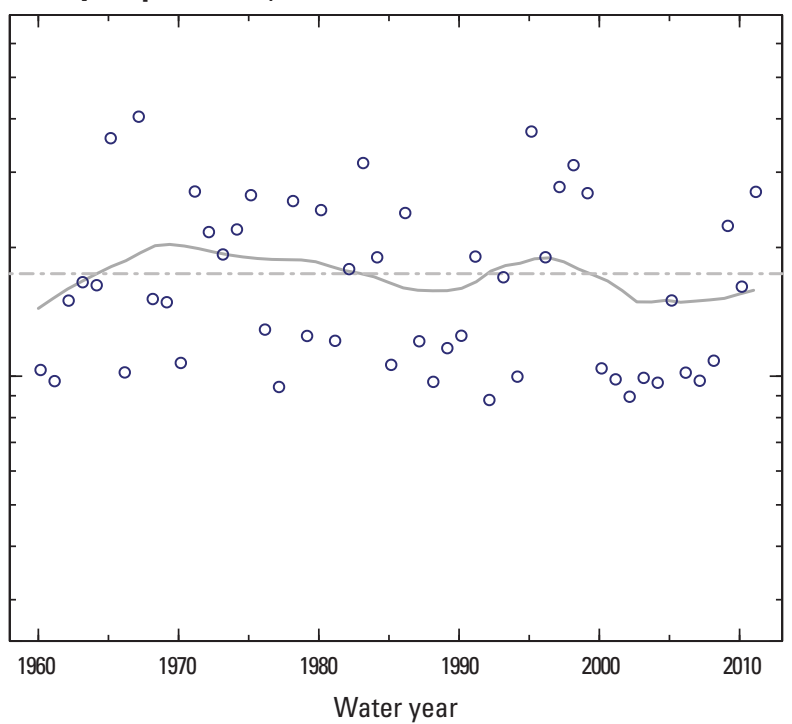

Figure 1-22. Wind River below Boysen Reservoir, Wyoming (streamgage 06259000), water years 1960-2011. 
A. Annual mean streamflow [probability value $(p$-value $)=0.004$, Kendall's tau $(\tau)=-0.2734$ ]

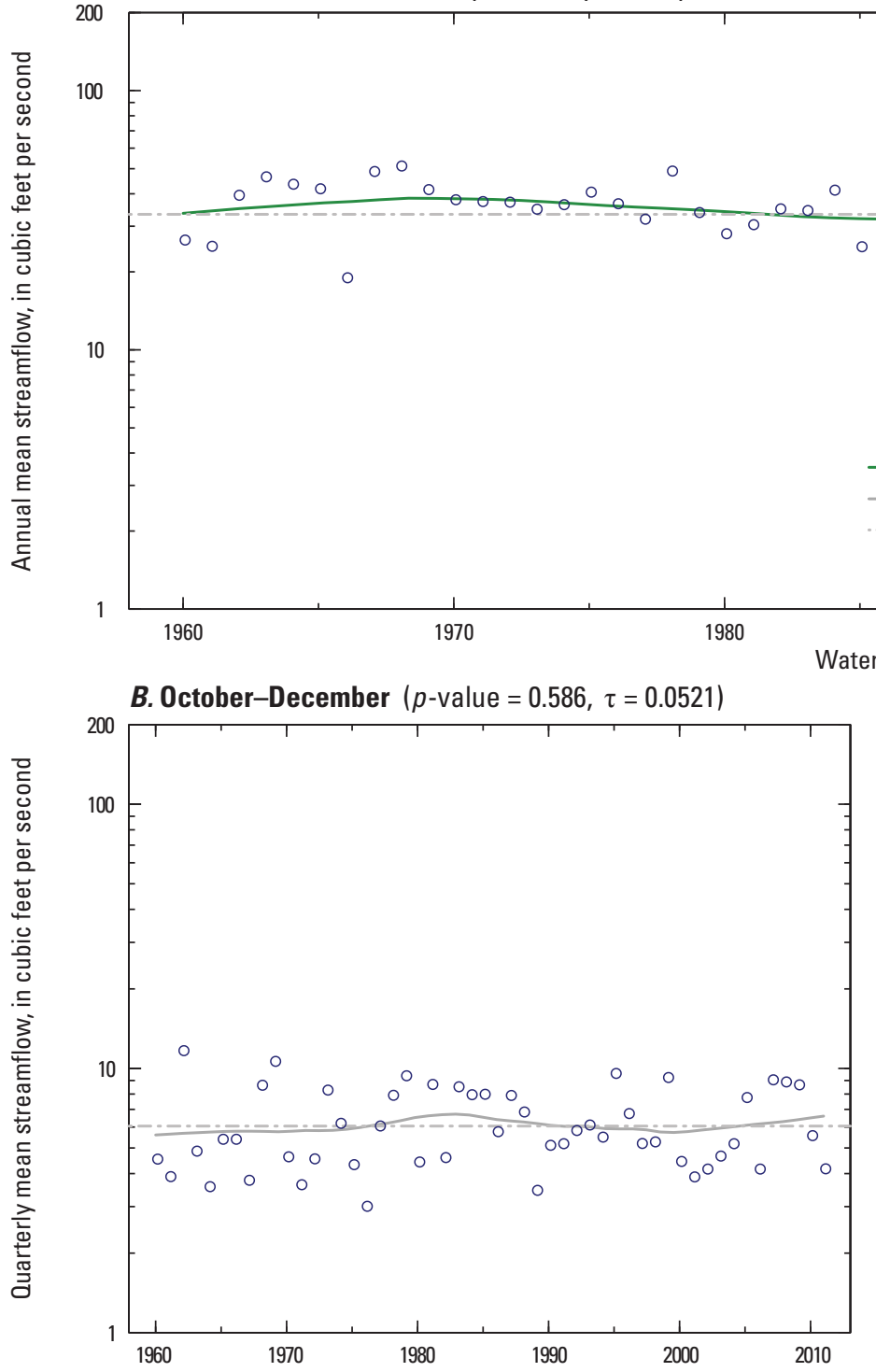

EXPLANATION

Locally weighted regression curve for significant streamflow trend _ Locally weighted regression curve for nonsignificant streamflow trend

-.-. Long-term mean streamflow

- Mean streamflow for period Water year

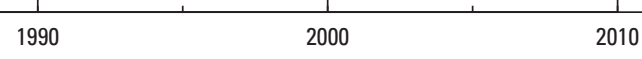

C. January-March $(p$-value $=0.007, \tau=0.2598)$

$D$. April-June $(p$-value $=0.005, \tau=-0.2700)$
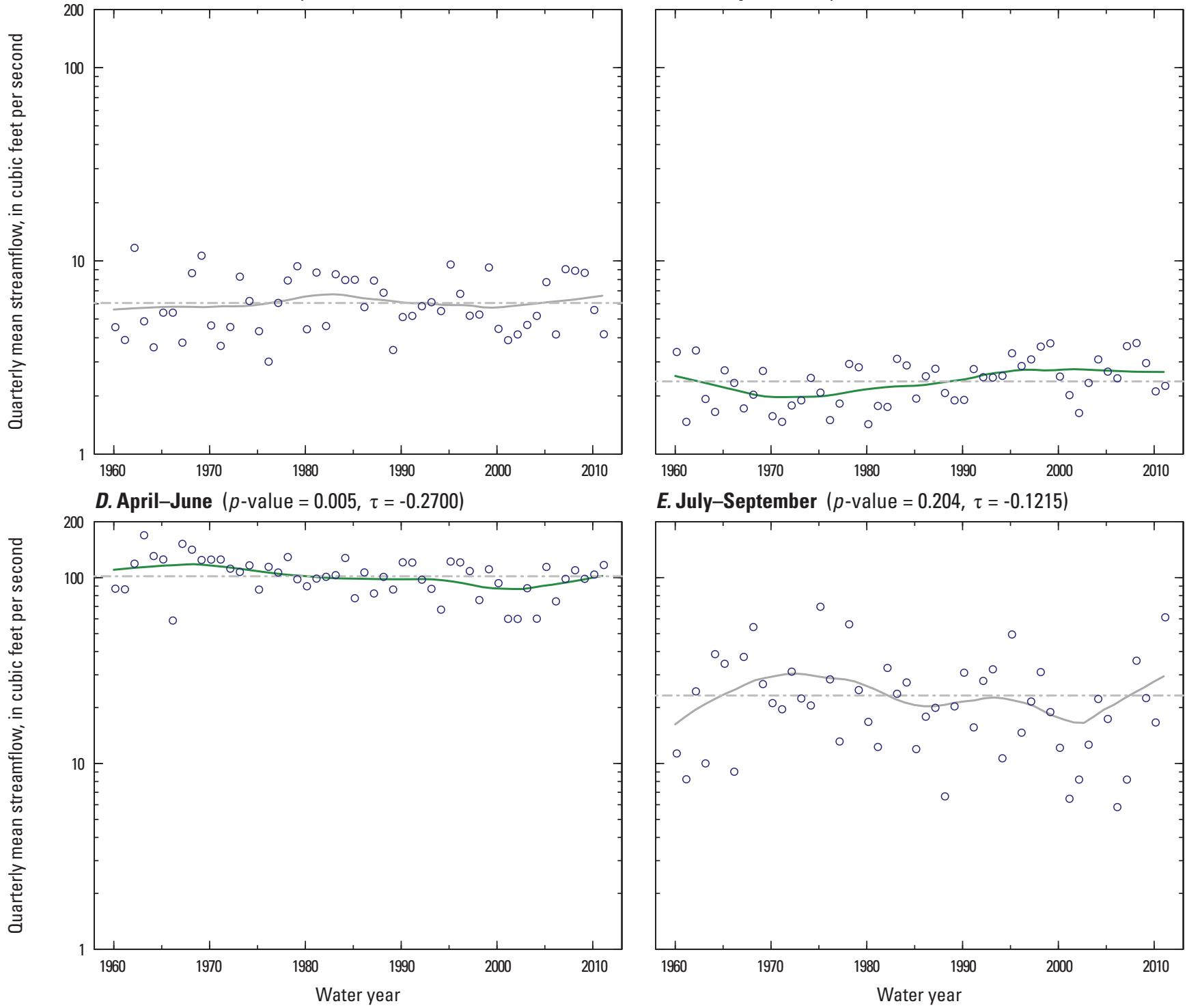

E. July-September $(p$-value $=0.204, \tau=-0.1215)$

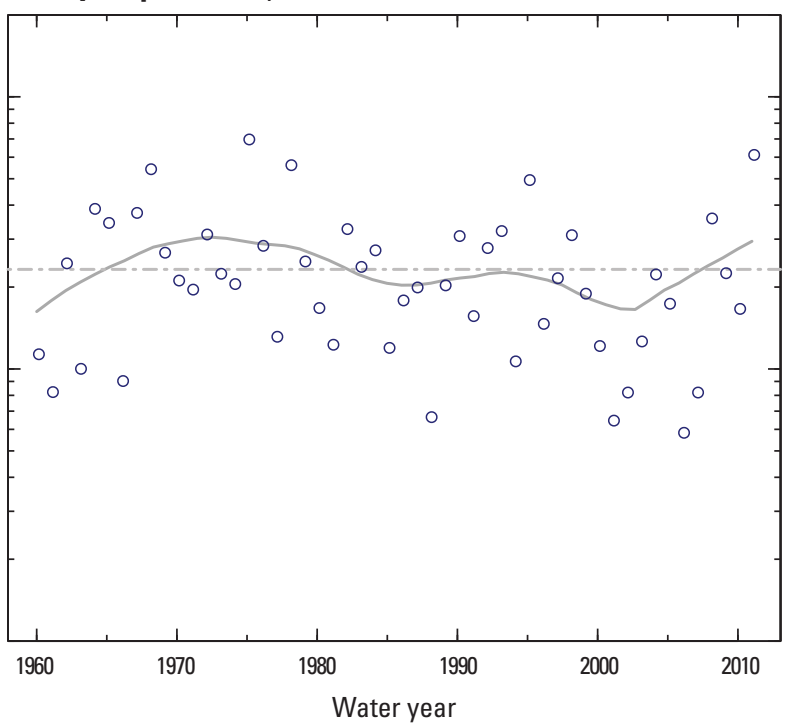

Figure 1-23. Shell Creek above Shell Creek Reservoir, Wyoming (streamgage 06278300), water years 1960-2011. 
A. Annual mean streamflow [probability value $(p$-value $)=0.046$, Kendall's tau $(\tau)=-0.1909$ ]
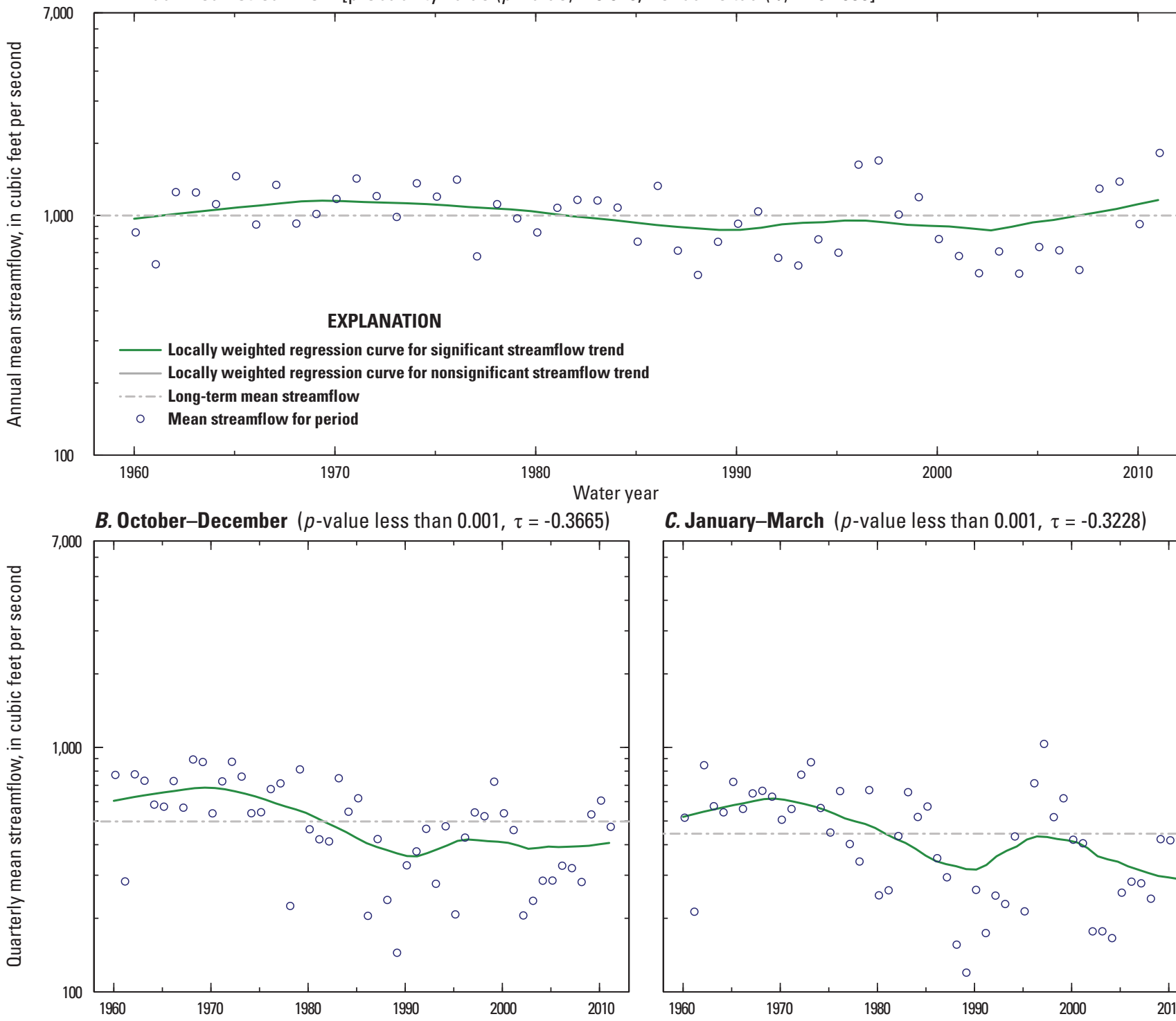

$$
\circ
$$

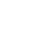

\section{EXPLANATION}

Locally weighted regression curve for significant streamflow trend

Locally weighted regression curve for nonsignificant streamflow trend

-. Long-term mean streamflow

Water year

B. October-December ( $p$-value less than $0.001, \tau=-0.3665)$

C. January-March ( $p$-value less than $0.001, \tau=-0.3228$ )

D. April-June ( $p$-value $=0.801, \tau=-0.02413)$
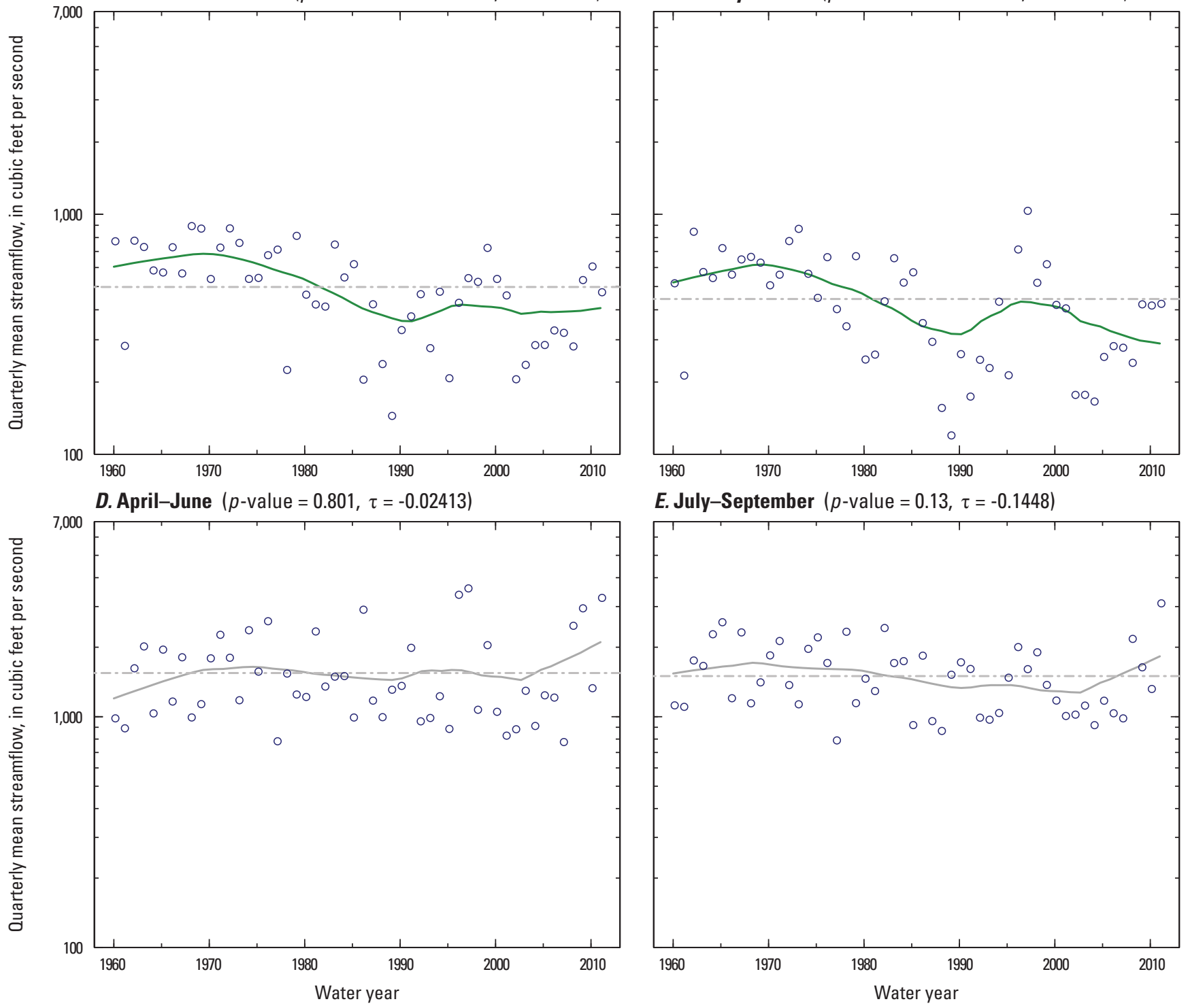

E. July-September $(p$-value $=0.13, \tau=-0.1448)$

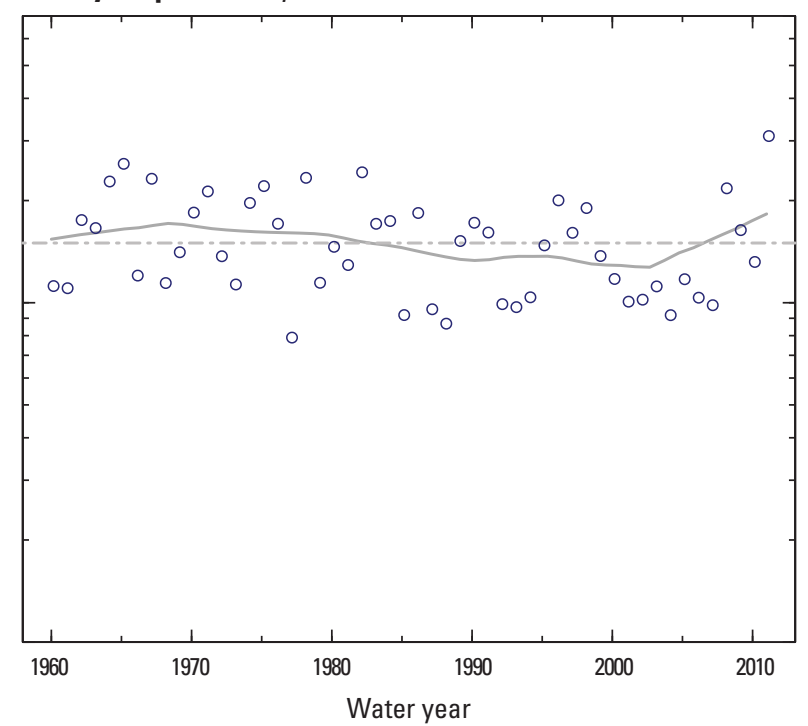

Figure 1-24. Shoshone River below Buffalo Bill Reservoir, Wyoming (06282000), water years 1960-2011. 

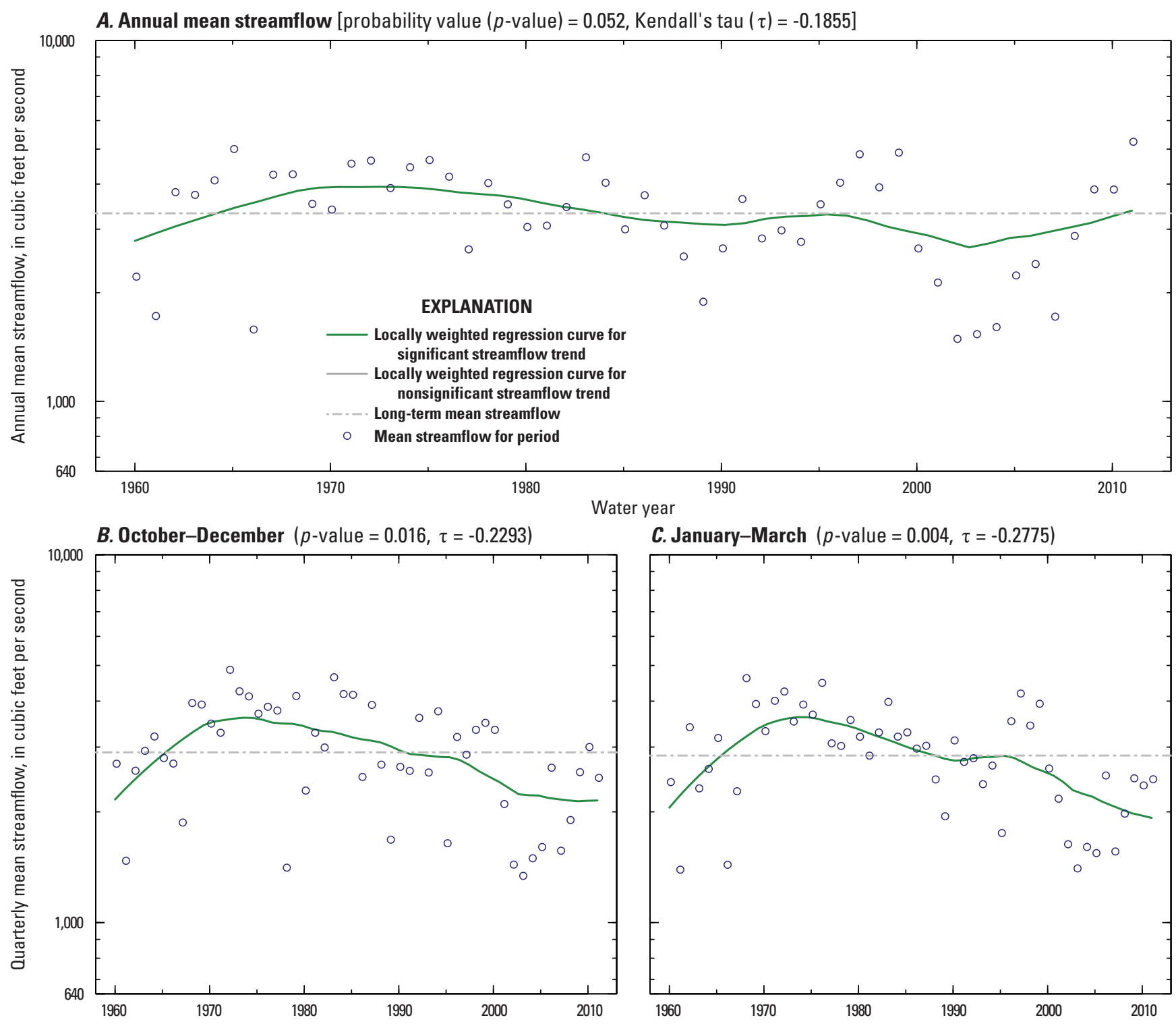

C. January-March $(p$-value $=0.004, \tau=-0.2775)$
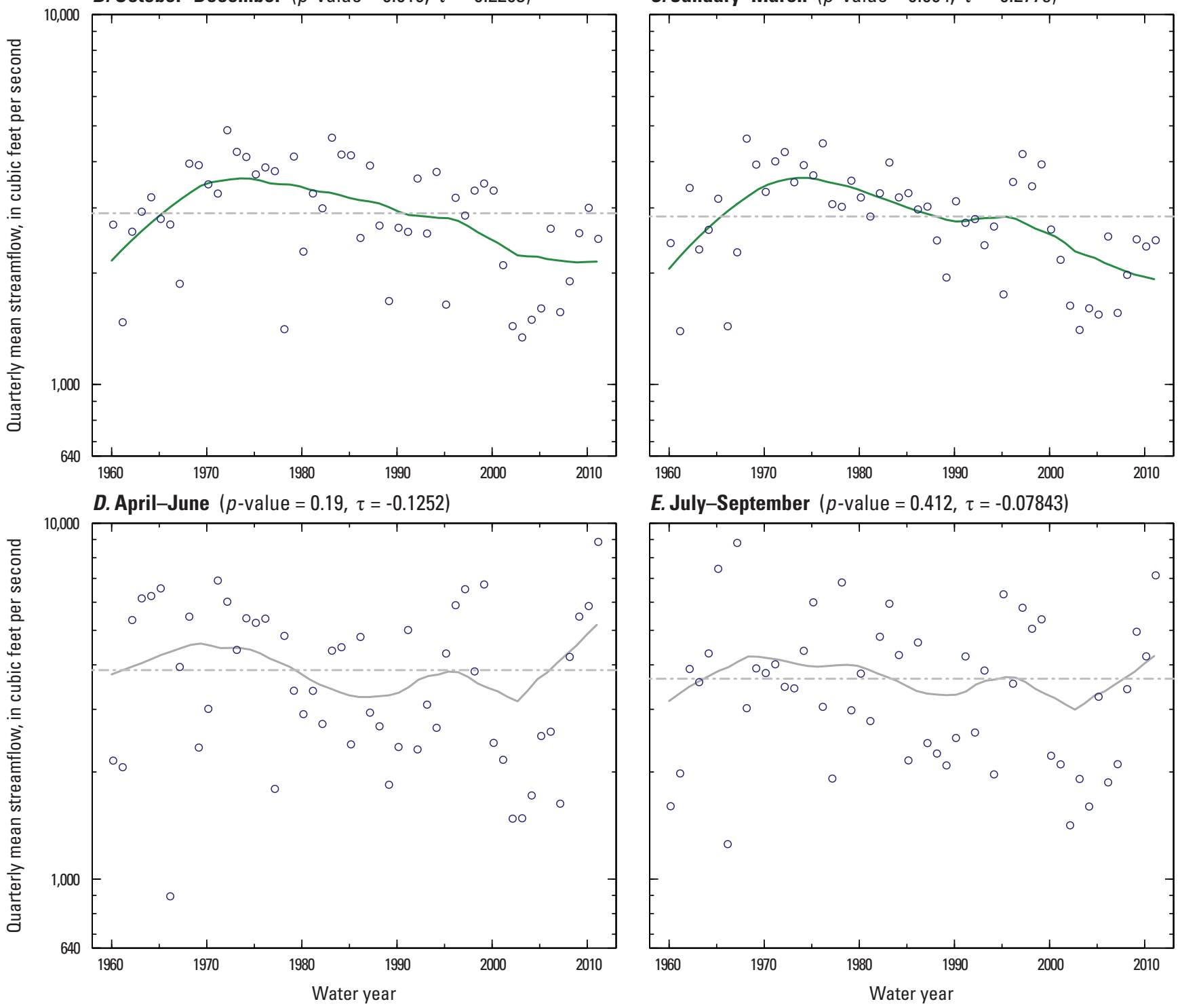

E. July-September $(p$-value $=0.412, \tau=-0.07843)$

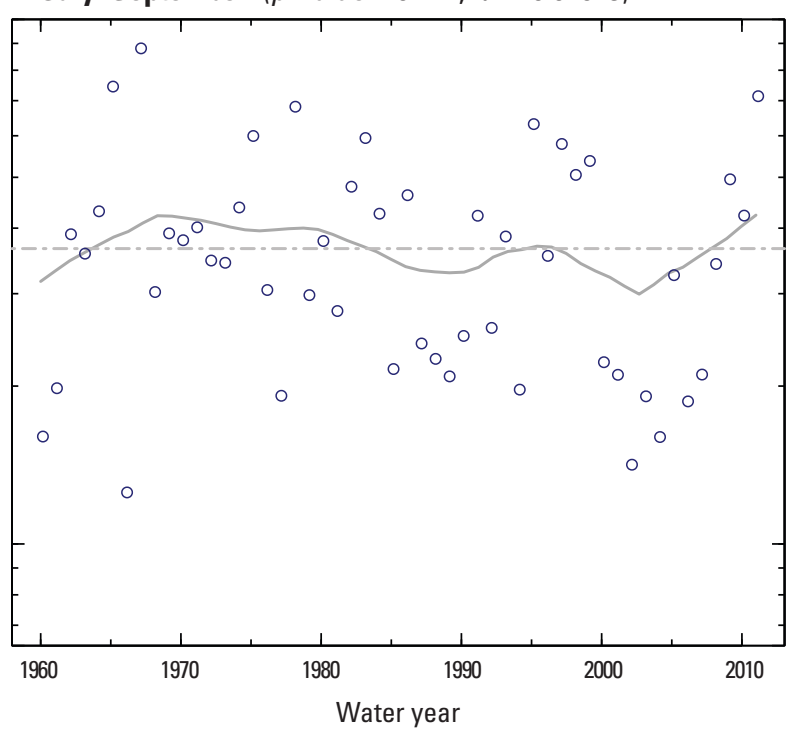

Figure 1-25. Bighorn River near St. Xavier, Montana (streamgage 06287000), water years 1960-2011. 
A. Annual mean streamflow [probability value $(p$-value $)=0.032$, Kendall's tau $(\tau)=-0.2051$ ]
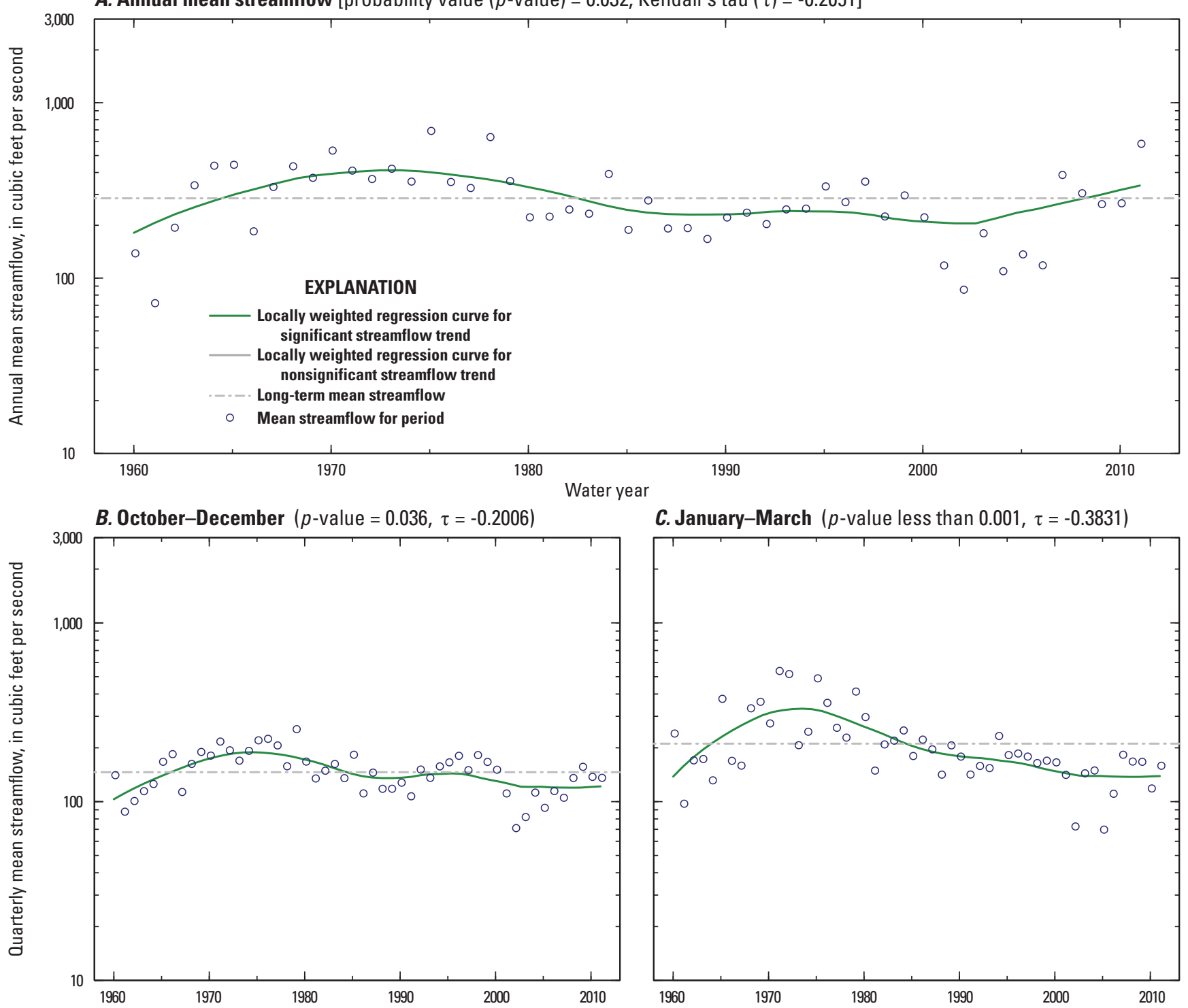

C. January-March ( $p$-value less than $0.001, \tau=-0.3831)$
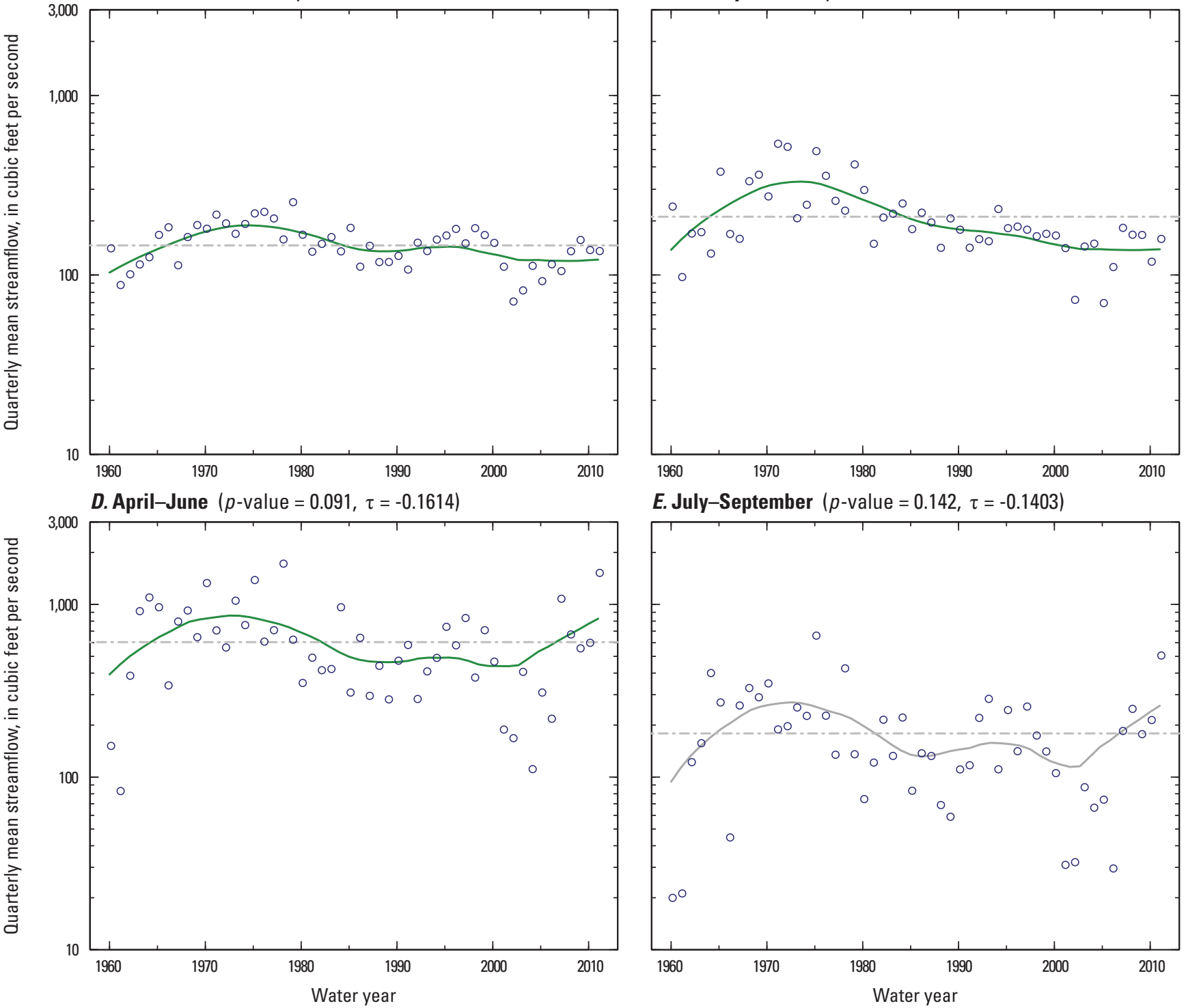

E. July-September $(p$-value $=0.142, \tau=-0.1403)$

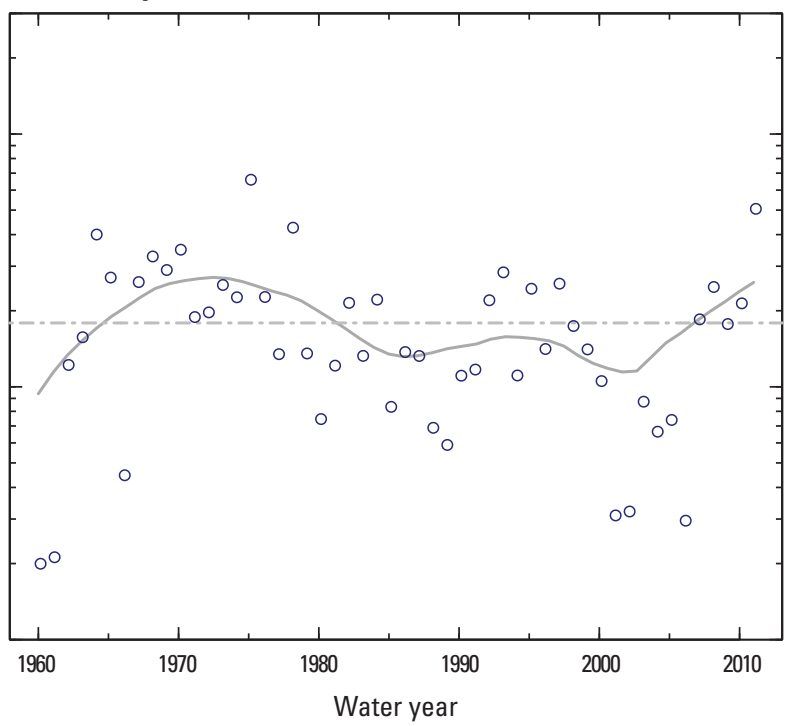

Figure 1-26. Little Bighorn River near Hardin, Montana (streamgage 06294000), water years 1960-2011. 

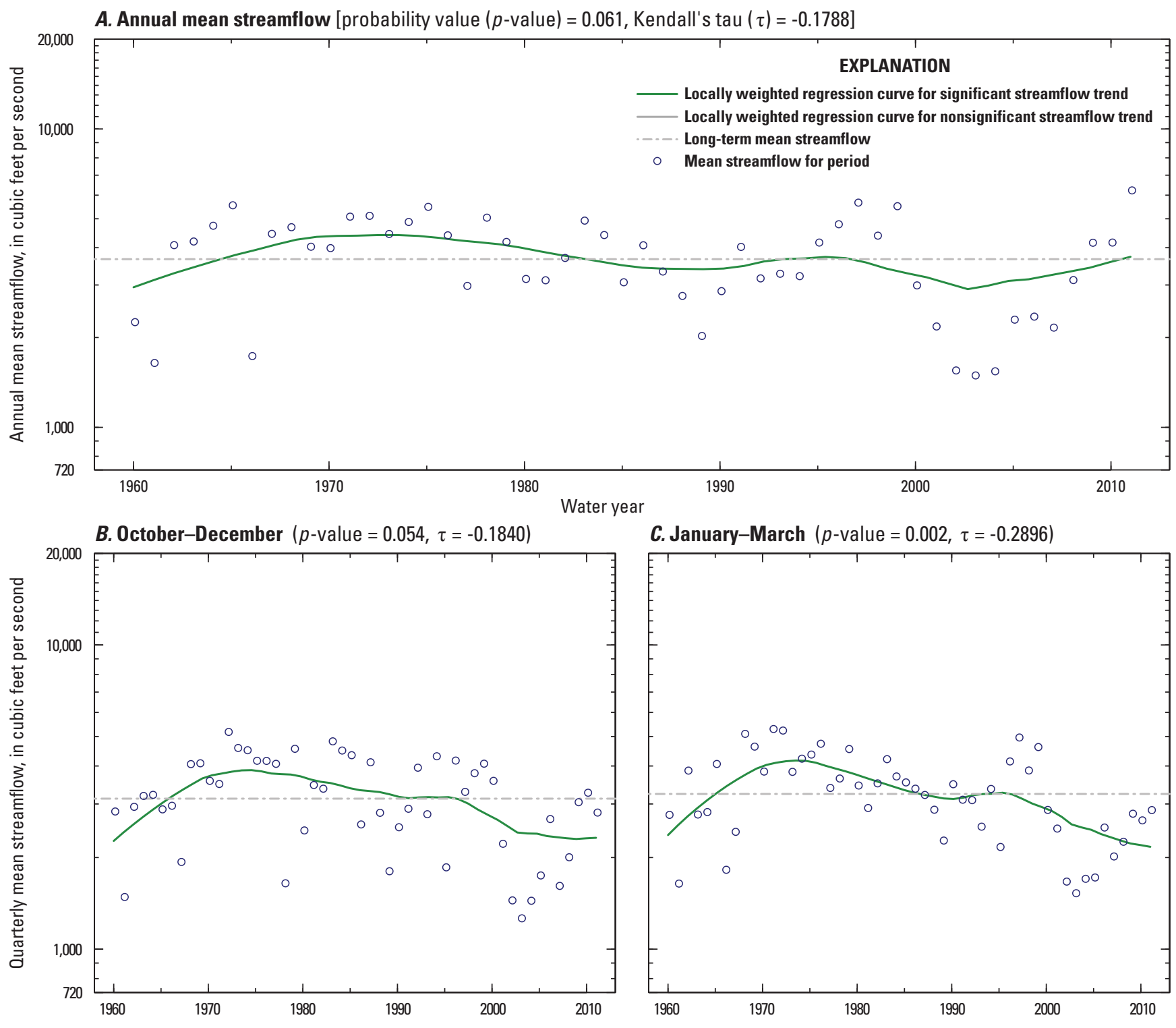

C. January-March $(p$-value $=0.002, \tau=-0.2896)$
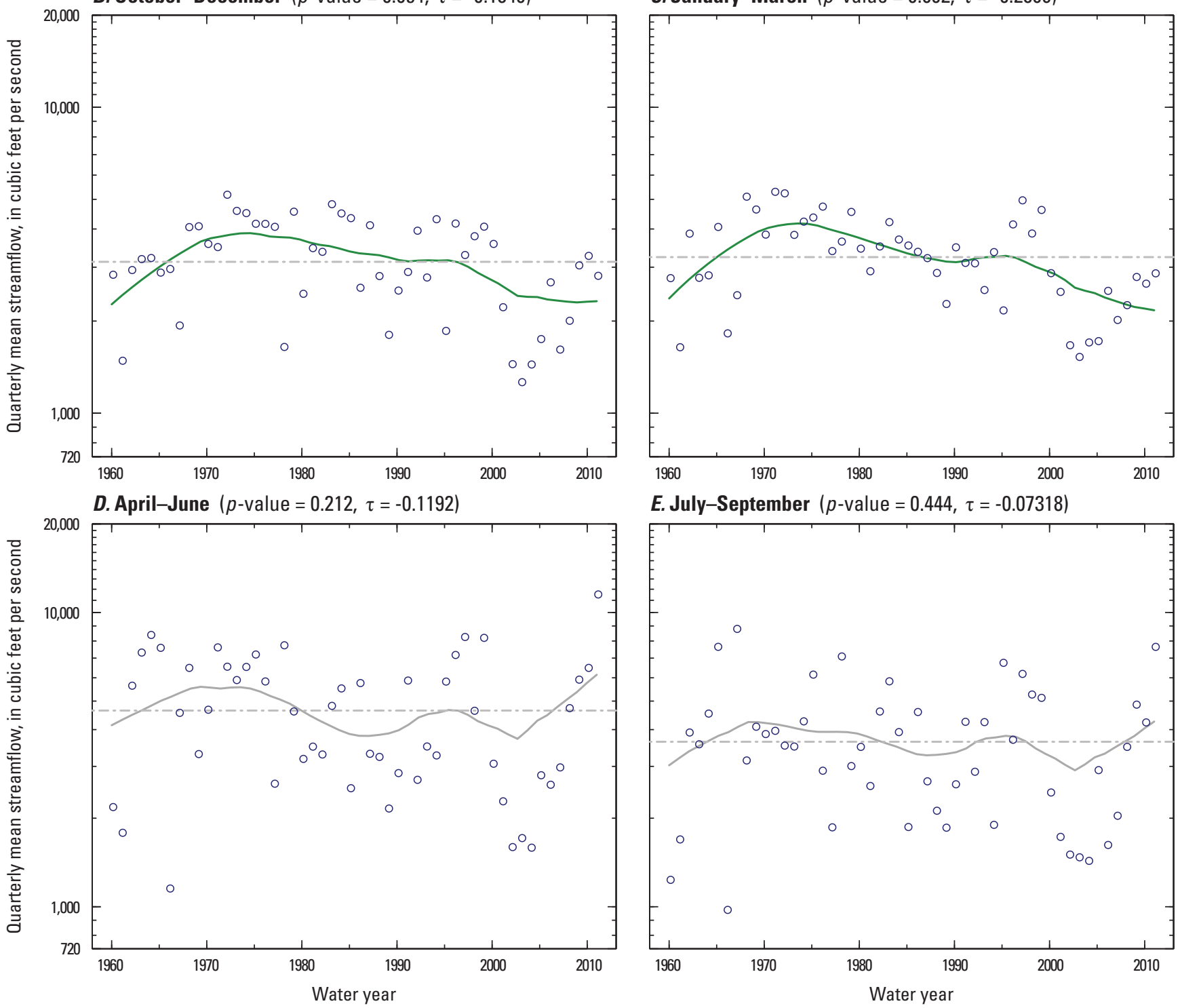

E. July-September $(p$-value $=0.444, \tau=-0.07318)$

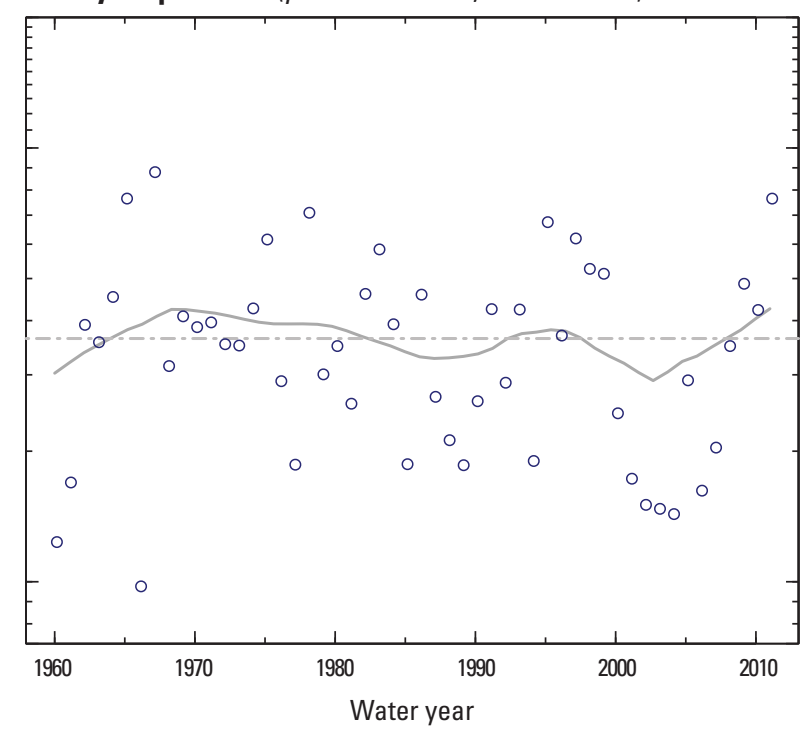

Figure 1-27. Bighorn River above Tullock Creek near Bighorn, Montana (streamgage 06294500), water years $1960-2011$. 
A. Annual mean streamflow [probability value $(p$-value $)=0.093$, Kendall's tau $(\tau)=-0.1607$ ]
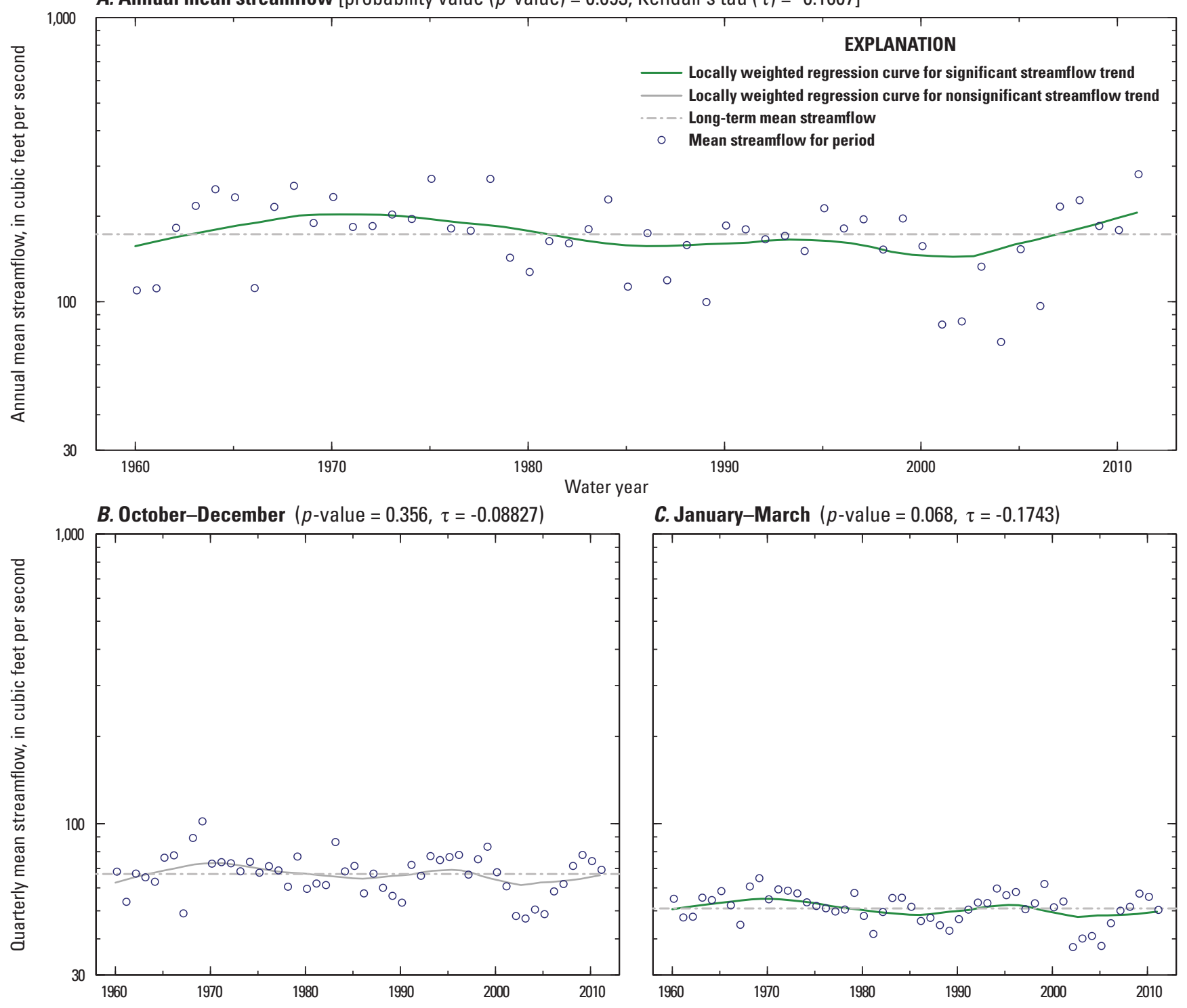

C. January-March ( $p$-value $=0.068, \tau=-0.1743)$
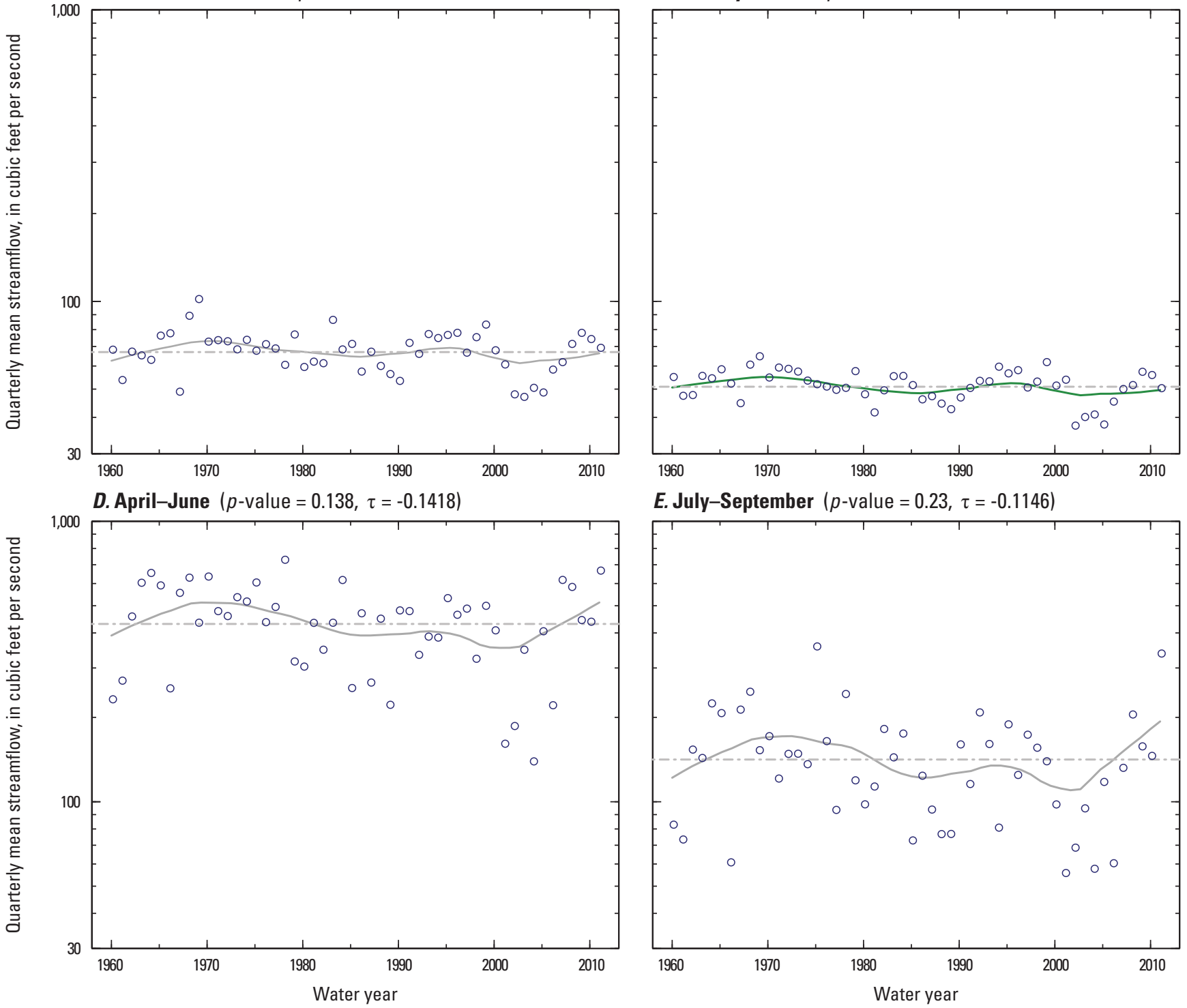

E. July-September $(p$-value $=0.23, \tau=-0.1146)$

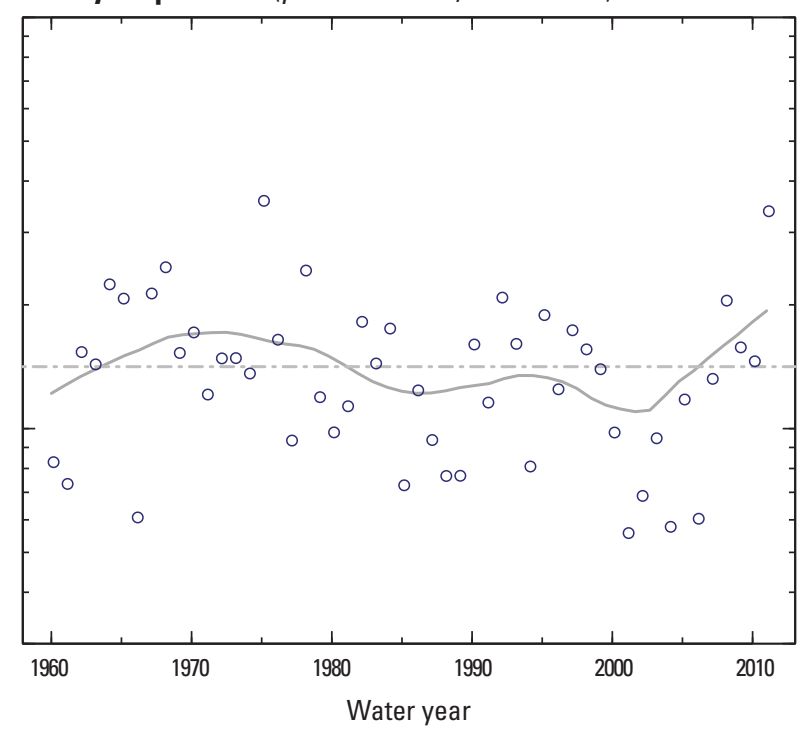

Figure 1-28. Tongue River near Dayton, Wyoming (streamgage 06298000), water years 1960-2011. 

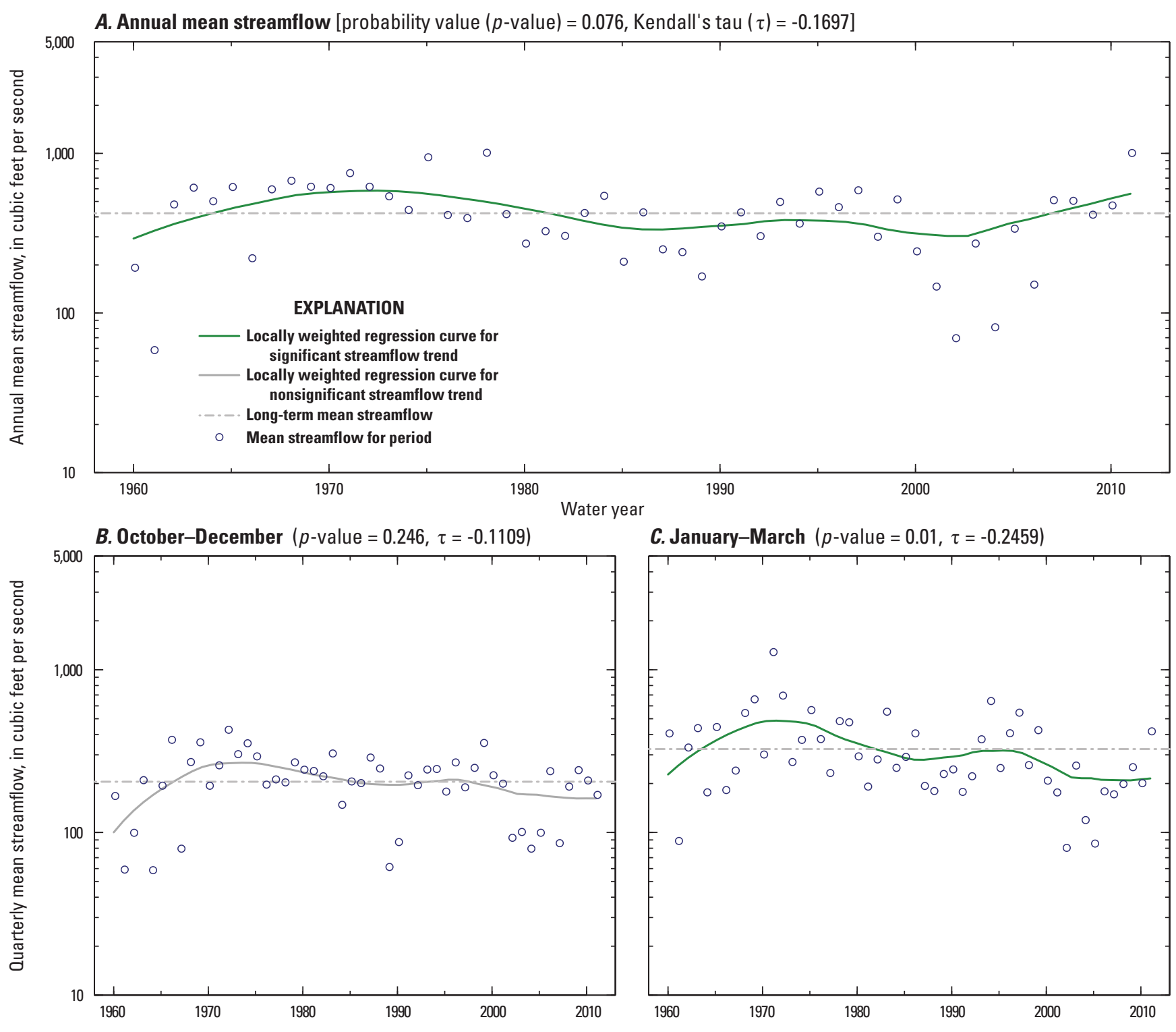

C. January-March $(p$-value $=0.01, \tau=-0.2459)$
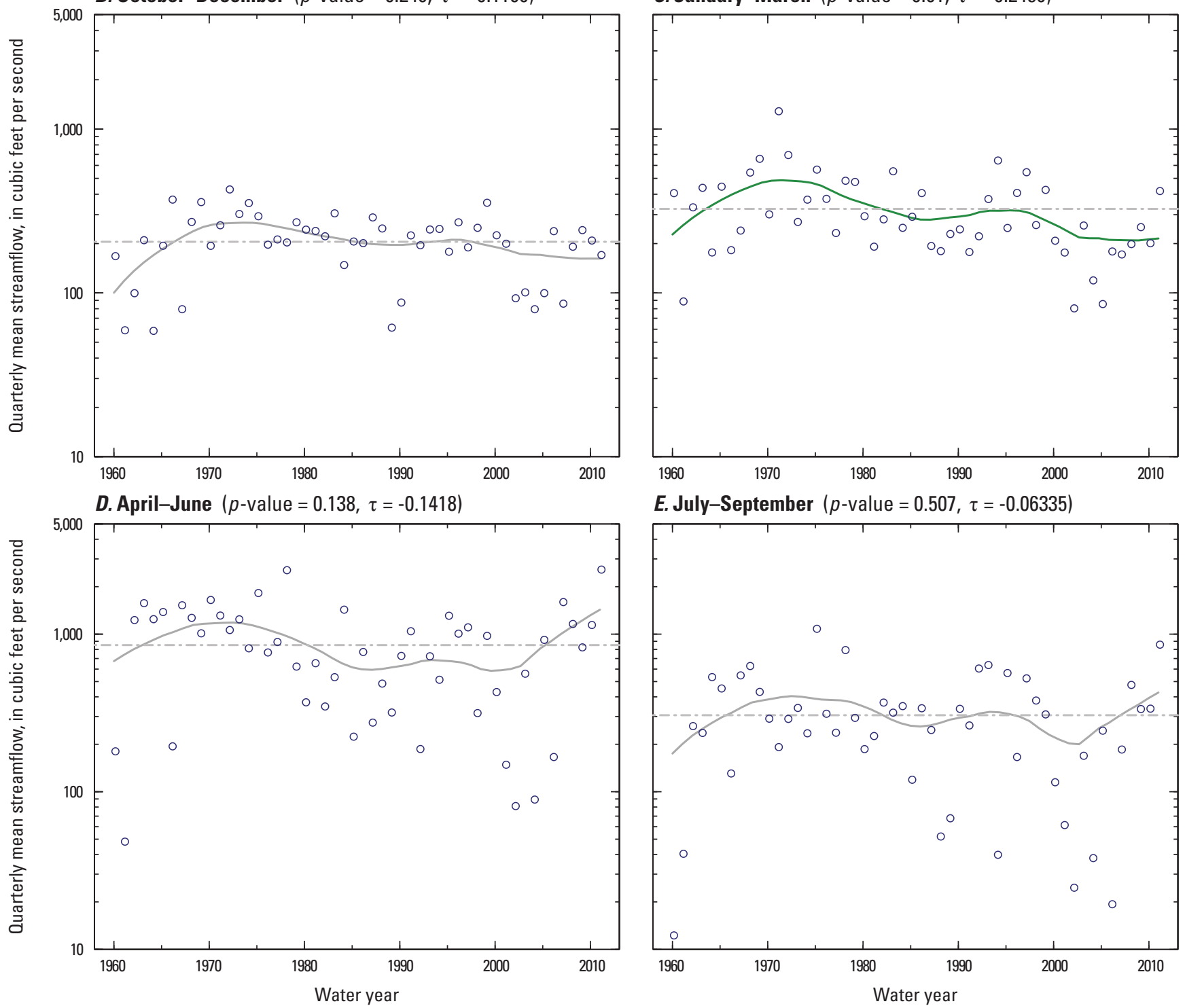

E. July-September $(p$-value $=0.507, \tau=-0.06335)$

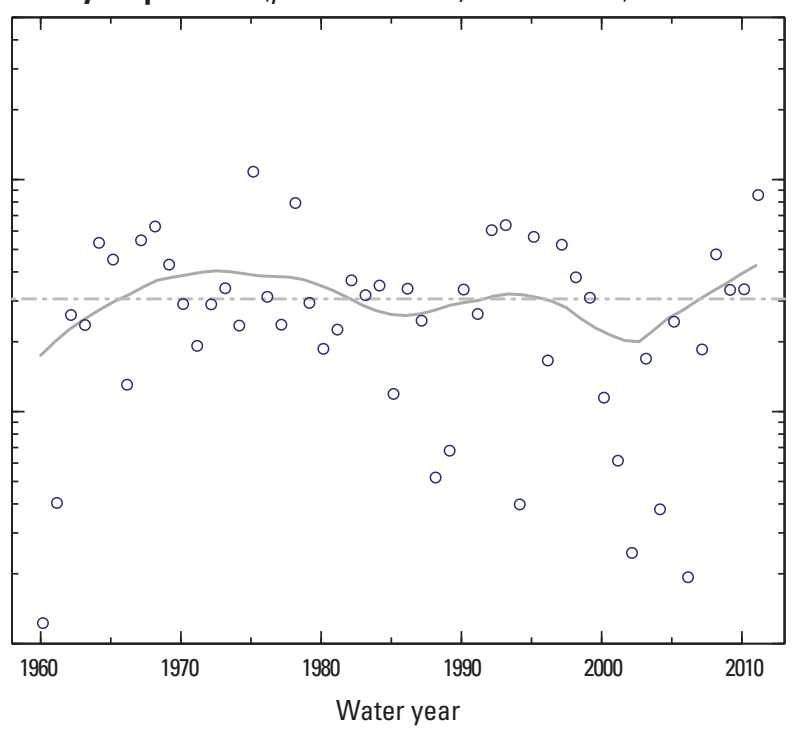

Figure 1-29. Tongue River at Miles City, Montana (streamgage 06308500), water years 1960-2011. 
A. Annual mean streamflow [probability value $(p$-value $)=0.065$, Kendall's tau $(\tau)=-0.1765$ ]
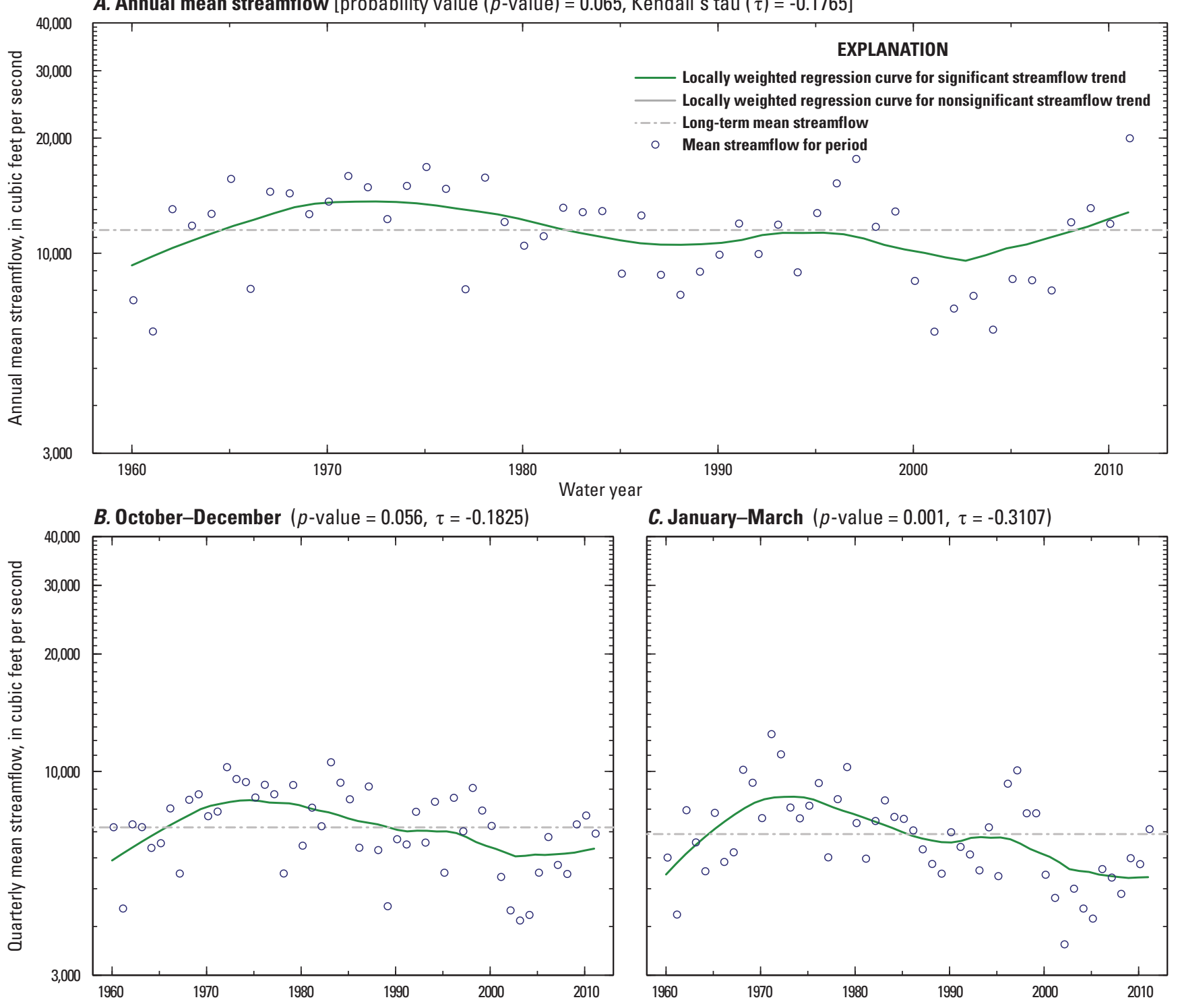

C. January-March $(p$-value $=0.001, \tau=-0.3107)$
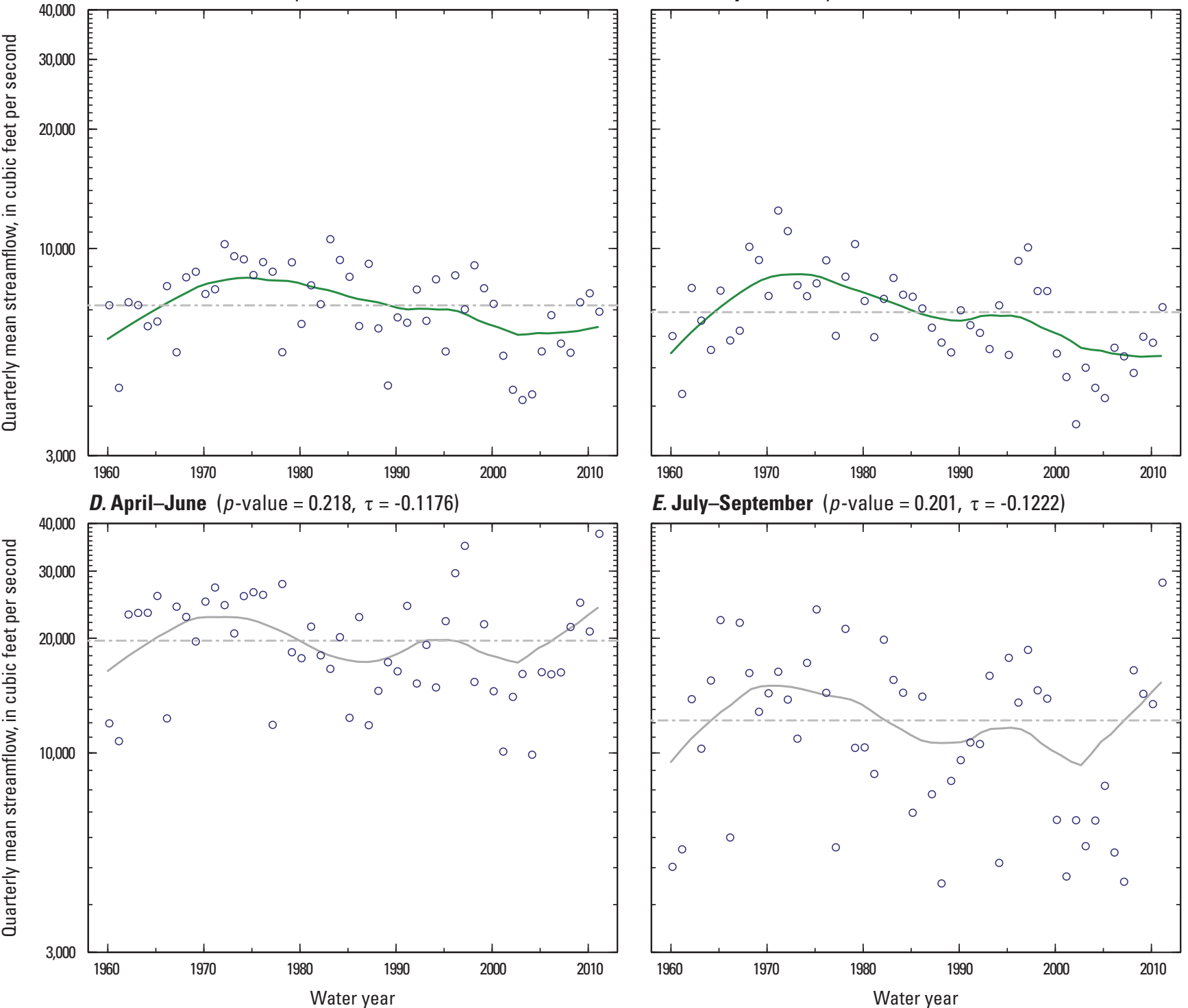

E. July-September $(p$-value $=0.201, \tau=-0.1222)$

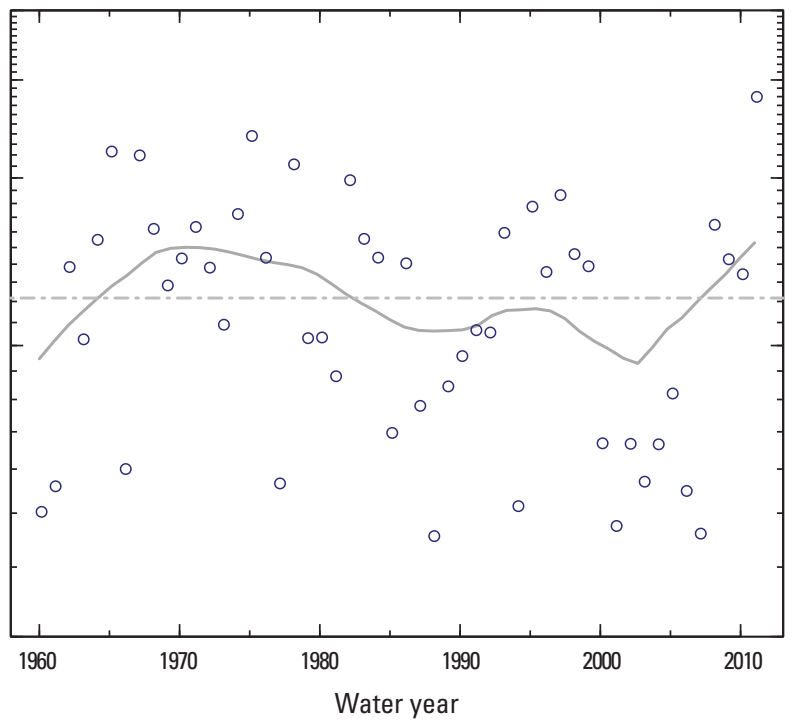

Figure 1-30. Yellowstone River at Miles City, Montana (streamgage 06309000), water years 1960-2011. 
A. Annual mean streamflow [probability value $(p$-value $)=0.01$, Kendall's tau $(\tau)=-0.2467$ ]
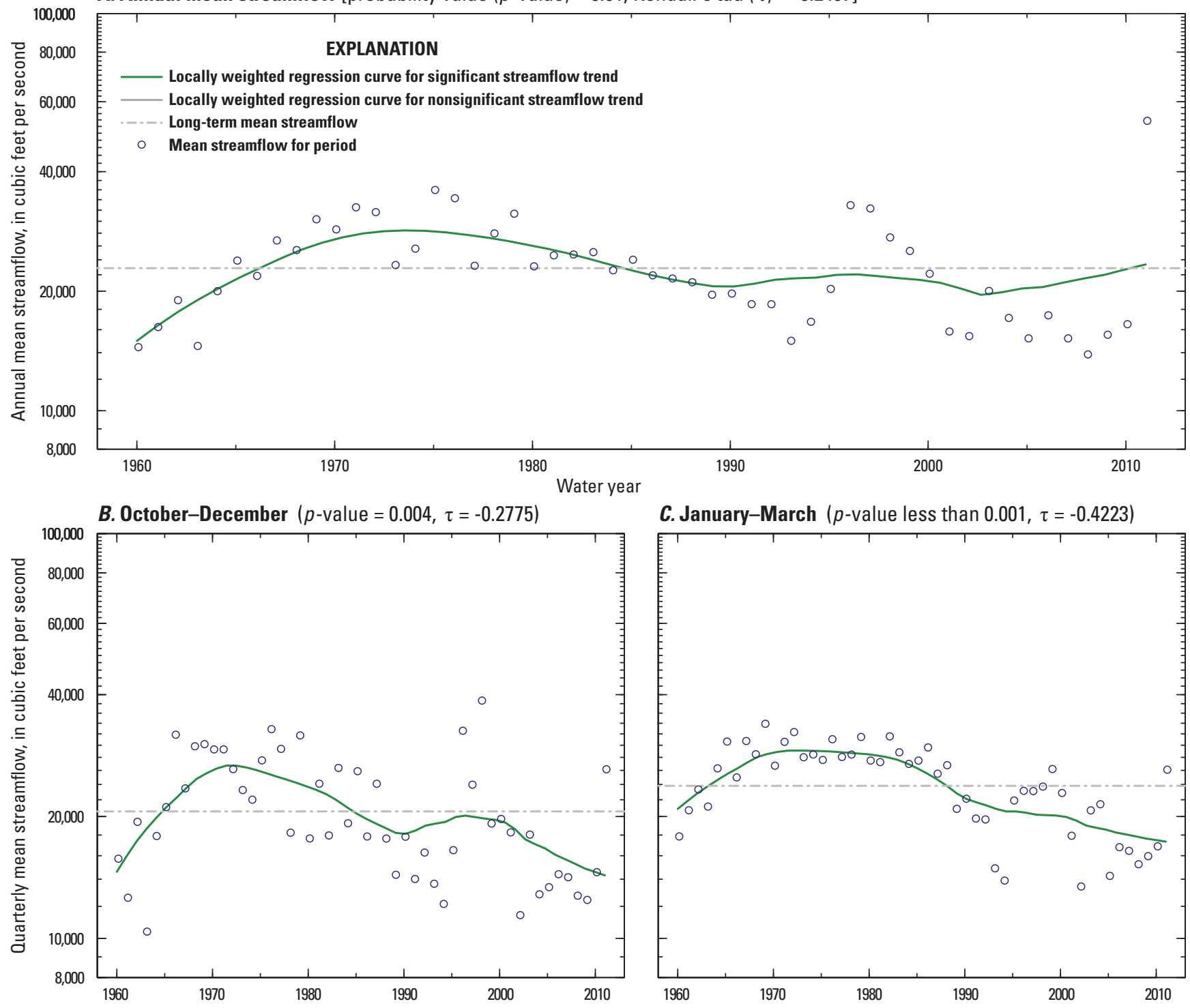

C. January-March ( $p$-value less than $0.001, \tau=-0.4223$ )
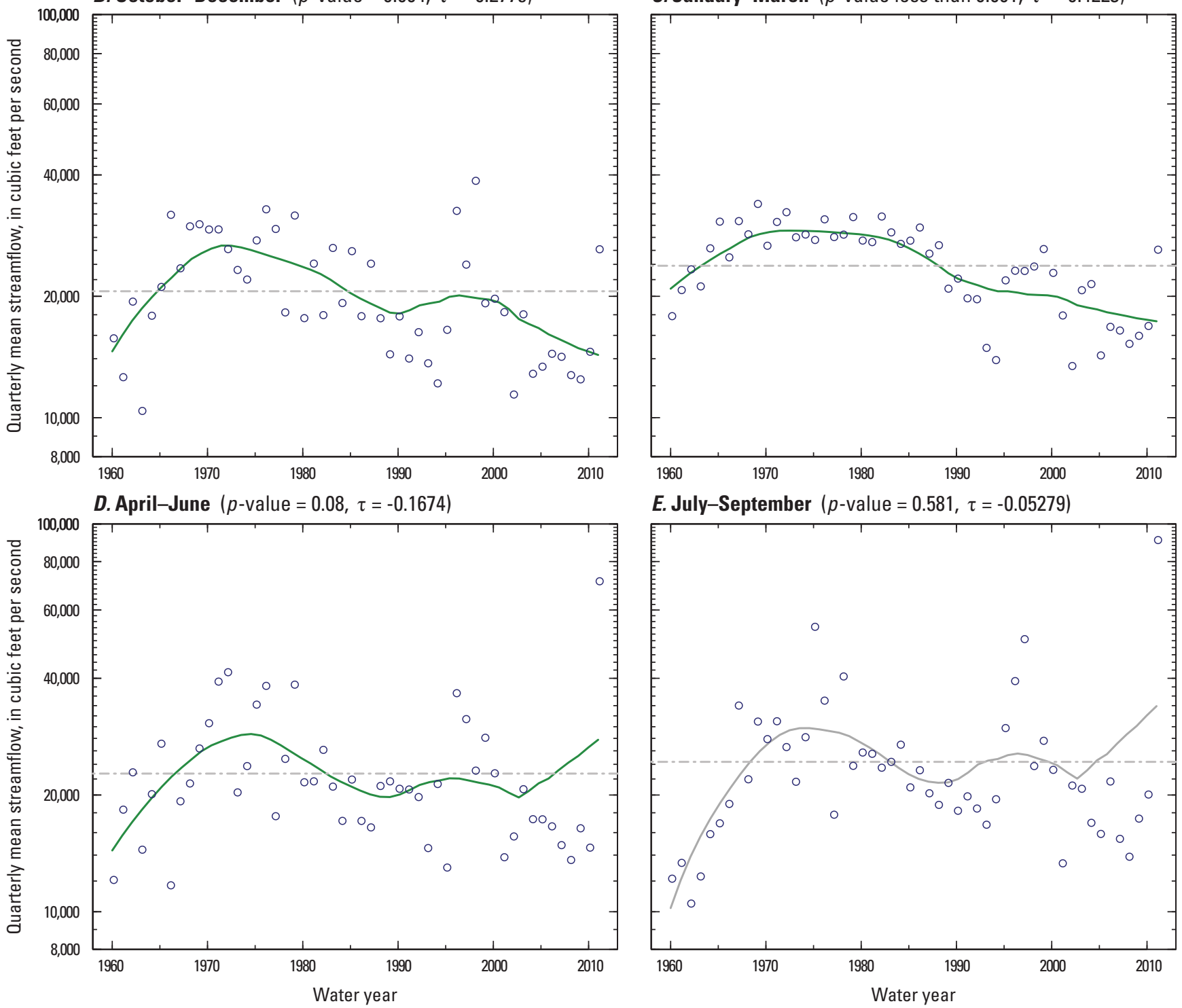

E. July-September $(p$-value $=0.581, \tau=-0.05279)$

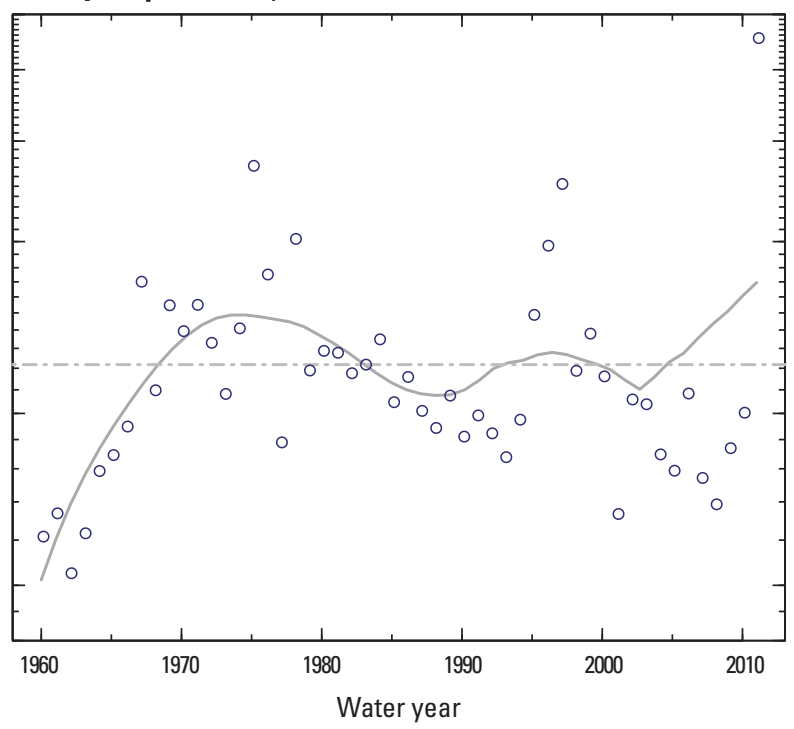

Figure 1-31. Missouri River at Bismarck, North Dakota (streamgage 06342500), water years 1960-2011. 
A. Annual mean streamflow [probability value ( $p$-value $)=0.037$, Kendall's tau $(\tau)=0.1991$ ]

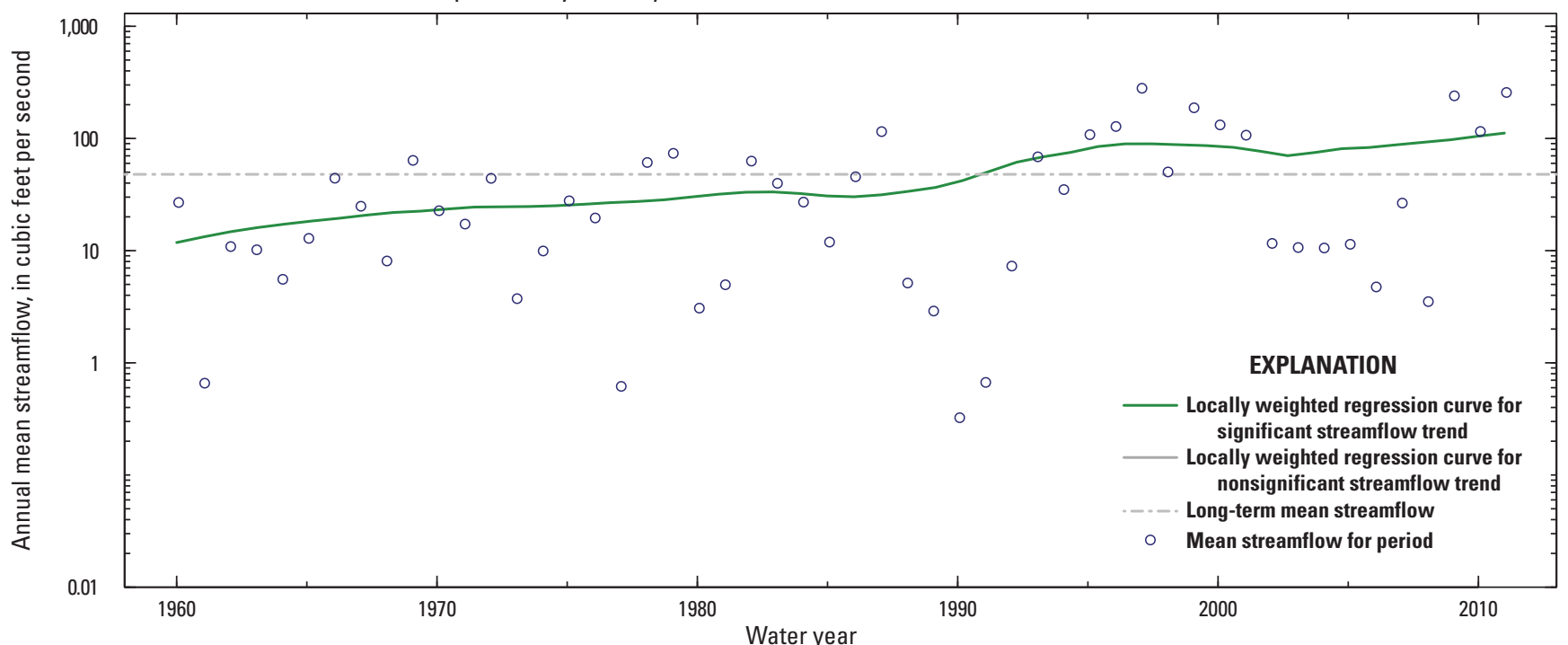

B. October-December ( $p$-value less than $0.001, \tau=0.3323$ )

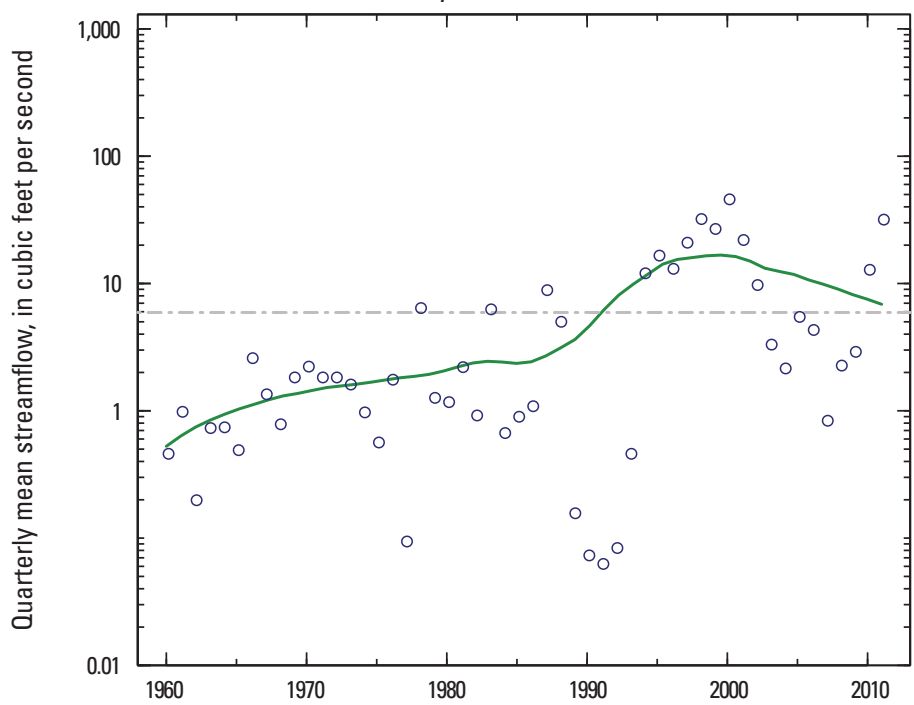

C. January-March ( $p$-value $=0.039, \tau=0.1976)$

D. April-June $(p$-value $=0.111, \tau=0.1523)$
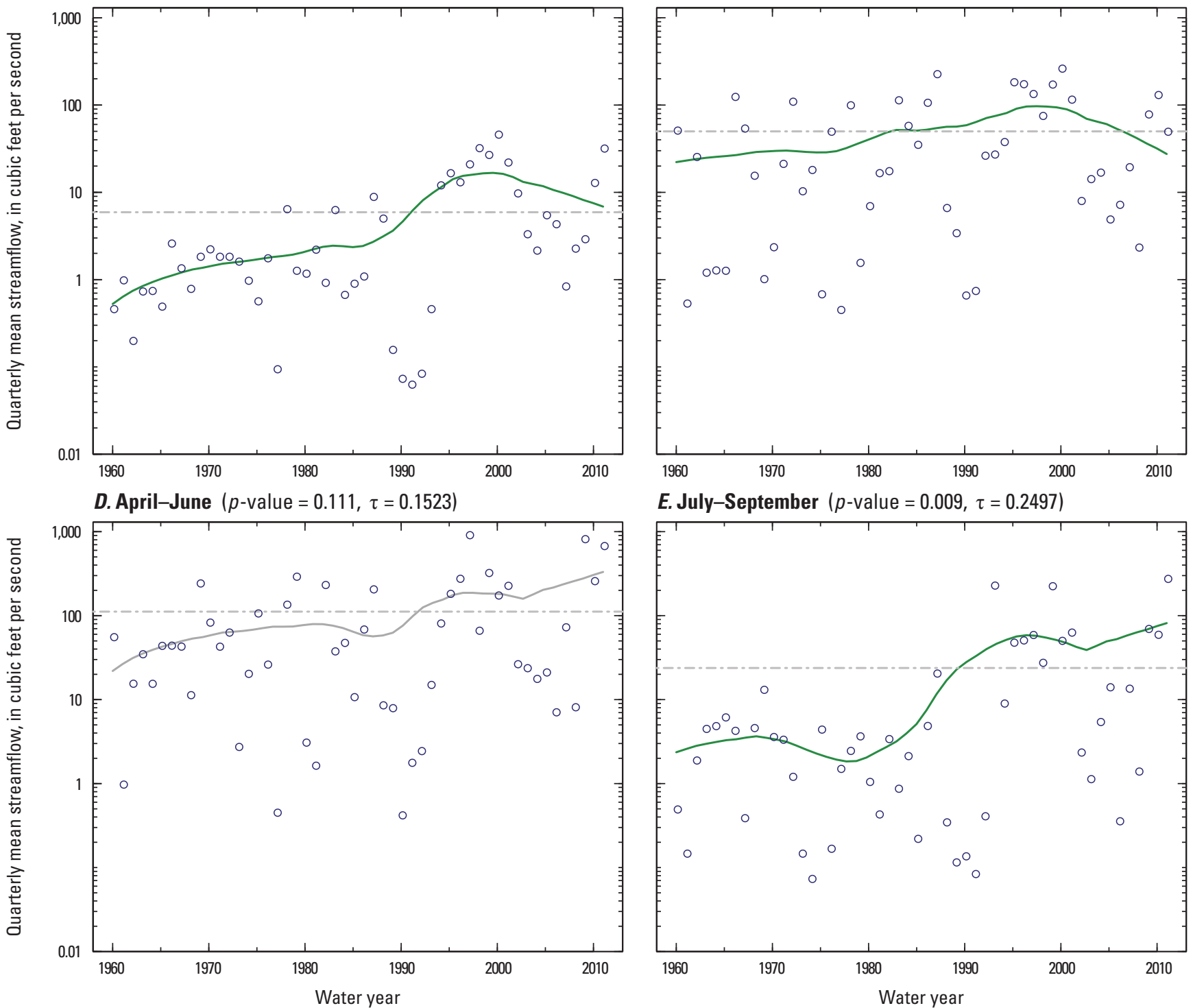

E. July-September $(p$-value $=0.009, \tau=0.2497)$

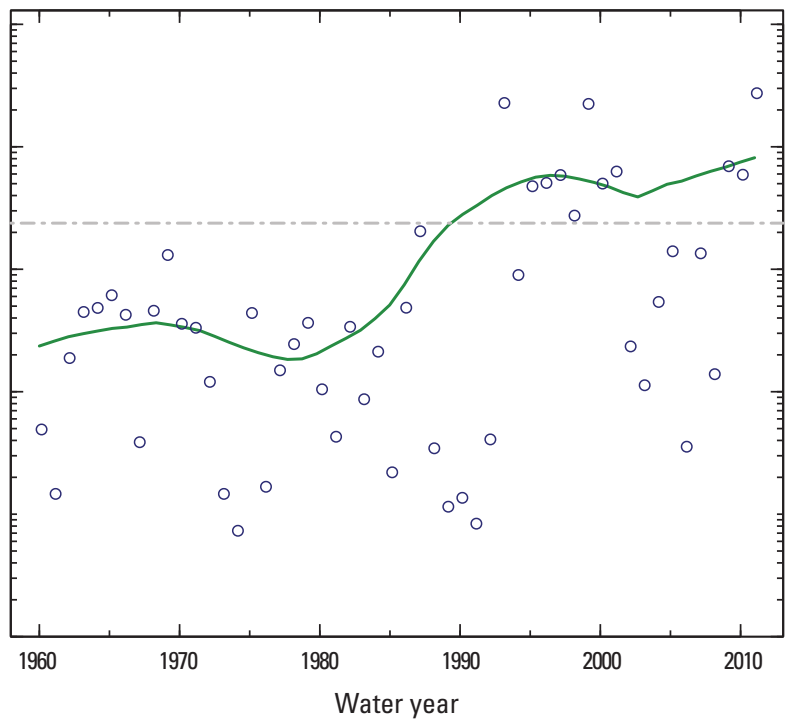

Figure 1-32. Apple Creek near Menoken, North Dakota (streamgage 06349500), water years 1960-2011. 
A. Annual mean streamflow [probability value $(p$-value $)=0.01$, Kendall's tau $(\tau)=0.2475$ ]
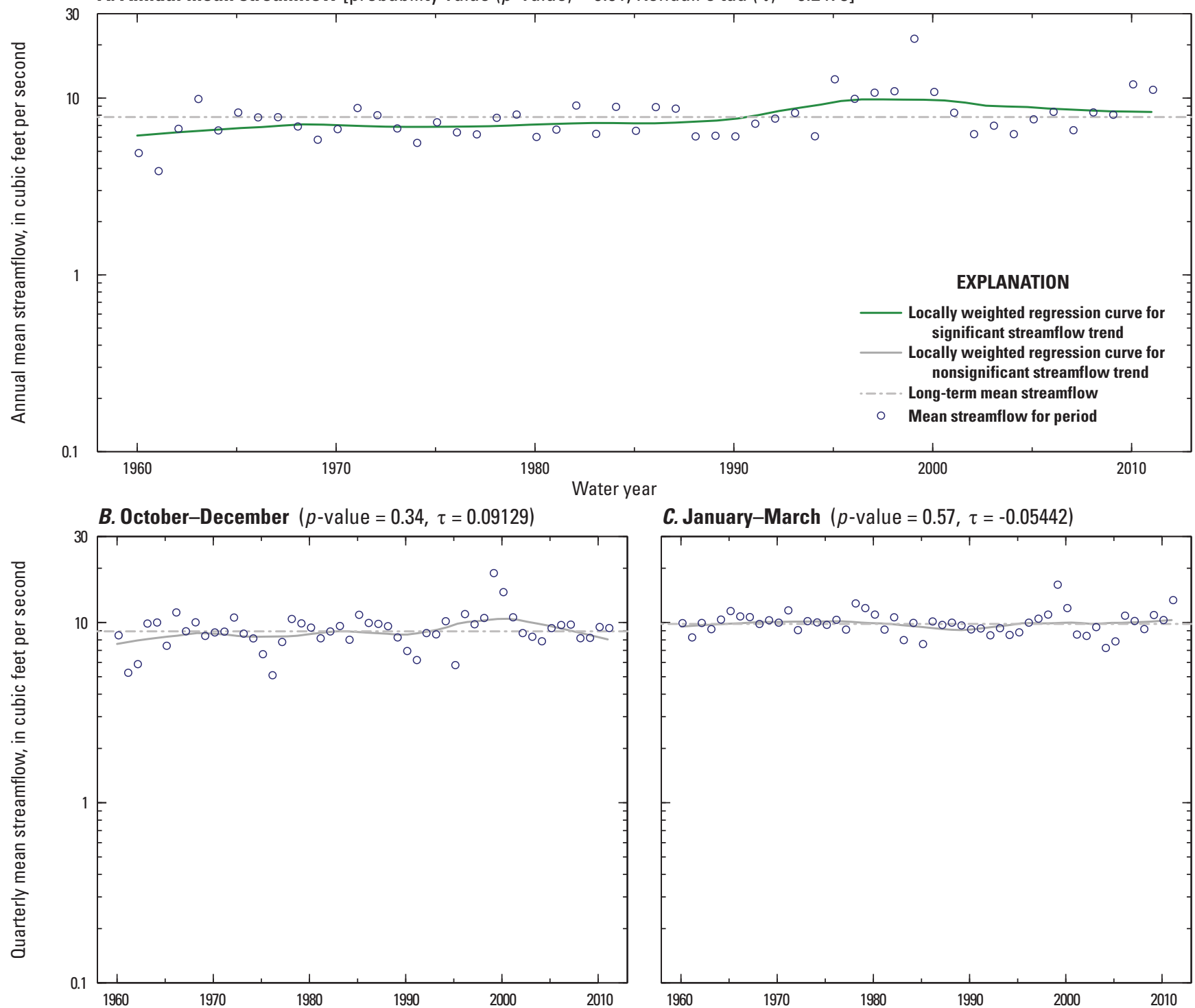

C. January-March ( $p$-value $=0.57, \tau=-0.05442)$

D. April-June $(p$-value $=0.002, \tau=0.3025)$
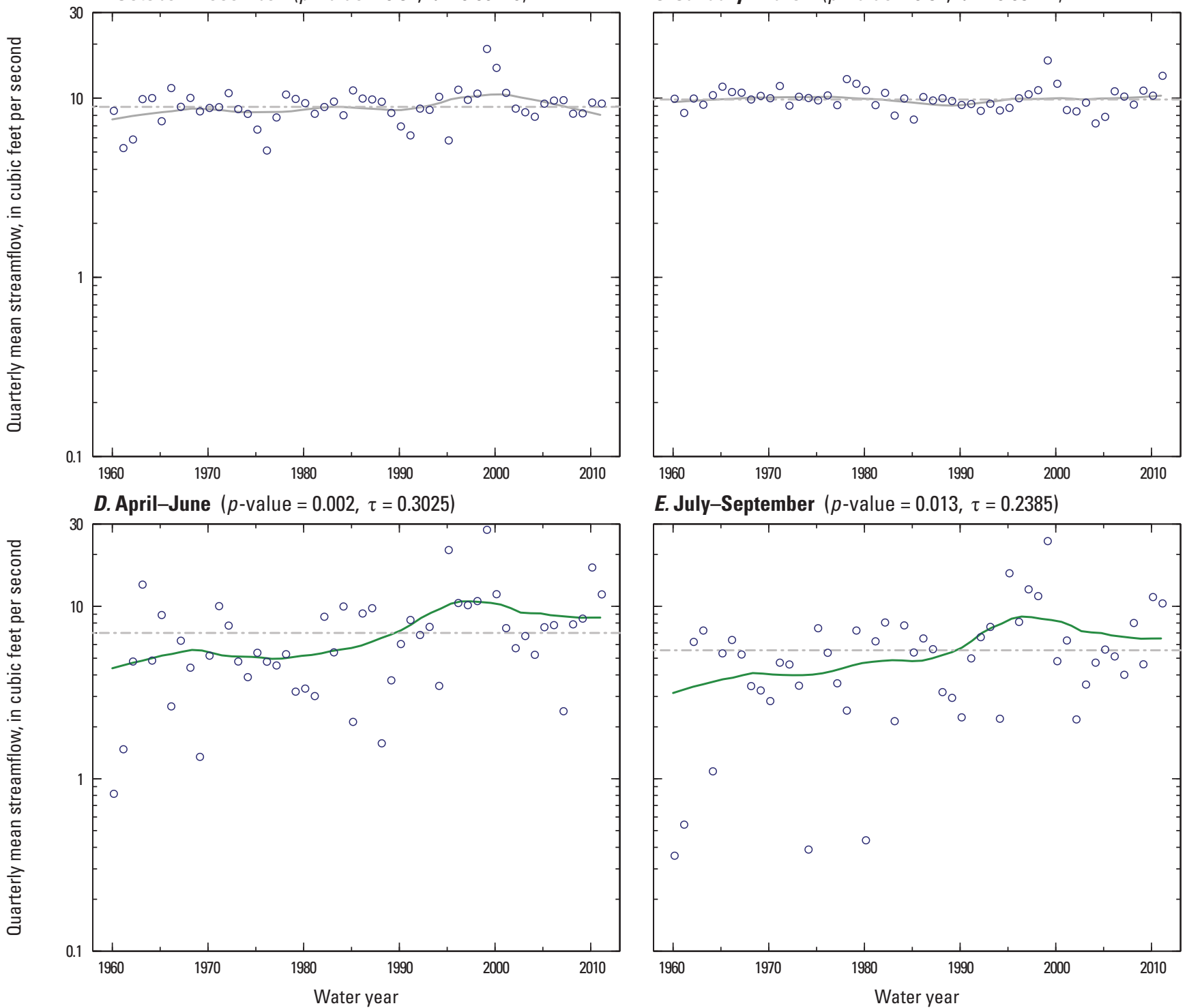

E. July-September ( $p$-value $=0.013, \tau=0.2385)$

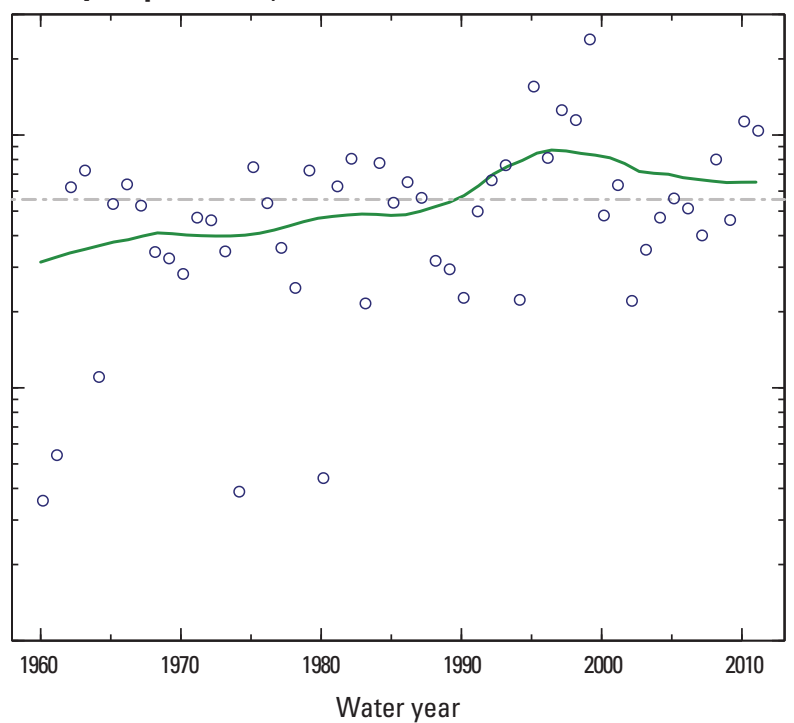

Figure 1-33. Beaver Creek near Buffalo Gap, South Dakota (streamgage 06402500), water years 1960-2011. 
A. Annual mean streamflow [probability value $(p$-value $)=0.096$, Kendall's tau $(\tau)=0.1592$ ]
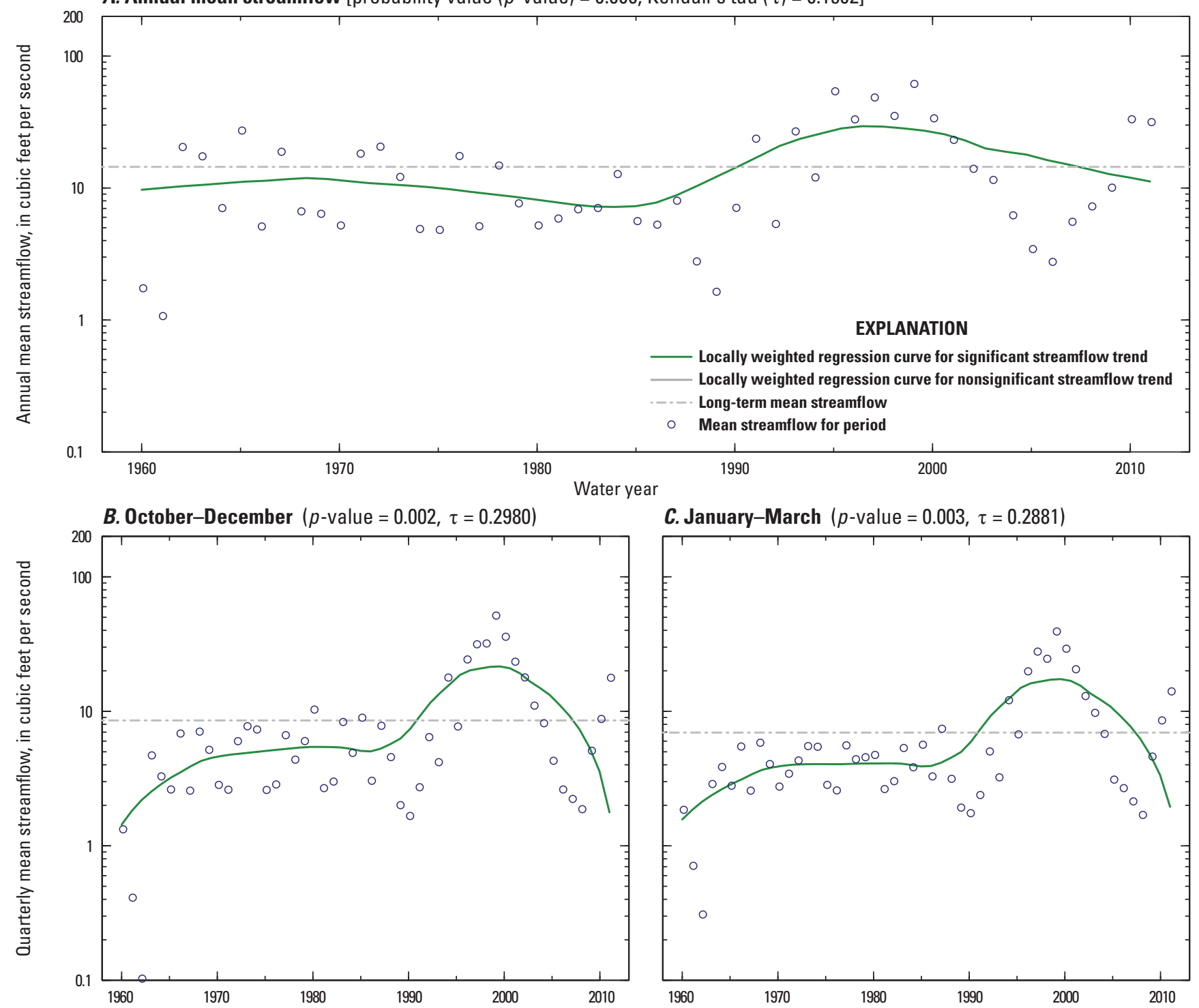

C. January-March ( $p$-value $=0.003, \tau=0.2881)$
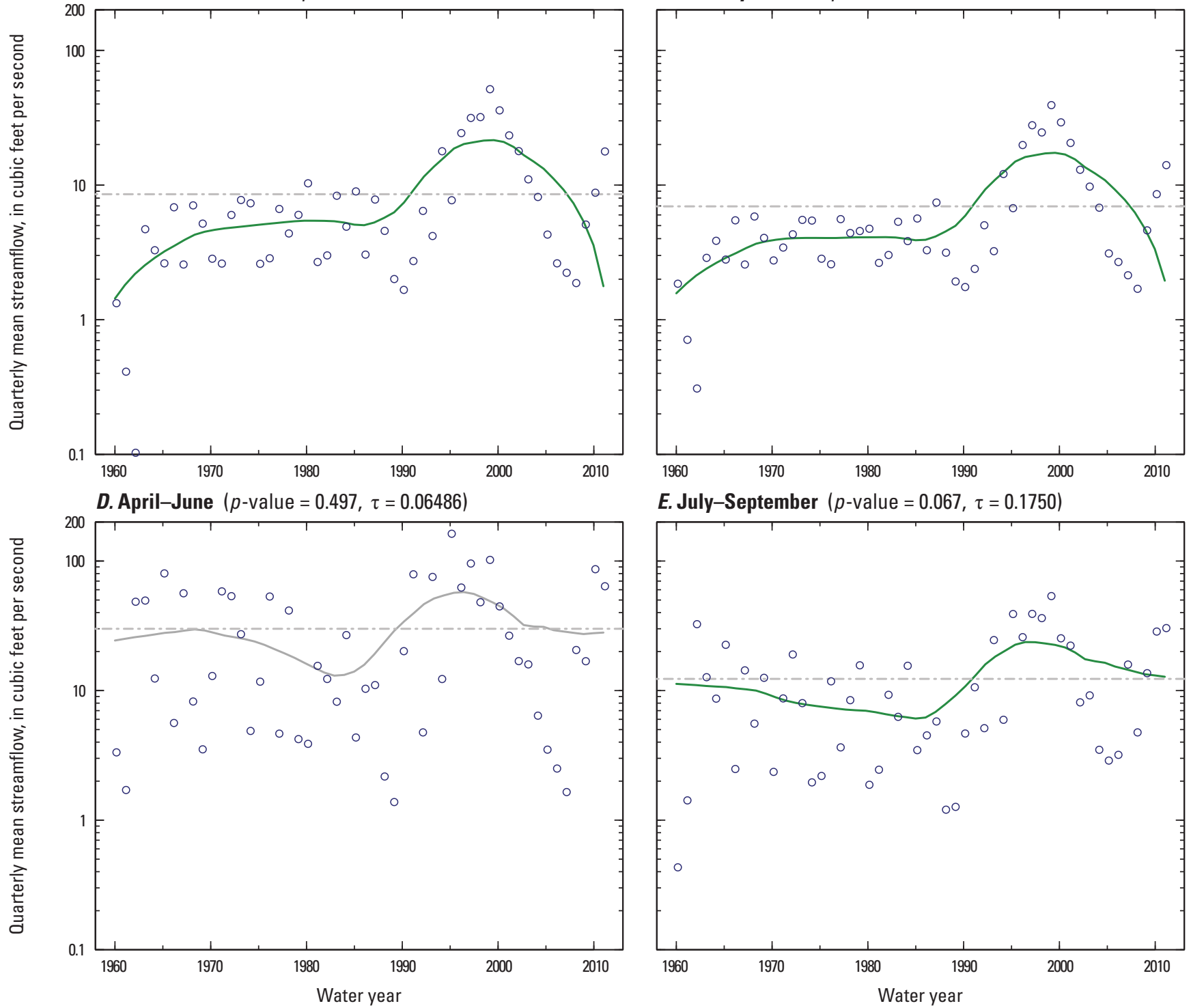

E. July-September $(p$-value $=0.067, \tau=0.1750)$

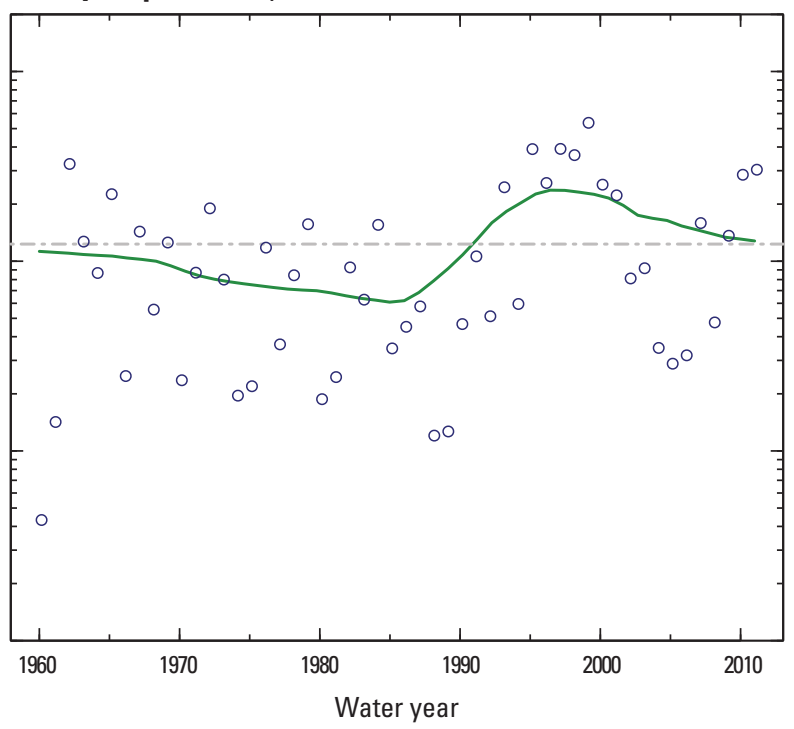

Figure 1-34. Battle Creek at Hermosa, South Dakota (streamgage 06406000), water years 1960-2011. 
A. Annual mean streamflow [probability value $(p$-value $)=0.032$, Kendall's tau $(\tau)=0.2045$ ]

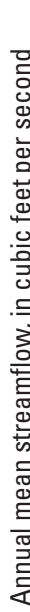

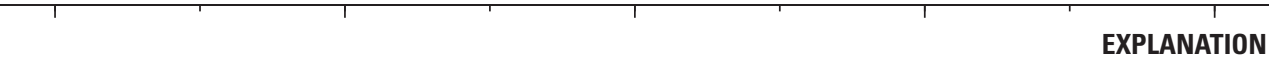

100

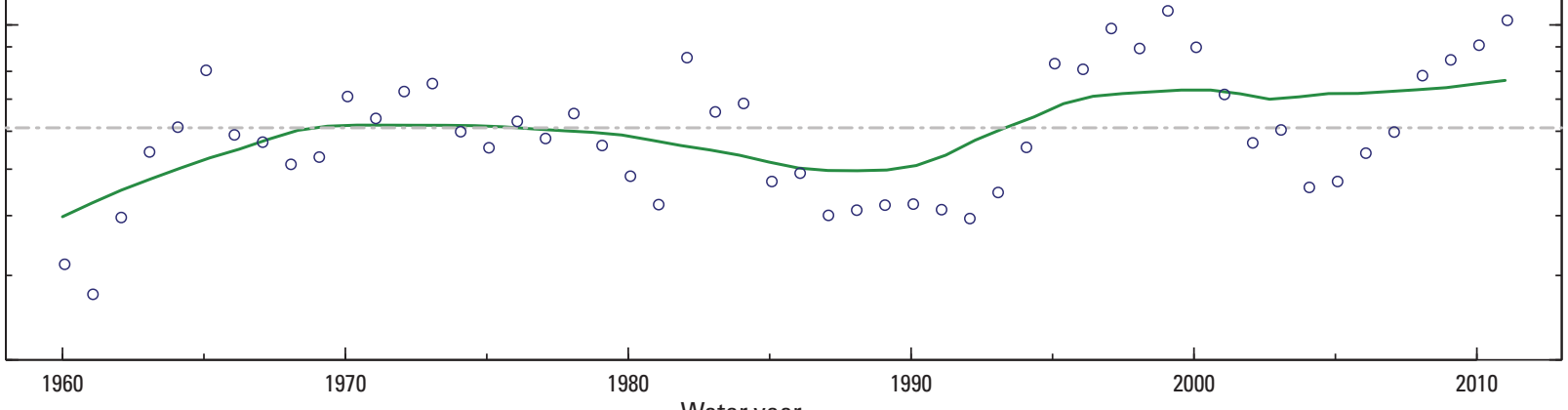

20

Water year

B. October-December ( $p$-value $=0.005, \tau=0.2665)$

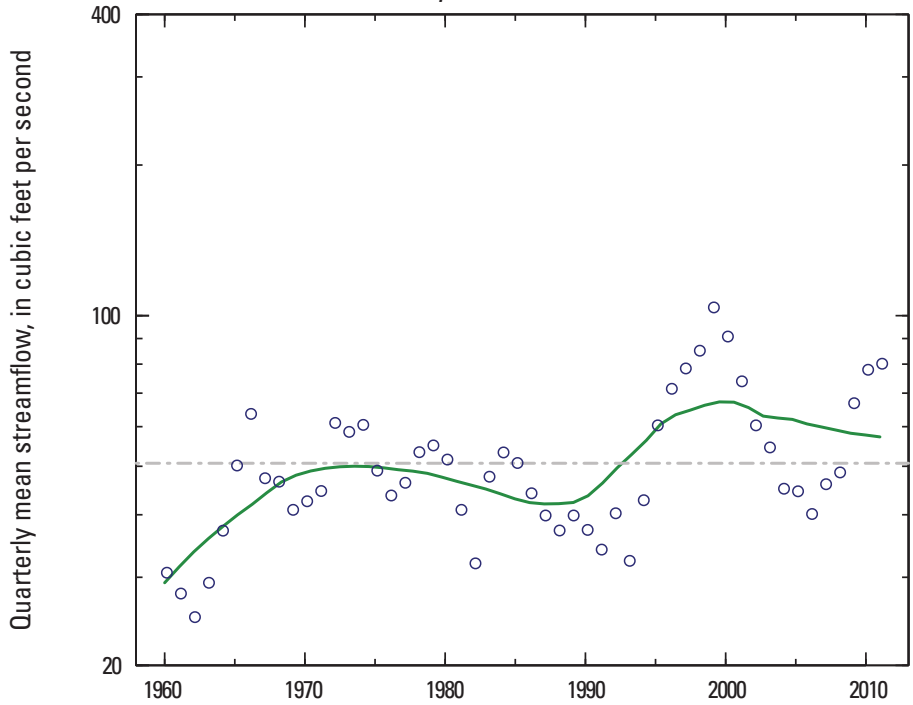

D. April-June $(p$-value $=0.344, \tau=0.0905)$

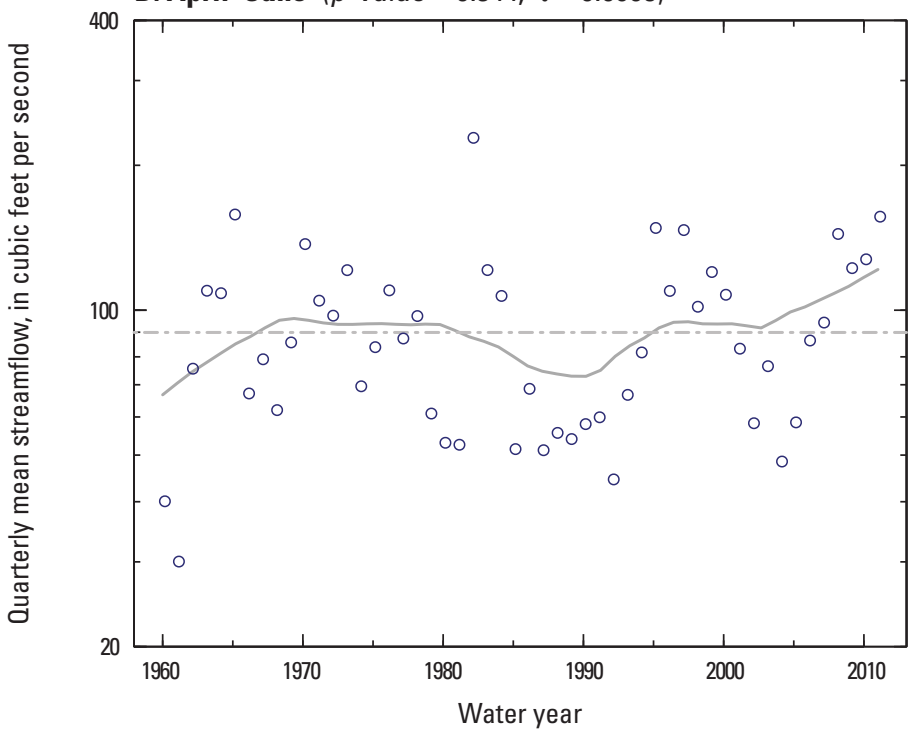

C. January-March $(p$-value $=0.006, \tau=0.2650)$

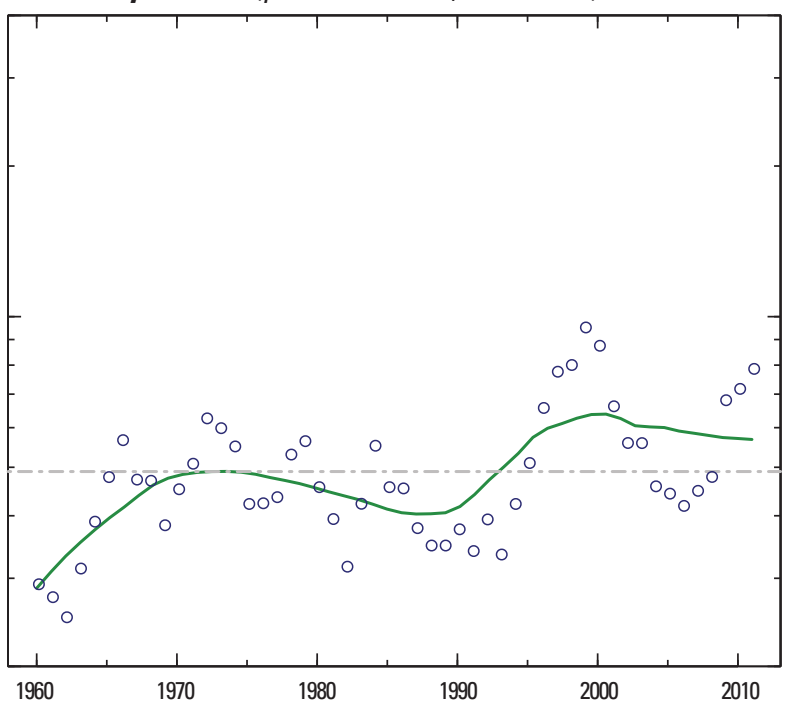

E. July-September $(p$-value $=0.029, \tau=0.2083)$

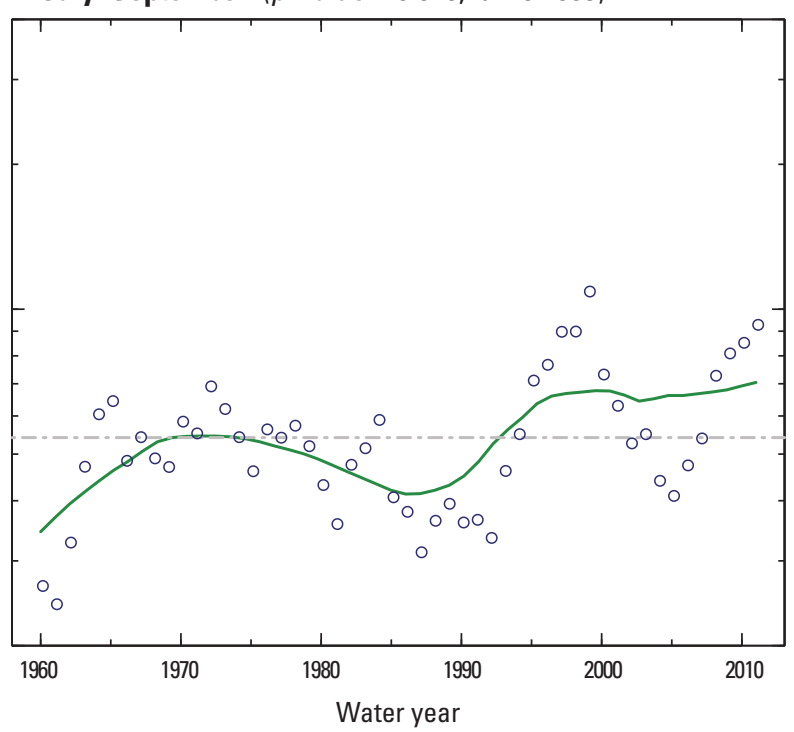

Figure 1-35. Spearfish Creek at Spearfish, South Dakota (streamgage 06431500), water years 1960-2011. 
A. Annual mean streamflow [probability value $(p$-value $)=0.007$, Kendall's tau $(\tau)=0.2558$ ]
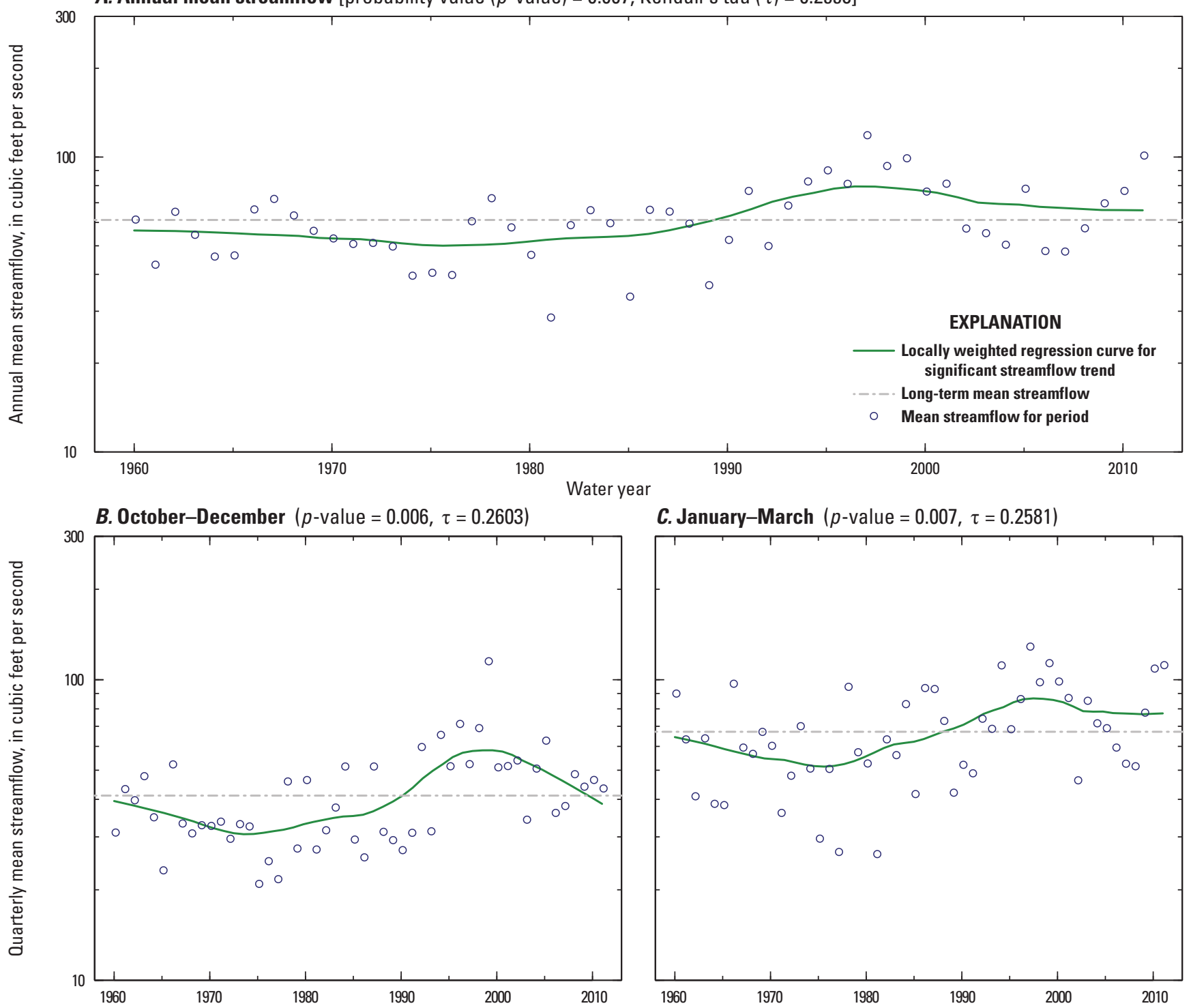

C. January-March ( $p$-value $=0.007, \tau=0.2581)$
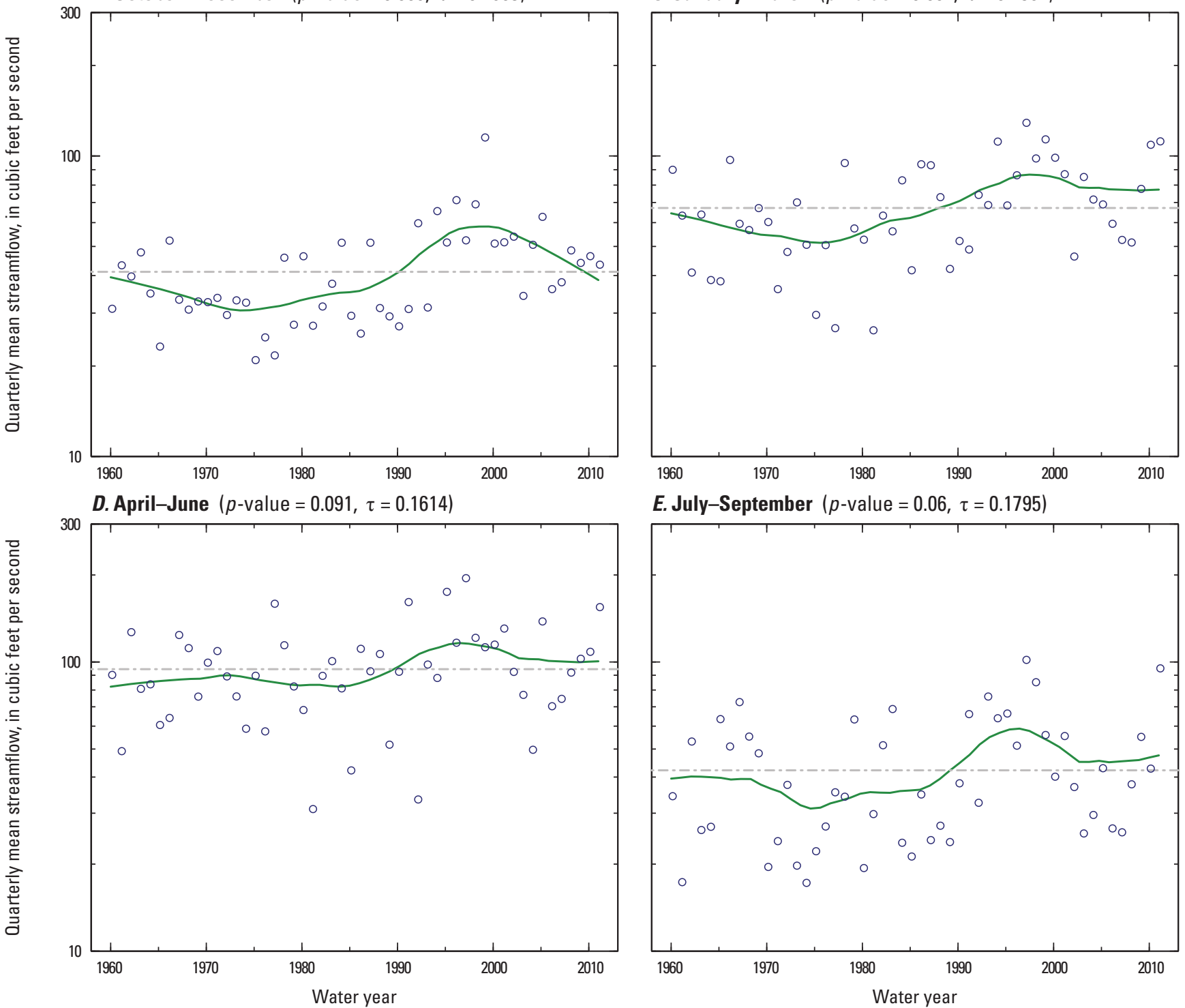

E. July-September $(p$-value $=0.06, \tau=0.1795)$

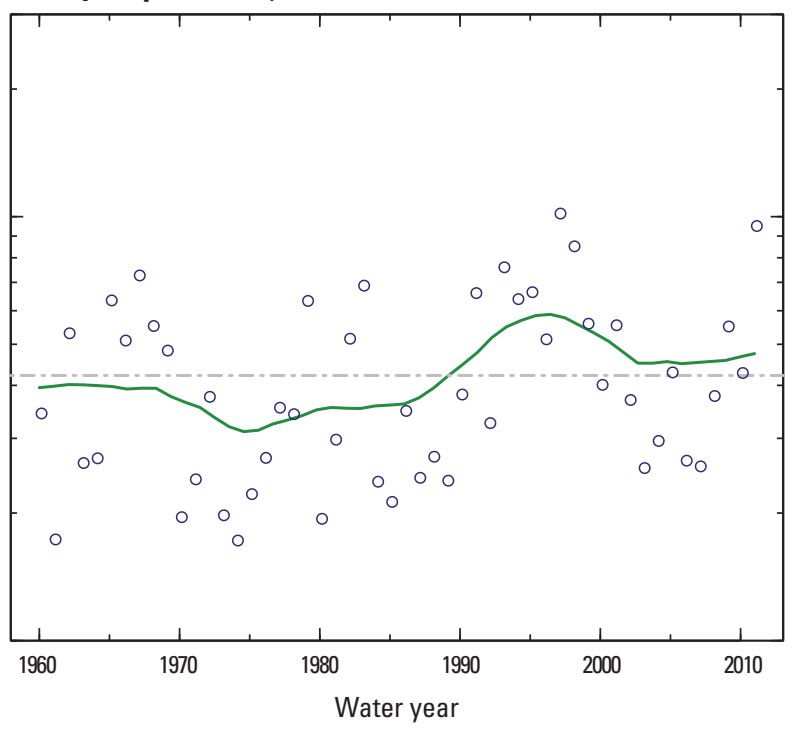

Figure 1-36. Little White River near Vetal, South Dakota (streamgage 06449100), water years 1960-2011. 
A. Annual mean streamflow [probability value ( $p$-value) less than 0.001 , Kendall's tau $(\tau)=0.3351$ ]

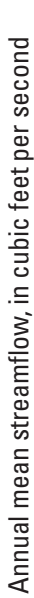

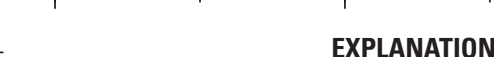

40

1960 EXPLANATION

100

_ Locally weighted regression curve for significant streamflow trend

-. Long-term mean streamflow

$\circ \quad$ Mean streamflow for period

40

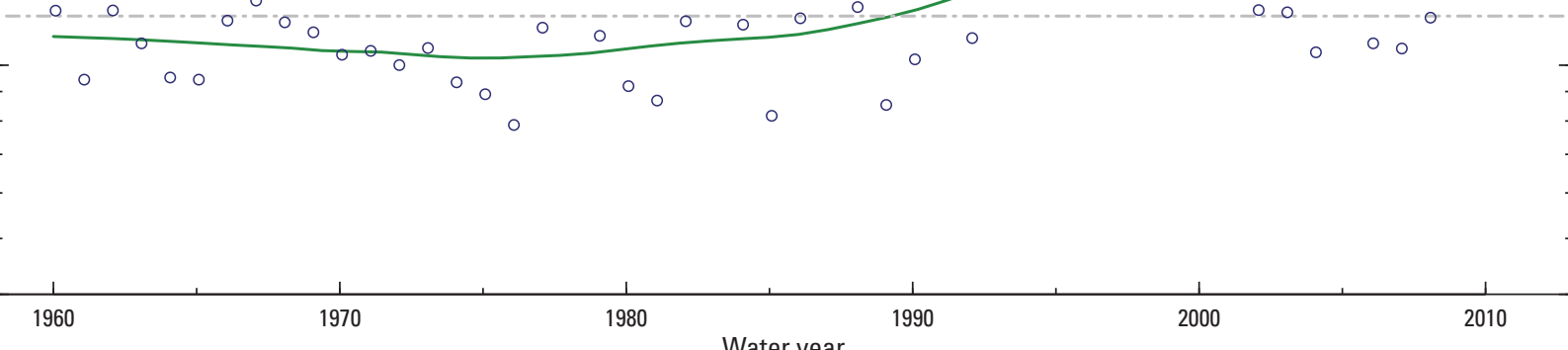

B. October-December ( $p$-value less than $0.001, \tau=0.3553$ )

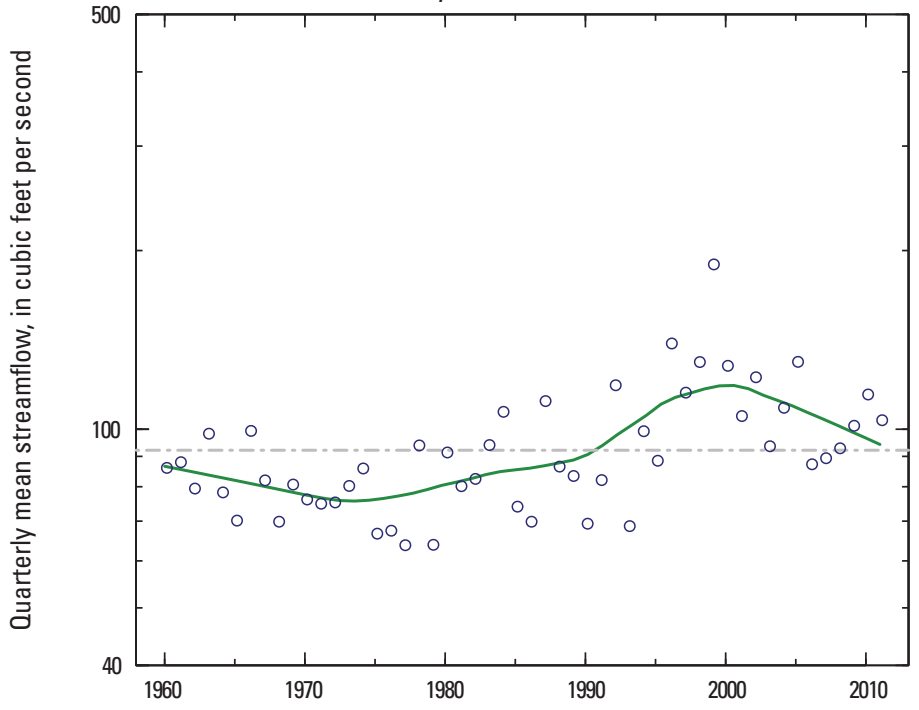

C. January-March ( $p$-value less than 0.001, $\tau=0.3635$ )

D. April-June $(p$-value $=0.063, \tau=0.1780)$
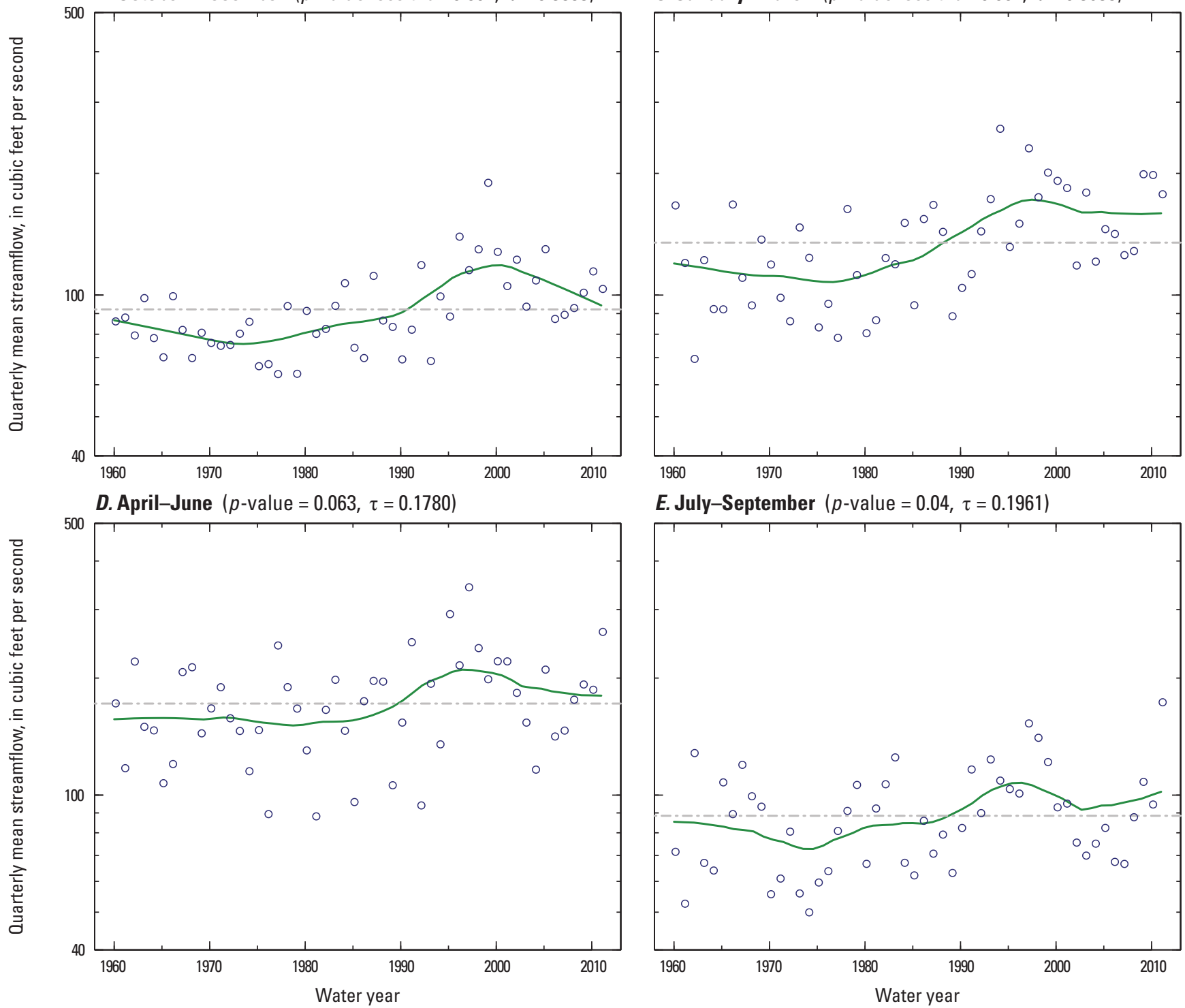

E. July-September $(p$-value $=0.04, \tau=0.1961)$

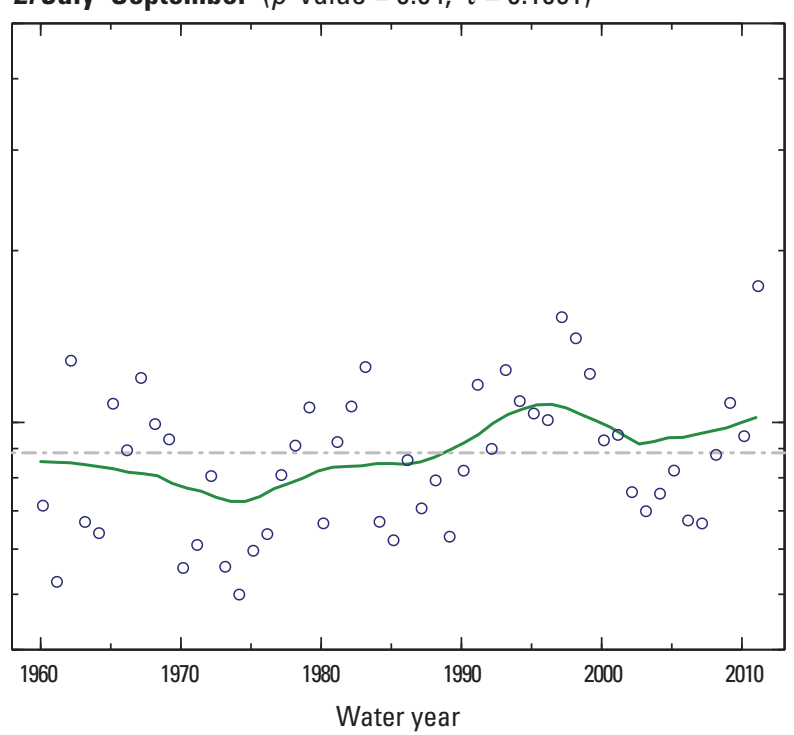

Figure 1-37. Little White River near Rosebud, South Dakota (streamgage 06449500), water years 1960-2011. 
A. Annual mean streamflow [probability value ( $p$-value $)=0.015$, Kendall's tau $(\tau)=0.2331$ ]

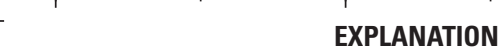

30

Locally weighted regression curve for significant streamflow trend
Locally weighted regression curve for nonsignificant streamflow tre

..... Long-term mean streamflow

$\circ \quad$ Mean streamflow for period

100

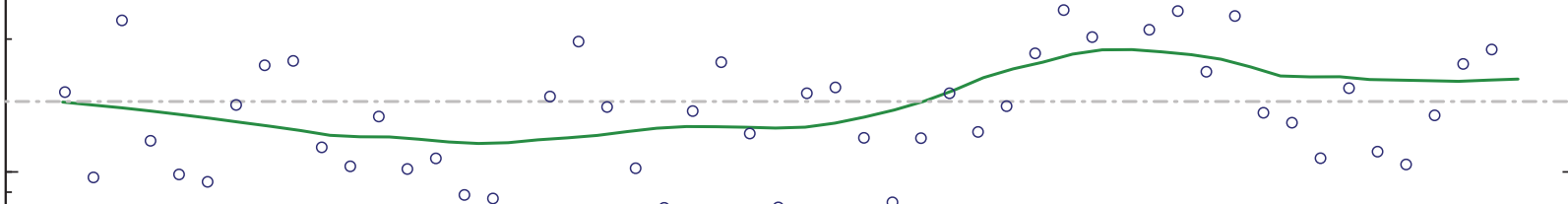

1960

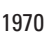

1980

Water year

B. October-December ( $p$-value less than $0.001, \tau=0.3635)$

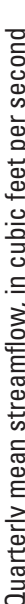

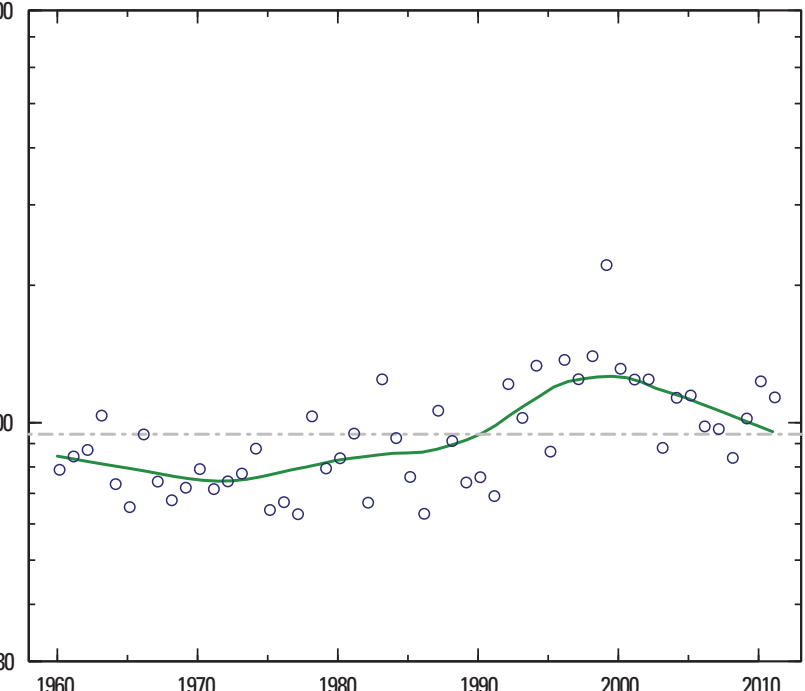

D. April-June $(p$-value $=0.151, \tau=0.1373)$

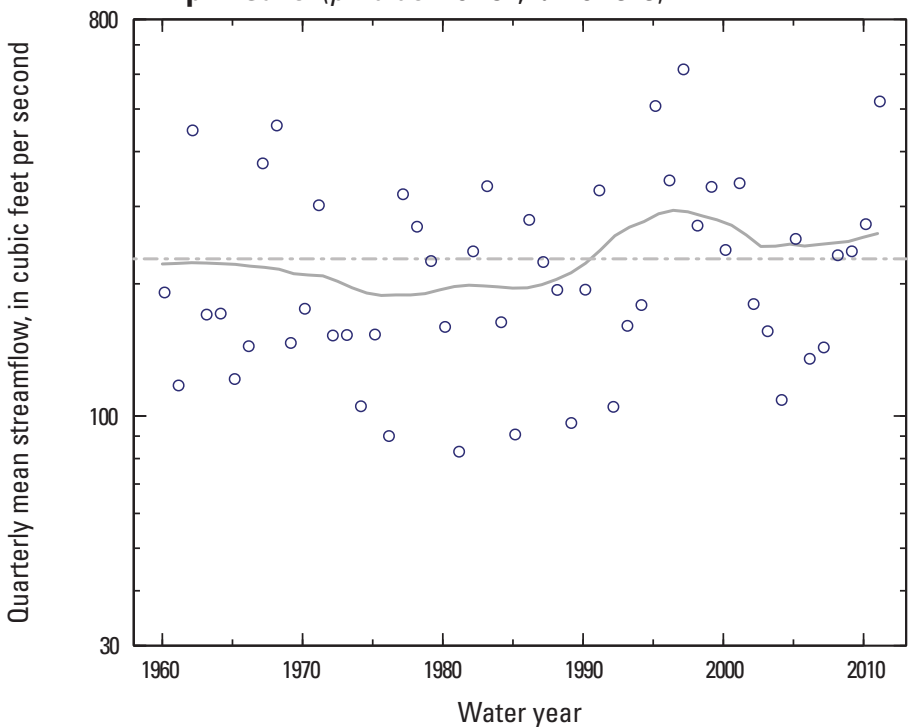

C. January-March ( $p$-value less than 0.001, $\tau=0.3394)$

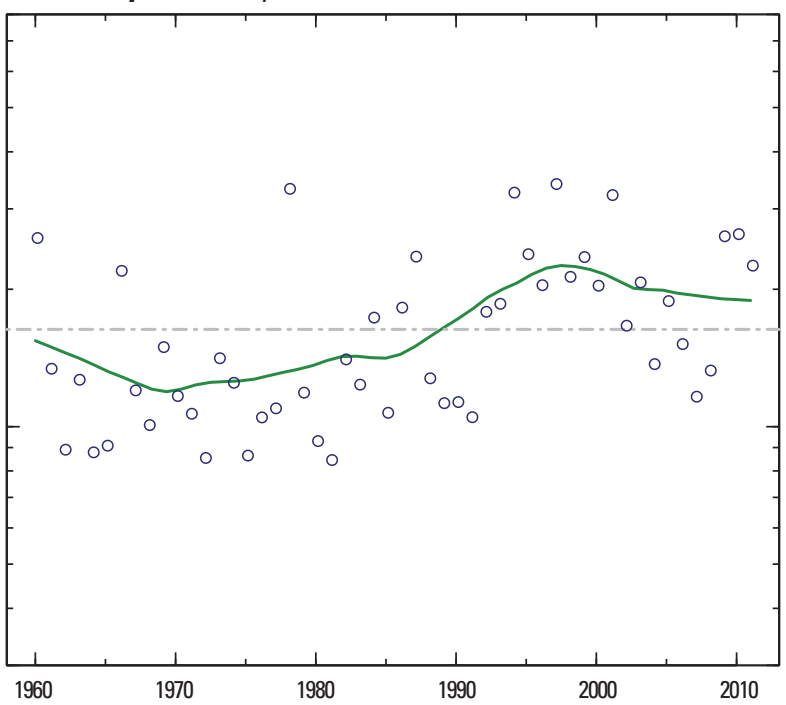

E. July-September $(p$-value $=0.111, \tau=0.1523)$

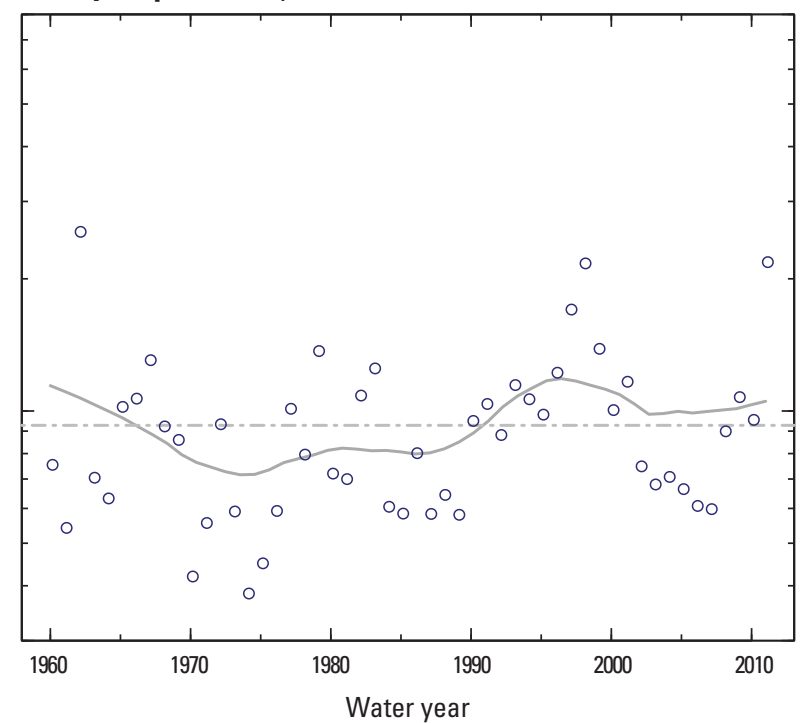

Figure 1-38. Little White River below White River, South Dakota (streamgage 06450500), water years 1960-2011. 
A. Annual mean streamflow [probability value ( $p$-value) less than 0.001 , Kendall's tau $(\tau)=0.5983$ ]

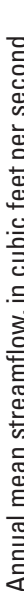

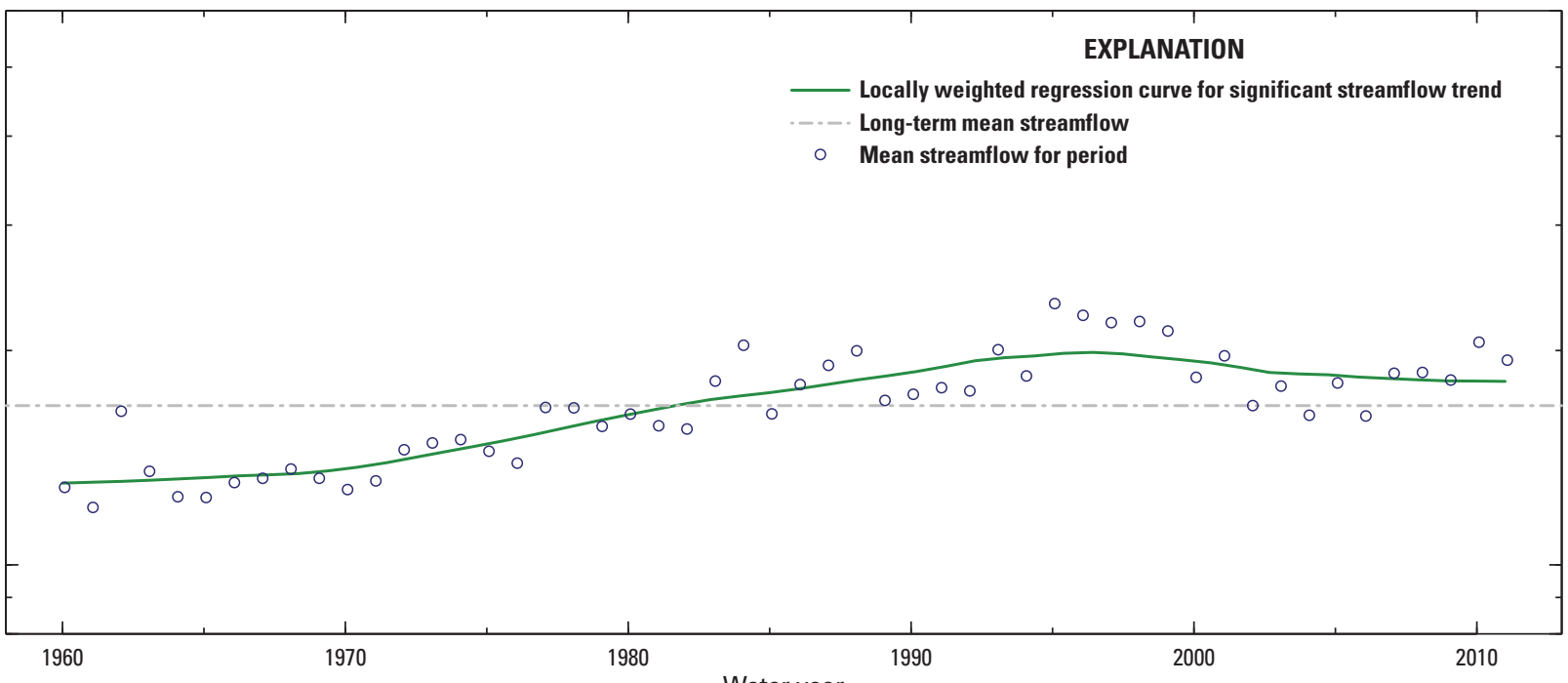

B. October-December ( $p$-value less than $0.001, \tau=0.5937$ )

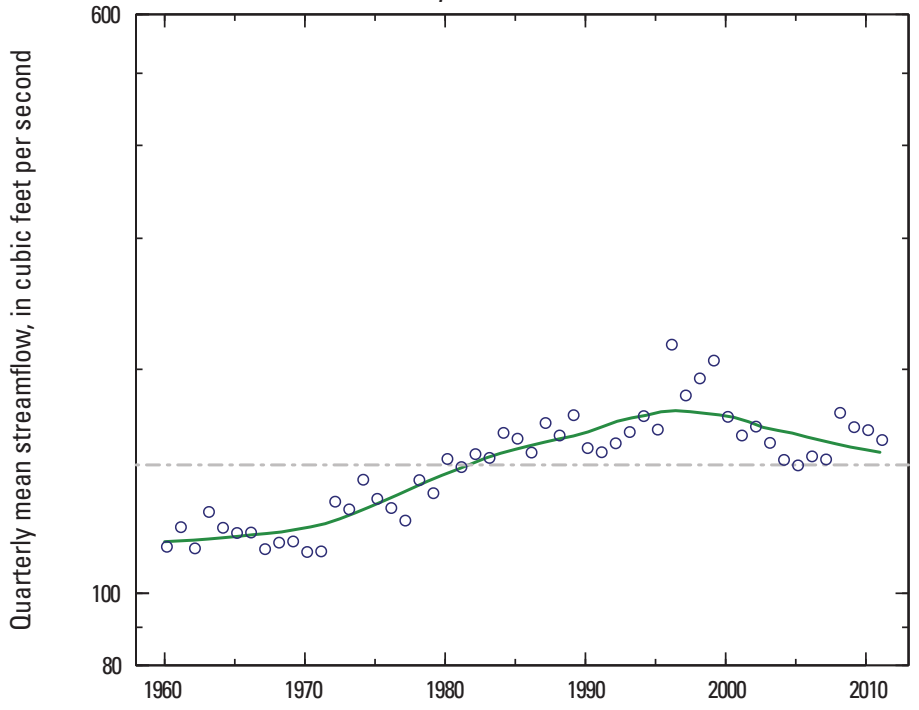

C. January-March ( $p$-value less than $0.001, \tau=0.5354$ )

D. April-June ( $p$-value less than 0.001, $\tau=0.5766)$
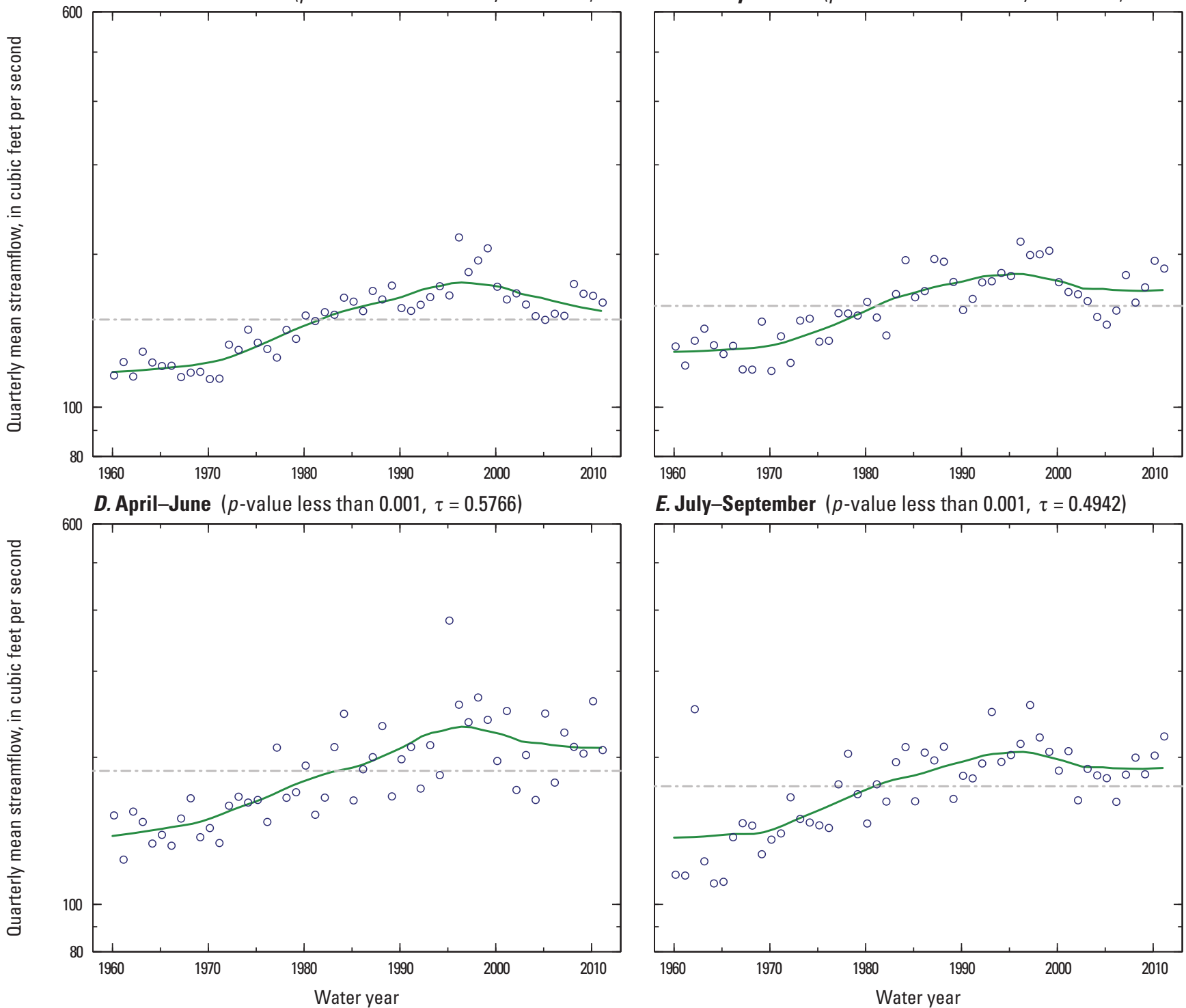

E. July-September ( $p$-value less than 0.001, $\tau=0.4942)$

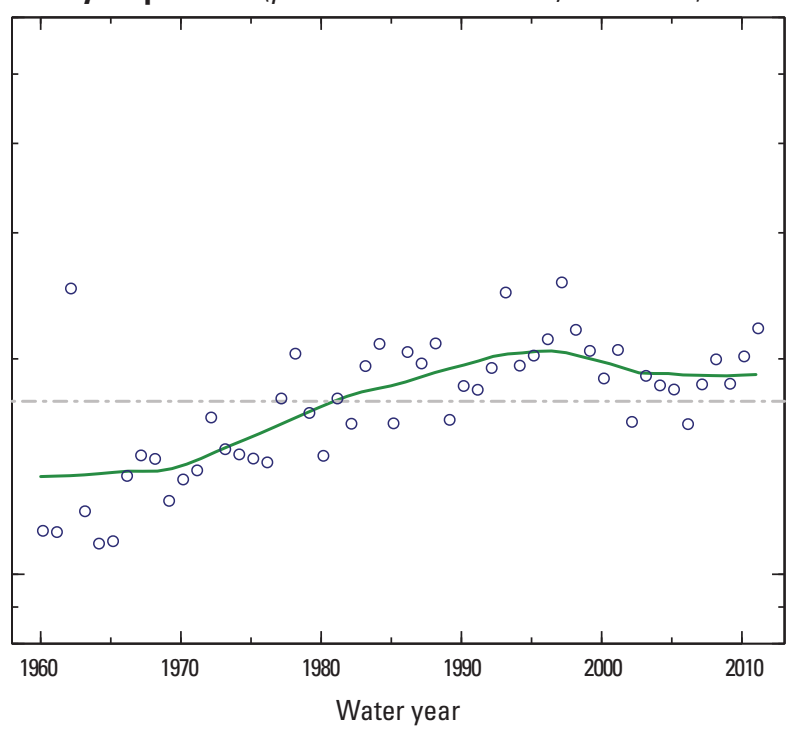

Figure 1-39. Long Pine Creek near Riverview, Nebraska (streamgage 06463500), water years 1960-2011. 
A. Annual mean streamflow [probability value $(p$-value $)=0.016$, Kendall's tau $(\tau)=0.2301$ ]
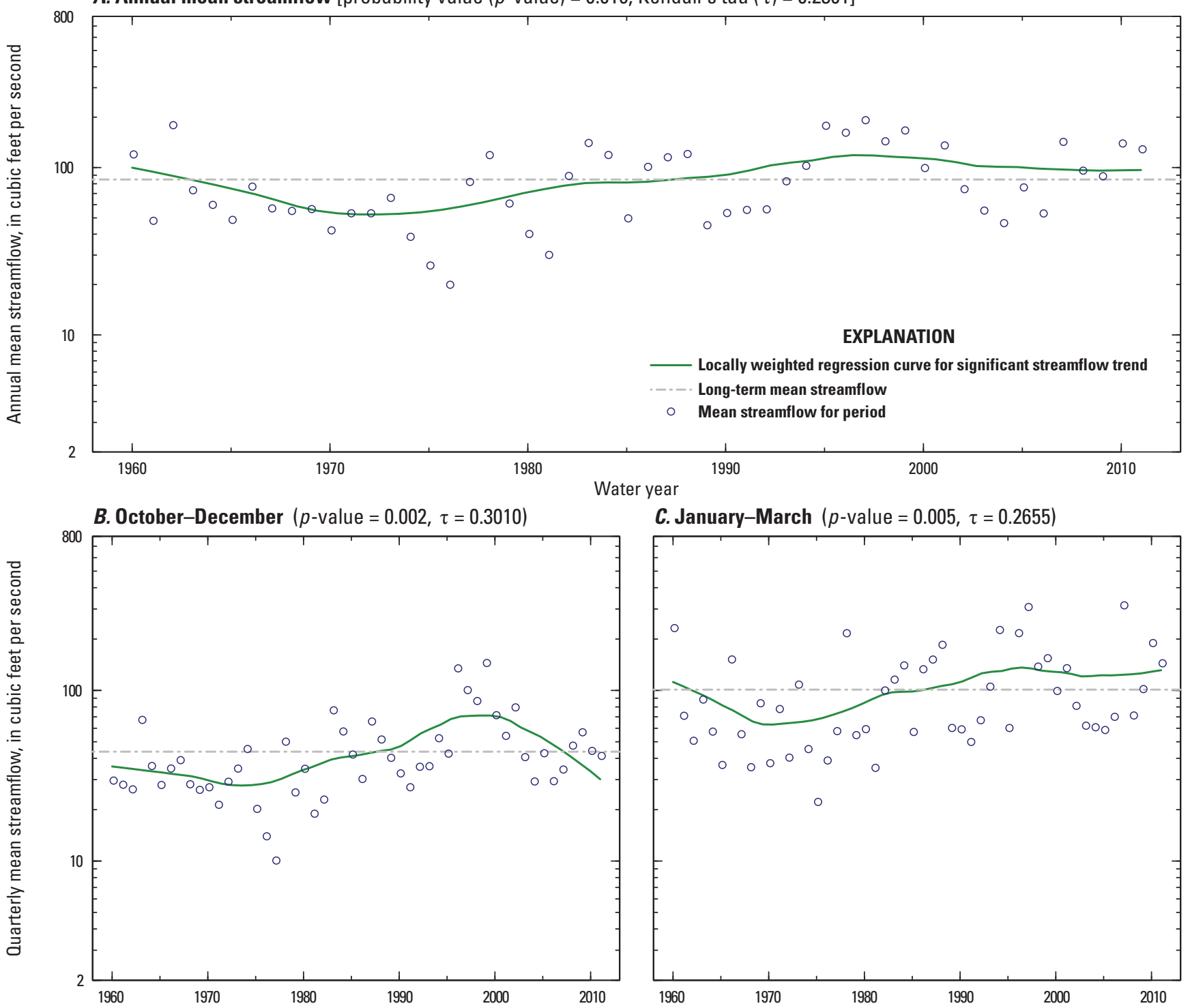

C. January-March $(p$-value $=0.005, \tau=0.2655)$
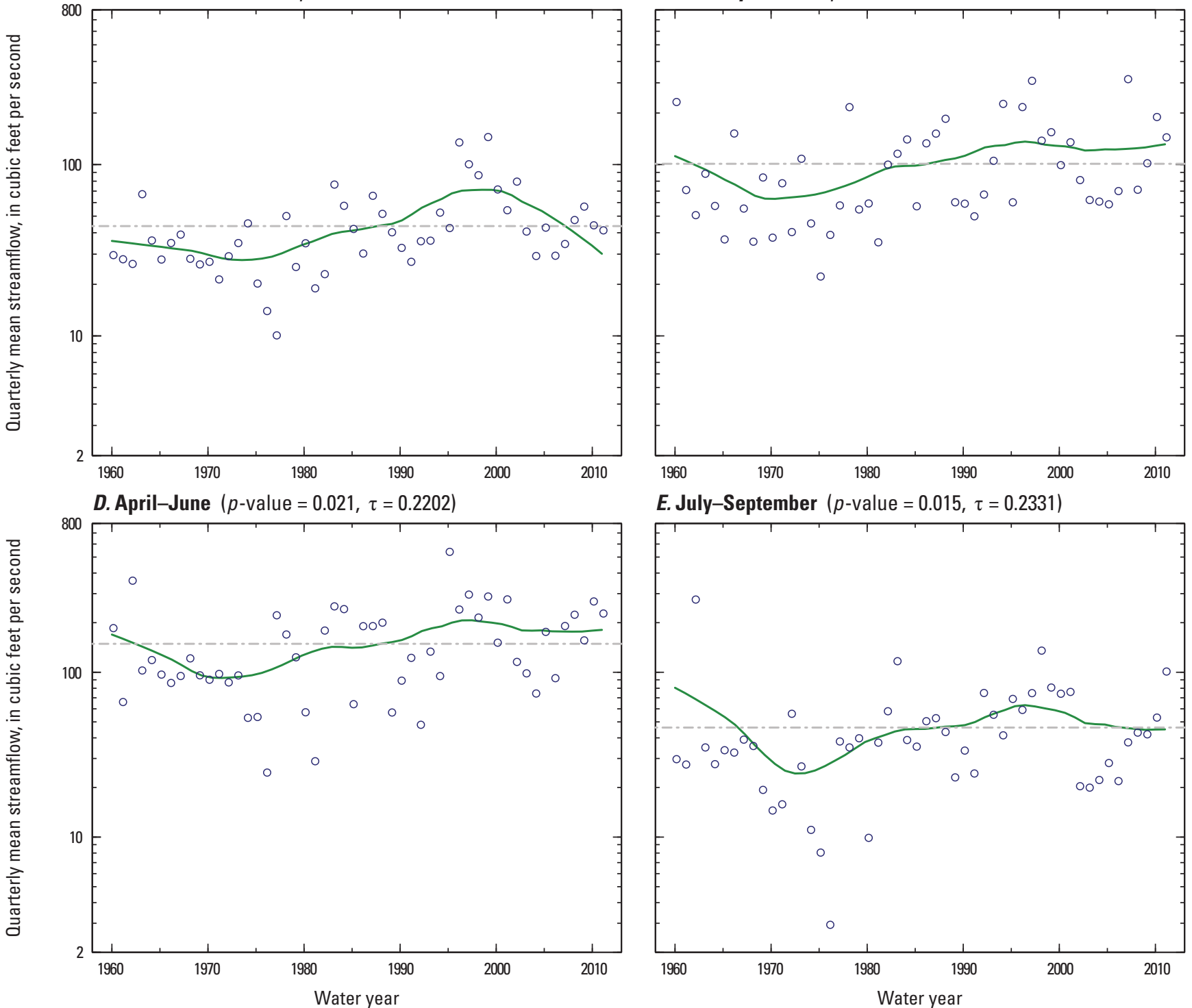

E. July-September $(p$-value $=0.015, \tau=0.2331)$

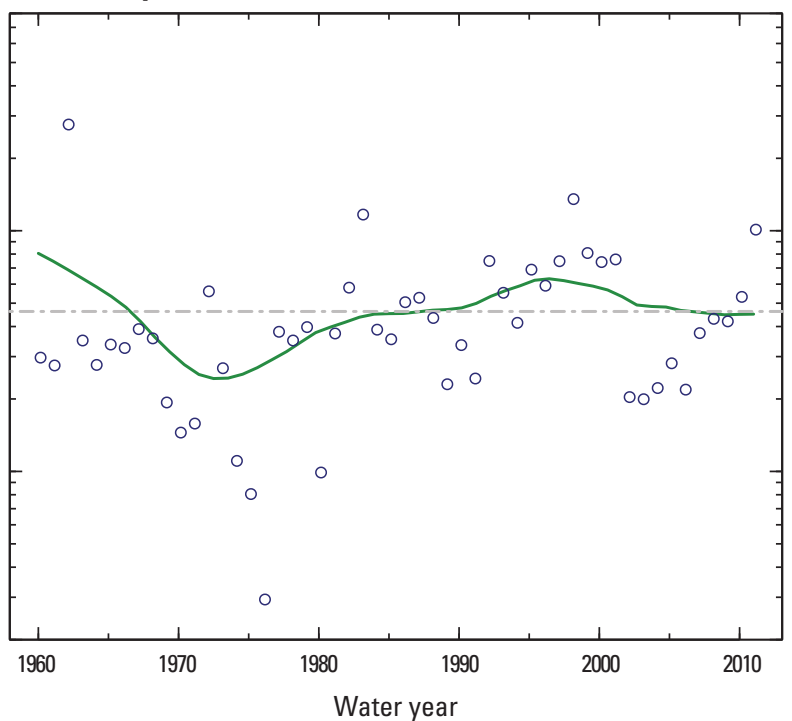

Figure 1-40. Keya Paha River at Wewela, South Dakota (streamgage 06464500), water years 1960-2011. 

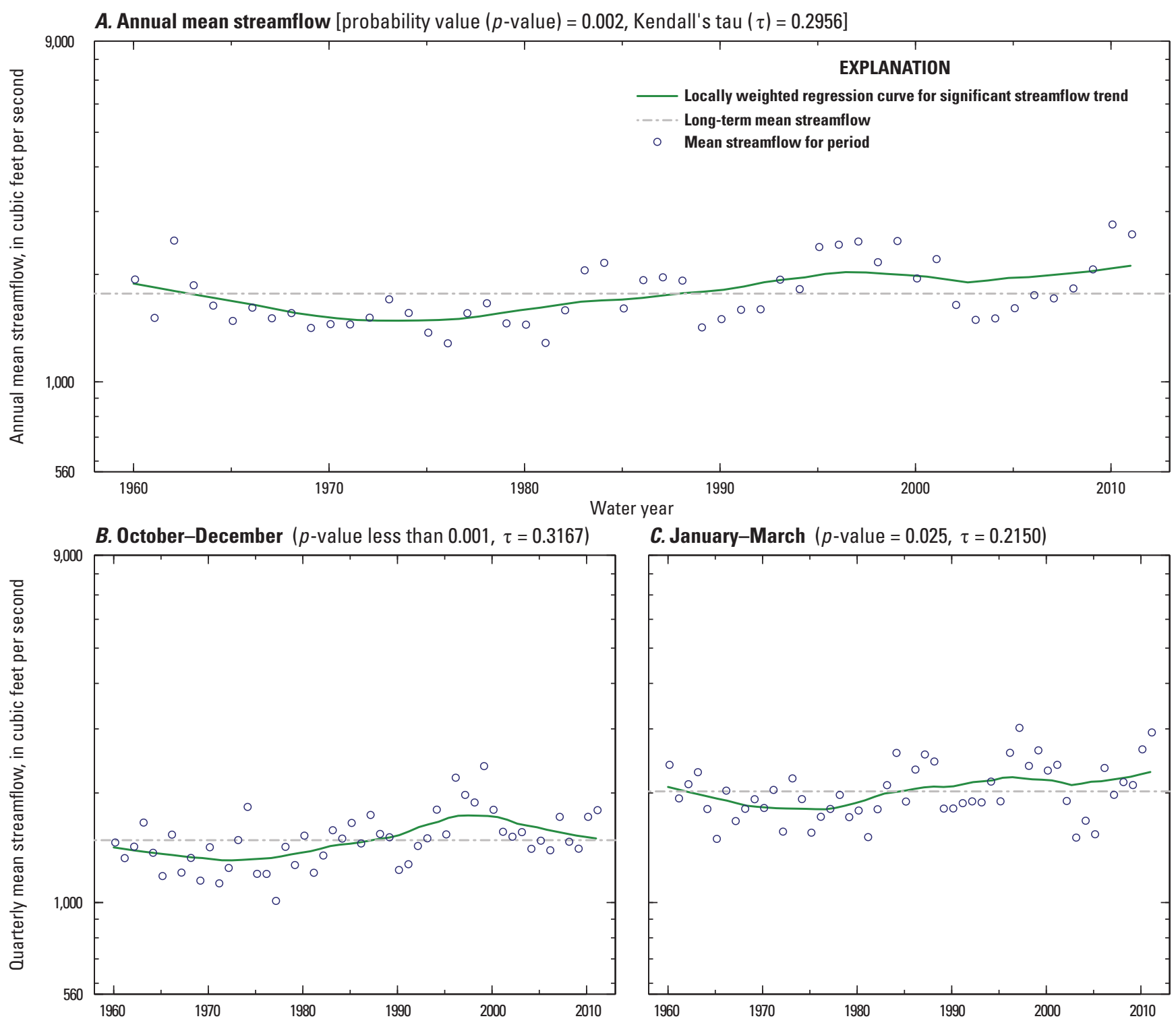

C. January-March $(p$-value $=0.025, \tau=0.2150)$
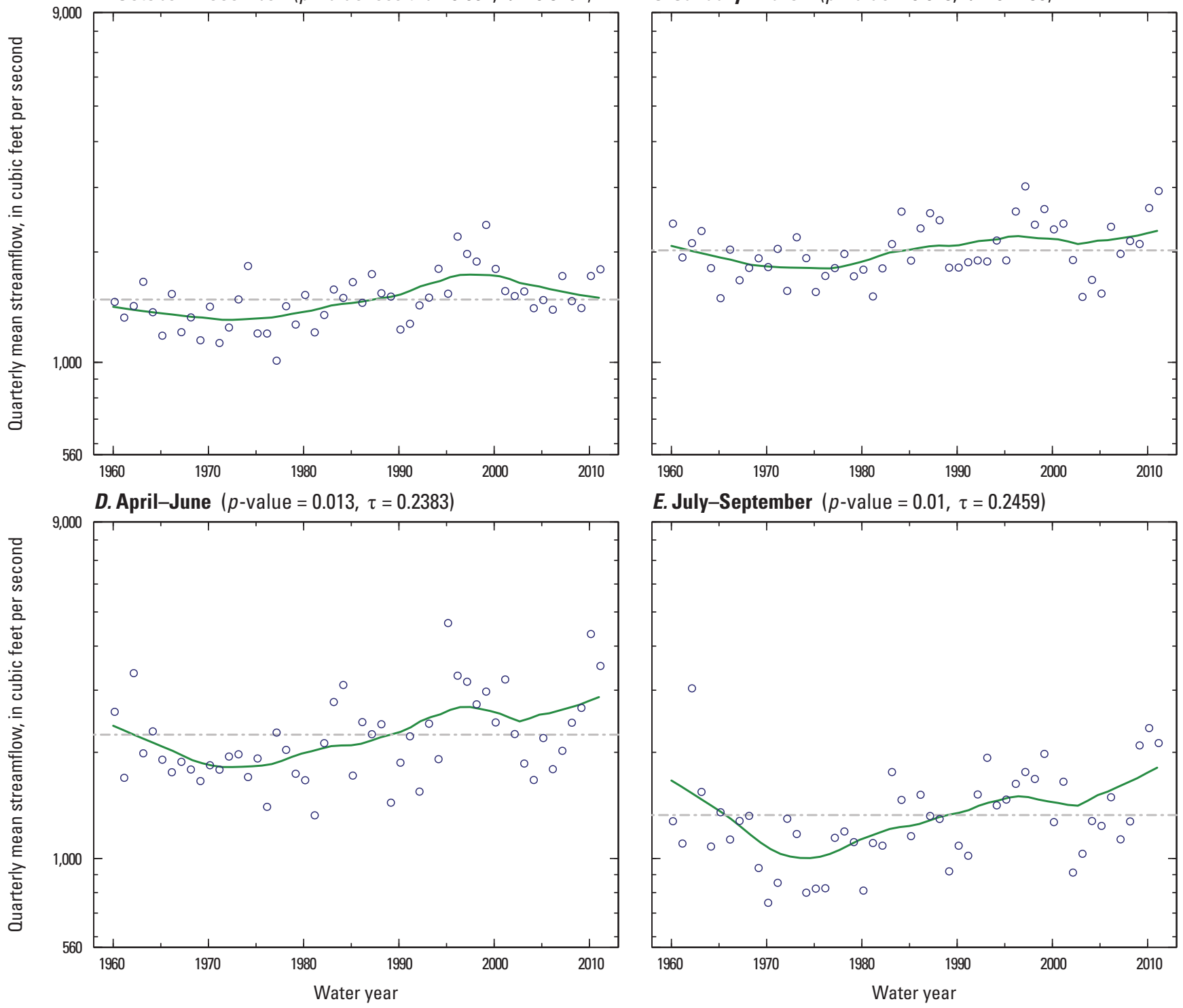

E. July-September $(p$-value $=0.01, \tau=0.2459)$

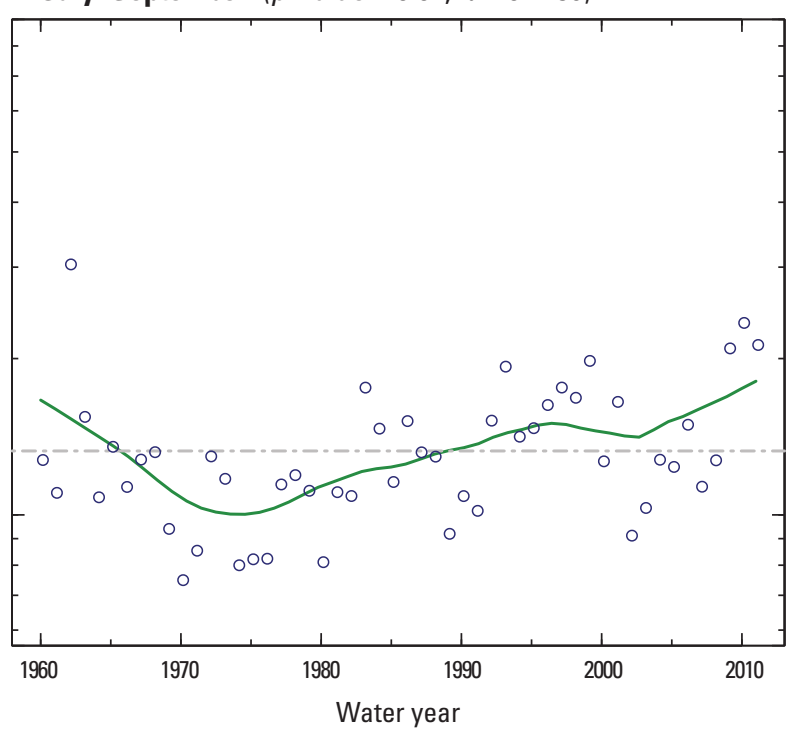

Figure 1-41. Niobrara River near Verdel, Nebraska (streamgage 06465500), water years 1960-2011. 
A. Annual mean streamflow [probability value $(p$-value $)=0.002$, Kendall's tau $(\tau)=0.2986$ ]
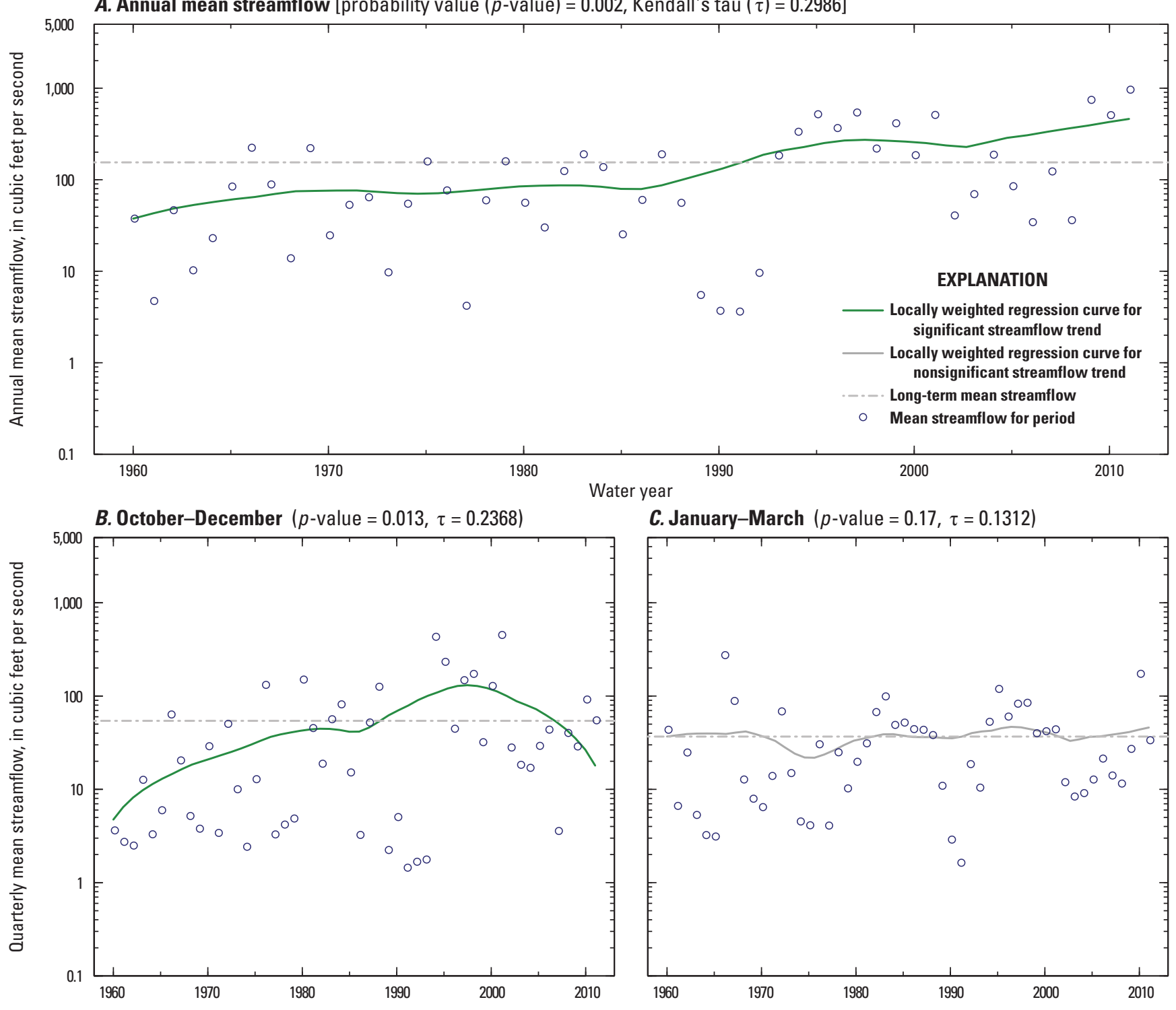

C. January-March ( $p$-value $=0.17, \tau=0.1312)$
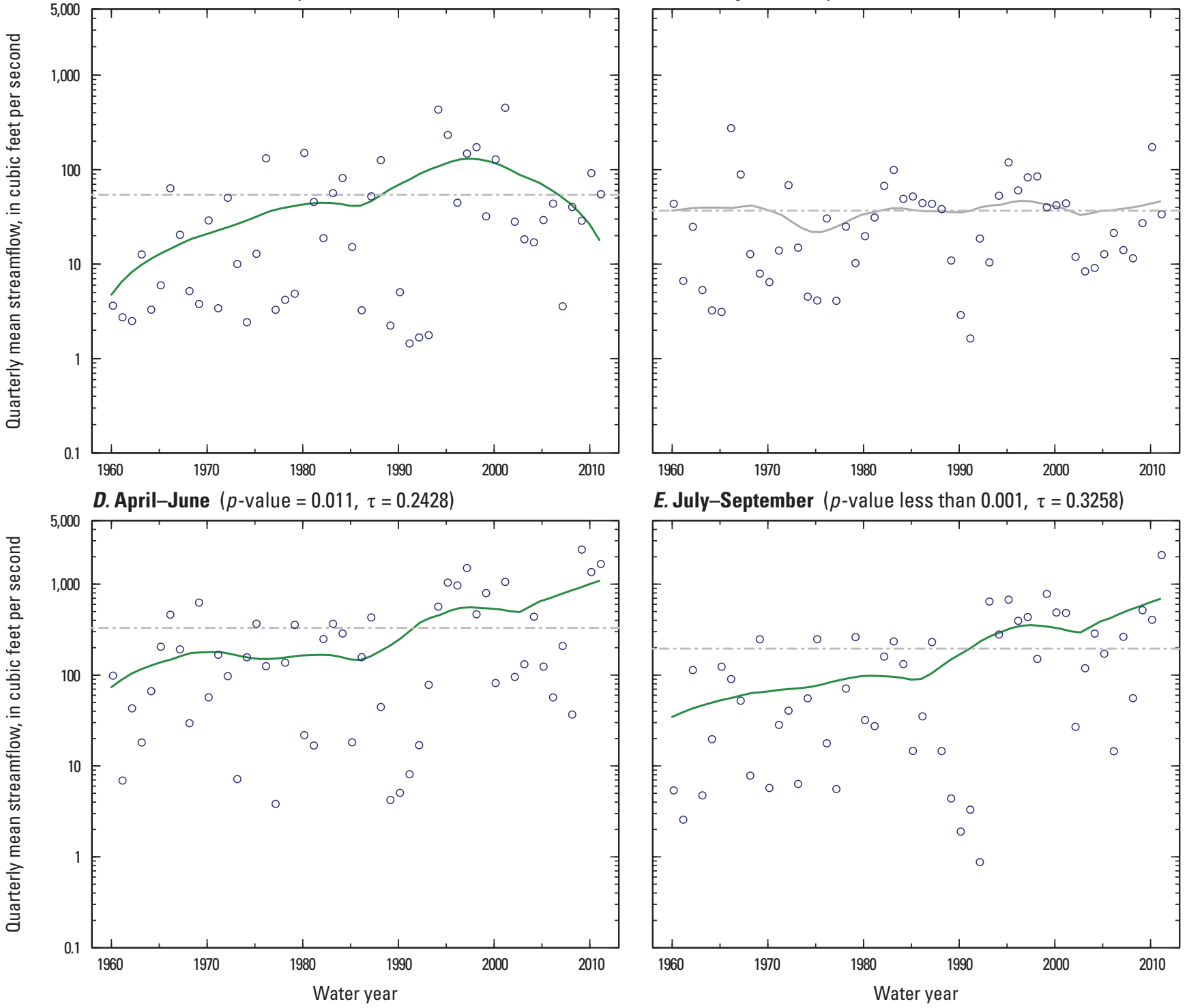

E. July-September ( $p$-value less than 0.001, $\tau=0.3258$ )

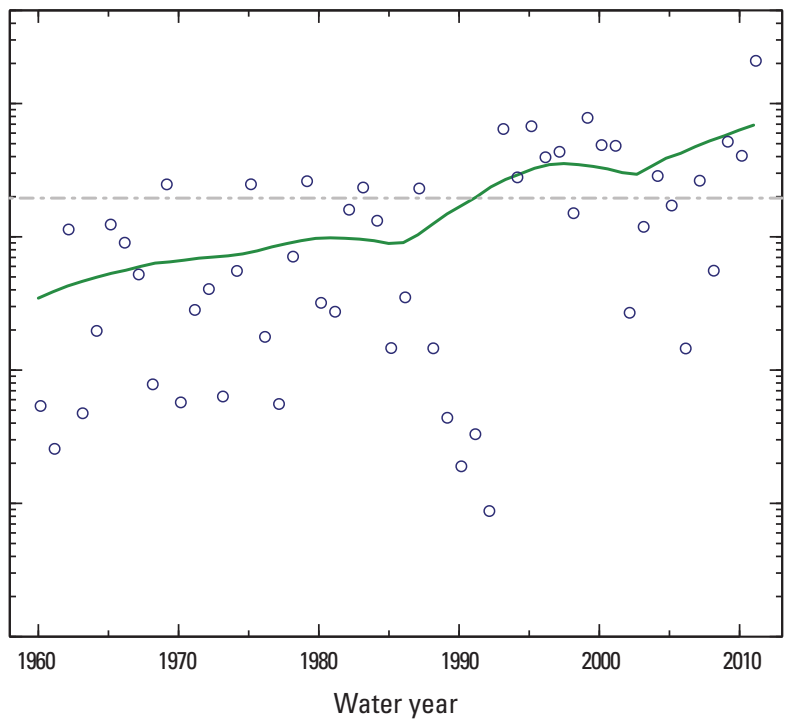

Figure 1-42. James River at Jamestown, North Dakota (streamgage 06470000), water years 1960-2011. 

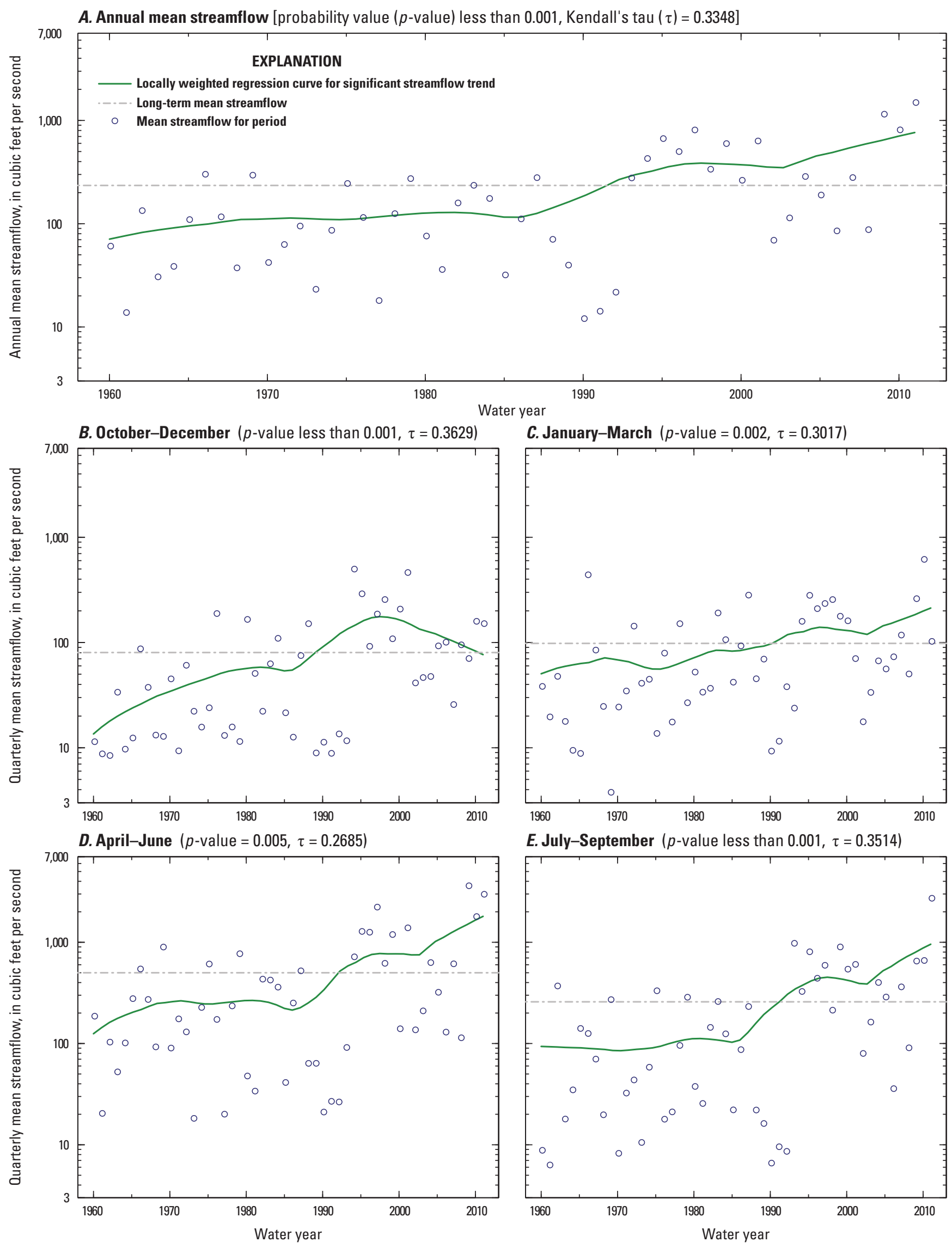

C. January-March $(p$-value $=0.002, \tau=0.3017)$

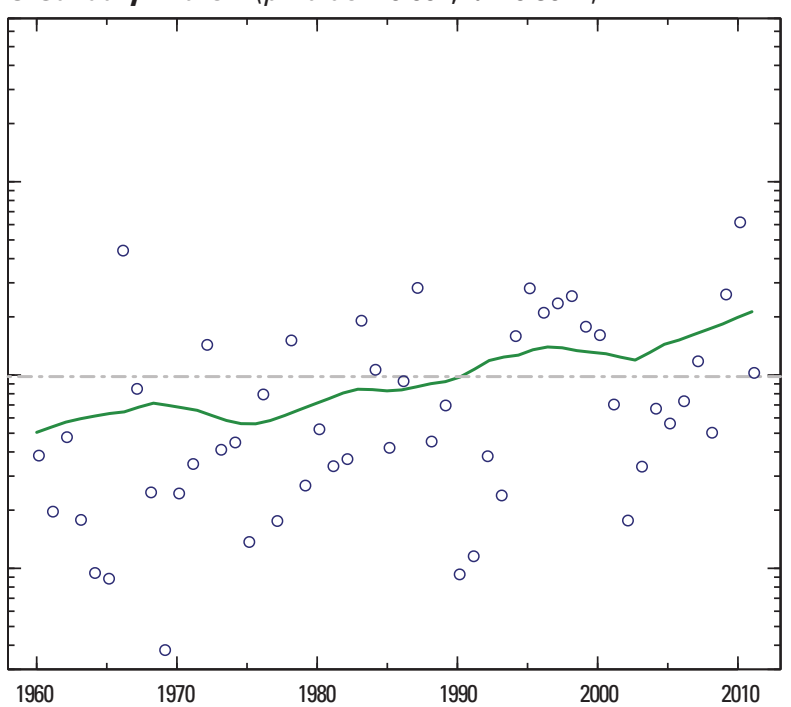

E. July-September ( $p$-value less than 0.001, $\tau=0.3514)$

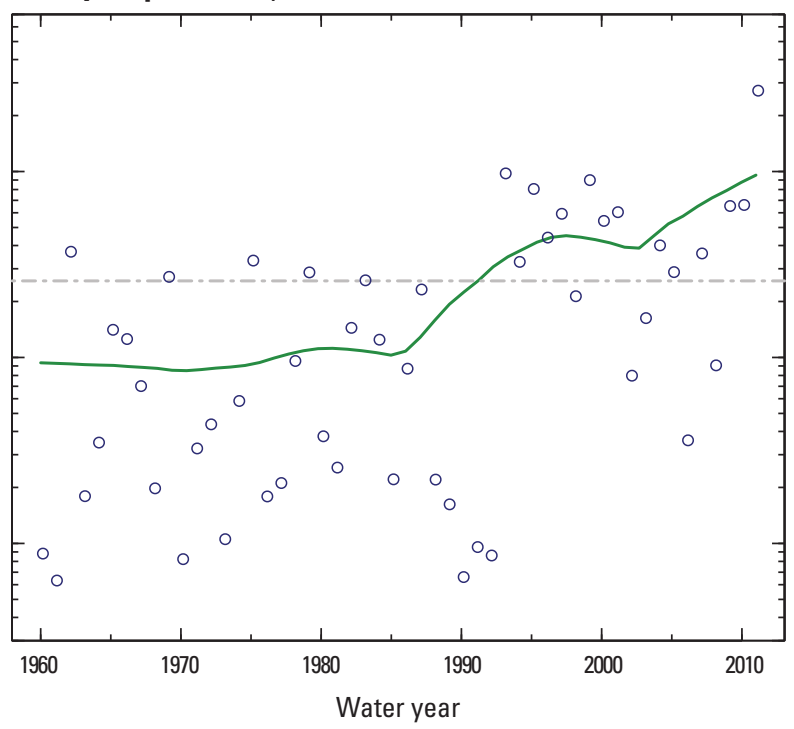

Figure 1-43. James River at Lamoure, North Dakota (streamgage 06470500), water years 1960-2011. 
A. Annual mean streamflow [probability value ( $p$-value) less than 0.001 , Kendall's tau $(\tau)=0.3680$ ]
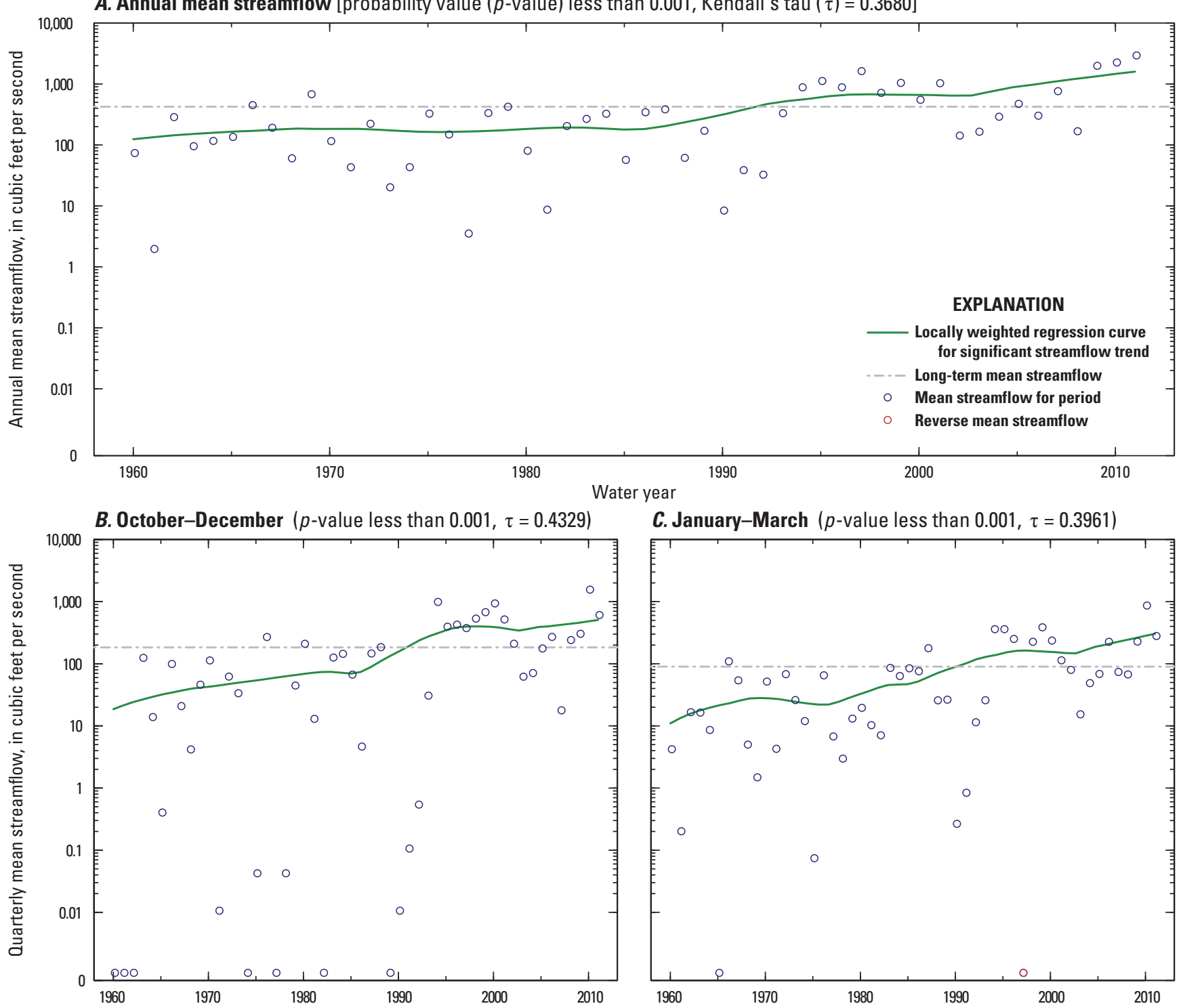

C. January-March ( $p$-value less than 0.001, $\tau=0.3961)$
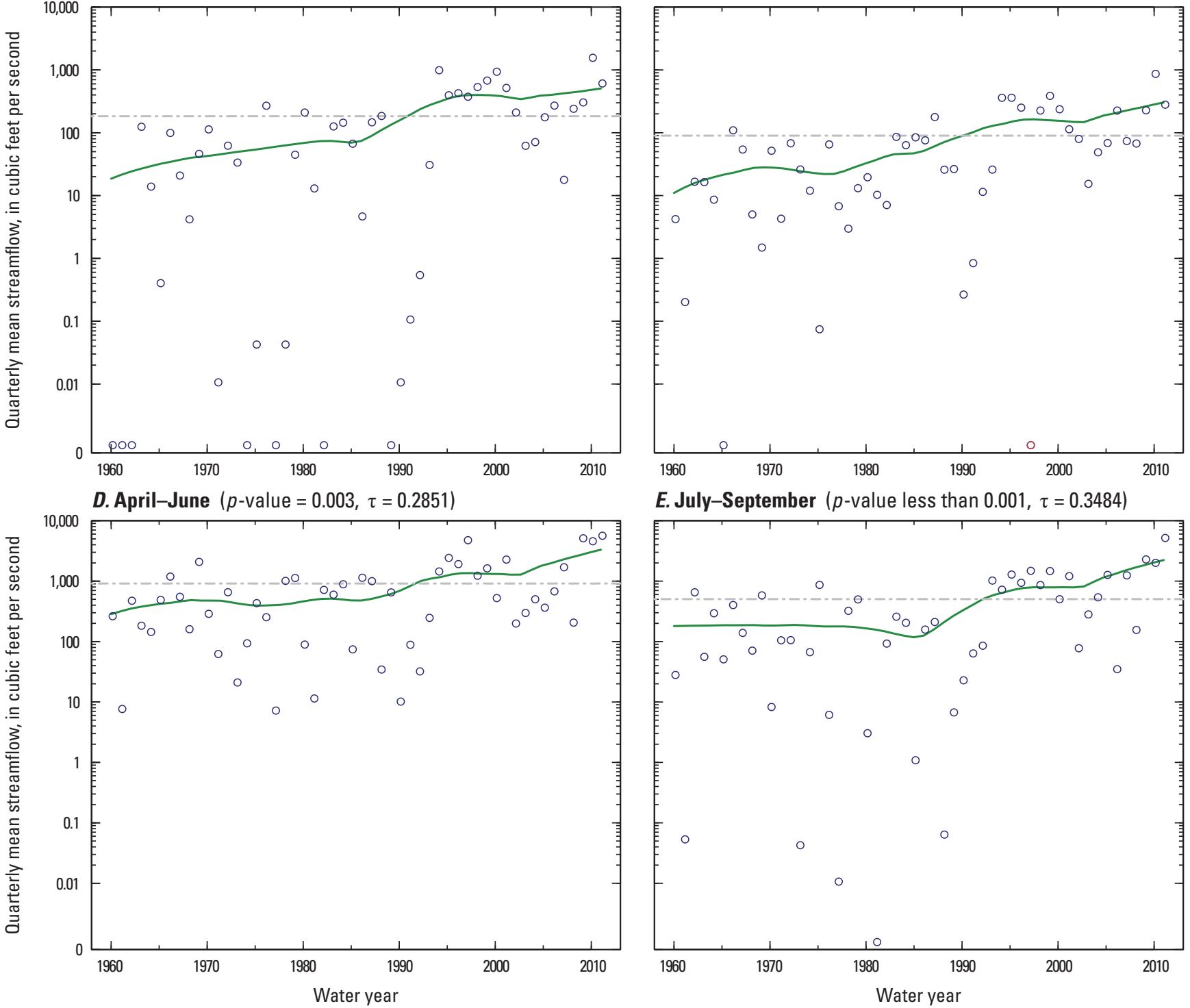

E. July-September ( $p$-value less than 0.001, $\tau=0.3484$ )

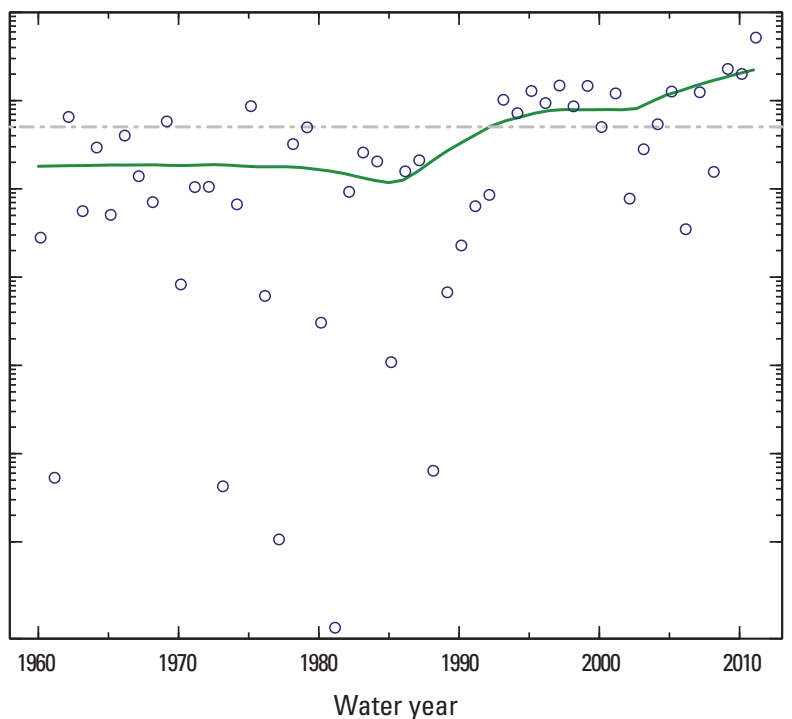

Figure 1-44. James River at Ashton, South Dakota (streamgage 06473000), water years 1960-2011. 
A. Annual mean streamflow [probability value ( $p$-value) less than 0.001 , Kendall's tau $(\tau)=0.3484$ ]

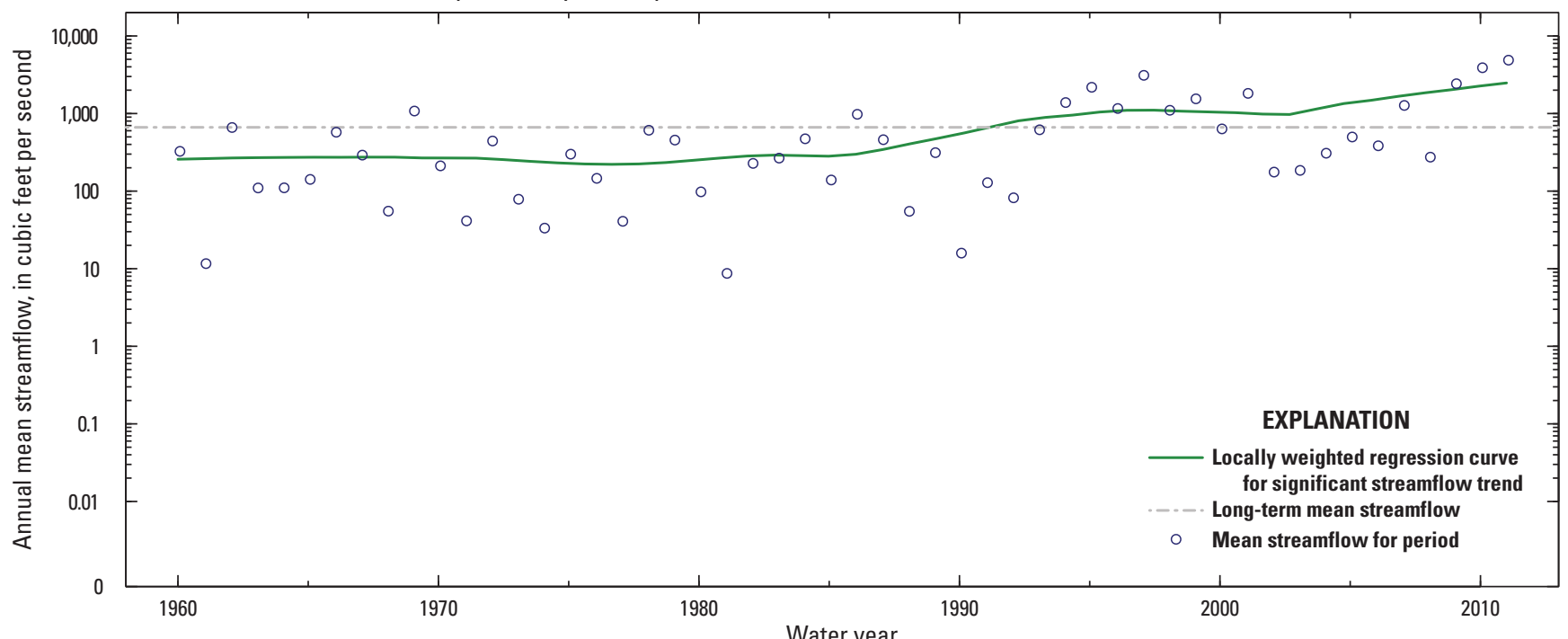

B. October-December ( $p$-value less than $0.001, \tau=0.4217$ )

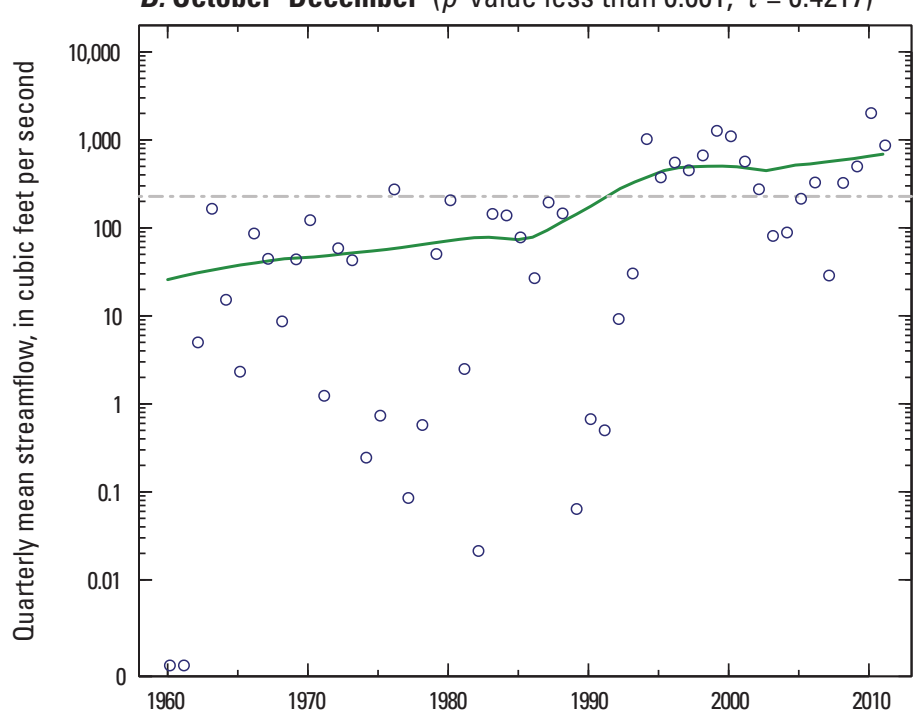

C. January-March $(p$-value $=0.004, \tau=0.2775)$

D. April-June $(p$-value $=0.009, \tau=0.2504)$
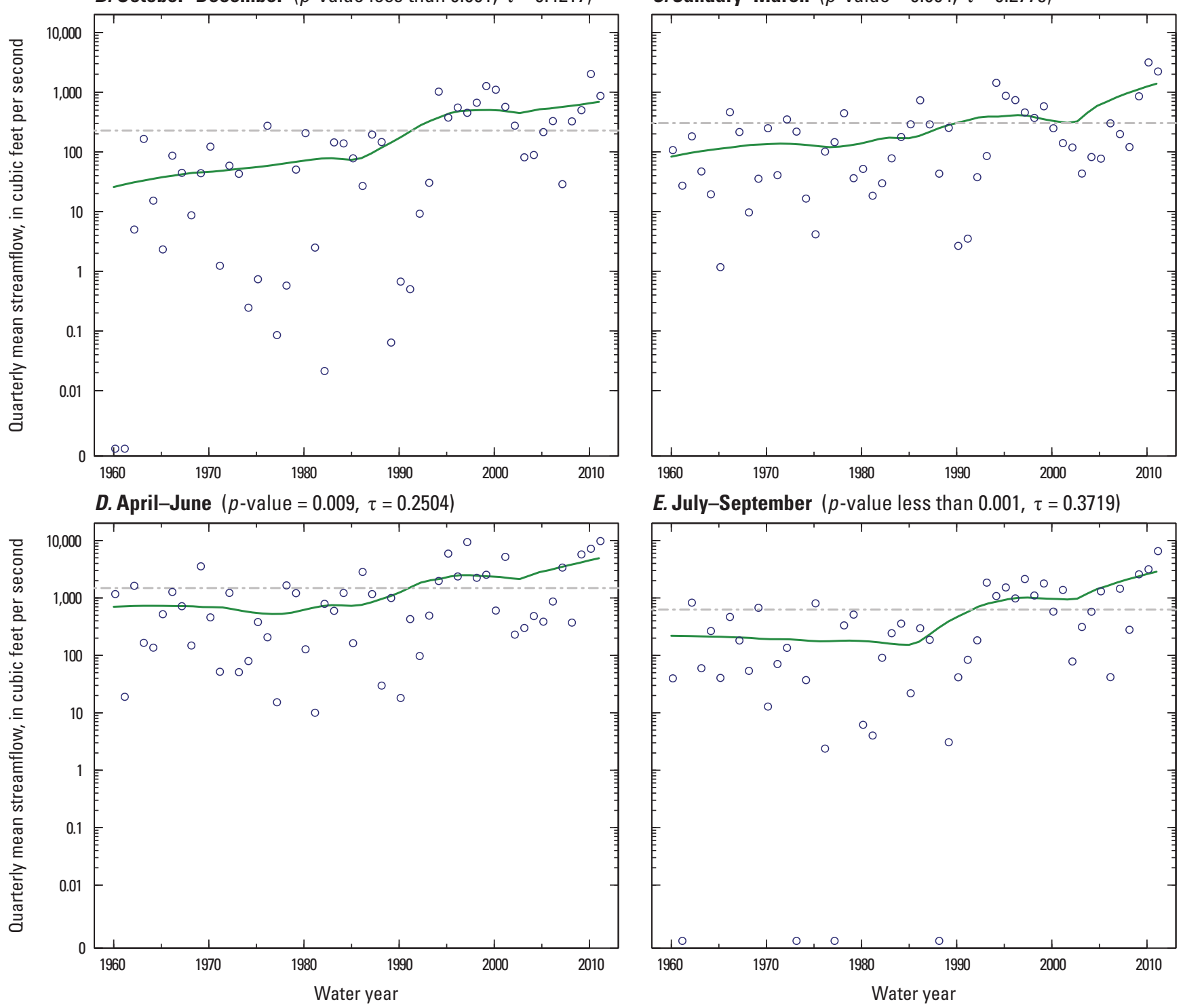

E. July-September ( $p$-value less than 0.001, $\tau=0.3719$ )

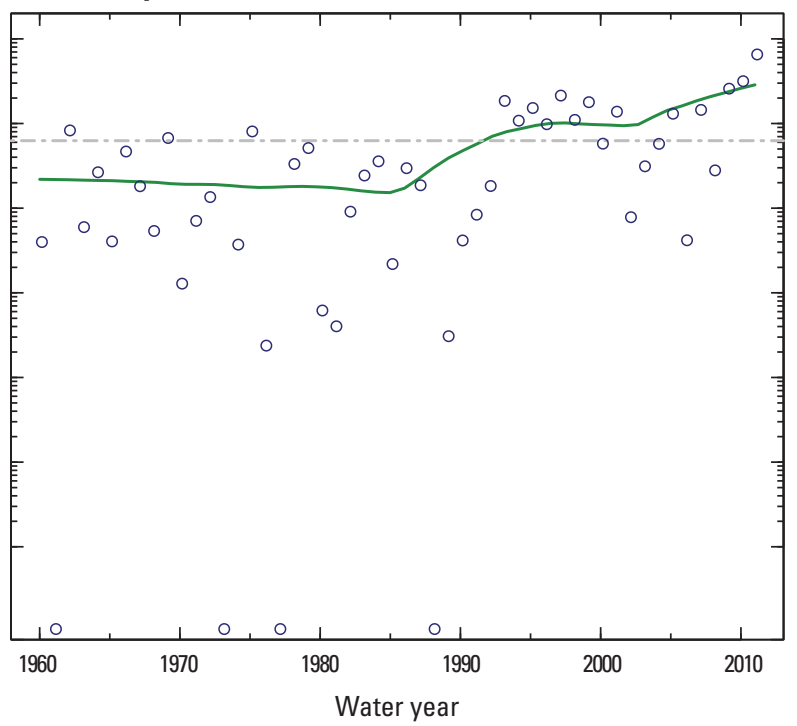

Figure 1-45. James River at Huron, South Dakota (streamgage 06476000), water years 1960-2011. 
A. Annual mean streamflow [probability value ( $p$-value) less than 0.001 , Kendall's tau $(\tau)=0.3342$ ]
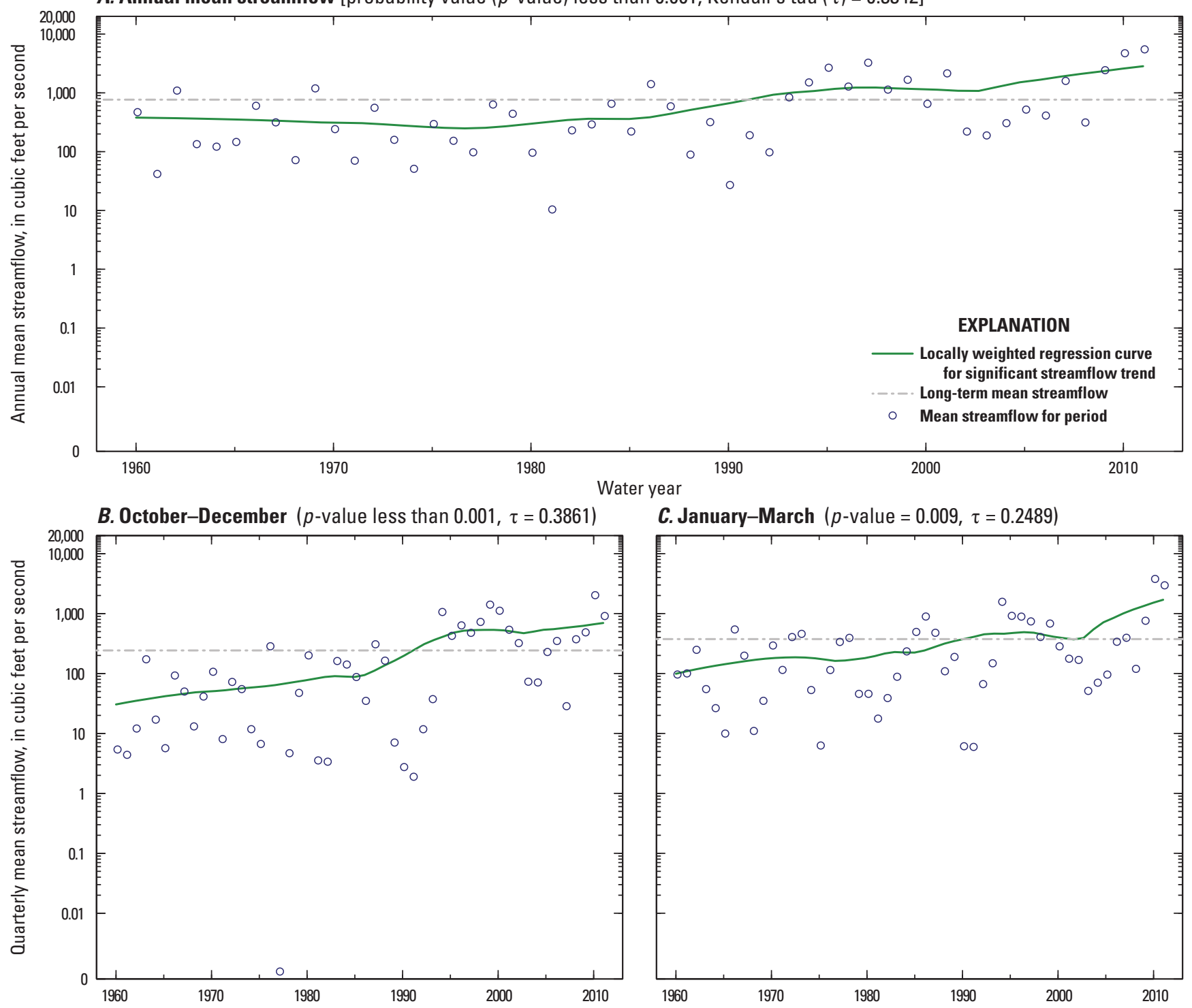

C. January-March $(p$-value $=0.009, \tau=0.2489)$

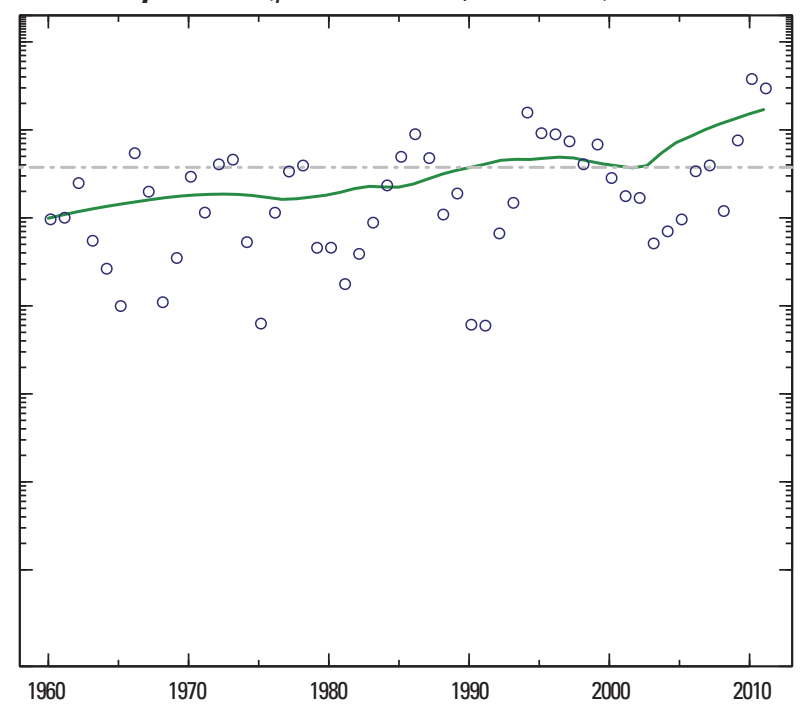

D. April-June $(p$-value $=0.009, \tau=0.2489)$

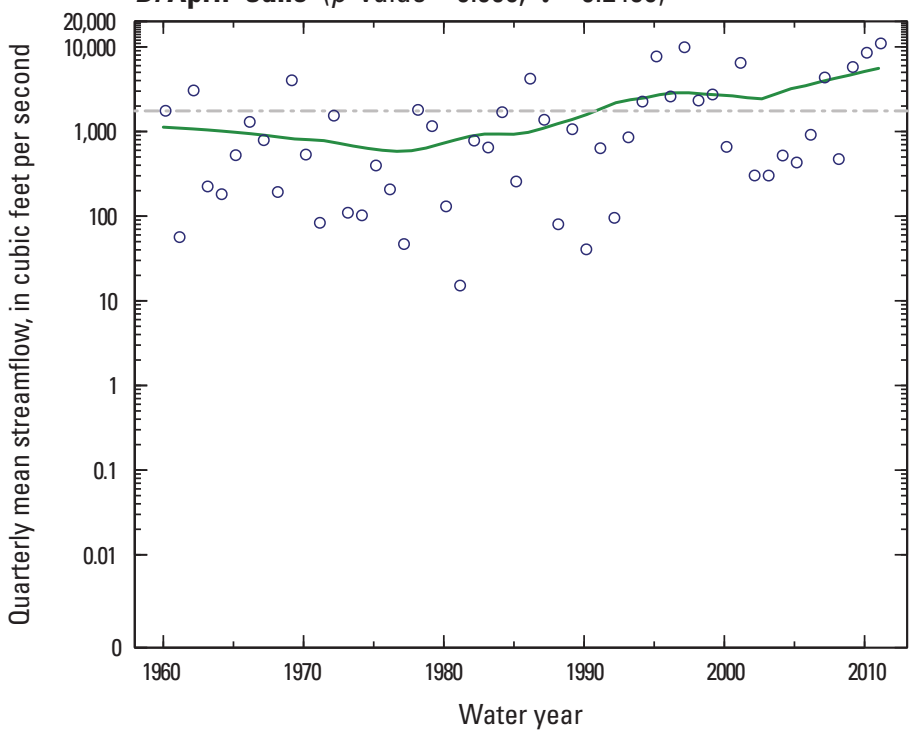

E. July-September ( $p$-value less than 0.001, $\tau=0.3680$ )

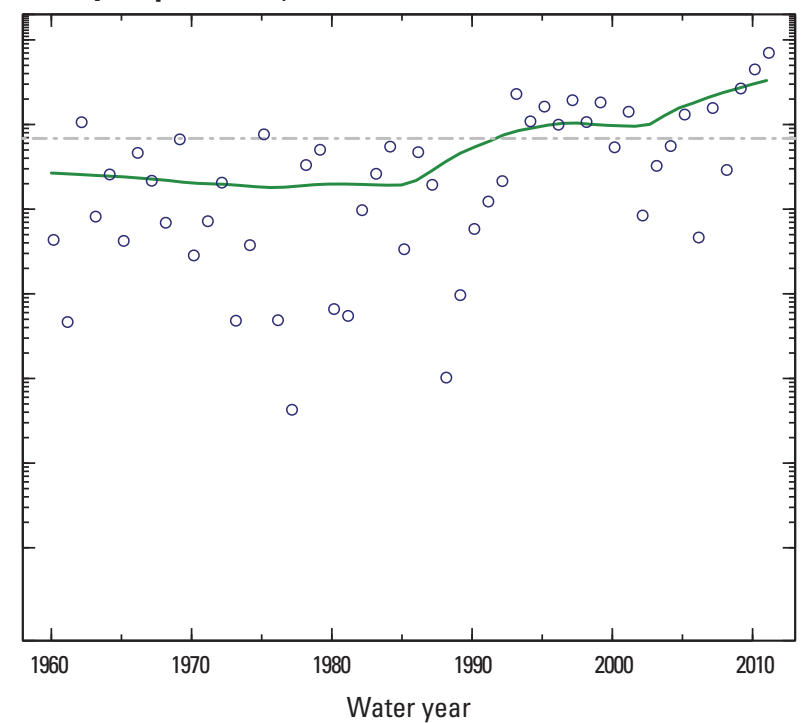

Figure 1-46. James River near Forestburg, South Dakota (streamgage 06477000), water years 1960-2011. 

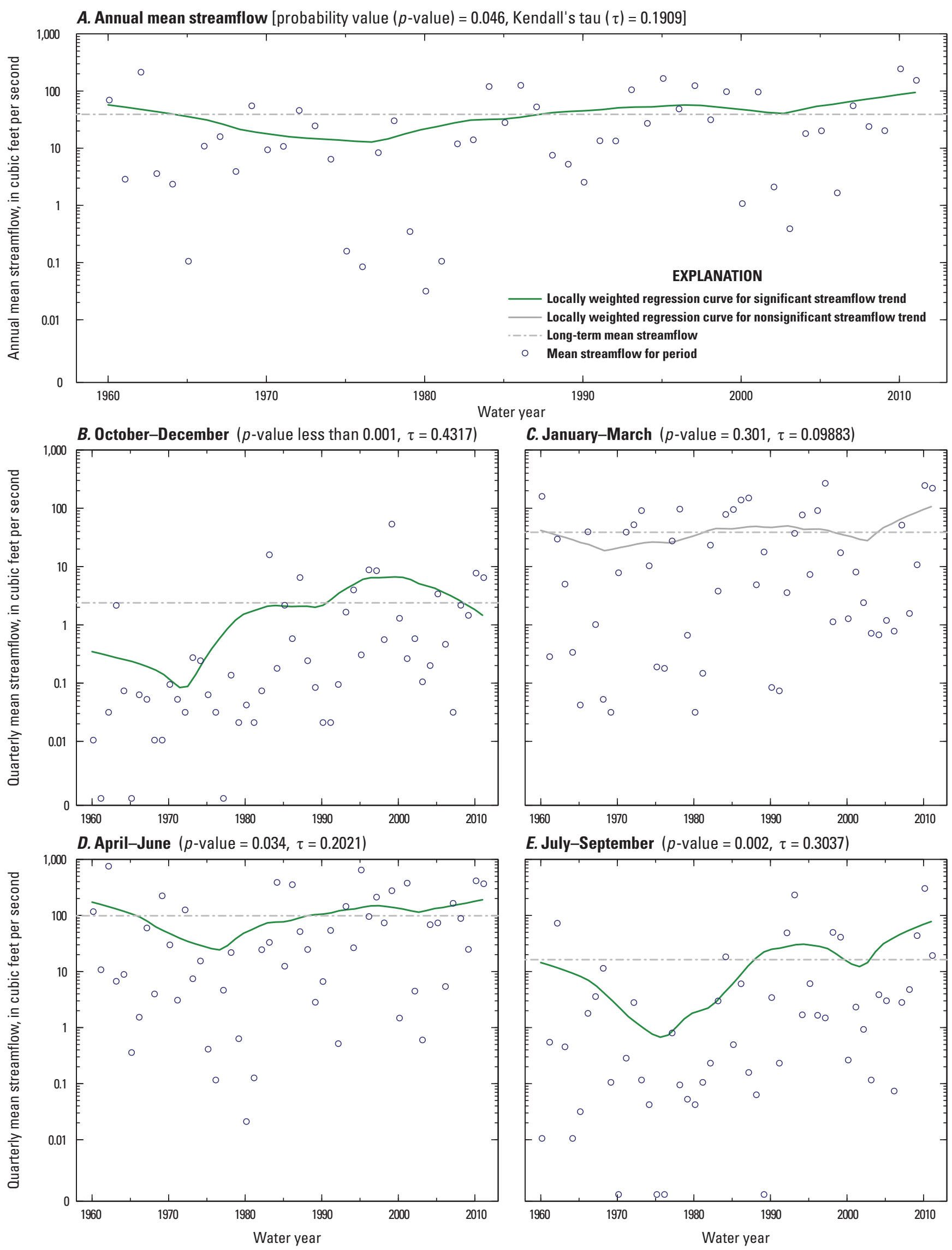

C. January-March $(p$-value $=0.301, \tau=0.09883)$

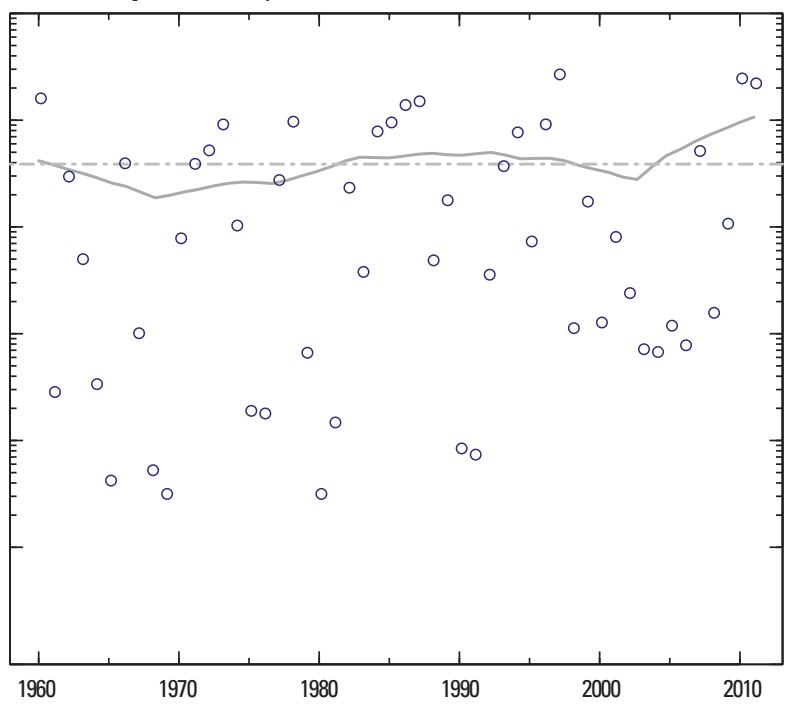

E. July-September $(p$-value $=0.002, \tau=0.3037)$

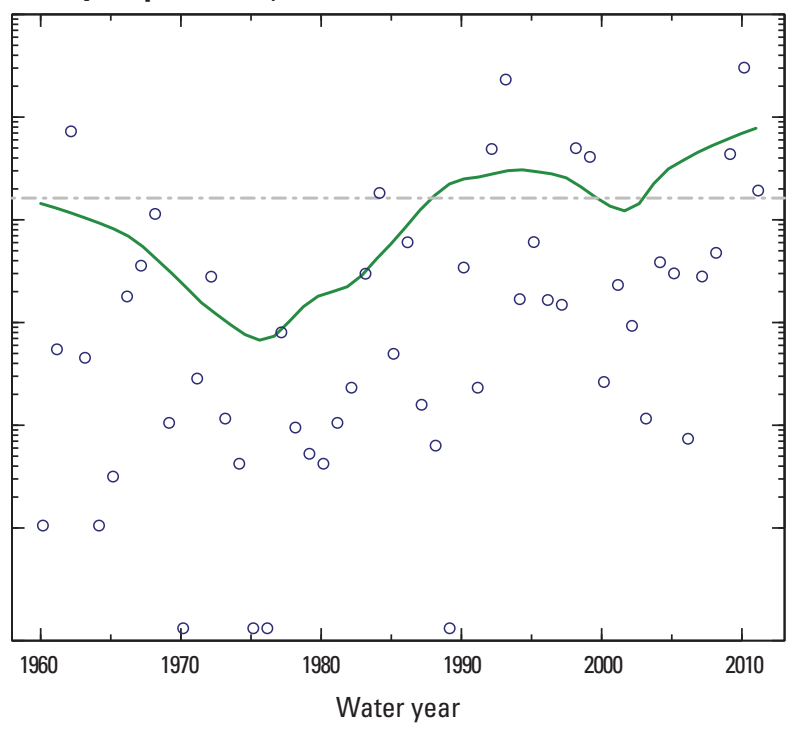

Figure 1-47. Firesteel Creek near Mount Vernon, South Dakota (streamgage 06477500), water years 1960-2011. 
A. Annual mean streamflow [probability value ( $p$-value $)=0.001$, Kendall's tau $(\tau)=0.3092$ ]

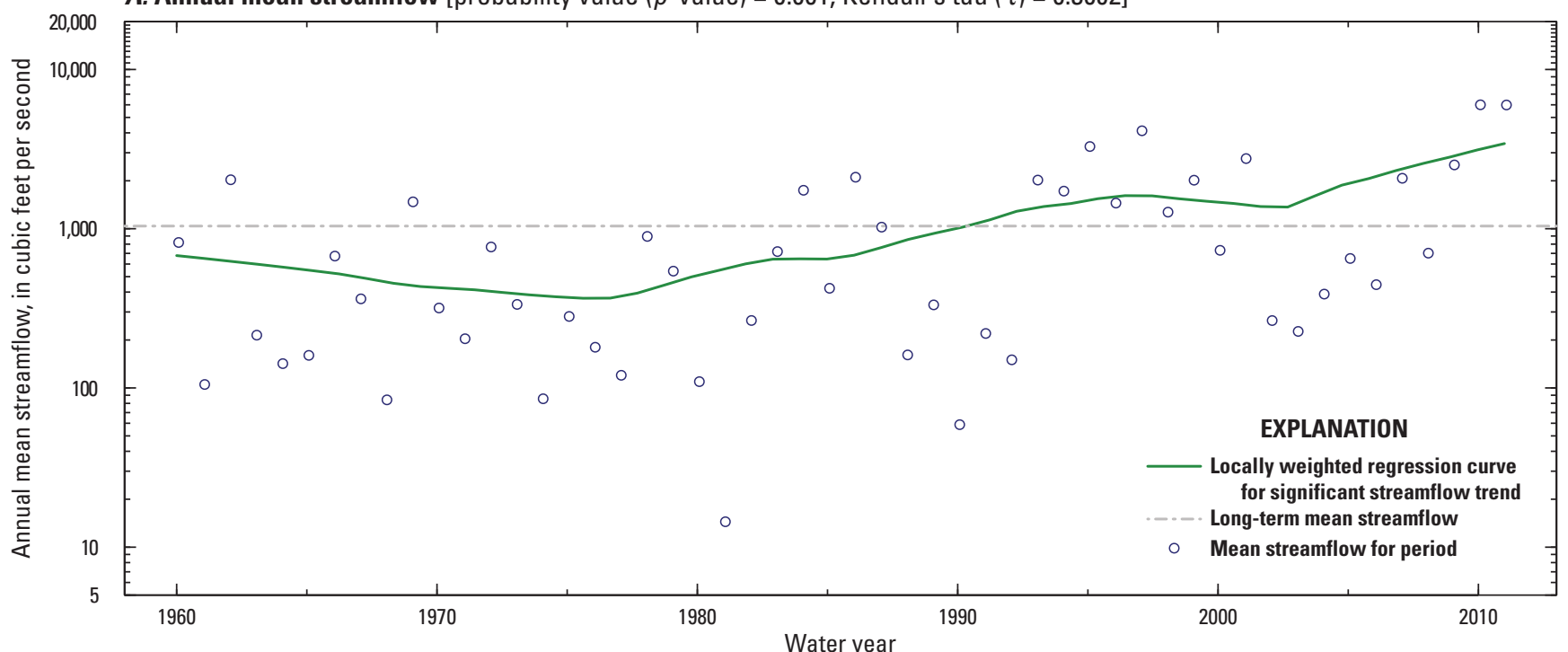

B. October-December ( $p$-value less than $0.001, \tau=0.4329$ )

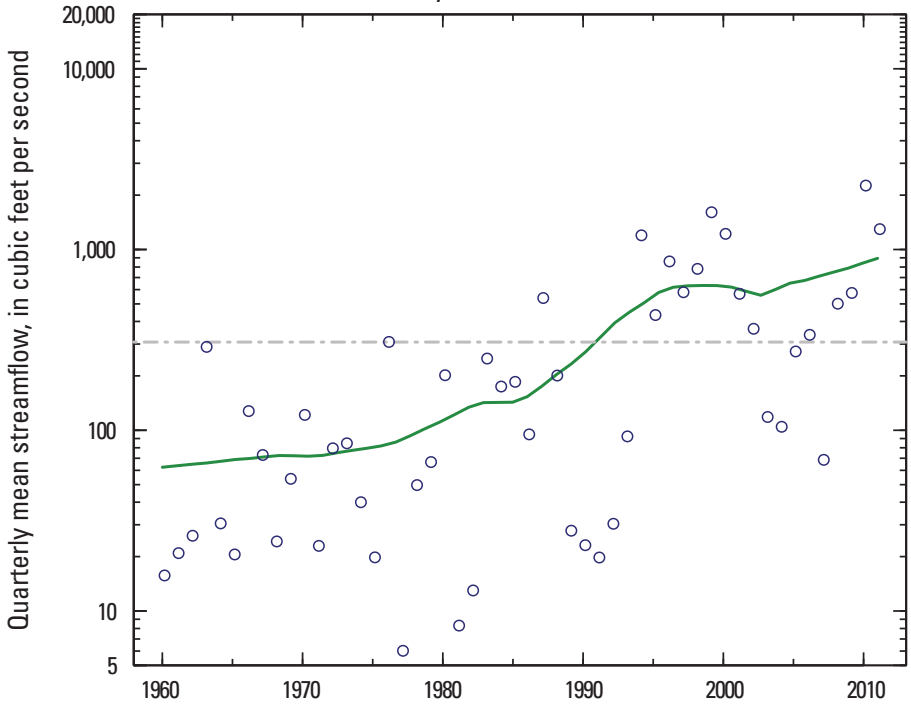

D. April-June $(p$-value $=0.006, \tau=0.2609)$

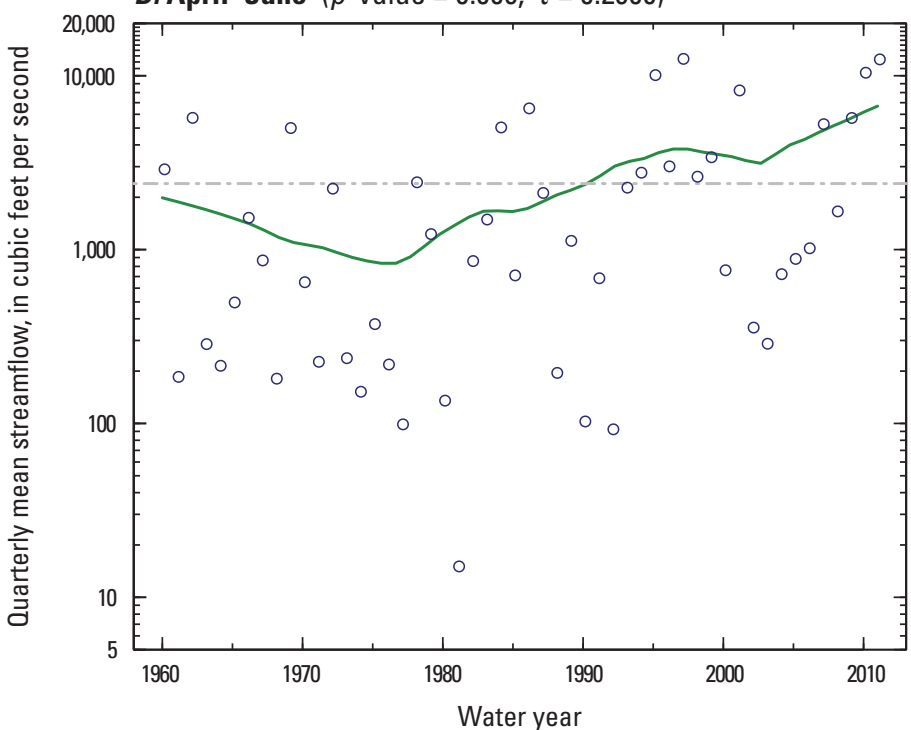

C. January-March ( $p$-value $=0.014, \tau=0.2353)$

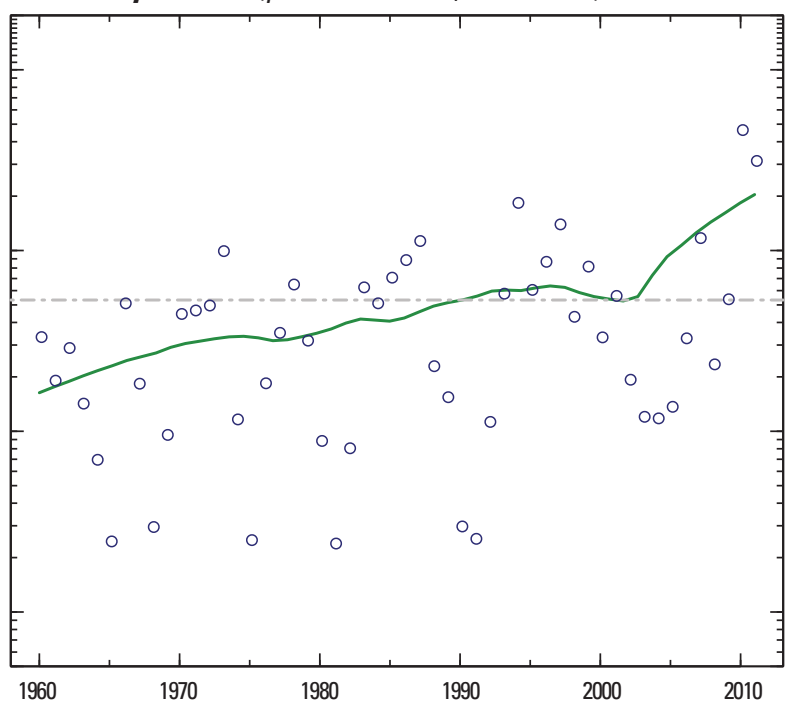

E. July-September ( $p$-value less than $0.001, \tau=0.3590)$

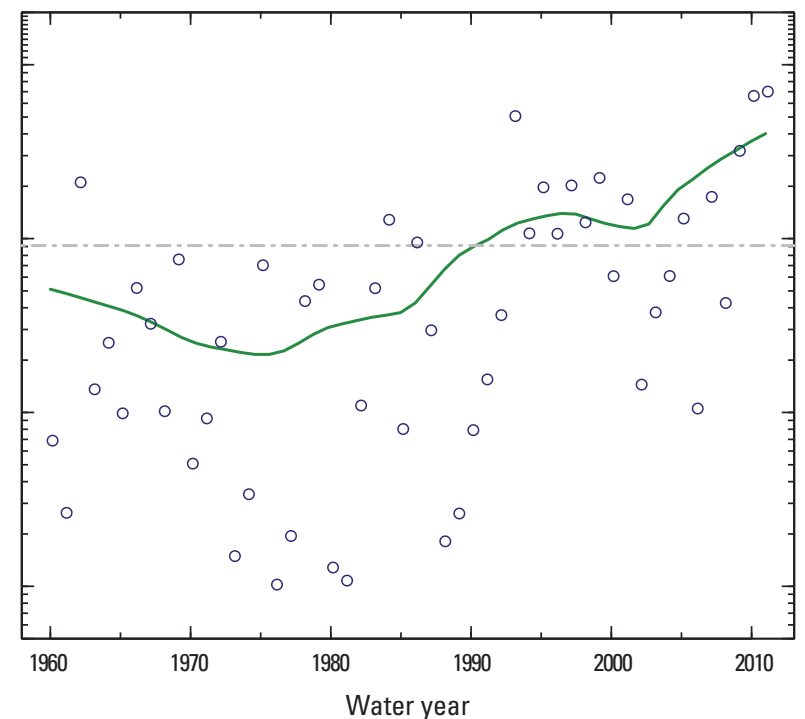

Figure 1-48. James River near Scotland, South Dakota (streamgage 06478500), water years 1960-2011. 

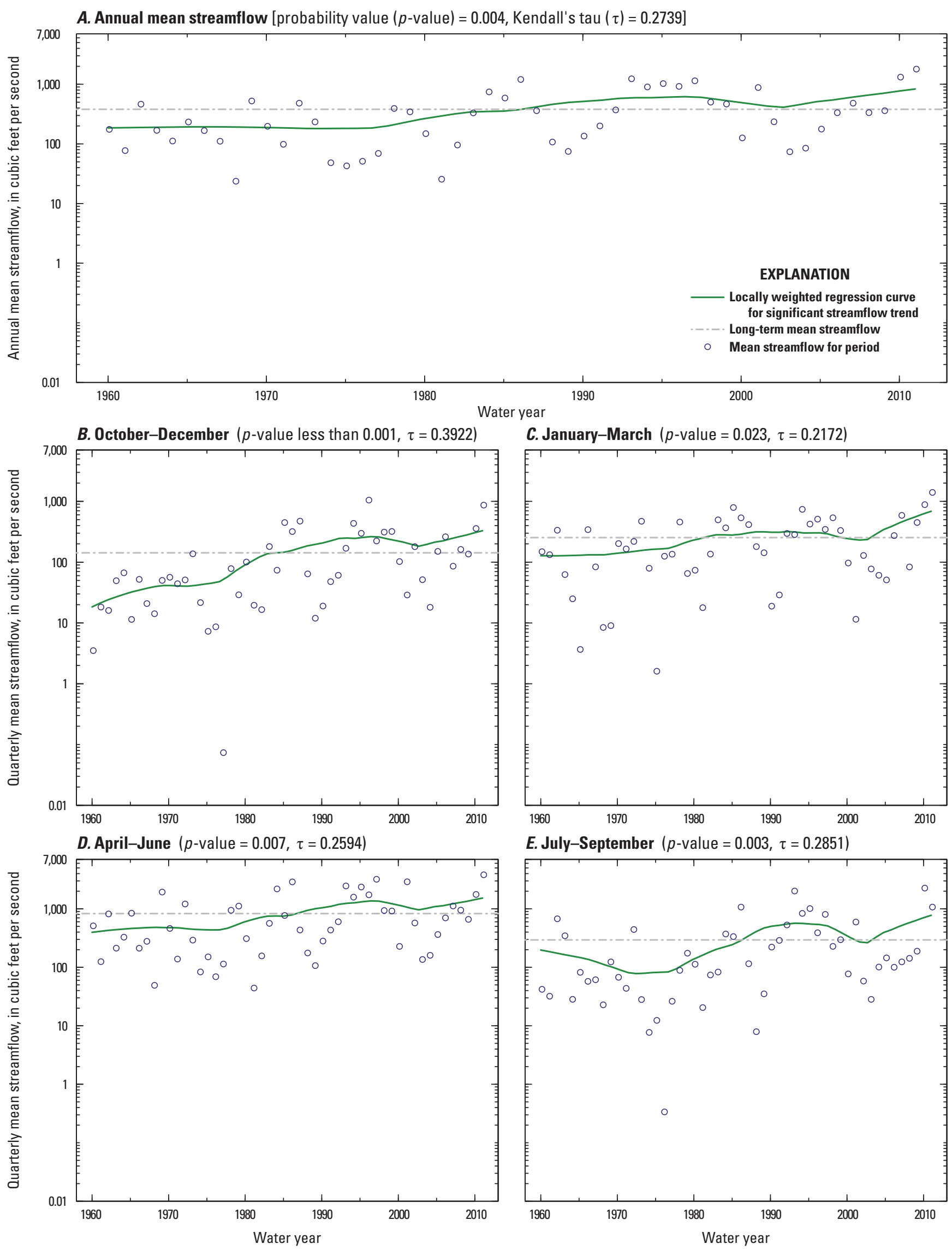

C. January-March $(p$-value $=0.023, \tau=0.2172)$

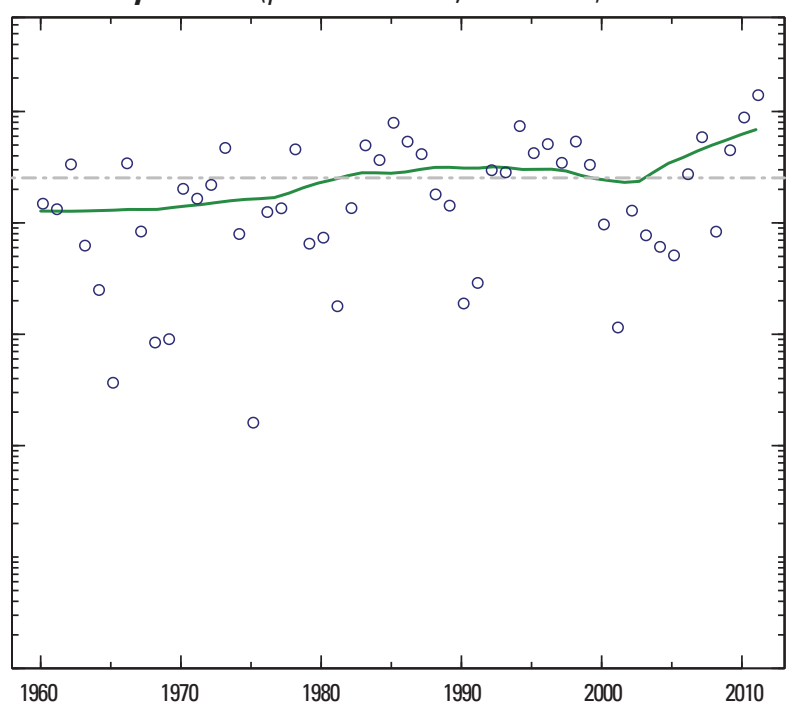

E. July-September $(p$-value $=0.003, \tau=0.2851)$

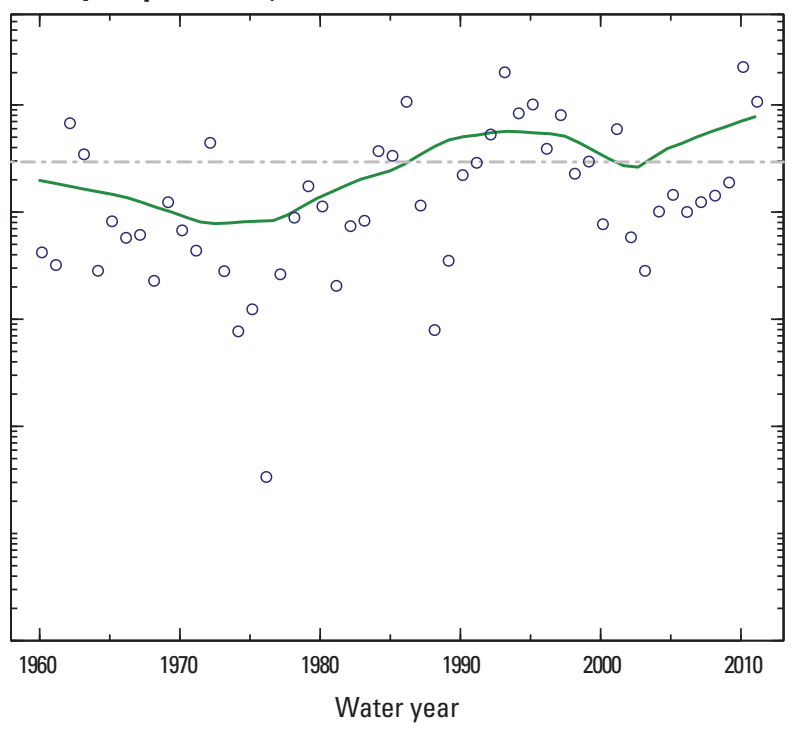

Figure 1-49. Big Sioux River near Brookings, South Dakota (streamgage 06480000), water years 1960-2011. 
A. Annual mean streamflow [probability value ( $p$-value $)=0.004$, Kendall's tau $(\tau)=0.2730$ ]

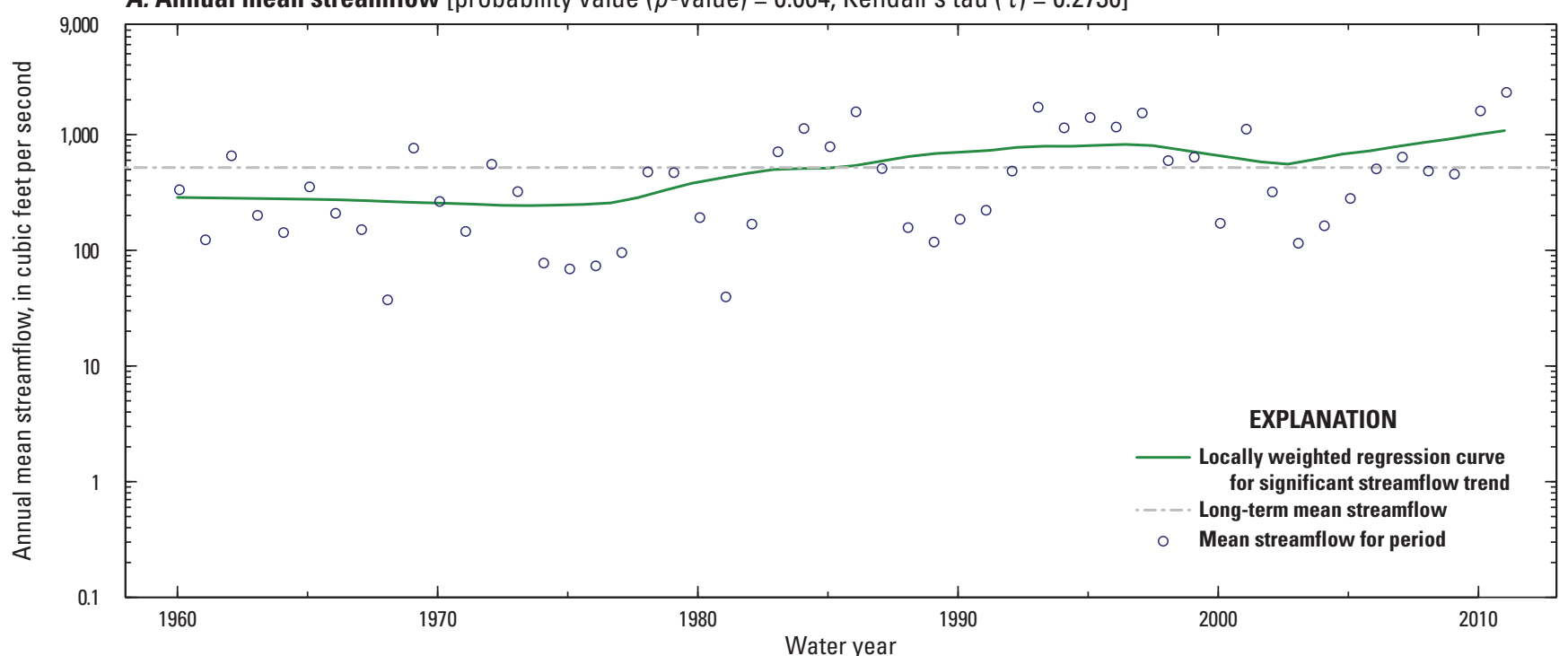

B. October-December ( $p$-value less than $0.001, \tau=0.3861$ )

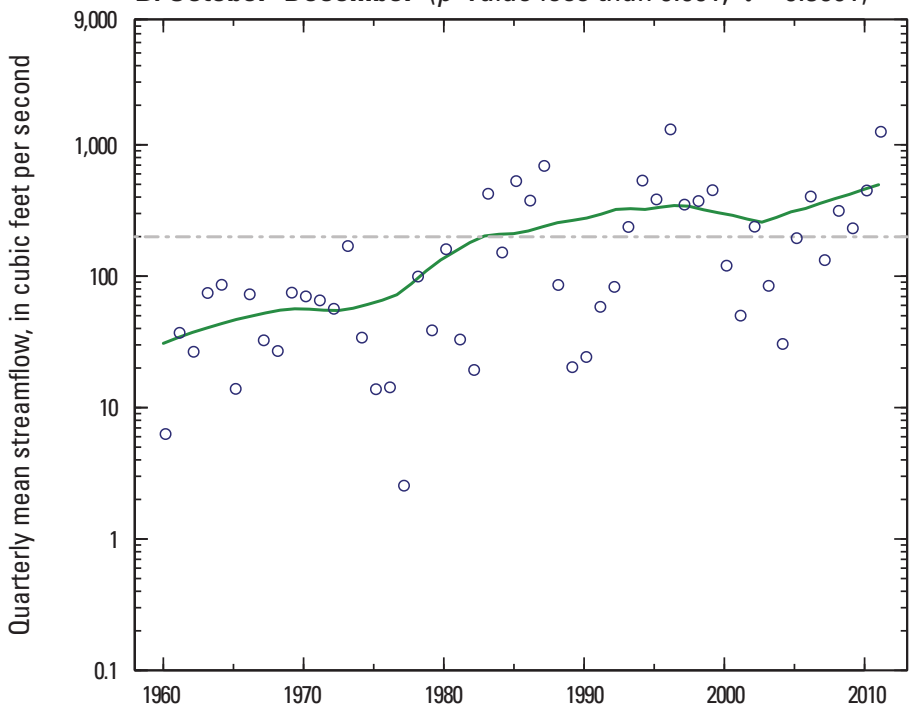

C. January-March ( $p$-value $=0.024, \tau=0.2157)$

D. April-June $(p$-value $=0.008, \tau=0.2519)$
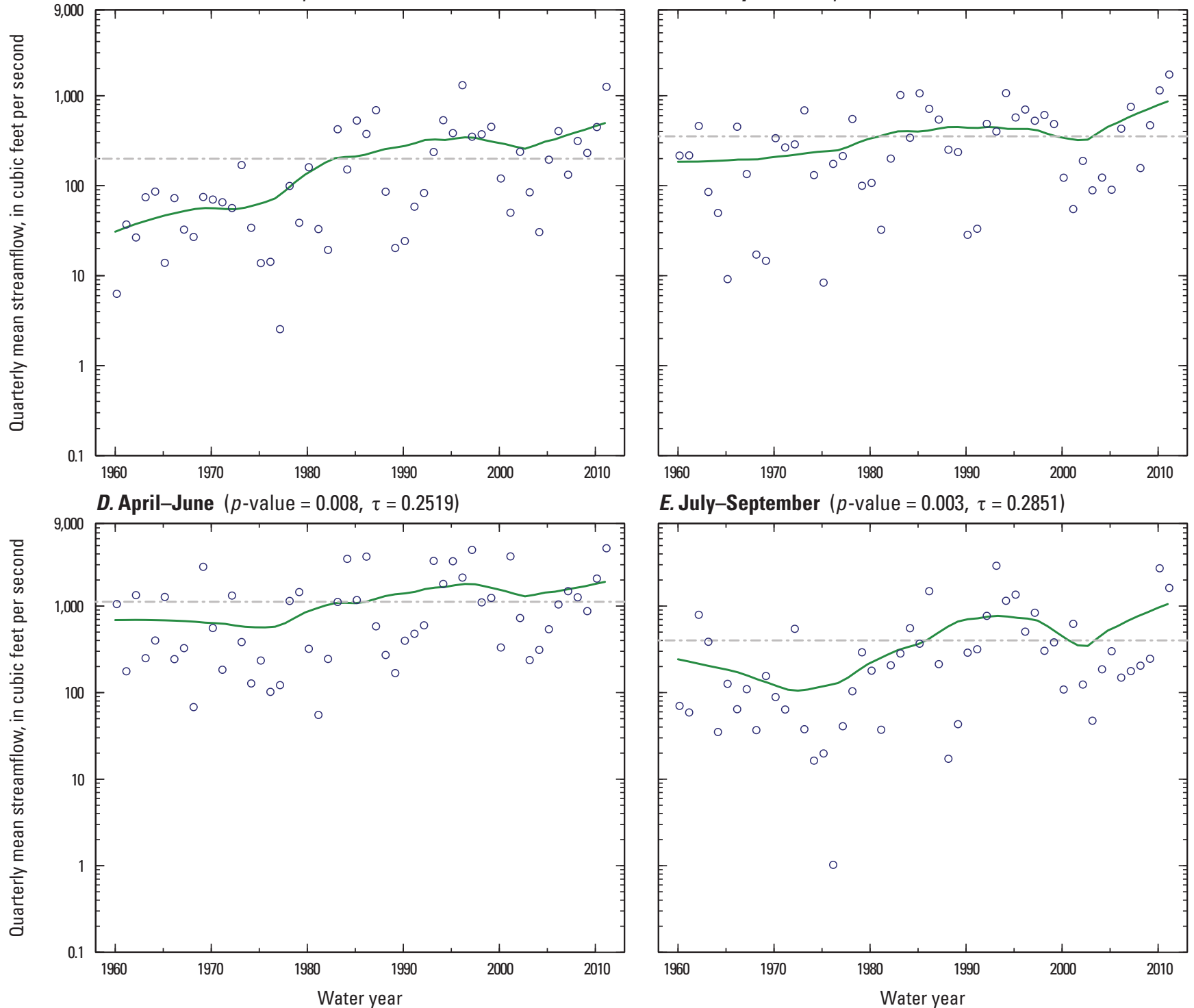

E. July-September $(p$-value $=0.003, \tau=0.2851)$

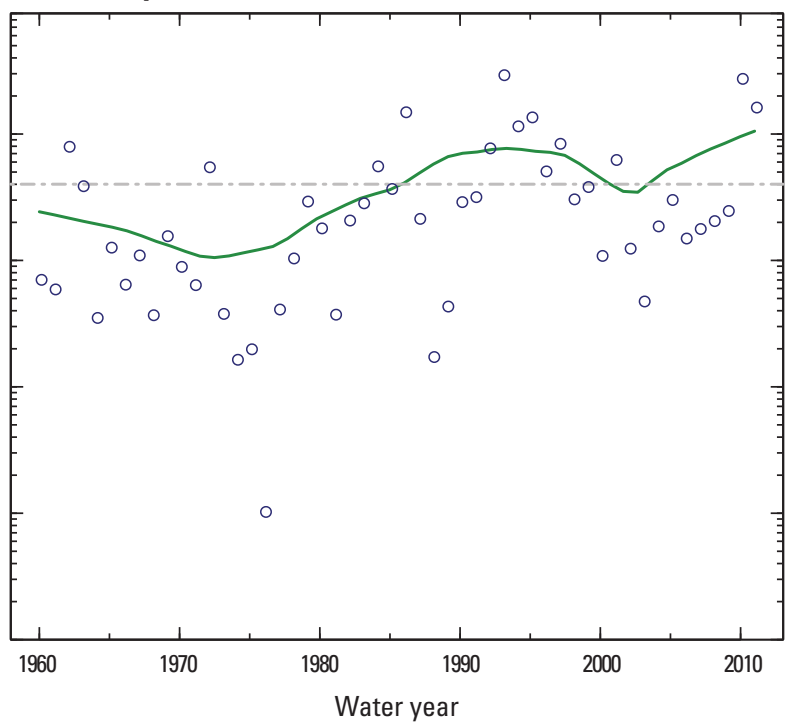

Figure 1-50. Big Sioux River near Dell Rapids, South Dakota (streamgage 06481000), water years 1960-2011. 

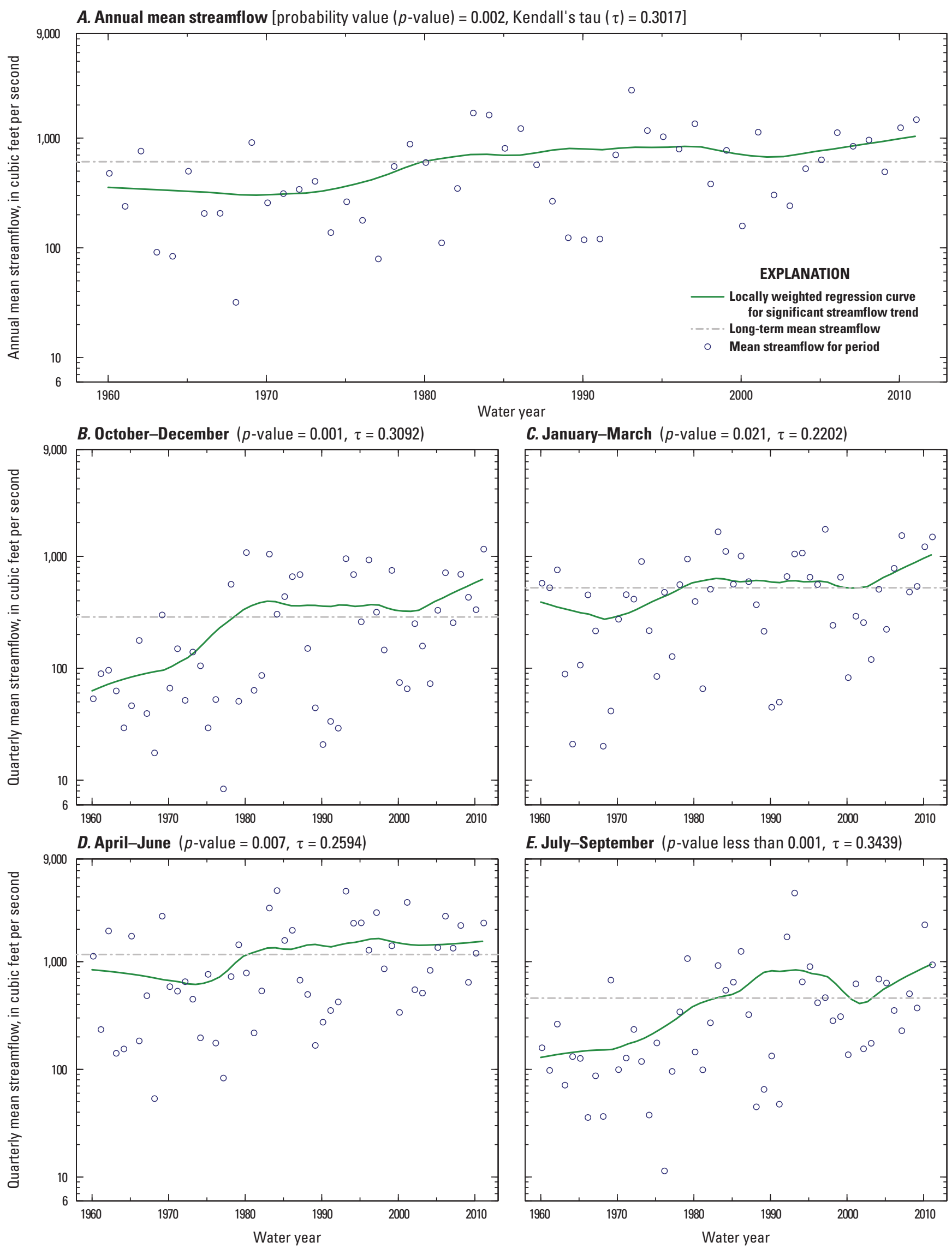

C. January-March ( $p$-value $=0.021, \tau=0.2202)$

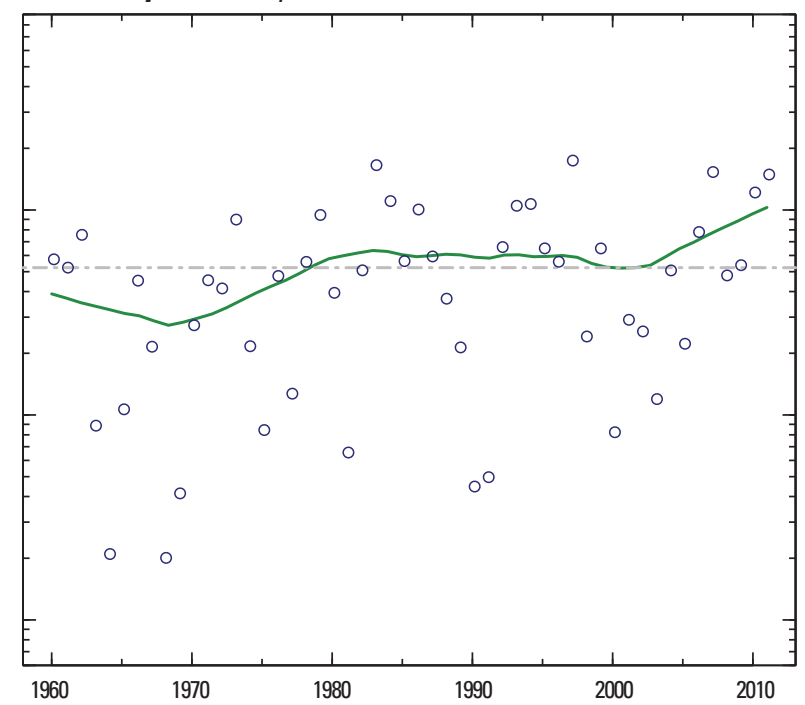

E. July-September ( $p$-value less than 0.001, $\tau=0.3439)$

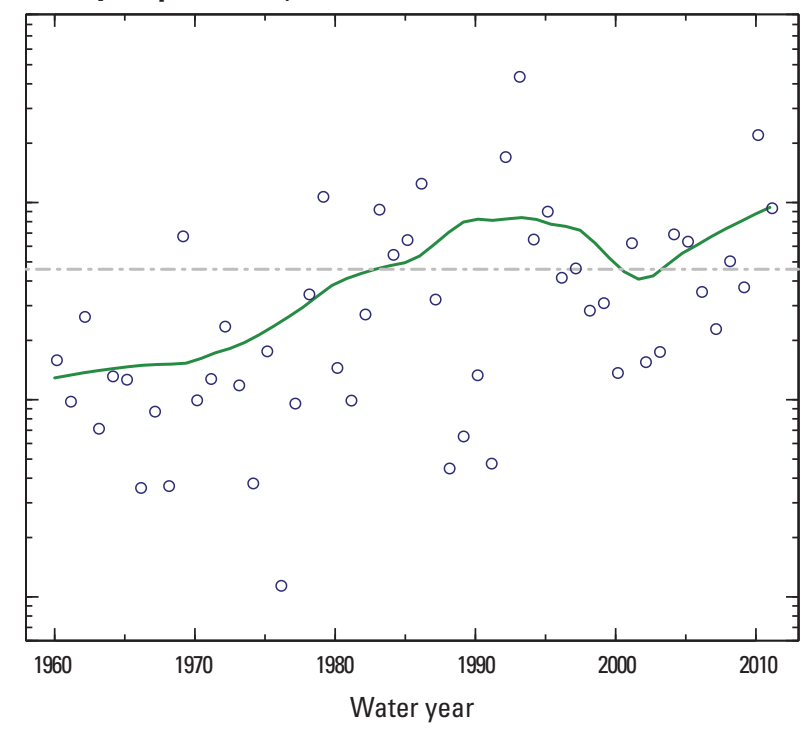

Figure 1-51. Rock River near Rock Valley, lowa (streamgage 06483500), water years 1960-2011. 
A. Annual mean streamflow [probability value ( $p$-value $)=0.001$, Kendall's tau $(\tau)=0.3122$ ]

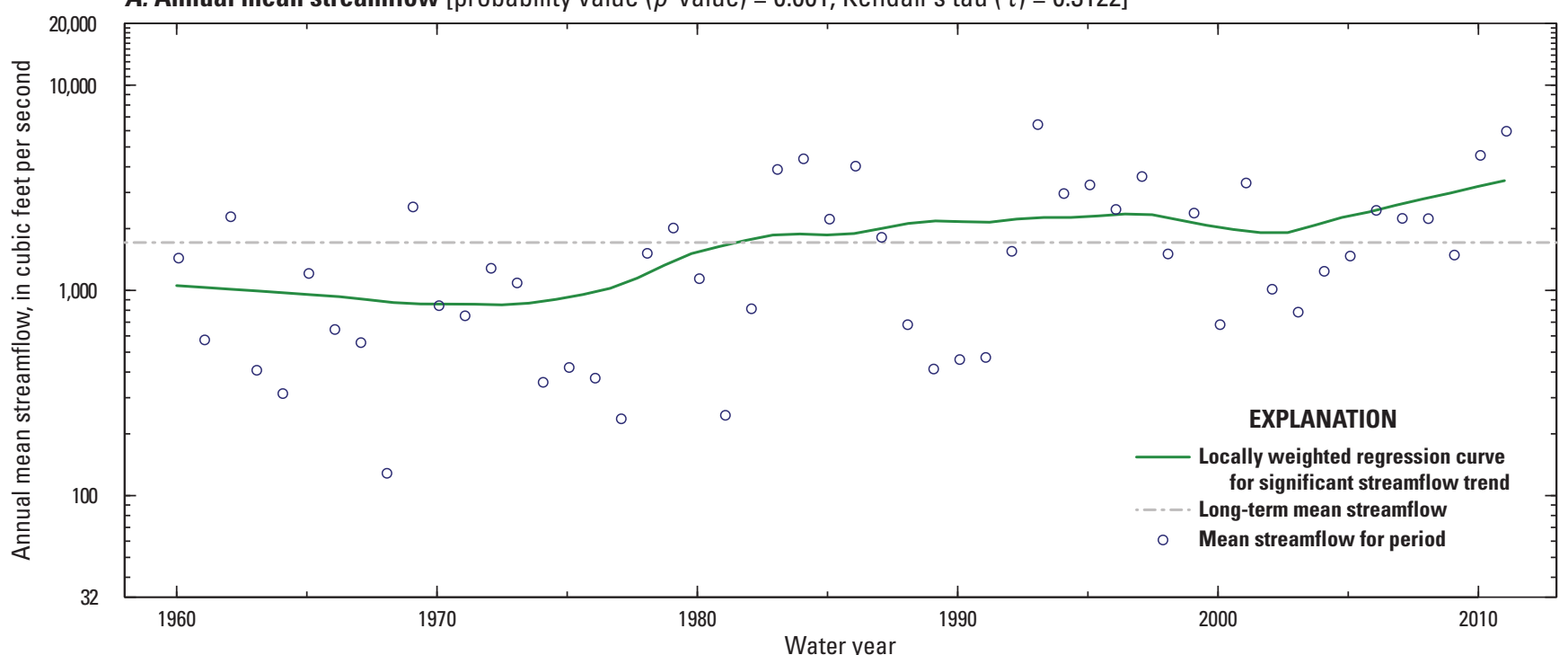

B. October-December ( $p$-value less than $0.001, \tau=0.3982$ )

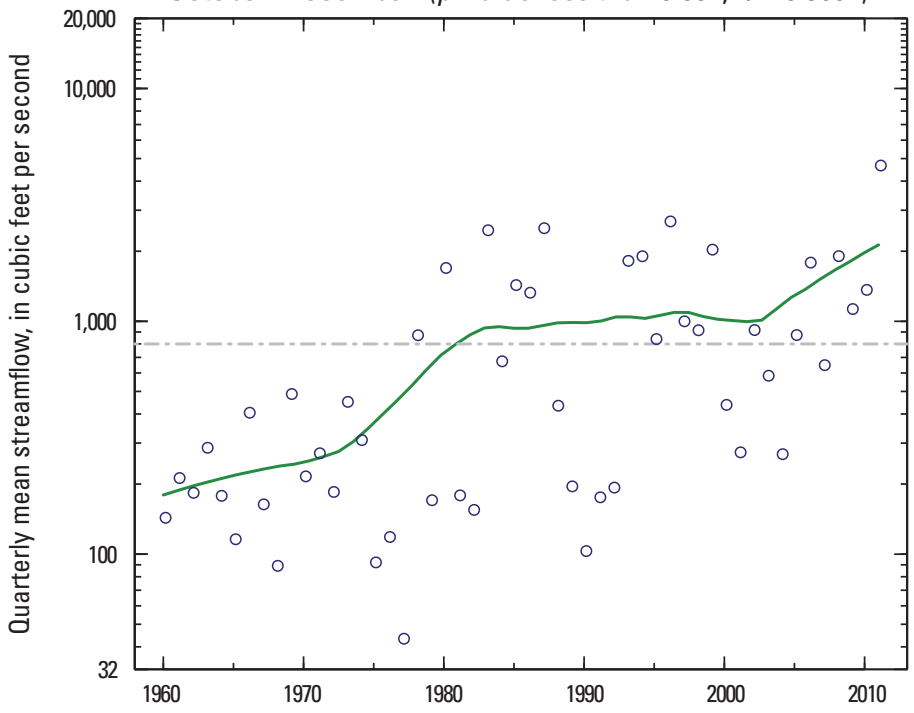

C. January-March ( $p$-value $=0.007, \tau=0.2564)$

D. April-June ( $p$-value $=0.003, \tau=0.2836)$
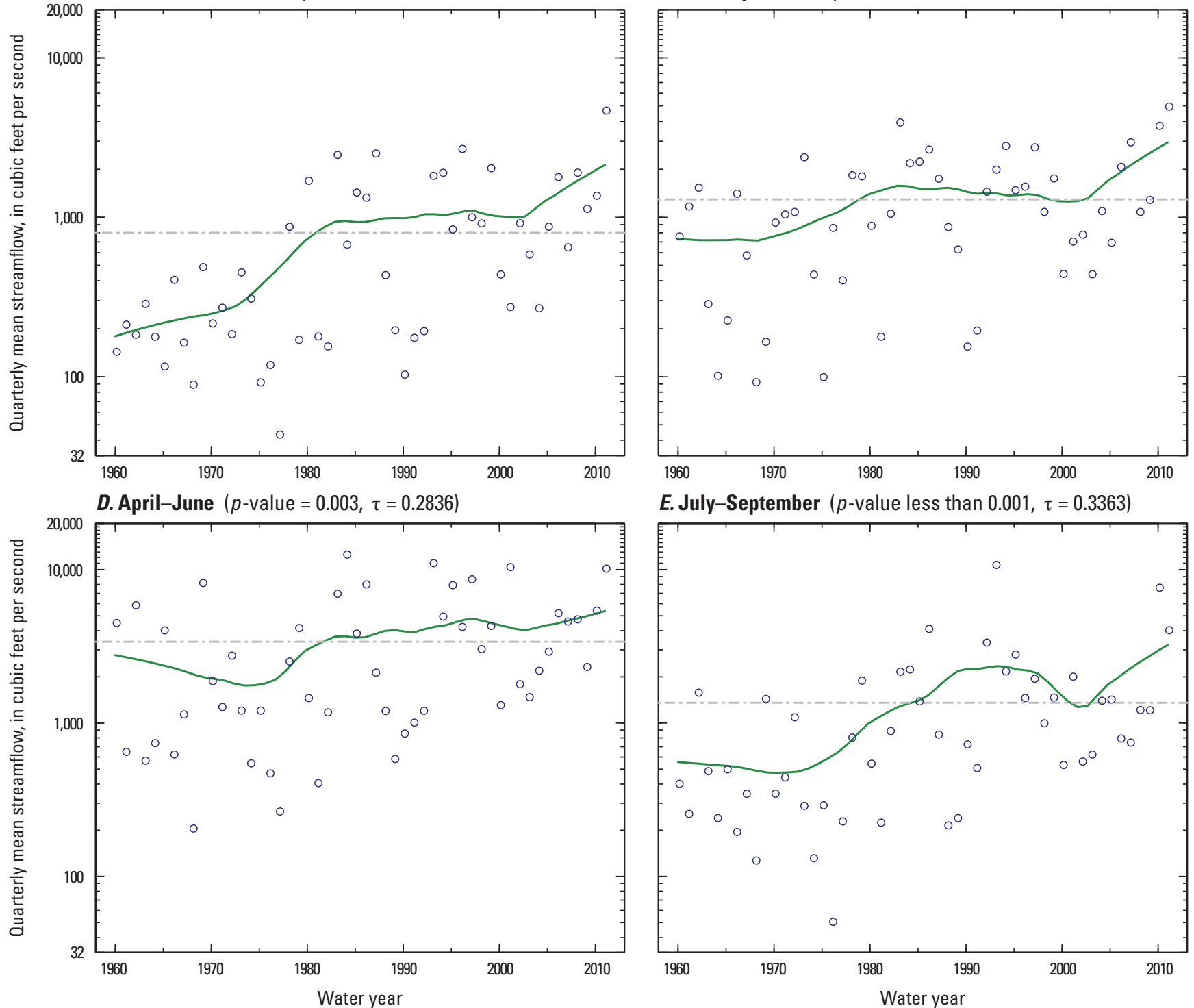

E. July-September ( $p$-value less than $0.001, \tau=0.3363$ )

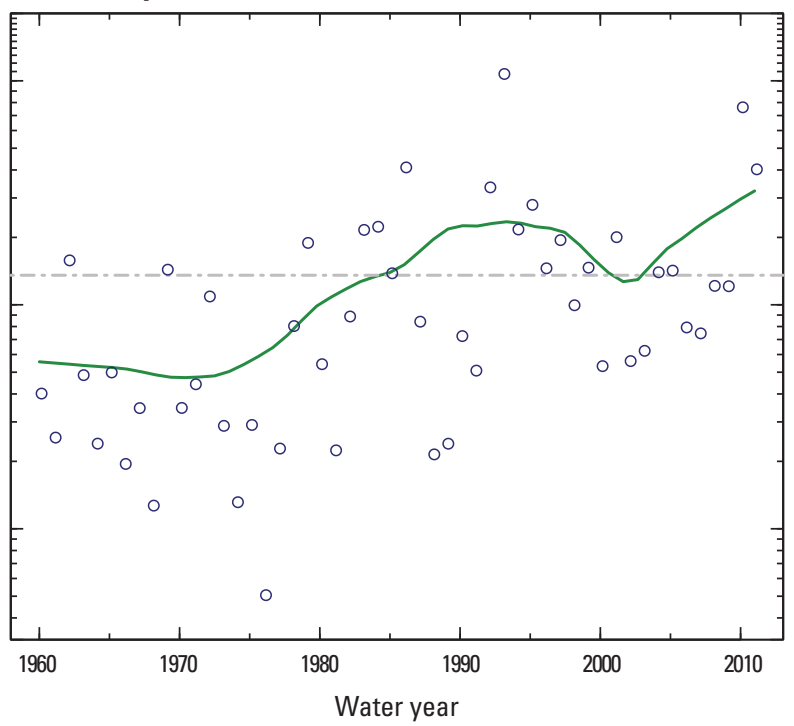

Figure 1-52. Big Sioux River at Akron, lowa (streamgage 06485500), water years 1960-2011. 

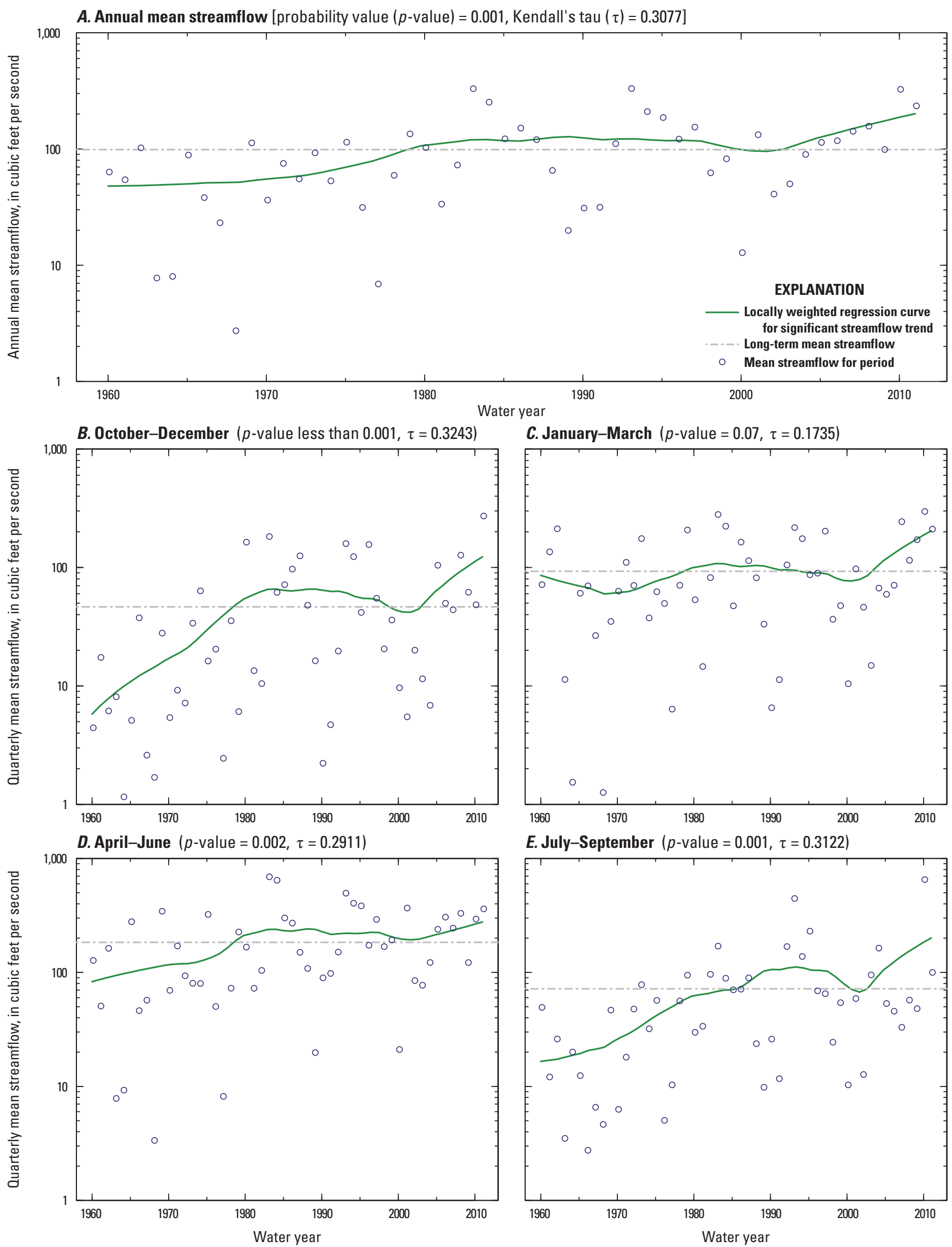

C. January-March $(p$-value $=0.07, \tau=0.1735)$

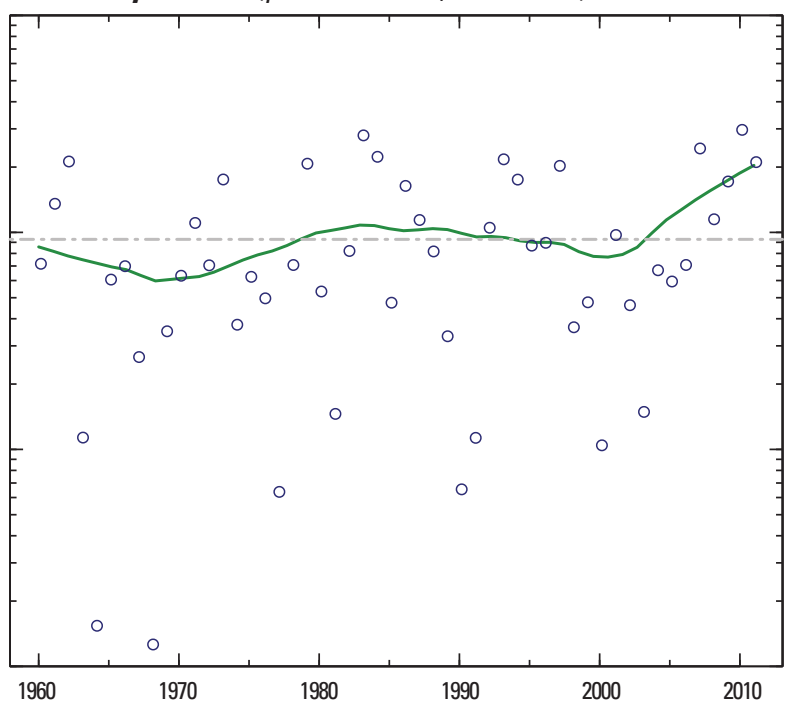

E. July-September $(p$-value $=0.001, \tau=0.3122)$

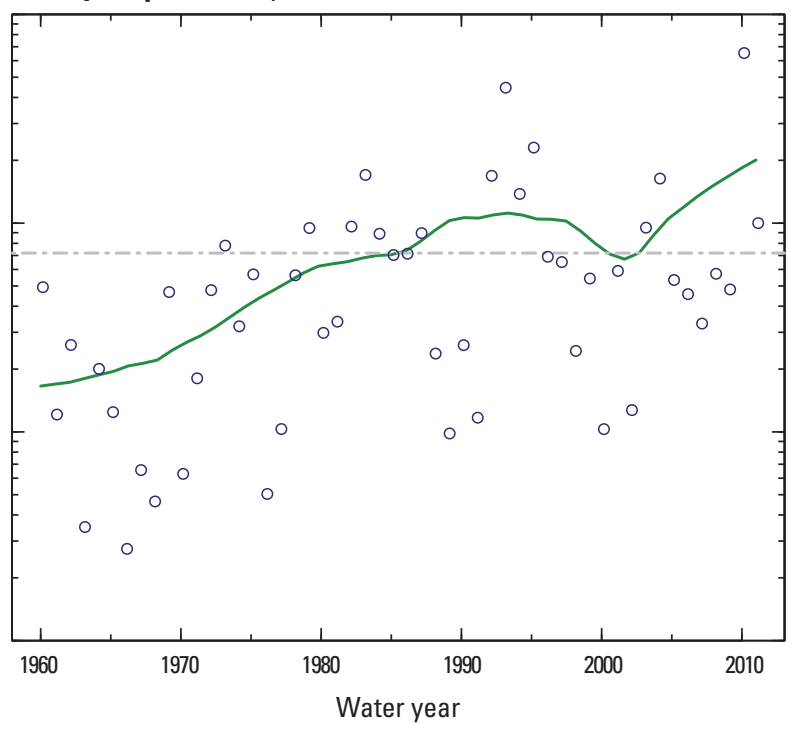

Figure 1-53. Floyd River at Alton, lowa (streamgage 06600100), water years 1960-2011. 
A. Annual mean streamflow [probability value ( $p$-value) less than 0.001 , Kendall's tau $(\tau)=0.3167$ ]
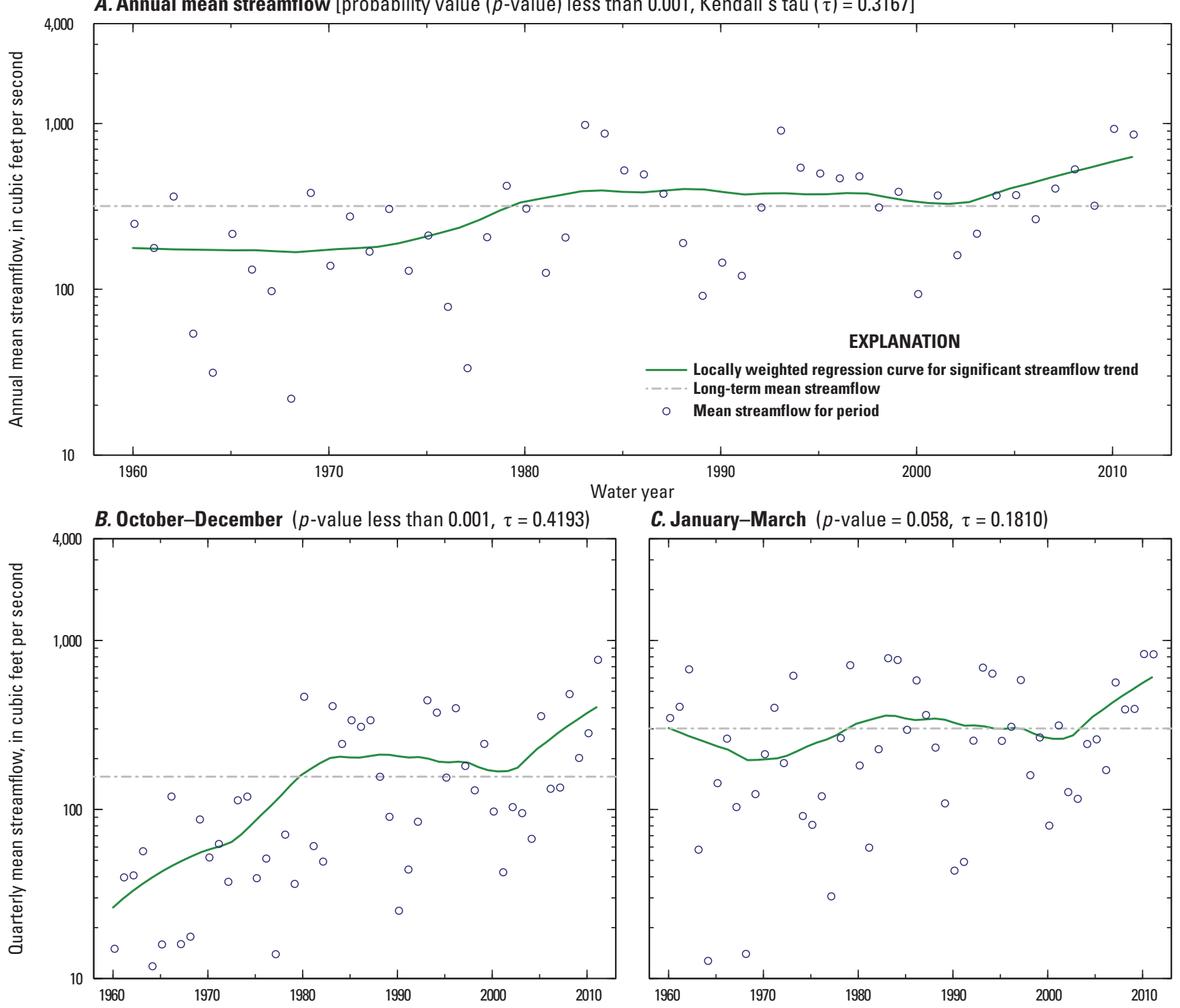

C. January-March $(p$-value $=0.058, \tau=0.1810)$
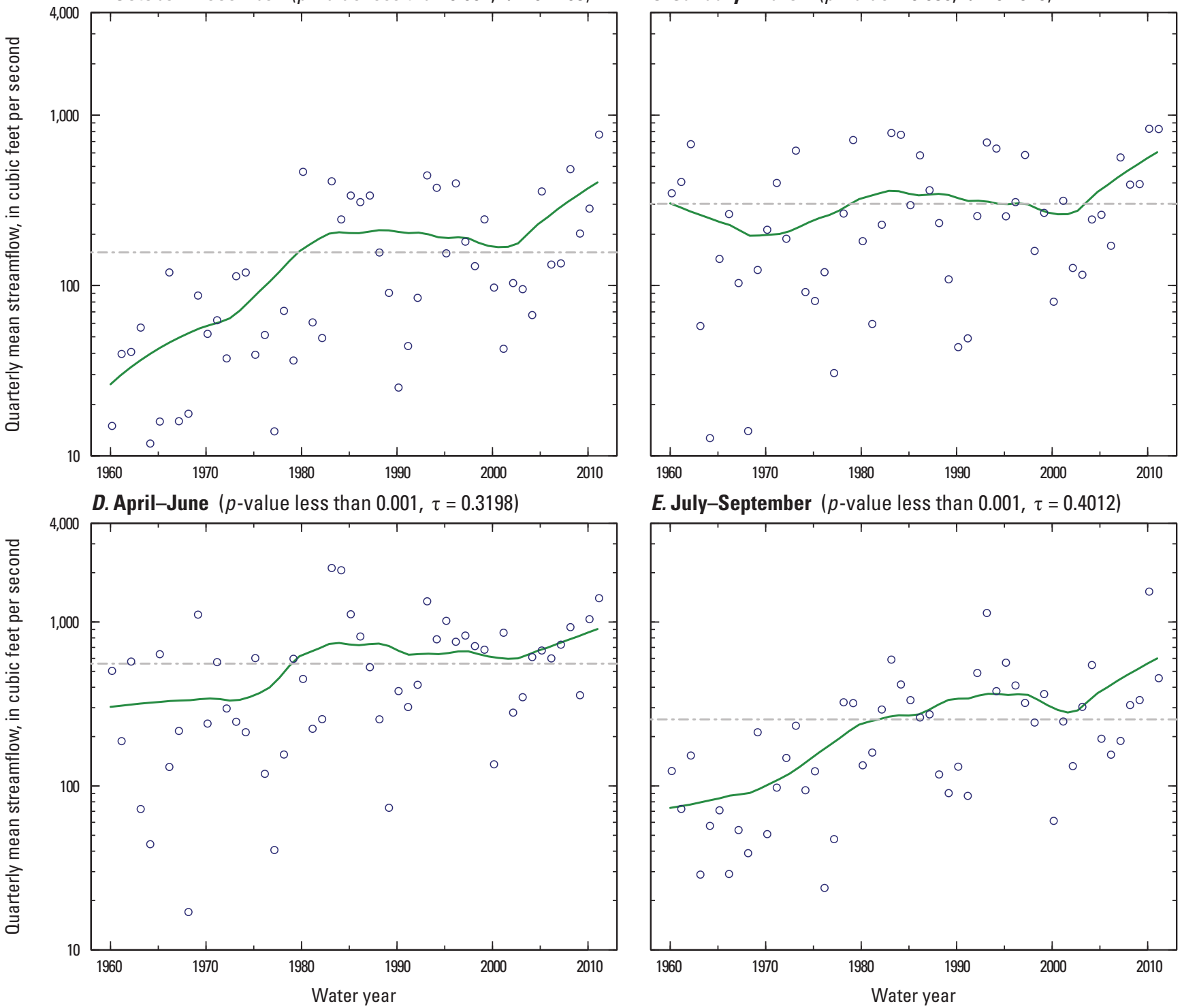

E. July-September ( $p$-value less than 0.001, $\tau=0.4012$ )

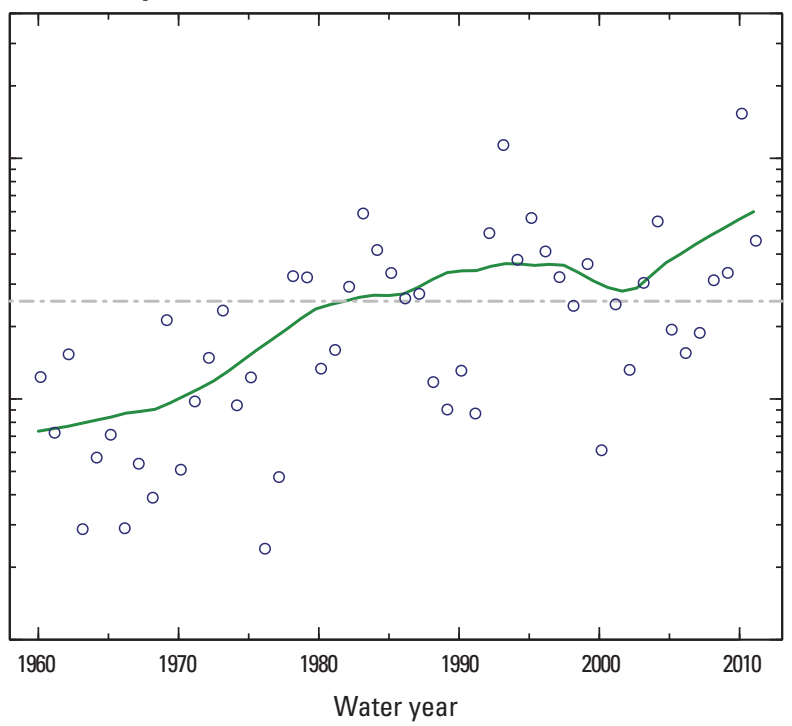

Figure 1-54. Floyd River at James, lowa (streamgage 06600500), water years 1960-2011. 
A. Annual mean streamflow [probability value $(p$-value) less than 0.001 , Kendall's tau $(\tau)=0.3185$ ]

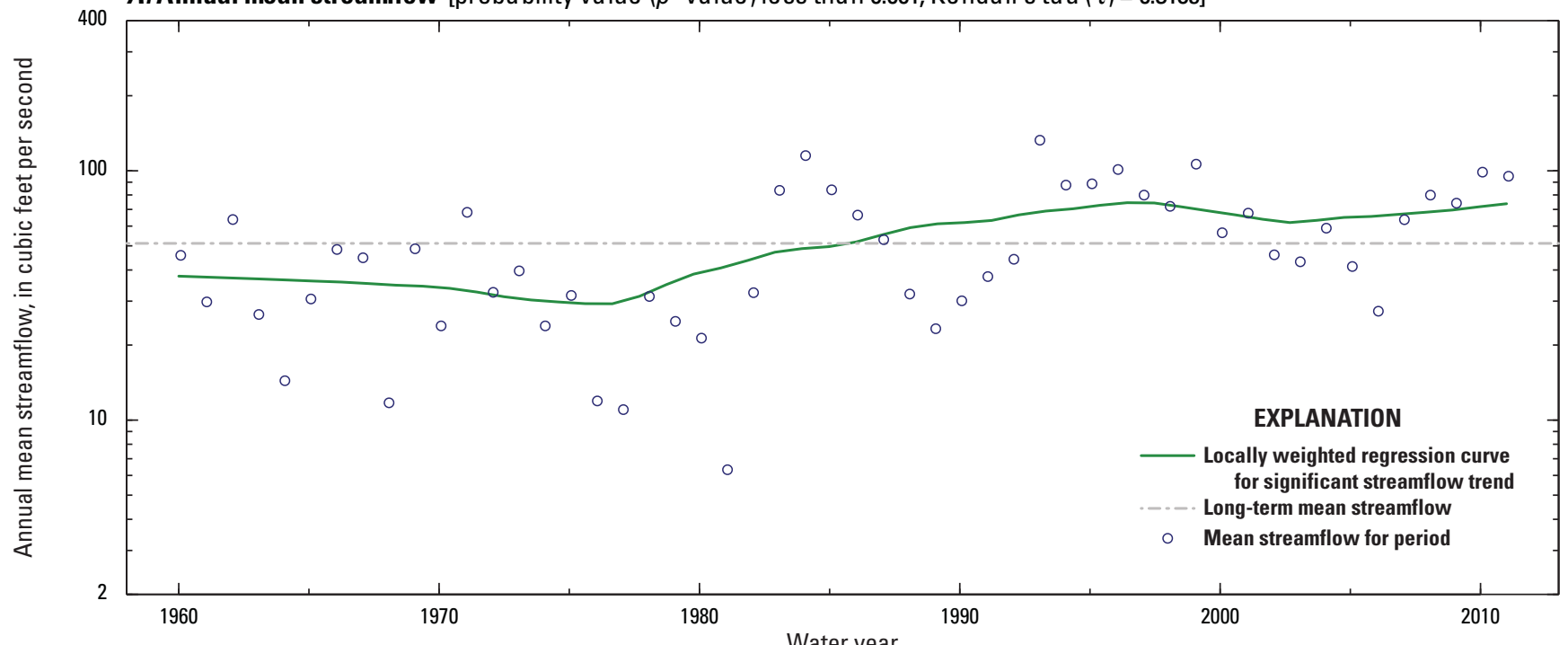

B. October-December ( $p$-value less than 0.001, $\tau=0.4525)$

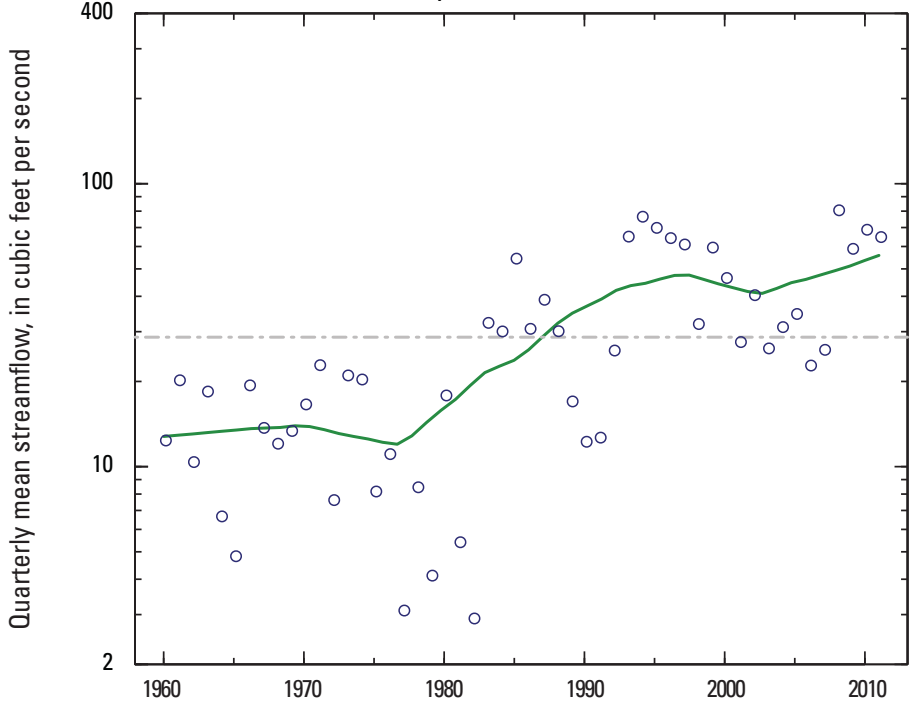

D. April-June $(p$-value $=0.004, \tau=0.2760)$

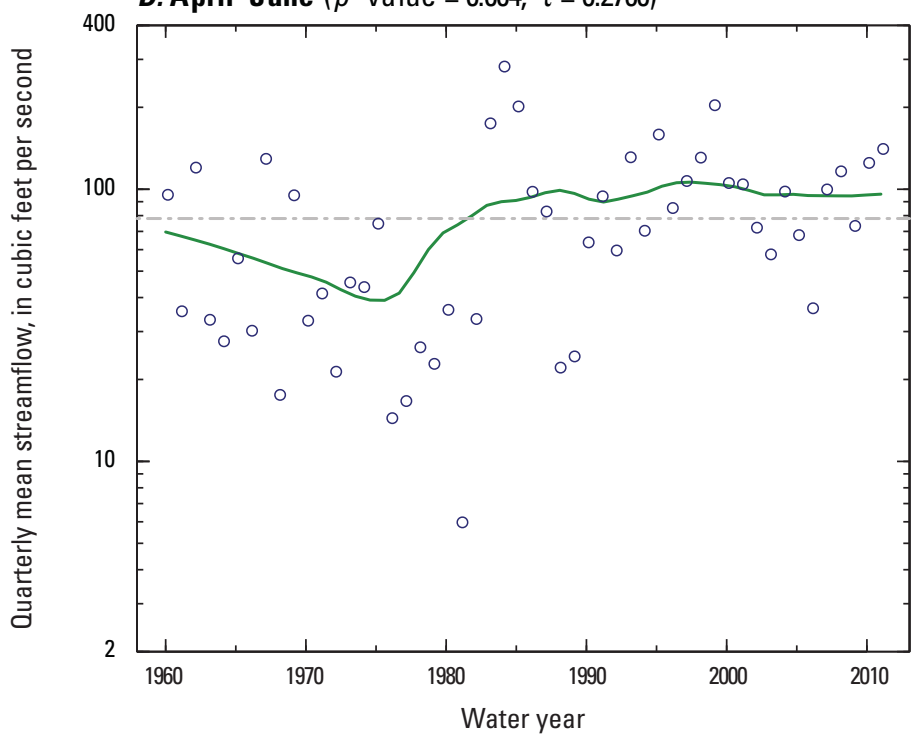

C. January-March $(p$-value $=0.028, \tau=0.2105)$

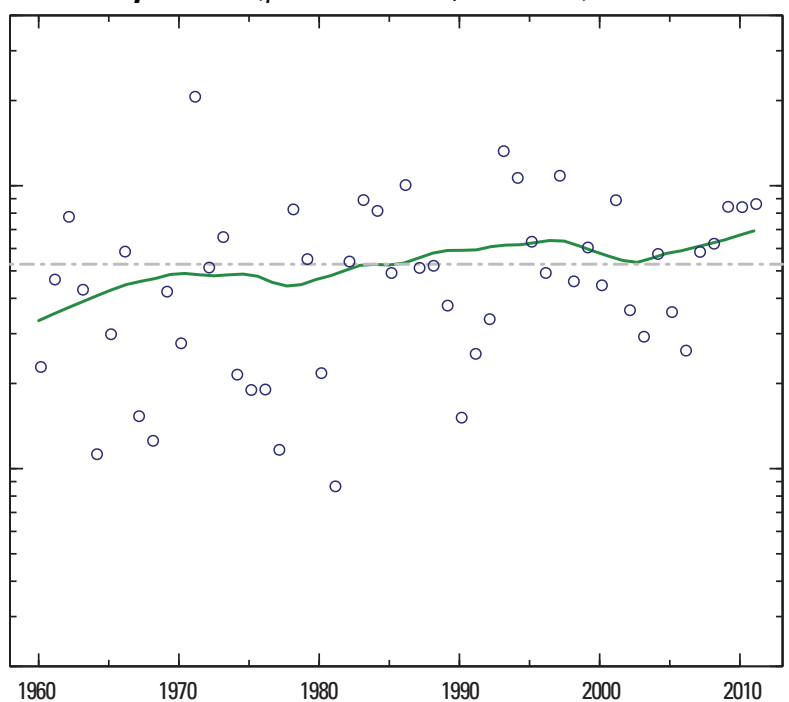

E. July-September ( $p$-value less than 0.001, $\tau=0.3484$ )

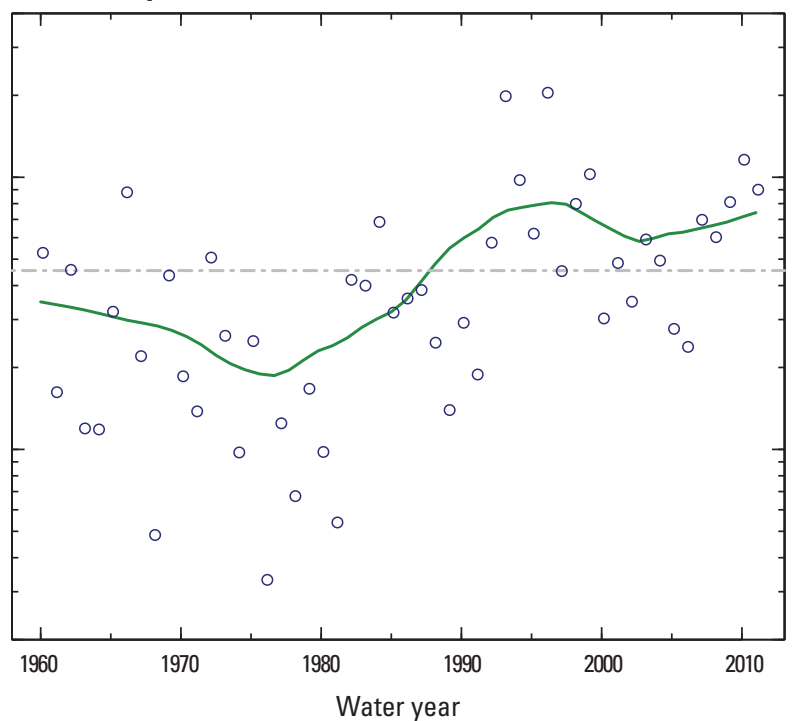

Figure 1-55. Omaha Creek at Homer, Nebraska (streamgage 06601000), water years 1960-2011. 
A. Annual mean streamflow [probability value ( $p$-value $)=0.014$, Kendall's tau $(\tau)=0.2355$ ]
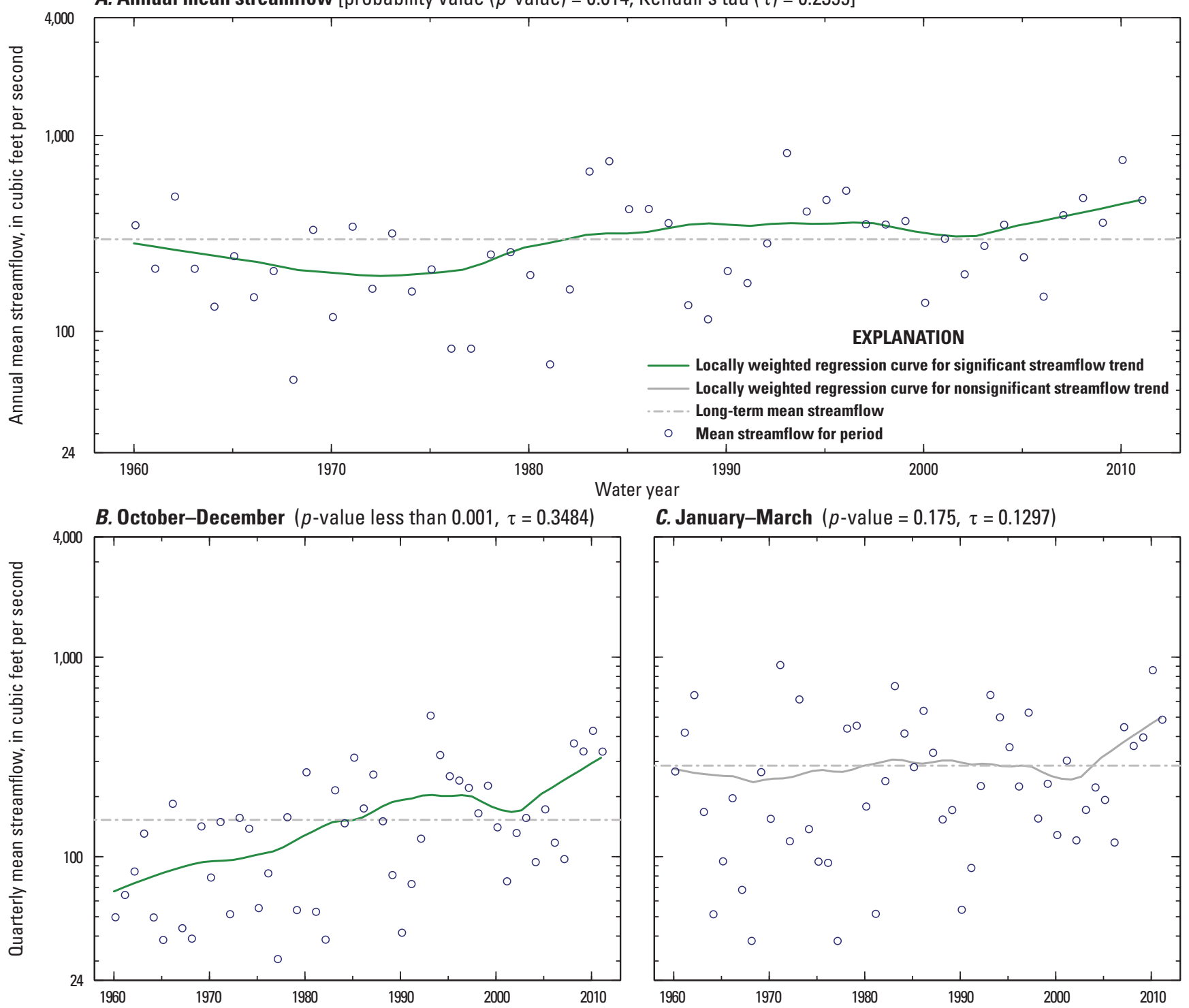

C. January-March $(p$-value $=0.175, \tau=0.1297)$
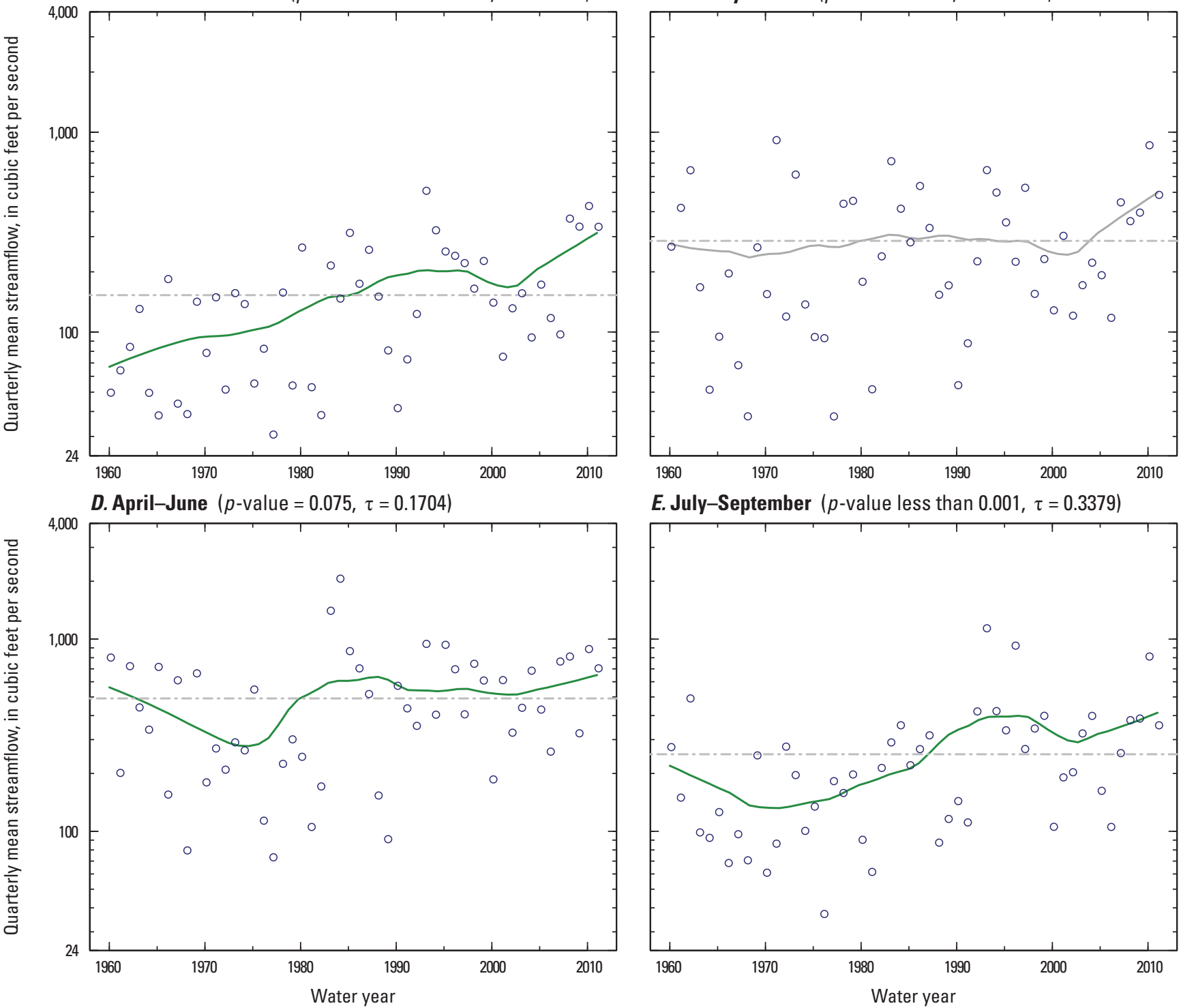

E. July-September ( $p$-value less than 0.001, $\tau=0.3379$ )

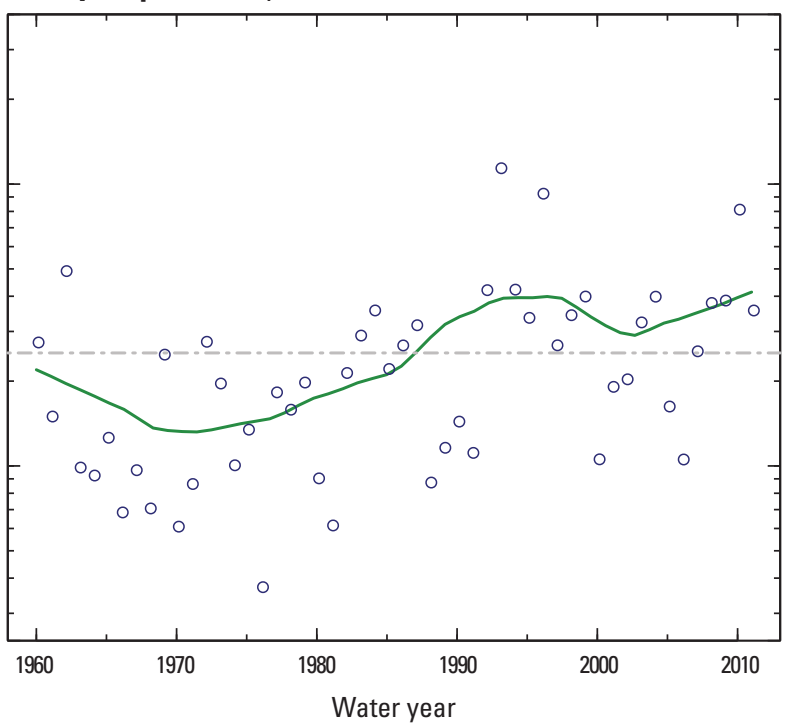

Figure 1-56. Monona-Harrison Ditch near Turin, lowa (streamgage 06602400), water years 1960-2011. 
A. Annual mean streamflow [probability value $(p$-value $)=0.008$, Kendall's tau $(\tau)=0.2534$ ]

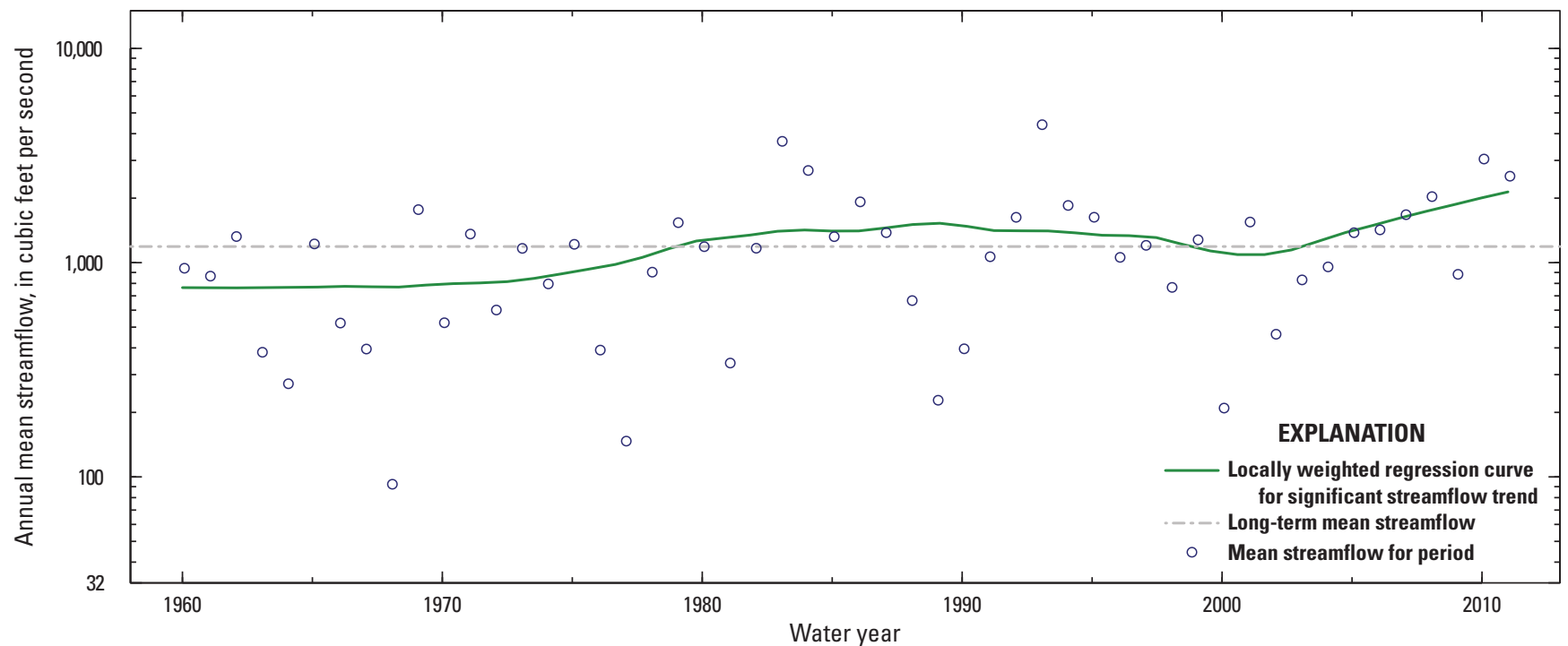

B. October-December $(p$-value $=0.047, \tau=0.1900)$

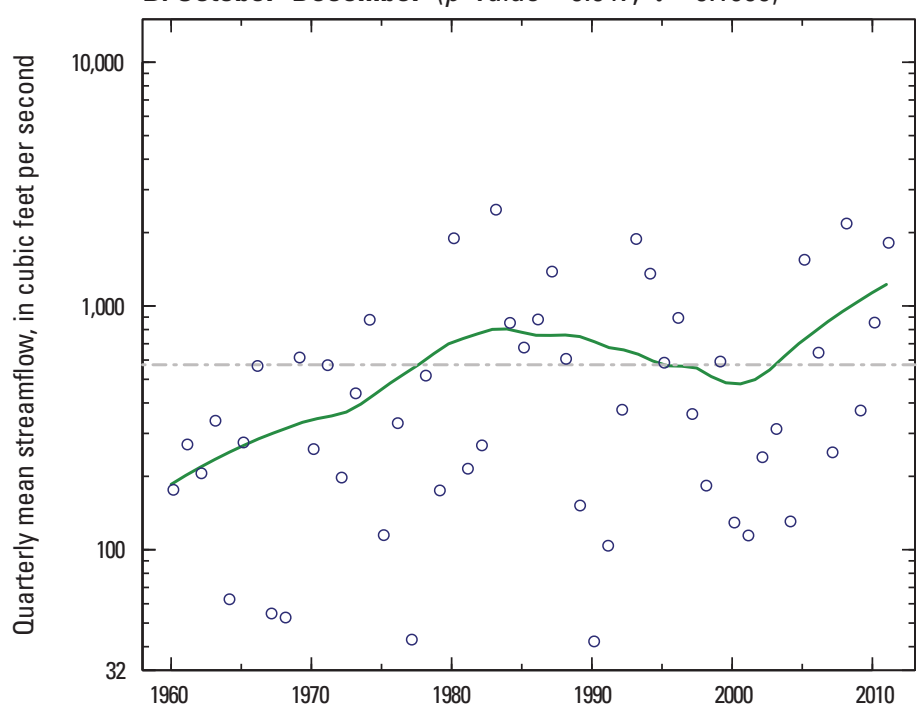

D. April-June ( $p$-value $=0.025, \tau=0.2142)$

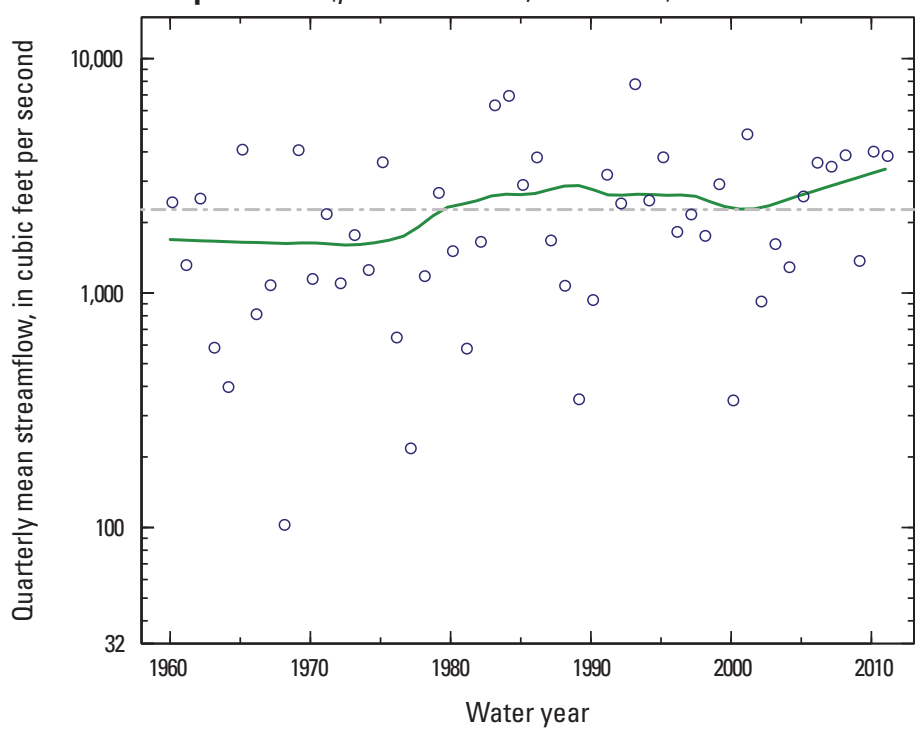

C. January-March ( $p$-value $=0.065, \tau=0.1765)$

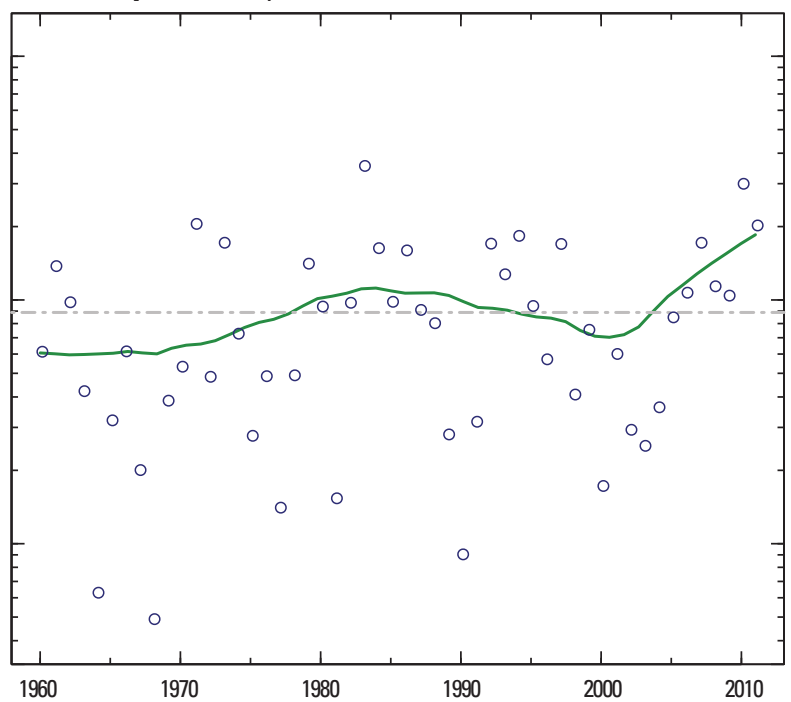

E. July-September $(p$-value $=0.013, \tau=0.2383)$

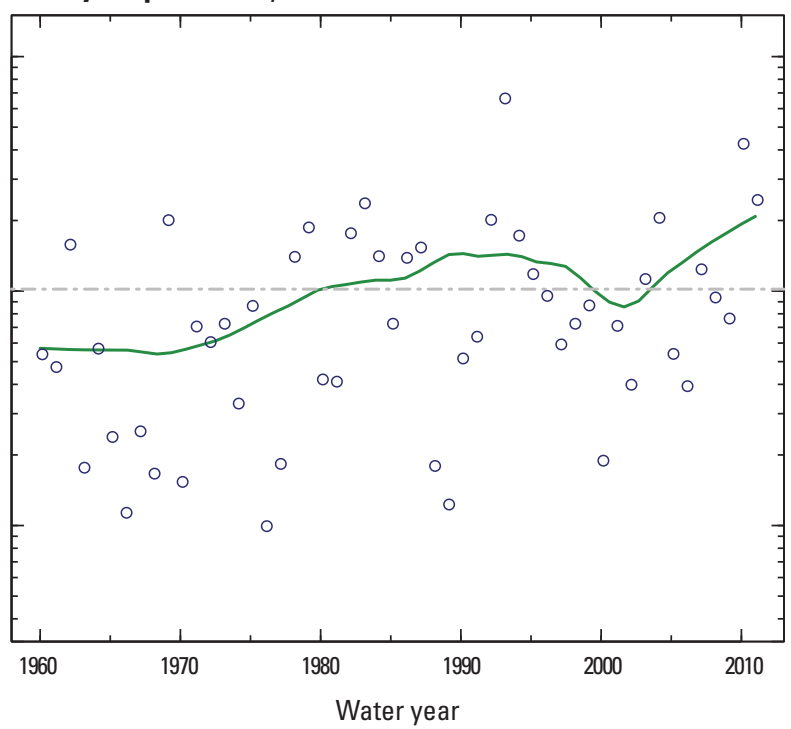

Figure 1-57. Little Sioux River at Correctionville, lowa (streamgage 06606600), water years 1960-2011. 
A. Annual mean streamflow [probability value $(p$-value $)=0.011$, Kendall's tau $(\tau)=0.2428$ ]
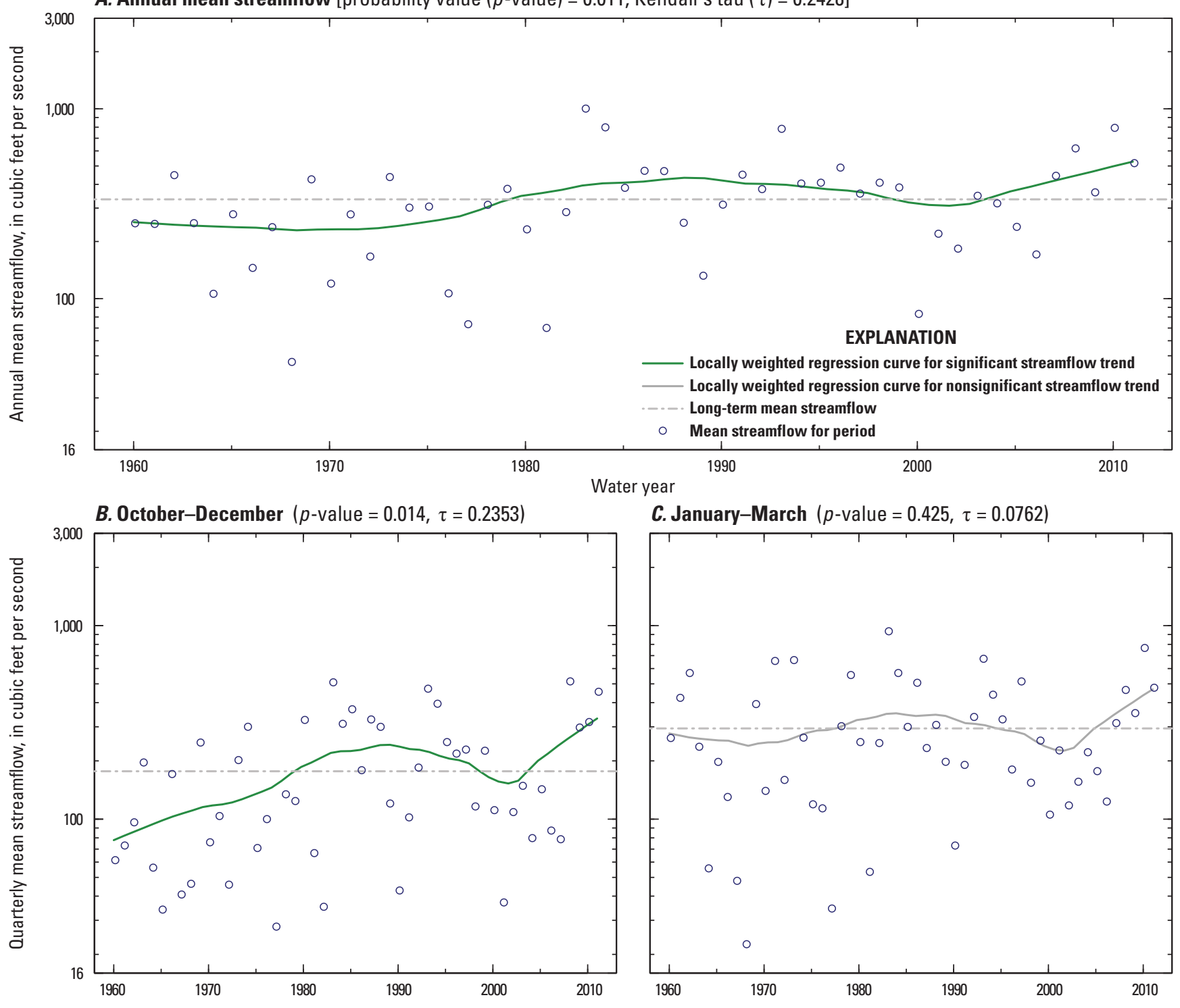

C. January-March $(p$-value $=0.425, \tau=0.0762)$
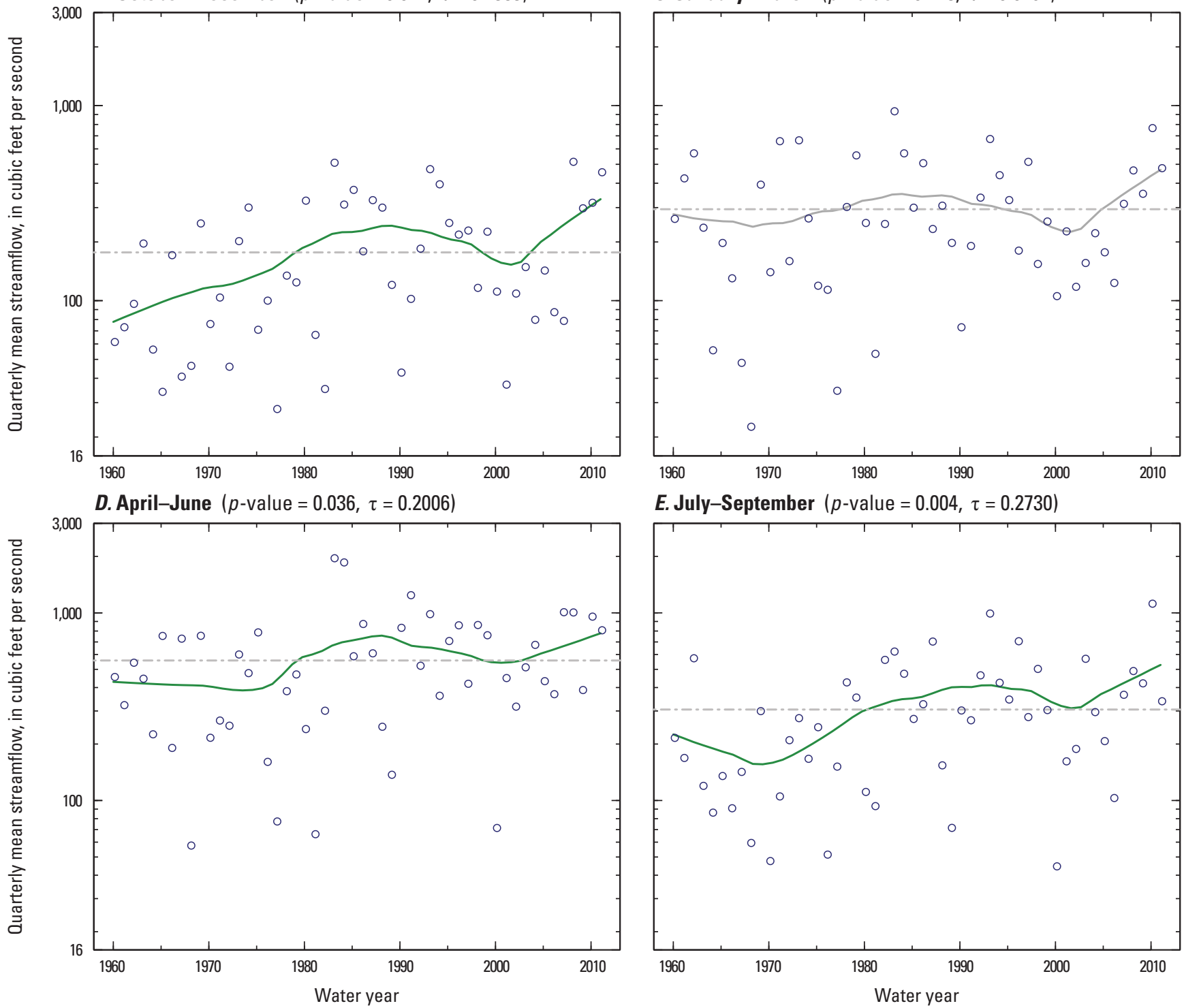

E. July-September $(p$-value $=0.004, \tau=0.2730)$

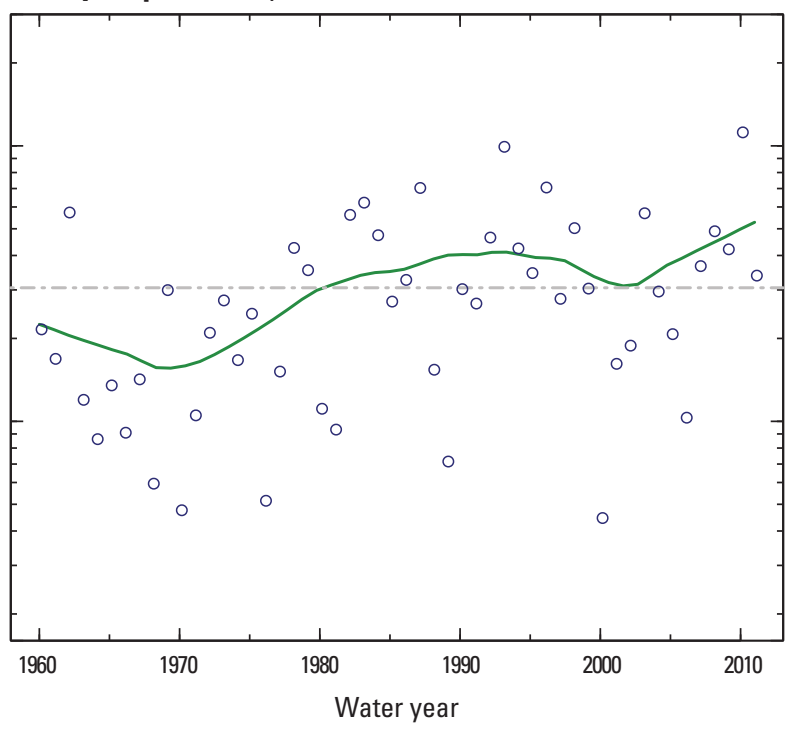

Figure 1-58. Maple River at Mapleton, lowa (streamgage 06607200), water years 1960-2011. 

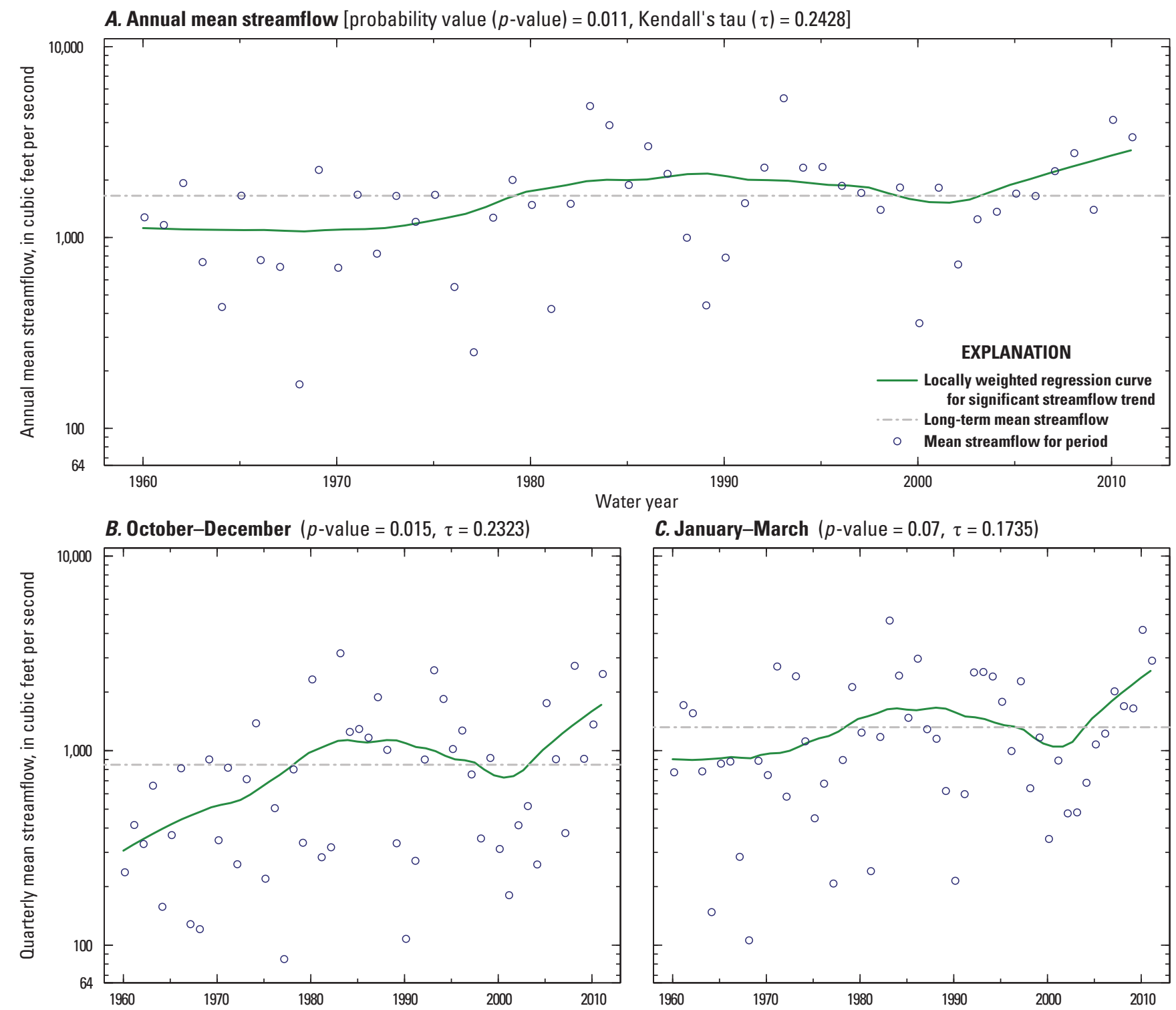

C. January-March $(p$-value $=0.07, \tau=0.1735)$
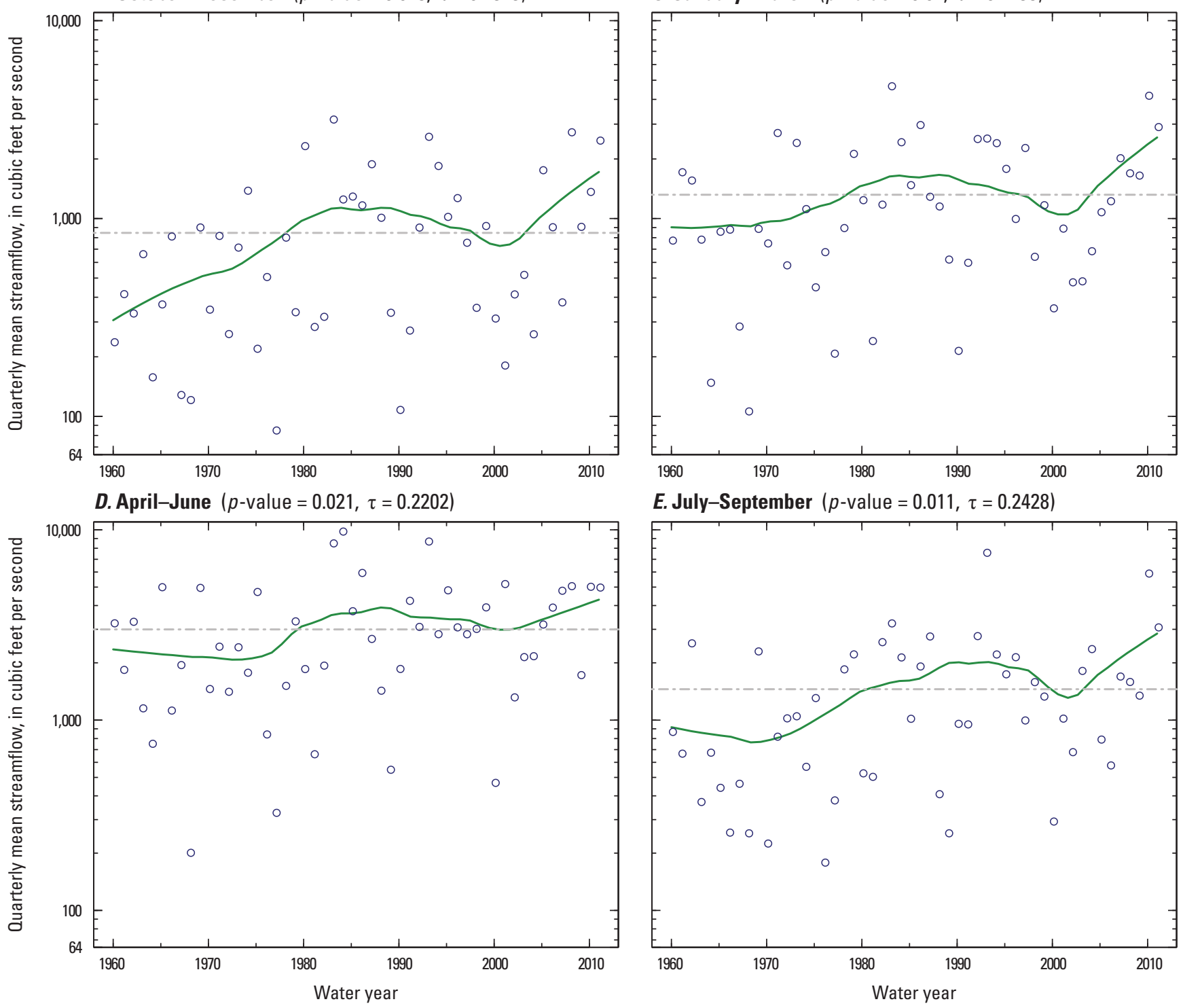

E. July-September $(p$-value $=0.011, \tau=0.2428)$

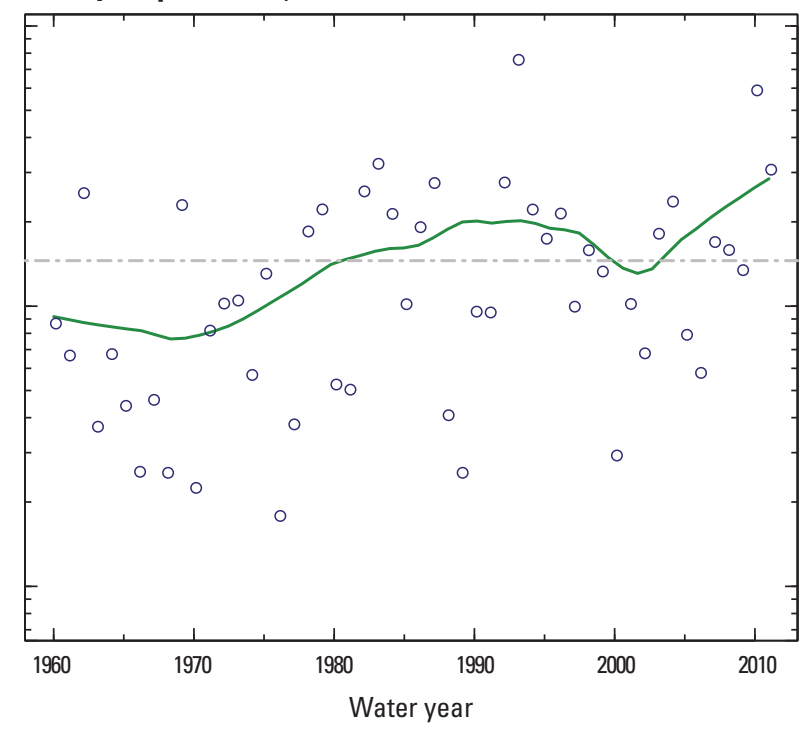

Figure 1-59. Little Sioux River near Turin, lowa (streamgage 06607500), water years 1960-2011. 
A. Annual mean streamflow [probability value $(p$-value $)=0.013$, Kendall's tau $(\tau)=0.2383$ ]

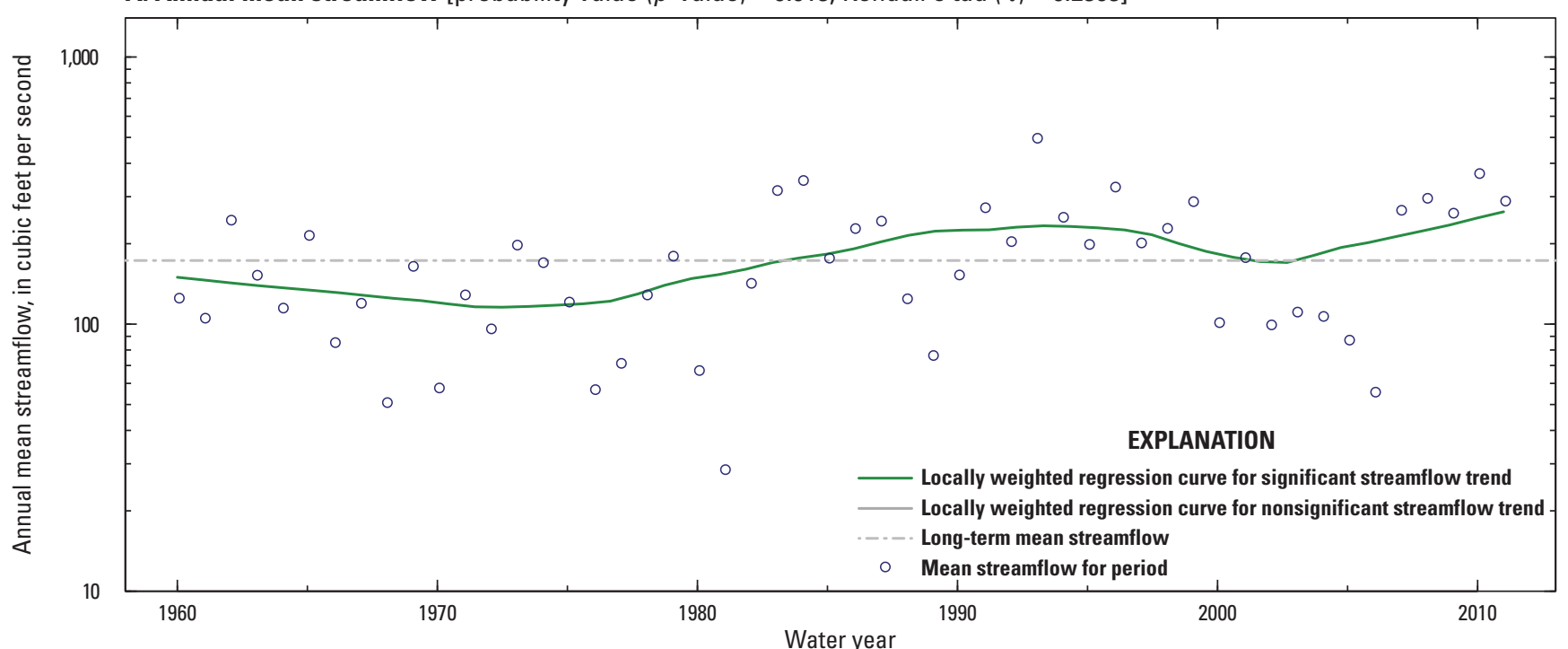

B. October-December ( $p$-value $=0.002, \tau=0.2986)$

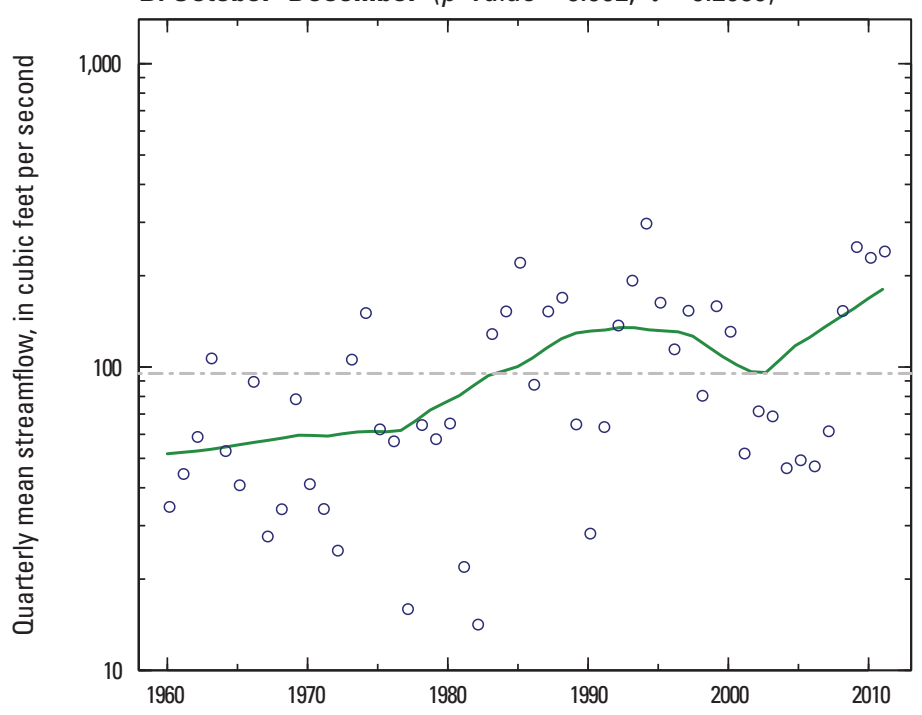

D. April-June $(p$-value $=0.111, \tau=0.1523)$

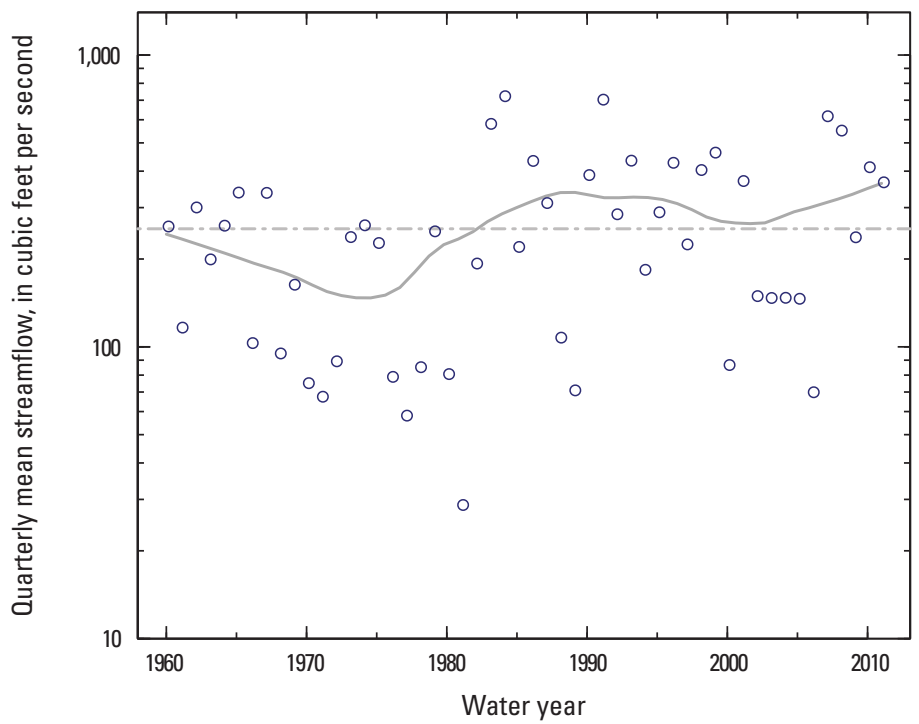

C. January-March $(p$-value $=0.273, \tau=0.1049)$

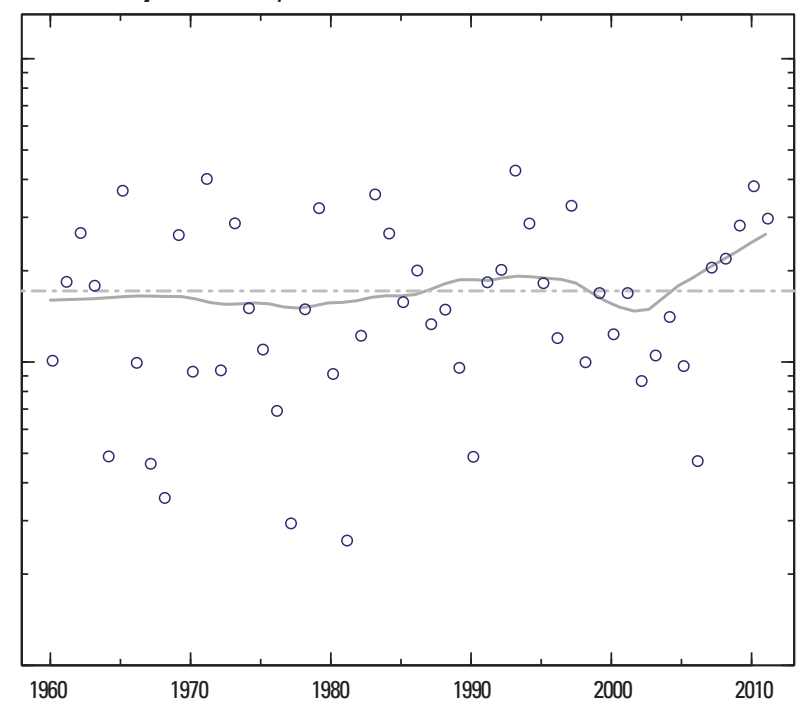

E. July-September $(p$-value $=0.016, \tau=0.2293)$

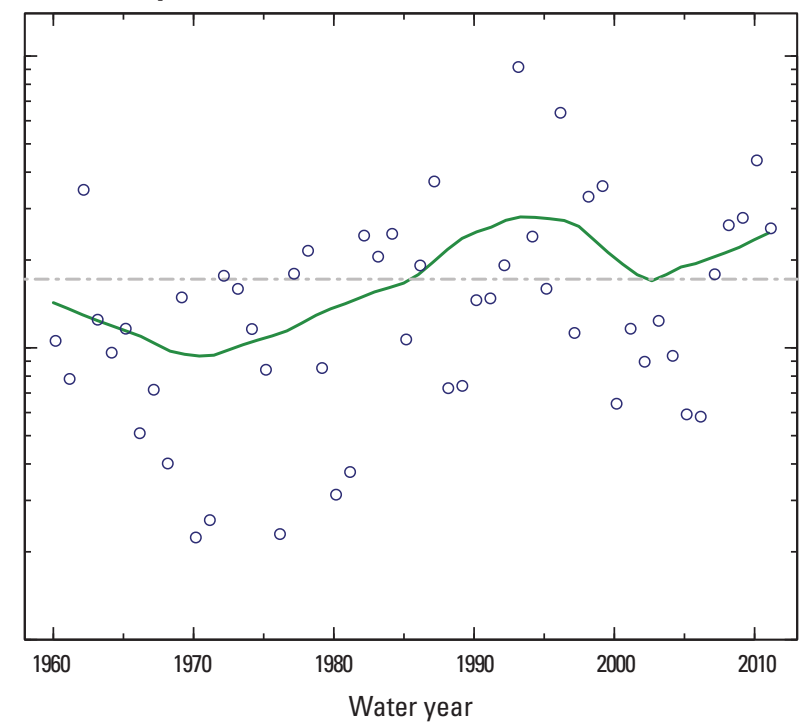

Figure 1-60. Soldier River at Pisgah, lowa (streamgage 06608500), water years 1960-2011. 

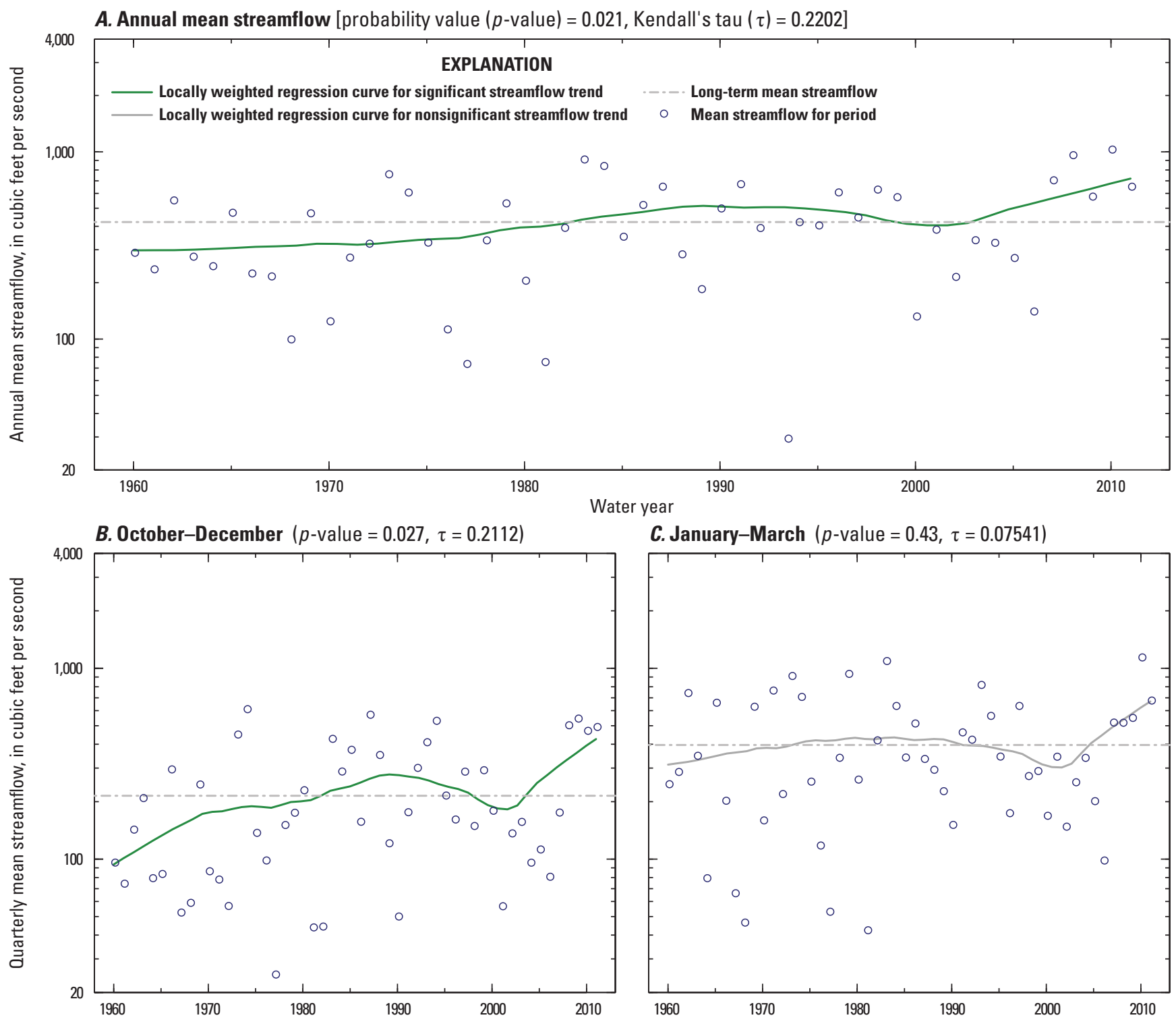

C. January-March $(p$-value $=0.43, \tau=0.07541)$
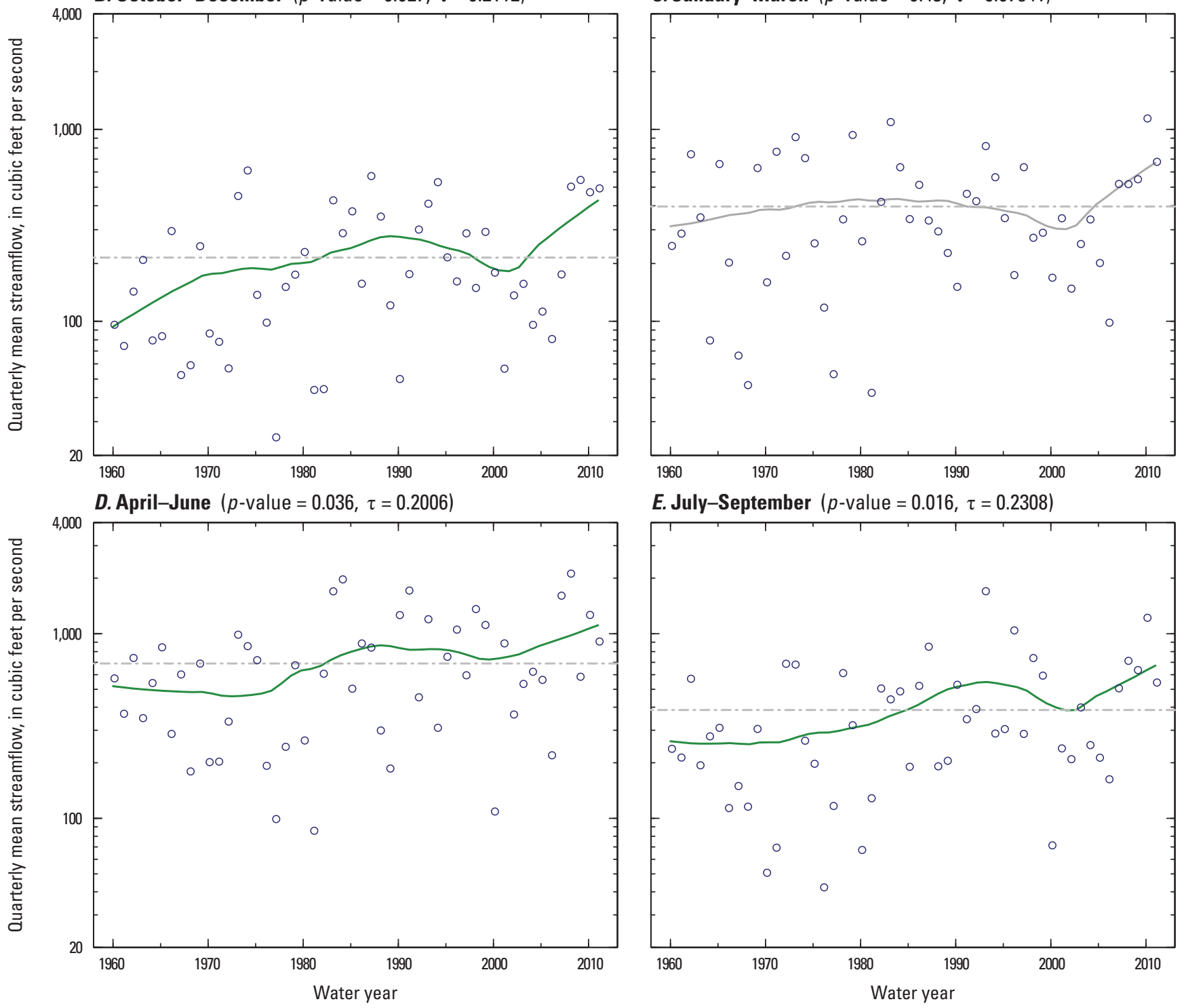

E. July-September ( $p$-value $=0.016, \tau=0.2308)$

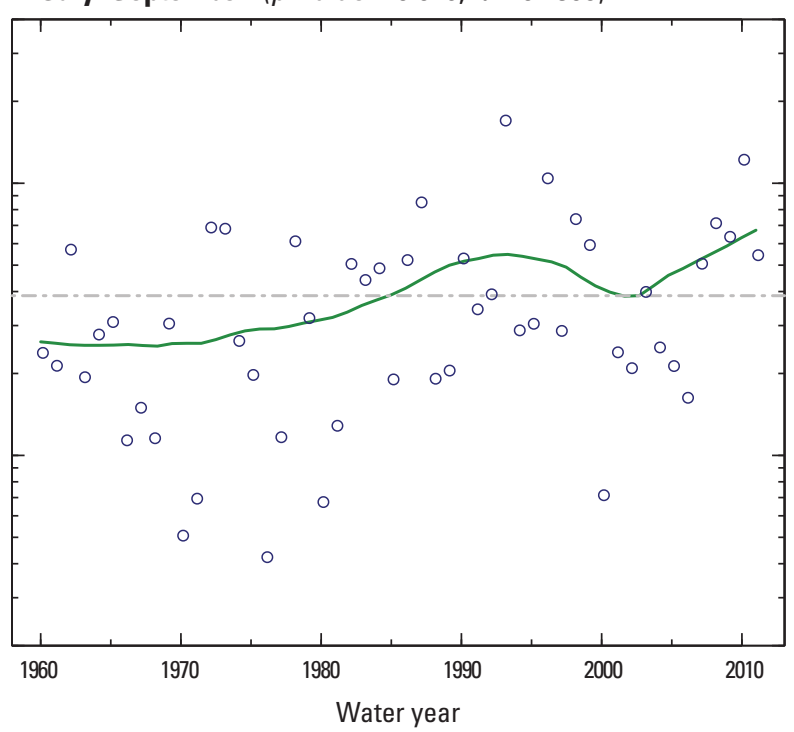

Figure 1-61. Boyer River at Logan, lowa (streamgage 06609500), water years 1960-2011. 
A. Annual mean streamflow [probability value $(p-$ value $)=0.018$, Kendall's tau $(\tau)=-0.2271$ ]
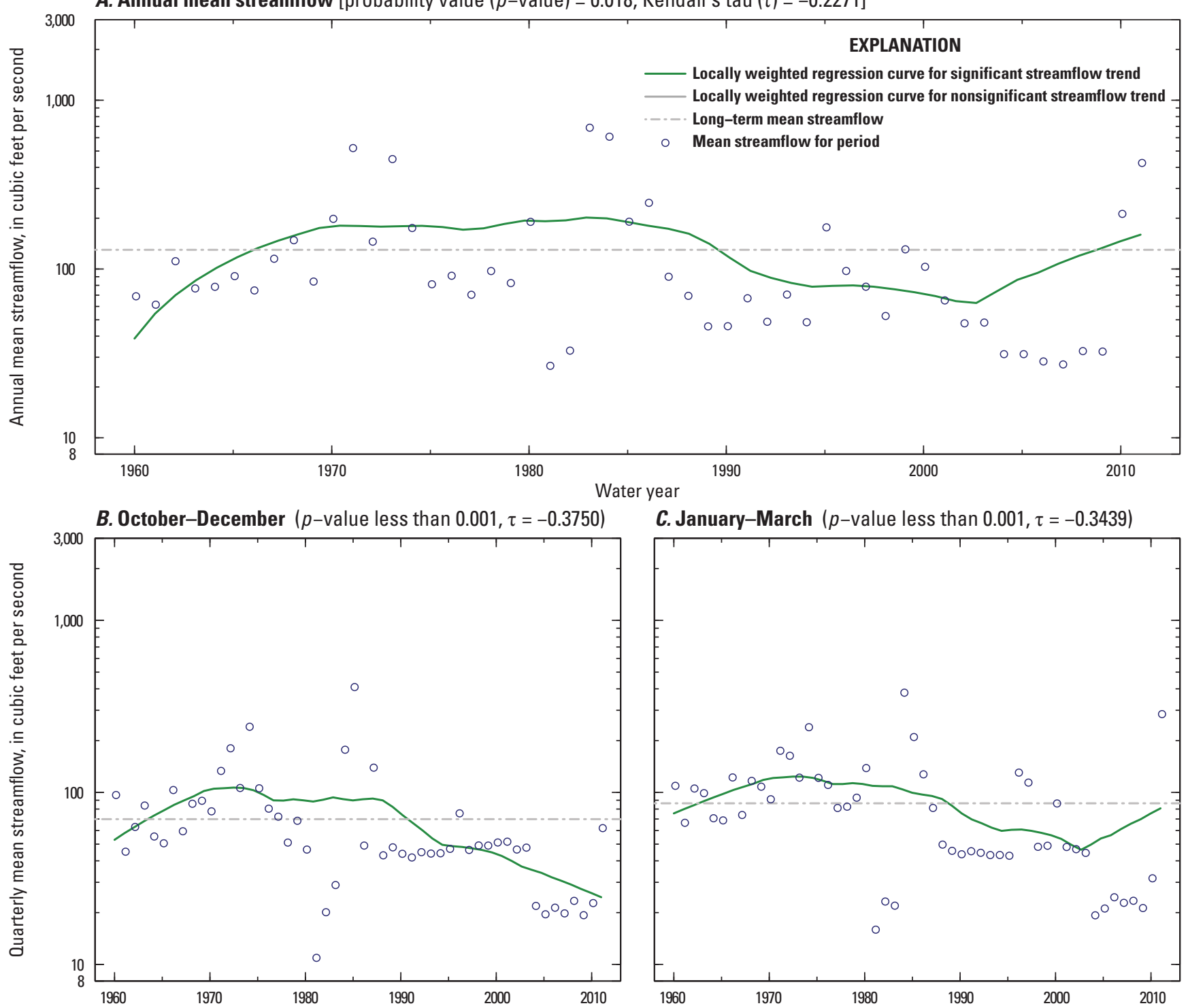

C. January-March ( $p$-value less than $0.001, \tau=-0.3439$ )
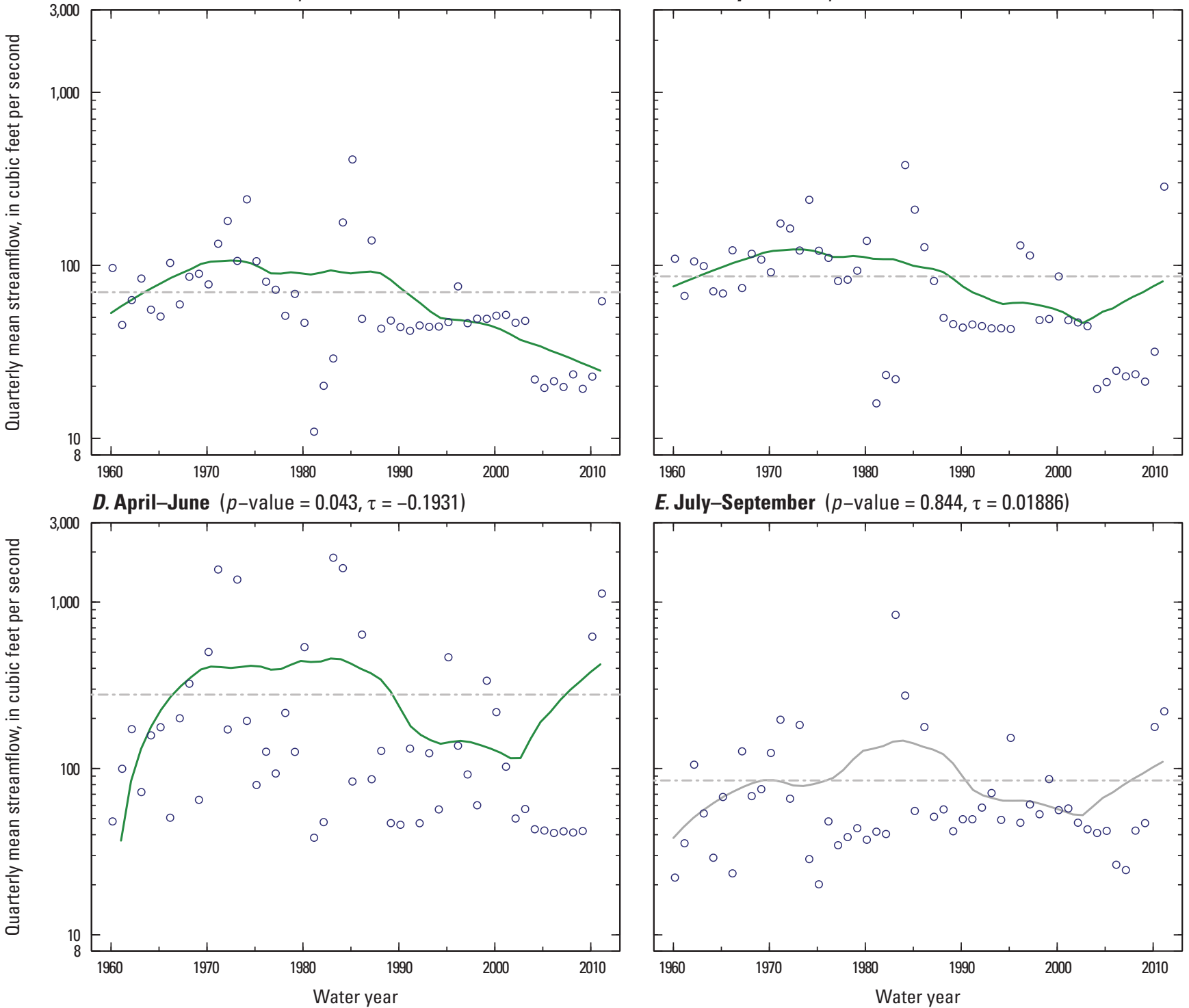

E. July-September $(p$-value $=0.844, \tau=0.01886)$

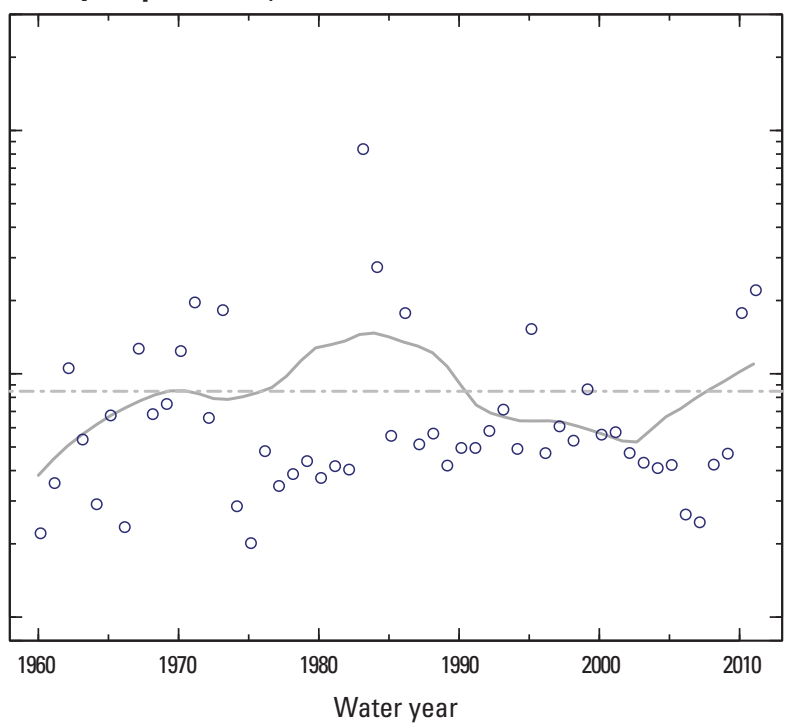

Figure 1-62. Laramie River near Fort Laramie, Wyoming (streamgage 06670500), water years 1960-2011. 
A. Annual mean streamflow [probability value ( $p$-value) less than 0.001 , Kendall's tau $(\tau)=0.5875$ ]

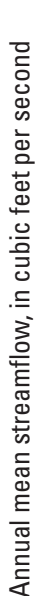

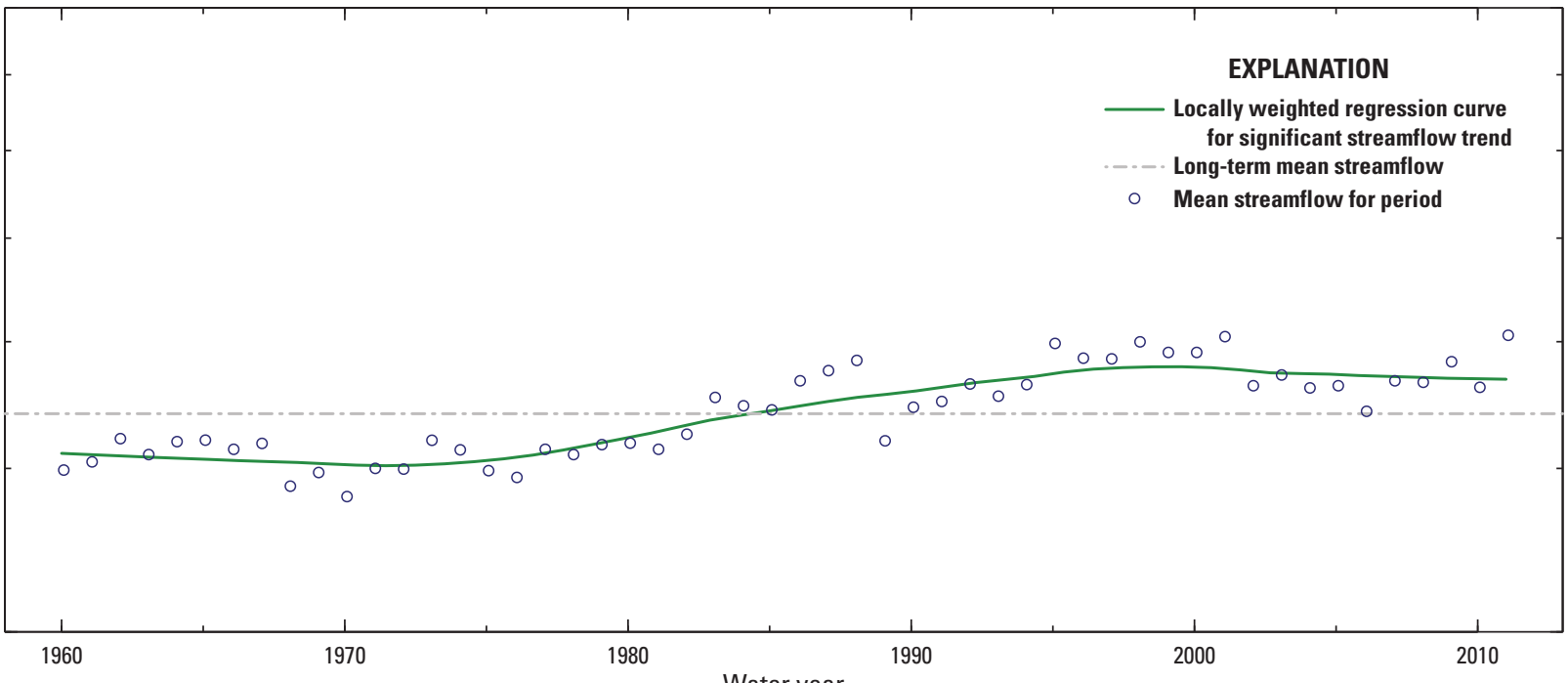

B. October-December ( $p$-value less than $0.001, \tau=0.5605)$

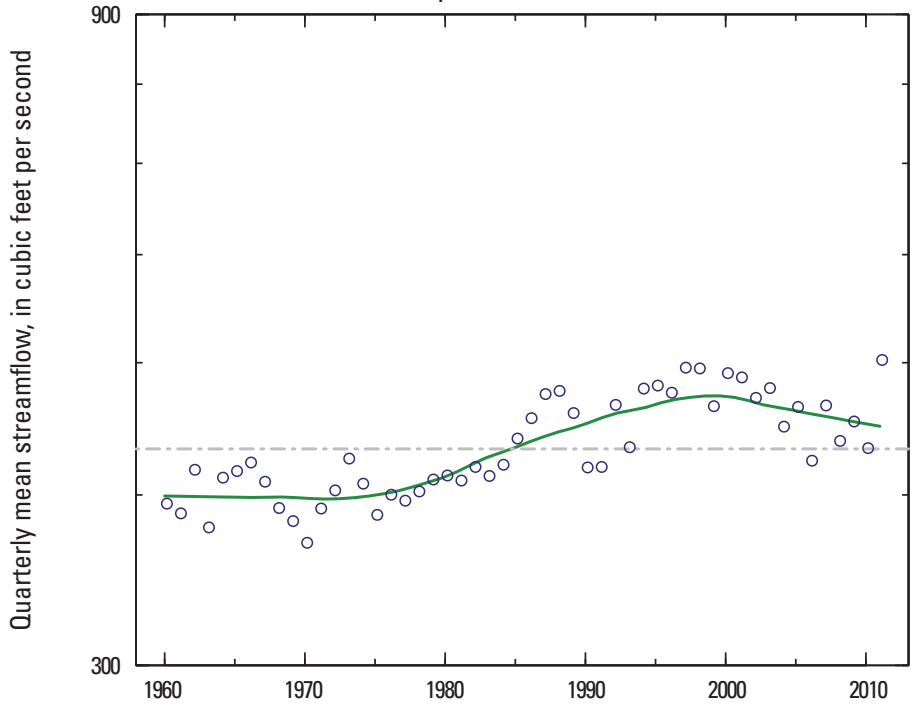

C. January-March ( $p$-value less than 0.001, $\tau=0.4857)$

D. April-June ( $p$-value less than 0.001, $\tau=0.5409)$
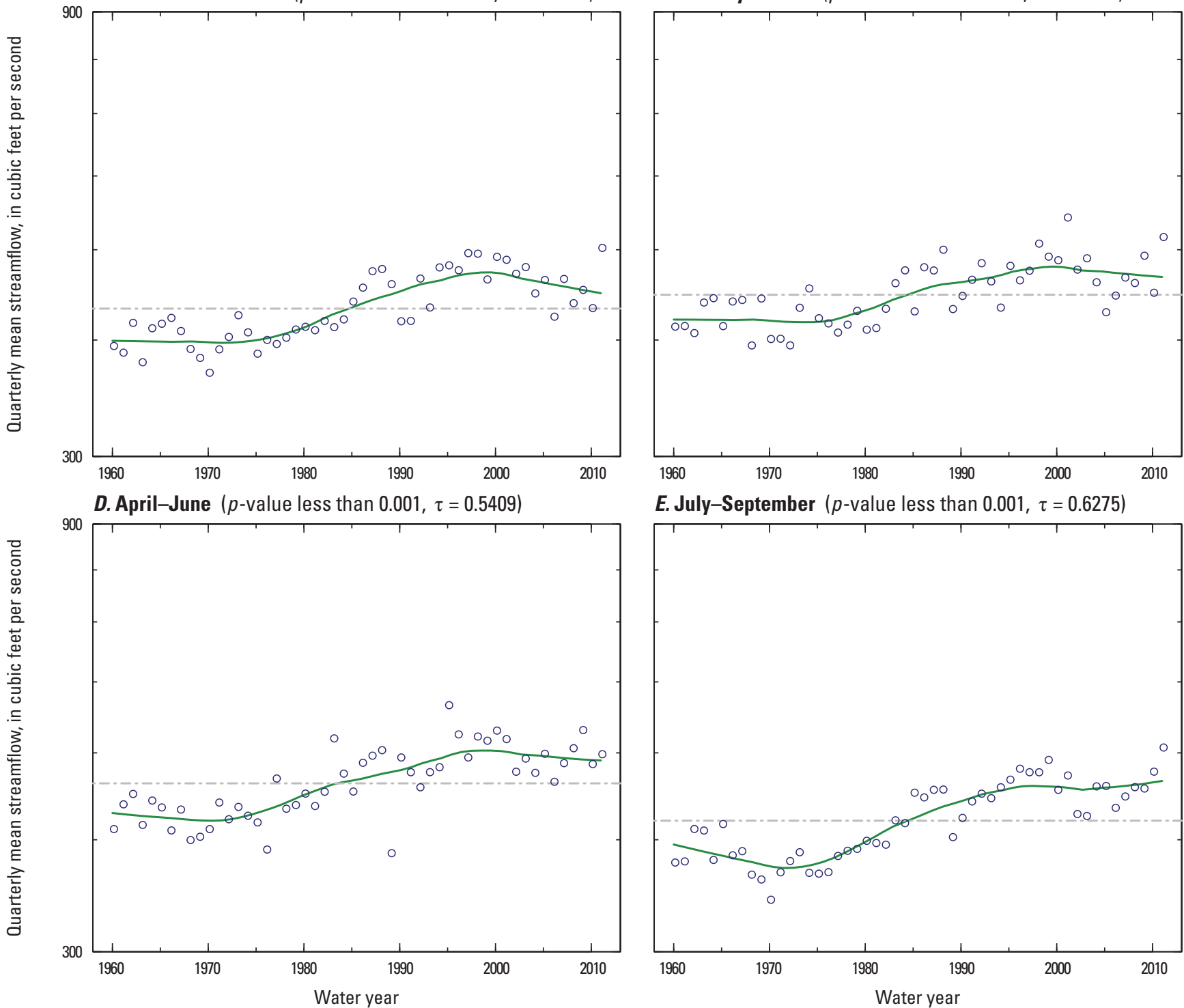

E. July-September ( $p$-value less than $0.001, \tau=0.6275)$

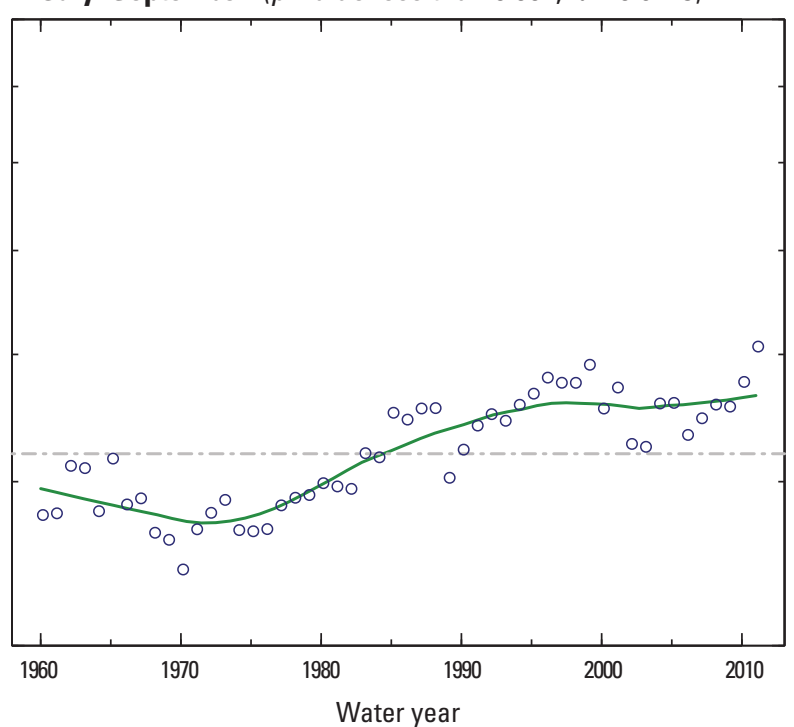

Figure 1-63. Middle Loup River at Dunning, Nebraska (streamgage 06775500), water years 1960-2011. 
A. Annual mean streamflow [probability value ( $p$-value) less than 0.001 , Kendall's tau $(\tau)=0.3568$ ]

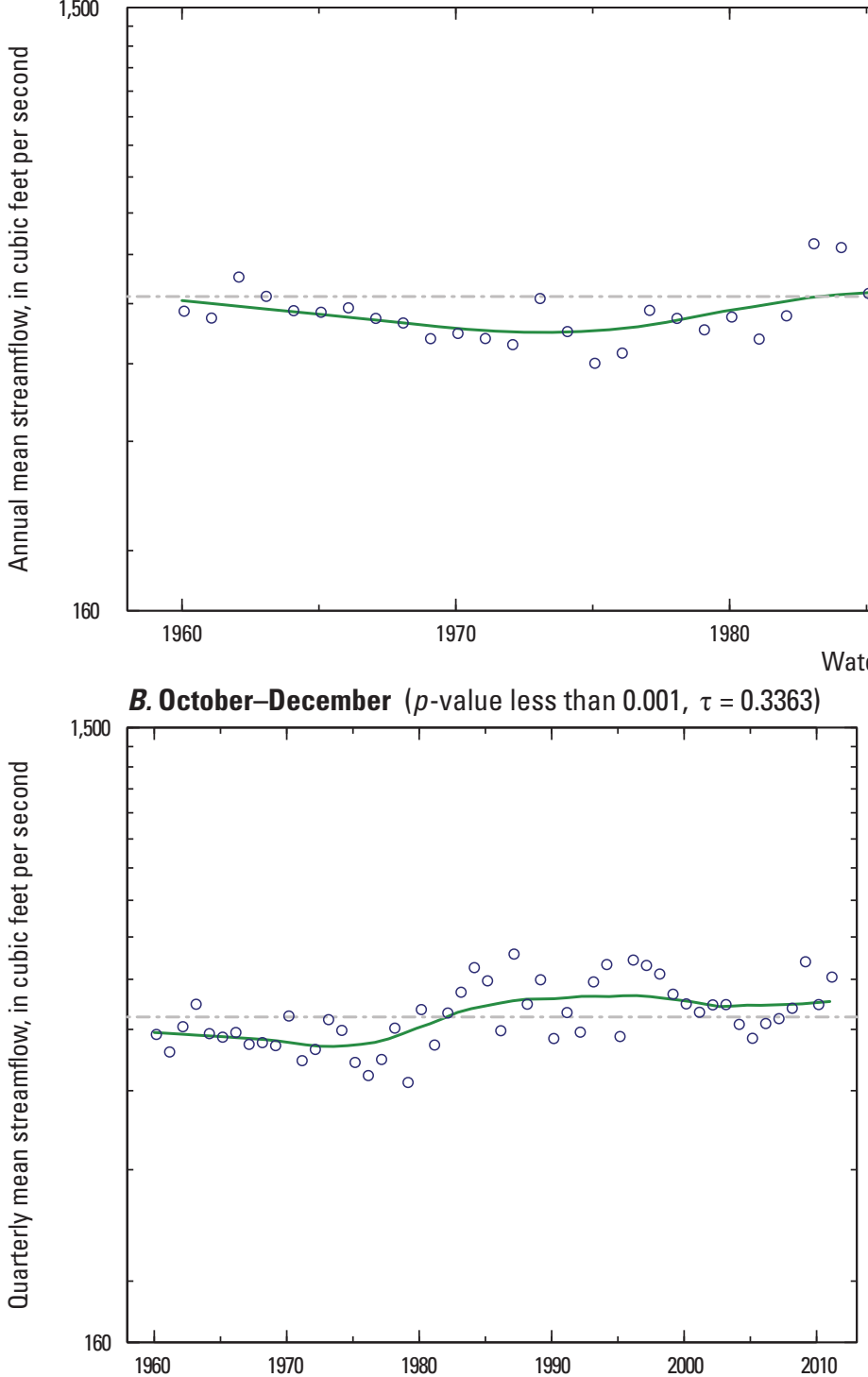

D. April-June $(p$-value $=0.002, \tau=0.2911)$

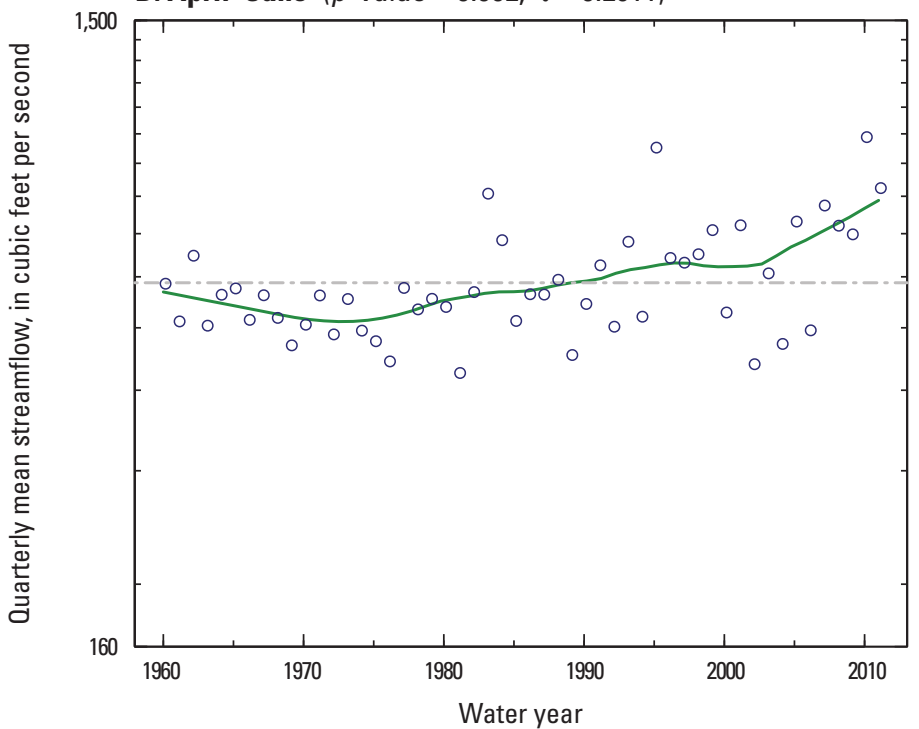

C. January-March $(p$-value $=0.002, \tau=0.2935)$

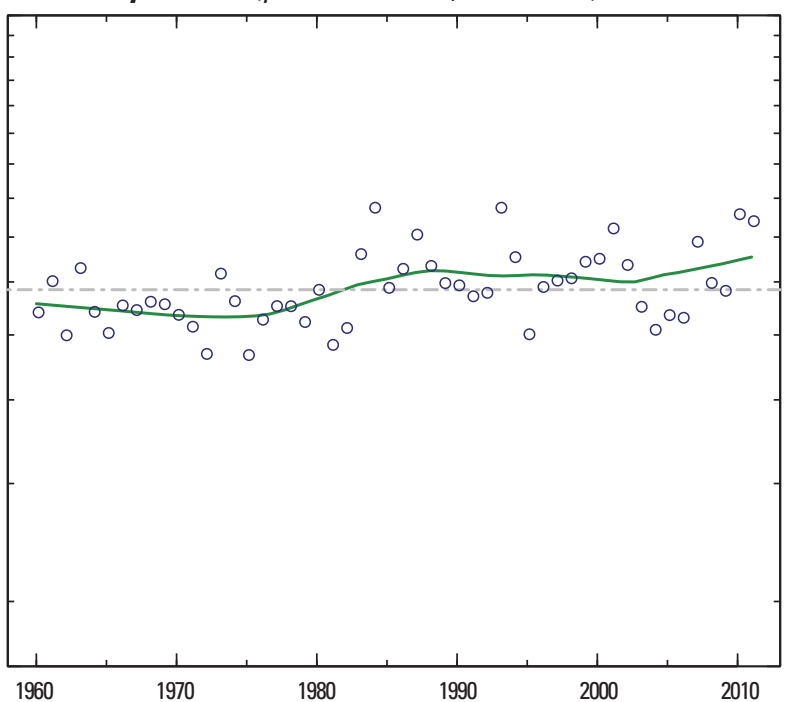

E. July-September $(p$-value $=0.039, \tau=0.1976)$

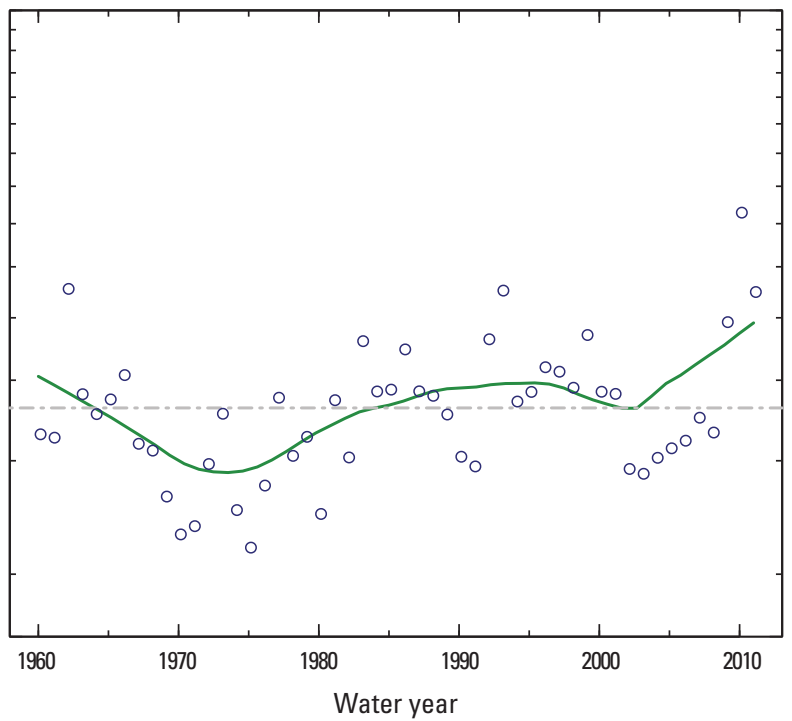

Figure 1-64. North Loup River at Taylor, Nebraska (streamgage 06786000), water years 1960-2011. 

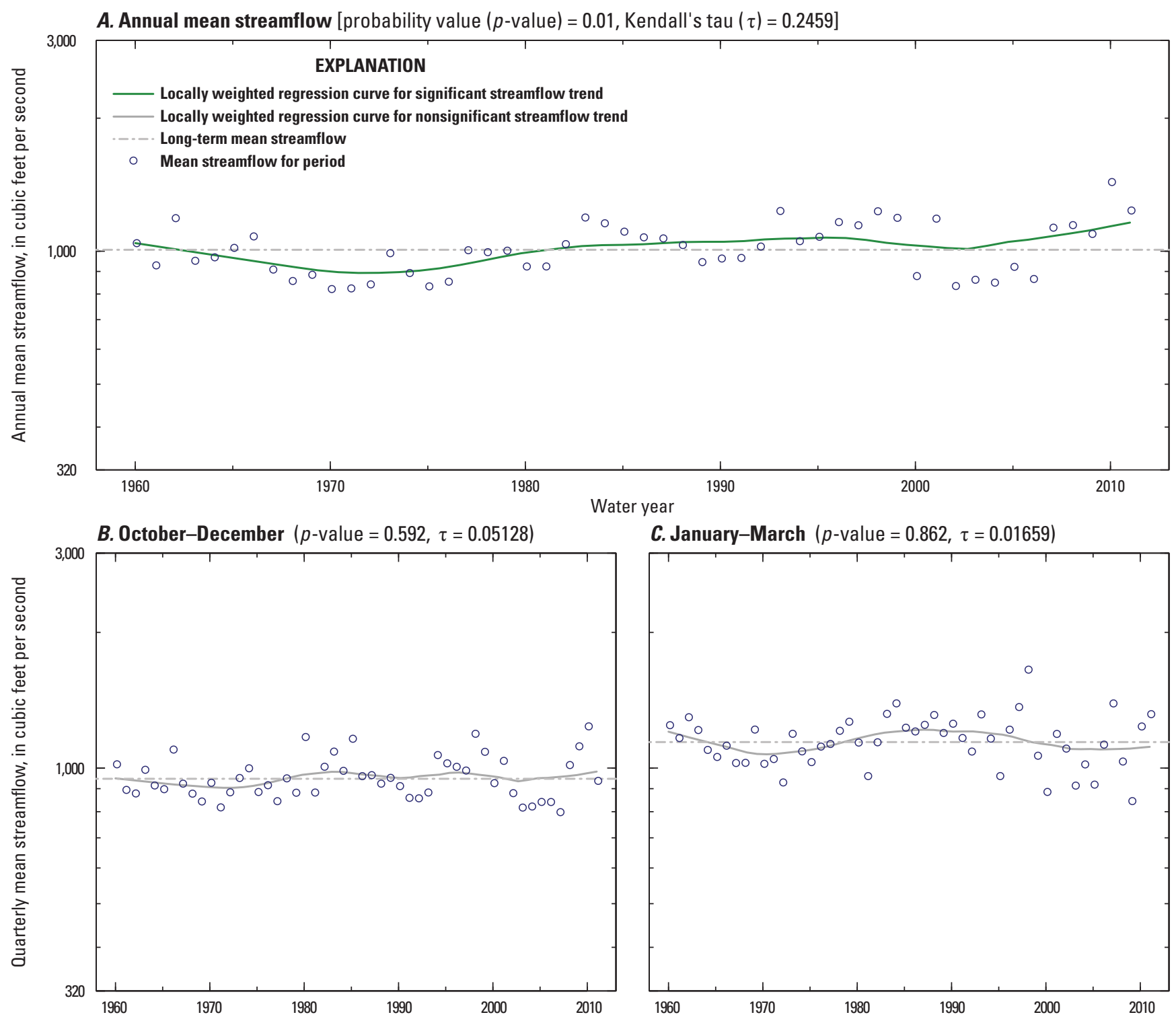

C. January-March $(p$-value $=0.862, \tau=0.01659)$
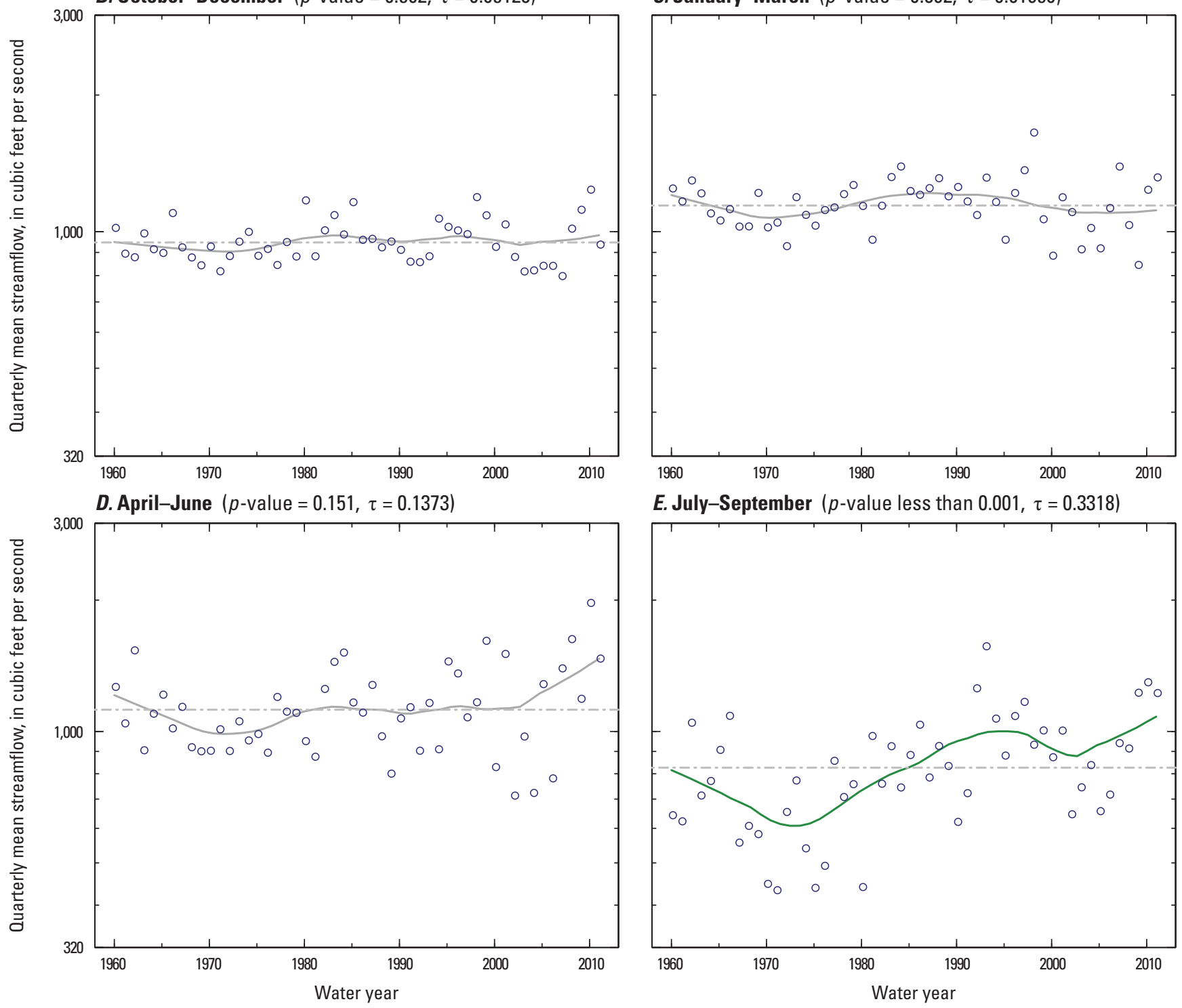

E. July-September ( $p$-value less than 0.001, $\tau=0.3318$ )

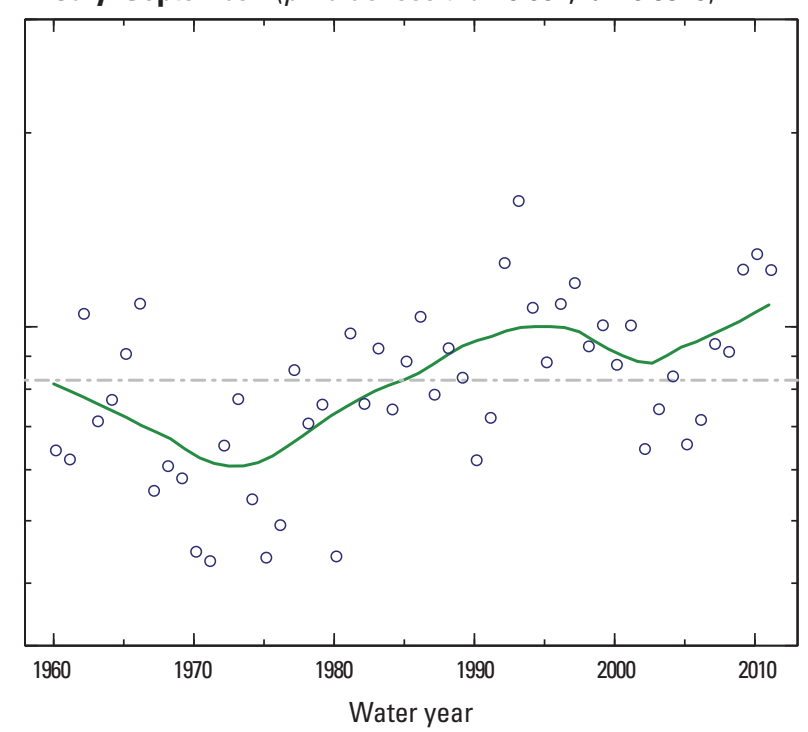

Figure 1-65. North Loup River near Saint Paul, Nebraska (streamgage 06790500), water years 1960-2011. 
A. Annual mean streamflow [probability value ( $p$-value) less than 0.001 , Kendall's tau $(\tau)=0.3620$ ]

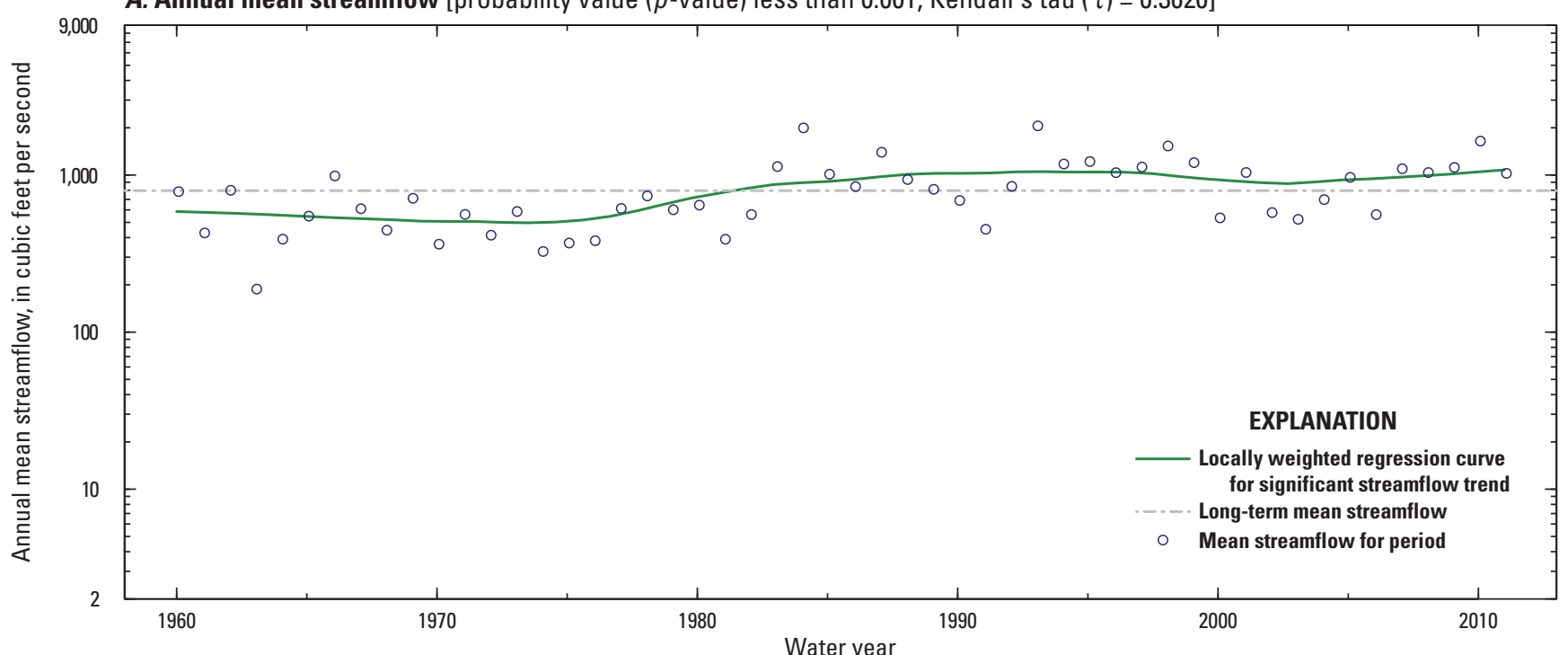

B. October-December ( $p$-value less than 0.001, $\tau=0.3891)$

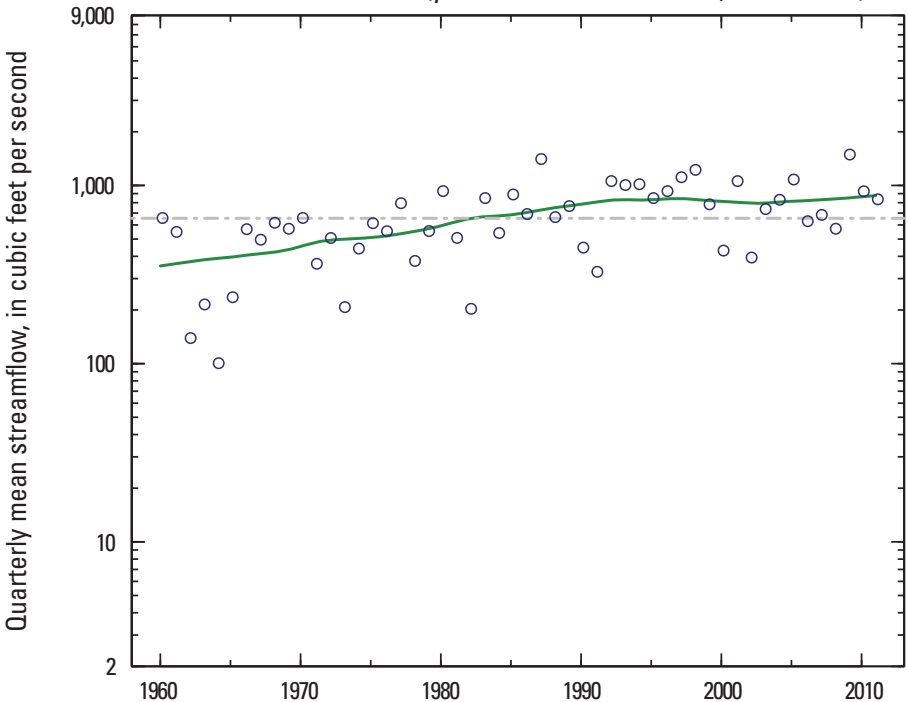

D. April-June $(p$-value $=0.031, \tau=0.2066)$

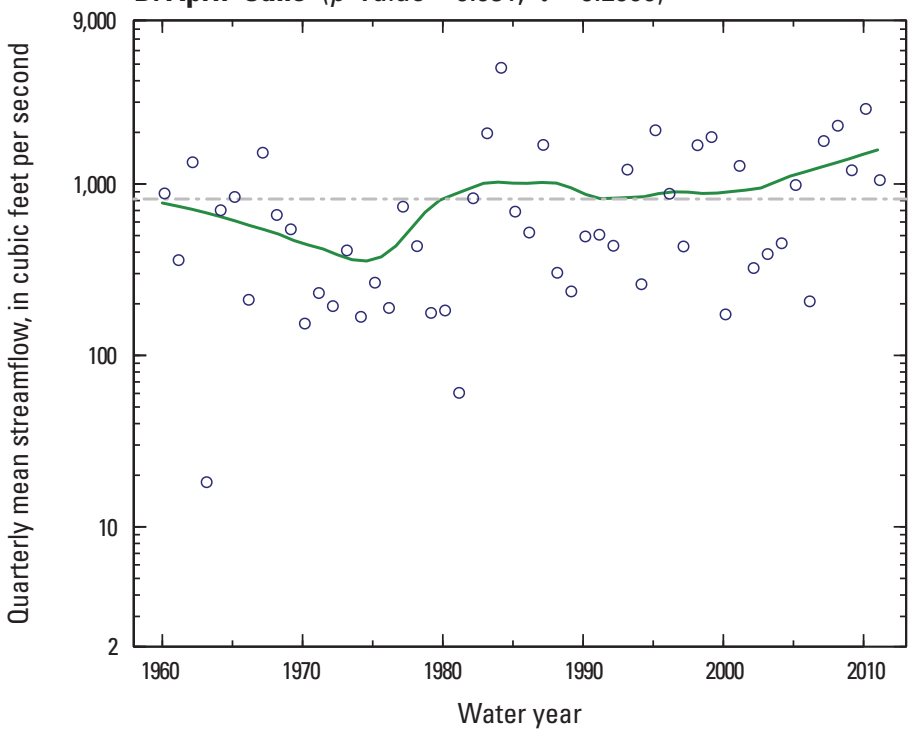

C. January-March $(p$-value $=0.009, \tau=0.2504)$

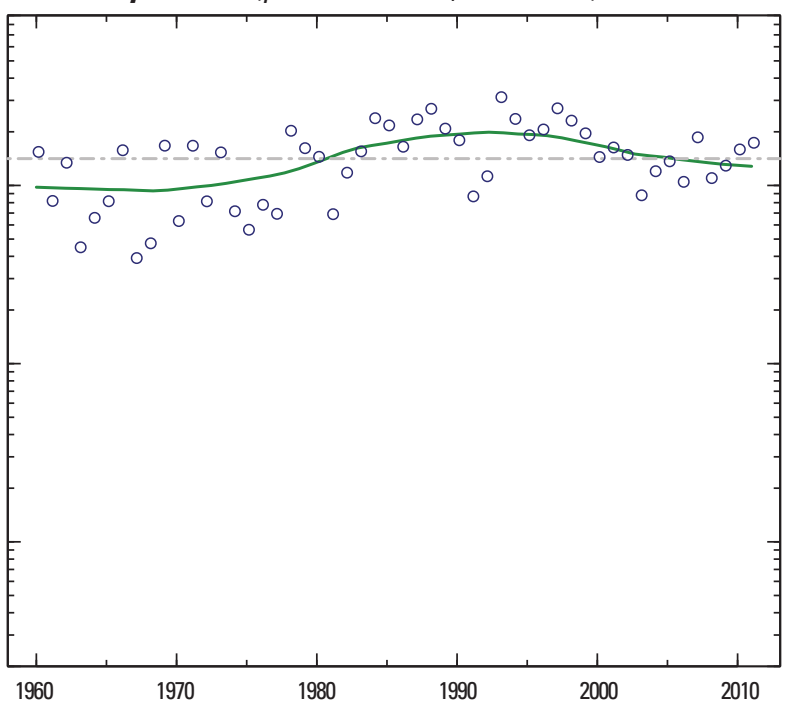

E. July-September ( $p$-value less than 0.001, $\tau=0.3394$ )

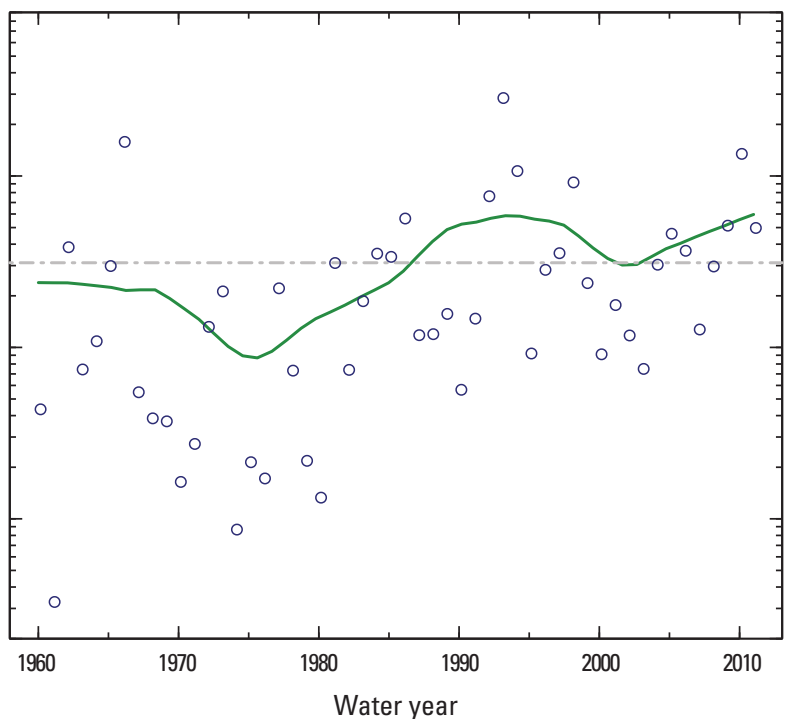

Figure 1-66. Loup River near Genoa, Nebraska (streamgage 06793000), water years 1960-2011. 

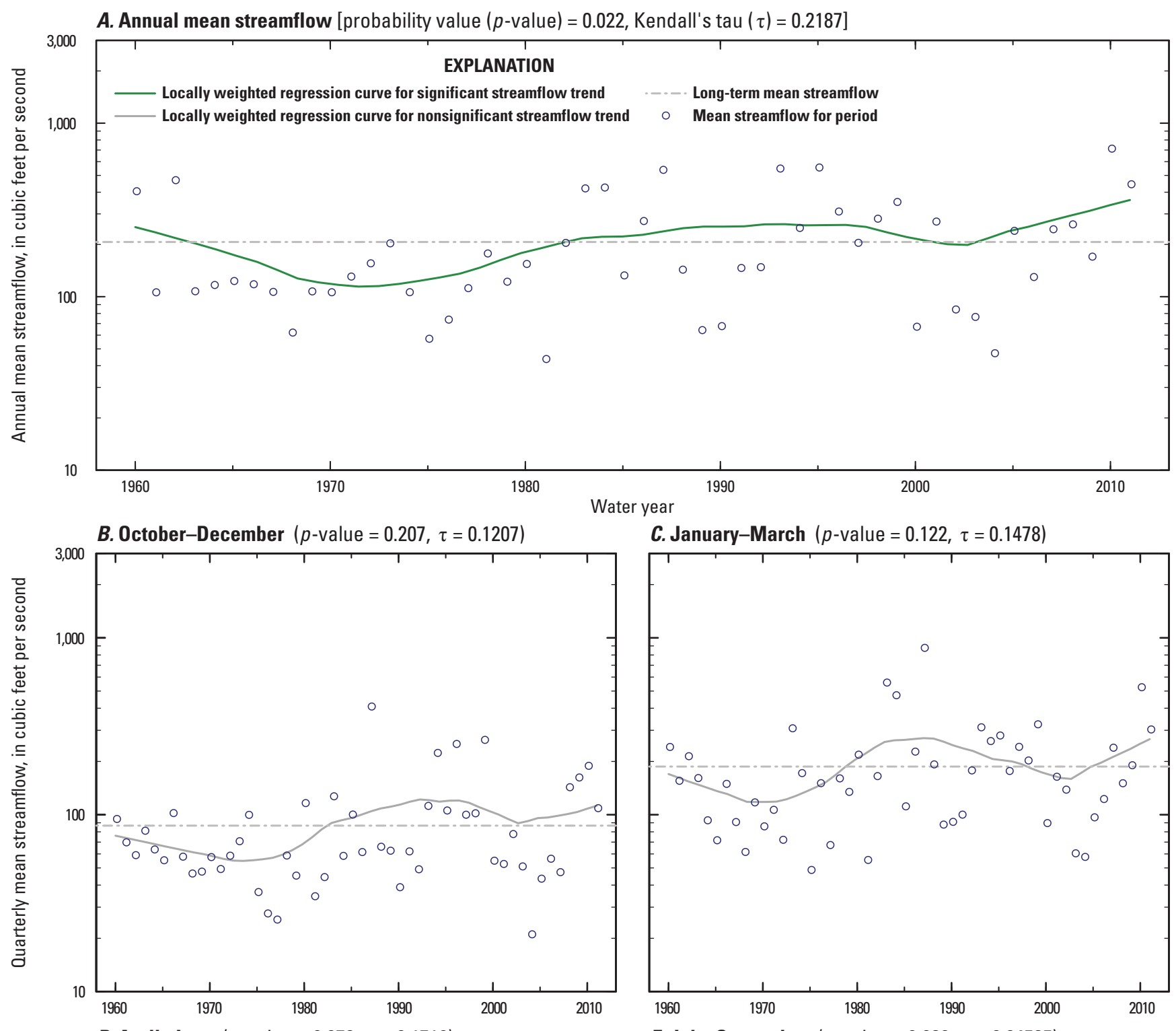

C. January-March ( $p$-value $=0.122, \tau=0.1478)$
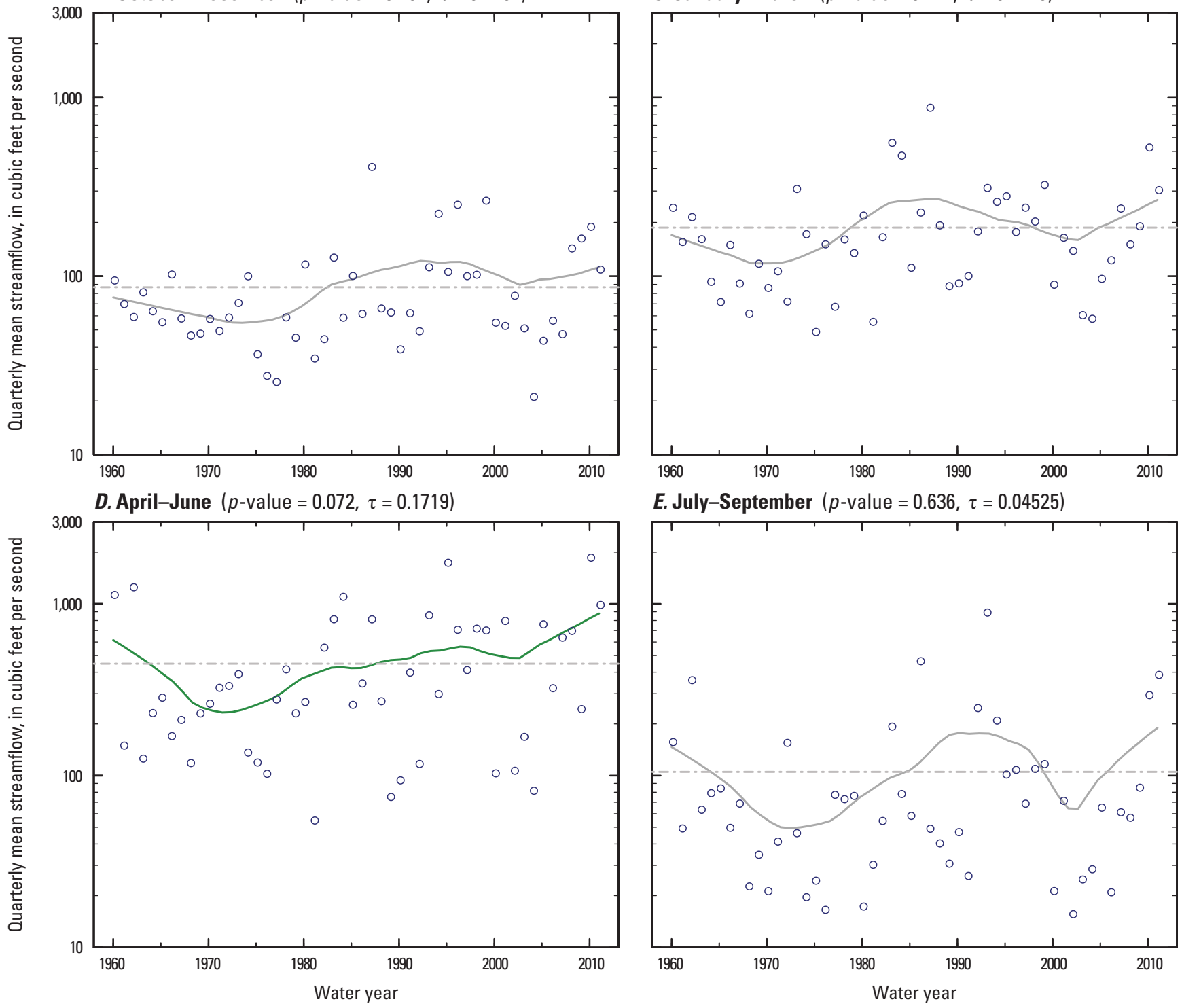

E. July-September $(p$-value $=0.636, \tau=0.04525)$

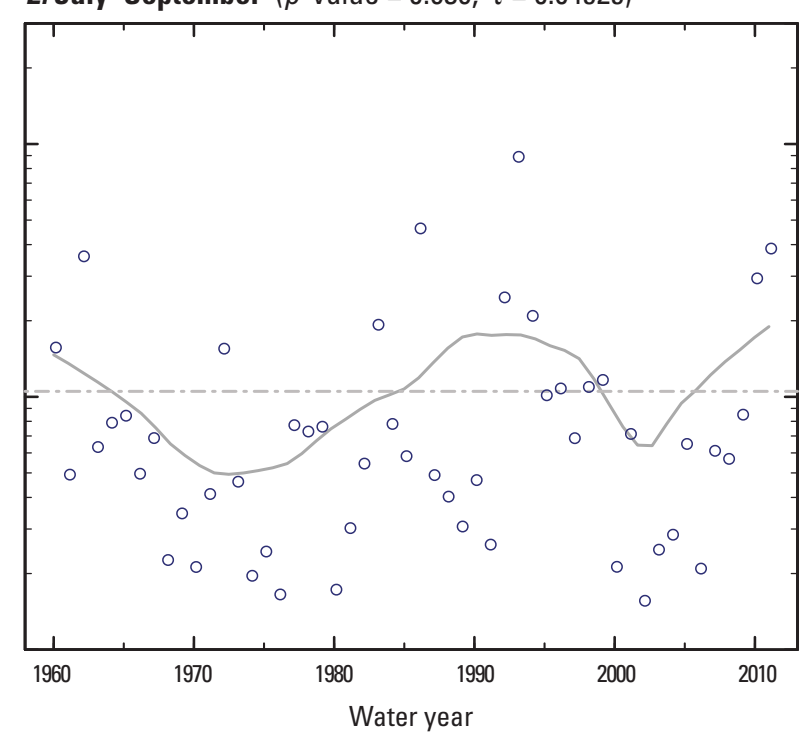

Figure 1-67. Elkhorn River at Ewing, Nebraska (streamgage 06797500), water years 1960-2011. 
A. Annual mean streamflow [probability value ( $p$-value $)=0.051$, Kendall's tau $(\tau)=0.1863$ ]

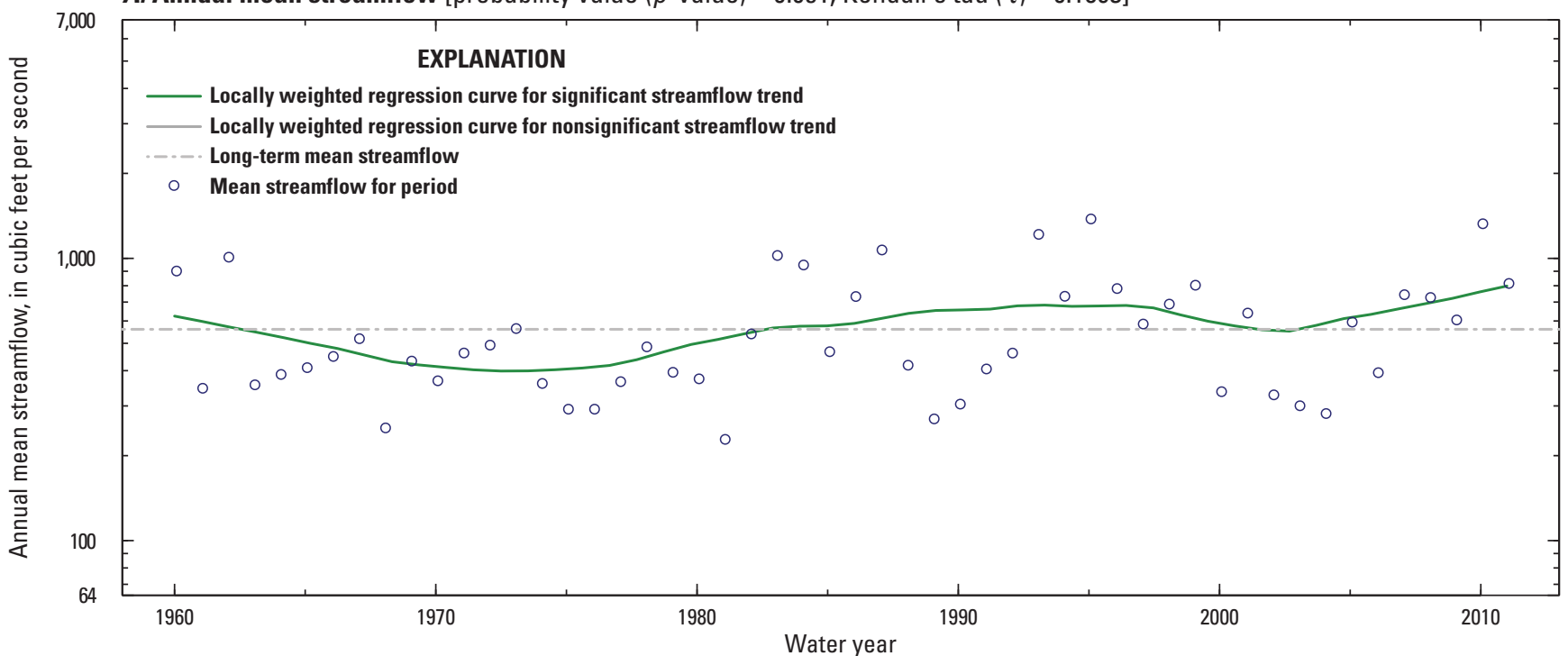

B. October-December ( $p$-value $=0.016, \tau=0.2301)$

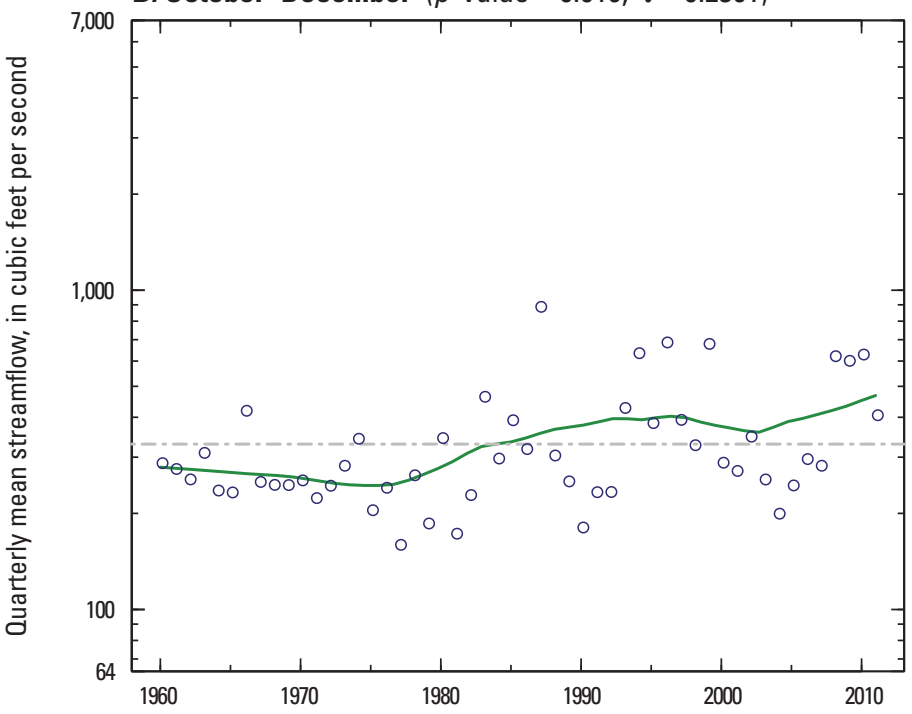

C. January-March ( $p$-value $=0.262, \tau=0.1071)$

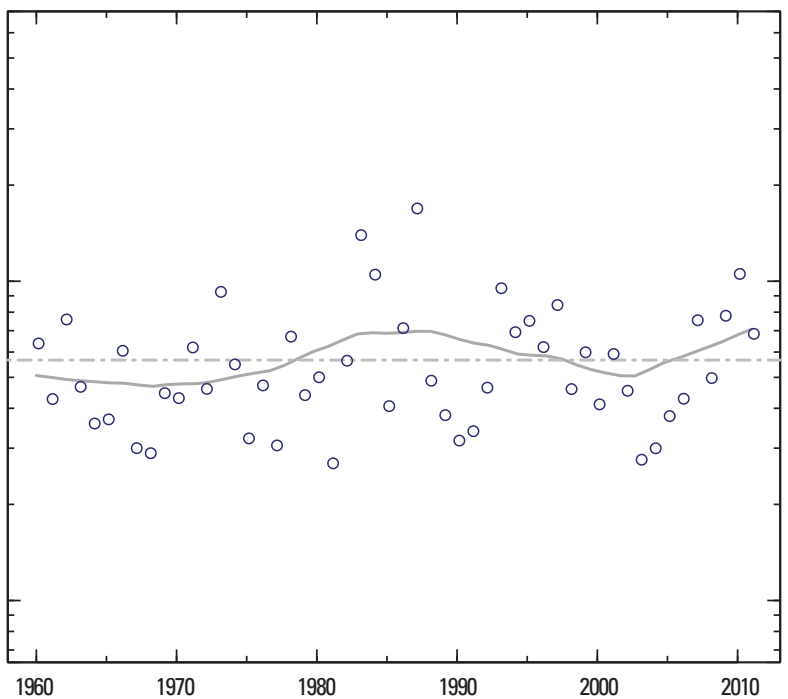

D. April-June $(p$-value $=0.058, \tau=0.1810)$

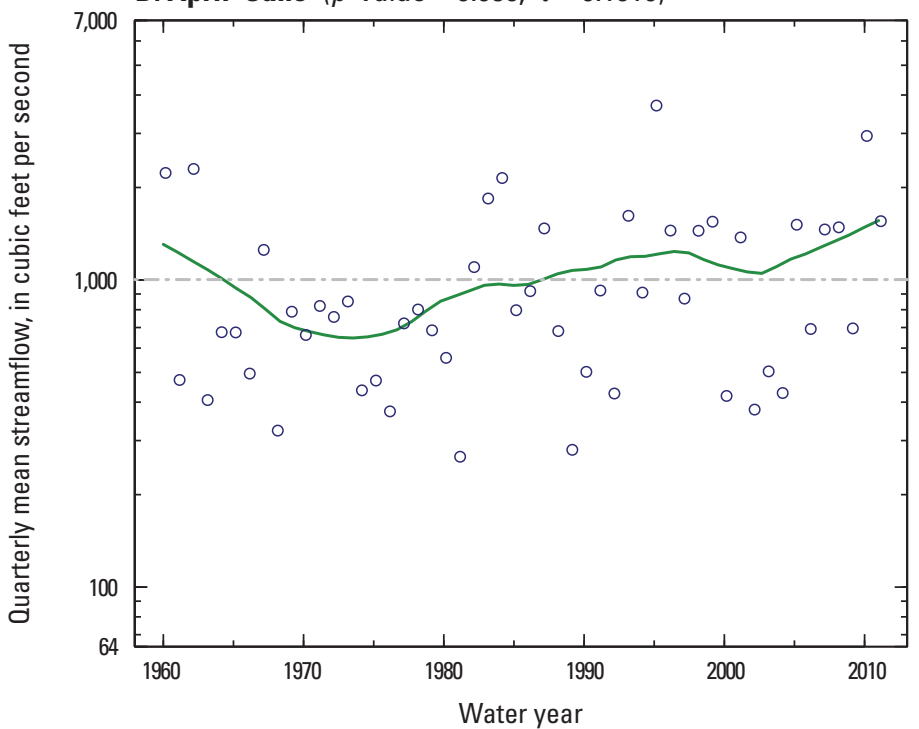

E. July-September $(p$-value $=0.344, \tau=0.0905)$

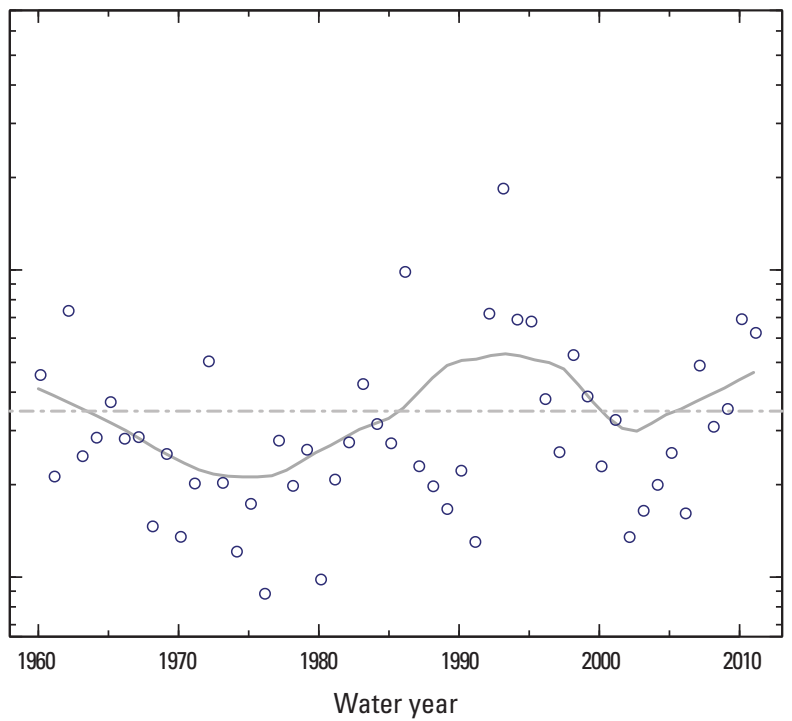

Figure 1-68. Elkhorn River at Norfolk, Nebraska (streamgage 06799000), water years 1960-2011. 
A. Annual mean streamflow [probability value $(p$-value $)=0.052$, Kendall's tau $(\tau)=0.1857$ ]

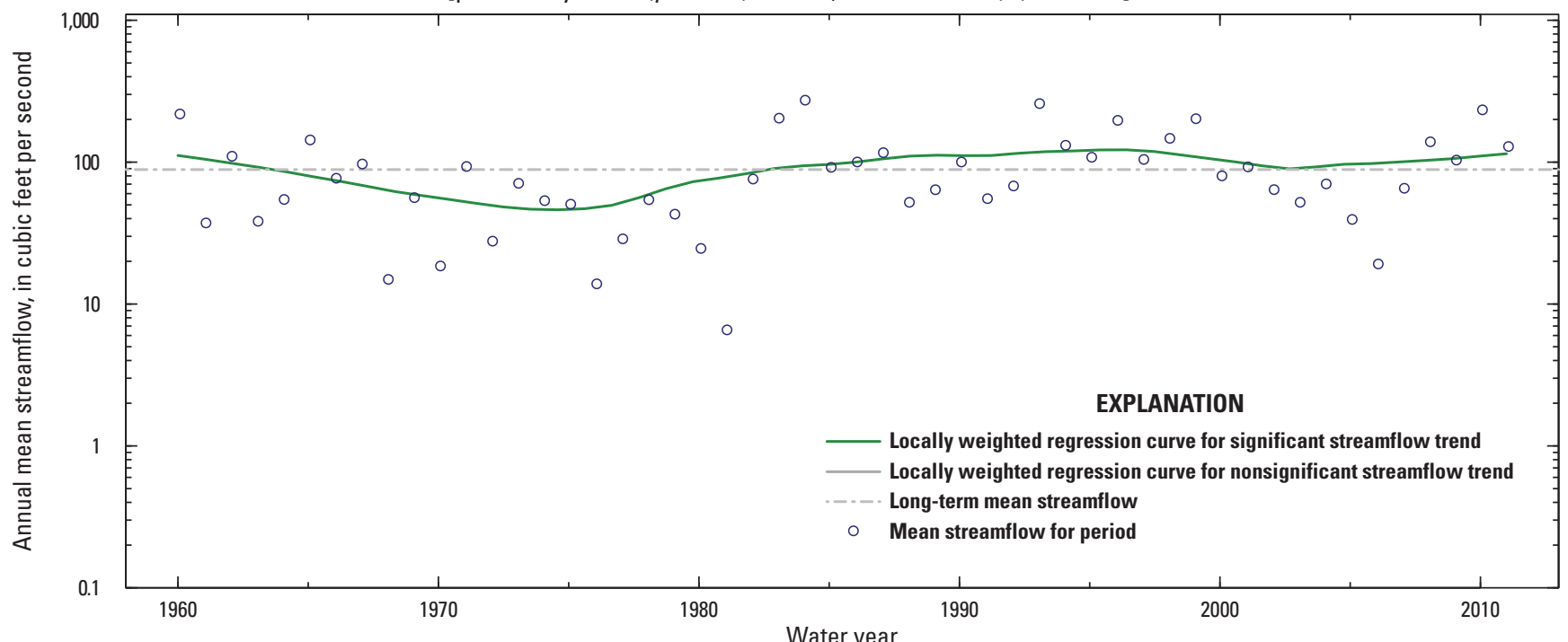

B. October-December $(p$-value $=0.008, \tau=0.2519)$

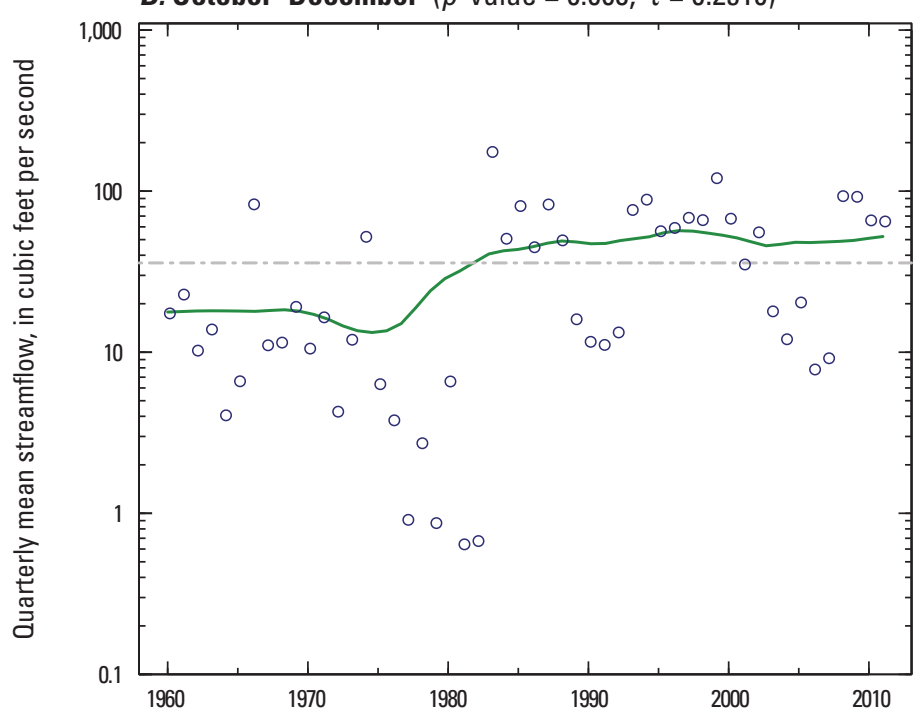

C. January-March $(p$-value $=0.74, \tau=0.03167)$

D. April-June $(p$-value $=0.085, \tau=0.1644)$
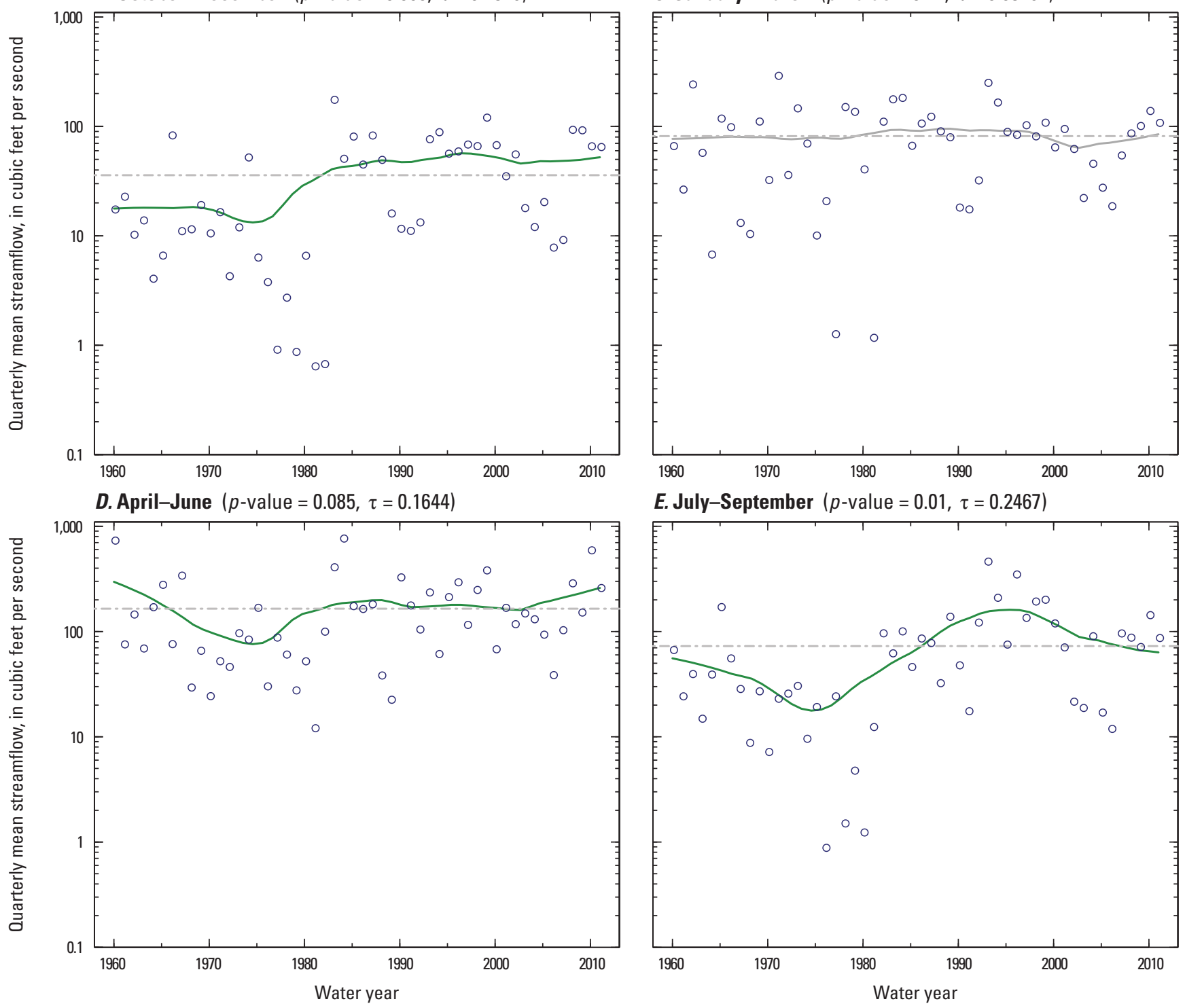

E. July-September $(p$-value $=0.01, \tau=0.2467)$

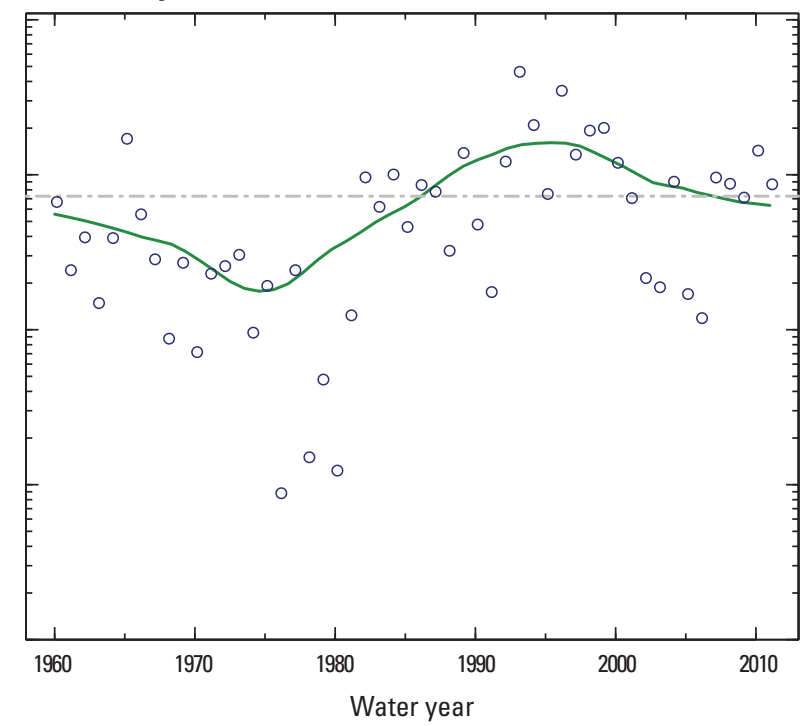

Figure 1-69. Maple Creek near Nickerson, Nebraska (streamgage 06800000), water years 1960-2011. 
A. Annual mean streamflow [probability value ( $p$-value $)=0.051$, Kendall's tau $(\tau)=0.1863$ ]
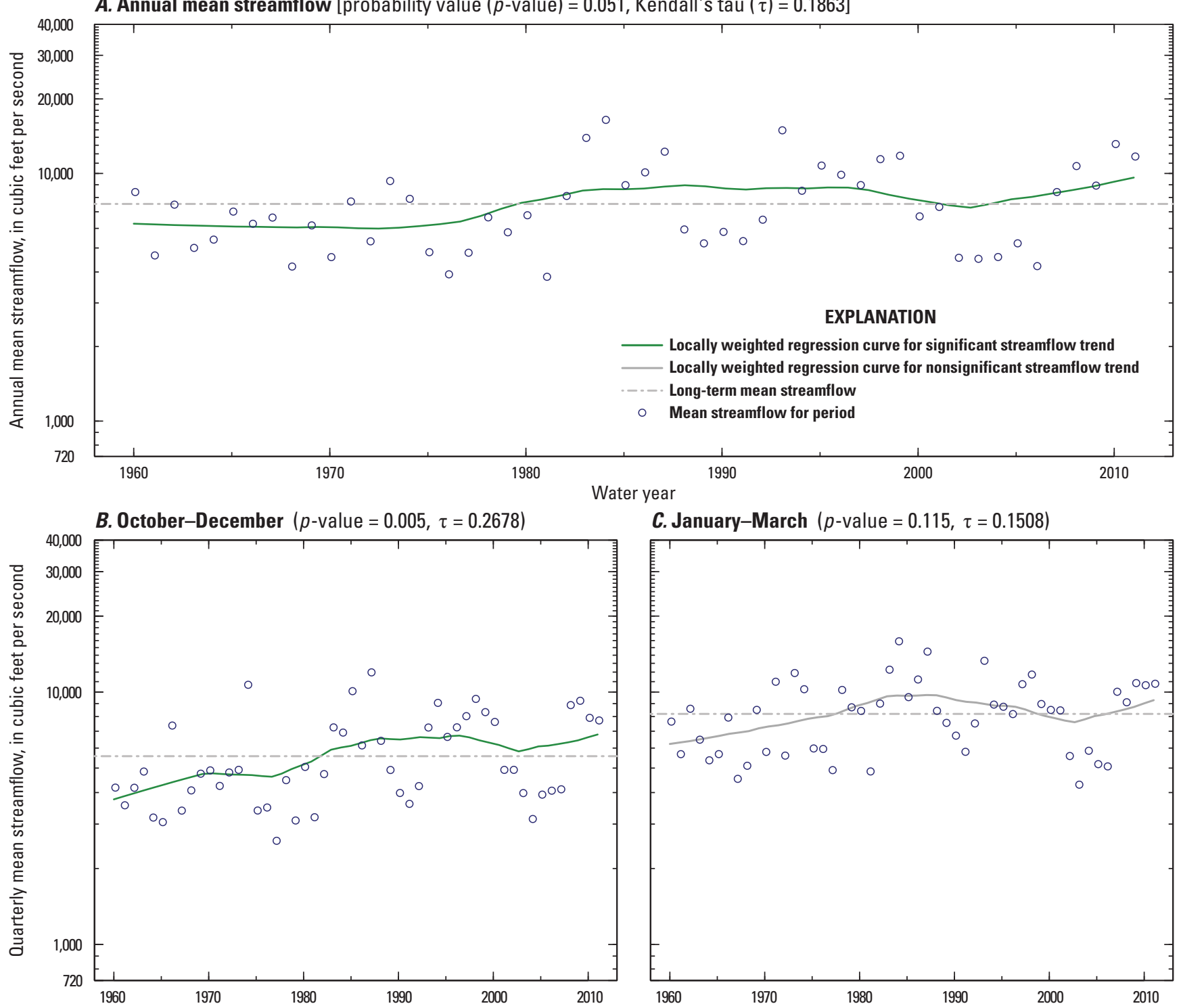

C. January-March $(p$-value $=0.115, \tau=0.1508)$

D. April-June $(p$-value $=0.16, \tau=0.1342)$
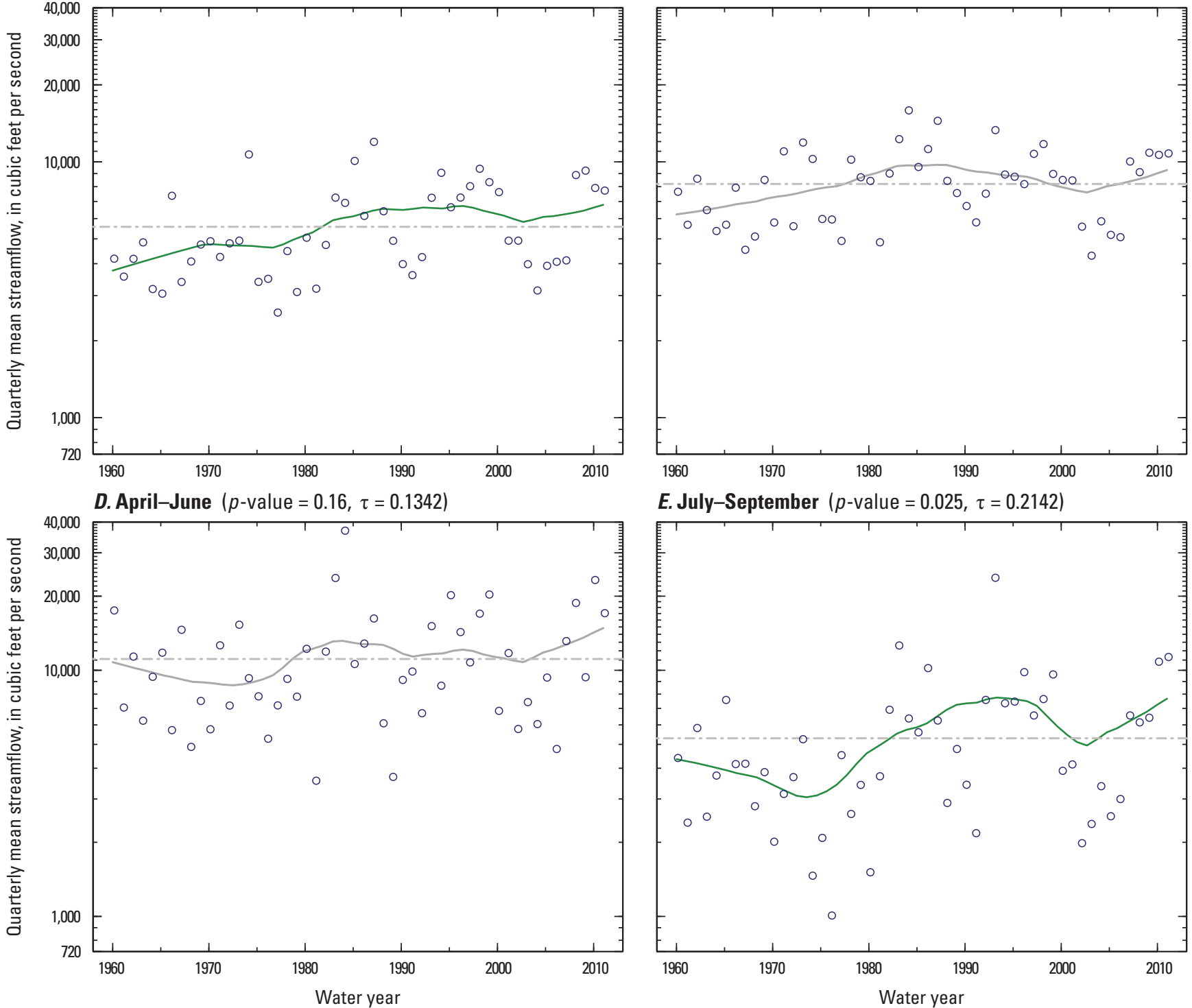

E. July-September $(p$-value $=0.025, \tau=0.2142)$

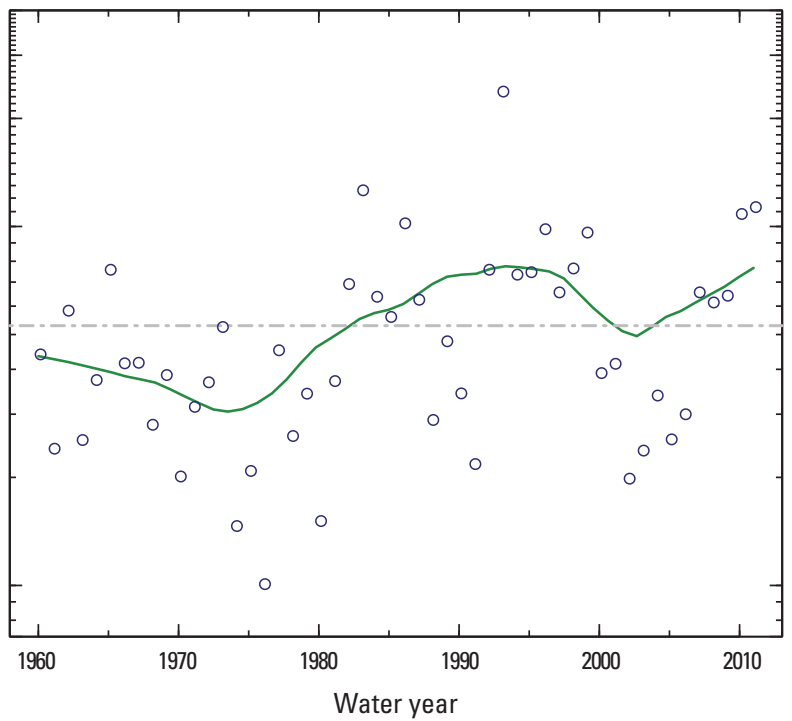

Figure 1-70. Platte River at Louisville, Nebraska (streamgage 06805500), water years 1960-2011. 

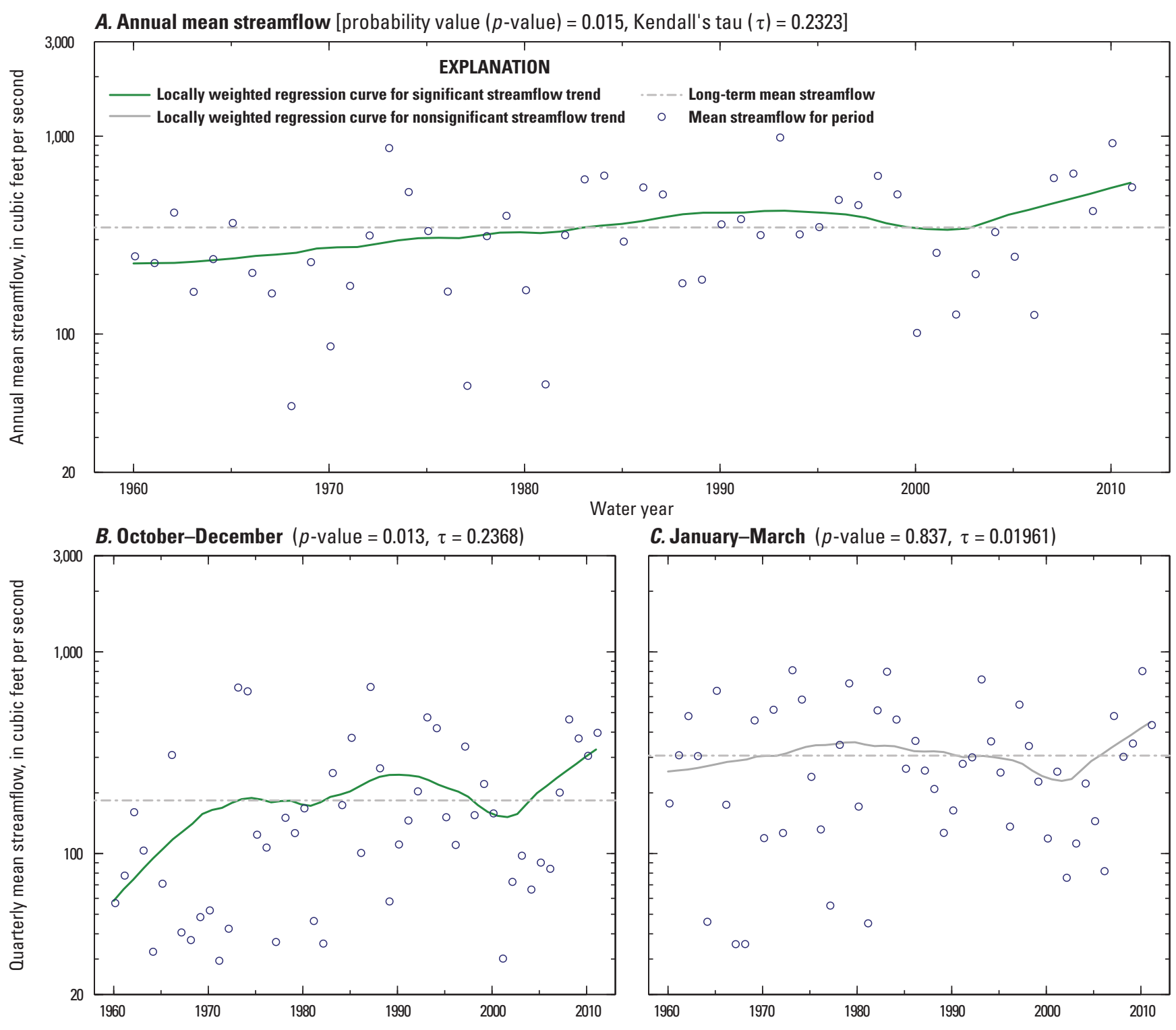

C. January-March $(p$-value $=0.837, \tau=0.01961)$
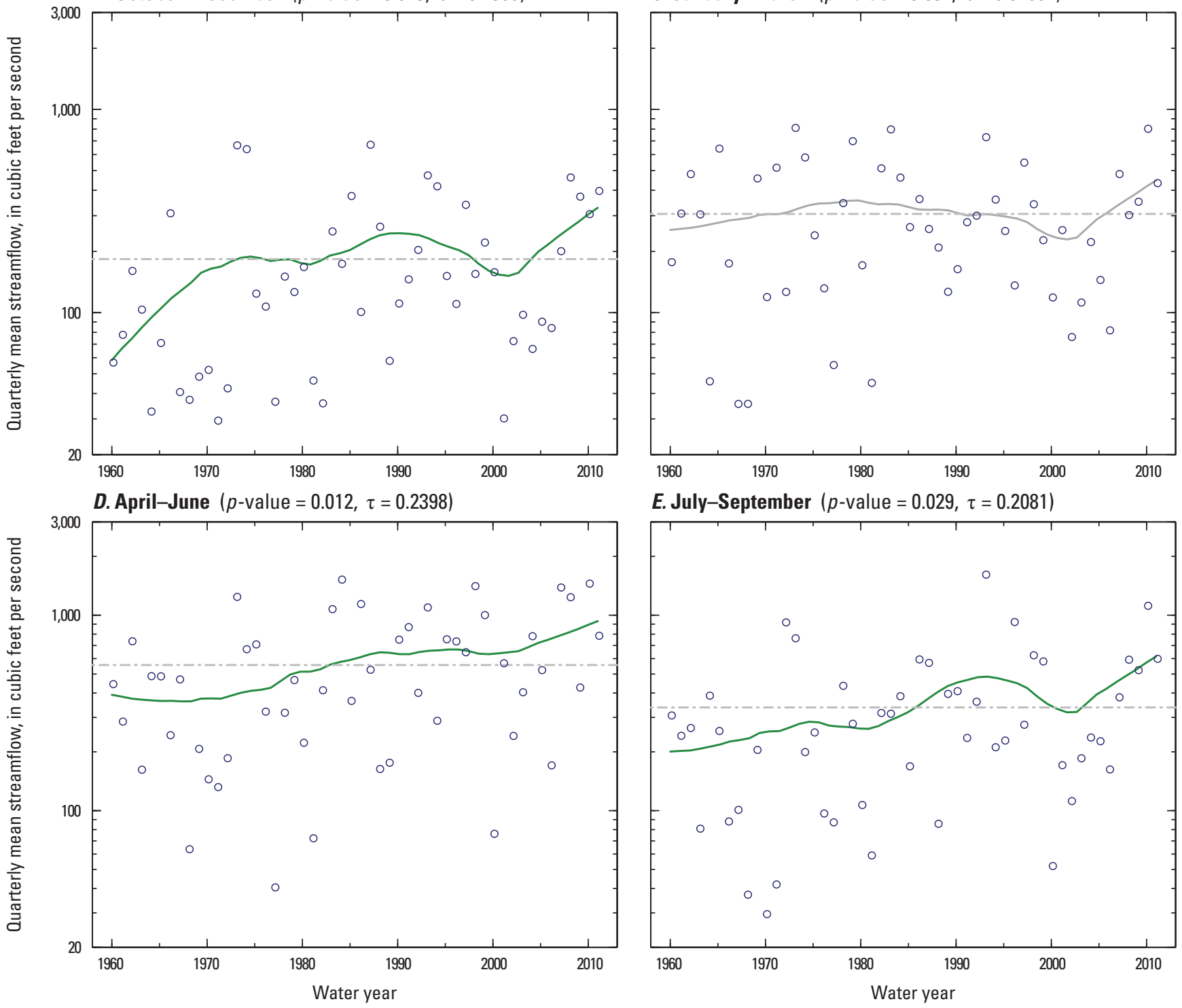

E. July-September $(p$-value $=0.029, \tau=0.2081)$

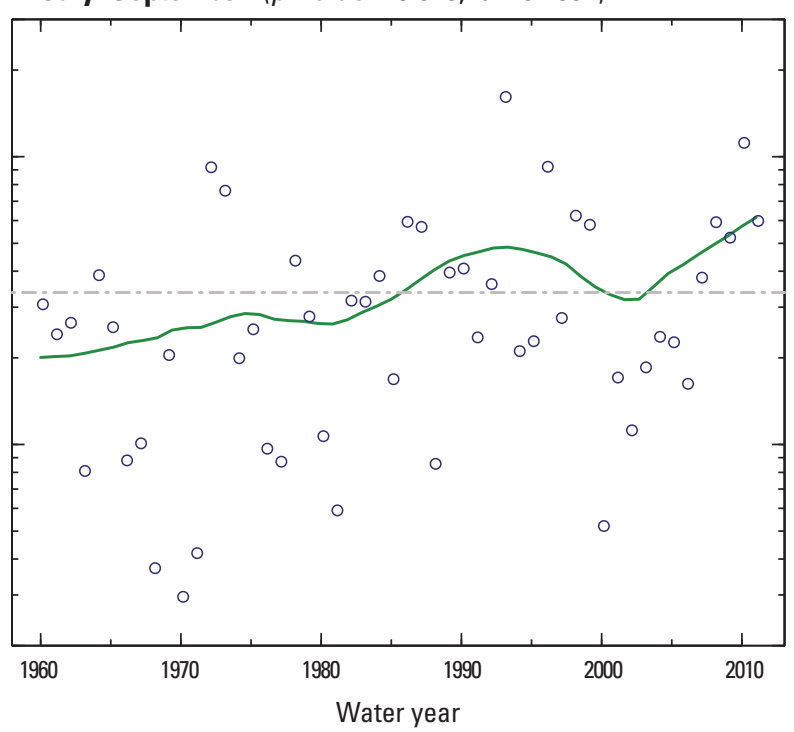

Figure 1-71. West Nishnabotna River at Hancock, lowa (streamgage 06807410), water years 1960-2011. 
A. Annual mean streamflow [probability value ( $p$-value $)=0.029$, Kendall's tau $(\tau)=0.2081$ ]
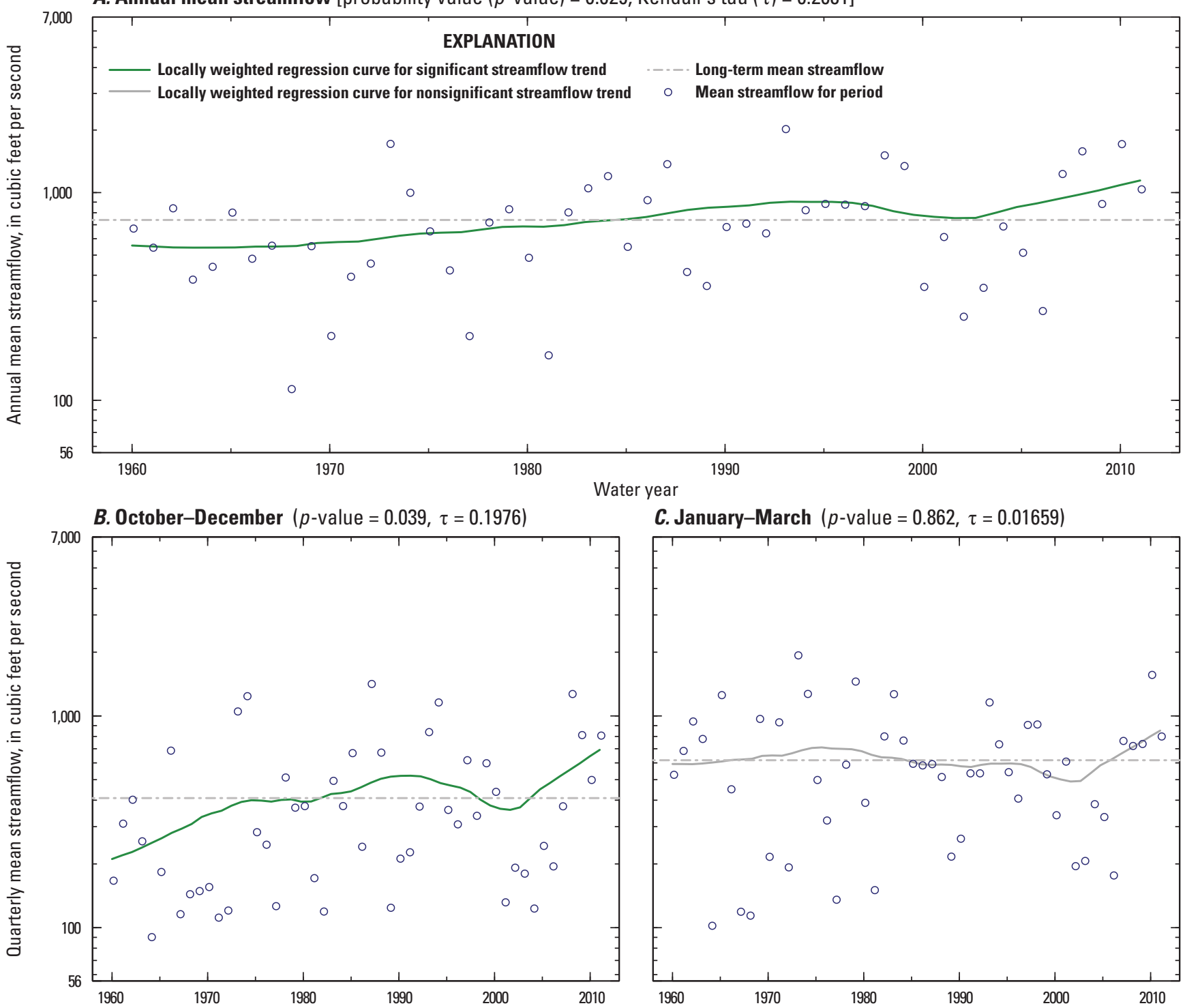

C. January-March ( $p$-value $=0.862, \tau=0.01659)$

D. April-June $(p$-value $=0.021, \tau=0.2202)$
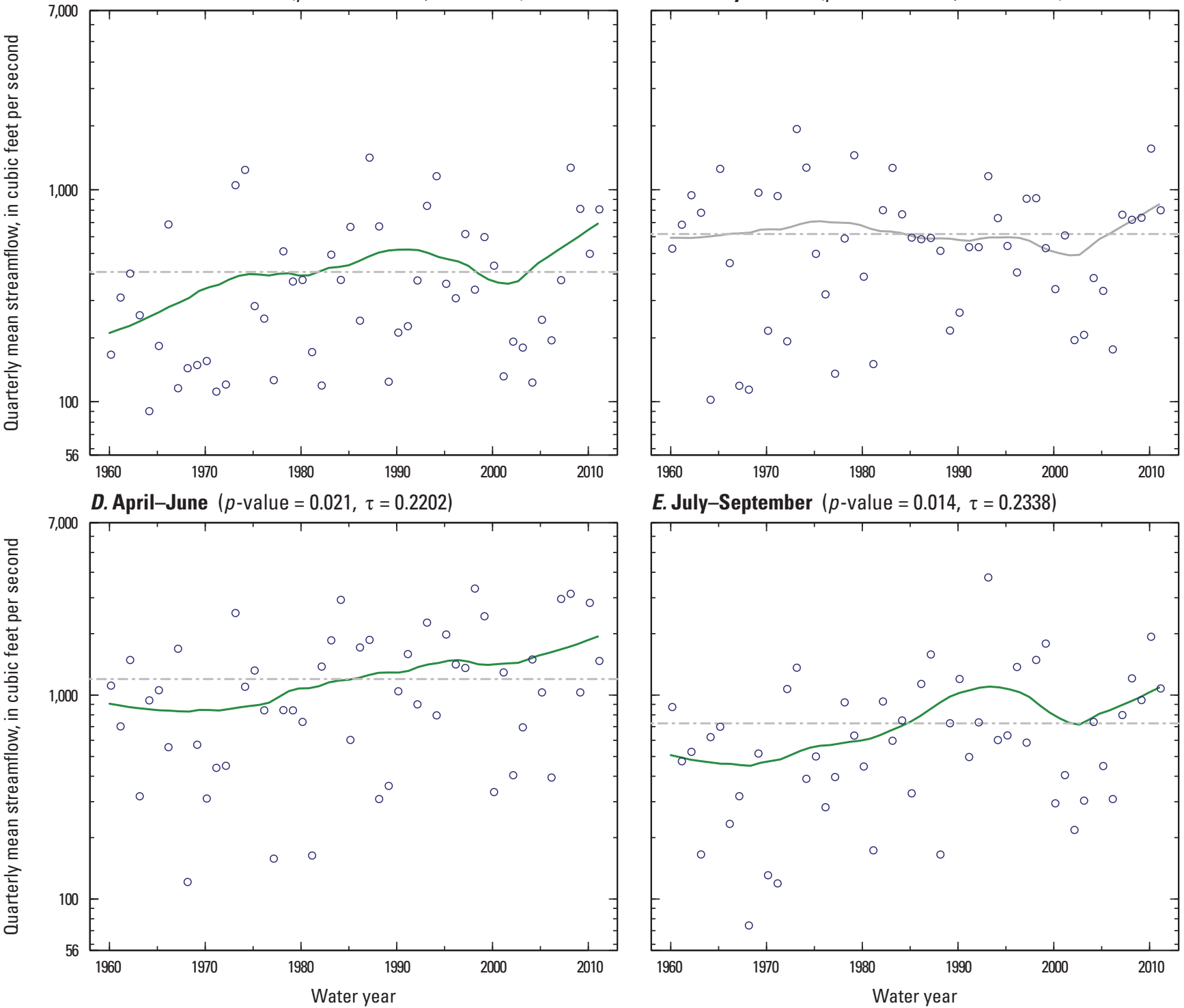

E. July-September $(p$-value $=0.014, \tau=0.2338)$

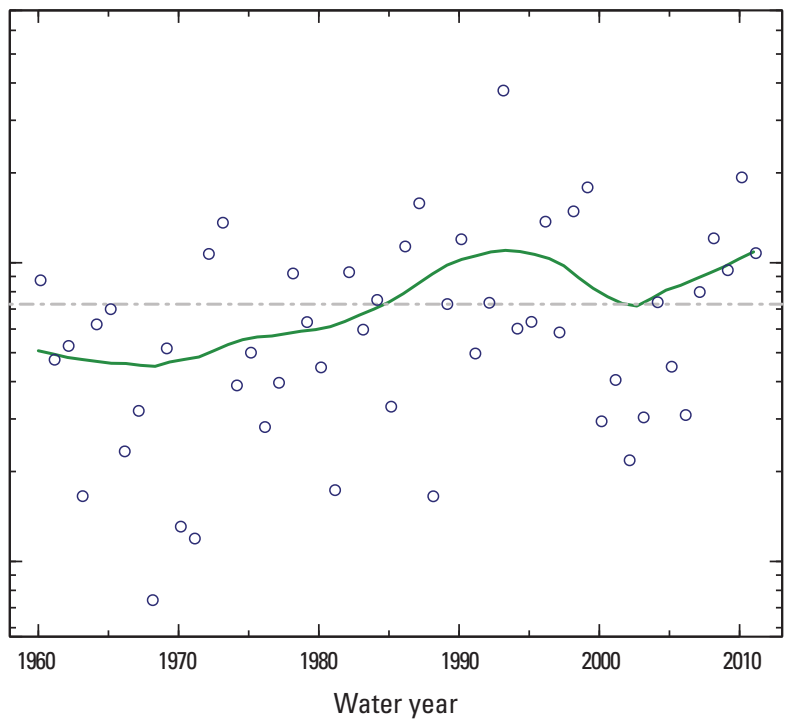

Figure 1-72. West Nishnabotna River at Randolph, lowa (streamgage 06808500), water years 1960-2011. 
A. Annual mean streamflow [probability value $(p$-value $)=0.032$, Kendall's tau $(\tau)=0.2051$ ]
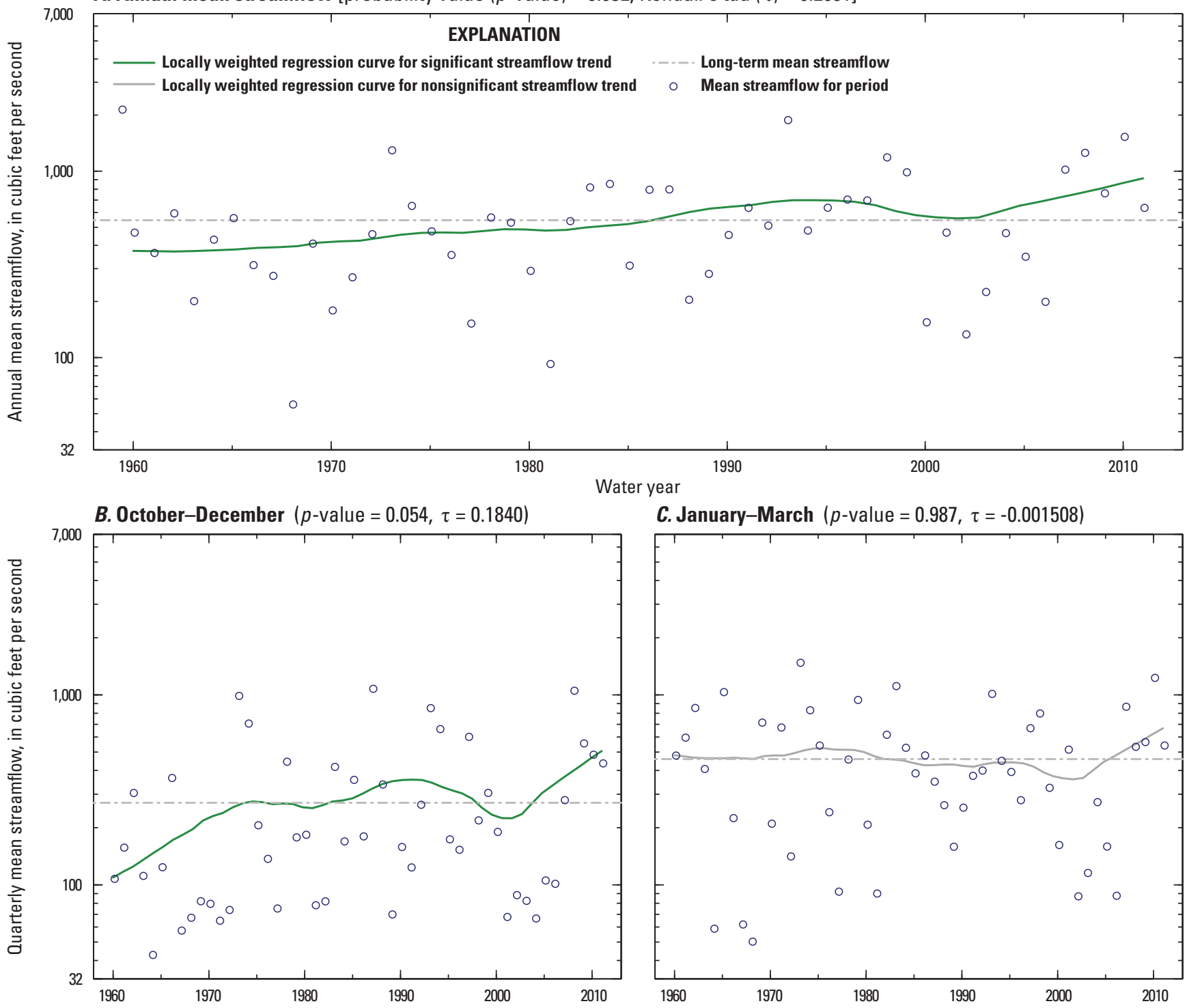

C. January-March ( $p$-value $=0.987, \tau=-0.001508)$

D. April-June $(p$-value $=0.005, \tau=0.2655)$
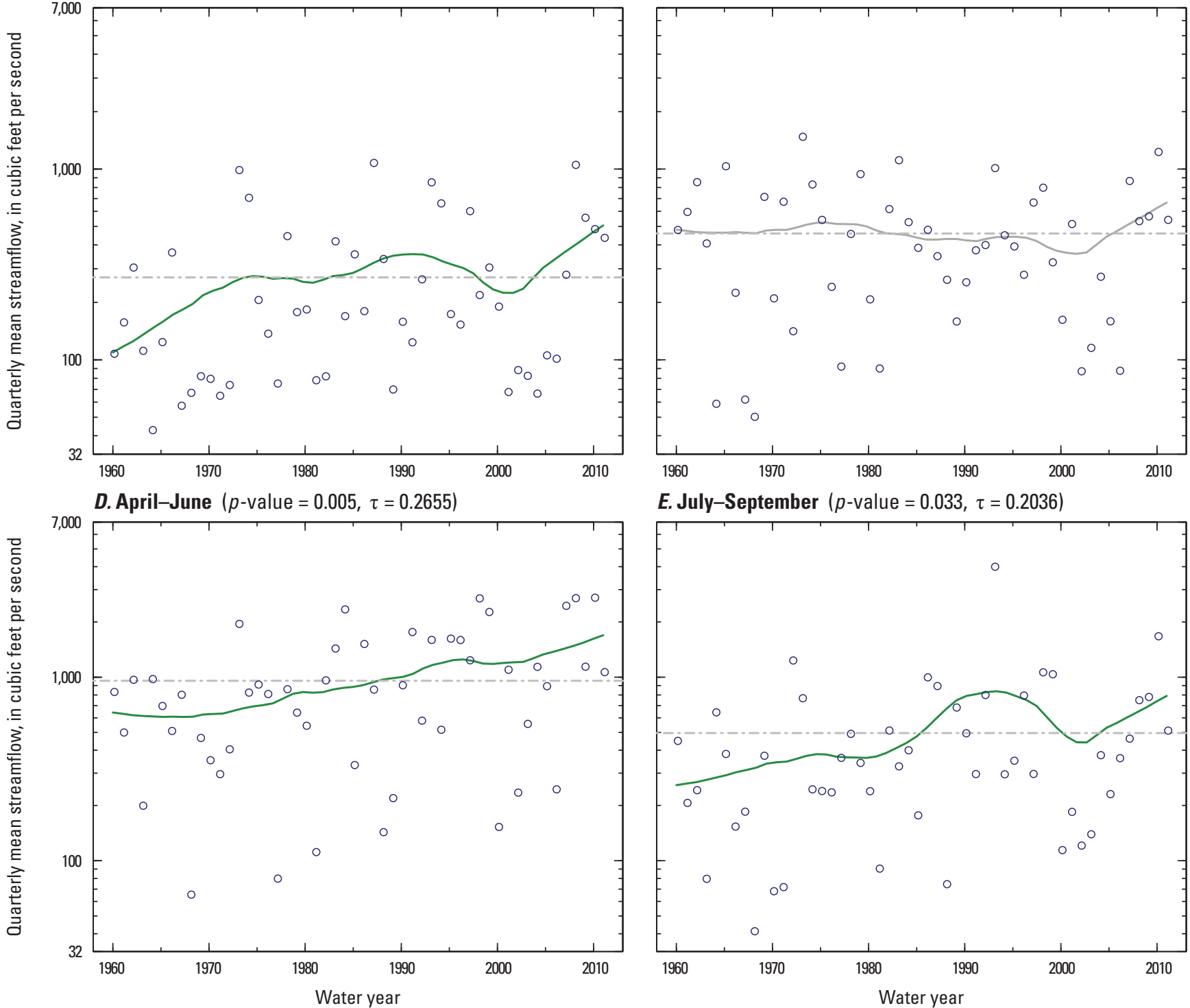

E. July-September $(p$-value $=0.033, \tau=0.2036)$

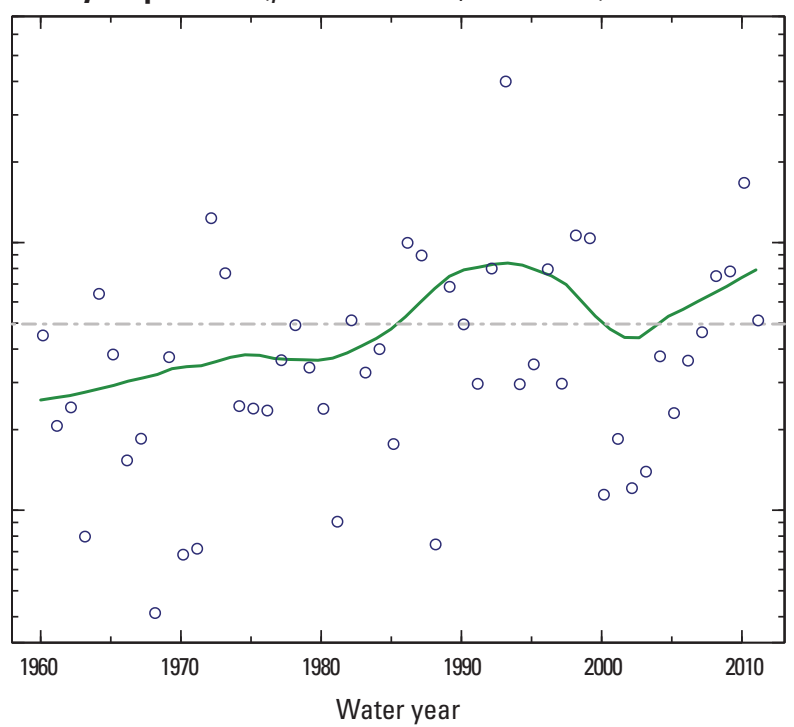

Figure 1-73. East Nishnabotna River at Red Oak, lowa (streamgage 06809500), water years 1960-2011. 
A. Annual mean streamflow [probability value ( $p$-value $)=0.035$, Kendall's tau $(\tau)=0.2014$ ]
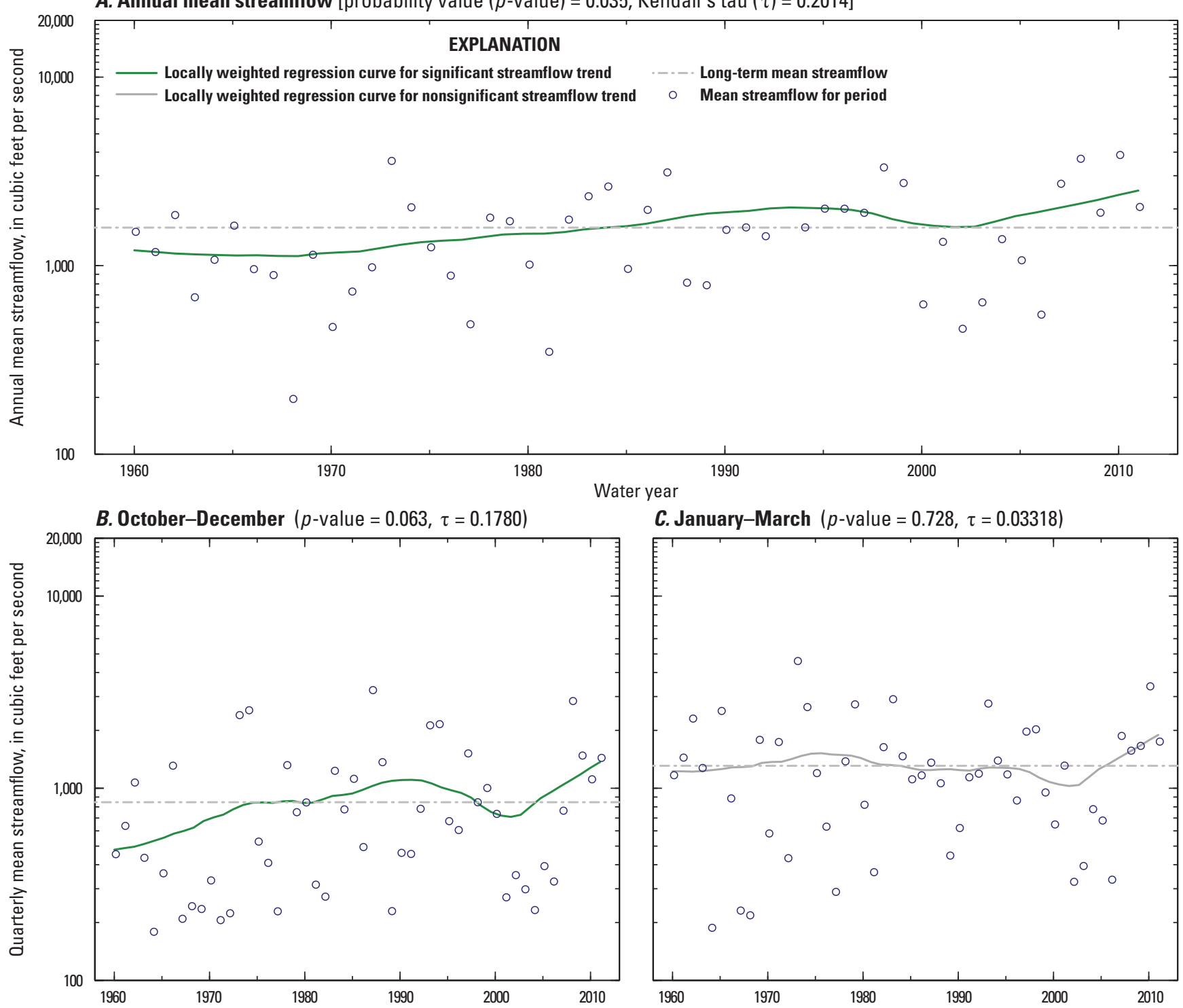

C. January-March ( $p$-value $=0.728, \tau=0.03318)$

D. April-June $(p$-value $=0.015, \tau=0.2323)$
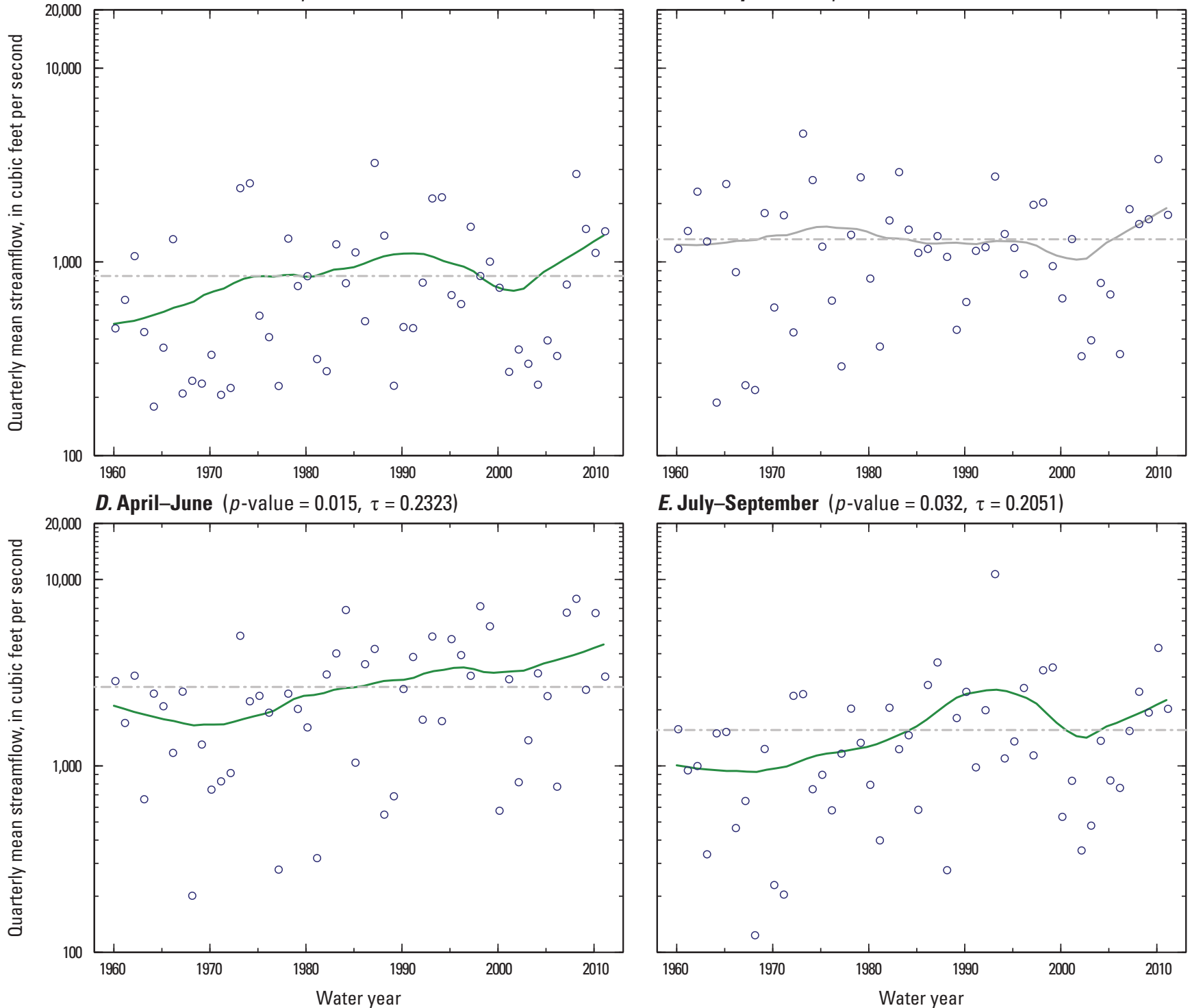

E. July-September $(p$-value $=0.032, \tau=0.2051)$

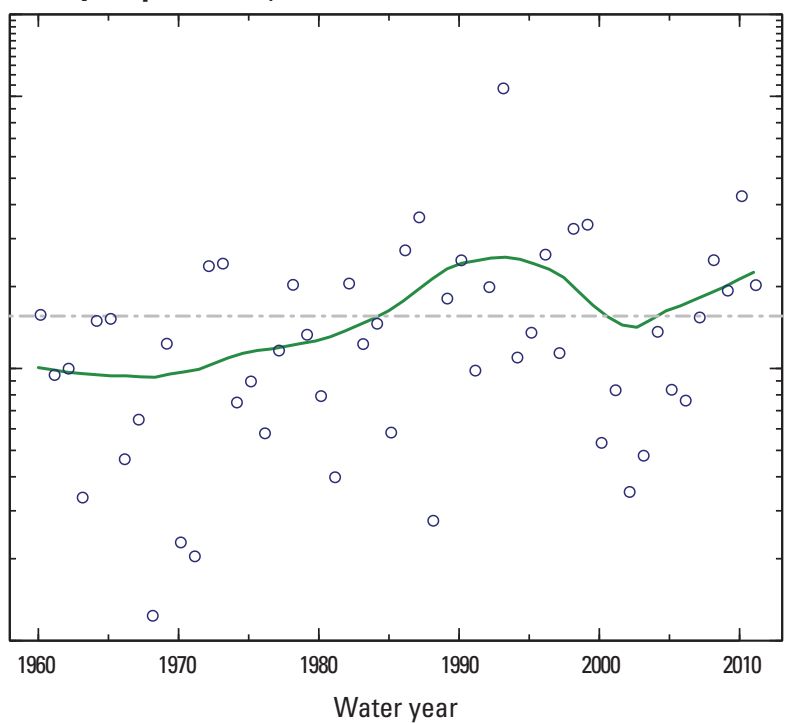

Figure 1-74. Nishnabotna River above Hamburg, lowa (streamgage 06810000), water years 1960-2011. 


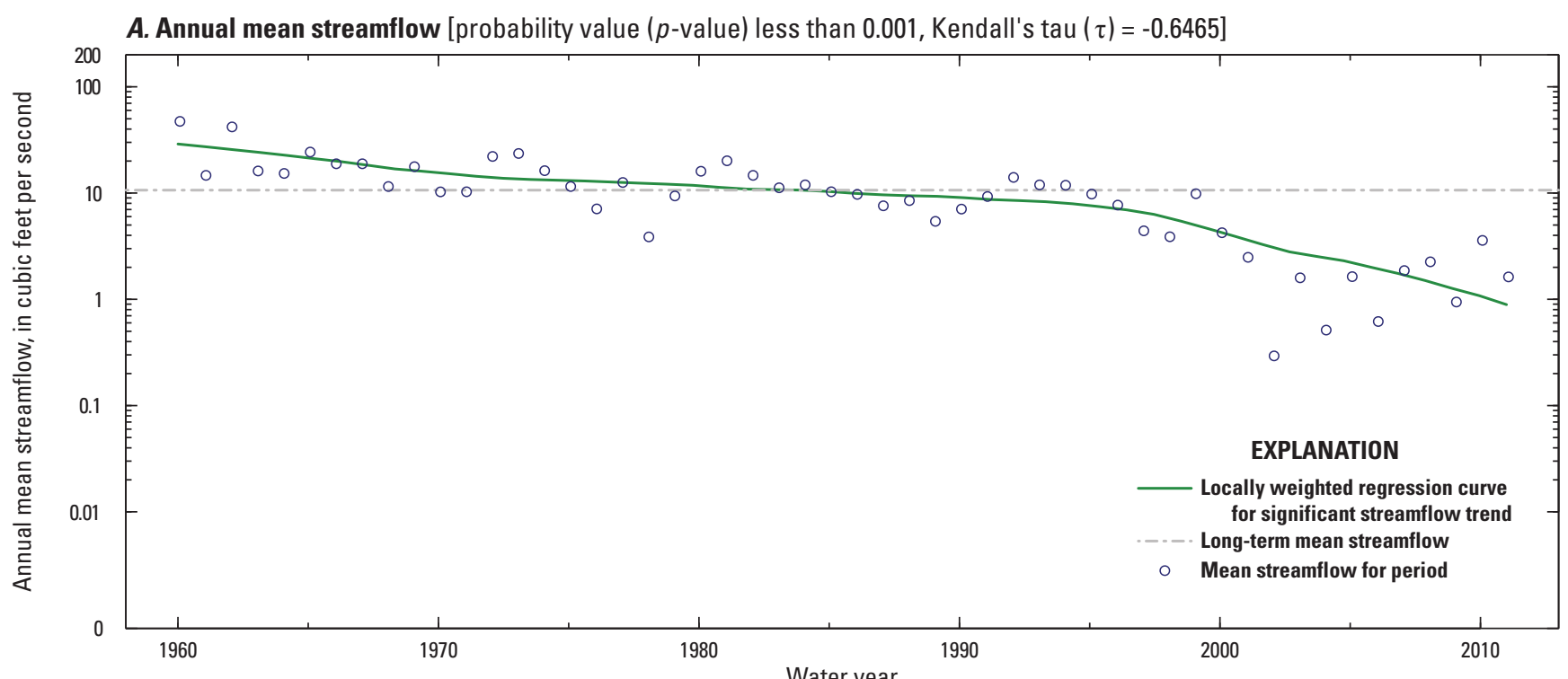

B. October-December ( $p$-value less than 0.001, $\tau=-0.5394)$

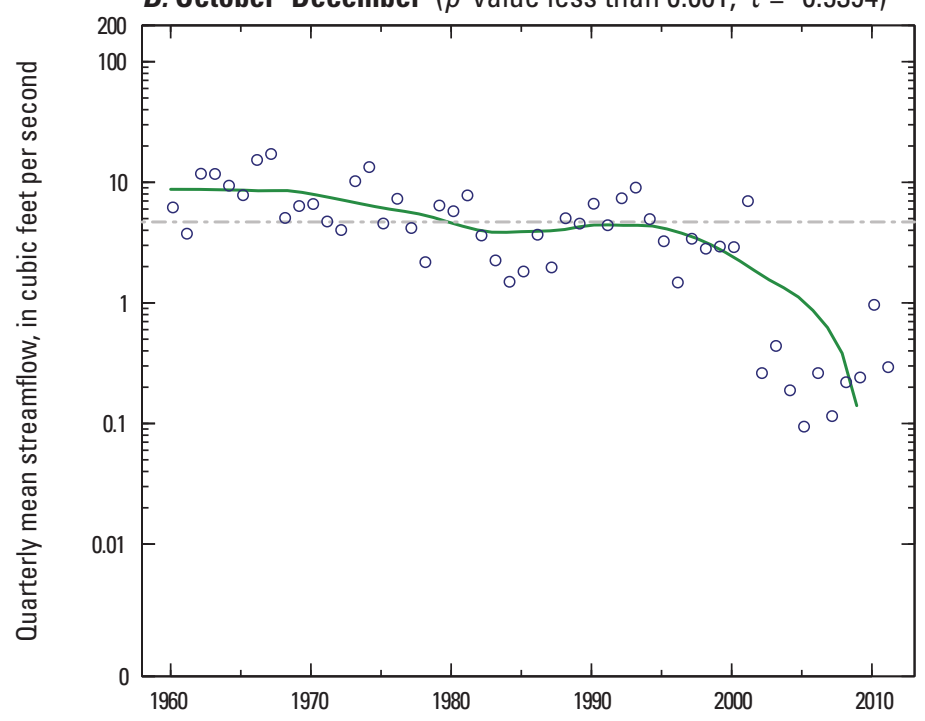

C. January-March ( $p$-value less than $0.001, \tau=-0.5364)$
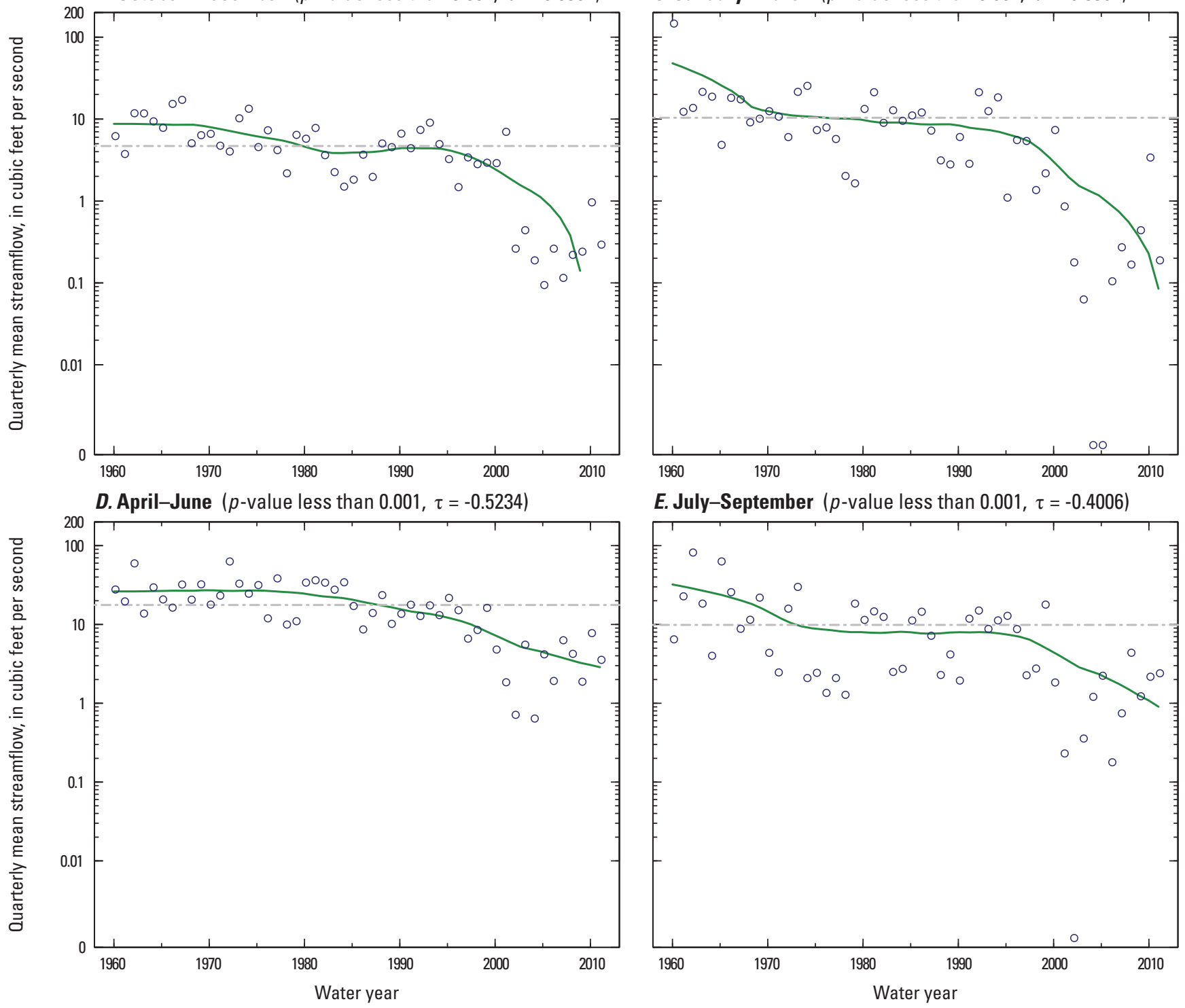

E. July-September ( $p$-value less than 0.001, $\tau=-0.4006)$

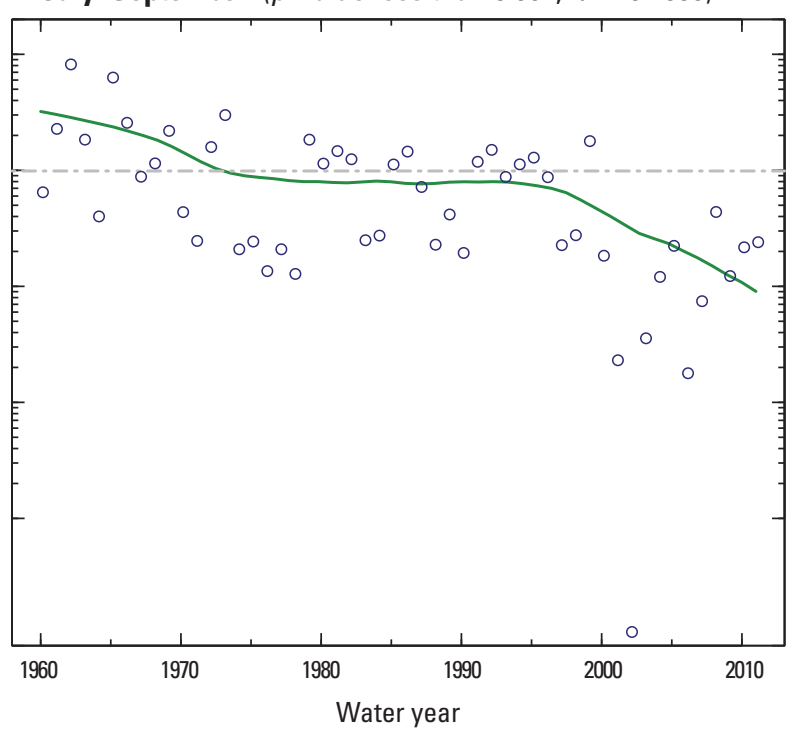

Figure 1-75. Arikaree River at Haigler, Nebraska (streamgage 06821500), water years 1960-2011. 
A. Annual mean streamflow [probability value ( $p$-value) less than 0.001 , Kendall's tau $(\tau)=-0.6828$ ]

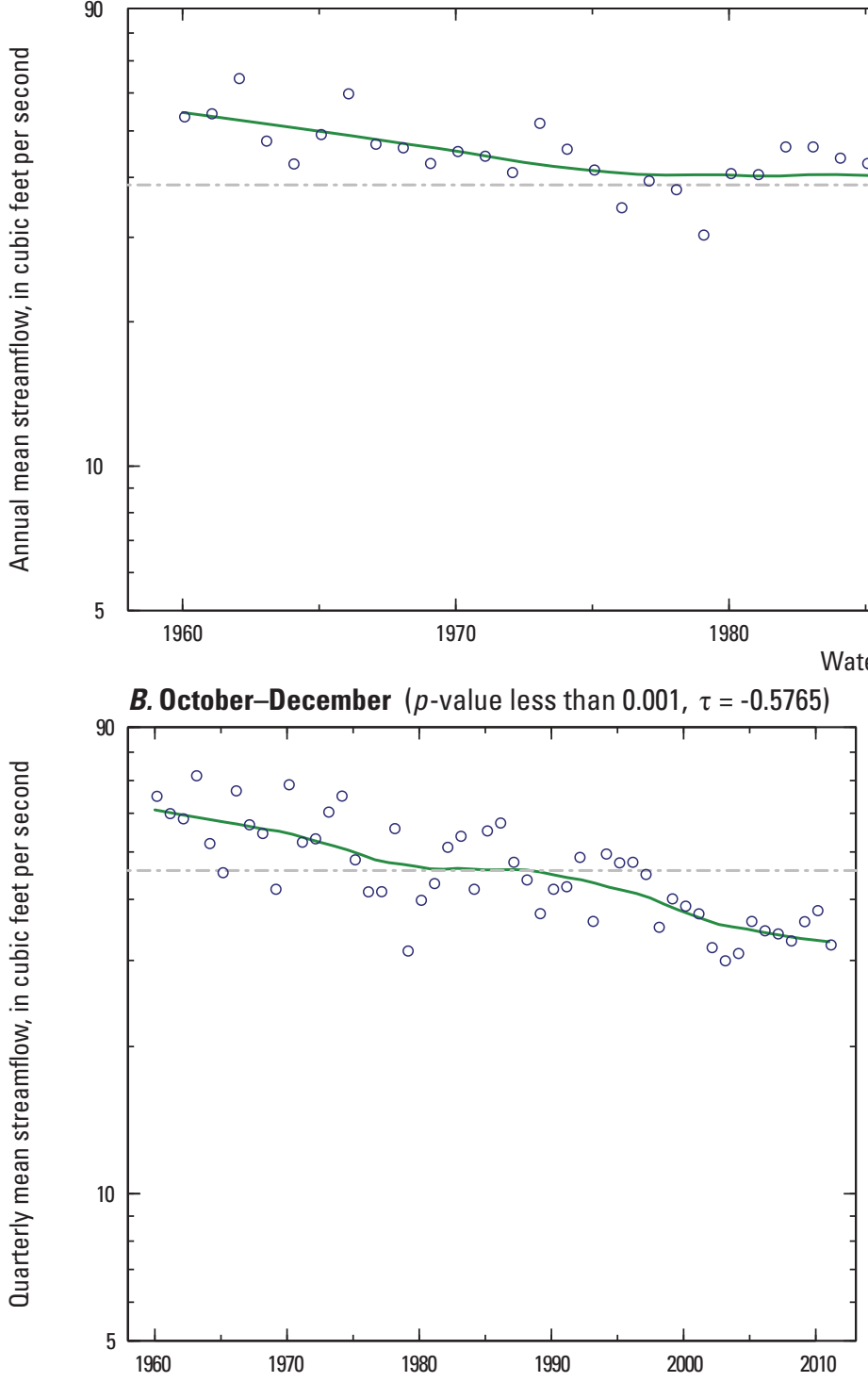

EXPLANATION

L Locally weighted regression curve for significant streamflow trend

-. Long-term mean streamflow

- Mean streamflow for period Water year

C. January-March ( $p$-value less than $0.001, \tau=-0.7925)$

D. April-June ( $p$-value less than 0.001, $\tau=-0.3916)$
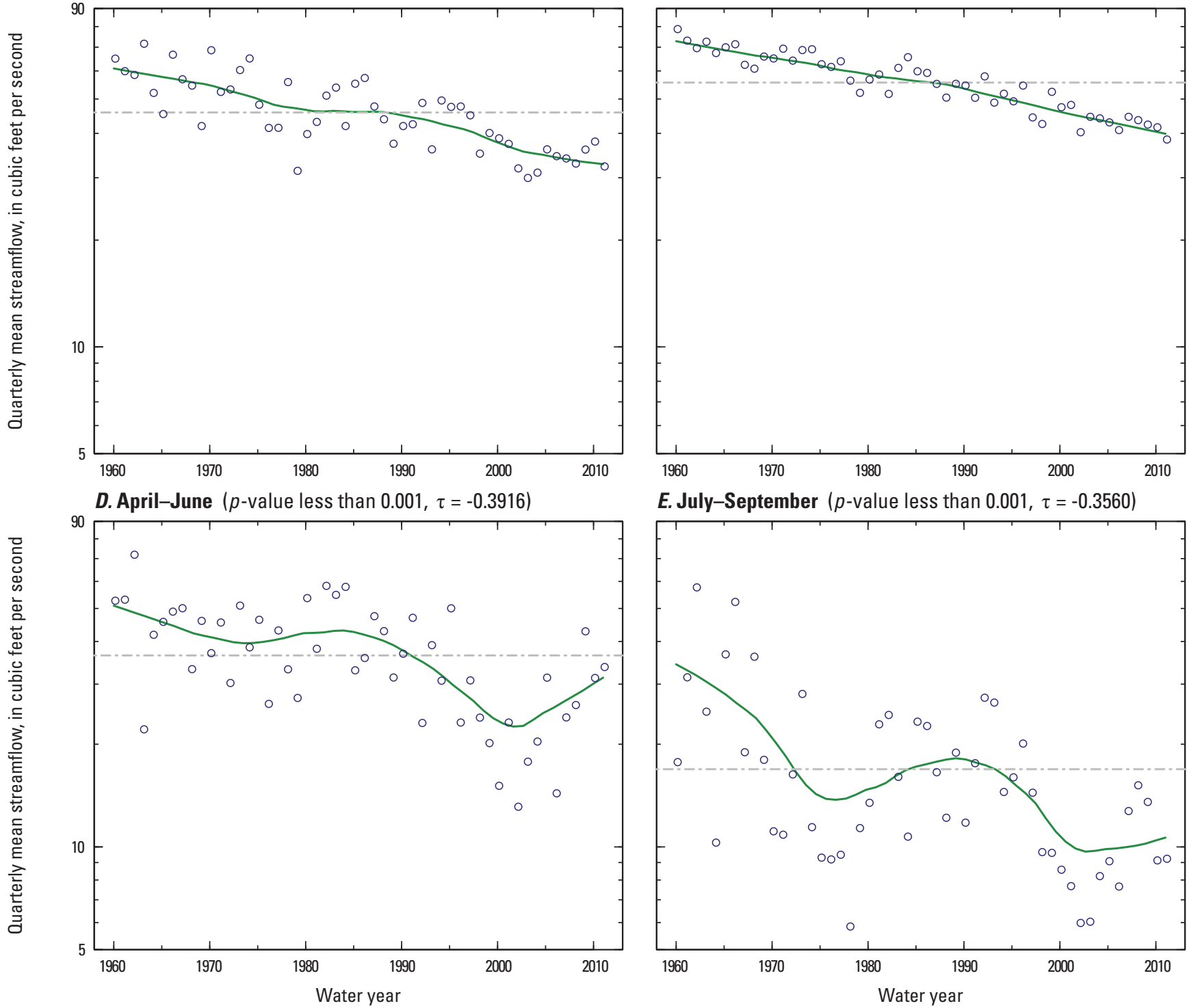

E. July-September ( $p$-value less than 0.001, $\tau=-0.3560$ )

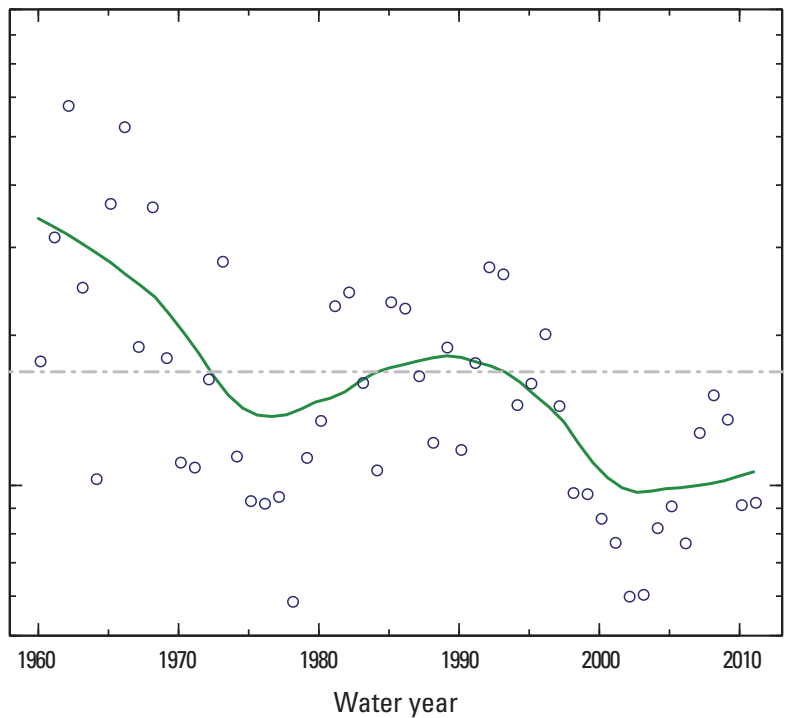

Figure 1-76. North Fork Republican River at Colorado-Nebraska State line (streamgage 06823000), water years 1960-2011. 
A. Annual mean streamflow [probability value ( $p$-value) less than 0.001 , Kendall's tau $(\tau)=-0.7432$ ]

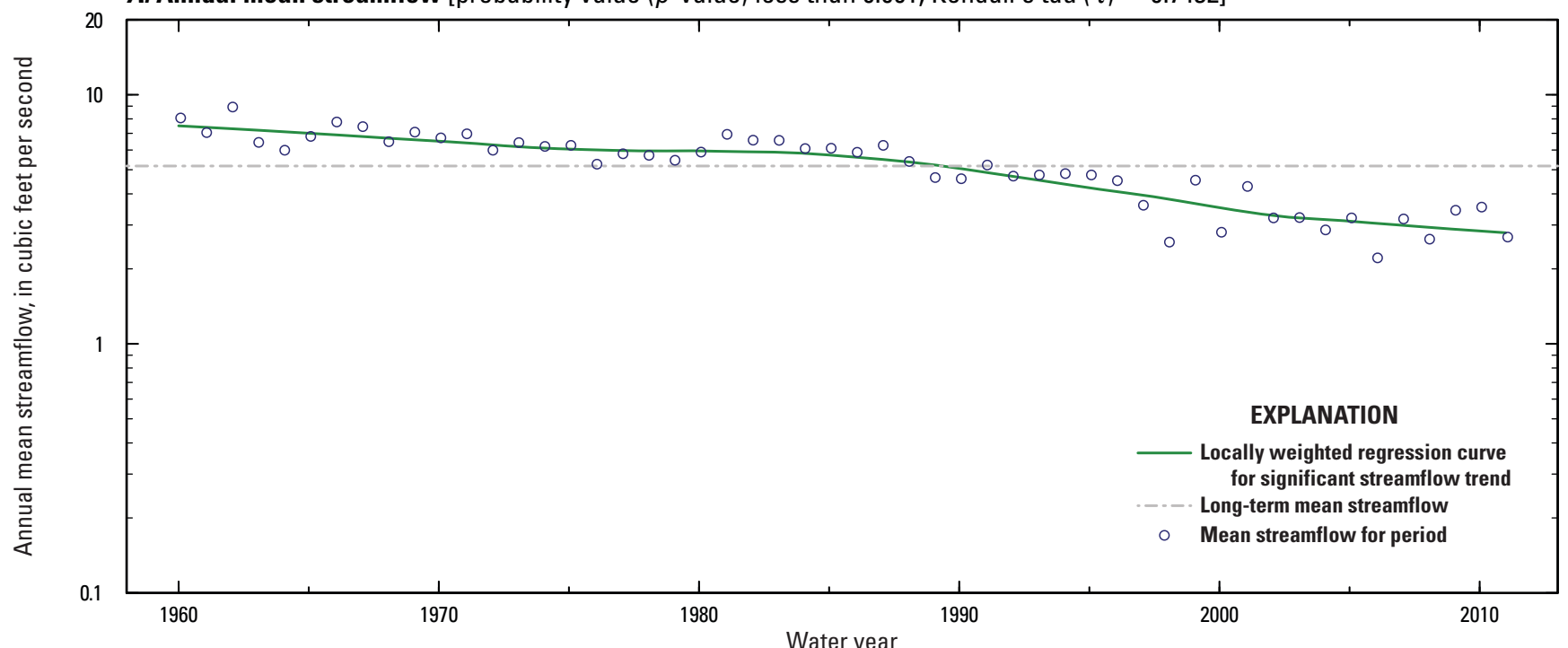

B. October-December ( $p$-value less than 0.001, $\tau=-0.7341)$

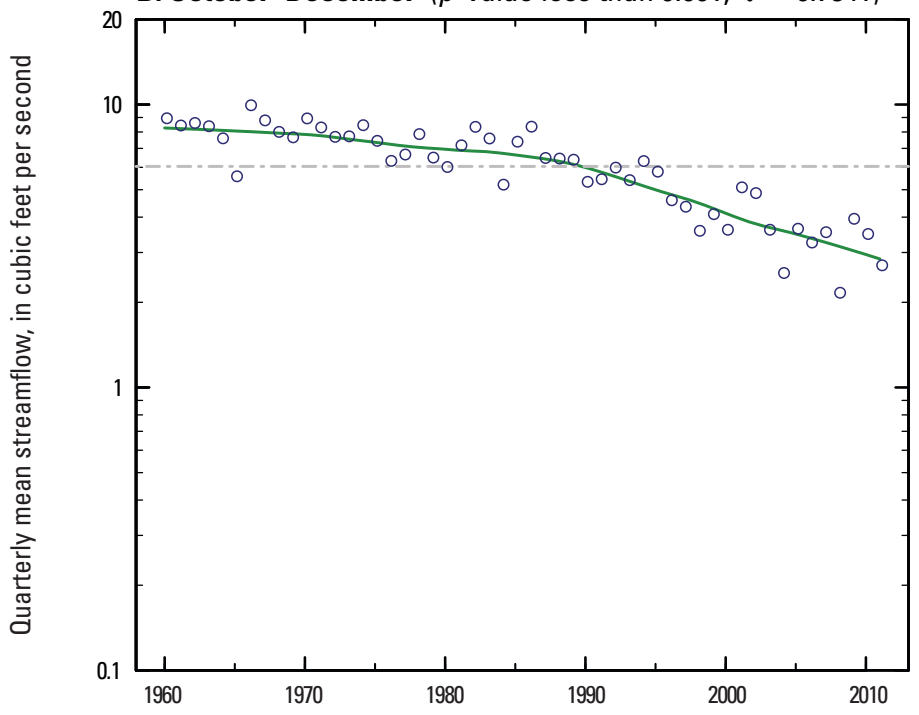

C. January-March ( $p$-value less than $0.001, \tau=-0.7684)$

D. April-June ( $p$-value less than 0.001, $\tau=-0.5102)$
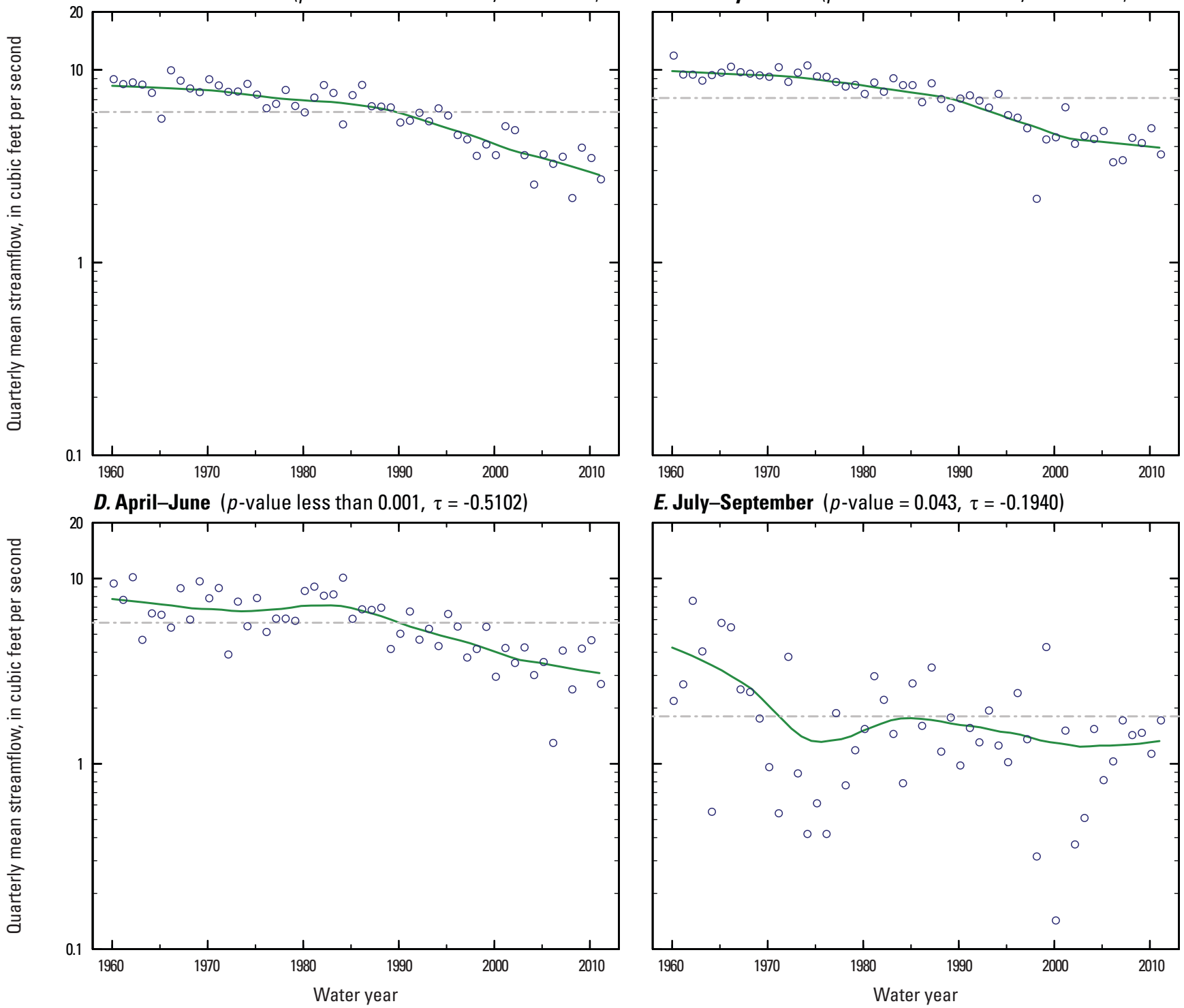

E. July-September $(p$-value $=0.043, \tau=-0.1940)$

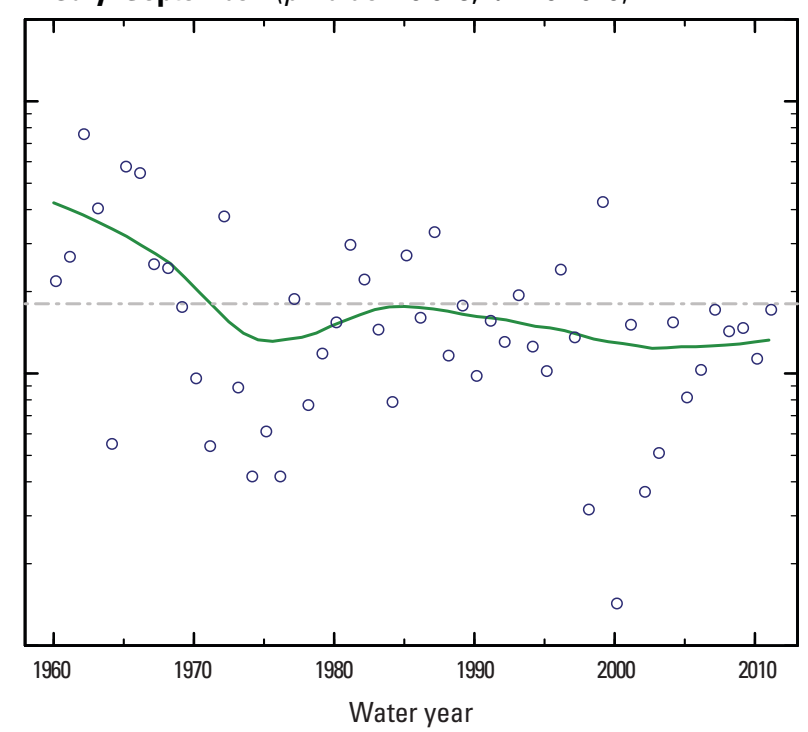

Figure 1-77. Buffalo Creek near Haigler, Nebraska (streamgage 06823500), water years 1960-2011. 
A. Annual mean streamflow [probability value ( $p$-value) less than 0.001 , Kendall's tau $(\tau)=-0.8797$ ]
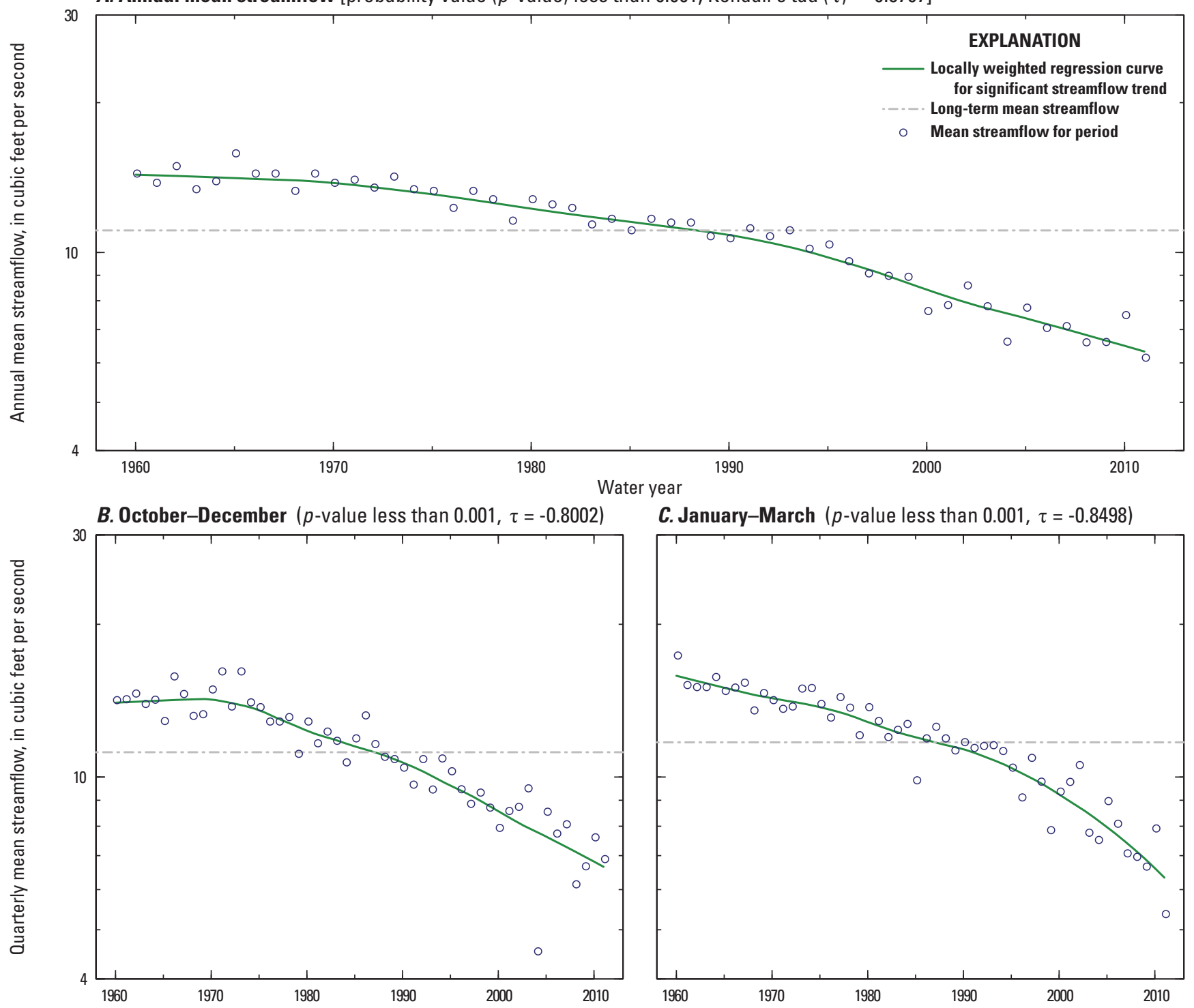

C. January-March ( $p$-value less than 0.001, $\tau=-0.8498$ )
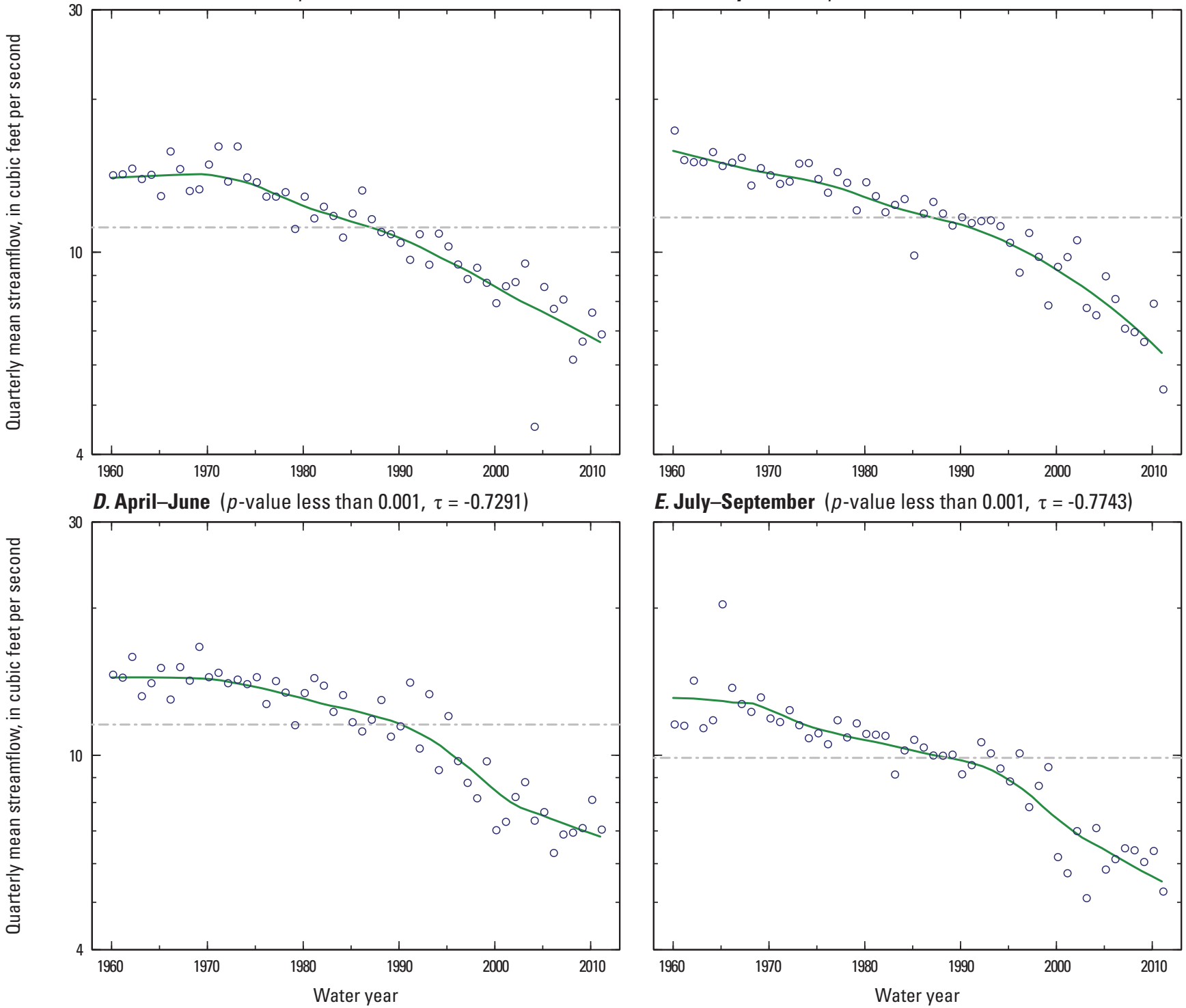

E. July-September ( $p$-value less than $0.001, \tau=-0.7743$ )

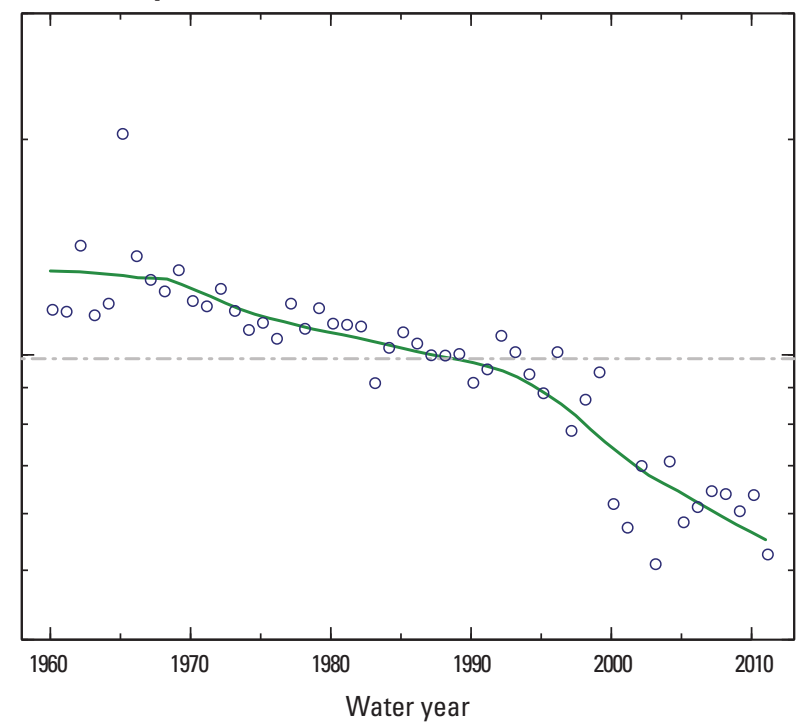

Figure 1-78. Rock Creek at Parks, Nebraska (streamgage 06824000), water years 1960-2011. 
A. Annual mean streamflow [probability value ( $p$-value) less than 0.001 , Kendall's tau $(\tau)=-0.6485$ ]

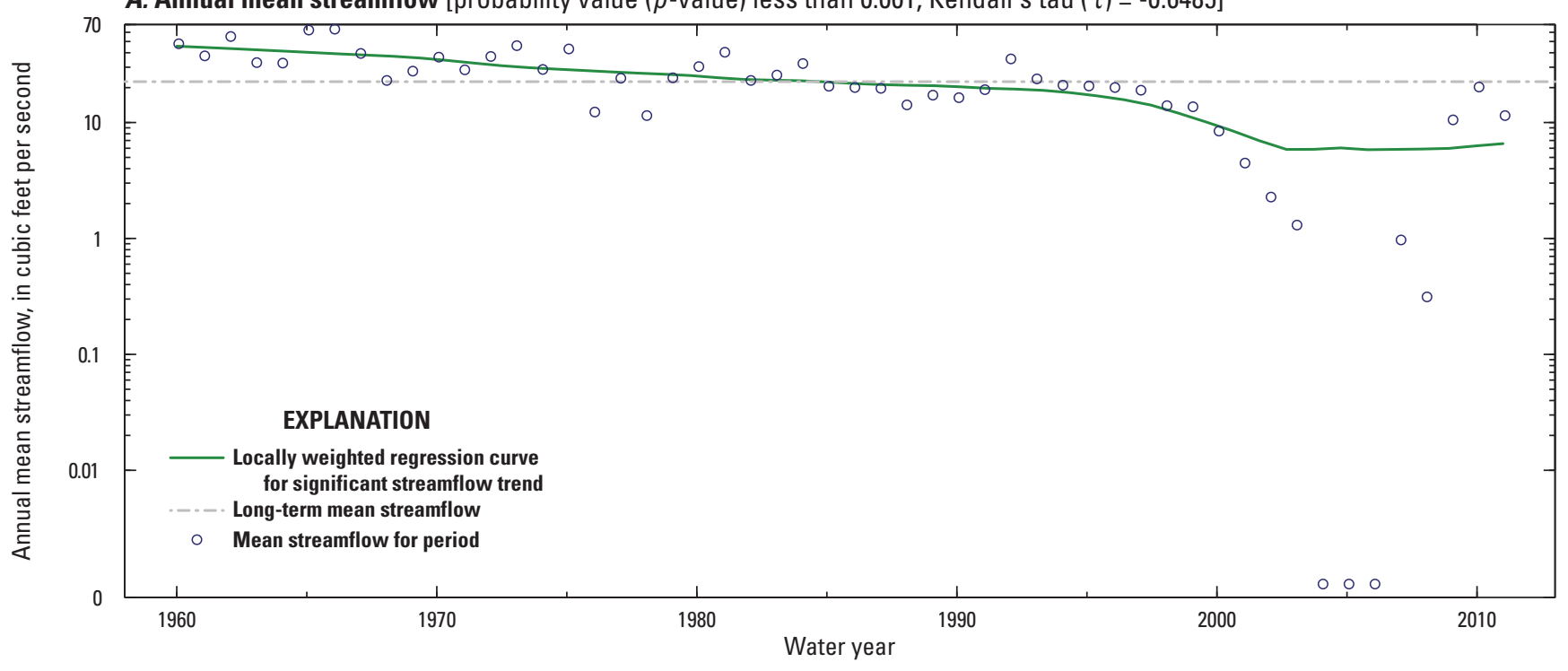

Note: Seasonal plots of streamflow are not presented for this streamgage because of gaps in the monthly streamflow data.

Figure 1-79. South Fork Republican River near Benkelman, Nebraska (streamgage 06827500), water years $1960-2011$. 
A. Annual mean streamflow [probability value ( $p$-value) less than 0.001 , Kendall's tau $(\tau)=-0.6672$ ]

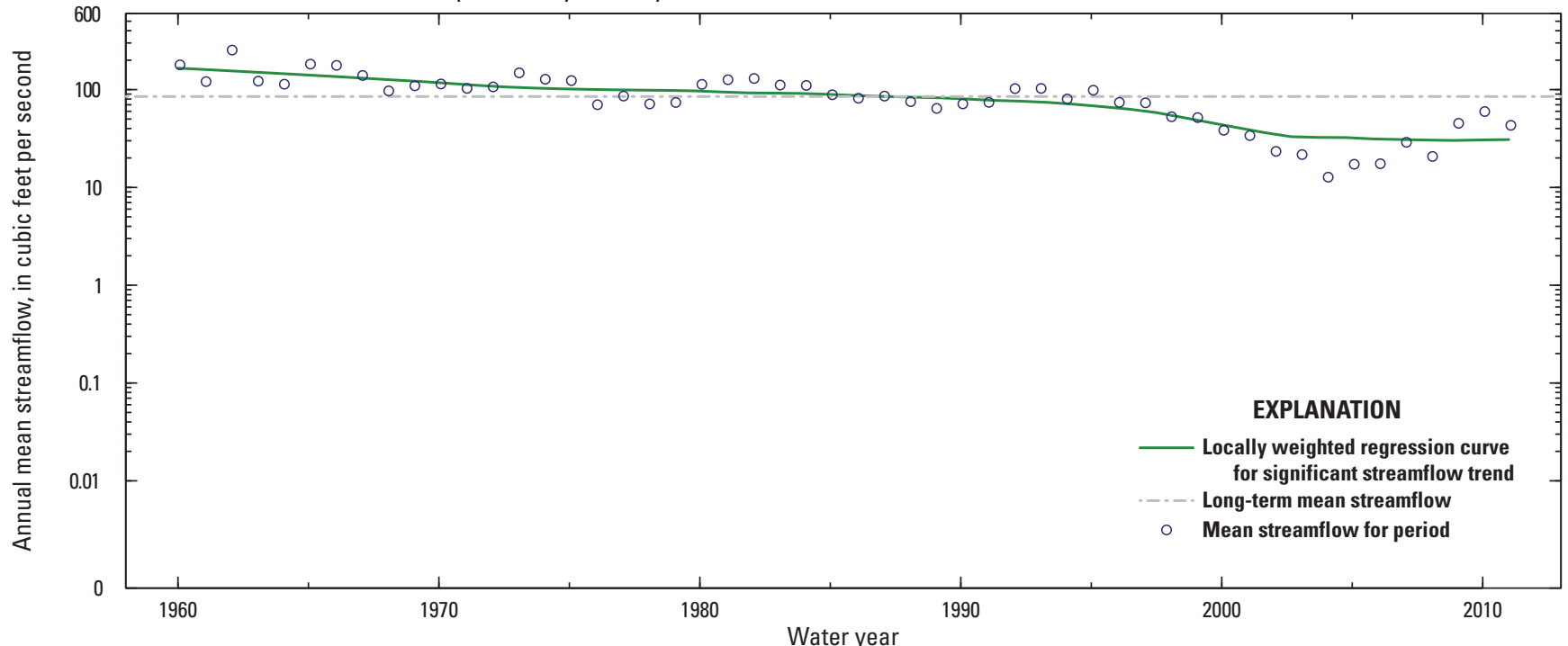

B. October-December ( $p$-value less than 0.001, $\tau=-0.4725$ )

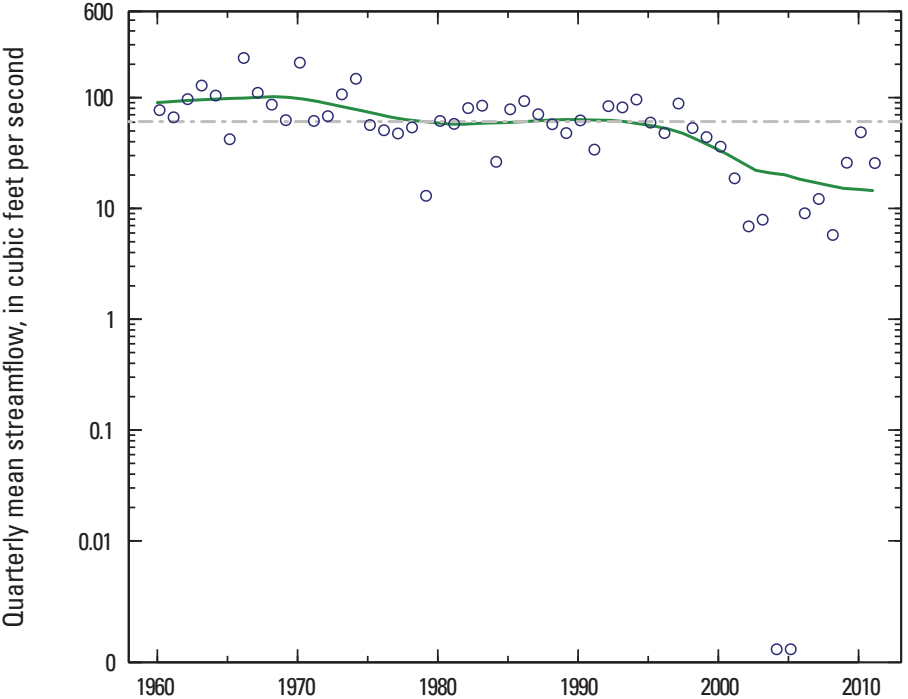

D. April-June ( $p$-value less than 0.001, $\tau=-0.5294)$

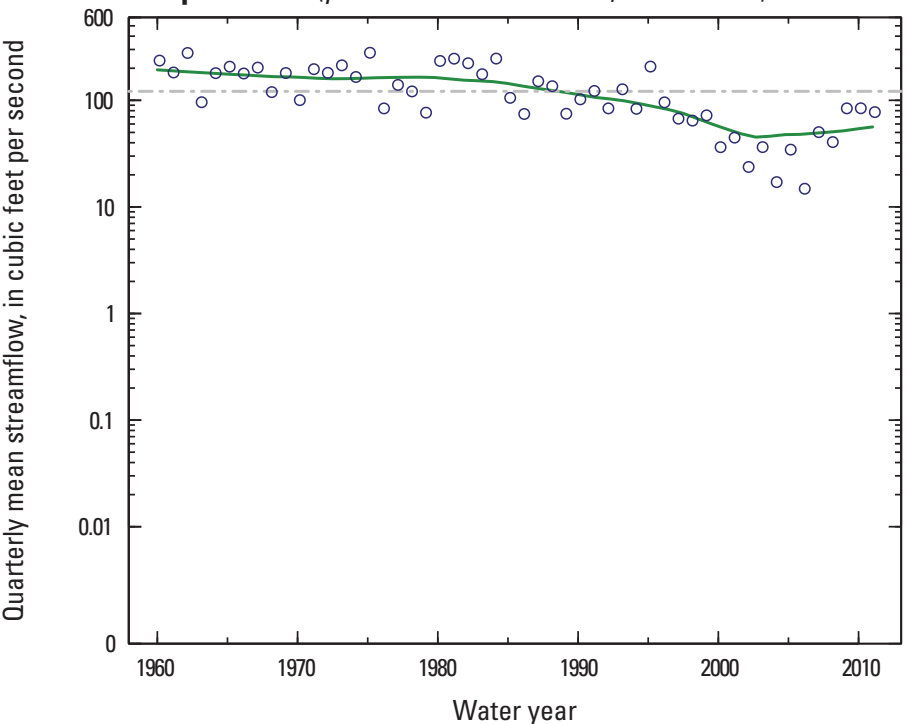

C. January-March ( $p$-value less than $0.001, \tau=-0.6365)$

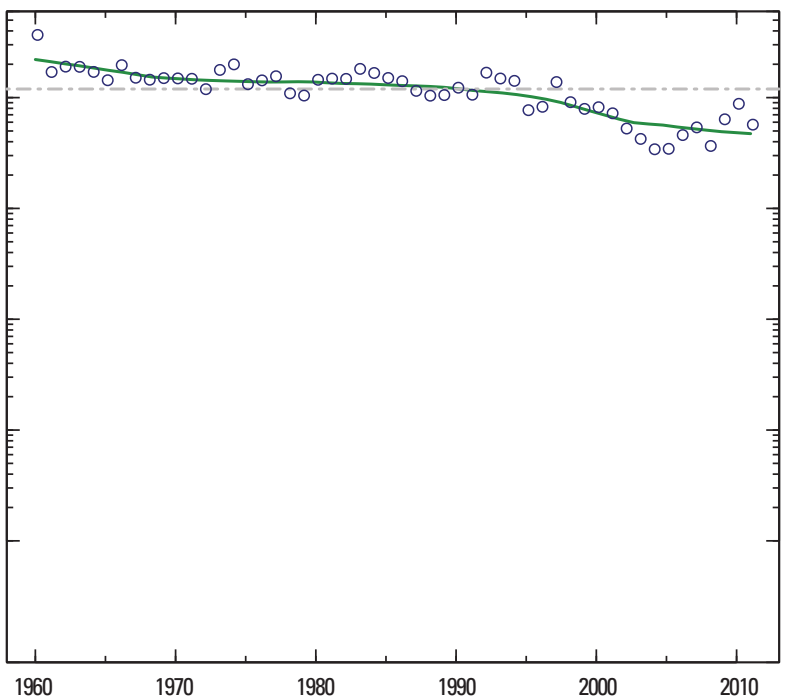

E. July-September ( $p$-value less than $0.001, \tau=-0.3623$ )

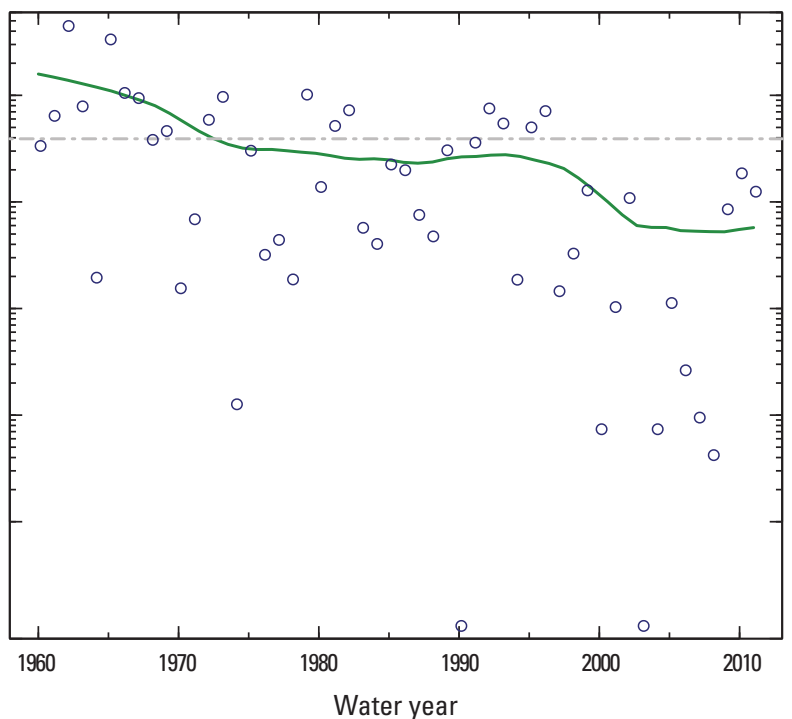

Figure 1-80. Republican River at Stratton, Nebraska (streamgage 06828500), water years 1960-2011. 
A. Annual mean streamflow [probability value $(p$-value) less than 0.001 , Kendall's tau $(\tau)=-0.6838$ ]

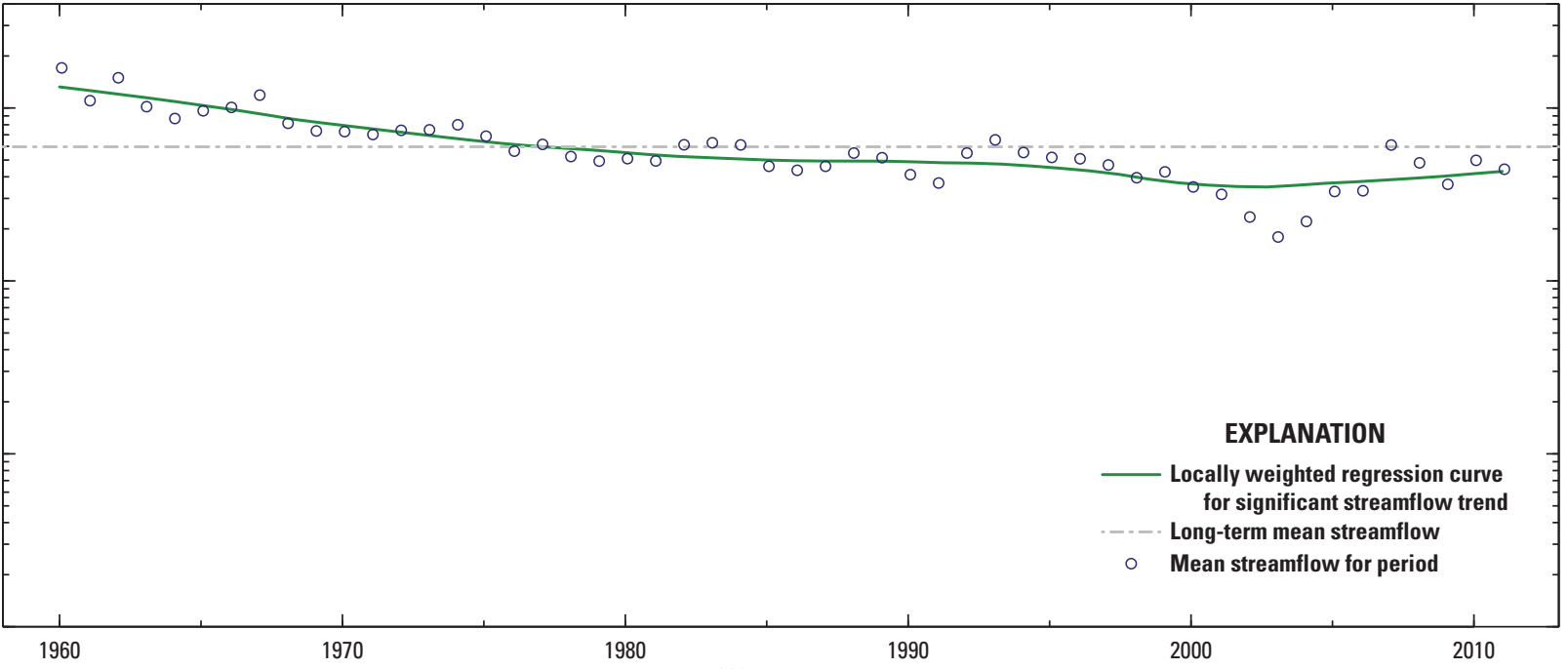

0.1 Water year

B. October-December ( $p$-value less than 0.001, $\tau=-0.6923$ )

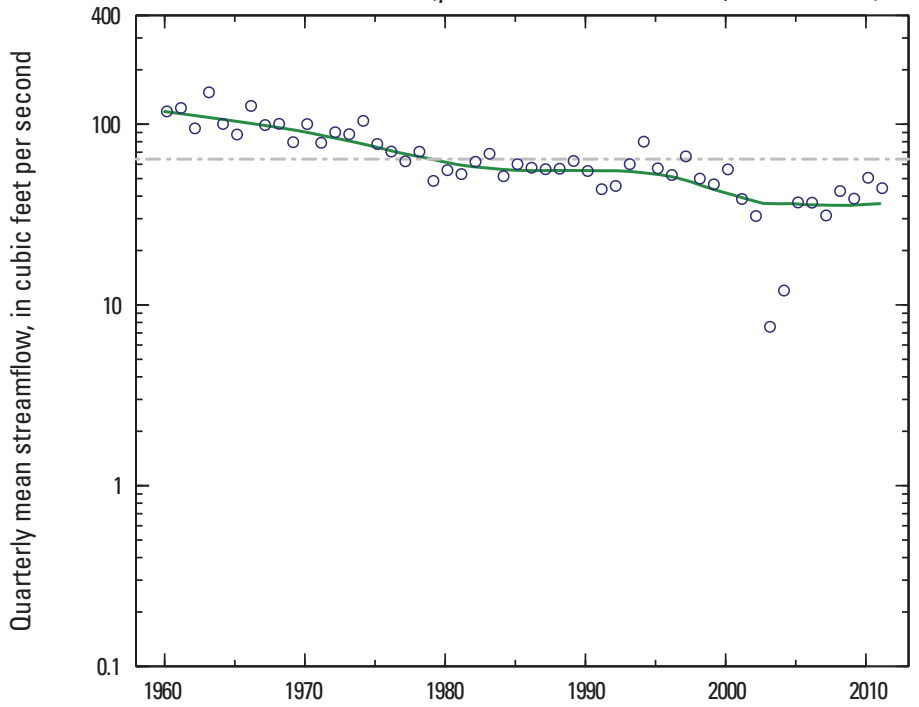

D. April-June ( $p$-value less than 0.001, $\tau=-0.4540)$

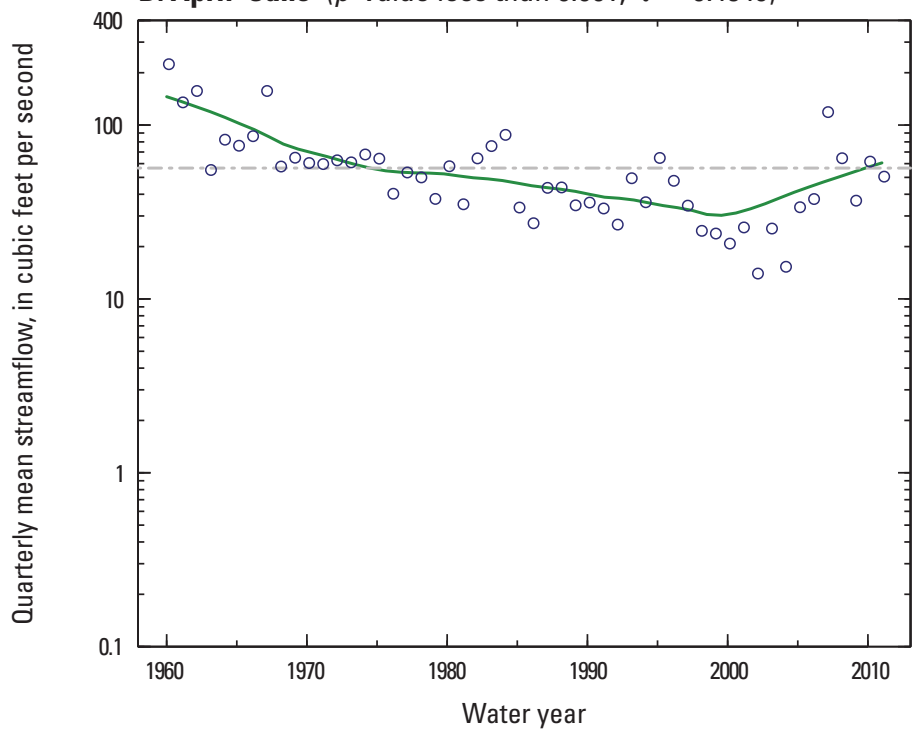

C. January-March ( $p$-value less than $0.001, \tau=-0.7974)$

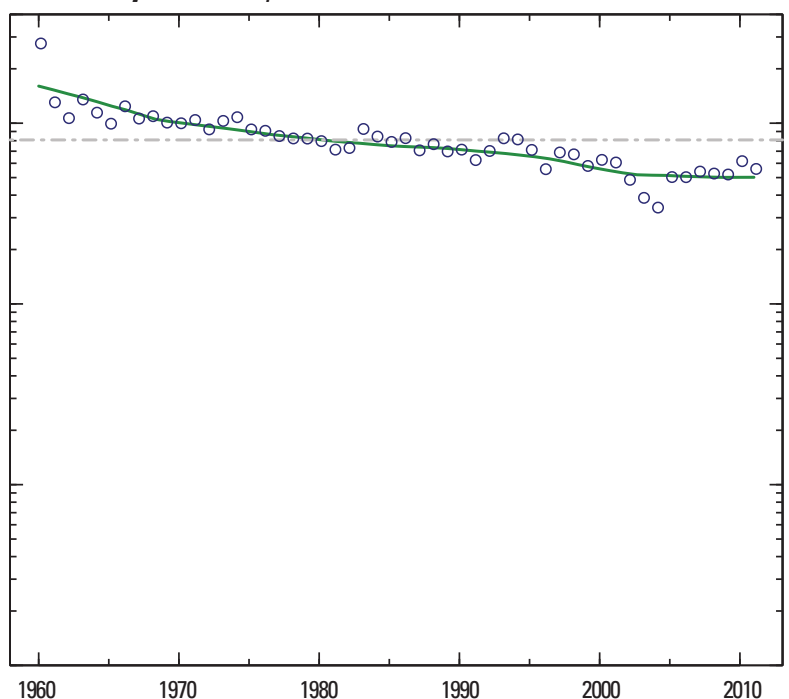

E. July-September ( $p$-value less than 0.001, $\tau=-0.4344)$

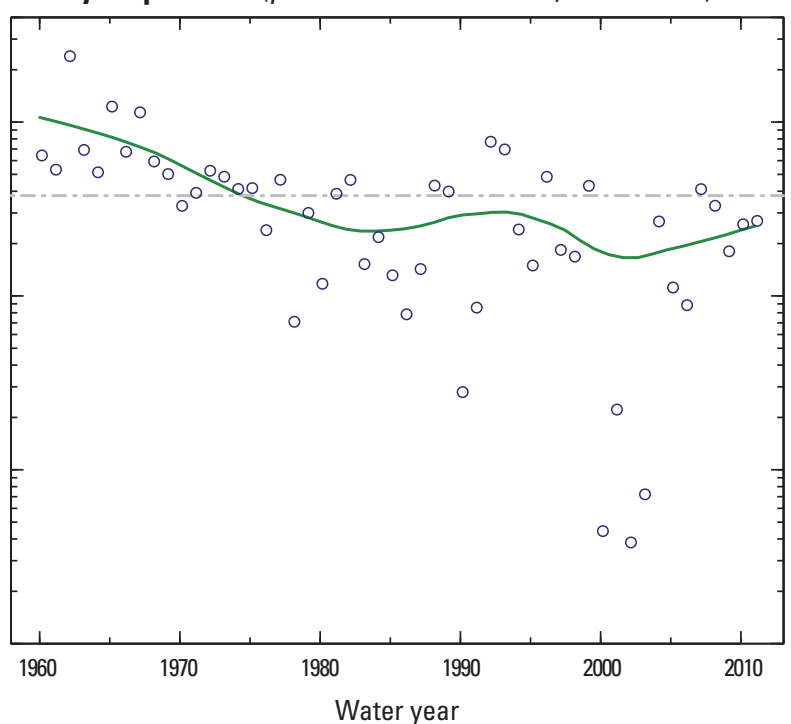

Figure 1-81. Frenchman Creek at Culbertson, Nebraska (streamgage 06835500), water years 1960-2011. 
A. Annual mean streamflow [probability value ( $p$-value) less than 0.001 , Kendall's tau $(\tau)=-0.5273$ ]

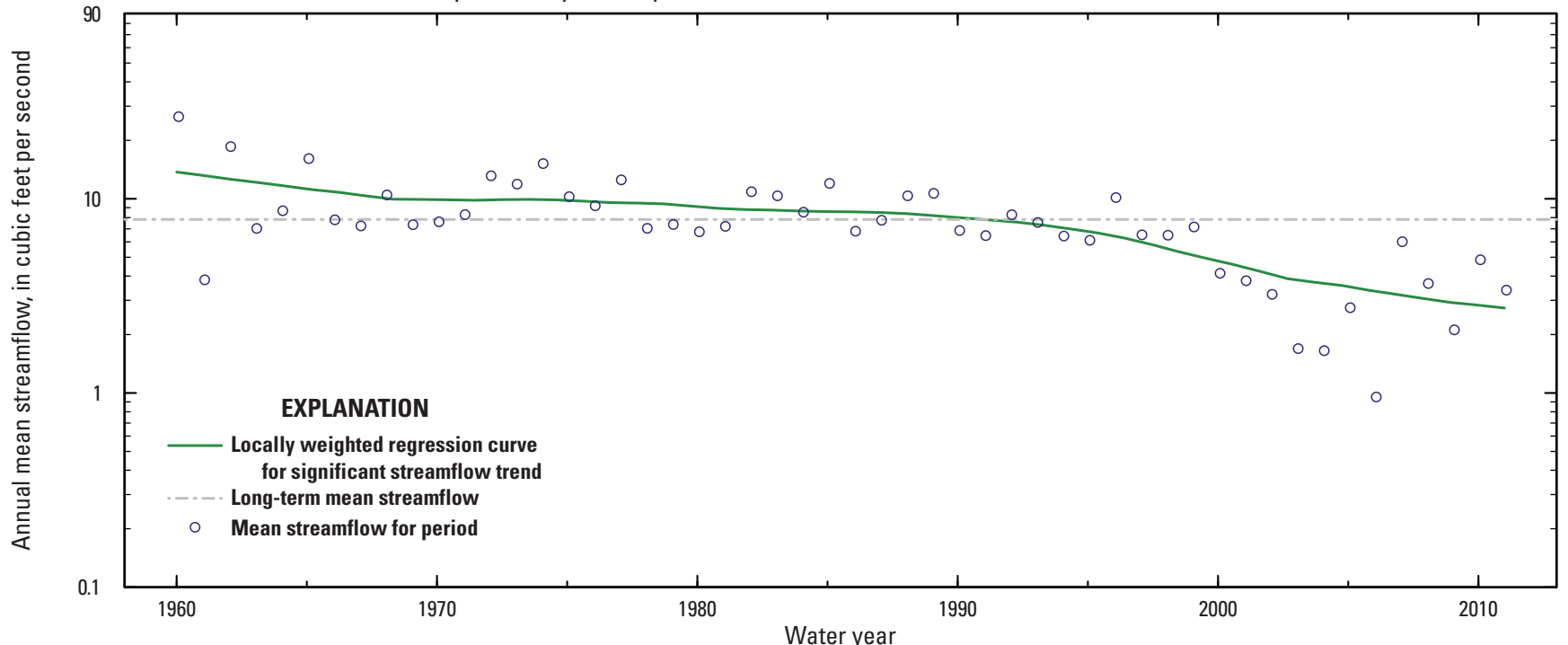

B. October-December $(p$-value $=0.076, \tau=-0.1700)$

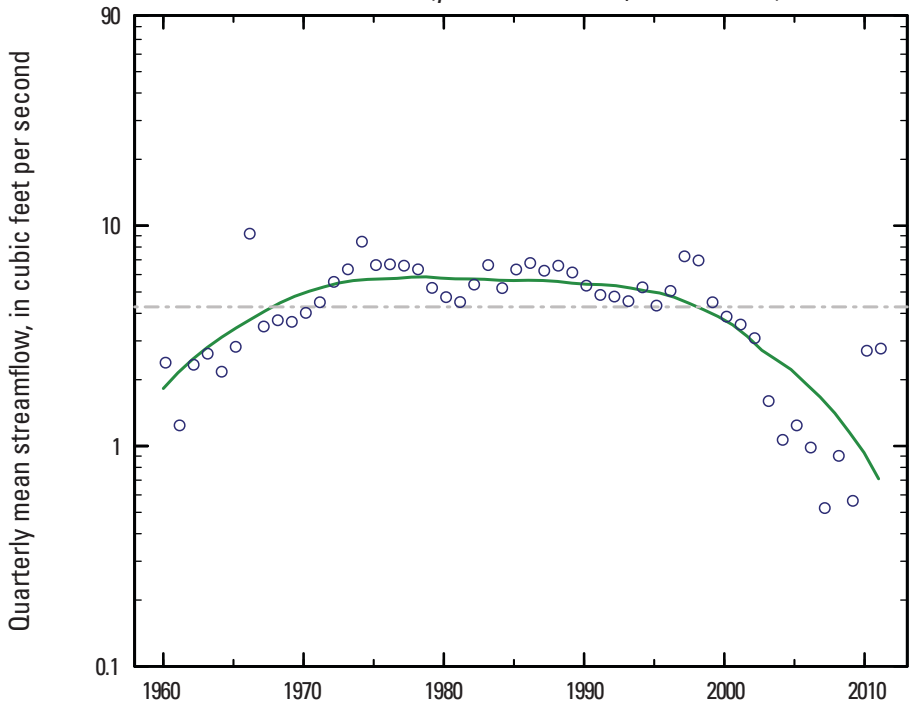

C. January-March ( $p$-value $=0.019, \tau=-0.2241)$

D. April-June ( $p$-value less than $0.001, \tau=-0.3185)$
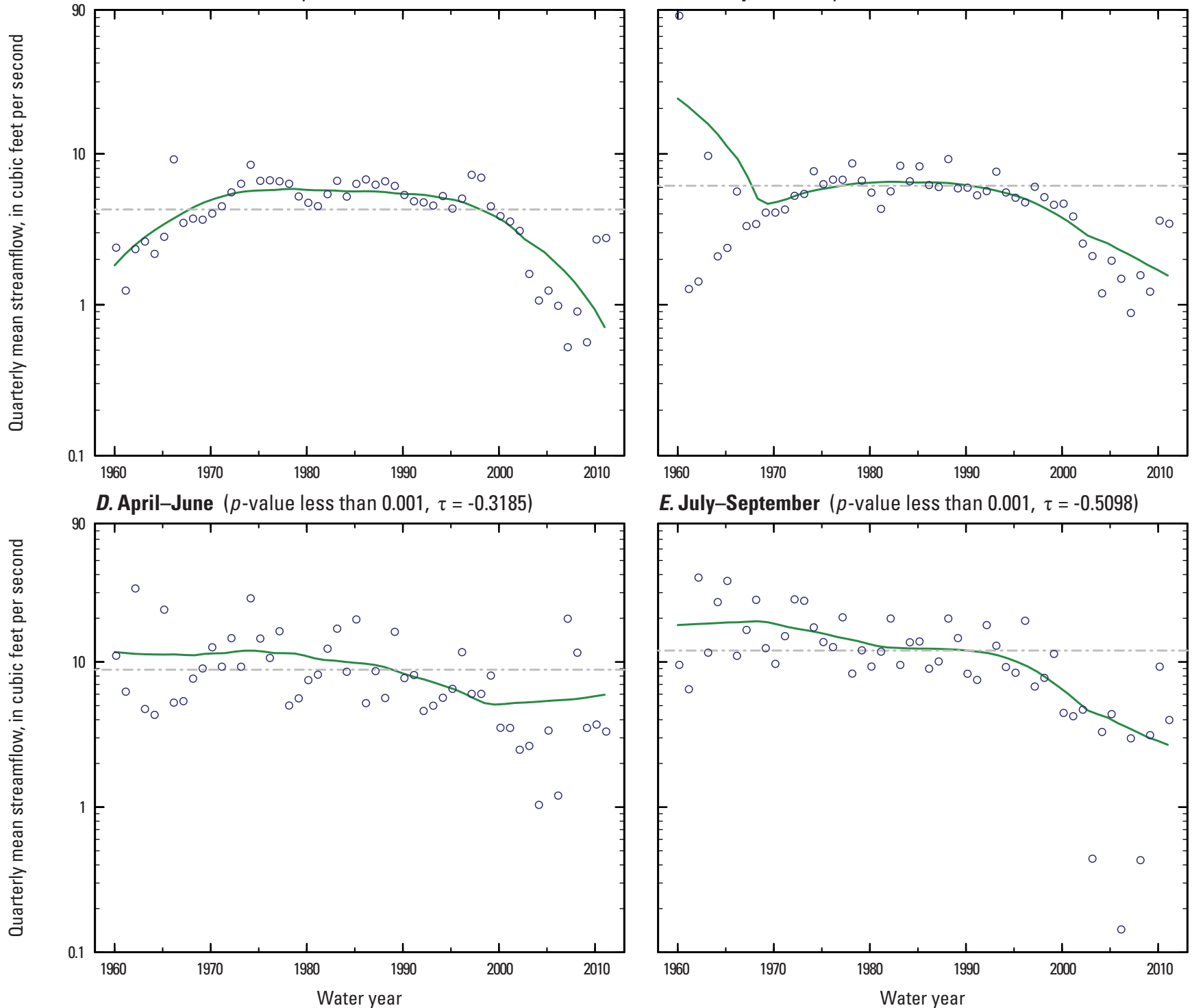

E. July-September ( $p$-value less than $0.001, \tau=-0.5098$ )

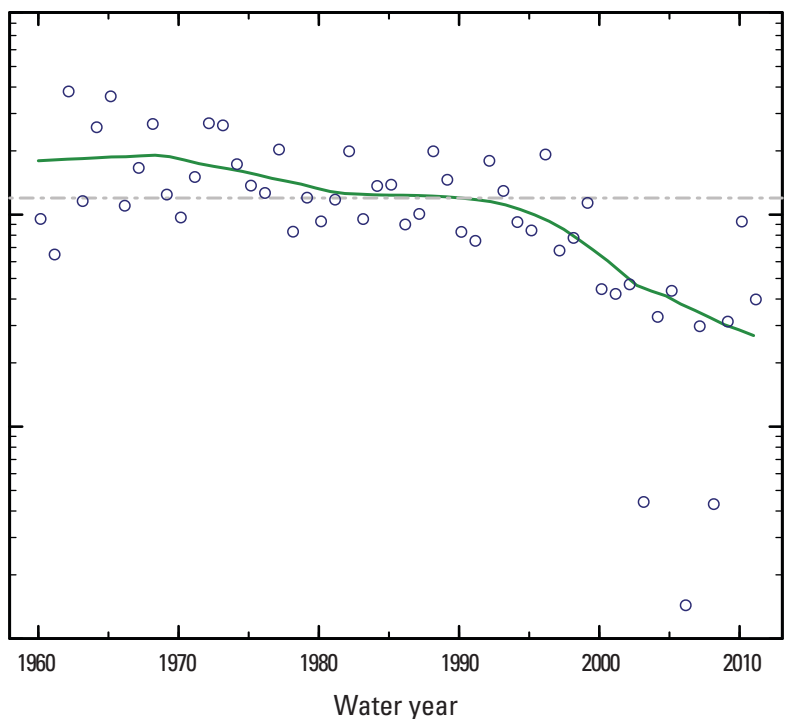

Figure 1-82. Driftwood Creek near Mccook, Nebraska (streamgage 06836500), water years 1960-2011. 
A. Annual mean streamflow [probability value ( $p$-value) less than 0.001 , Kendall's tau $(\tau)=-0.7094$ ]

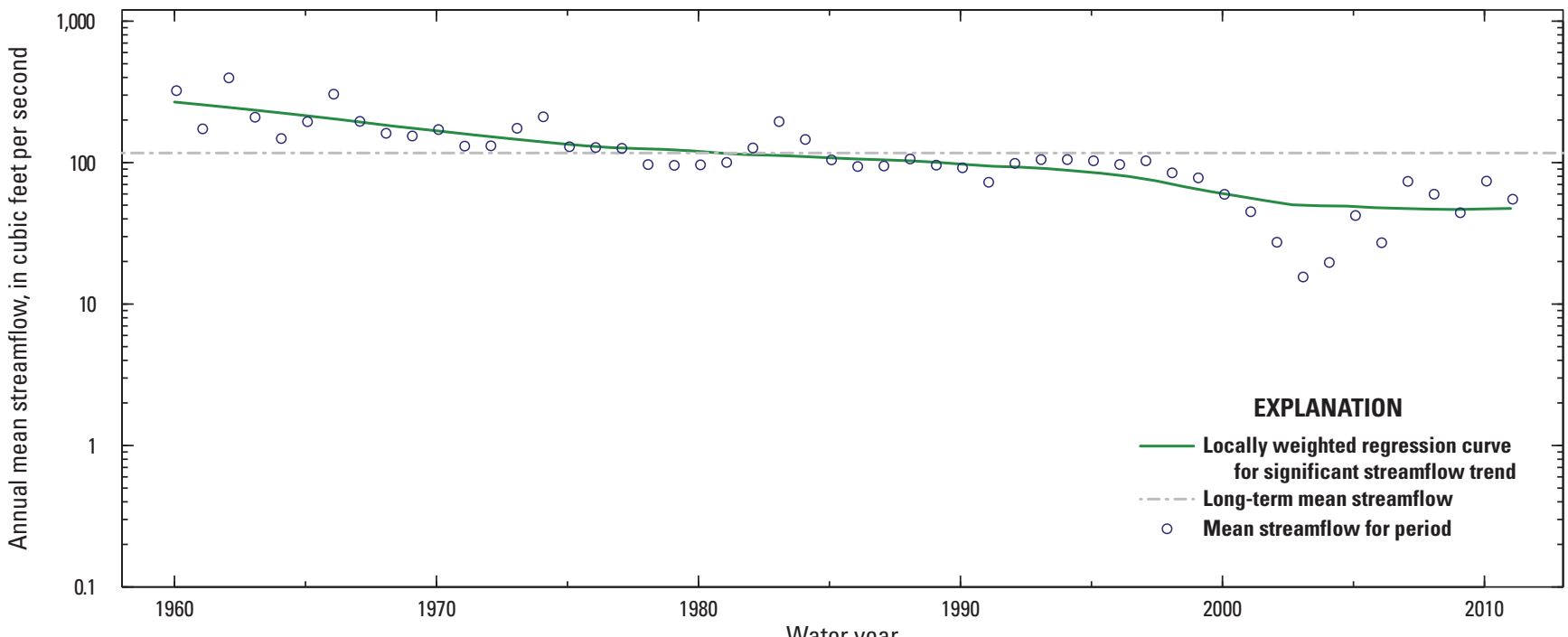

B. October-December $(p$-value less than $0.001, \tau=-0.6501) \quad$ C. January-March $(p$-value less than $0.001, \tau=-0.7195)$
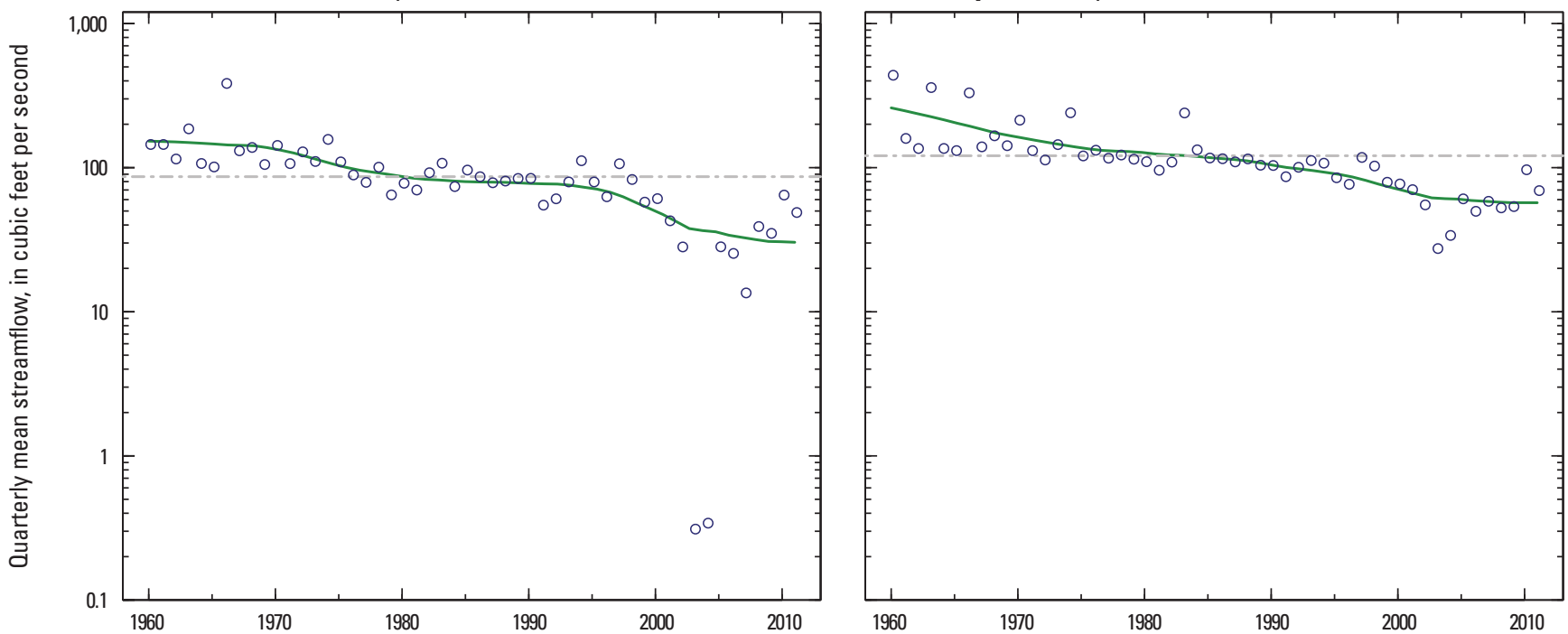

D. April-June ( $p$-value less than 0.001, $\tau=-0.6139$ )

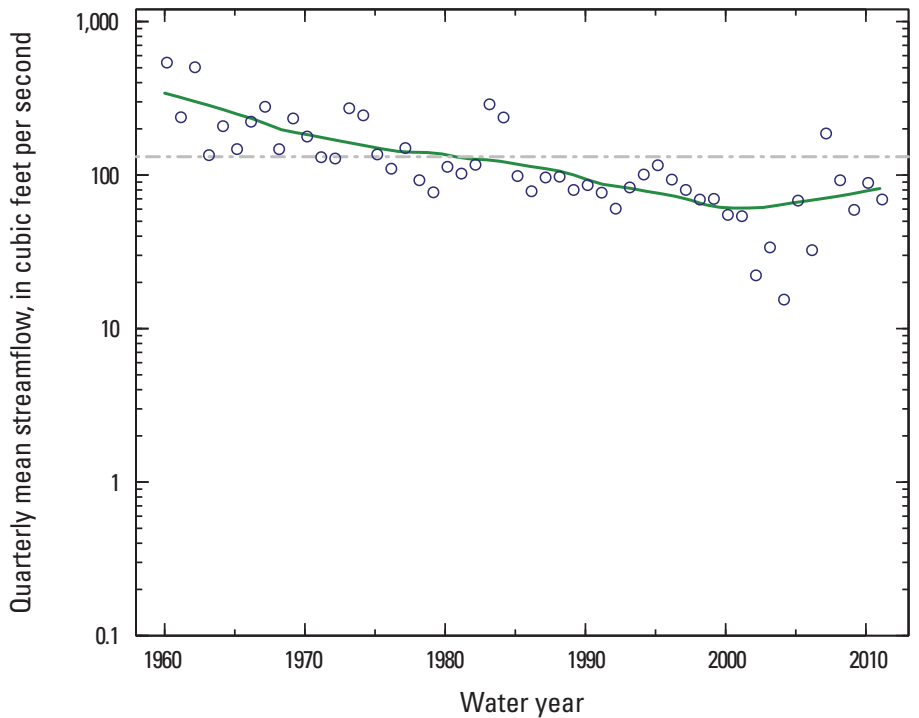

E. July-September ( $p$-value less than 0.001, $\tau=-0.6124)$

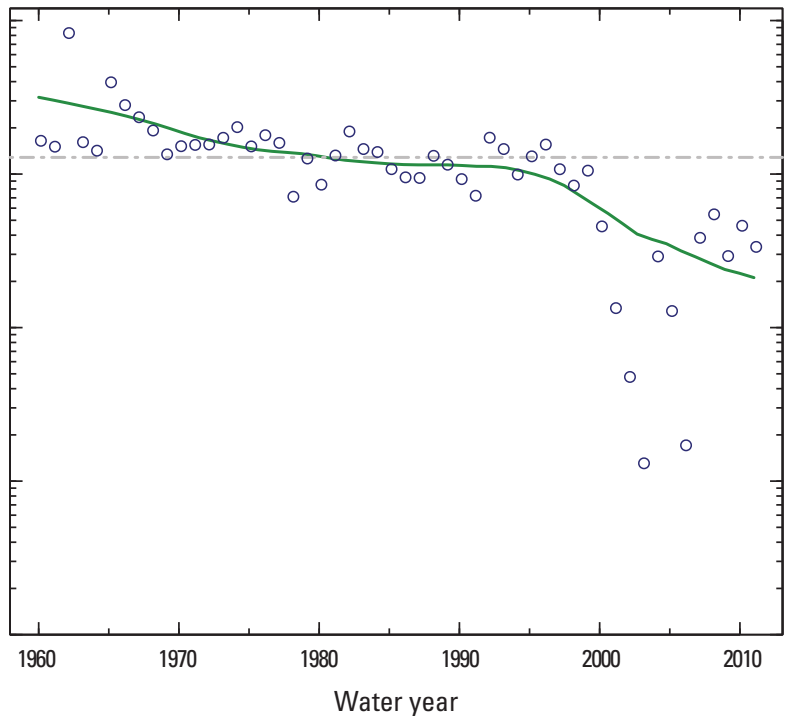

Figure 1-83. Republican River at Mccook, Nebraska (streamgage 06837000), water years 1960-2011. 
A. Annual mean streamflow [probability value ( $p$-value) less than 0.001 , Kendall's tau $(\tau)=-0.5968$ ]
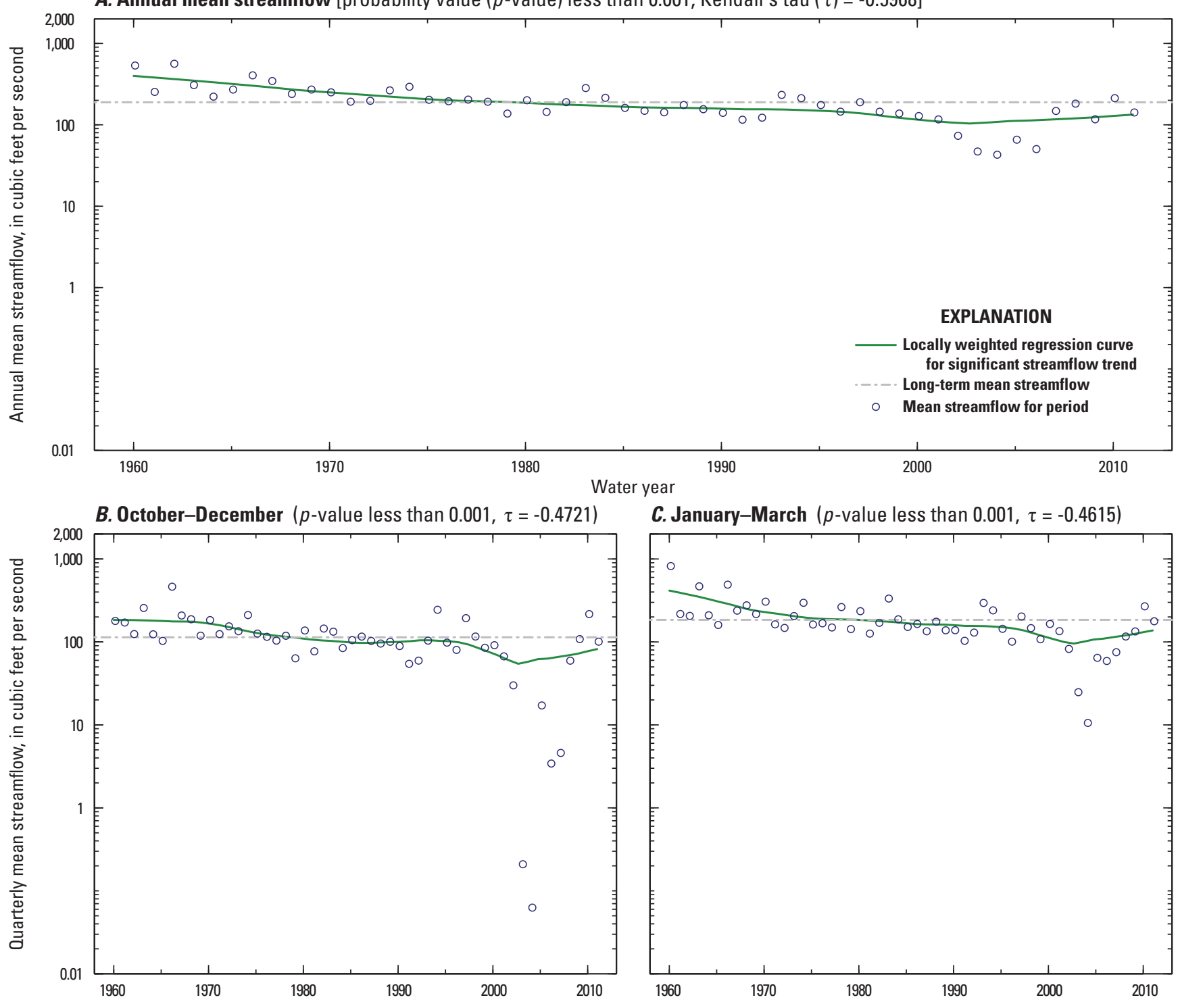

C. January-March ( $p$-value less than $0.001, \tau=-0.4615)$
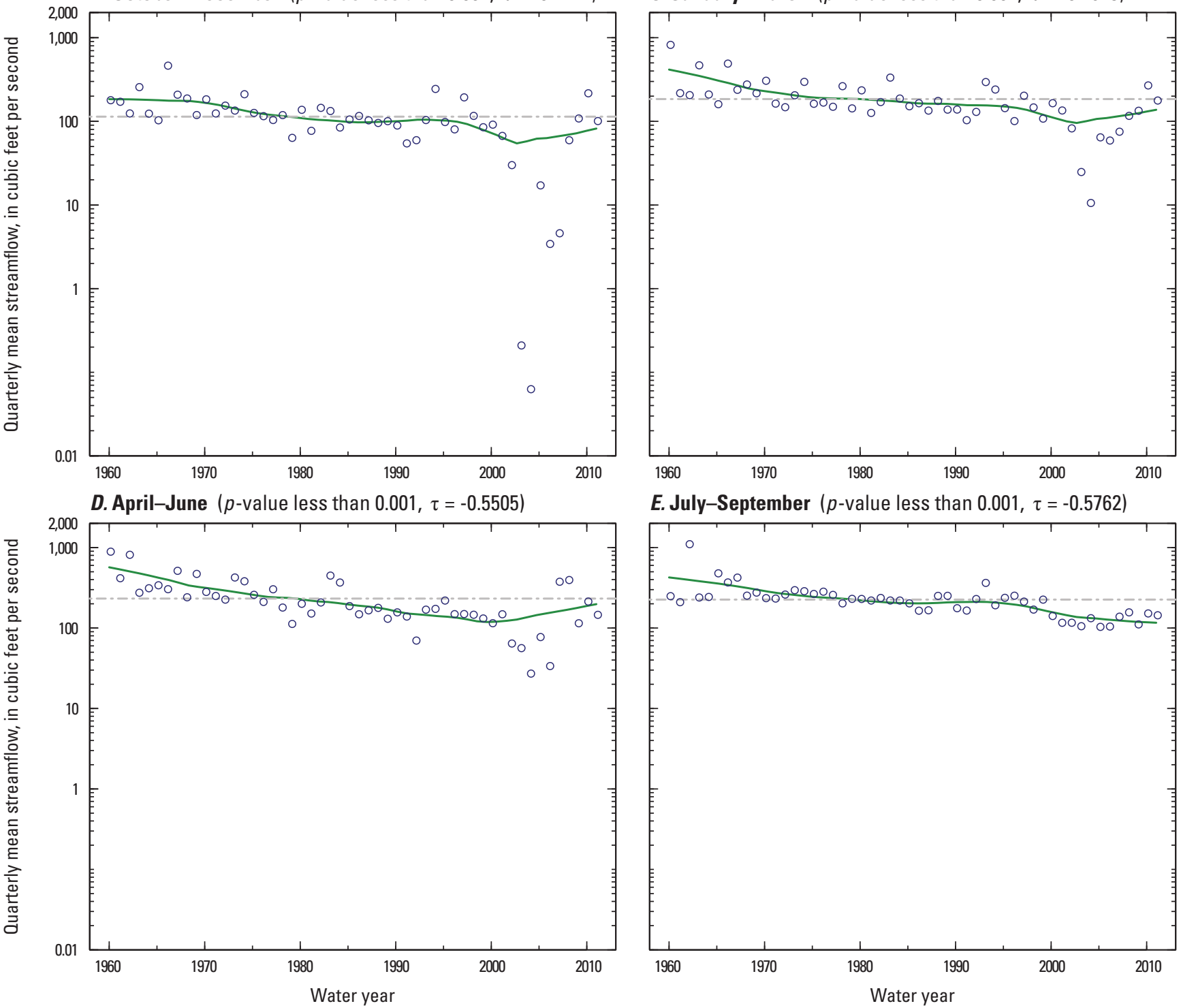

E. July-September ( $p$-value less than $0.001, \tau=-0.5762$ )

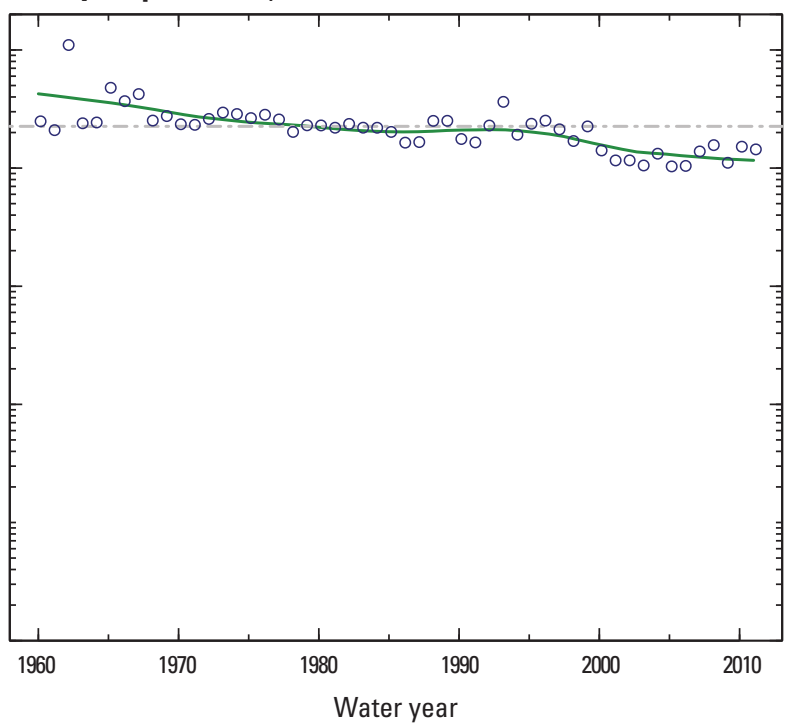

Figure 1-84. Republican River at Cambridge, Nebraska (streamgage 06843500), water years 1960-2011. 

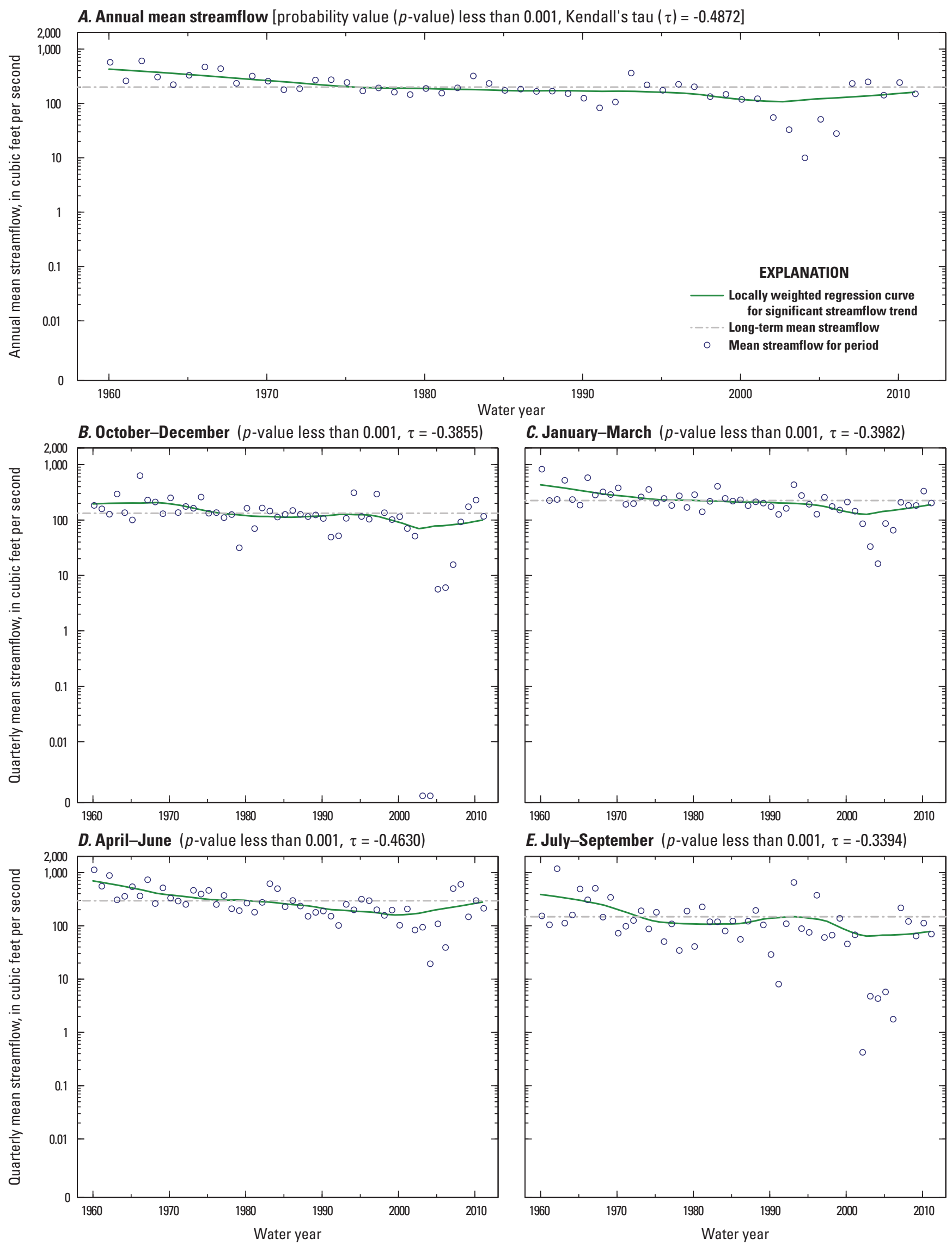

E. July-September ( $p$-value less than $0.001, \tau=-0.3394)$

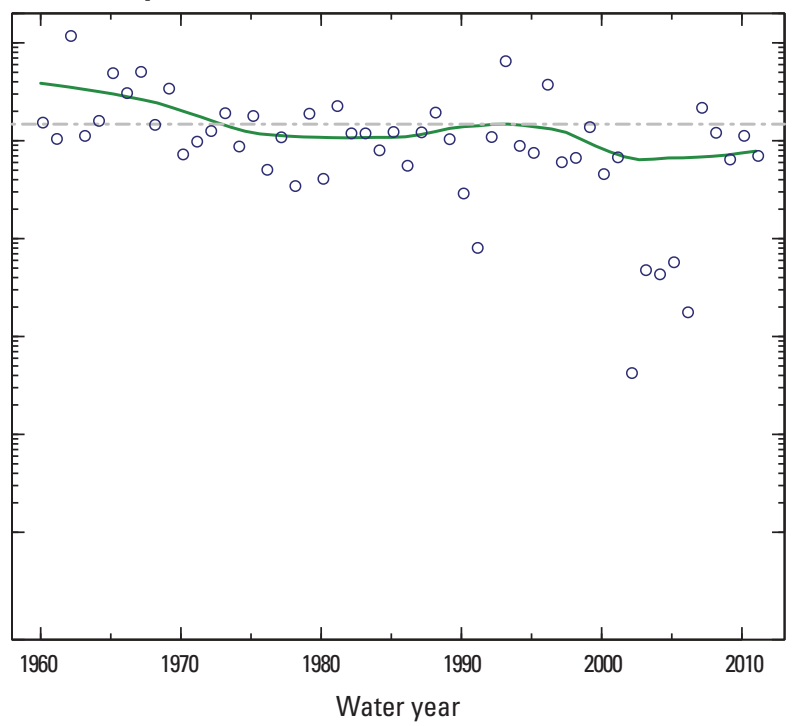

Figure 1-85. Republican River near Orleans, Nebraska (streamgage 06844500), water years 1960-2011. 
A. Annual mean streamflow [probability value ( $p$-value) less than 0.001 , Kendall's tau $(\tau)=-0.4794$ ]
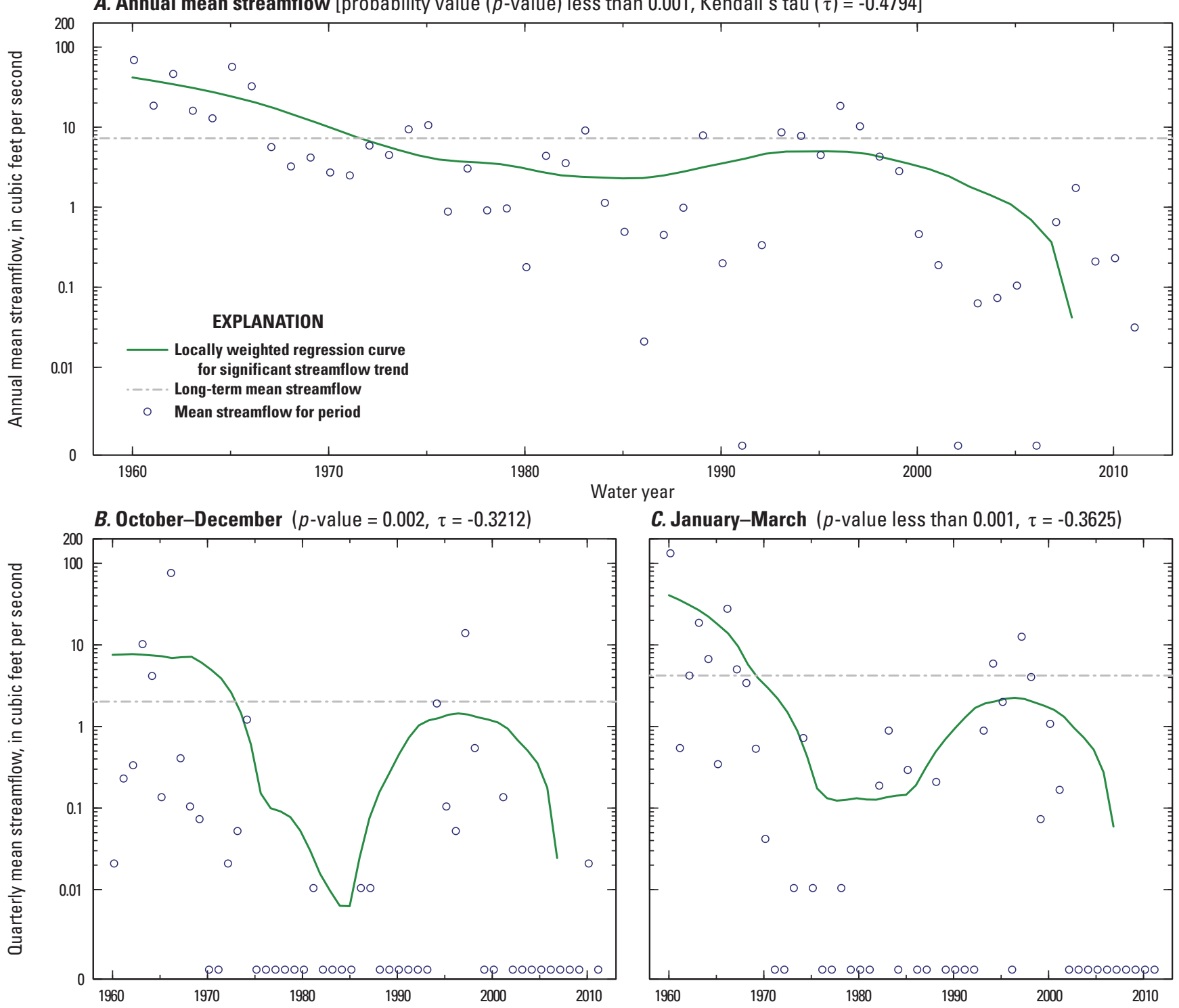

C. January-March ( $p$-value less than $0.001, \tau=-0.3625)$

D. April-June ( $p$-value less than 0.001, $\tau=-0.4302$ )
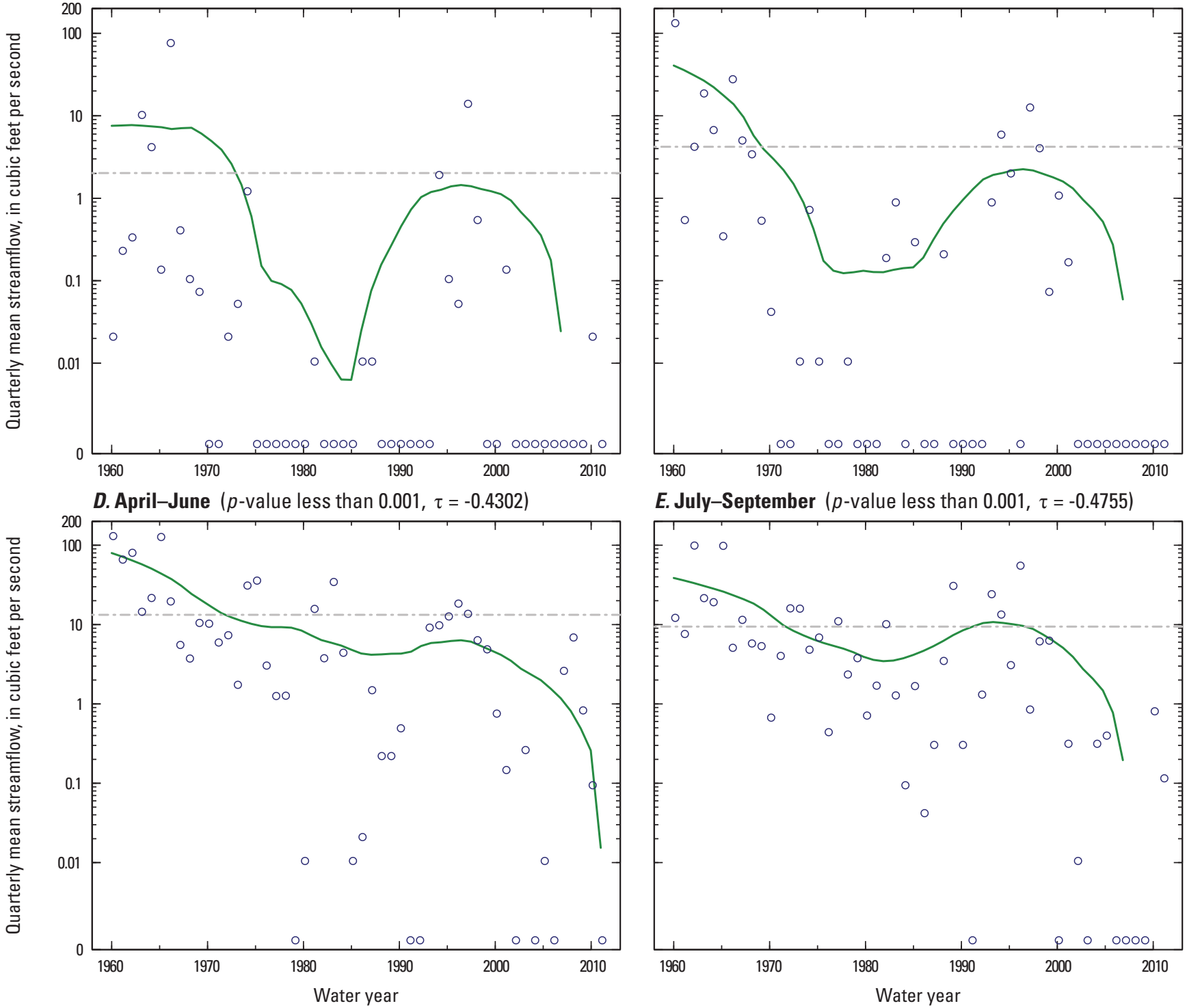

E. July-September ( $p$-value less than 0.001, $\tau=-0.4755)$

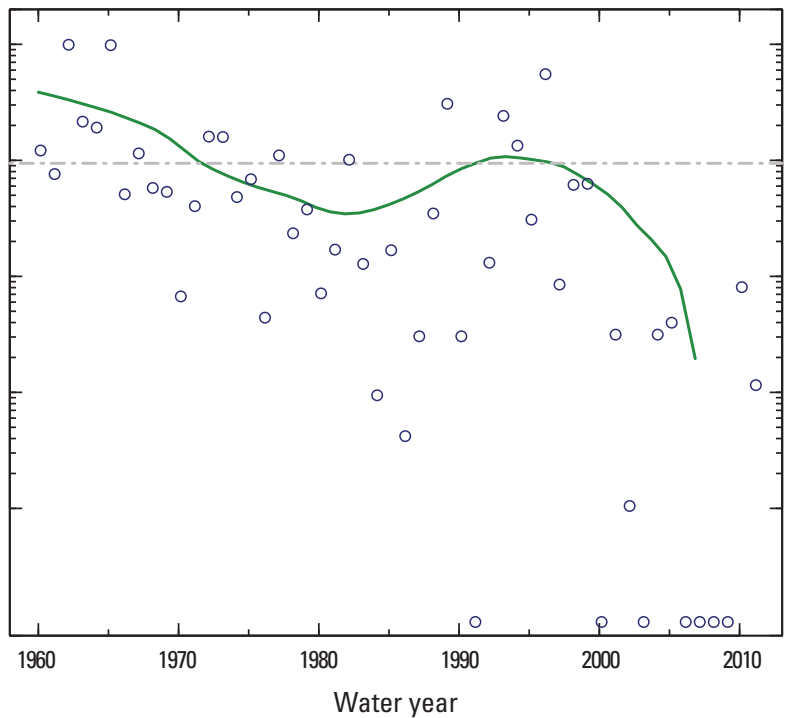

Figure 1-86. Beaver Creek at Cedar Bluffs, Kansas (streamgage 06846500), water years 1960-2011. 
A. Annual mean streamflow [probability value ( $p$-value) less than 0.001 , Kendall's tau $(\tau)=-0.3342$ ]

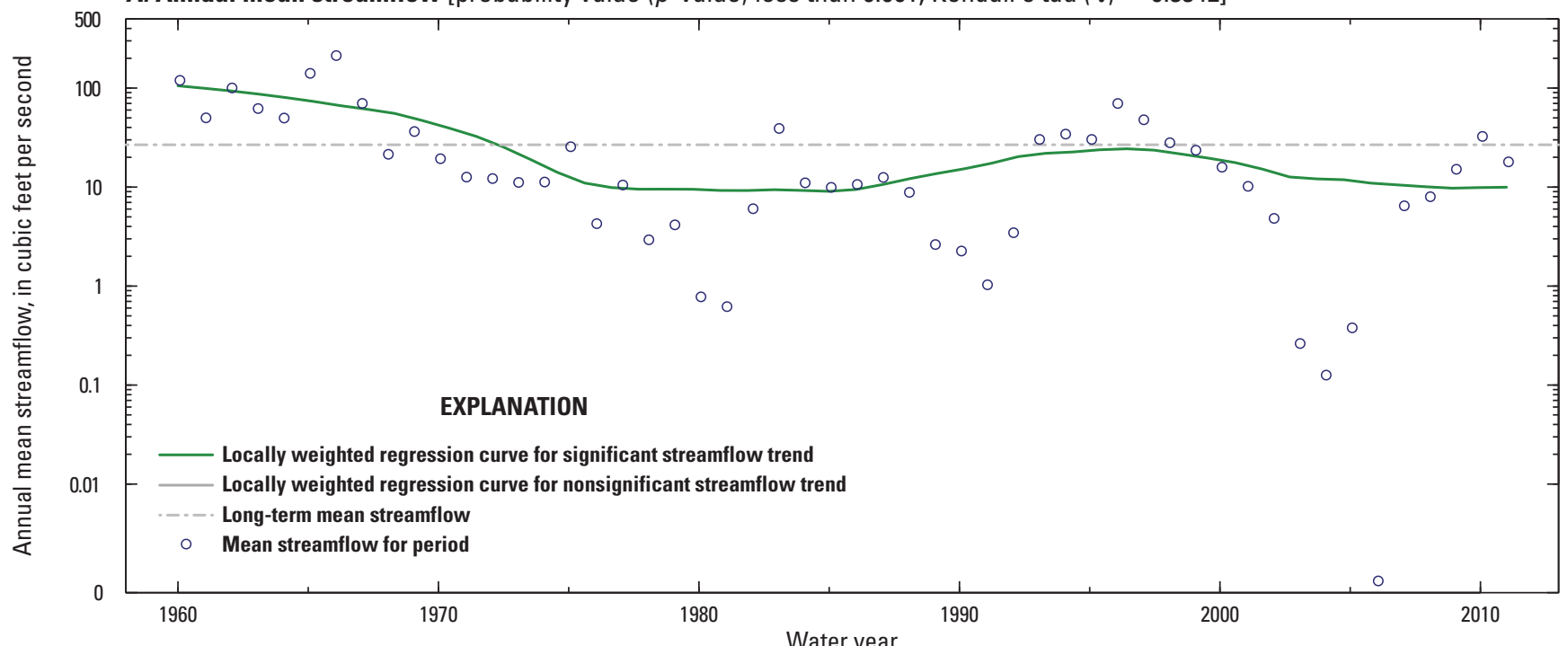

B. October-December $(p$-value $=0.38, \tau=-0.0880) \quad$ C. January-March $(p$-value $=0.208, \tau=-0.1216)$
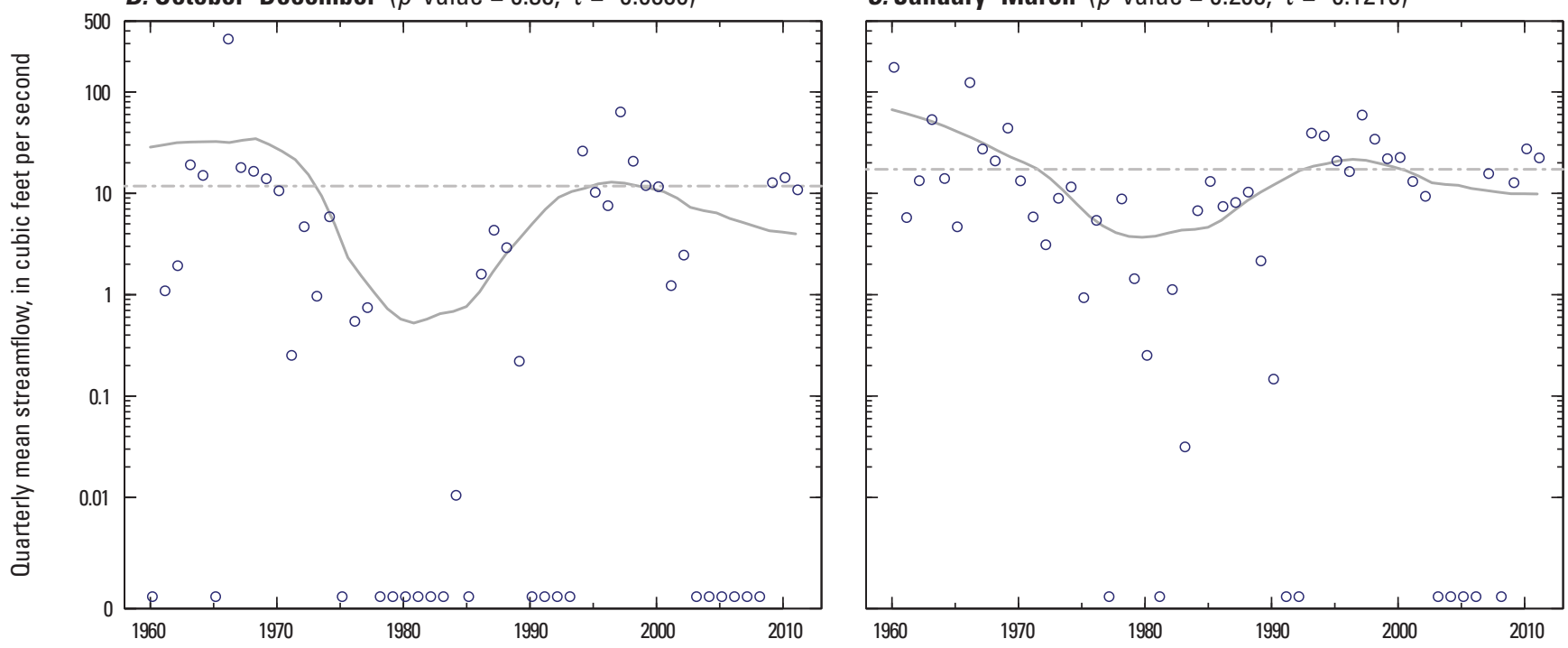

D. April-June ( $p$-value less than 0.001, $\tau=-0.3319$ )

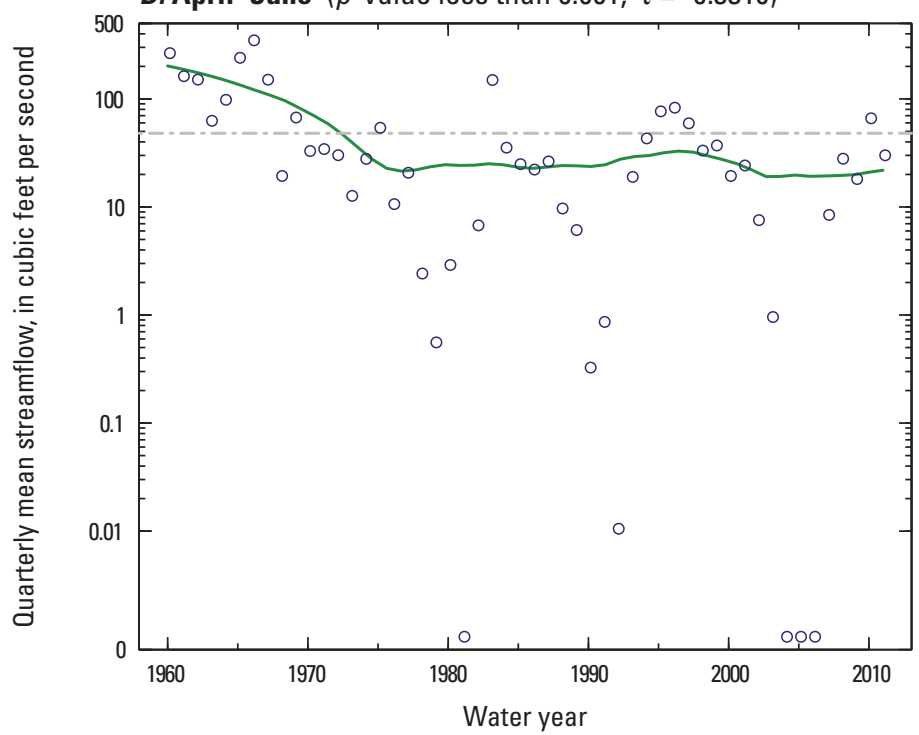

E. July-September ( $p$-value less than $0.001, \tau=-0.3170)$

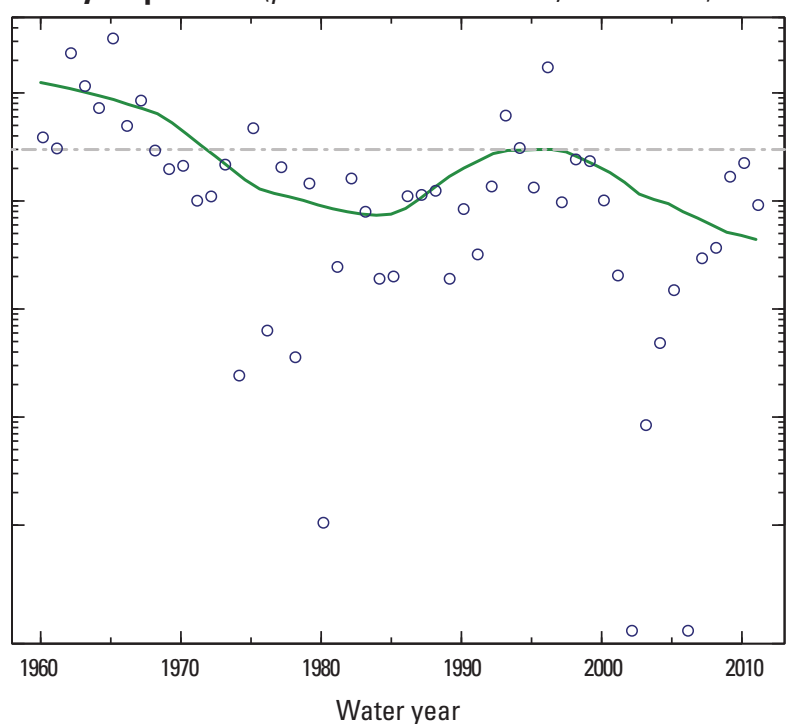

Figure 1-87. Sappa Creek near Stamford, Nebraska (streamgage 06847500), water years 1960-2011. 
A. Annual mean streamflow [probability value $(p$-value $)=0.037$, Kendall's tau $(\tau)=-0.1992$ ]
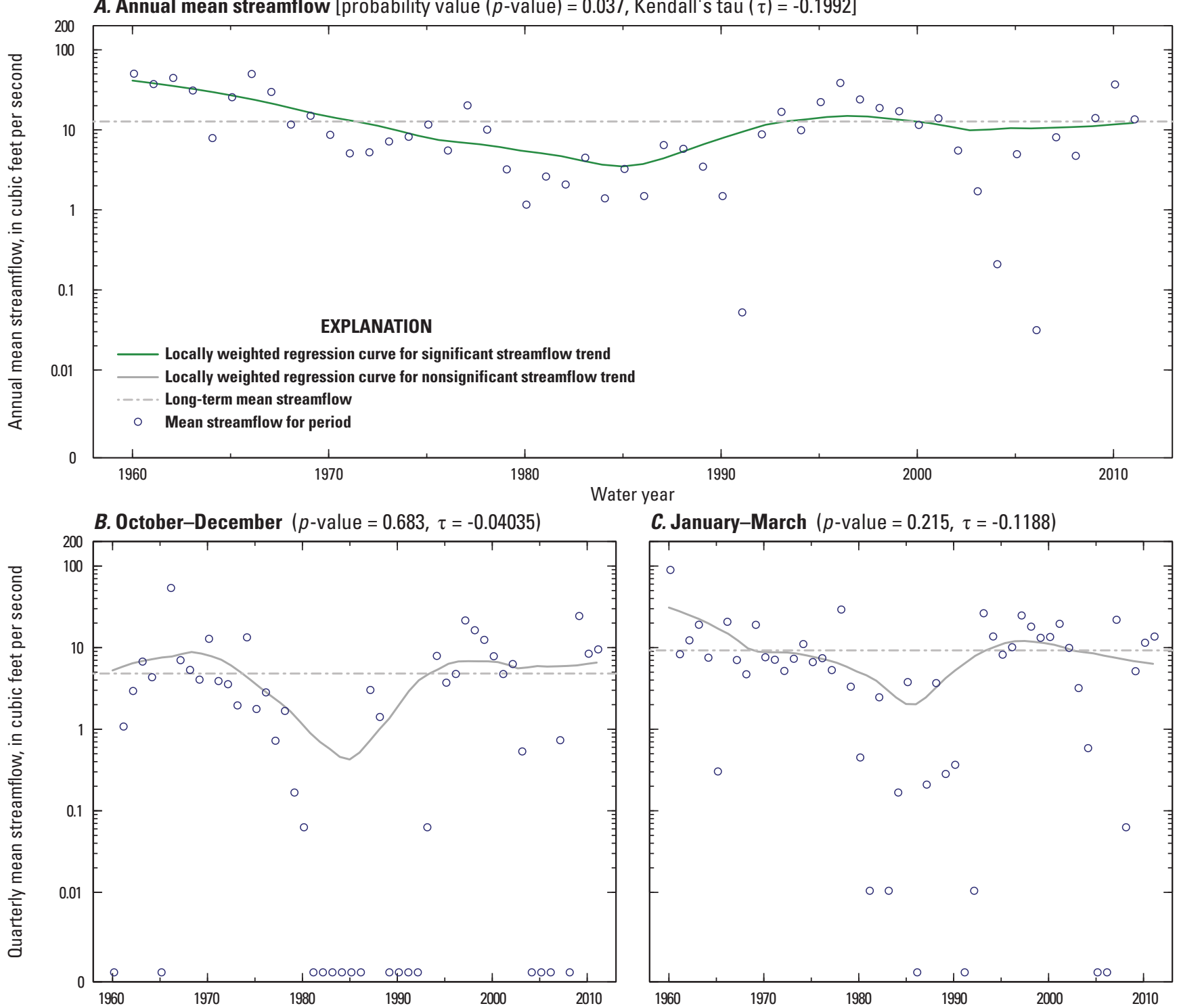

C. January-March ( $p$-value $=0.215, \tau=-0.1188)$

D. April-June ( $p$-value $=0.165, \tau=-0.1328)$
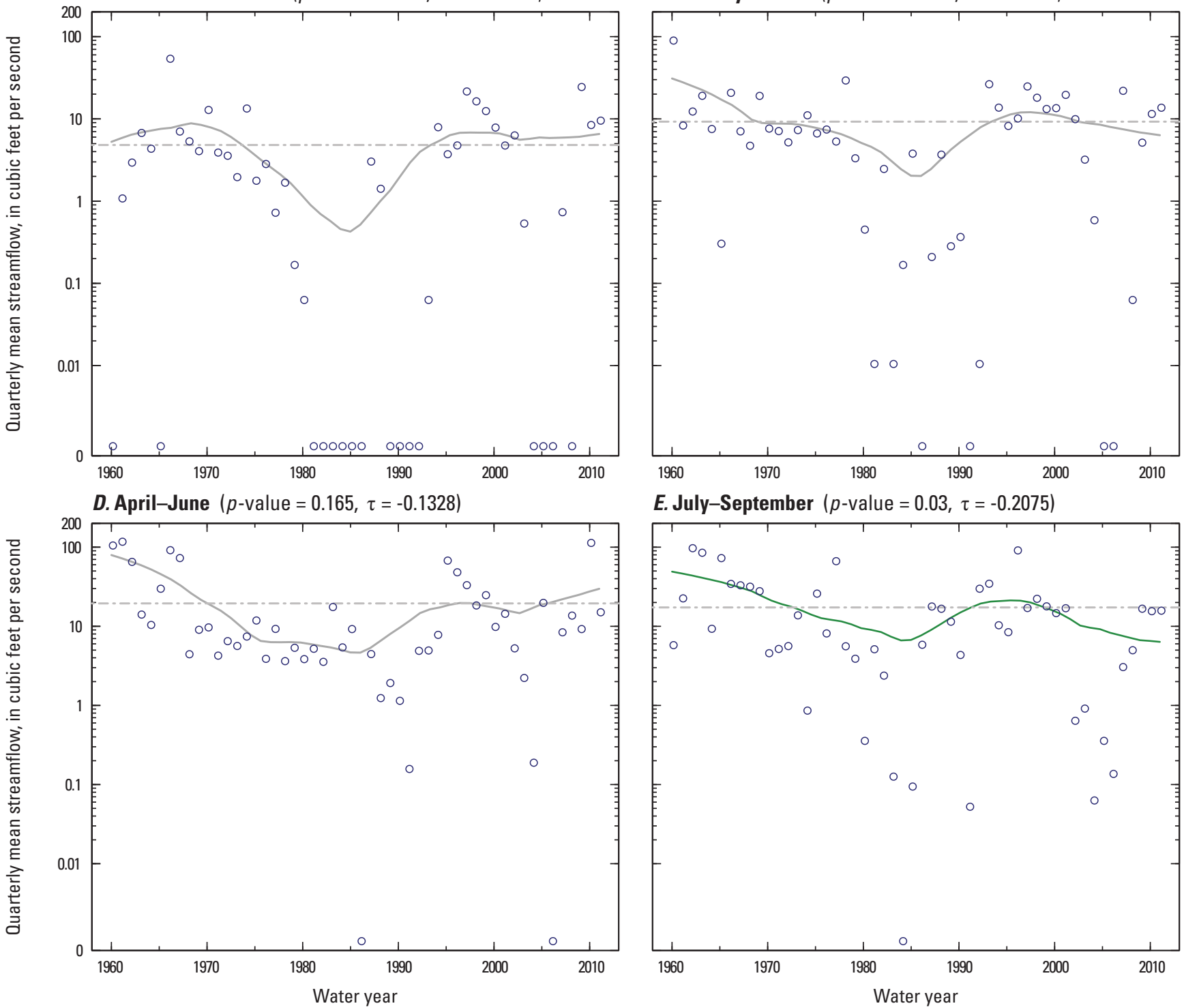

E. July-September $(p$-value $=0.03, \tau=-0.2075)$

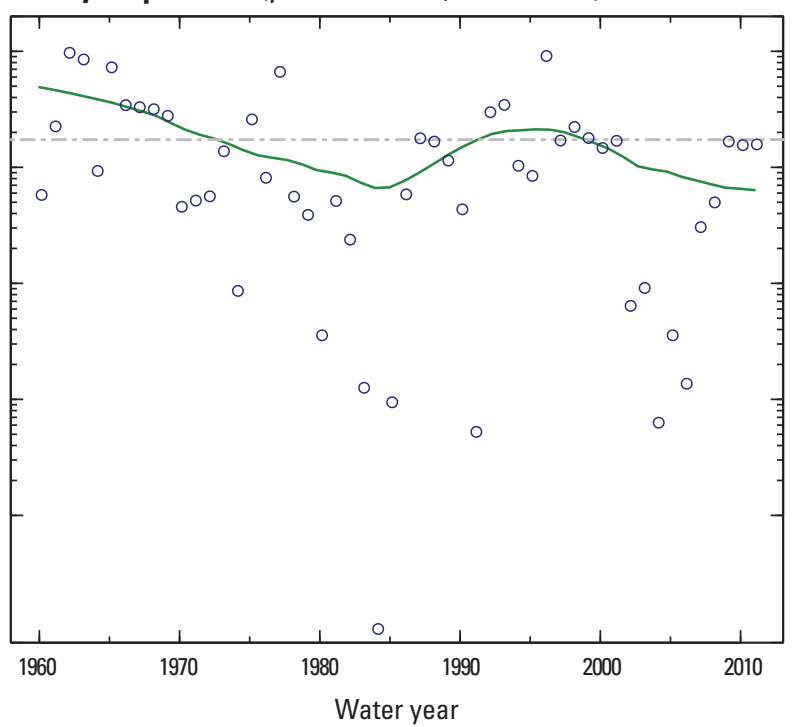

Figure 1-88. Prairie Dog Creek near Woodruff, Kansas (streamgage 06848500), water years 1960-2011. 
A. Annual mean streamflow [probability value $(p$-value $)=0.041$, Kendall's tau $(\tau)=-0.1957$ ]
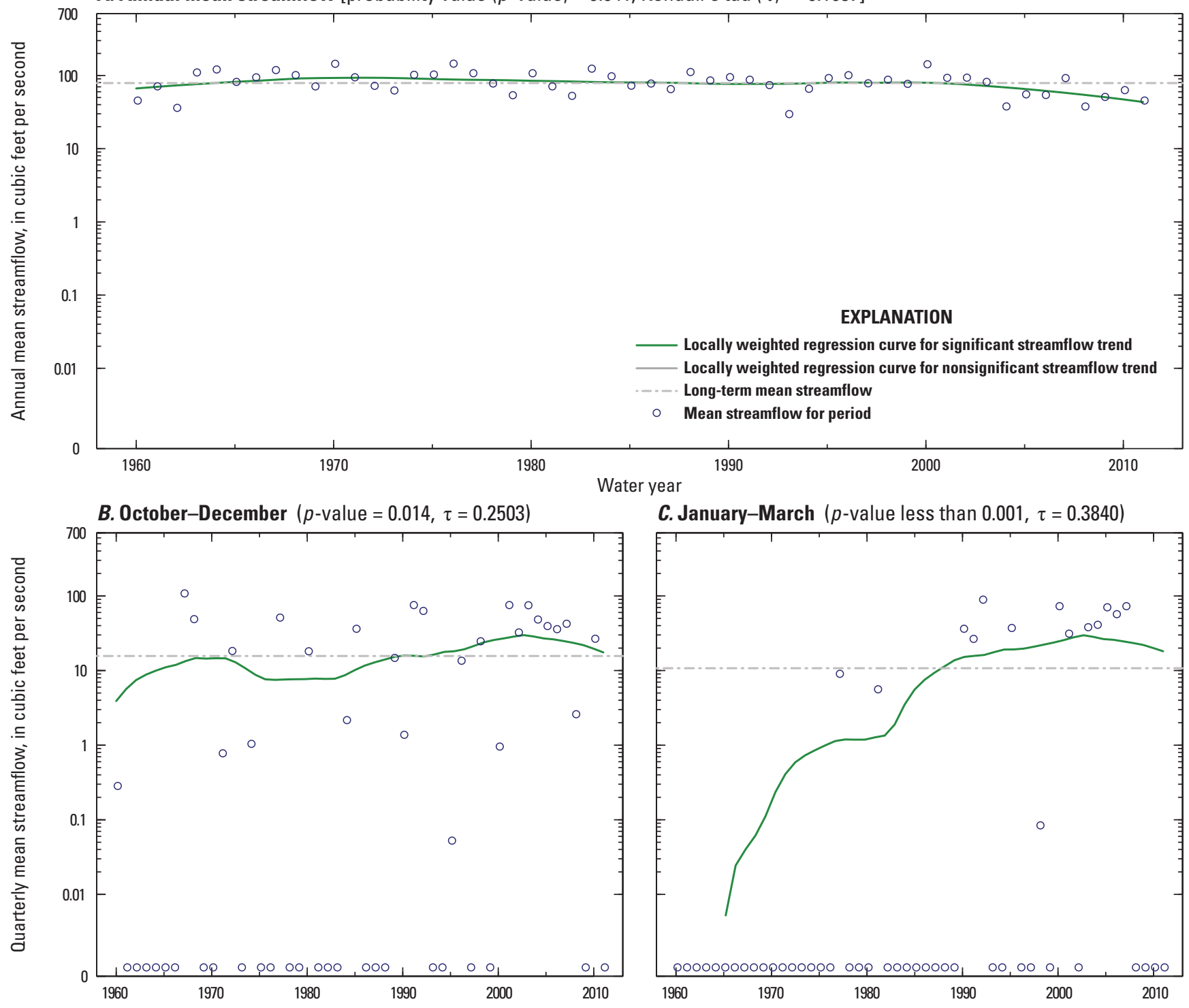

C. January-March ( $p$-value less than 0.001, $\tau=0.3840$ )
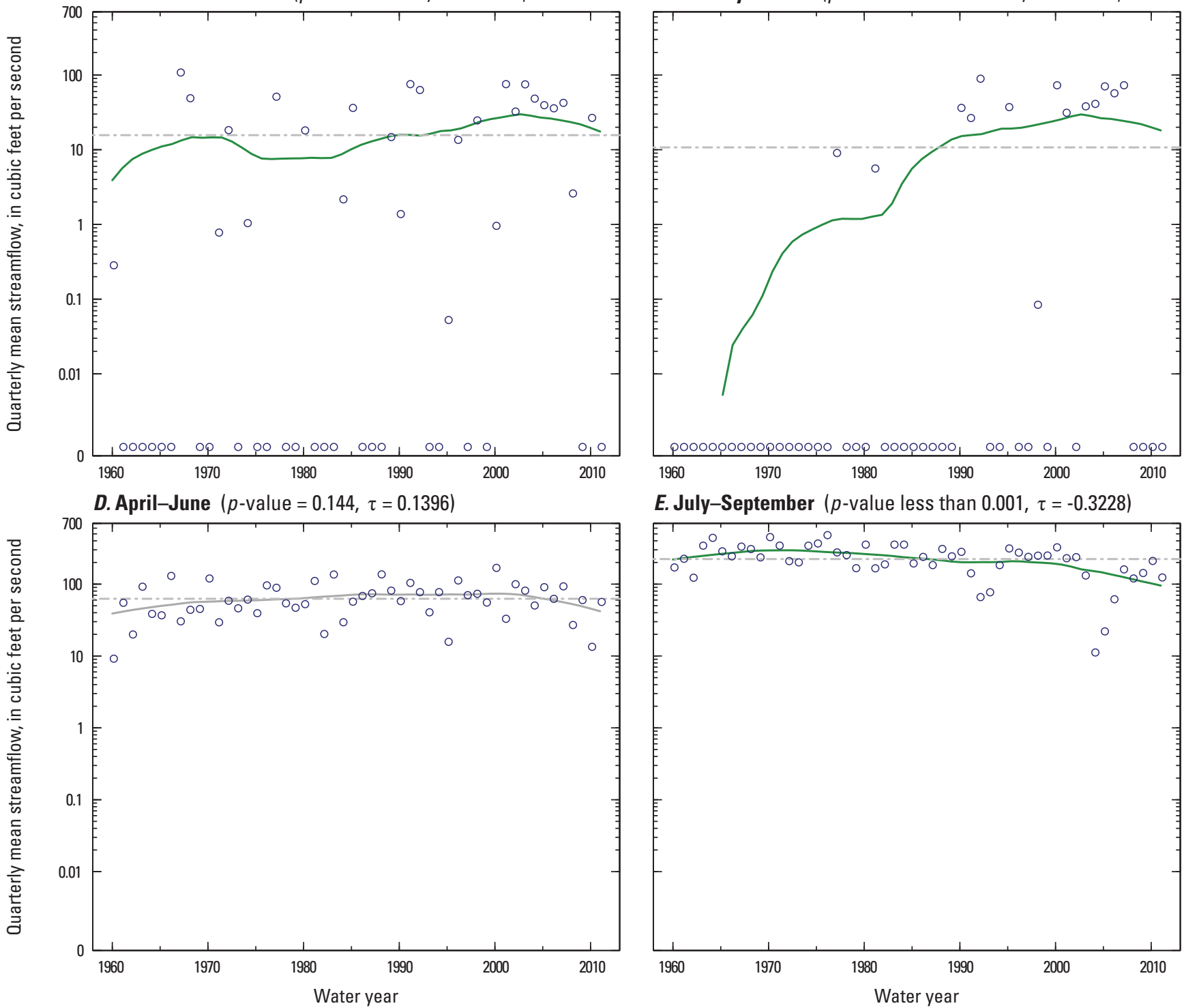

E. July-September ( $p$-value less than $0.001, \tau=-0.3228)$

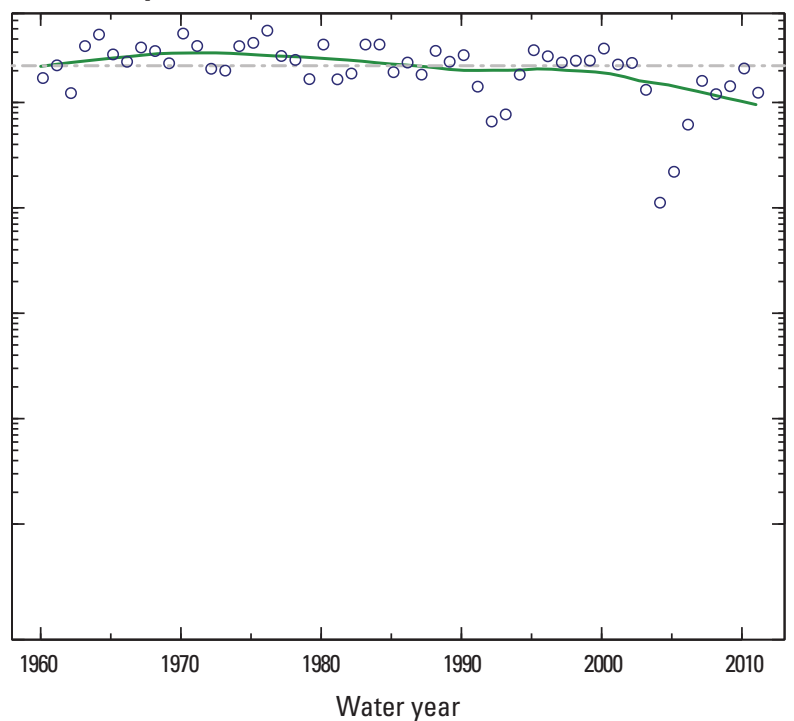

Figure 1-89. Courtland Canal at Nebraska-Kansas State line (streamgage 06852500), water years 1960-2011. 
A. Annual mean streamflow [probability value $(p$-value $)=0.003$, Kendall's tau $(\tau)=-0.2821$ ]
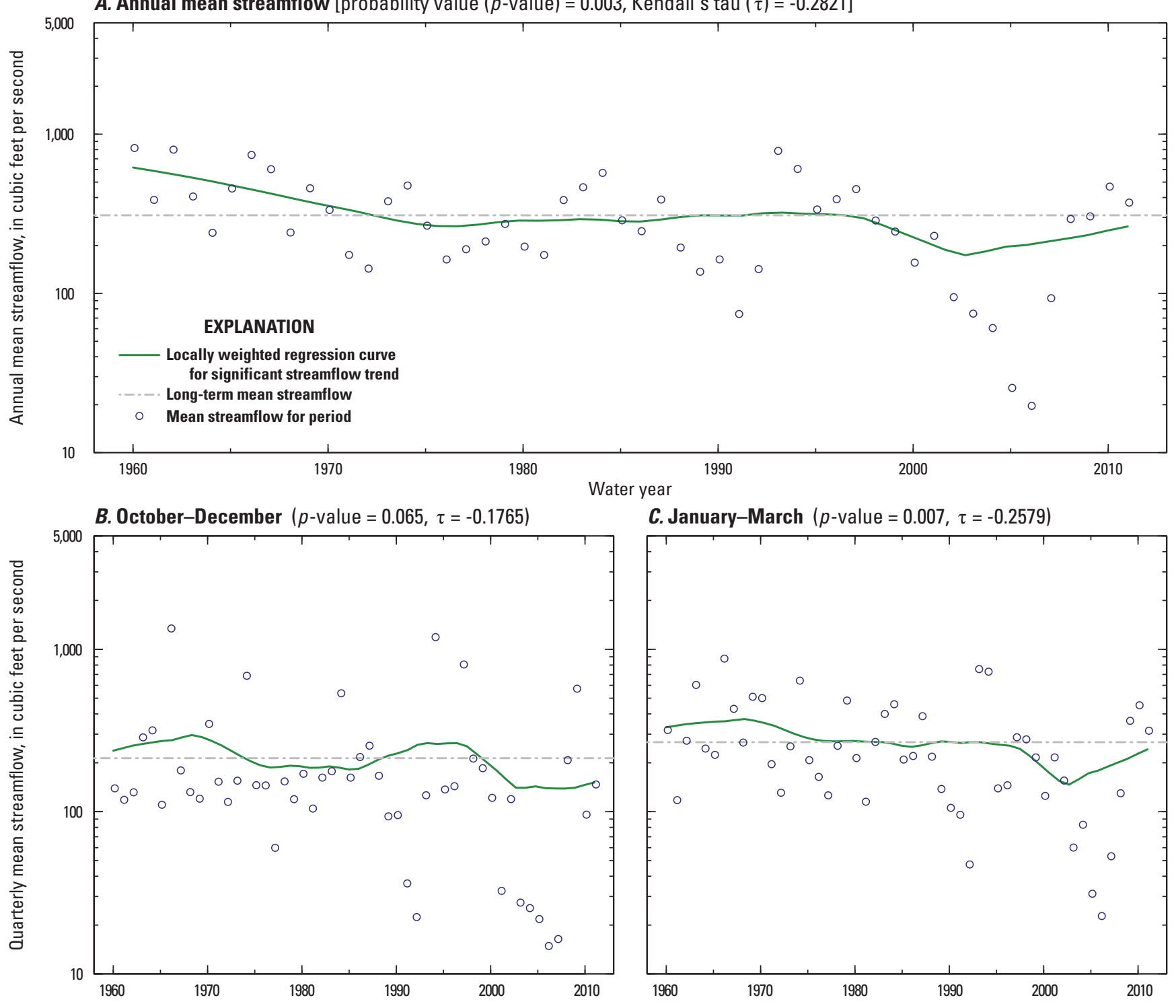

C. January-March ( $p$-value $=0.007, \tau=-0.2579)$
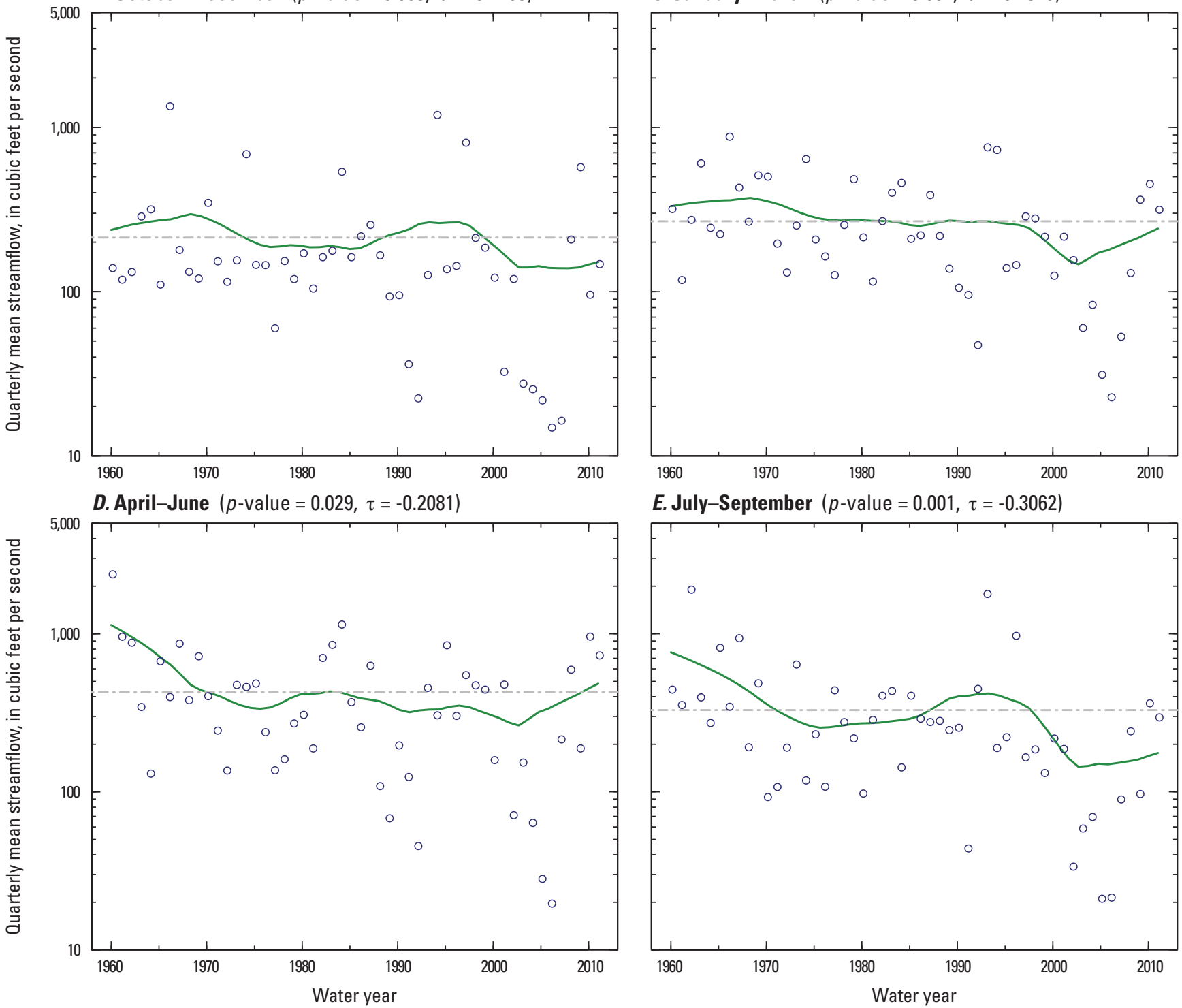

E. July-September $(p$-value $=0.001, \tau=-0.3062)$

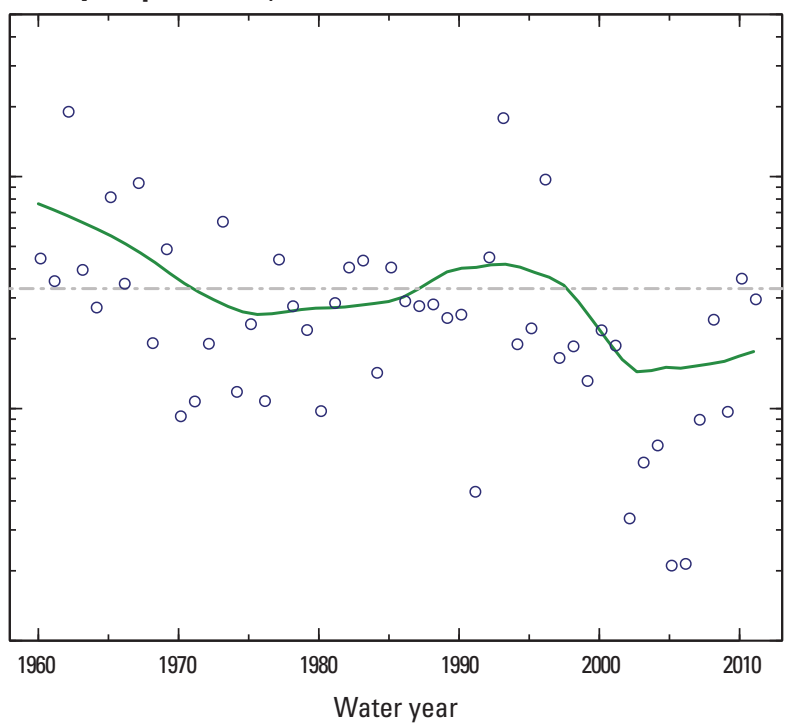

Figure 1-90. Republican River near Hardy, Nebraska (streamgage 06853500), water years 1960-2011. 

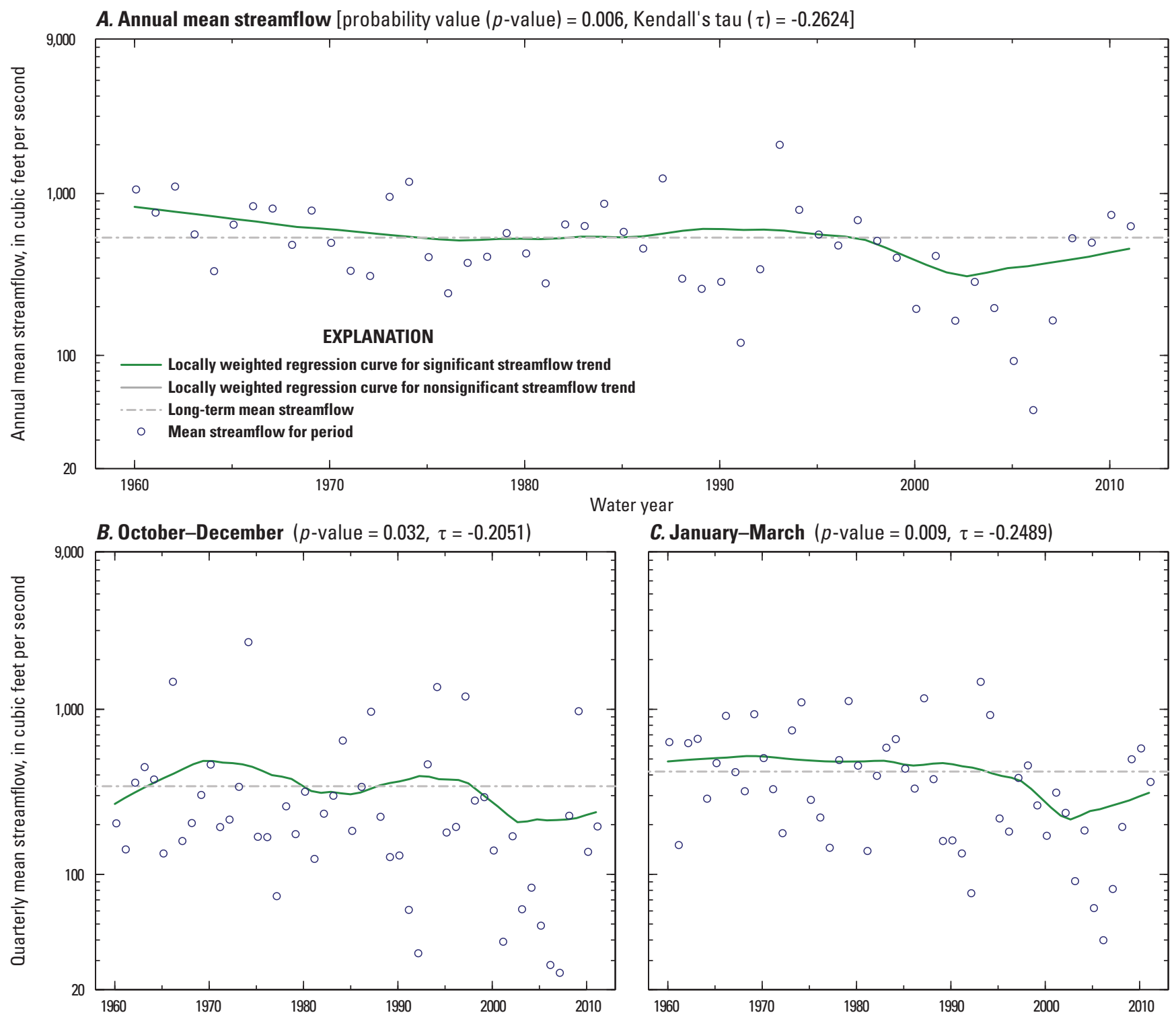

C. January-March $(p$-value $=0.009, \tau=-0.2489)$
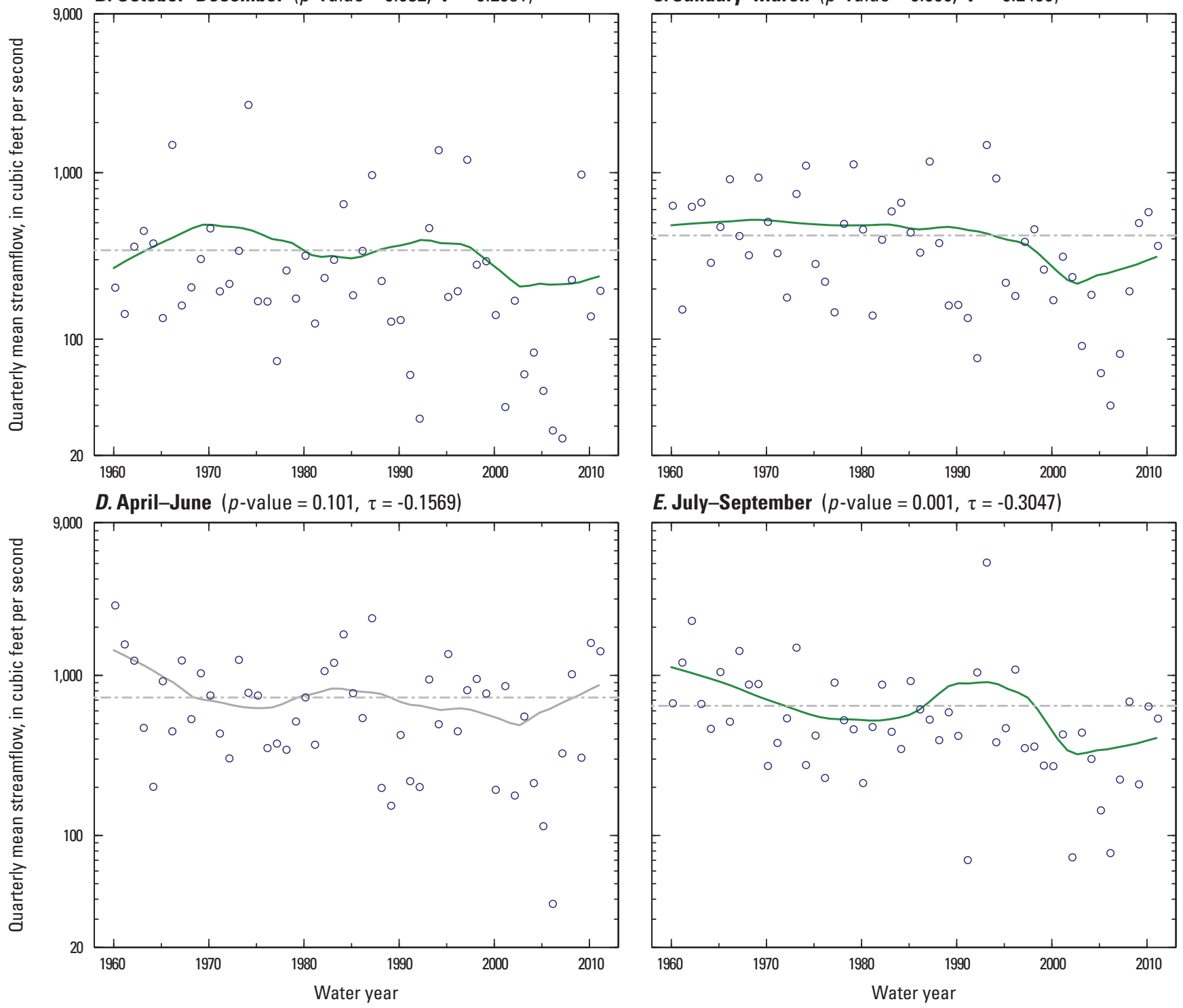

E. July-September $(p$-value $=0.001, \tau=-0.3047)$

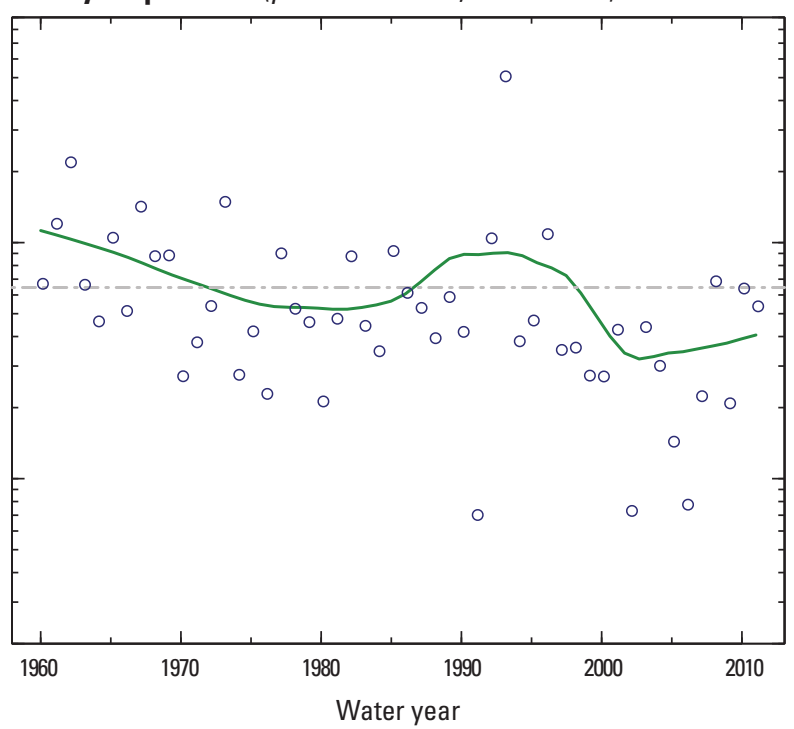

Figure 1-91. Republican River at Concordia, Kansas (streamgage 06856000), water years 1960-2011. 
A. Annual mean streamflow [probability value $(p$-value $)=0.05$, Kendall's tau $(\tau)=-0.1870$ ]
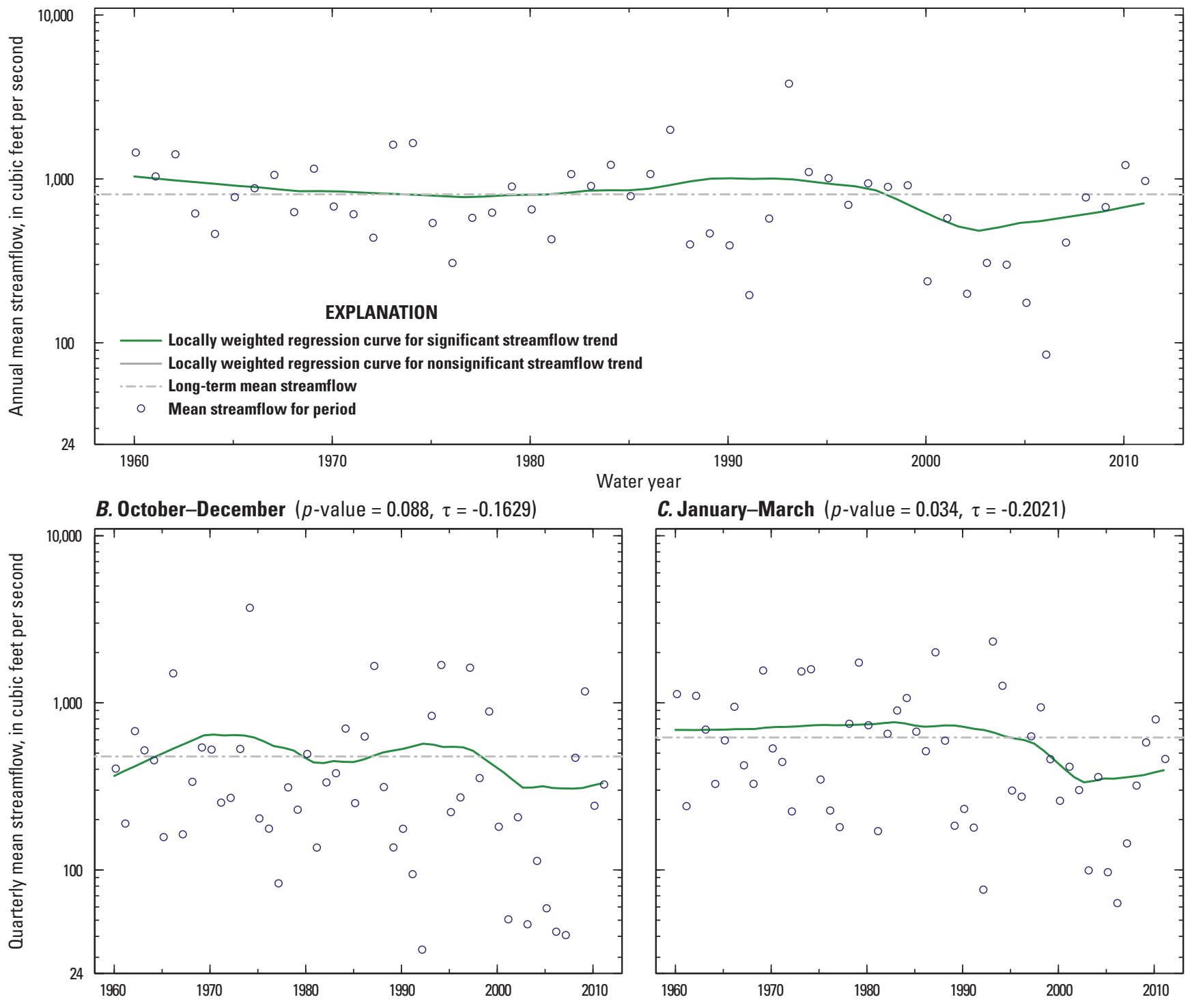

C. January-March $(p$-value $=0.034, \tau=-0.2021)$

D. April-June $(p$-value $=0.385, \tau=-0.08296)$
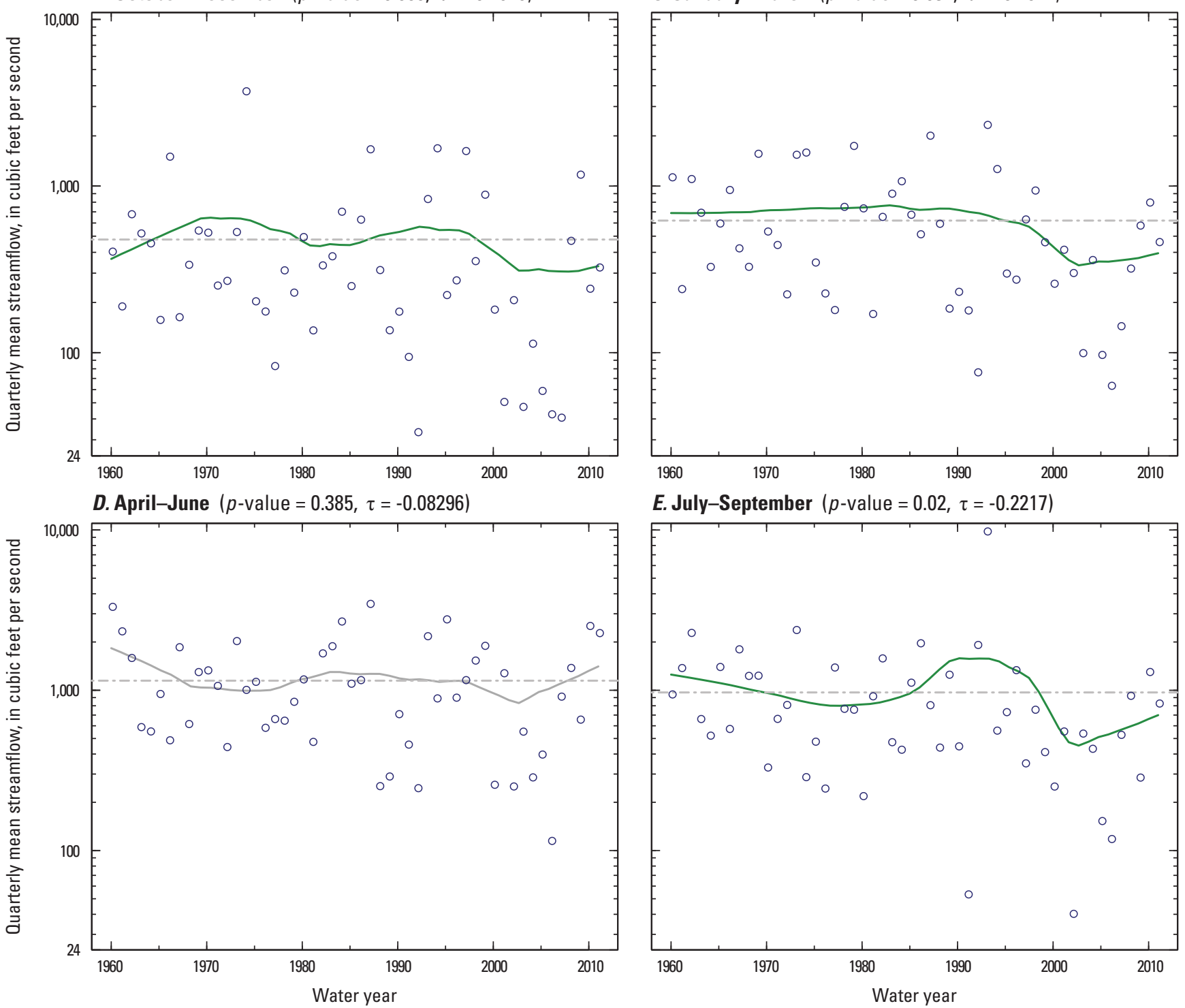

E. July-September $(p$-value $=0.02, \tau=-0.2217)$

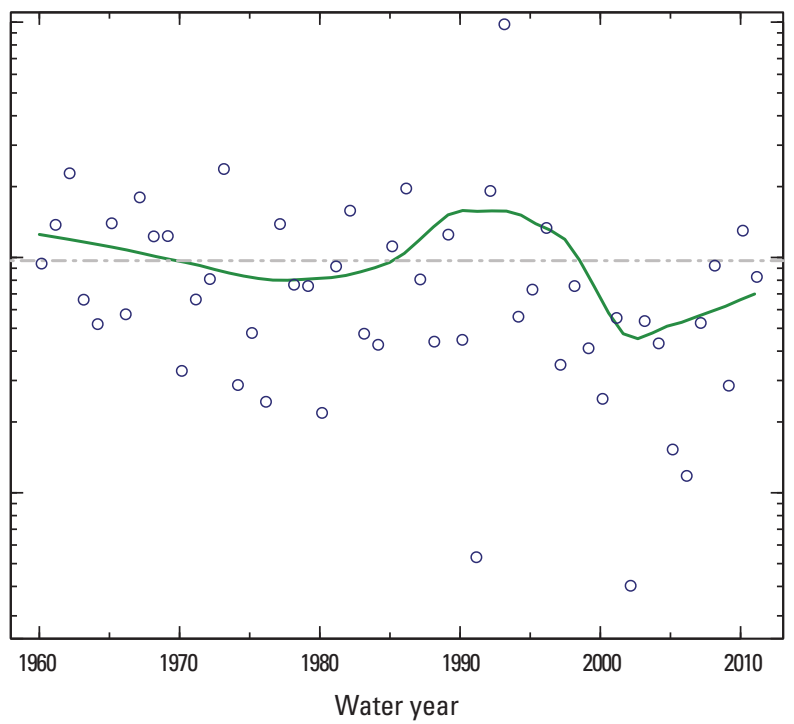

Figure 1-92. Republican River at Clay Center, Kansas (streamgage 06856600), water years 1960-2011. 

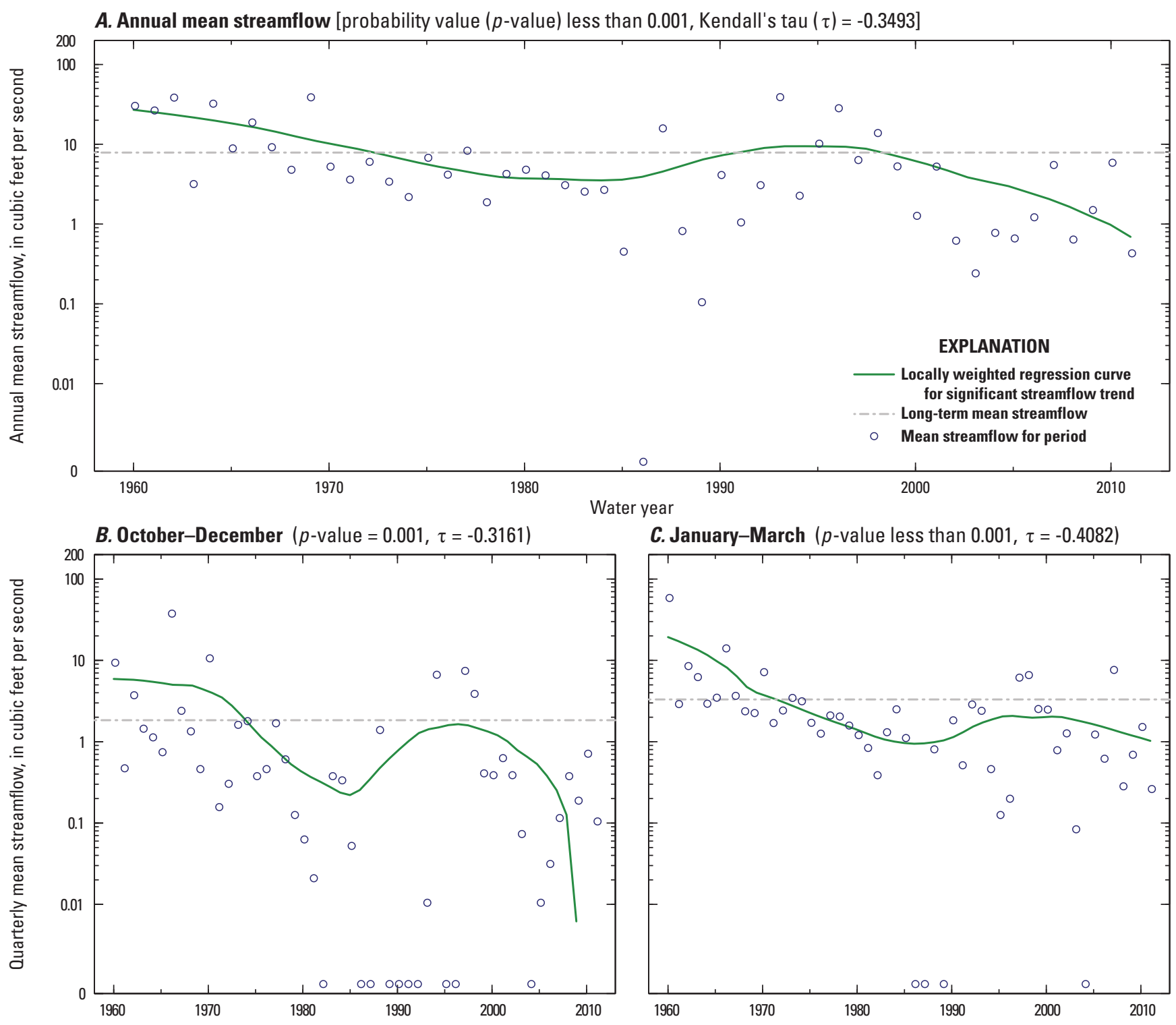

C. January-March ( $p$-value less than 0.001, $\tau=-0.4082$ )
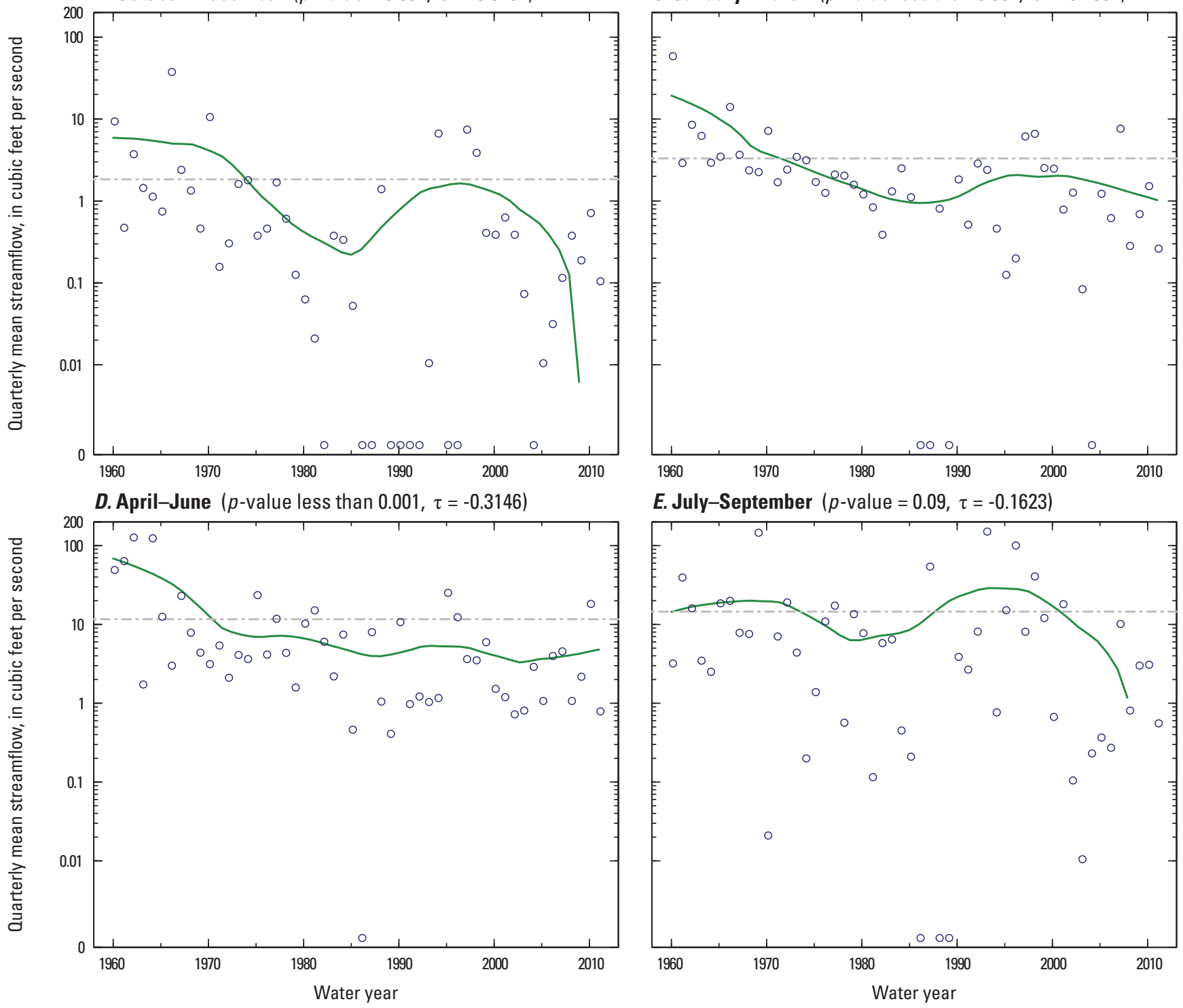

E. July-September $(p$-value $=0.09, \tau=-0.1623)$

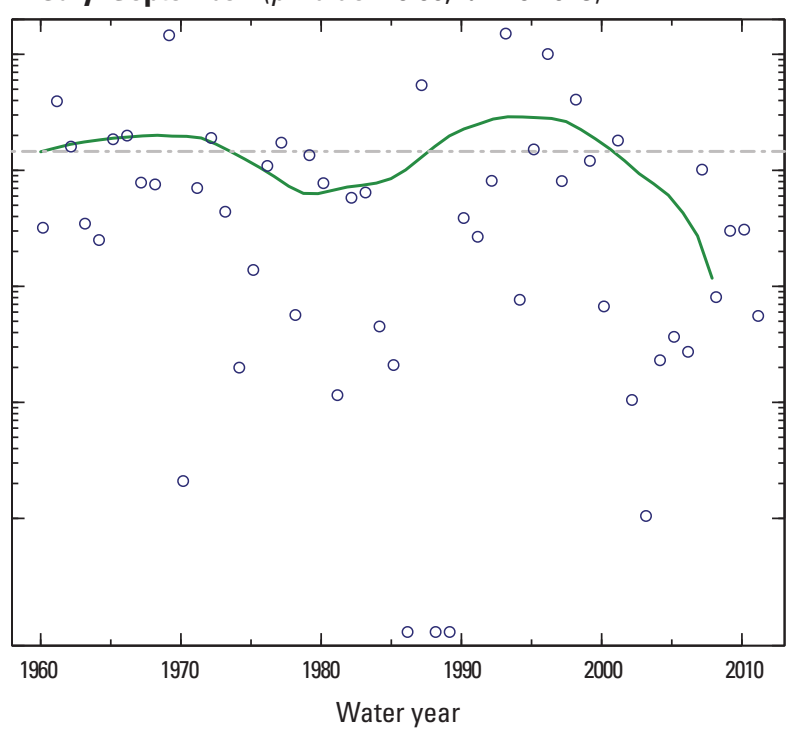

Figure 1-93. Smoky Hill River at Elkader, Kansas (streamgage 06860000), water years 1960-2011. 
A. Annual mean streamflow [probability value ( $p$-value) less than 0.001 , Kendall's tau $(\tau)=-0.3155$ ]
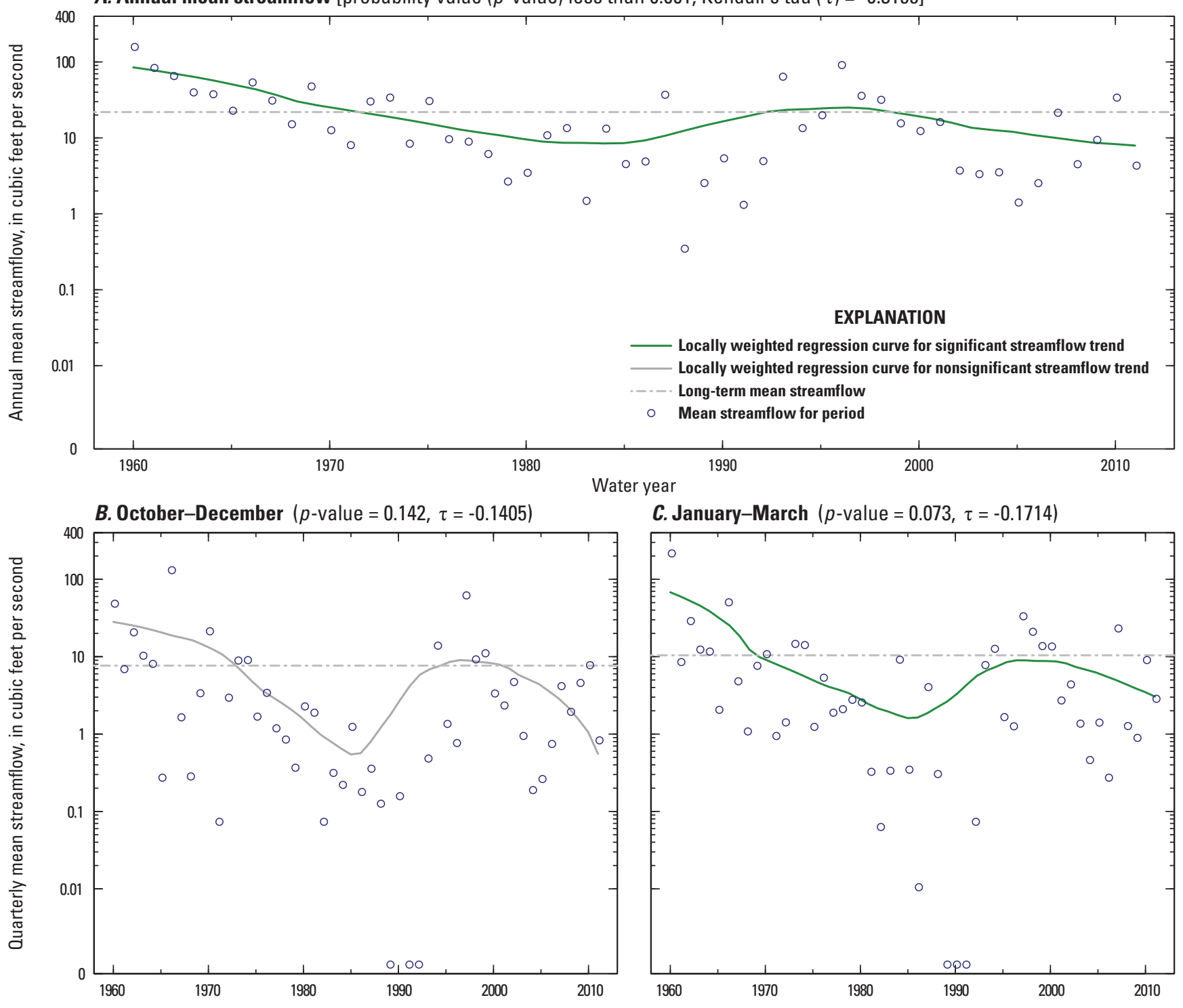

C. January-March ( $p$-value $=0.073, \tau=-0.1714)$

D. April-June $(p$-value $=0.028, \tau=-0.2097)$
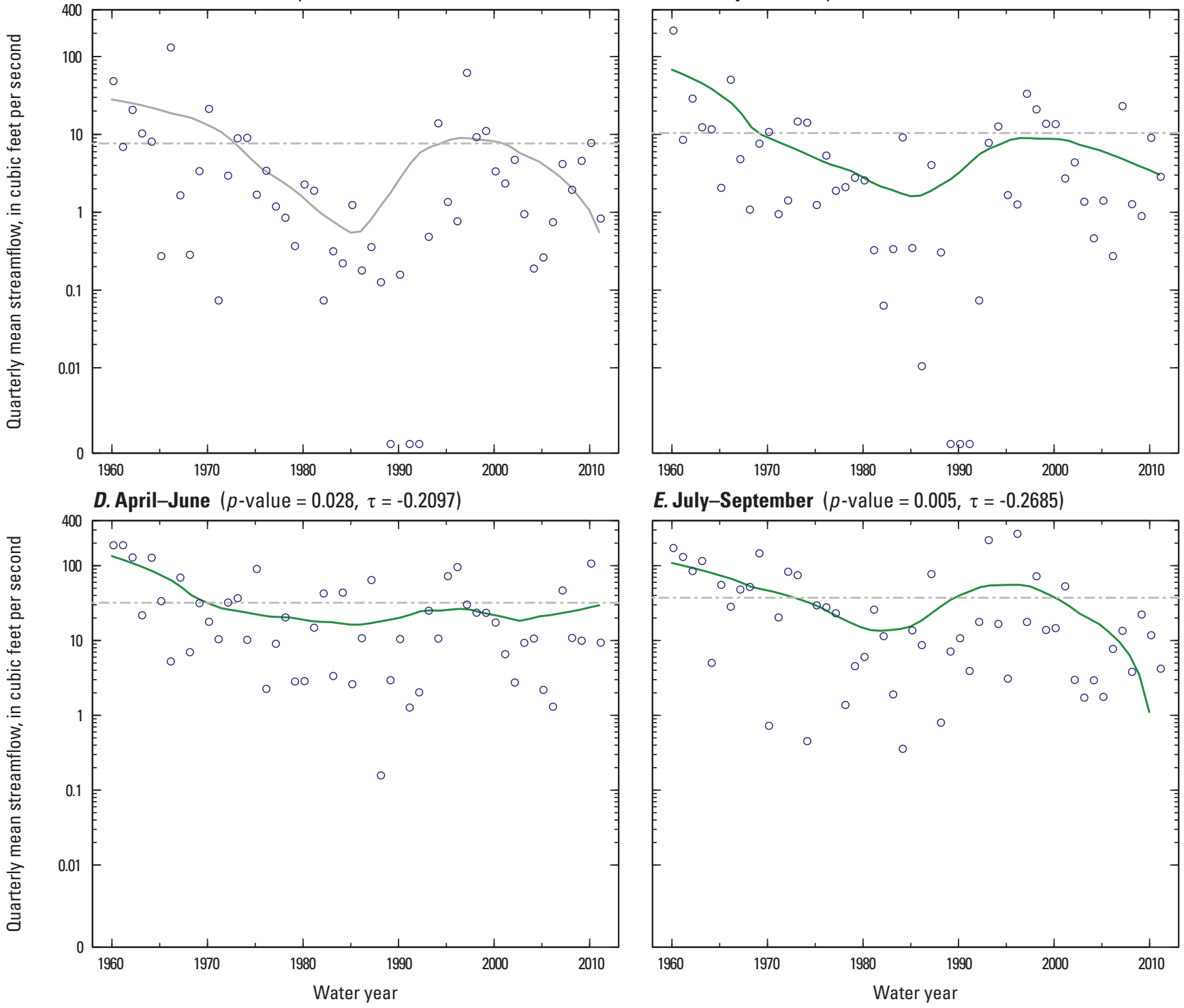

E. July-September $(p$-value $=0.005, \tau=-0.2685)$

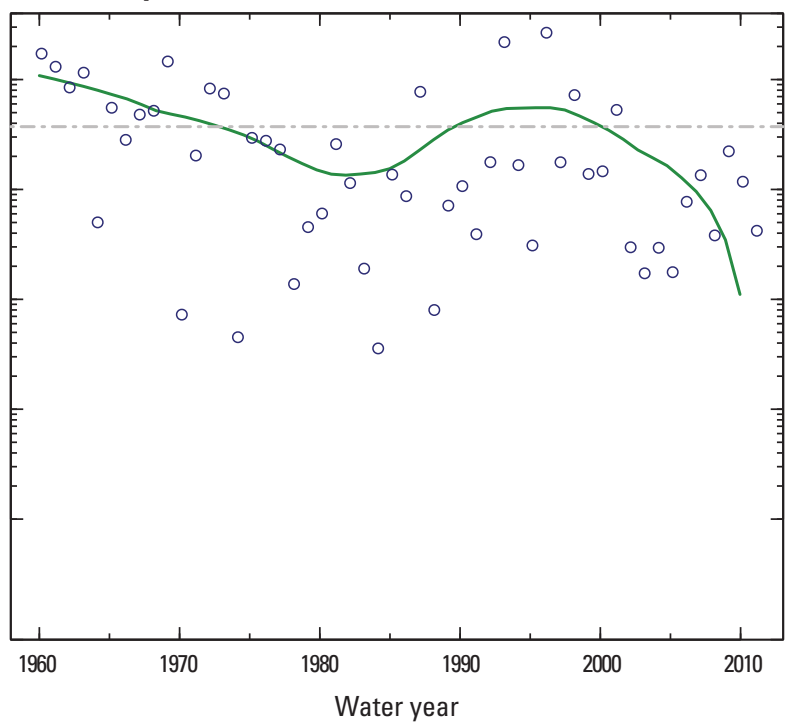

Figure 1-94. Smoky Hill River near Arnold, Kansas (streamgage 06861000), water years 1960-2011. 
A. Annual mean streamflow [probability value $(p$-value $)=0.029$, Kendall's tau $(\tau)=-0.2091$ ]

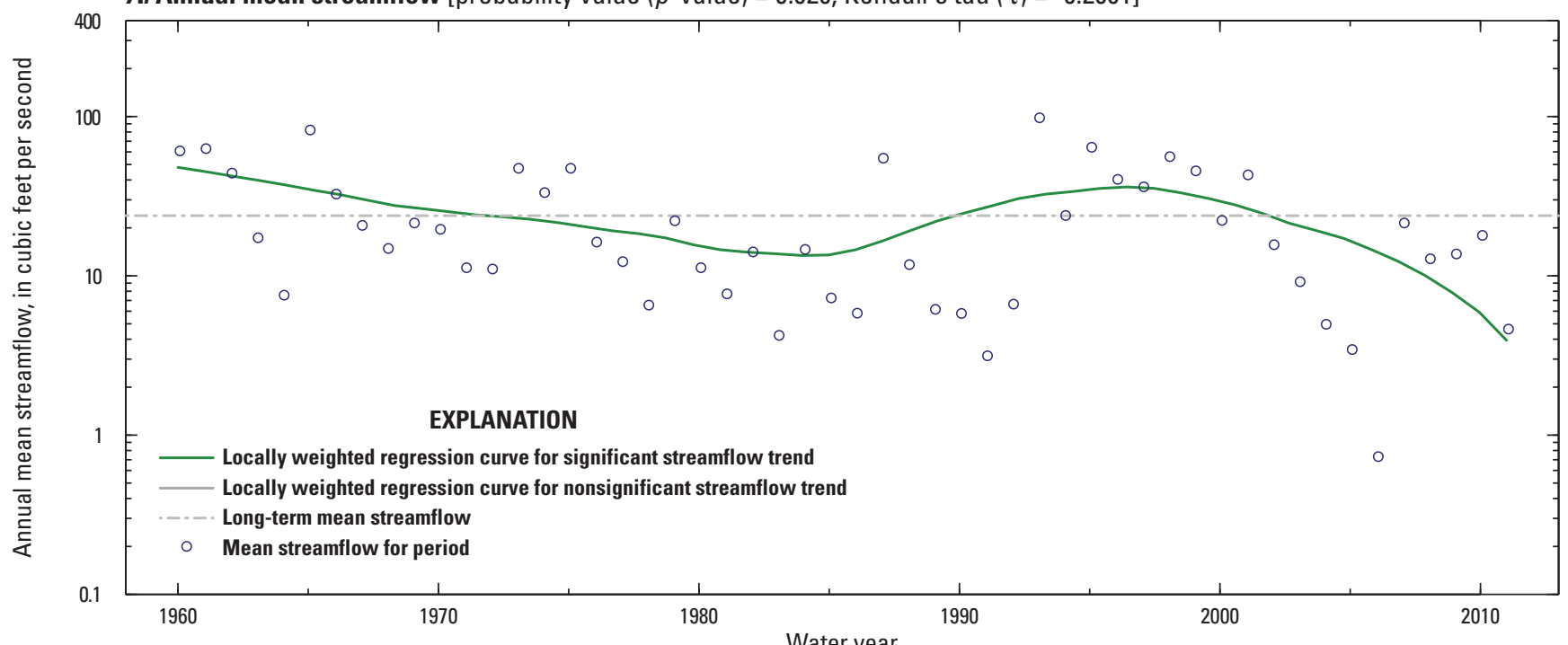

B. October-December $(p$-value $=0.253, \tau=-0.1094)$

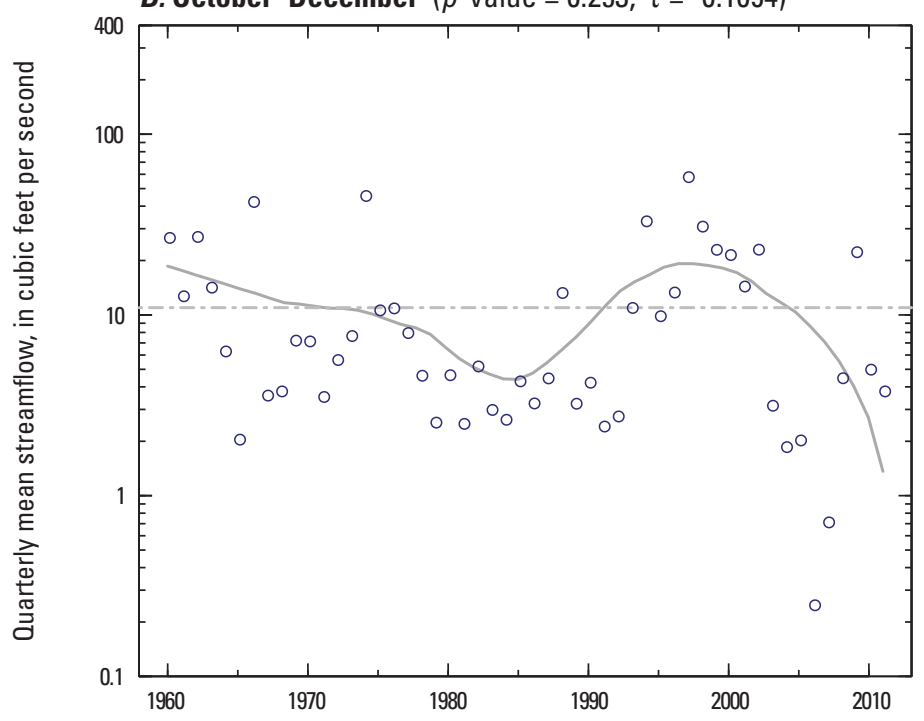

C. January-March ( $p$-value $=0.67, \tau=-0.04072)$
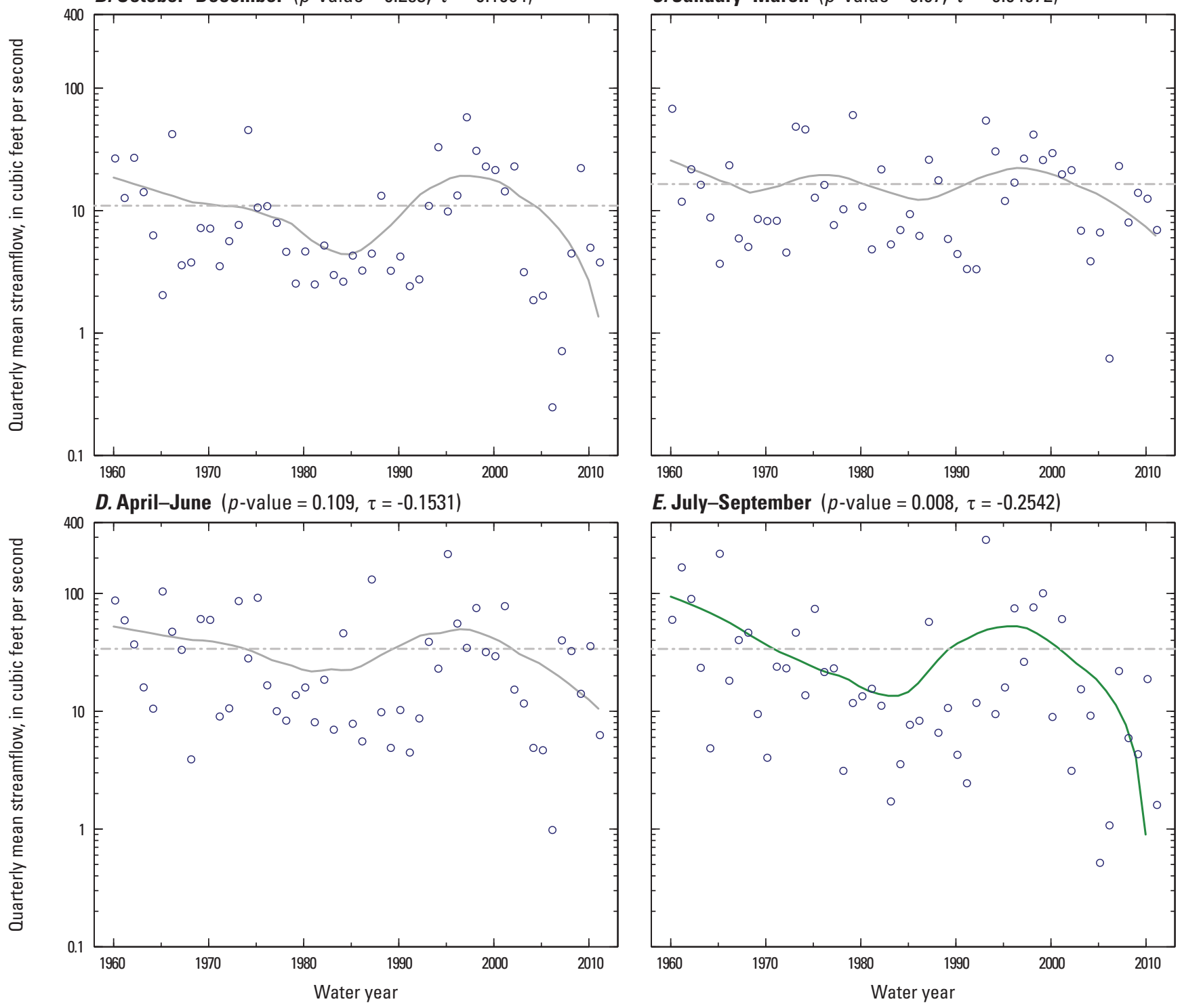

E. July-September $(p$-value $=0.008, \tau=-0.2542)$

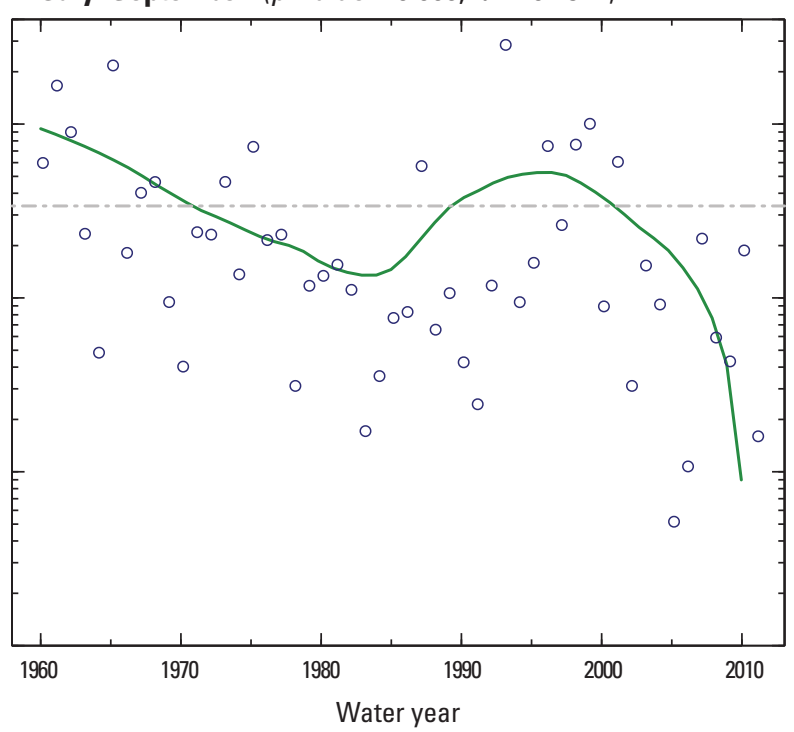

Figure 1-95. Big Creek near Hays, Kansas (streamgage 06863500), water years 1960-2011. 
A. Annual mean streamflow [probability value $(p$-value $)=0.047$, Kendall's tau $(\tau)=-0.1900$ ]
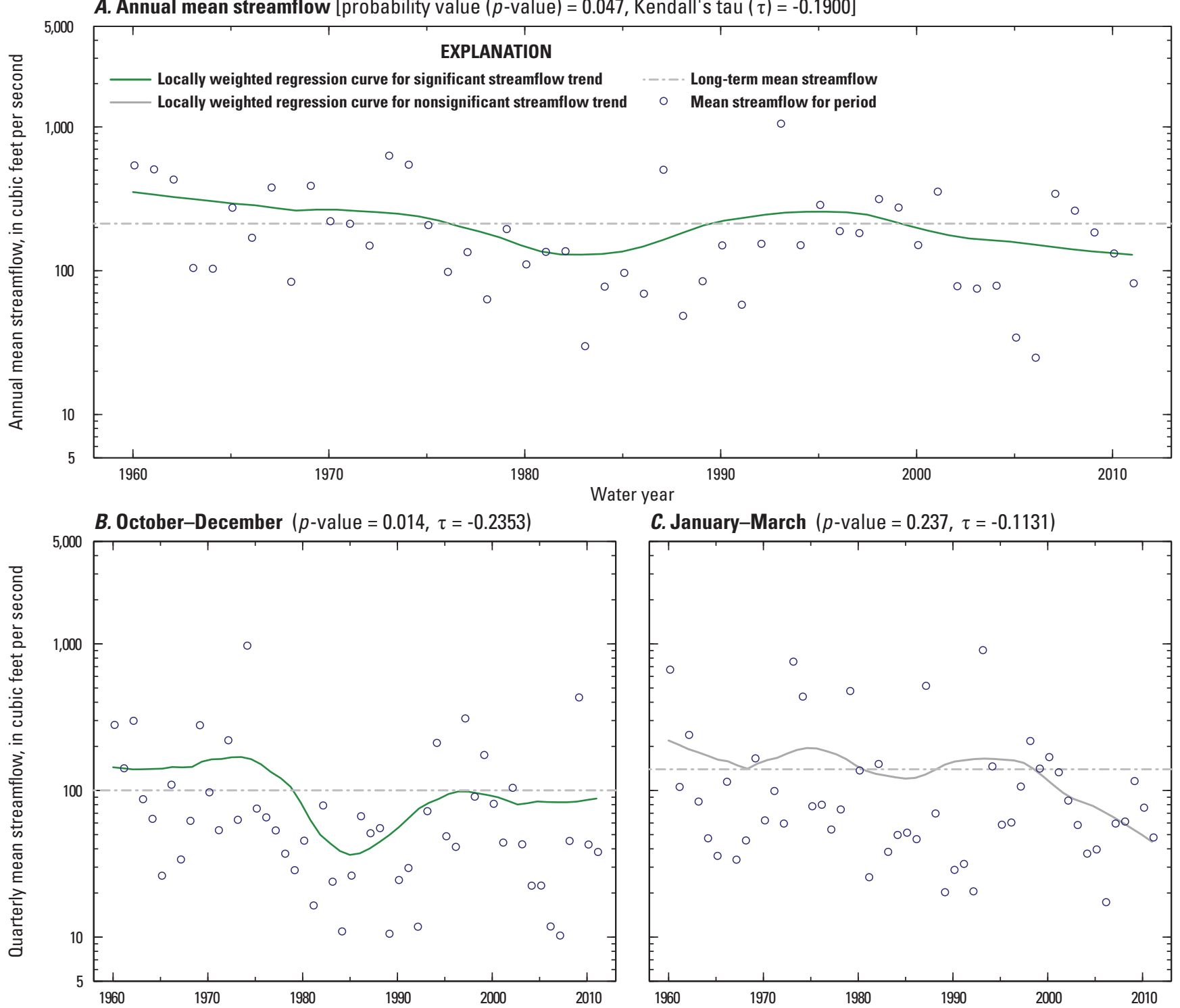

C. January-March $(p$-value $=0.237, \tau=-0.1131)$
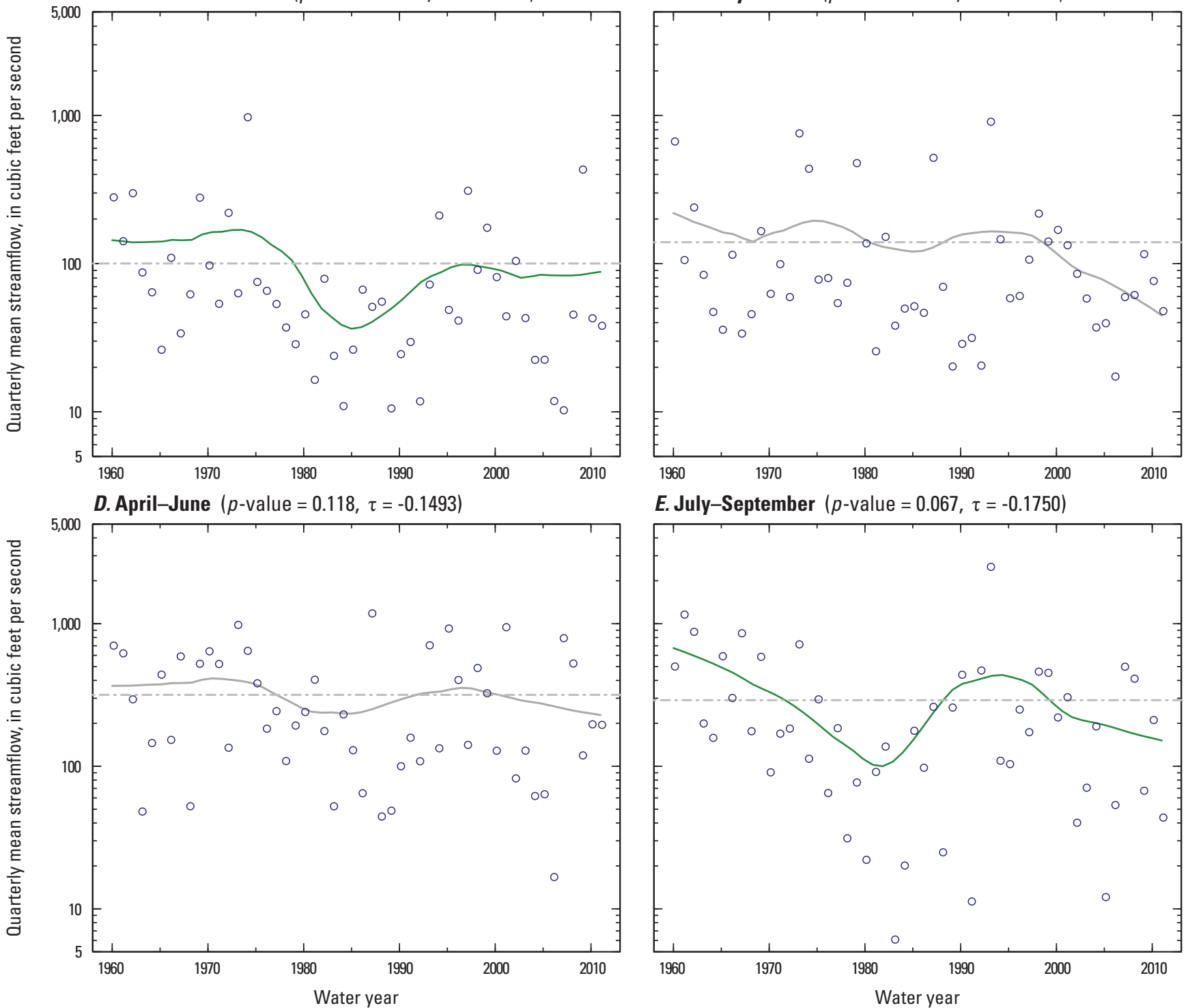

E. July-September $(p$-value $=0.067, \tau=-0.1750)$

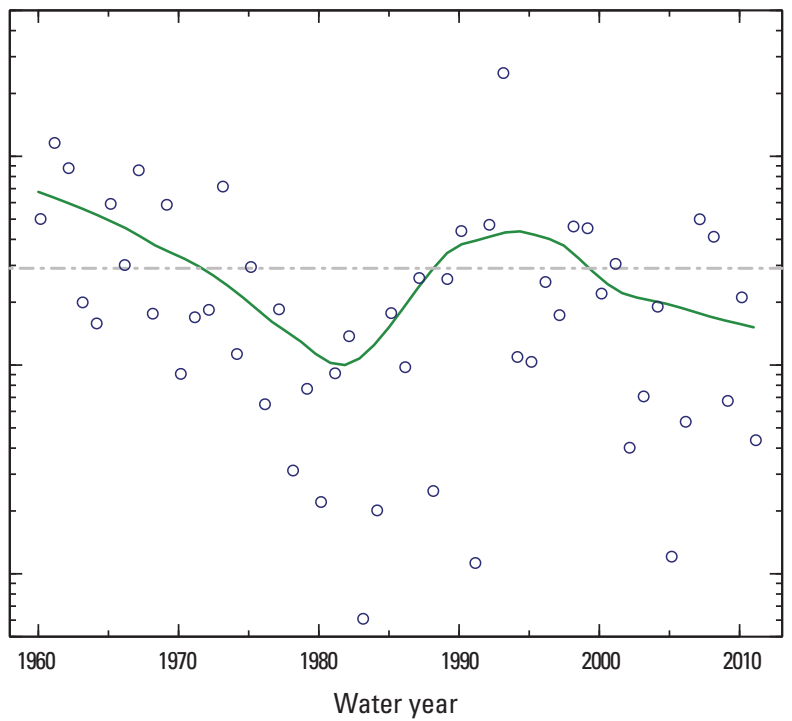

Figure 1-96. Smoky Hill River at Ellsworth, Kansas (streamgage 06864500), water years 1960-2011. 

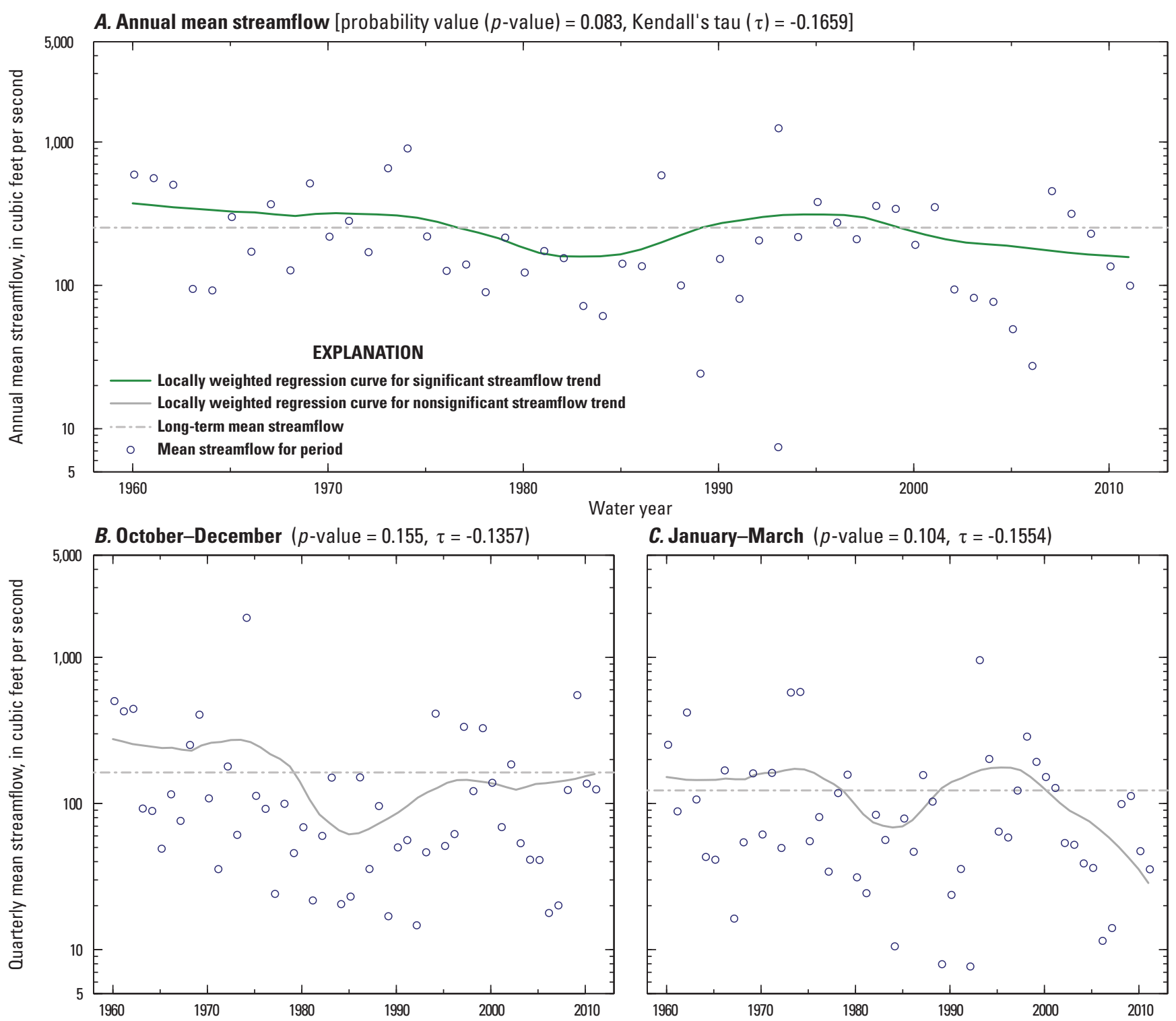

C. January-March $(p$-value $=0.104, \tau=-0.1554)$
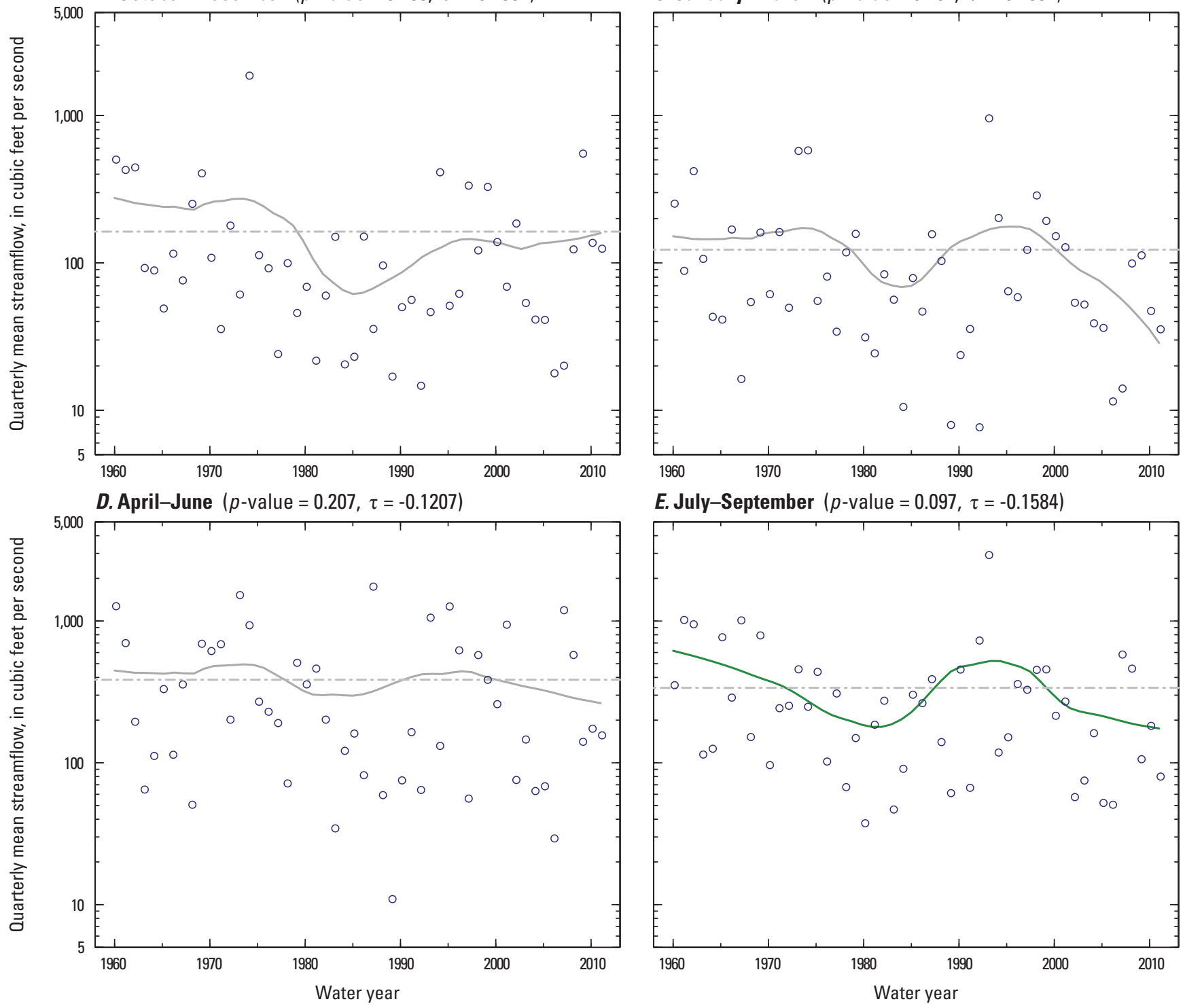

E. July-September $(p$-value $=0.097, \tau=-0.1584)$

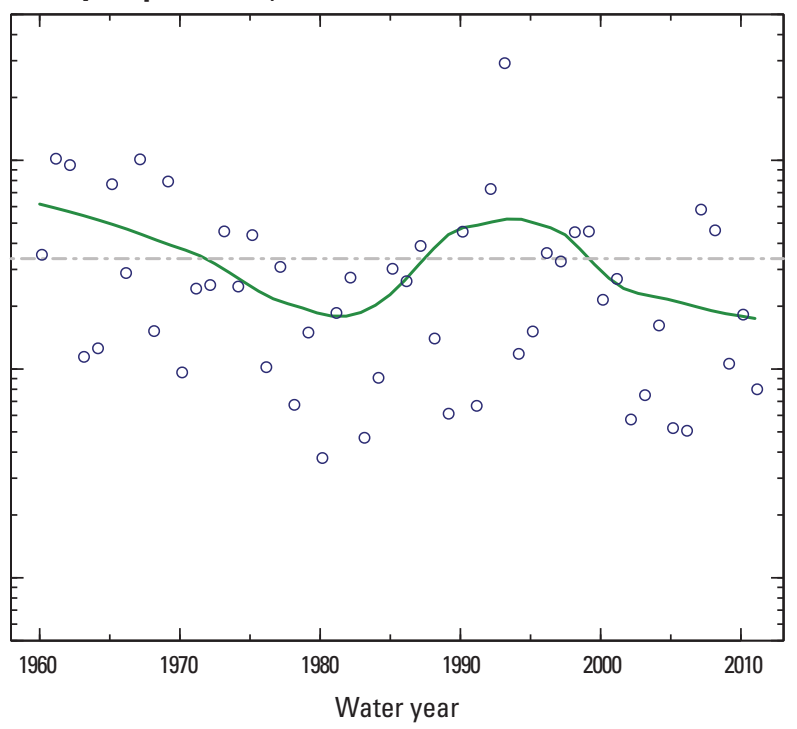

Figure 1-97. Smoky Hill River near Langley, Kansas (streamgage 06865500), water years 1960-2011. 
A. Annual mean streamflow [probability value $(p$-value $)=0.075$, Kendall's tau $(\tau)=-0.1704$ ]

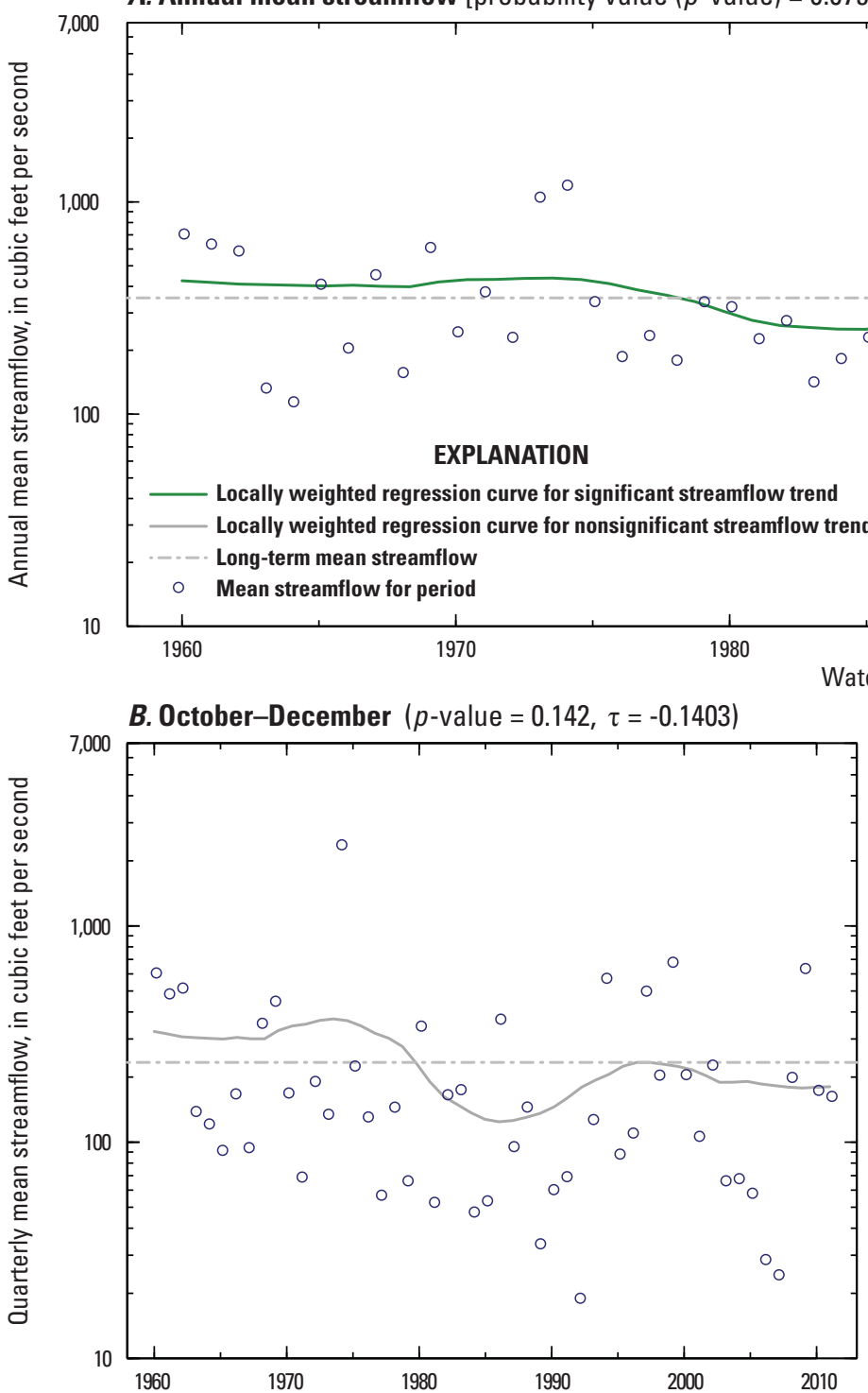

Water year
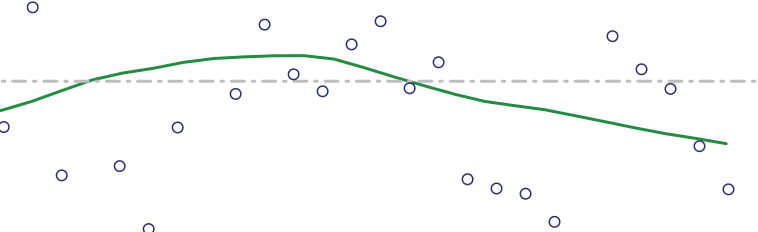

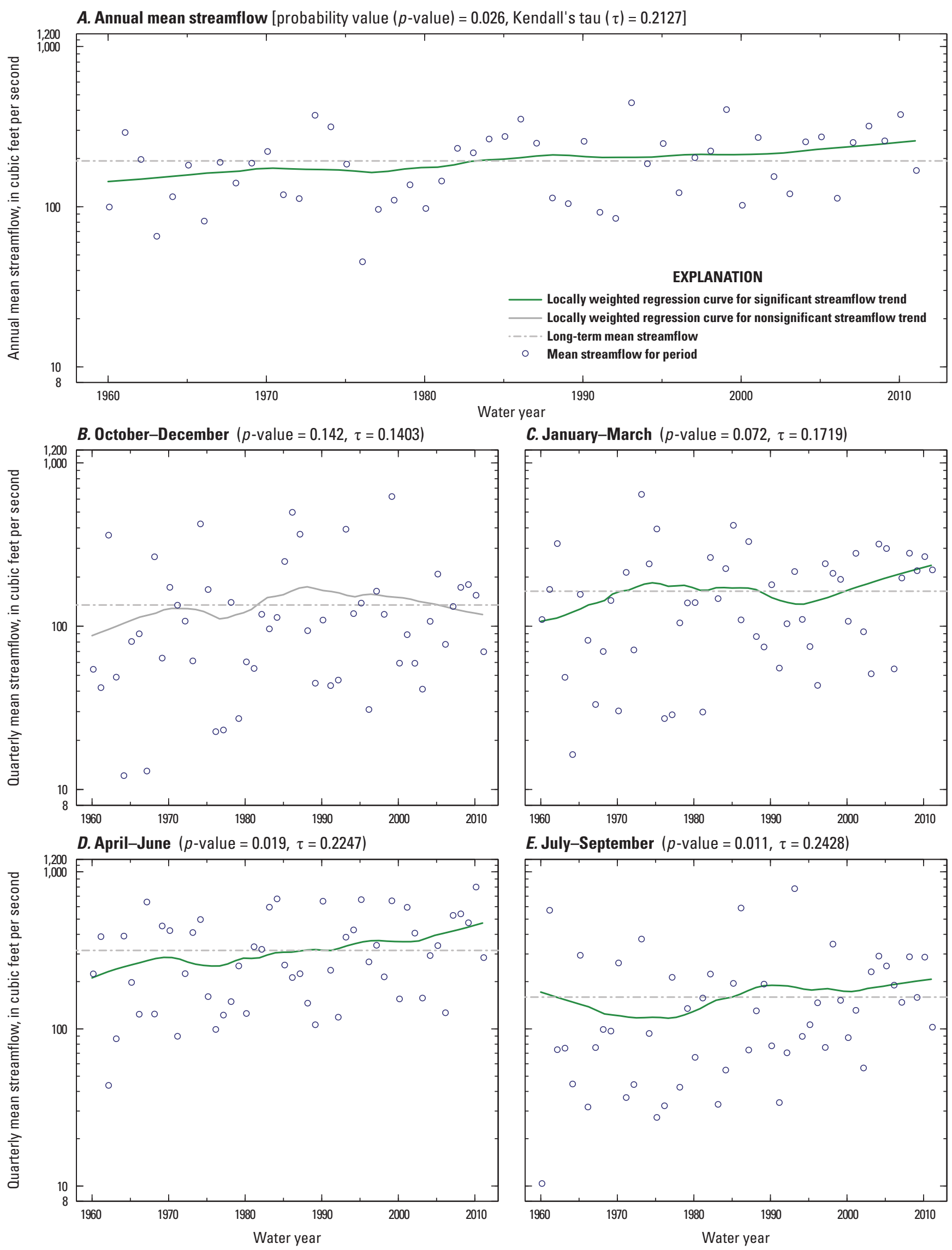

C. January-March ( $p$-value $=0.072, \tau=0.1719)$

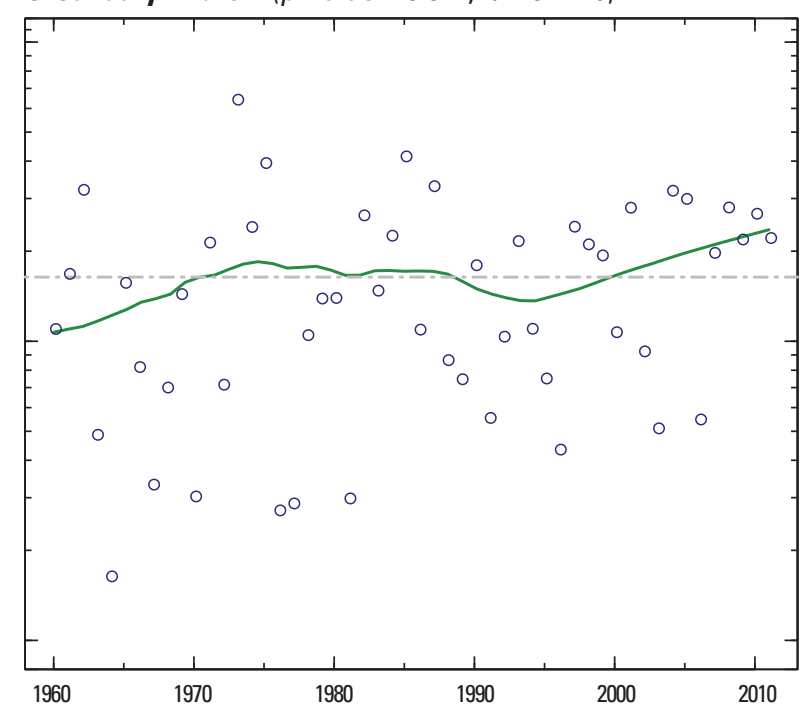

E. July-September $(p$-value $=0.011, \tau=0.2428)$

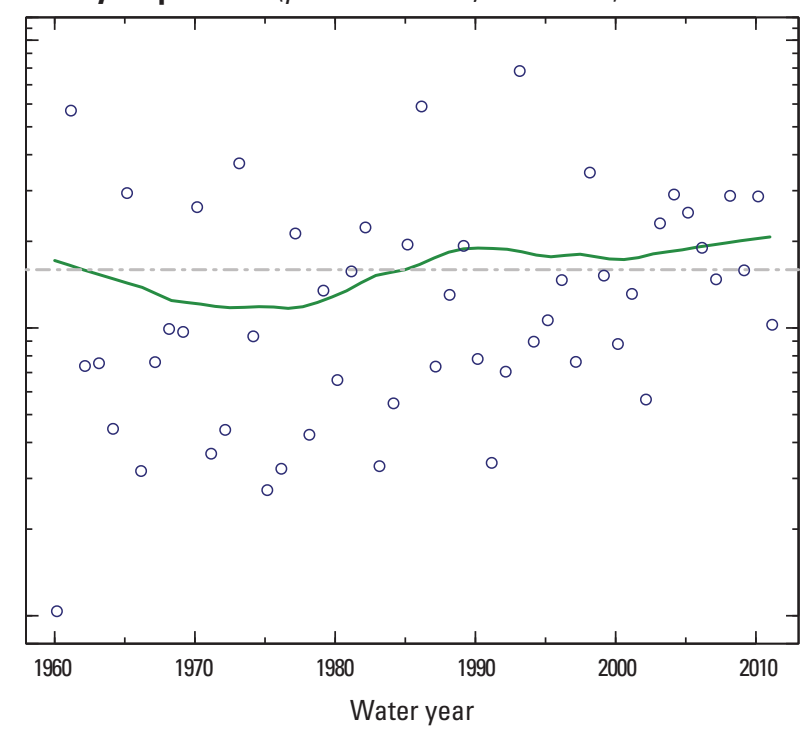

Figure 1-99. Blue River at Kansas City, Missouri (streamgage 06893500), water years 1960-2011. 
A. Annual mean streamflow [probability value $(p$-value $)=0.006$, Kendall's tau $(\tau)=0.2648$ ]

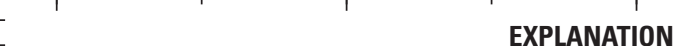

过

30

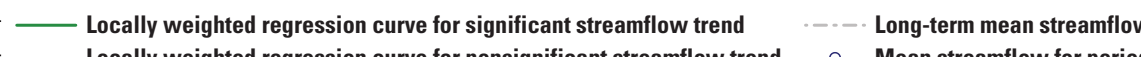

Lcally weighted regression curve for nonsignificant streamflow trend $\circ$ Mean streamflow for period
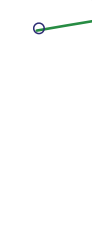

1960

1970

1980

Water year

B. October-December $(p$-value $=0.237, \tau=0.1131)$

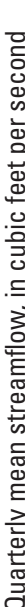

900

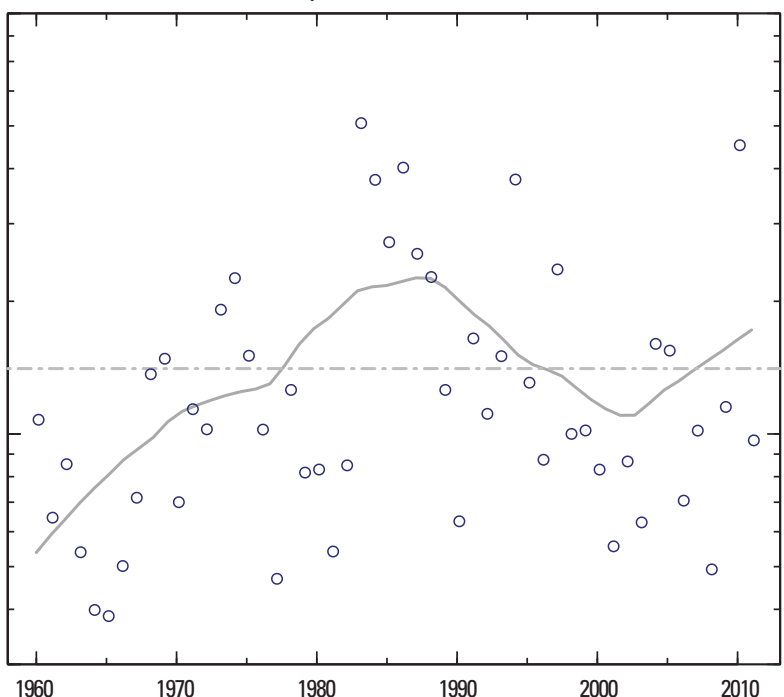

D. April-June $(p$-value $=0.07, \tau=0.1735)$

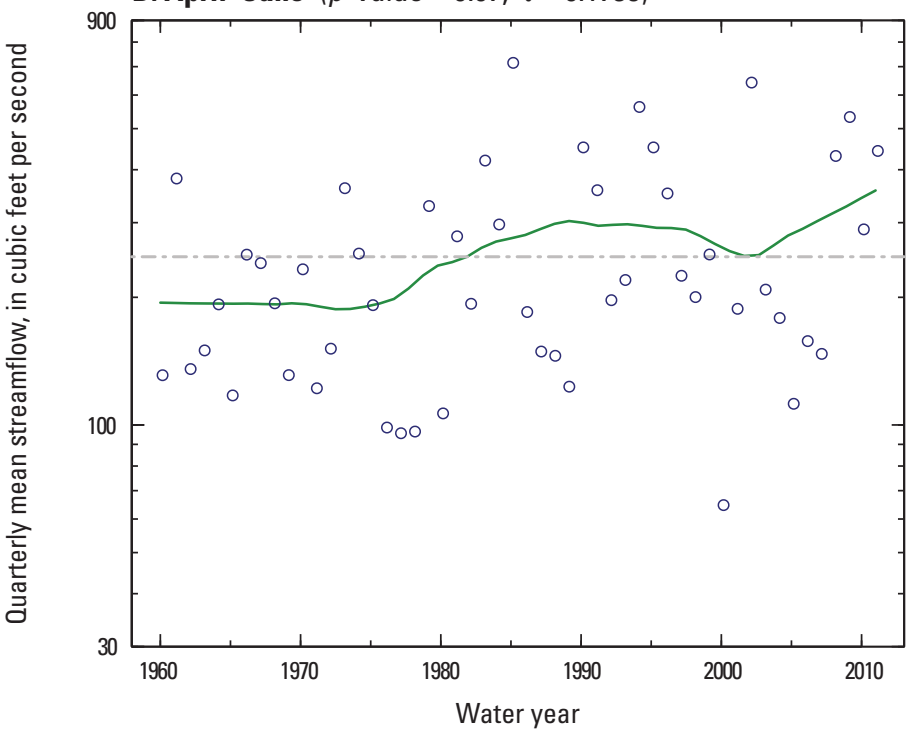

C. January-March $(p$-value $=0.056, \tau=0.1825)$

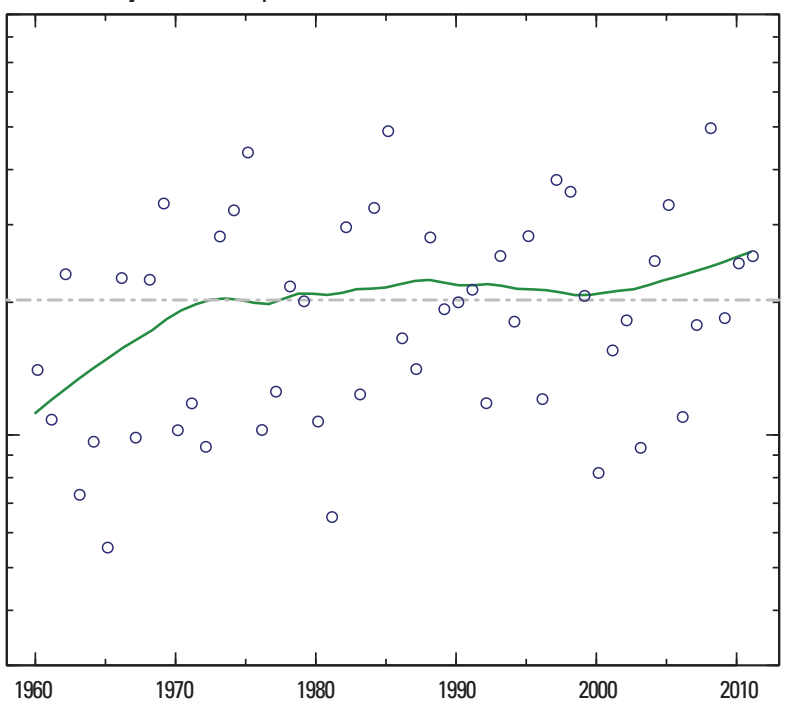

E. July-September $(p$-value $=0.018, \tau=0.2262)$

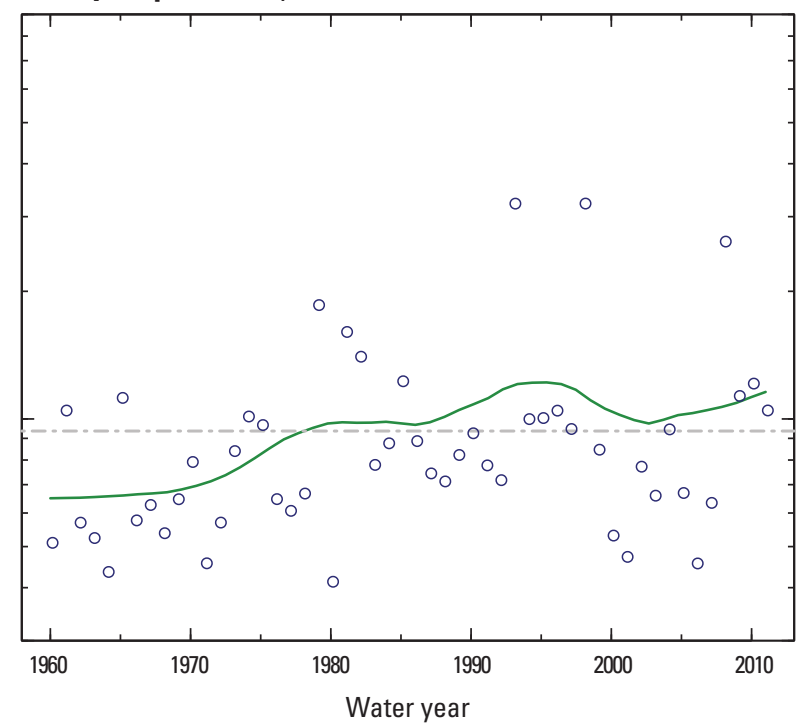

Figure 1-100. Little Piney Creek at Newburg, Missouri (streamgage 06932000), water years 1960-2011. 
A. Annual mean streamflow [probability value $(p$-value $)=0.091$, Kendall's tau $(\tau)=0.1614$ ]

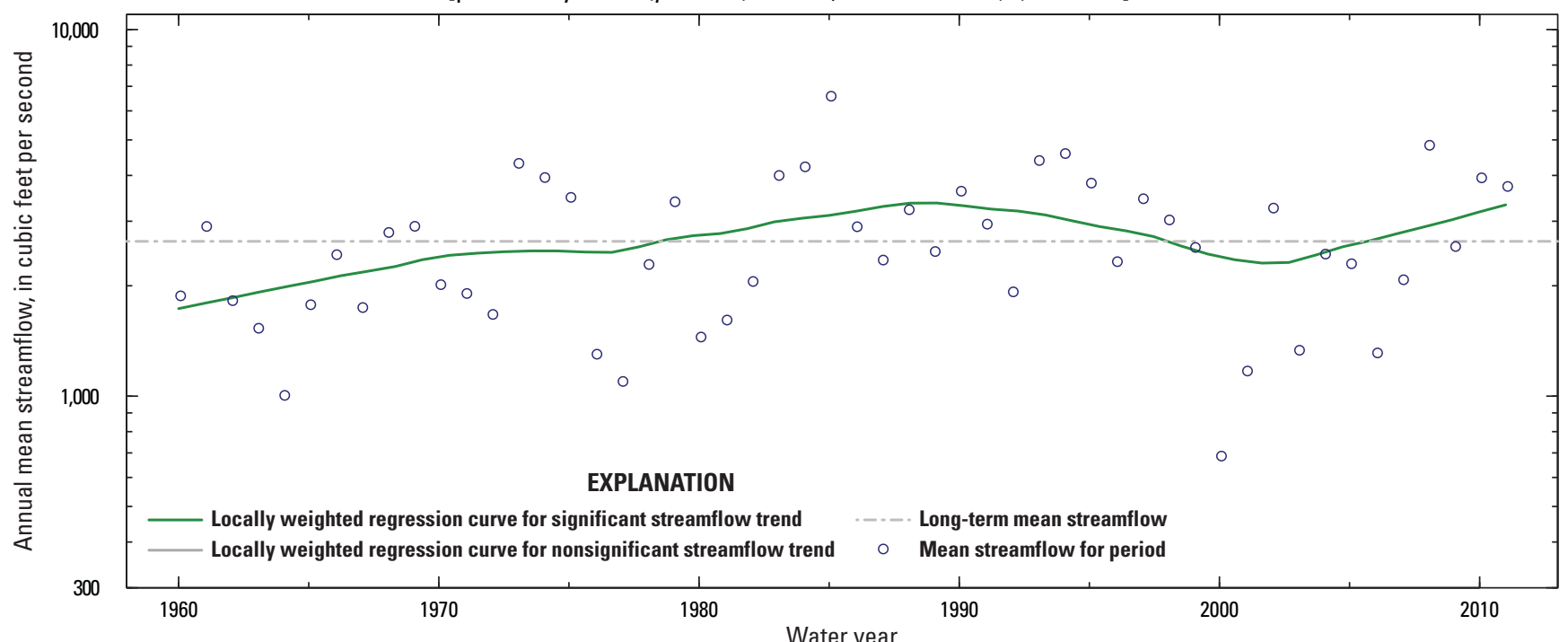

B. October-December $(p$-value $=0.987, \tau=-0.001508) \quad$ C. January-March $(p$-value $=0.17, \tau=0.1312)$
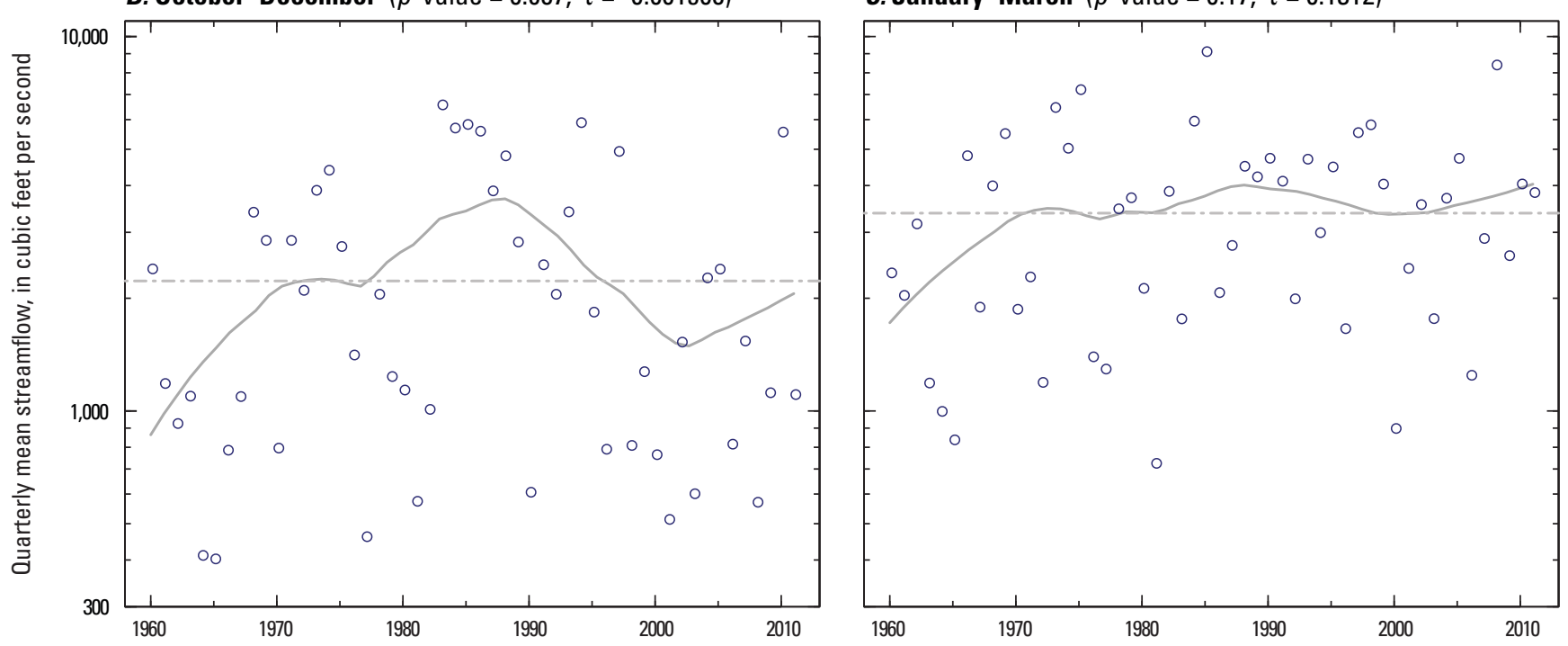

D. April-June $(p$-value $=0.32, \tau=0.09502)$

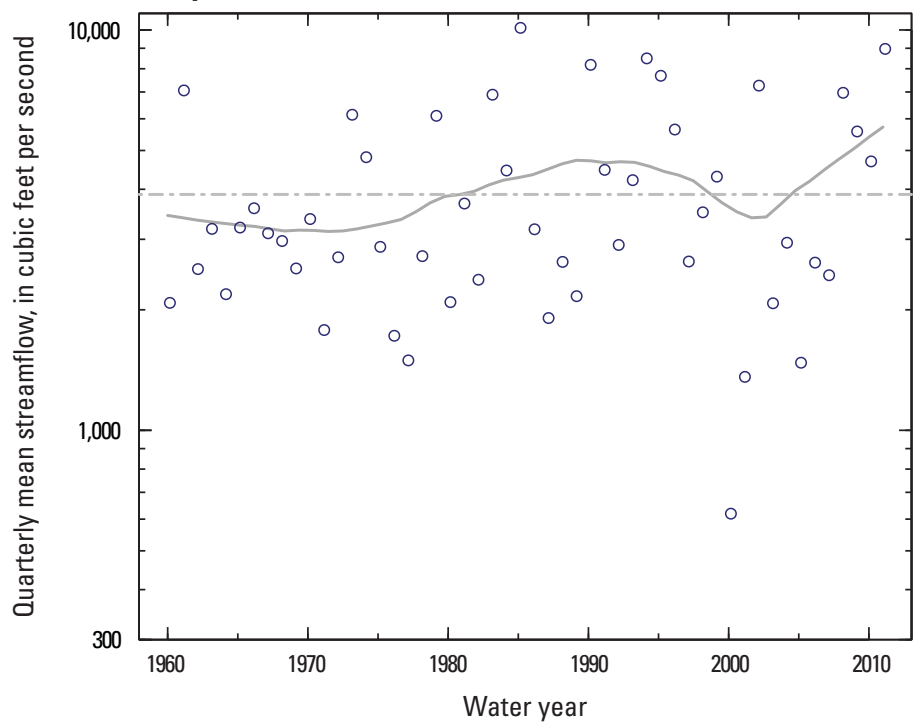

E. July-September $(p$-value $=0.463, \tau=0.07016)$

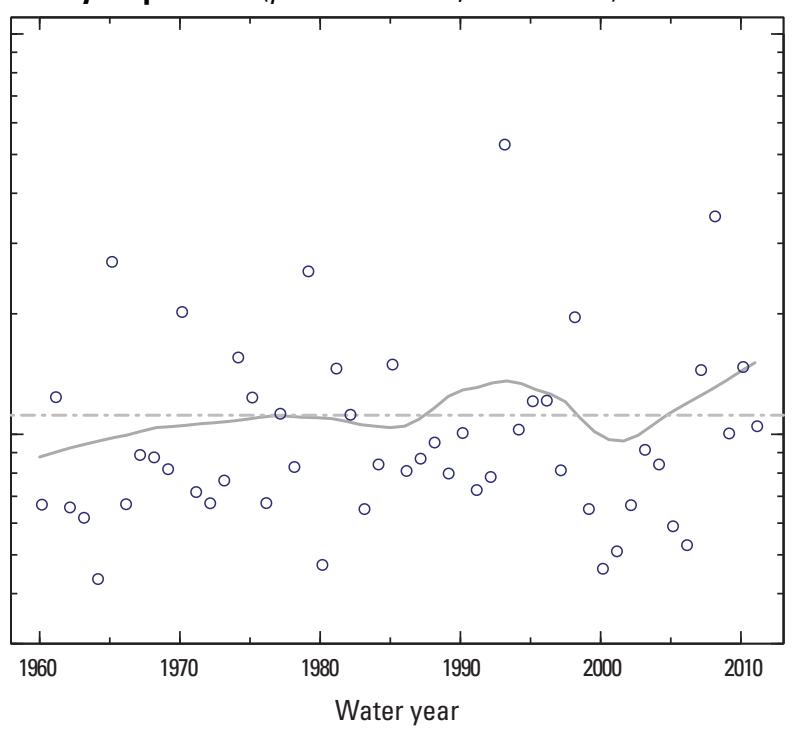

Figure 1-101. Gasconade River at Jerome, Missouri (streamgage 06933500), water years 1960-2011. 
Publishing support provided by: Rolla Publishing Service Center

For more information concerning this publication, contact: Director, USGS South Dakota Water Science Center 1608 Mountain View Road

Rapid City, South Dakota 57702

(605) 394-3200

Or visit the South Dakota Water Science Center Web site at: http://sd.water.usgs.gov/ 


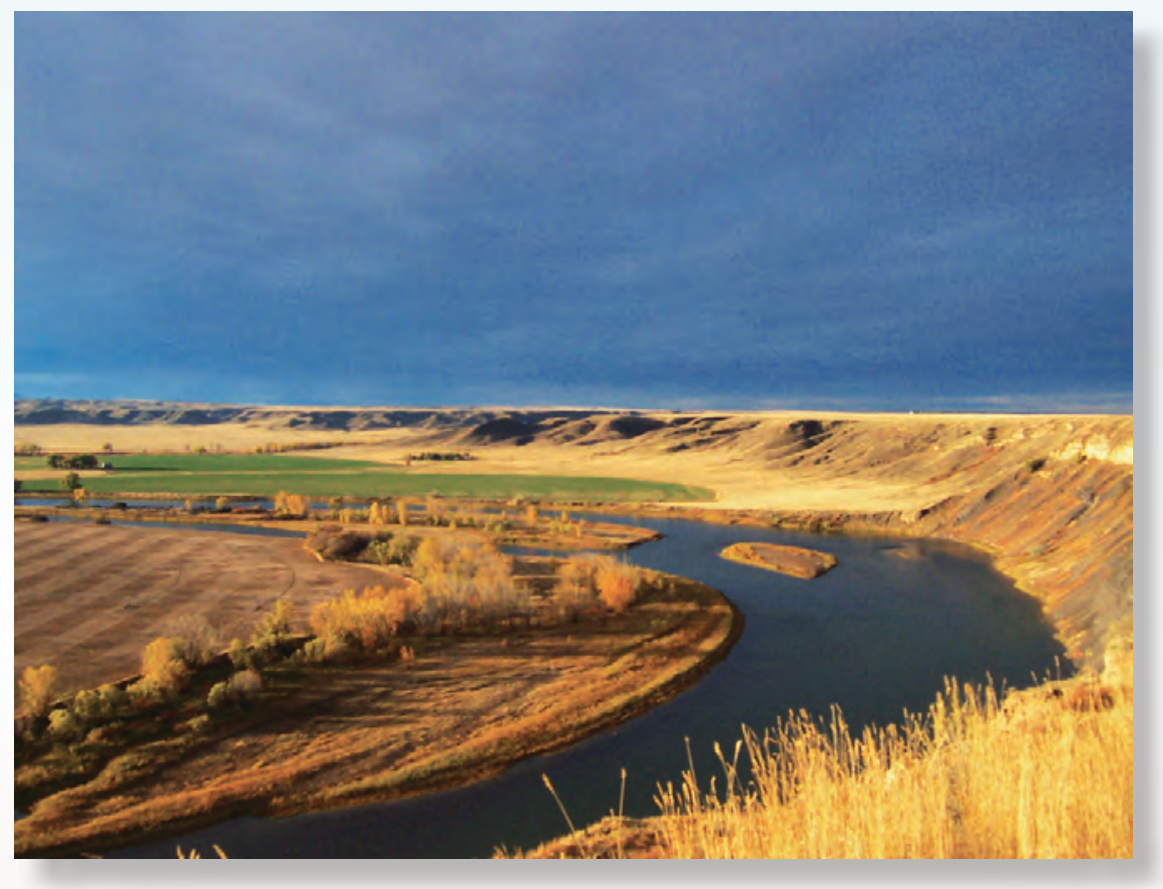

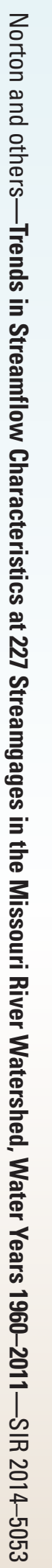

